UNIVERSIDADE DE SÃO PAULO

INSTITUTO DE GEOCIÊNCIAS

\title{
CARACTERIZAÇÃO ESTRUTURAL E GEOCRONOLÓGICA DOS DOMÍNIOS TECTÔNICOS DA PORÇÃO SUL-ORIENTAL DO ESTADO DE SÃO PAULO
}

\section{CLÁUDIA REGINA PASSARELLI}

Orientador: Prof. Dr. Mário da Costa Campos Neto

TESE DE DOUTORAMENTO

COMISSÃO JULGADORA

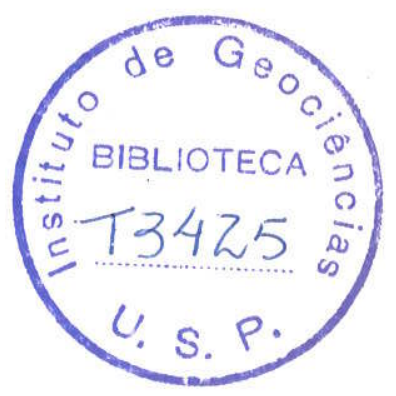

Nome

Presidente: Prof. Dr. Mário da Costa Campos Neto

Examinadores: Prof. Dr. Claudio Morisson Valeriano

Prof. Dr. José Manoel dos Reis Neto

Prof. Dr. Peter Christian Hackspacher

Prof. Dr. Wilson Teixeira
Assinatura

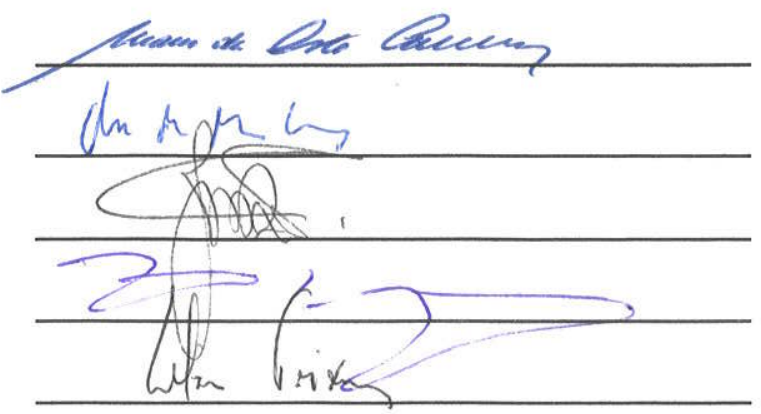


UNIVERSIDADE DE SÃO PAULO

INSTITUTO DE GEOCIÊNCIAS

CARACTERIZAÇÃO ESTRUTURAL E GEOCRONOLÓGICA DOS DOMÍNIOS TECTÔNICOS DA PORÇÃO SUL-ORIENTAL DO ESTADO DE SÃO PAULO

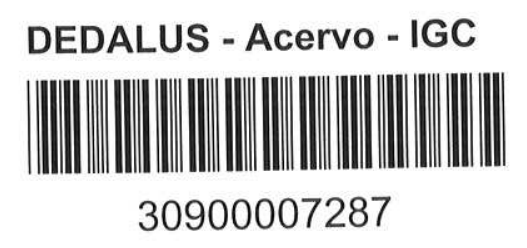

Cláudia Regina Passarelli

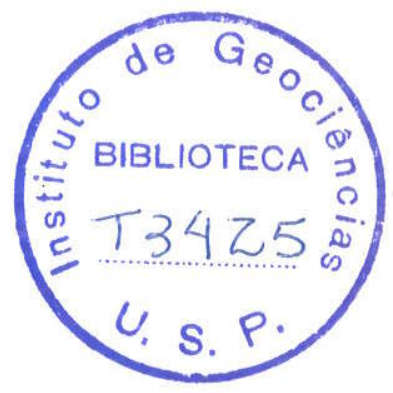

Orientador: Prof. Dr. Mário da Costa Campos Neto

TESE DE DOUTORAMENTO

Programa de Pós-Graduação em Geoquímica e Geotectônica

SÃO PAULO

2001 
A alma se transvia e perturba, quando se serve do corpo para considerar qualquer objeto; tem vertigem, como se estivesse ébria, porque se prende a coisas que estão, por sua natureza, sujeitas a mudanças; ao passo que, quando contempla a sua própria essência, dirige-se para o que é puro, eterno, imortal e, sendo ela dessa natureza, permanece aí ligada, por tanto tempo quanto possa. Cessam então os seus transviamentos, pois que está unida ao que é imutável e a esse estado da alma é que se chama sabedoria.

Platão

Dedico este trabalho ao sábio, poeta e grande admirador da natureza e da música. Meu Pai. 


\section{INDICE}

1. INTRODUÇÄO

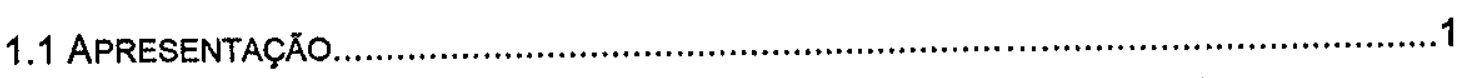

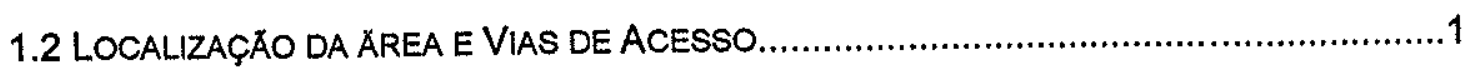

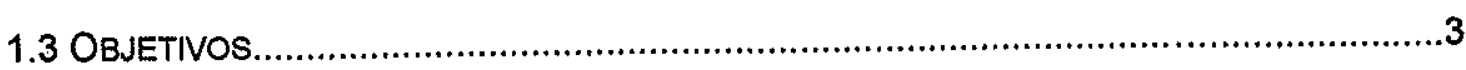

2. Metodologia

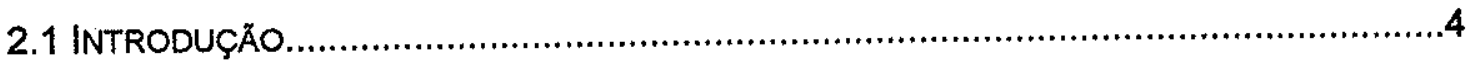

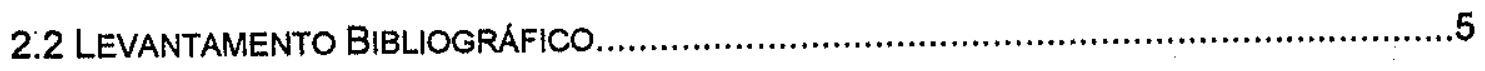

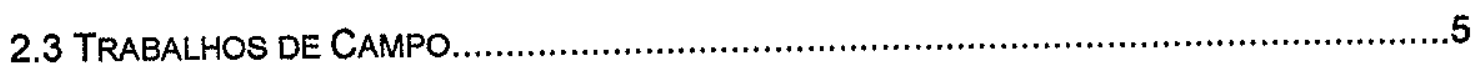

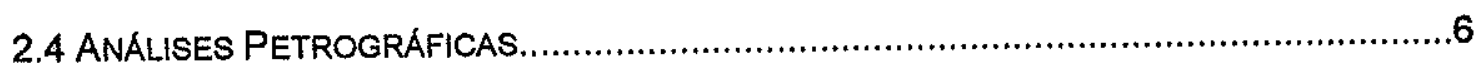

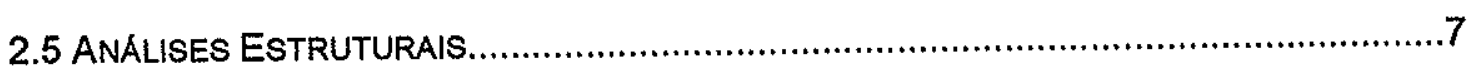

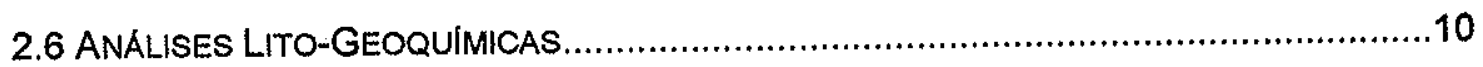

2.7 ANALISES GEOCRONOLOGICAS............................................................... 11

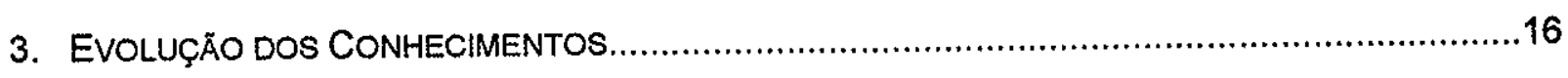

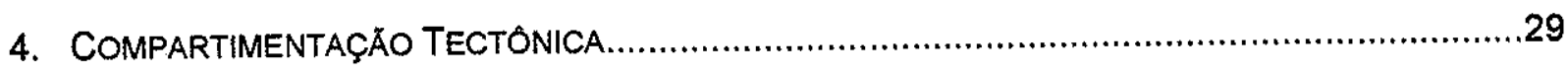

5. Bloco EMBU

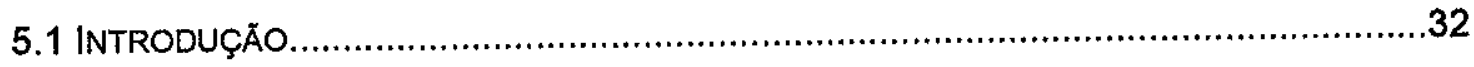

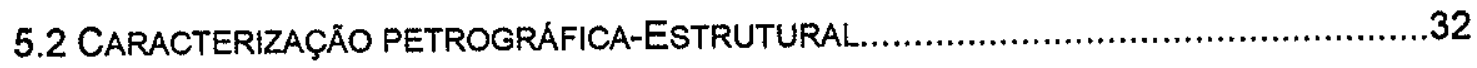

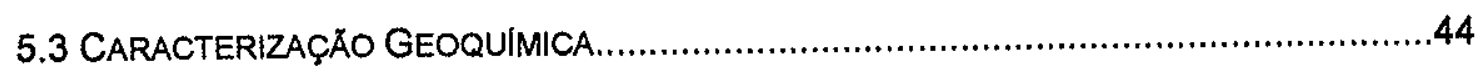

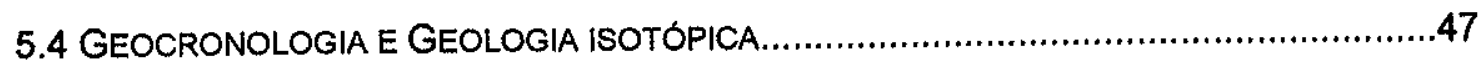

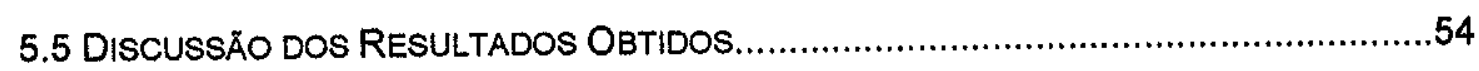

6. BLOCO MONGAGUA

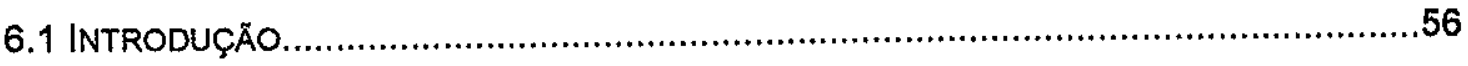

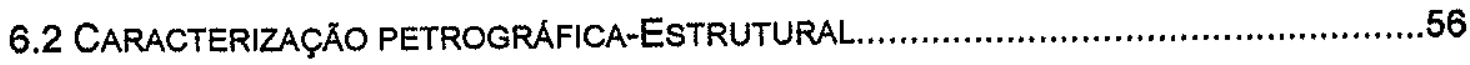

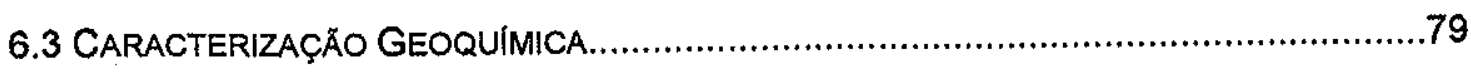

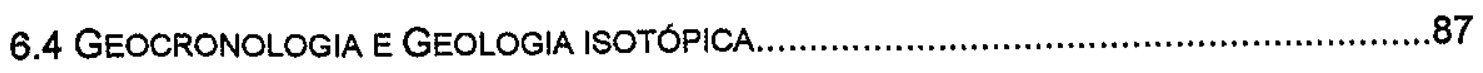

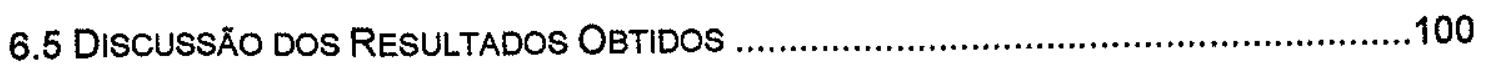


7. BLOCO REGISTRO

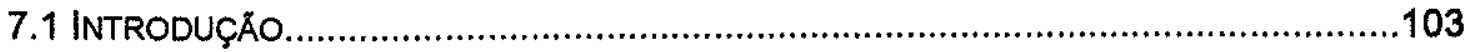

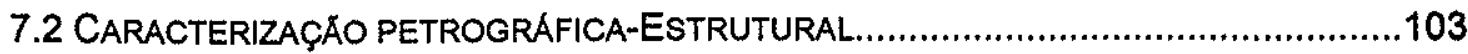

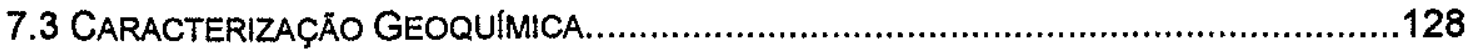

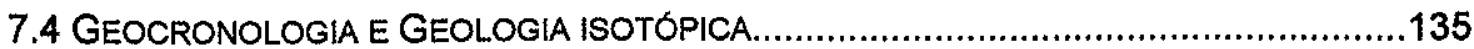

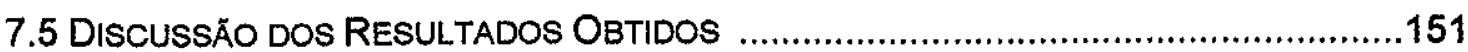

8. BLOCO IGUAPE

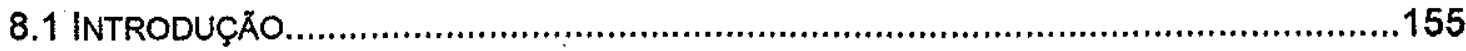

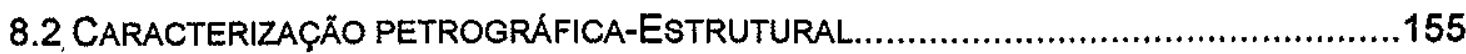

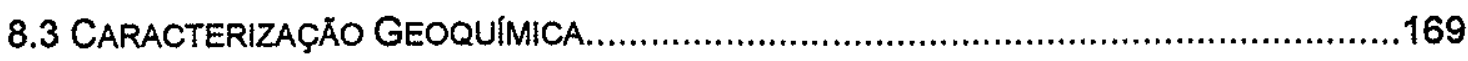

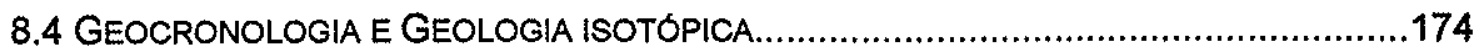

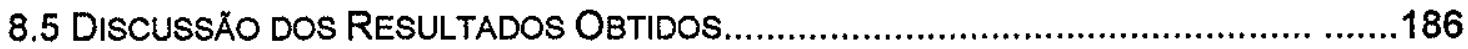

9. ZONA DE CISALHAMENTO ITARIRI / CUBATÃO

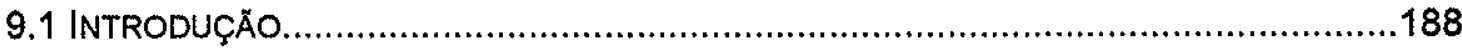

9.2 CARACTERIZAÇÃO PETROGRAFICA-ESTRUTURAL.................................................189

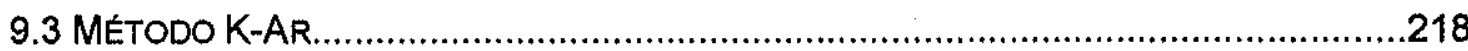

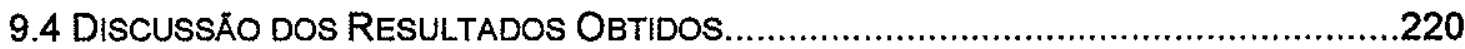

10. ZONA DE CISALHAMENTO SERRINHA

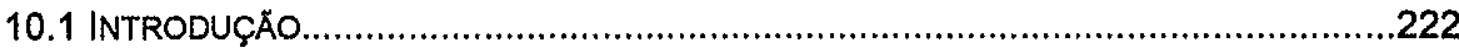

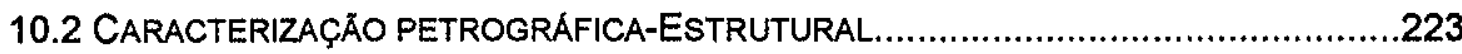

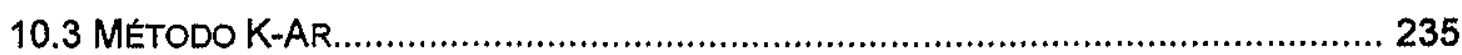

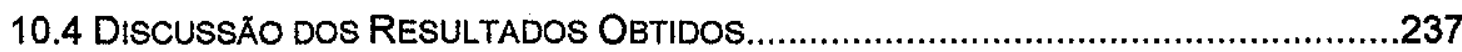

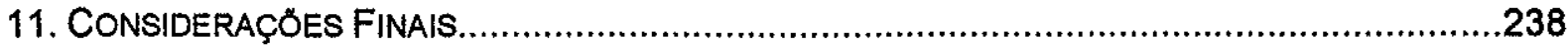

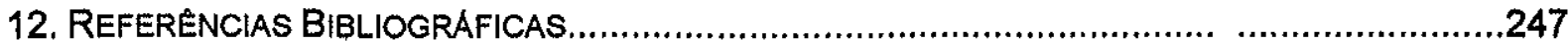

APÉNDICES

1. DADOS GEOQUIMICOS

2. CONSTANTES RADIOMÉTRICAS

ANEXOS

1. MAPA GEOLÓGICO COMPILADO NA ESCALA 1: 250.000 (SIMPLIFICADO)

2. MAPA ESTRUTURAL NA ESCALA 1: 250.000 
Figura 1.1 - Localização da área e principais vias de acesso.........................................02

Figura 4.1 - Esboço da compartimentação tectônica SE de SP e NE do PR.......................29

Figura 4.2 - Esboço da compartimentação tectônica da área estudada..............................30

Figura 5.2.1 - Bloco Embu - Rochas metassedimentares. Estereograma.............................33

Figura 5.2.2 - Bloco Embu - Rochas metassedimentares. Estereograma............................34

Figura 5.2.3 - Bloco Embu - Biotita Monzogranitos. Estereograma..................................37

Figura 5.2 .4 - Elipses obtidas pelo método de Fry. Bloco Embu.......................................42

Figura 5.2.5 - Diagrama de Flinn. Granitos deformados Bloco Embu.............................43

Figura 5.3.1 - Diagrama de razões moleculares - Bloco Embu....................................44

Figura 5.3.2 - Diagrama de ETR normalizado ao condrito (Nakamura, 1977) ......................45

Figura 5.3.3 - Diagrama de variação de multielementos - Bloco Embu............................46

Figura 5.4.1 - Diagrama Concórdia ${ }^{207} \mathrm{~Pb} /{ }^{235} \mathrm{U} \times{ }^{206} \mathrm{~Pb} /{ }^{238} \mathrm{U}$. Gr. Juquiá-Bloco Embu............48

Figura 5.4.2 - Diagrama Concórdia ${ }^{207} \mathrm{~Pb} / 235 \mathrm{U} \mathrm{x}^{206} \mathrm{~Pb} /{ }^{238} \mathrm{U}$. Gr.Sete Barras-Bloco Embu......50

Figura 5.4.3 - Diagrama de evoluçăo $\varepsilon N d x$ tempo $(\mathrm{Ga})$ - Gr.Juquiá-Bloco Embu...............52

Figura 5.4.4 - Diagrama $\varepsilon \operatorname{Sr} \times \varepsilon N d(t=600 \mathrm{Ma})$ - Granito Juquiá - Bloco Embu..................53

Figura 6.2.1 - Bloco Mongaguá - Gn. migmatíticos Mongaguá. Estereograma....................58

Figura 6.2.2 - Bloco Mongaguá - Gn.migmatíticos Itanhaém. Estereograma......................62

Figura 6.2.3 - Método de Fry aplicado às rochas do Bloco Mongaguá...............................77

Figura 6.2.4 - Diagrama de Flinn. Granitos Tipo Itariri - Bloco Mongaguá...........................78

Figura 6.3.1 - Diagrama Irvine \& Baragar (1971) - Bloco Mongaguá................................80

Figura 6.3.2- Diagrama Maniar \& Piccoli (1989)-Bloco Mongaguá......................................81

Figura 6.3.3 - Diagrama $\mathrm{Na}_{2} \mathrm{O} \times \mathrm{K}_{2} \mathrm{O}$, Middlemost (1975). Bloco Mongaguá......................82

Figura 6.3.4 - Diagramas de $\mathrm{SiO}_{2} \times$ óxidos - Bloco Mongaguá......................................83

Figura 6.3.5 - Diagramas de $\mathrm{SiO}_{2} \times$ elementos traços - Bloco Mongaguá............................84

Figura 6.3.6 - Diagrama de ETR (Nakamura, 1977). - Bloco Mongaguá................................85

Figura 6.3.7 - Diagrama de ETR (Nakamura, 1977). Bloco Mongaguá................................86

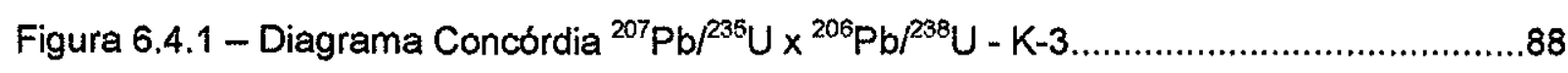

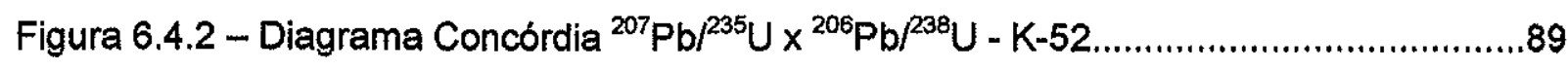

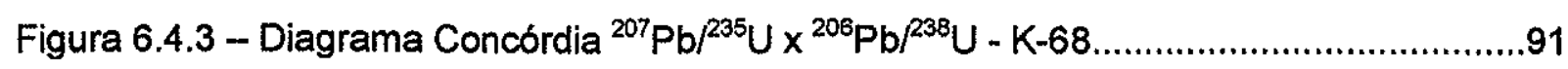

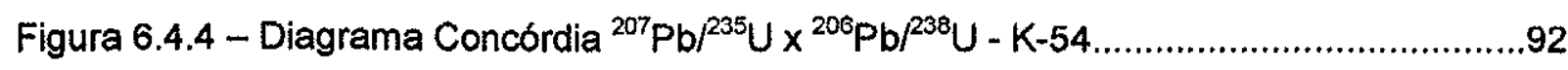

Figura 6.4.5 - Diagrama de evolução eNd x tempo $(\mathrm{Ga})$. - Bloco Mongaguá.......................96

Figura 6.4.6 - Diagrama de evolução $\varepsilon N d x$ tempo (Ga). - Bloco Mongaguá........................97

Figura 6.4.7 - Diagrama de evolução $\varepsilon N d$ x tempo (Ga). - Bloco Mongaguá.........................98

Figura 6.4.8 - Diagrama $\varepsilon S r \times \varepsilon N d(t=600 \mathrm{Ma})$ - Bloco Mongaguá.....................................98

Figura 7.2.1 - Bloco Registro - Rochas migmatíticas. Bandamento...................................109

Figura 7.2.2 - Bloco Registro - Rochas gnáissicas miloníticas....................................111 
Figura 7.2.3 - Bloco Registro/ZCl - Representação estereográfica. .113

Figura 7.2.4 - Método de Fry aplicado às rochas do Bloco Registro

Figura 7.3.1 - Diagrama $\mathrm{SiO}_{2} \times \mathrm{Na}_{2} \mathrm{O}+\mathrm{K}_{2} \mathrm{O}$ Irvine \& Baragar (1971). Bloco Registro. 129

Figura 7.3.2 - Diagrama $\mathrm{SiO}_{2} \times \mathrm{K}_{2} \mathrm{O}$ (Le Maitre et al., 1989) - Bloco Registro. 130

Figura 7.3.3 - Diagrama de razões moleculares Bloco Registro. 131

Figura 7.3.4 - Diagramas de $\mathrm{SiO}_{2} \times$ óxidos - Bloco Registro. 132

Figura 7.3.5 - Diagramas de $\mathrm{SiO}_{2} \times$ Elementos traços - Bloco Registro 133

Figura 7.3.6 - Diagrama de ETR (Nakamura, 1977) Bloco Registro. 134

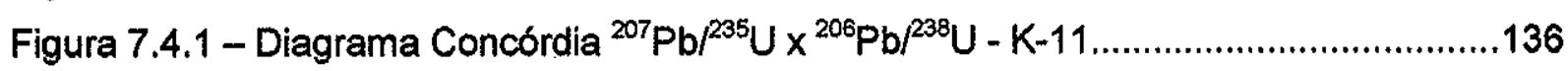

Figura 7.4.2 - Diagrama Concórdia ${ }^{207} \mathrm{~Pb} /{ }^{235} \mathrm{U} \mathrm{x}^{206} \mathrm{~Pb} /{ }^{238} \mathrm{U}$ - K-16....................................137

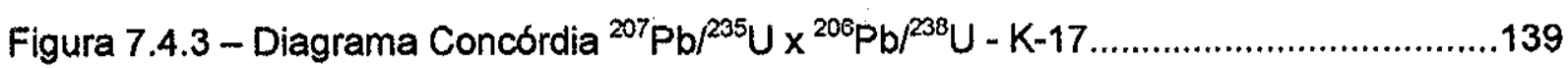

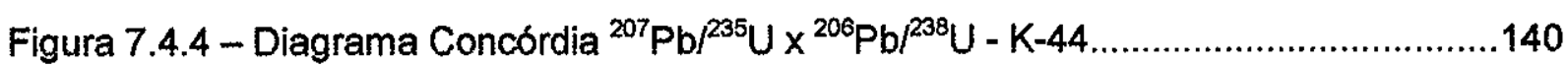

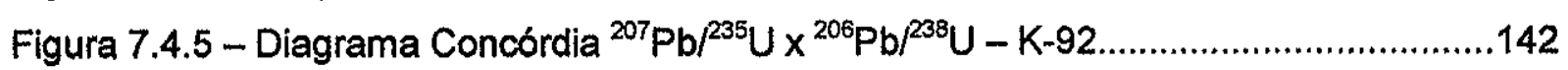

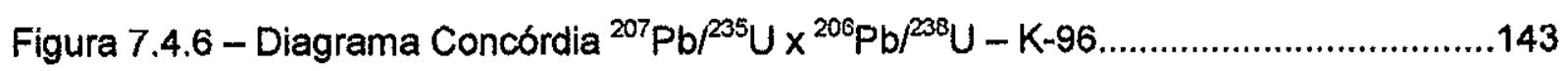

Figura 7.4.7 - Diagrama de evolução $\varepsilon N d x$ tempo $(\mathrm{Ga})$. - Bloco Registro..........................148

Figura 7.4.8 - Diagrama de evolução $\varepsilon N d x$ tempo $(\mathrm{Ga})$. - Bloco Registro..........................148

Figura 7.4.9 - Diagrama $\varepsilon \operatorname{Sr} x \varepsilon \mathrm{Nd}(\mathrm{t})$ - Bloco Registro................................................149

Figura 8.2.1 - Bloco Iguape - Metassedimentos. Foliação principal................................156

Figura 8.2.2 - Bloco Iguape - Granitos miloníticos........................................................159

Figura 8.2.3 - Método de Fry aplicado ás rochas graníticas do Bloco Iguape...................167

Figura 8.2.4 - Diagrama de Flinn. Granitos Bloco Iguape.............................................168

Figura 8.3.1 - Diagrama de razões moleculares - Bloco Iguape......................................169

Figura 8.3.2 - Diagrama $\mathrm{Na}_{2} \mathrm{O} \times \mathrm{K}_{2} \mathrm{O}$ (Middlemost, 1975). Granitos - Bloco Iguape...........170

Figura 8.3.3 - Diagrama discriminante $(\mathrm{Y}+\mathrm{Nb}) \times \mathrm{Rb}$. Pearce et al. (1984)......................171

Figura 8.3.4 - Diagrama Rb x Ba x Sr (elementos em ppm).......................................171

Figura 8.3.5 - Diagramas de variação multielementar, Pearce et al. (1984).......................172

Figura 8.3.6 - Diagrama de ETR normalizado ao condrito (Nakamura, 1977)....................173

Figura 8.3.7 - Diagrama de ETR normalizado ao condrito (Nakamura, 1977)....................173

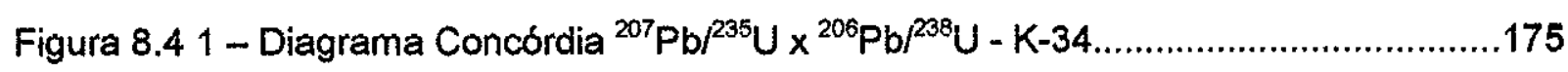

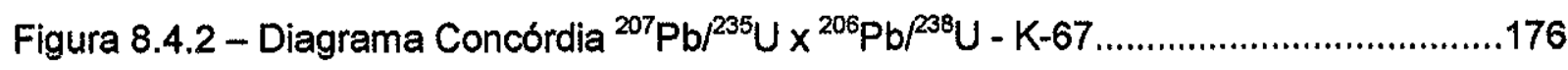

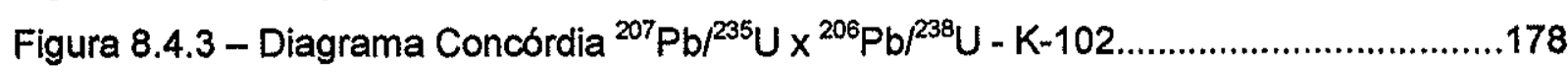

Figura 8.4.4 - Diagrama de evolução $\varepsilon \mathrm{Nd} x$ tempo (Ga). Granitos Iguape e ZCS.............182

Figura 8.4.5 - Diagrama de evolução $\varepsilon$ Nd x tempo (Ga). Granitos NE de Iguape.............182

Figura 8.4.6 - Diagrama de evolução $\varepsilon \mathrm{Nd} \times$ tempo (Ga). Granitos Itapitangui e Paratiú....183

Figura 8.4.7 - Diagrama $\varepsilon \mathrm{Sr} \times \varepsilon N d(t=600 \mathrm{Ma})$ - Rochas graníticas - Bloco lguape...........184

Figura 9.1.1 - Sistema de Cisalhamento Cubatão - Itariri na área de estudo....................188

Figura 9.2.1 - Setor centro-oeste da ramificação A-B do SCCl.....................................189

Figura 9.2.2 - Croqui esquemático de movimentaçăo sinistral .......................................190 
Figura 9.2.3 - Representação estereográfica ramo A-B - setor centro-oeste. 191

Figura 9.2.4 - Croqui de dobras assimétricas associadas à $1^{\text {a }}$ fase - ramo $A-B$ 191

Figura 9.2.5 - Setor centro-leste da ramificação A-B do SCCl. ..192

Figura 9.2.6 - Representação estereográfica ramo A-B - setor leste. 193

Figura 9.2.7 - Setor centro-leste da ramificação A-B do $\mathrm{SCCl}$........................................193

Figura 9.2.8 - Representação estereográfica ramo C. ..................................................194

Figura 9.2.9 - Representação estereográfica ramo A-B. ...............................................196

Figura 9.2.10 - Croqui de dobras assimétricas associadas à $2^{\mathrm{a}}$ fase - ramo A-B.............196

Figura 9.2.11 - Acavalamento de boudins...............................................................197

Figura 9.2.12 - Representação estereográfica - ramo B. ............................................198

Figura 9.2.13 - Representaçāo estereográfica setor central - ramo B. .............................199

Figura 9.2.14 - Representação estereográfica setor extremo leste - ramo B. ...................200

Figura 9.2.15 - Representação estereográfica - ramo B................................................201

Figura 9.2.16 - Representação estereográfica de foliação milonítica ..............................202

Figura 9.2.17 - Representação estereográfica de fraturas e falhamentos.........................203

Figura 9.2 18A - Método de Fry. Rochas miloníticas ramos A-B setor oeste - $\mathrm{ZCl}$.............213

Figura 9.2 18B - Método de Fry. Rochas miloníticas ramos A-B setor central - $\mathrm{ZCl}$..........215

Figura $9.218 \mathrm{C}$ - Método de Fry. Rochas miloníticas ramos A-B setor leste $-\mathrm{ZCl} \ldots \ldots \ldots \ldots . . .216$

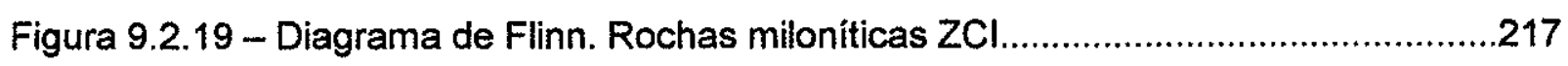

Figura 9.3.1 - Mapa estrutural esquemático com localização das amostras datadas.........218

Figura 10.1.1 - Mapa estrutural esquemático da área estudada....................................222

Figura 10.2.1 - Mapa estrutural esquemático dos setores estudados da ZCS..................223

Figura 10.2.2 - ZCS - setor oeste. Milonitos graníticos e de metassedimentos..................224

Figura 10.2.3 - ZCS - setor central. Milonitos graníticos e de metassedimentos................225

Figura 10.2.4 - Ramificação da ZCS - Milonitos...........................................................227

Figura 10.2.5 - ZCS - setor leste. Paragnaisses miloníticos.........................................228

Figura 10.2.6 - Método de Fry -rochas miloníticas ZCS - setores leste e central...............233

Figura 10.2.7 - Diagrama de Flinn. Milonitos setores leste e central - ZCS.......................234

Figura 10.3.1 - Mapa estrutural esquemático com localização das amostras datadas.......235 
Tabela 5.2.1 - Eixos do elipsóide de deformação obtidos pelo Método de Fry......................40

Tabela 5.2.2 - Dados obtidos pelo método de Fry e aplicaçăo de Diagrama de Flinn...........41

Tabela 5.4.1 - Dados analíticos U.Pb (zircăo e monazita) - Bloco Embu................................51

Tabela 5.4.2 -Dados analíticos da sistemática Sm-Nd - Granito Juquiá..............................52

Tabela 5.4.3 -Dados analíticos da sistemática Rb-Sr - Granito Juquiáa................................53

Tabela 6.2.1 - Eixos do elipsóide obtidos pelo Método de Fry ...........................................76

Tabela 6.2.2 - Dados obtidos pelo método de Fry e aplicação de Diagrama de Flinn..........78

Tabela 6.4.1 - Dados analíticos U-Pb (zircão) - Bloco Mongaguá........................................93

Tabela 6.4.2 - Dados analíticos K-Ar - Bloco Mongaguá.....................................................94

Tabela 6.4.3 - Dados analíticos da sistemática Sm-Nd - Bloco Mongaguá.............................99

Tabela 6.4.4 - Dados analíticos da sistemática Rb-Sr - Bloco Mongaguá..............................99

Tabela 7.2.1 - Eixos do elipsóide obtidos pelo Método de Fry ...........................................125

Tabela 7.4.1 - Dados analíticos U-Pb (zircão e monazita) - Bloco Registro..........................144

Tabela 7.4.2 - Dados analíticos K-Ar - Bloco Registro..................................................145

Tabela 7.4.3 -Dados analíticos da sistemática Sm-Nd - Bloco Registro..............................150

Tabela 7.4.4 - Dados analíticos da sistemática Rb-Sr - Bloco Registro..............................150

Tabela 8.2.1 - Eixos do elipsóide obtidos pelo Método de Fry........................................165

Tabela 8.2.2 - Dados obtidos pelo método de Fry e aplicação de Diagrama de Flinn........166

Tabela 8.4.1 - Dados analíticos U.Pb (zircão/monazita) - Bloco Iguape..............................179

Tabela 8.4.2 - Dados analíticos K-Ar Granito Cordeiro - Bloco Iguape..............................180

Tabela 8.4.3 - Dados analíticos da sistemática Sm-Nd - Bloco lguape ...............................185

Tabela 8.4.4 - Dados analíticos da sistemática Rb-Sr - Bloco lguape.................................185

Tabela 9.2.1 - Eixos do elipsóide obtidos pelo Método de Fry.........................................211

Tabela 9.2.2 - Dados obtidos pelo método de Fry e aplicação de Diagrama de Flinn........213

Tabela 9.3.1 - Dados analíticos da sistemática K-Ar - rochas miloníticas - ZCI..................219

Tabela 10.2.1 - Eixos do elipsóide obtidos pelo Método de Fry. .......................................231

Tabela 10.2.2 - Dados obtidos pelo método de Fry e aplicação de Diagrama de Flinn......232

Tabela 10.3.1 - Dados analíticos da sistemática K-Ar - rochas miloníticas - ZCS...............236 


\section{BLOCO EMBU}

PRANCHA 1 - Fotos 1 a 6 Aspectos gerais rochas metassedimentares...........................35

PRANCHA 2 - Fotos 1 a 6 Aspectos gerais granitos peraluminosos...................................39

BLOCO MONGAGUÁ

PRANCHA 3 - Fotos 1 a 6 Aspectos gerais rochas gnáissico-migmatíticas Mongaguá.......64

PRANCHA 4 - Fotos 1 a 5 Aspectos gerais rochas gnáissico-migmatíticas Mongaguá........65

PRANCHA 5 - Fotos 1 a 6 Fotomicrografias. Rochas gnáissico-migmatíticas Mongaguá....66

PRANCHA 6 - Fotos 1 a 6 Aspectos gerais rochas gnáissicas ltanhaém.........................67

PRANCHA 7 - Fotos 1 a 6 Aspectos gerais Granitos Itariri.............................................73

PRANCHA 8 - Fotos 1 a 6 Aspectos gerais Granito Areado..............................................74

PRANCHA 9 - Fotos 1 a 6 Aspectos gerais Granito Ribeirão do Óleo.................................75

BLOCO REGISTRO

PRANCHA 10 - Fotos 1 a 6 Rochas gnáissico-migmatíticas Região de Oliveira Barros....116

PRANCHA 11 - Fotos 1 a 6 Rochas gnáissico-migmatíticas Região de Oliveira Barros....117

PRANCHA 12 - Fotos 1 a 6 Rochas gnáissico-migmatíticas Região de Oliveira Barros....118

PRANCHA 13 - Fotos 1 a 5 Aspectos gerais rochas gnáissico-migmatíticas ....................119

PRANCHA 14 - Fotos 1 a 6 Aspectos gerais. Granodiorito - Região de Oliveira Barros.....120

PRANCHA 15 - Fotos 1 a 5 Fotomicrografias. Rochas gnáissico-migmatíticas...................121

PRANCHA 16 - Fotos 1 a 6 Aspectos gerais rochas gnáissico-migmatíticas.....................122

PRANCHA 17- Fotos 1 a 6 Aspectos gerais rochas metassedimentares.........................123

PRANCHA 18 - Fotos 1 a 6 Aspectos gerais rochas metassedimentares/G.Votupoca......124

BLOCO IGUAPE

PRANCHA 19 - Fotos 1 a 5 Rochas metassedimentares/Gr. Itapitangui/Cordeiro.............162

PRANCHA 20 - Fotos 1 a 4 Aspectos gerais Granitos Iguape........................................163

PRANCHA 21 - Fotos 1 a 4 Fotomicrografias. Granitos Iguape........................................164

SISTEMA DE CISALHAMENTO CUBATÃO - ITARIRI

PRANCHA 22 - Fotos 1 a 6 Aspectos gerais rochas miloníticas ramo A-B .......................204

PRANCHA 23 - Fotos 1 a 5 Aspectos gerais rochas miloníticas ramo A-B......................205

PRANCHA 24 - Fotos 1 a 6 Fotomicrografias. Rochas miloníticas ramo A-B....................209

PRANCHA 25 - Fotos 1 a 6 Fotomicrografias. Rochas miloníticas ramo A-B ...................210

ZONA DE CISALHAMENTO SERRINHA

PRANCHA 26 - Fotos 1 a 6 Aspectos gerais rochas miloníticas setor oeste e central.......229

PRANCHA 27 - Fotos 1 a 6 Aspectos gerais rochas miloníticas setor central e leste.........230 
Foto 5.4.1 - Fotomicrografias de lupa binocular de zircões e monazitas - amostra K-20: a) cristais de zircão (aumento 107X); b) cristais de monazita (aumento $220 \mathrm{X}$ ).

Foto 5.4.2 - Fotomicrografias de lupa binocular de zircões e monazitas - amostra K-23: a) cristais de zircão (aumento 135X); b) cristais de monazita (aumento $275 \mathrm{X}$ ).

Foto 6.4.1 - Fotomicrografias de lupa binocular de cristais de zircão - amostra K-3. a) fração $M-5$, (aumento $165 \mathrm{X}$ ); b) fração $M-4$, (aumento $54 \mathrm{X}$ )

Foto 6.4.2 - Fotomicrografia de lupa binocular de cristais de zircão fração M-3. .88

Foto 6.4.3 - Fotomicrografia de lupa binocular de cristais de zircão fração $M-4$, não abradada (aumento $135 \mathrm{X}$ ) - amostra K-68. .90

Foto 6.4.4 - Fotomicrografia de lupa binocular de cristais de zircão fração $M-3$, não abradada (aumento $275 \mathrm{X}$ ) - amostra K-54.

Foto 7.4.1 - Fotomicrografia de lupa binocular de cristais de zircão fração $M-3$, não abradada (aumento $108 \mathrm{X}$ ) - amostra K-11 135

Foto 7.4.2 - Fotomicrografia de lupa binocular de cristais de zircão fração NM-4, abradada por 1 hora (aumento $108 \mathrm{X}$ ) - amostra K-16. .137

Foto 7.4.3 - Fotomicrografia de lupa binocular de cristais de zircão fração $M-4$, não abradada (aumento $135 \mathrm{X}$ ) - amostra K-17.

Foto 7.4.4 - Fotomicrografia de lupa binocular de cristais de zircão fração $\mathrm{M}-4$, abradada por 1 hora (aumento $162 \mathrm{X}$ ) - amostra K-44. 140

Foto 7.4.5 - Fotomicrografia de lupa binocular de cristais de zircão fração $M-3$, não abradada (aumento $162 \mathrm{X}$ ) - amostra K-92. 141

Foto 7.4.6 - Fotomicrografia de lupa binocular de cristais de monazita fração M 0.6 (aumento $275 \mathrm{X})$ - amostra K-96 142

Foto 8.4.1 - Fotomicrografia de lupa binocular de cristais de zircão fração NM-5, abradada por 1 hora (aumento $135 \mathrm{X}$ ) - amostra K-34. 174

Foto 8.4.2 - Fotomicrografia de lupa binocular de cristais de zircão fração $M-3$, não abradada (aumento $108 \mathrm{X}$ ) - amostra K-67.

Foto 8.4.3 - Fotomicrografias de lupa binocular de zircões e monazitas - amostra K-102: a) cristais de zircão (aumento 135X); b) cristais de monazita (aumento $208 \mathrm{X}$ ). 
Durante a realização deste trabalho, conheci e convivi com pessoas que em muito contribuíram para meu crescimento pessoal e profissional.

Inicialmente, gostaria de agradecer meus orientadores Mário da Costa Campos Neto, Miguel Ângelo Stipp Basei, que me apoiaram, incentivaram nos momento dificeis, e confiaram na minha capacidade profissional. Extendo este agradecimento em especial ao amigo e também orientador Oswaldo Siga Jr. (Osbaldo), por sempre ter uma palavra amiga e de incentivo, e pela incalculável contribuição em várias etapas deste trabalho.

Ao amor da minha vida, por tudo. Sem você não teria conseguido. Você participou comigo nos momentos alegres e me ajudou a levantar nos momentos mais difíceis. O que mais posso dizer ... Bunitus, o amor que nos une é a coisa mais importante para mim.

Durante os trabalhos de campo, agradeço o apoio, atenção e dedicação recebidos por Hélcio José dos Prazeres Filho, meu companheiro e colega de campo, à Vanessa, e Strupis. Aos Profs. Miguel A. S. Basei e Francisco Hervé, pelo dia de campo muito proveitoso.

Durante todo periodo de Doutorado, gostaria de agradecer em especial, ao Prof. Bley pelo interesse, preocupação, incentivo e carinho. Aos Profs. Gergely e Valdecir pela disposição em ajudar e colaboração em diversas etapas. Ao Prof. lan pelo inglês impecável.

Durante os trabalhos realizados no CPGeo, gostaria de agradecer os funcionários Walter M. Spröesser e Vasco Loios, pela grande ajuda e carinho. Extendo os agradecimentos a Liliane Petronilho, Artur T. Onoe, Key Sato, Solange Lucena de Souza, Ivone K. Sonoki e Helen M. Sonoki, pela paciência e ajuda.

Nas confecções de lâminas e polimento das fatias de rochas, gostaria de agradecer Samuel Pedro Egídio (Samuca), Cláudio Hopp e seus funcionários, pela atenção recebida.

Ao CNPq, agradeço a bolsa de Doutorado, no período de 03/96 a 08/2000.

$\mathrm{Na}$ confecção do mapa geológico, agradeço profundamente meu companheiro Hélcio, por todo trabalho.

Às secretárias, Nícia, Soninha e Valéria, meus sinceros agradecimentos pela atenção recebida. Em especial, à Verinha pelo carinho. 
À equipe do setor gráfico, pela paciência e auxílio na encadernação e reprodução deste trabalho.

$\mathrm{Na}$ fase final, agradeço meu companheiro Hélcio, Prof. Miguel Basei, Prof. Oswaldo Siga Jr. pelas revisões, correções e incentivo.

Ao amigo Ossama, por todos estes anos desde os remotos display always, na rapidade, na neblina e........eu tô bem Kaú! Pela consideração, afeição e visitas inesperadas.

Aos amigos Cuca, Rosa Bello, Strupis, Xhó, Weber, Gilberto, Mauro, pela companhia, atenção e grande ajuda nos momentos dificeis, e pelos saudosos Almeida $O$ Som!, churrascos, e Blues Sessions.

Aos vizinhos mais queridos, Seu Cesário e Regina, Deise, pela preocupação e amizade, muito obrigada. Às amigas Rosana e Rosângela, pela presença e amizade.

Aos amigos Laurene, Calvino e Vanessa pelo carinho e amizade, e pelos sempre divertidos e revigorantes fins de semana. Como diz o ditado, mano, as gatuíras fizeram a festa.

Ao Dr. Giordano Estevão, pela atenção e preocupação durante todos estes anos.

A minha segunda familia, seu Hélcio, apesar do pequeno convívio que tivemos, agradeço a preciosa oportunidade de tê-lo conhecido e recebido seu carinho. À Dna. Elizete, a sogra mais querida do mundo. Ao Lica e Rosali, pela preocupação, cuidado e carinho. Ao Fernando, Bruno, Guilherme e Gustavo, pelos bons momentos.

Finalmente gostaria de agradecer aos meus queridos, minha família, meu saudoso pai João (pá), por tudo que me ensinou, me proporcionou, e pelos maravilhosos anos em que esteve aqui, que esteja em paz. Minha mãe Mirna (mã/bunitas), minha irmă Yara (Tatinha), meu companheiro Hélcio (Bunitus) pela convivência, paciência, amor, enfim, por tudo. 
O grande incentivo para realização deste trabalho, foi a complexidade geológica que envolve os terrenos Pré-Cambrianos da porção sul-oriental do Estado de São Paulo, tendo como cidades limites principais, Mongaguá, Sete Barras, Pariquera-Açu, Iguape e Peruíbe.

Utilizando-se de diversas ferramentas como a petrologia, geologia estrutural, geoquímica, geocronologia e geologia isotópica, procurou-se melhor definir e caracterizar os terrenos que constituem a área de estudo, reconhecendo-se quatro importantes blocos tectônicos.

O quadro tectônico atual observado na região estudada, estabeleceu-se no final do Neoproterozóico, como resultado de colagens associadas à formação do Gondwana Ocidental.

O Bloco Embu, ocorre a norte da Zona de Cisalhamento Cubatão (ZCC), predominando, na área de estudo, rochas metassedimentares, localmente migmatíticas, e granitos peraluminosos intrusivos. Apresentam forte estruturação em torno de E-W, reflexo do Sistema de Cisalhamento Cubatão Itariri (SCCI). Os litotipos graníticos apresentaram idades de formação em torno de $600 \mathrm{Ma}$ (U-Pb - monazitas), interpretadas como, relacionadas à fase tardi-colisional do Cinturão Ribeira, responsável pelo desenvolvimento do SCCI.

O Bloco Mongaguá, é limitado a NW pela ZCC, a SW pela Zona de Cisalhamento Itariri $(\mathrm{ZCl})$ e a leste pelo Oceano Atlântico. Predominam rochas gnáissico-migmatíticas, envolvendo termos graníticos e dioríticos. As rochas graníticas deste domínio foram subdivididas em três grupos principais: Granito Tipo Itariri, Areado e Ribeirão do Oleo. Apresentam estruturação geral E-NE, com exceção das rochas gnáissicas de Itanhaém, com estruturação NW e mergulhos sub-horizontais. Os termos graníticos apresentaram heranças isotópicas com idades U-Pb (zircões) no intercepto inferior entre 580 e 640 Ma. Os valores próximos a $600 \mathrm{Ma}$, foram interpretados como relacionados à época de mistura de magmas (mingle / mix), possivelmente em processos distensionais. As análises isotópicas de $\mathrm{Nd}$ e $\mathrm{Sr}$ indicam que os precursores crustais destas rochas se diferenciaram do manto em épocas paleoproterozóicas distintas e tiveram origens a partir de fontes distintas com características de reservatórios crustais.

O Bloco Registro é limitado a norte pelo $\mathrm{SCCl}$ e a sul pela Zona de Cisalhamento Serrinha (ZCS). É composto por rochas graníticas com feições migmatiticas, que mostram diferentes graus de assimilação com material máfico diorítico, e rochas metassedimentares, representadas pelos paragnaisses do Maciço da Juréia. Apresenta 
estruturação NW, e E-NE, quando influenciadas pela cinemática do SCCl. As rochas granito-migmatíticas sugerem associação com processos distensionais, com formação de diques sin-plutônicos e enclaves, relacionados a mingling e mixing de materiais distintos, ocorrido possivelmente em épocas paleoproterozóicas (idades U-Pb zircőes entre 2.2 e $1.9 \mathrm{Ga}$ ). Adicionalmente, mostram-se intensamente afetadas pelo evento tectono-termal brasiliano, apresentando rochas gnáissicas com idades U-Pb (zircões) de $600 \mathrm{Ma}$, e idades intercepto inferior em torno de $580 \mathrm{Ma}$. As idades TDM obtidas concentram-se principalmente entre 2.7 e $2.9 \mathrm{Ga}$. As rochas gnáissicas do Maciço da Juréia apresentaram idade U-Pb em monazitas de $750 \mathrm{Ma}$, interpretada como importante evento térmico gerador de metamorfismo do fácies anfibolito. 0 Granito Votupoca, intrusivo nas rochas gnáissico-migmatíticas, correlacionado à Suíte Granítica Serra do Mar, apresentou idade de $582 \mathrm{Ma}$.

O SCCl, constitui-se por granitóides, e subordinadamente metassedimentos, miloníticos e protomiloníticos. Para facilidade de estudo, foram considerados domínios distintos, onde o ramo A-B apresenta direção preferencial em torno de E-W e o ramo $C$ em torno de N60E. As rochas afetadas pelo SCCI registraram, pelo menos, 2 fases importantes distintas de deformação. Uma fase está relacionada a uma movimentação sinistral com componente de abatimento para NW, com idade máxima de $600 \mathrm{Ma}$, e outra associada a movimentações sinistrais e dextrais com componente compressiva para SW. Reativações posteriores em condições mais rúpteis são observadas.

Os litotipos investigados do Bloco Iguape, limitado a norte pela ZCS e a S-SE pelo Oceano Atlântico, envolvem rochas graníticas e metassedimentares com estruturação principal NE. As rochas metassedimentares englobam principalmente metassedimentos de baixo grau metamórfico. As rochas graníticas foram subdivididas em três grupo principais. Granitos que ocorrem no Maciço de Iguape, normalmente protomiloníticos, com idades em torno de $600 \mathrm{Ma}$, com assinatura geoquímica sugestiva de granitos de arcos-vulcánicos ou sin-colisionais. Os granitos da Serra do Paratiú / Cordeiro e os Granitos da Serra de Itapitangui, apresentam características de rochas graníticas do tipo intra-placa e idades em torno de $580 \mathrm{Ma}$. Os três grupos graníticos apresentaram características geoquímicas e isotópicas distintas.

A ZCS, apresenta direção principal em torno de E-W, com movimentação dextral e afeta rochas graníticas e metassedimentares. Apresenta importante ramificação com direção SE, e movimentação sinistral.

Possivelmente, a justaposição entre estes blocos tectônicos ocorreu em épocas neoproterozóicas muito próximas. Neste trabalho sugere-se que a justaposição do Bloco Embu ao Bloco Registro, através de em zona de cisalhamento com direção 
aproximadamente E-W, deu-se em torno de $606 \mathrm{Ma}$. Granitos peraluminosos intrusivos no Bloco Embu, com cerca de $598 \mathrm{Ma}$, associados ao SCCl, podem estar relacionados à justaposição do Bloco Mongaguá, aos Blocos Registro e Embu. Esta justaposição se deu através de uma movimentação sinistral na ramificaçăo $B$ (direção $E-W$ ) e dextral na ramificação $\mathrm{C}$ (direção $\mathrm{NE}$ ) do $\mathrm{SCCl}$.

A associação do regime distensivo, interpretado como responsável pela geração as rochas gnáissico-migmatíticas do Bloco Mongaguá (612 $\pm \mathrm{Ma}$ ), à cinemática de justaposição do Bloco Mongaguá aos Blocos Embu e Registro (598 $\pm 8 \mathrm{Ma})$ ainda é incerta, podendo representar um regime anterior à justaposição dos blocos, ou mesmo um regime distensional associado a esta justaposição.

A época mais provável da justaposição do Bloco lguape ao Registro, entre 570 e $580 \mathrm{Ma}$ é sugerida através de dataçōes U-Pb em monazitas de protomilonito granítico da ZCS.

Datações K-Ar em biotitas em torno de $500 \mathrm{Ma}$, obtidas em rochas miloníticas do $\mathrm{SCCl}$ e da ZCS, são interpretadas como referentes à reativações posteriores ocorridas nestas zonas de cisalhamento. 


\section{ABSTRACT}

The main stimulus for the execution of this study was the geological complexity of the Precambrian terrains in the southeastern part of the State of São Paulo, between the cities of Mongaguá, Pariquera-Açu, Iguape and Peruíbe.

An attempt was made to define the main features of the terrains in this area, using petrology, structural geology, geochemistry, geochronology and isotope geology. Four major tectonic blocks were separated. The present tectonic situation in the studied area is the product of collages related to the formation of West Gondwanaland, which ended in the Neoproterozoic.

The Embu Block occurs north of the Cubatão shear zone (CSZ). In the studied area it is mainly composed of metasedimentary rocks, locally migmatized, and peraluminous granites. The structure is strongly $E-W$ oriented as a result of the action of the Cubatão - Itariri shear system (CISS). U-Pb (monazite) ages of the granites of about $600 \mathrm{Ma}$ are interpreted as reflecting the late collisional stage of the Ribeira Belt which was responsible for the formation of the CISS.

The NW limit of the Mongagua block is the CSZ, while the western limit is the Itariri shear zone (ISZ), and the eastern limit is the Atlantic Ocean. The main rock type is gneiss-migmatite with granitic and dioritic compositions. Three main groups of granite, the Itariri, Areado and Ribeirão do Óleo types, are encountered. The main structural direction in $\mathrm{E}$ to NE, with the exception of the Itanhaem gneisses which have a NW-SE structure and sub-horizontal dip. Analyses of zircon indicate crustal inheritance, and lower intercept U-Pb (zircon) ages fall between 580 and $640 \mathrm{Ma}$. Ages around 600Ma are believed to date a magma mixing/mingling event, which probably occurred during an extensional event. $\mathrm{Sr}$ and $\mathrm{Nd}$ isotopic compositions demonstrate that differentiation of the different crustal sources from the mantle occurred during different paleoproterozoic events.

The Registro Block, with the CISS as its northern limit and the Serrinha shear zone (SSZ) as its southern limit, is formed by granitic rocks with migmatitic aspect and showing different degrees of assimilation by dioritic material, and by the paragneisses of the Juréia massif. It has an NW-SE structure which swings to $E$ or NE under the influence of the CISS. The migmatitic granites present evidence for the action of extensional processes in the form of syn-plutonic dykes and enclave swarms. Mixing and mingling between the granitic and dioritic materials probably occurred between 2.2 and $1.9 \mathrm{Ga}$ as shown by U-Pb (zircon) ages. The rocks were intensely affected by the Brasiliano tectono-thermal event, as shown by the lower intercept U-Pb (zircon) ages of about 580Ma in gneisses which have model Nd $T_{D M}$ ages concentrated in the $2.7-2.9$ 
$\mathrm{Ga}$ interval. Gneiss from the Juréia massif has a U-Pb (monazite) age of $750 \mathrm{Ma}$, believed to register the thermal event responsible for amphibolite-grade metamorphism. The Votupoca granite, a member of the Serra do Mar suite intruded into the gneissmigmatites, has an age of $582 \pm 8 \mathrm{Ma}$.

The CISS cuts granitoids and subordinate metasediments, which are now protomylonites or mylonites. To simplify the study, the systems was divided into two different domains, in which the structure of the A-B domain is mainly E-W, while the structural direction of the $\mathrm{C}$ domain is $\mathrm{N} 60^{\circ} \mathrm{E}$. At least two major deformation events affected the rocks. One of the phases, younger than 600Ma, was sinistral with northwestwards dip-slip. The other phase with southwestward compression involved both sinistral and dextral movements. Later reactivations under more brittle conditions also occurred.

Rocks of the Iguape Block, limited northwards by the SSZ and southsoutheastwards by the Atlantic Ocean, include granites and metasediments with a dominantly NE structural orientation. The metasediments are mostly in low metamorphic grade, while the granites comprise three separate geochronological and geochemical groups. Protomylonitic granites of the Iguape massif have ages around $600 \mathrm{Ma}$, and have geochemical signatures of volcanic arc or syncollision granites. The granites of the Paratiú - Cordeiro and Itapitangui hills are $580 \mathrm{Ma}$ intraplate granites. The SSZ has a dominantly E-W direction and dextral sense, but an important SE-oriented branch is sinistral.

It is probable that the tectonic blocks were united during a short time interval in the Neoproterozoic. Here we suggest that the joining of the Embu Block to the Registro Block occurred at about $606 \mathrm{Ma}$ along an E-W shear zone. The 598Ma peraluminous granites intruded into the Embu Block may register the arrival of the Mongagua Block against the newly formed Registro-Embu domain. This welding occurred along the sinistral, E-W oriented branch (B) and the NE-oriented dextral movement along branch C of the Ciss.

It is still uncertain whether there is an association between the tensional regime responsible for the formation of the gneiss-migmatites of the Mongagua Block at about $612 \pm 3 \mathrm{Ma}$, and the cinematic situation created by the union of the Mongaguá and EmbuRegistro blocks at $598 \pm 8 \mathrm{Ma}$.

The welding of the Iguape and Registro blocks probably occurred between 580 and $570 \mathrm{Ma}$, as suggested by the U-Pb (monazite) age of the protomylonitic granites of the SSZ. Later reactivations of the CISS and SSZ at about 500Ma are suggested by K-Ar ages of biotites. 


\section{INTRODUÇÃO}

\subsection{APRESENTAÇÃO}

A região sul-oriental do Estado de São Paulo, é constituída por diferentes compartimentos tectônicos que englobam distintos litotipos, afetados por importantes zonas de cisalhamento, cuja compreensão é fundamental ao quadro geotectônico regional. Tais fatos, aliados ao quadro geocronológico precário, despertou grande interesse científico no desenvolvimento deste trabalho.

A escolha da área é consequência da sua grande complexidade geológica, bem como de sua importância dentro do contexto geotectônico mais amplo. Com intuito de facilitar os estudos, a região de interesse foi compartimentada em quatro grandes Blocos. Tratam-se de domínios que apresentam características litológicas, metamórficas, estruturais e geocronológicas distintas, limitados por importantes zonas de cisalhamento. Essa subdivisão possibilitou o estudo individualizado desses domínios e uma comparação mais precisa entre esses compartimentos, permitindo melhor caracterizá-los dentro do quadro tectônico regional.

As dificuldades encontradas na região em questão, referem-se principalmente à grande cobertura dos sedimentos Terciários e Quaternários e, áreas Pré-Cambrianas aflorantes muito intemperizadas, ou de difícil acesso. Este normalmente associado a regiões de relevo acidentado ou mesmo áreas de preservação.

Ressalta-se que este trabalho não teve como enfoque o mapeamento geológico da área de interesse, e sim uma melhor caracterização, notadamente estrutural e geocronológica, dos principais blocos tectônicos delimitados, bem como sua importância dentro do quadro tectônico regional.

\subsection{Localização E VIAS de ACEsso}

A área de estudo situa-se na região sul-sudeste do Estado de São Paulo, abrangendo os municípios litorâneos de Mongaguá, Itanhaém, Peruíbe e lguape, e os municípios de Itariri, Pedro de Toledo, Miracatu, Juquiá, Sete Barras, Registro e Pariquera-Açu (Figura 1.1). Está inserida na porção centro-sul da Folha Topográfica Iguape - SP (SG-23-V-A), editada pelo Instituto de Geografia e Estatística (IBGE) em 
1979, na escala de 1:250.000. A área delimitada para este trabalho, cujos limites geográficos principais são os meridianos $48^{\circ} 00^{\prime}$ e $46^{\circ} 37^{\prime}$ oeste e os paralelos $24^{\circ} 00^{\prime}$ e $24^{\circ} 05^{\prime}$ sul, possui aproximadamente $5.900 \mathrm{~km}^{2}$.

Partindo-se da cidade de São Paulo, as principais vias de acesso à área, são as Rodovias: Federal BR-116 (Regis Bittencourt) e as estaduais SP-160 (Rodovia dos Imigrantes) ou SP-150 (Via Anchieta), SP 055 (Rodovia Pedro Taques). De Peruíbe a Pedro Barros, SP-165, de Pariquera-Açu - Iguape - Miracatu SP-222. Rodovias não pavimentadas, em boas condições (fora de épocas de chuvas): SP-193 (JacupirangaItapitangui), SP-139 (Registro-Sete Barras). As demais estradas vicinais não pavimentadas, são de acesso razoável a difícil, e unem municípios ou vilarejos a fazendas ou sítios.

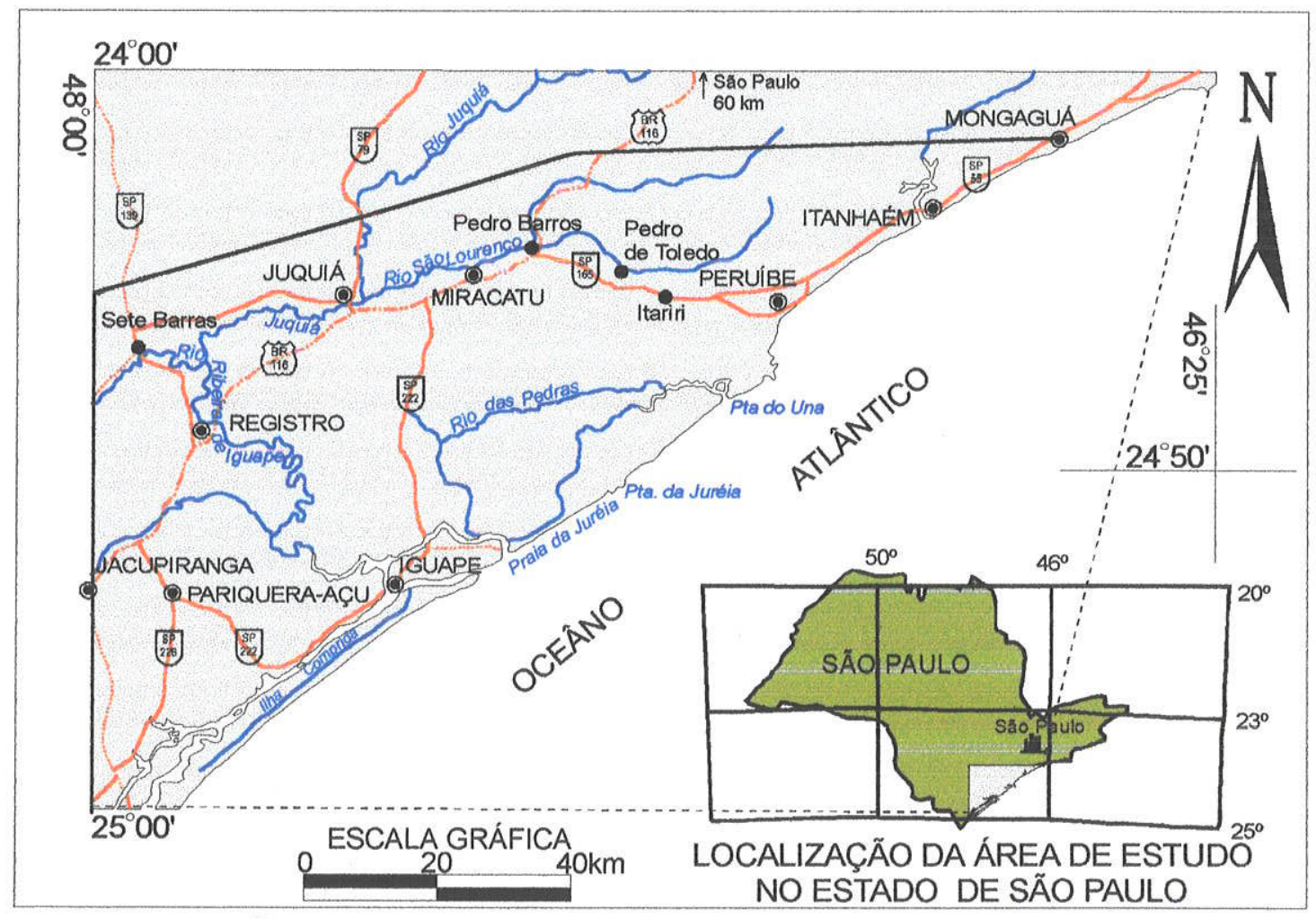

Figura 1.1 - Localização da área e principais vias de acesso. 


\subsection{OBjetivos}

A principal proposição deste trabalho foi a de se efetuar um estudo geológico da porção sul-oriental paulista posicionando-a dentro do quadro geotectônico da região sul-sudeste brasileira.

As metas deste trabalho estiveram centradas na caracterização dos principais compartimentos tectônicos da porção sul-oriental do Estado de São Paulo, na delimitação das zonas de cisalhamento, e no estabelecimento de um quadro cinemático geral dos principais Blocos tectônicos. Para tal, procurou-se caracterizar, litológica, geocronológica, geoquímica e estruturalmente as rochas de cada bloco e, a partir dessas informações, estabelecer:

1) a relação entre os episódios de deformação e metamorfismo (idade e superposição de eventos) para cada bloco tectônico;

2) caracterização da cronologia relativa e absoluta das rochas igneas e ortoderivadas;

3) caracterização do padrão estrutural dos blocos tectônicos;

4) estabelecimento da história metamórfico - deformacional das principais zonas de cisalhamento delimitadoras dos blocos tectônicos;

5) proposição de um modelo para a justaposição dos blocos tectônicos caracterizados. 


\section{METODOLOGIA}

\subsection{INTRODUÇÃO}

Devido a complexidade geológica da região de interesse, os estudos foram divididos e concentrados em quatro Blocos tectônicos principais, que encontram-se representados na Figura 4.2. Essa subdivisão possibilitou, maior facilidade no estudo de cada domínio, a comparação e relação entre os diferentes compartimentos, bem como a importância dos mesmos dentro do quadro tectônico regional.

Foram realizados perfis geológico-estruturais, sempre que possiveis, normais às estruturas regionais, com a finalidade maior de se conhecer as relaçöes entre as diferentes unidades geológicas reconhecidas. Os estudos de campo compreenderam o reconhecimento litológico da rocha presente, sua caracterização estrutural, bem como, seu enquadramento dentro das unidades maiores. Ressalta-se novamente, que o presente trabalho não teve como enfoque o mapeamento geológico da área de interesse, e sim uma melhor caracterização geológica dos principais terrenos delimitados.

Em cada afloramento estudado, além da descrição litológica, foram tomadas medidas estruturais, coletadas amostras para análises petrográficas, lito-geoquímicas e geocronológicas, bem como de amostras orientadas visando, estudos de microtectônica para caracterização dos esforços principais que atuaram na região.

Inicialmente foram realizadas análises petrográficas, com a finalidade da caracterização mineralógica e metamórfica dos litotipos amostrados, fundamentais para a seleção de amostras para estudos lito-geoquímicos e geocronológicos.

As análises geocronológicas constituíram uma ferramenta importante no estudo pretendido. A utilização preferencial da metodologia U-Pb (zircões e monazitas) permitiu, com precisão, a definição das principais épocas de colocação dos corpos ígneos. Essa informação foi complementada com análises K-Ar em minerais, com informações sobre as épocas de metamorfismo e resfriamento regional. Adicionalmente, foram efetuadas análises pelos métodos $\mathrm{Sm}-\mathrm{Nd}$, e $\mathrm{Sr}-\mathrm{Sr}$, em rocha total com intuito de se caracterizar épocas de diferenciação do manto dos protólitos crustais das rochas estudadas e consequentemente adquirir informações relativas ao tempo de residência crustal. 


\subsection{LeVANTAMENTO BiBLIOGRÁFICO}

Este trabalho foi iniciado a partir do levantamento bibliográfico, com a integração da geologia local e regional; e compilação dos mapas geológicos existentes da região. Para esta etapa utilizou-se:

-Bibliografia pertinente a geologia regional e local da área de estudo;

-Folhas Topográficas na escala 1:50:000: Rio São Lourencinho, Pedro Barros, Foz do Açungui, São José, Pedro de Toledo, Miracatu, Juquiá, Registro, Ponta da Juréia, Barra do Ribeira, Iguape, e Pariquera-Açu, editadas pelo IBGE (1973);

-Folhas Topográficas na escala 1:50:000: Mongaguá e Itanhaém, editadas pelo IGGSP (1972);

-Mapa Topográfico, escala 1:250.000: Folha Iguape, editada pelo IBGE (1979);

-Mapas Geológicos em escala 1: 50.000 (Morgental et al., 1975; Battola Jr, et al., 1981; Dantas et al., 1987); em escala 1: 500.000 (Hasui et al., 1981); 1:1.000.000 (Silva, 1981).

\subsection{TRABALHOS DE CAMPO}

Foram realizadas 3 principais etapas de campo, e estudos adicionais em afloramentos considerados 'chave', que totalizaram o estudo de 104 afloramentos. $O$ reconhecimento litológico e estrutural envolveu os seguintes perfis:

-ao longo da Zona de Cisalhamento Itariri (ZCl) e Zona de Cisalhamento Cubatão (ZCC): coleta de amostras orientadas e de amostras para datação K-Ar;

-Registro - região de Sete Barras: coleta de amostras orientadas e de amostras para análises geoquímica e geocronológica ( $\mathrm{Sm}-\mathrm{Nd}$, U-Pb e K-Ar);

-BR-116 - SP-165 (próximo a Juquiá): coleta de amostras orientadas e de amostras para análises geoquímica e geocronológica ( $\mathrm{Sm}-\mathrm{Nd}$, U-Pb e K-Ar);

-BR-116 a norte de Pedro Barros: coleta de amostras orientadas;

-proximidades de Pariquera-Açu, abrangendo as localidades de Vapamirim, Serra de Pariquera-Mirim, Serra do Cordeiro, Serra do Paratiú e Itapitangui: coleta de amostras orientadas e de amostras para análises geoquímica e geocronológica ( $\mathrm{Sm}-\mathrm{Nd}$, $U-\mathrm{Pb}$ e K-Ar); 
-Miracatu - Iguape: coleta de amostras orientadas e de amostras para análises geoquímica e geocronológica ( $\mathrm{Sm}-\mathrm{Nd}$, U-Pb e K-Ar).

Após os trabalhos de campo foi elaborado mapa de afloramentos.

\section{COLETA DE AMOSTRAS}

A coleta de amostras foi realizada segundo alguns critérios considerados fundamentais aos estudos pretendidos, com dimensões adequadas para representar o sistema rocha-total, evitando-se, sempre que possivel, rochas intemperizadas.

Foram coletadas amostras orientadas em 41 afloramentos, preferencialmente, com foliação milonítica e lineação de estiramento mineral bem evidenciadas, com o seguinte procedimento:

1) Anotação do plano orientado, marcando-se a horizontal do plano na amostra com uma seta indicativa de que a leitura foi feita na ponta norte. Faz-se a anotação na amostra coletada se o plano orientado é positivo ou negativo (normal ou invertido). De preferência orienta-se um plano normal para maior facilidade de manuseio posterior.

2) Confecção de 93 seções delgadas para posteriores análises estruturais, realização de cortes $\mathrm{XZ}$ (normal à $\mathrm{Sm}$ e paralelo à $\mathrm{Lm}$ ) e $\mathrm{YZ}$ (normal à $\mathrm{Sm}$ e normal à $\mathrm{Lm}$ ). Realizados os cortes determina-se a orientação destes. Marca-se a direção dos cortes do mesmo modo com que se marcou o plano orientado no campo. Como último passo desta etapa, a certificação de que as seções delgadas foram realizadas nos cortes na posição normal.

Quanto à utilização das seções delgadas orientadas para estudos de eixos-c de quartzo, são utilizados os cortes $X Z$ não importando a direção do corte, apenas se 0 corte é normal (positivo). Já para a aplicação do Método de Fry, são utilizados os cortes $X Z$ e $Y Z$, importando também a direção dos cortes, pois a partir desta direção determinam-se as direções dos eixos do elipsóide de deformação.

\subsection{ANÁLISES PETrográficas}

Analisaram-se seções delgadas de granitóides isótropos e de rochas miloníticas, em um total de 129 seções delgadas, sendo 93 cortes orientados XZ (normais à foliação 
milonítica $\mathrm{Sm}$ e paralelos à lineação de estiramento $\mathrm{Lm}$ ) e $\mathrm{YZ}$ (normais à foliação milonítica Sm e normais à lineação de estiramento mineral).

A microscopia ótica de amostras não orientadas possibilitou a caracterização petrográfica dos diferentes tipos de granitóides, propiciando, nas rochas miloníticas, o estabelecimento do metamorfismo que atuou na zona de cisalhamento. Nas amostras orientadas, a microscopia ótica permitiu a caracterização estrutural da superfície principal das rochas miloníticas e também a caracterização cinemática das principais zonas de cisalhamento, através da análise dos indicadores cinemáticos.

\subsection{ANÁLISES EstRUTURAIS MiCROSCÓPICAS}

A microscopia ótica de amostras orientadas permitiu a caracterização petrográfica e estrutural da foliação milonítica, caracterização cinemática através da análise de indicadores cinemáticos; determinação dos centros de porfiroclastos para posicionamento do elipsóide de deformação através do método de Fry.

As seções delgadas foram realizadas em cortes $X Z$ (normais à foliação milonítica $\mathrm{Sm}$ e paralelos à lineação de estiramento $\mathrm{Lm}$ ) e $\mathrm{YZ}$ (normais à foliação milonítica $\mathrm{Sm}$ e normais à lineação de estiramento mineral).

Os softwares utilizados incluíram: Stereonet (for windows, versão 2.06, $1992-$ 1993, Un. of Western Ontario e versão $2.40,1999)$ para confecção de diagramas em geral e GeoFry Plots 3.0 (1999).

\section{ANÁLISE DA DEFORMAÇÃO}

Um dos métodos utilizados para análise da deformação é o método centro a centro (Ramsay \& Huber, 1983), que envolve a determinação dos centros de partículas que foram originalmente, os vizinhos estatisticamente mais próximos, definindo-se linhas entre estes centros $e$ analisando as mudanças no comprimento das mesmas. Este método é utilizado em rochas que contém oólitos ou clastos.

Entretanto, não se pode determinar a deformação somente através da forma do objeto pois, a relação entre esta forma depois da deformação é uma função complexa da interação entre a forma original, diferença de competência entre o objeto $e$ a matriz $e$ a influência dos objetos vizinhos. 
Quando isto ocorre, não se pode tirar medidas das formas dos mais e menos competentes para chegar na deformação total da rocha. Então este método permite que a deformação total da rocha seja calculada através da redistribuição dos pontos na rocha deformada $e$, das distâncias entre estes pontos como elementos lineares estendidos.

Se a rocha original possui uma distribuição inicial dos pontos totalmente randômico, é impossível usar a distribuição dos pontos para calcular a deformação, pois a distribuição resultante, após a deformação, permanece randômica. Entretanto, em muitas situações geológicas a distribuição dos pontos não é randômica de modo geral. Os pontos são dispersos, mas distribuídos de modo que as distâncias entre eles são mais ou menos constantes, denominada por Ramsay \& Huber (1983) de distribuição estatisticamente uniforme. Neste caso, não observam-se grandes concentrações e vazios como em uma distribuição verdadeiramente randômica.

Esta distribuição geralmente ocorre porque os objetos têm um tamanho inicial característico e isto significa que as separações centro a centro dos vizinhos próximos é controlada pela geometria intrínseca do pacote. Este agregado de pontos com esta distribuição, tem propriedades geométricas especiais quando deformados: há uma maior separação dos pontos paralela ao eixo maior da elipse de deformação $(X)$ e uma aproximação máxima das distâncias paralela ao eixo menor da elipse de deformação (Z). As distâncias entre os pontos na rocha deformada é uma função da elongação na direção da junção dos pontos.

O Método de Fry (Fry, 1979, 1999) permite uma solução gráfica, de modo prático e acurado, sendo uma das vantagens em relação ao método anterior. O princípio do método baseia-se em que o agregado a ser estudado possua partículas de tamanhos estatisticamente uniformes, produzindo uma série de centros de vizinhos. Se as partículas têm raios idênticos, e o empacotamento é perfeito, esta repetição zonal das distâncias dos centros a partir de qualquer centro, mostrarão variações periódicas regulares. Entretanto, em agregados naturais, a regularidade diminui com a distância a partir de qualquer ponto escolhido. Com uma deformação superimposta, as distâncias entre os centros das partículas modificam-se proporcionalmente ao valor da deformação longitudinal, ao longo desta direção, que é proporcional aos diâmetros da elipse de 
deformação. Como os valores das distâncias periódicas são sistematicamente modificados de acordo com a forma da elipse, esta geometria pode ser utilizada para estabelecer a forma e orientação desta elipse.

O uso do método de Fry em isolado não é aconselhado, pois uma de suas premissas baseia-se no fato de que o centro de cada cristal sempre permanece como o centro, mesmo a rocha sofrendo deformação posterior, premissa esta, nem sempre respeitada. Conforme Dunne et al. (1990) o cálculo da deformação finita pelo Método de Fry é subestimada quando os centros finais dos marcadores não coincide com os centros originais, ou seja, a amostra é deformada heterogeneamente na escala dos marcadores a serem utilizados. Algumas características envolvem a migração dos centros, como: grãos originalmente circulares, mecanismo de deformação heterogênea por dissolução transgranular, deformação acomodada inteiramente por perda de volume ou recristalização localizada.

Assim sendo, é recomendada a utilização dessa metodologia em conjunto com outras informações, sendo utilizado neste trabalho, para a determinação qualitativa da orientação espacial dos esforços principais das zonas de cisalhamento estudadas, bem como para determinação da forma do elipsóide de deformação em Diagrama de Flinn.

Utilizaram-se os cortes $X Z$ e $Y Z$ de rochas miloníticas e protomiloníticas graníticas orientadas. Com os cortes prontos, porfiroclastos (normalmente de feldspatos) foram desenhados em câmara-clara. Estes desenhos foram feitos em lupa ou microscópio, dependendo da granulometria da amostra. A partir dos desenhos plotam-se os centros dos porfiroclastos em papel, que são posteriormente digitalizados, para cálculo através do software Geofry Plots 3.0 (1999). Parte das amostras foram trabalhadas manualmente, utilizando-se o procedimento apresentado por Ramsay \& Huber (1983), para confirmação do método utilizado por software.

Simplificadamente, as distribuições que resultam dos Diagramas de Fry, caracterizam-se por vazios (elípticos, se a rocha estiver deformada) circundados por faixas com alta densidade de pontos. É importante salientar que, se $\circ \mathrm{n}^{\circ}$ de pontos adjacentes ao vazio é pequeno, a probabilidade de erro é alta (Crespi, 1986). 
A partir dos diagramas obtidos em seções previamente orientadas, determinamse as direções dos eixos principais dos elipsóides de deformação, bem como os valores de suas elipsidades ( $R x z, R y z)$.

O Diagrama de Flinn (Ryz x Rxy), Flinn (1962), permite a determinação do elipsóide gerado na deformação e sua utilização pode ser de grande utilidade na caracterização do padrão de deformação. $O$ parâmetro $K$ define a posição geral da plotagem do elipsóide: $K=(R x y-1 / R y z-1)$. Elipsóides com valores $0<K<1$, são oblatos e posicionam-se no campo do achatamento aparente; com valores de $K=0$, posicionam-se no campo do achatamento uniaxial e valores $1<K<\infty$ estão relacionados a elipsóides prolatos, do campo da constriç̧ão aparente. $O$ parâmetro $D$ relaciona-se à distância do ponto à origem: $D=\left\{(R x y-1)^{2}+(R y z-1)^{2}\right\}^{1 / 2}$, e pode estar diretamente relacionado à taxa de deformação.

\subsection{ANÁLISES LITO-GEOQUIMICAS}

Foram realizadas análises de elementos maiores, traços e terras raras em rocha total, em 30 amostras. Estas análises foram realizadas em laboratório no Canadá (Activation Laboratories Ltd) e no Laboratório de Geoquímica do IGc-USP. Os resultados obtidos encontram-se no Apêndice 1. O preparo do material procedeu-se como segue:

-seleção de amostras, sempre que possível isentas de alteração intempérica, com análise petrográfica prévia;

-seleção de amostras de perfis representativos, incluindo amostras representativas de todos os blocos definidos;

-quebra manual e posterior britagem em britador de mandíbulas;

-quarteamento e moagem.

Para a confecção de gráficos e diagramas, utilizou-se o programa Minpet versão 2.02. No presente estudo, foram analisadas amostras de rochas frescas (verificadas em seções delgadas), assumindo-se, como premissa para o tratamento dos dados geoquímicos, que as variações observadas nos teores dos elementos se referem à composição original da rocha, ou então, às modificações introduzidas associadas aos processos de cisalhamento. 


\subsection{ANÁLISES GEOCRONOLÓGICAS}

Foram realizados estudos isotópicos em minerais e rocha total, envolvendo os métodos $\mathrm{K}-\mathrm{Ar}$, $\mathrm{Rb}-\mathrm{Sr}$, U-Pb (zircão e monazita) e $\mathrm{Sm}-\mathrm{Nd}$, função dos valores interpretativos dos mesmos, conforme descrito sucintamente a seguir.

- Método K-Ar; (biotita, muscovita): obtenção dos padröes de resfriamento das rochas analisadas, e, em biotitas e muscovitas neoformadas de rochas miloníticas, para obter-se a idade de movimentação da zona de cisalhamento, neste caso, as idades de resfriamento destas rochas.

- Método Rb-Sr: (rocha total): obtenção das razões isotópicas de $\mathrm{Sr}$, não sendo calculadas as idades isocrônicas. A relação inicial $\left(\mathrm{Sr}^{87} / \mathrm{Sr}^{86}\right)_{i}$ isocrônica, pode ser utilizada como traçador petrogenético, diferenciando fontes de crosta superior, de fontes mantélicas / crosta inferior.

- Método Sm-Nd (rocha total): obtenção das razões isotópicas de $\mathrm{Nd}$ como importante parâmetro petrogenético, $\varepsilon N d$, que permite a caracterização quanto a residência crustal dessas rochas, e cálculo de idades modelo, interpretadas como da época em que os precursores crustais (protólitos) se diferenciaram do manto superior.

- Método U-Pb (zircão e monazita). Utilizado em rochas representativas dos blocos estudados, fornecendo a época de cristalização destes minerais $e_{1}$ consequentemente, a idade de formação desses corpos ígneos.

As constantes radiométricas utilizadas encontram-se no Apêndice 2.

\subsection{1 - Preparação das amostras}

E aqui apresentada a rotina utilizada nos laboratórios do CPGeo para a preparação das amostras relativas às metodologias que envolvem rocha total e minerais (zircão, monazita, biotita e muscovita):

\subsection{1a- Métodos isotópicos em Rocha Total}

Ressalta-se que a utilização dos métodos $\mathrm{Sm}-\mathrm{Nd}$, e $\mathrm{Rb}-\mathrm{Sr}$ em rocha total não envolveu a caracterização das idades isocrônicas, mas sim a obtenção das razões 
isotópicas de $\mathrm{Nd}$ e $\mathrm{Sr}$. Os teores de Rb utilizados nos cálculos das razões isotópicas foram obtidos das análises químicas realizadas.

Realiza-se a quebra manual das amostras, em pedaços com cerca de $5 \mathrm{~cm}$ para sua utilização no britador de mandíbulas, onde os fragmentos são reduzidos a dimensões inferiores a $0,3 \mathrm{~mm}$. Após quarteação, a fração escolhida é pulverizada a uma granulometria inferior a 200 mesh $(0,074 \mathrm{~mm})$ em moinho de ágata.

\section{Metodologia Nd-Nd e Sr-Sr}

A dissolução total da amostra é realizada em "savilex" utilizando-se de $\mathrm{HNO}_{3}$ e $\mathrm{HF}$, seguida da utilização de $\mathrm{HCl} 6.2 \mathrm{~N}$ e $2.5 \mathrm{~N}$ em diferentes etapas para eliminação de resíduos, a solução final é então encaminhada para as colunas de troca iônica.

A separação dos elementos é feita em duas etapas, sendo a primeira realizada em coluna com resina catiônica do tipo AG 50WX8 (200-400 mesh) com a utilização de $\mathrm{H}_{2} \mathrm{O}$ e HCl em diferentes normalidades para separação dos ETR dos demais elementos químicos. Nesta etapa, num primeiro estágio, coleta-se o $\mathrm{Sr} c o m \mathrm{HCl} 2.5 \mathrm{~N}$ e após a secagem o resíduo é levado para o espectrômetro de massa. Os ETR (no caso Sm e $\mathrm{Nd}$ ), são coletados no seguinte estágio com $\mathrm{HCl} 6.2 \mathrm{~N}$ que após a secagem o resíduo é levado para a coluna de pó de teflon. Nessa segunda etapa são separados o $\mathrm{Nd}$ e o Sm com HCl em concentrações de $0.26 \mathrm{~N}$ e $0.55 \mathrm{~N}$. Coleta-se o $\mathrm{Nd}$ utilizando $\mathrm{HCl} 0.26 \mathrm{~N}$ e o $\mathrm{Sm}$ com $\mathrm{HCl} 0.55 \mathrm{~N}$. Os resíduos contendo $\mathrm{Nd}$, após secagem da solução, e os resíduos contendo $\mathrm{Sm}$ são levados para o espectrômetro de massa. As razões isotópicas foram medidas com espectrômetro de massa VG-354 e Finnigan MAT 262.

\subsection{1b - Métodos isotopicos em minerais}

As metodologias utilizadas em minerais foram $\mathrm{U}-\mathrm{Pb}$, em zircões e monazitas e $\mathrm{K}$ Ar em biotitas e muscovitas.

O procedimento inicial de preparação das amostras para ambos os métodos é semelhante, sendo descrito a seguir.

São coletadas cerca de $20 \mathrm{~kg}$ de amostra que, após fragmentação em britador de mandíbulas, é reduzida e moída em moinho de disco. Este material é submetido a uma bateria de peneiras, que cobrem o intervalo de 60, 100 e 250 mesh, para a obtenção da 
amostra no intervalo granulométrico desejado, definido de acordo com a granulometria original e quantidade existente de agregados nos minerais a serem separados.

Para posterior separação de biotitas e muscovitas, foram utilizados tanto os concentrados da fração 60-100 mesh como da fração 100-250 mesh. Para obtenção dos zircões e monazitas foram utilizados os concentrados das frações entre 100-250 mesh.

As frações escolhidas são passadas em mesa vibratória, para separação dos minerais pesados (zircão, monazita, titanita, granada, epídoto, magnetita, alanita, apatita, anfibólio entre outros) concentrados principalmente na caneca 1 e subordinadamente na caneca 2 , eventualmente havendo a necessidade de reciclagem da caneca 2, dos minerais mais leves com densidade em torno de 2,6 (quartzo e feldspatos), mais concentrados nas canecas 2 e 3 . Embora biotitas e muscovitas possuam densidade entre 2,7 a 3,2, o hábito placóide destes minerais permite que eles se concentrem junto com os leves principalmente nas canecas 4 e 5 . Após a secagem dos concentrados, passa-se ímã de mão para retirada dos minerais mais magnéticos (magnetita).

A partir dessa última etapa as técnicas de separação dos minerais para as duas metodologias geocronológicas seguem rumos diferentes.

\section{Método U-Pb em zircões e monazitas}

A porção rica em minerais pesados (caneca 1) é tratada primeiramente com o líquido denso Bromofórmio $\left(\mathrm{d}=2,89 \mathrm{~g} / \mathrm{cm}^{3}\right.$ ), e o concentrado 'pesado', é passado no separador magnético 'Frantz', a $20 \times 10 \times 0.4 \mathrm{~A}$. Se houver grande quantidade de minerais máficos na amostra, primeiramente a amostra é passada no separador Frantz e posteriormente no Bromofórmio.

Para separação de monazitas a fração não magnética (NM 0.4) é tratada no lodeto de Metileno ( $d=3,2 \mathrm{~g} / \mathrm{cm}^{3}$ ), e por sua vez, o concentrado pesado é passado no separador 'Frantz'. Na separação realizada foram obtidas boas frações magnéticas com monazitas em $0.5,0.6$ e $0.7 \mathrm{~A}$. A purificação final das frações é realizada por catação manual sob lupa binocular. 
A pesagem das monazitas, de 1 a 4 cristais, é realizada através do cálculo do volume e posterior cálculo do peso. Após a pesagem, as monazitas são lavadas com água Mili-Q, para posterior ataque químico.

Na separação dos zircões, a fração não magnética (NM 0.4) é tratada no lodeto de Metileno ( $\left.d=3,2 \mathrm{~g} / \mathrm{cm}^{3}\right)$, e por sua vez, o concentrado pesado é passado novamente no separador 'Frantz' a 1.0 e $1.5 \mathrm{~A}$. Normalmente, é realizada lavagem com ácido nítrico $\left(\mathrm{HNO}_{3}\right)$, principalmente para eliminação de sulfetos. Após a lavagem, a fração NM 1.5 A, é passada novamente no separador 'Frantz' para realização do 'Split' de modo que se obtenha, no final, várias frações magnéticas (M6, M5,..,M-4,...) ricas em zircões.

A purificação final de cada uma das frações (preferencialmente as menos magnéticas) é realizada por catação manual sob lupa binocular. Nesta etapa, pode ser realizada a abrasão de pequena quantidade de zircões com igual quantidade de piritas, por aproximadamente 1 hora. Em seguida, a fração é lavada com $\mathrm{HNO}_{3}(50 \%)$ a quente para retirada de piritas e posteriormente com água (mili-Q), no ultrassom.

Após a pesagem dos zircões, normalmente determinada através da relação volume/densidade, realiza-se a lavagem com $\mathrm{HNO}_{3}(50 \%)$ para limpeza de eventual material orgânico, e posterior condicionamento em $\mathrm{HNO}_{3}$ (concentrado).

$\mathrm{O}$ ataque químico é realizado com Ácido Fluorídrico (HF) e $\mathrm{HNO}_{3}$ (gota já contendo os zircões) em micro-bombas de Teflon (envoltas em um Kit de aço), devidamente 'spikadas', (spike utilizado $\mathrm{Pb}^{205}, 7 \mu l$ ) em estufa a $200^{\circ} \mathrm{C}$, por três dias. Posteriormente evapora-se o $\mathrm{HF}$ e adiciona-se $\mathrm{HCl}(6 \mathrm{~N})$ dentro das micro-bombas, ficando em estufa por 24 horas. No caso das monazitas, o ataque químico foi realizado em savilex com $\mathrm{H}_{2} \mathrm{SO}_{4 \text { (conc.), }} \mathrm{HCl}$ e $\mathrm{HNO}_{3}$, sendo colocado em chapa aquecedora a temperatura em torno de $100^{\circ} \mathrm{C}$ por 3 dias. Posteriormente evapora-se $\circ \mathrm{HCl}$ e $\mathrm{HNO}_{3}$, restando apenas a microgota de $\mathrm{H}_{2} \mathrm{SO}_{4}$, e adiciona-se $\mathrm{HCl}(6 \mathrm{~N}) . \mathrm{O}$ tratamento químico posterior é o mesmo utilizado para os zircões.

Após a evaporação, coloca-se $\mathrm{HCl}(3 \mathrm{~N})$ nas micro-bombas (ou savilex). Primeiramente a coluna para separação do $\mathrm{U}$ e $\mathrm{Pb}$ é lavada, e posteriormente coleta-se - U e Pb de cada amostra. A amostra é depositada em filamento para posterior leitura no espectrômetro de massa, que fornece as medidas das razões isotópicas. 
Os resultados são tratados em programa PbDAT e ISOPLOT, para confecção dos diagramas.

\section{Método K-Ar em micas}

Normalmente para concentração de biotitas e muscovitas utilizam-se as canecas 4 e 5 obtidas após passagem da amostra pela mesa vibratória. Realiza-se uma primeira etapa de separação magnética no aparelho Frantz a $20 \times 10 \times 0,4 \mathrm{~A}$ para uma separação grosseira dos minerais não magnéticos (muscovitas, quartzo e feldspatos, etc) dos magnéticos (biotitas, anfibólios, etc). Como a biotita e muscovita são placóides, a separação entre estes minerais é realizada no Frantz com alterações na inclinação e amperagem, pois a muscovita é menos magnética que a biotita. Quando uma máxima purificação é conseguida através do Frantz, a biotita e a muscovita, já separadas em fraçöes distintas, são separadas dos demais minerais, normalmente quartzo, feldspatos, e anfibólios através do bateiamento em papel. Este procedimento permite uma concentração gradativa dos minerais placóides que tendem a ficar retidos no papel, sendo que os minerais prismáticos rolam devido a vibração. Nesta etapa também podese utilizar a separação manual.

A separação pelo líquido pesado Bromofórmio $\left(\mathrm{d}=2,89 \mathrm{~g} / \mathrm{cm}^{3}\right)$ pode ser utilizada como complementação dos procedimentos anteriores. Os minerais menos densos (quartzo e feldspato) permanecem em suspensão no líquido, enquanto que os de maior densidade tendem a decantar.

Como a biotita e o anfibólio podem ter susceptibilidade magnética muito similar, a separação fina, após as possíveis alteraçōes na inclinação e amperagem no Frantz, é realizada através do bateiamento em papel, onde as biotitas tendem a ficar retidas, e os anfibólios (prismáticos) rolam devido a vibração. 


\section{EVOLUÇÃO DOS CONHECIMENTOS}

Durante os últimos anos inúmeros pesquisadores se dedicaram ao estudo geológico - geotectônico da porção sul-oriental brasileira, envolvendo terrenos da região sul-sudeste de São Paulo e os domínios costeiros do Paraná, Santa Catarina, e Rio Grande do Sul. Grande parte dos trabalhos existentes abrangem áreas especificas, sem contudo correlacioná-las a uma evolução geotectônica comum.

Neste capítulo, será apresentada uma revisão dos principais trabalhos elaborados sobre a região de interesse, com objetivo de situar o leitor no contexto geológico no qual está inserida a área estudada. Devido a proliferação de nomenclaturas atribuídas ao Pré-Cambriano do SE do Estado de São Paulo, procurarse-á posicionar os terrenos estudados no presente trabalho nas principais referéncias apresentadas.

A região sul-sudeste do Estado de São Paulo, tem sido alvo de estudos desde o início do século $\mathrm{XX}$, com trabalhos de mapeamento em escalas pequenas e trabalhos específicos acerca de ocorrências minerais e rochas alcalinas próximas ao Rio Ribeira de Iguape. O primeiro mapa geológico, que inclui a área em questão, de escala 1: 1.000.000, foi editado pelo Instituto Geográfico e Geológico (IGG) em 1947, reeditados e complementados em 1954, 1963 e 1974 (apud Silva et al., 1978).

A década de 70 foi caracterizada por importantes trabalhos de reconhecimento geológico, com abordagens locais, que acarretou em uma proliferação de nomes, de diferentes hierarquias. Trabalhos com enfoque geotectônico também tiveram destaque.

Em 1971, Coutinho define o Falhamento de Cubatão, de movimentos transcorrentes, no Estado de São Paulo, atravessando os municípios de Eldorado, Sete Barras, Juquiá, Miracatu, Pedro de Barros, Cubatão, Paranapiacaba e Biritiba-Mirim. Evidencia um processo de migmatização posterior à milonitização ,e ainda possíveis reativaçōes da falha até o Terciário. Refere-se pela primeira vez à justaposição de dois Blocos distintos: Bloco Cotia, a norte da falha, ectinitos intercalados por gnaisses e intrusões graníticas; e Bloco Costeiro, composto por rochas de alto grau metamórfico, a saber, gnaisses, migmatitos e granulitos. A área de estudo englobaria parte dos dois blocos. 
Em 1973, Almeida et al., descrevem o Cinturão Ribeira e sua relação com o Cinturão Paraíba do Sul. Melcher et al., no mesmo ano, apresentam uma síntese regional do sul do Estado de São Paulo.

Sadowski (1974 a, b) focaliza seus trabalhos na tectônica da Serra de Cubatão, definindo três blocos distintos: Bloco Juquitiba (predomínio de migmatitos estromáticos) e Litorâneo (migmatitos oftalmíticos) separados pelo Falhamento de Cubatão, limitados a sul por extenso falhamento E-W que os separa do Bloco Itatins (rochas do fácies granulito, rochas básicas, granitóides e metassedimentos). Enfatiza os diferentes estilos de dobramento nos três blocos e grau metamórfico associado. Caracteriza os lineamentos de maior expressão na área, bem como suas possíveis reativações. A área de estudo englobaria parte dos três blocos.

Carneiro et al. (1974) através de conceitos faixa de dobramentos e altos estruturais (tipo Maciços Medianos) e lançamento de datações geocronológicas em mapa geológico compilado 1:1.000.000 da região sul-sudeste brasileira, estrutura os terrenos Pré-Cambrianos, principalmente no que se refere aos estados do RS, SC e PR.

Morgental et al. (1975) realizaram importante trabalho de mapeamento geológico na região S-SE do estado de São Paulo, apresentando relatório detalhado e mapa geológico na escala 1:250.000.

Importante trabalho de cunho geotectônico foi realizado por Hasui et al. (1975), ao longo da região costeira entre Bahia e Uruguai, onde caracterizam o Cinturão de Dobramentos Ribeira. Neste trabalho definem a Zona Transcorrente São Paulo, com movimentação dextral e deslocamento mínimo de $300 \mathrm{~km}$, que separa o Segmento Meridional do Segmento Setentrional. O Segmento Meridional, seria composto pelo Sistema de Dobramentos Apiaí ( $1^{\circ}$ sistema de ectinitos), Maciço Mediano de Joinville $\left(1^{\mathrm{a}}\right.$ zona gnáissico-migmatítica), Sistema Dobrado Tijucas ( $2^{\circ}$ sistema de ectinitos), Maciço Mediano Pelotas ( $2^{\mathrm{a}}$ zona gnáissico-migmatítica) e Sistema Dobrado Uruguai Oriental ( $3^{\circ}$ sistema de ectinitos). A área do presente estudo envolveria $01^{\circ}$ sistema de ectinitos (Grupo Açungui), diferenciando este do Grupo São Roque, e a $1^{\mathrm{a}}$ zona gnáissicomigmatítica (porção norte do Maciço Mediano de Joinville). O Segmento Setentrional estende-se desde o Rio de Janeiro até o sul da Bahia, constituído pela Faixa de Dobramentos Pilar do sul e pela infraestrutura da Faixa Dobrada Ribeira. 
Em 1976, Sadowski relaciona as direções gerais das Falhas Transformantes do Oceano Atlântico Sul com a disposição e evolução das estruturas continentais das Plataformas Brasileira e Patagônica. Adicionalmente cita estruturas importantes relacionadas a reativações de linhas de fraqueza pré-cambrianas, entre elas zonas de falhamento transcorrentes que bordejam o estado de São Paulo, a saber, Falhas de Cubatão, Freires-Jurubatuba e Mongaguá, paralelas à borda da Bacia de Santos.

Hasui \& Sadowski (1976) resumem e discutem uma série de nomenclaturas atribuídas ao Pré- Cambriano do SE do Estado de São Paulo, e descrevem uma compartimentação tectônica através dos falhamentos Jundiuvira-ltu, Taxaquara e Cubatão. Salientam que a região se constitui em blocos falhados e justapostos que podem ser agrupados em 4 conjuntos: 1) Jundiaí ( $\mathrm{N}$ da Falha de Jundiuvira-ltu); 2) São Roque ( $\mathrm{N}$ da Falha de Taxaquara), compreende os Blocos Pirapitangui, Juqueri, Moreiras e Ituparanga; 3) Paranapiacaba (entre as Falhas de Taxaquara e Cubatão), compreende os Blocos Cotia e Juquitiba, separados pela Falha Caucaia e 4) Conjunto Costeiro (a S da Falha de Cubatão), inclui os Blocos Jurubatuba, Itapanhaú e Santo Amaro. Enfatizam que a configuração atual dos Blocos não se deve apenas aos movimentos dos falhamentos durante o Ciclo Brasiliano e também a reativações posteriores. A área de estudo estaria inserida no Conjunto Costeiro e no Bloco Juquitiba do Conjunto Paranapiacaba.

Sadowski et al. (1978) em estudos estruturais no Maciço de ltatins, mantém a denominação de Bloco Juquitiba e Bloco Costeiro, limitados pela Falha de Cubatão, este separado do Maciço Itatins pela Falha de Itatins de direção E-W. Divide o Maciço Itatins em dois blocos: Miracatu (migmatitos, granitóides e metassedimentos metamorfisados no fácies anfibolito) e Peruíbe (rochas do fácies granulito com estruturas de migmatização). Enfatiza as diferenças nas direções estruturais do Maciço (NW-E-W) com as da Faixa Ribeira.

Silva et al. (1978), apresentam a geologia das Folhas Iguape e Cananéia, e esboçam uma evolução geotectônica para área, definindo importantes aspectos geomorfológicos. Sustentam que os Blocos Costeiro e Itatins, integrariam o Maciço de Joinville, e os Blocos Juquitiba e Cotia a Faixa de Dobramentos Apiaí. Elaboram uma coluna estratigráfica com as várias associações litológicas da área. O Complexo Itatins 
se posicionaria na base da coluna, sendo limitado a norte pela Falha de Itarii, a sul pelos sedimentos recentes, a oeste pelos Rios do Peixe e Espraiado, e a leste pelo Oceano Atlântico. Dividem o Complexo Gnáissico-Migmatítico em duas faixas distintas: a sul da Falha de Cubatão (Bloco Costeiro e Itatins) representado por rochas gnáissico-migmatíticas policíclicas, e a norte da Falha, por migmatitos unicíclicos brasilianos que gradam para as sequências Açungui. No entanto descrevem os ectinitos que ocorrem na liha do Cardoso, e Pariquera - Açu como pertencentes ao Grupo Açungui. A área de estudo englobaria rochas do Complexo Gnáissico-migmatítico, maciços graníticos sin a tardi cinemáticos (Serra do ltapitangui), embrechitos facoidais e metassedimentos do Açungui.

A década de 80 destaca-se por importantes trabalhos de mapeamento que permitiram melhor compreender as áreas do setor sul-sudeste brasileiro.

Hasui et al. (1981), em trabalhos de reconhecimento geológico das unidades que compõem o embasamento Pré-Cambriano do Estado de São Paulo, apresentam um esboço da distribuição das unidades litoestratigráficas. A área do presente estudo, conforme compartimentação dos autores, englobaria o Complexo Costeiro, de idade arqueana, que se estende a sul da Falha de Cubatão, Complexo Turvo-Cajati, de idade Proterozóica inferior, limitados pela Falha de Cubatão com o Grupo Açungui (Complexo Embu e Pilar), de idade proterozóica superior. O Complexo Costeiro seria constituído por rochas migmatíticas, rochas granulíticas, na área representada pelo Maciço Itatins, rochas básicas, e ectinitos pertencentes à Sequência Cachoeira. $O$ Complexo Turvo-Cajati (Silva \& Algarte, 1981), compreende uma associação ectinítica (xistos, filitos, quartzitos, mármores e cálcio-silicáticas), metabasitos, uma associação gnáissico-migmatítica predominante e uma subsequência migmatítica. O Complexo Embu, classificado pelos autores como pertencente aos níveis inferiores do Grupo Açungui, é delimitado a sul pela Falha de Cubatão, formado principalmente por gnaisses e migmatitos com intercalaçőes de xistos, filitos, quartzitos e rochas calcárias.

Ainda em 1981 importantes trabalhos na região foram elaborados como resultado do Mapeamento e Integração Geológica do Vale do Rio Ribeira (Silva et al., 1981).

Silva \& Algarte (1981 a, b) definem a cronoestratigrafia da Sequência TurvoCajati, de idade pré-brasiliana, apresentando sua gênese e evolução geotectônica. 
Dividem a sequência em três associações: rochas ectníticas (sub-sequência TurvoAreado, Cajati e Capela do Cedro), rochas gnáissicas, e rochas migmatíticas estromáticas. Definem como embasamento pré-transamazônico desta sequência os granulitos do Complexo Serra Negra, ectinitos da Sequência Cachoeira, os gnaisses da Fazenda Faxinal (a oeste da área de estudo) e migmatitos cuja migmatização principal teria ocorrido durante o Ciclo Transamazônico. As rochas da Sequência Turvo-Cajati que ocorrem na área fariam parte da sub-sequência Cajati e dos migmatitos de paleossoma ectinitico.

Silva (1981) e Batolla Jr. et al. (1981) apresentam relações cronoestrátigraficas e evolução geológica das diferentes sequências que ocorrem entre a região de Peruíbe $e$ Curitiba. Definem, provisoriamente, a Sequência Cachoeira, representada por uma sequência metavulcano-sedimentar de idade arqueana, com idades K-Ar em minerais (Cordani, 1974) em torno de $2.300 \mathrm{Ma}$. Conforme os autores, as rochas gnáissicomigmatíticas, de grande expressão na área, representariam rochas arqueanas retrabalhadas, que sofreram importante migmatização durante o Proterozóico Inferior, ocorrida após a deposição das Sequências supracrustais de idade proterozóica inferior (Setuva, Turvo-Cajati). Os granitóides foliados (representada principalmente por corpos a sul de Juquiá, oeste do Maciço de Itatins e oeste-sudoeste de Registro) teriam se originado de intensa granitização provavelmente ocorrida no Proterozóico Inferior. A Sequência Turvo-Cajati, foi desvinculada do Grupo Açungui, localizada na porção SW da área, próximo a Pariquera-Açu. Os granitóides embrechíticos, correspondentes aos granitóides de fácies migmatítica e Cantareira (Hasui et al., 1978), intrusivos nas rochas Turvo-Cajati e nas rochas gnáissico-migmatíticas, representando os corpos graníticos que ocorrem na região de lguape, e das Serras do Cordeiro e Paratiú. Os granitóides magmáticos, são associados ao magmatismo pós-cinemático brasiliano (550-500 Ma) representados pela Serra do Itapitangui, porção SW da área de estudo.

Trabalhos específicos em geologia estrutural foram realizados entre as regiões de Juquiá e Pedro Barros, Silva (1981), onde o autor reconhece 2 zonas de cisalhamento na área de estudo: Cubatão e ltariri, que delimitam os blocos norte, central e sul. 
Em 1982, Kaul \& Teixeira associam os Complexos Luis Alves, Serra Negra e Itatins, formados no Arqueano e Proterozóico inferior, principalmente por processos crustais de acresção e diferenciação.

Sadowski (1984), em trabalho estrutural sobre os grandes falhamentos, caracteriza o Falhamento de Cubatão com feições de empurrão e movimentação dextral. Sugere um deslocamento médio de $129 \mathrm{~km}$ para este falhamento e também seu prolongamento para NE e SW, definindo o Sistema de falhamento Lancinha-CubatãoAlém Paraíba.

Em trabalho geotectônico mais amplo de Almeida \& Hasui (1984) a área ocuparia a porção central da Província Mantiqueira, englobando o Maciço Mediano de Joinville e a Faixa Apiaí, correspondendo às unidades Complexo Costeiro, Grupo Açungui ou (Grupo Açungui e Complexo Embu, Hasui et al. 1981) e Complexo Setuva.

Fiori (1985 a, b). discute importantes aspectos estruturais acerca do Falhamento da Lancinha e Morro Agudo no Estado do Paraná.

Sadowski \& Motidome (1987) definem o Sistema de Falhas Além ParaibaCubatão-Lancinha com mais de $1000 \mathrm{~km}$ comprimento. Caracterizam uma deformação progressiva, com cisalhamento dextral dúctil e posterior cisalhamento rúptil.

Em 1987 Campanha et al. discutem o quadro controverso existente quanto às definições, relações e denominações das unidades litoestratigráficas da Faixa de Dobramentos Apiaí, no Pré-Cambriano do Estado de São Paulo e Paraná.

A partir de trabalhos de mapeamento geológico das Folhas Juquiá e Miracatu, em escala 1:50.000, (Dantas et al., 1987a) importantes artigos foram publicados, como: Dantas et al. (1987); Gimenez Filho et al. (1987); Teixeira et al. , 1987).

Nas regiões de Juquiá e Miracatu os autores caracterizam a existência de dois blocos tectônicos, justapostos através da Zona de Cisalhamento de Cubatão: o Bloco Costeiro (a sul) e o Bloco Embu (a norte). No Bloco Costeiro predominam rochas gnáissico-migmatíticas e granitóides migmatíticos, que apresentam denominações locais, tais como Complexo Turvo - Cajati e Complexo Piaçaguera (Hasui \& Sadowski, 1976). Ocorrem ainda remanescentes vulcano-sedimentares de grau metamórfico médio a alto, representados por ganisses kinzigíticos, rochas cálcio-silicáticas, metabásicas, e hornblenda-gnaisses, atribuídos por Dantas et al. (1987) à Sequência Cachoeira. $\mathrm{Na}$ 
porção norte deste bloco os autores individualizam rochas enderbíticas, opdalíticas e charnoquíticas (Suíte Itatins) e rochas gnáissico-migmatíticas de natureza tonalítica a granítica (Suíte Ortognáissica).

Vieira \& Tassinari, 1988 apresentam novos dados geocronológicos para os terrenos do Embu. Segundo os autores, as sequências metassedimentares alóctones estão por sobre um complexo migmatítico-ortognáissico. Estas, apresentam metamorfismo regional, e são intrudidas por plutonismo peraluminoso em 750-700 Ma, seguido por plutons tipo $S$ associados a biotita-granitos porfiríticos com características tardi-colisionais a $610 \mathrm{Ma}$.

$\mathrm{Na}$ década de 90 importantes trabalhos foram realizados nos estados de SC e PR, no que diz respeito a compartimentação tectônica do até então denominado Maciço Mediano de Joinville. Dentre eles, podemos citar: Basei et al., 1990, 1992; Siga Jr., 1995, Siga Jr et al., 1994, 1995, 1997.

Basei et al. 1990, sobre estudos do Batólito Paranaguá, dentro de uma interpretação mais mobilista, dividem o Maciço de Joinville nos estado do PR e SC em três grandes Domínios geológicos distintos denominados de Domínio Setentrional, Meridional e Costeiro. O Domínio Setentrional limitado a norte pelos metassedimentos da Faixa Apiaí, a sul por cavalgamentos que o separam do Domínio Meridional, a leste por falha com o Domínio Costeiro e a oeste é coberto pelos sedimentos da Bacia do Paraná. Composto principalmente por ortognaisses graníticos, migmatíticos e núcleos gnáissico-granulíticos e por granitóides intrusivos. O Domínio Meridional é limitado a norte pelo Domínio Setentrional, a leste, por falha com o Domínio Costeiro, a sul por cavalgamentos, com o Cinturão Dom Feliciano e a oeste é recoberto pelos sedimentos da Bacia do Paraná. Composto principalmente por ortogranulitos, metabásicas, quartzitos e formações ferríferas. O Domínio Costeiro (porção NE do Maciço de Joinville) é limitado pela linha de costa, a leste e sudeste, porção sul-SE por falha com o Domínio Meridional e porção W-NW por cavalgamento com o Domínio Setentrional. Os autores apresentam uma idade Proterozóica Superior para os granitóides porfiróides do Batólito Paranaguá (Domínio Costeiro) cujas características isotópicas indicam fusão de crosta inferior, cuja diferenciação do manto ocorreu no Proterozóico Inferior (2.000 Ma). 
Este magmatismo teria sido gerado em regime tectônico compressivo, desenvolvido em toda borda Sul e NE do Maciço de Joinville no Proterozóico Superior.

Ainda em 1990, Fassbinder desenvolve importante trabalho na Zona de Cisalhamento Lancinha no estado do Paraná.

Sadowski (1991) define a Megafalha de Cubatão, um sistema de falhamento com mais de $2000 \mathrm{~km}$ constituído por falhas transcorrentes que bordejam a costa SE brasileira, com evolução da deformação extremamente complexa, desde falhamento inverso até movimentos transcorrentes dextral e sinistral. $O$ autor apresenta um sistema de compressão horizontal no quadrante $\mathrm{N} 60$ a $100^{\circ}$, associado a uma colisão continental brasiliana que colocou no mesmo nivel granulitos e rochas metamórficas de baixas profundidades. Ainda enfatiza que a estrutura arqueada do Bloco 'Curitiba-Itatins' provavelmente estaria associada ao lançamento deste Bloco sobre a área dos metassedimentos do Grupo Açungui.

Em importante trabalho de compilação sobre os corpos graníticos do Estado de São Paulo, Janasi \& Ulbrich (1992) adotam a compartimentação: Maciço Mediano de Guaxupé subdividido em três domínios, 1-Guaxupé, a norte da Falha de Jacutinga, 2Amparo, entre esta falha e a base da nappe de cavalgamento de Socorro, e 3-Jundiaí, terrenos a norte da Falha de Jundiuvira. O Maciço Mediano de Joinville foi subdividido em Domínios Iguape (a oeste) e Ubatuba (a leste), separados pela Falha de Itariri. As faixas dobradas foram divididas em três domínios: São Roque (entre as falhas de Taxaquara e Jundiuvira), Açungui (a norte do lineamento da Figueira) e Embu (a sul do lineamento da Figueira-Falha de Taxaquara e a norte da Falha de Cubatão). A área aqui estudada englobaria o Domínio Iguape, e a porção $W$ do Domínio Ubatuba; e parte do Dominio Embu.

Basei et al. (1992) sugerem o abandono do termo Maciço de Joinville e substituição pelas denominações das entidades que formam os terrenos gnáissicomigmatíticos existentes entre os Cinturões Dom Feliciano e Ribeira por: Microplaca Curitiba (parte norte) composta principalmente por gnaisses bandados com $2.1 \mathrm{Ga} \mathrm{e}$ migmatitos de $600 \mathrm{Ma}$, Microplaca Luis Alves (parte sul) representada por ortogranulitos e rochas gnáissicas com idades entre 2.7 e $2.0 \mathrm{Ga}$, e Cinturão Granitóide Costeiro, representado por granitóides cálcio-alcalinos (idades de 600 a $550 \mathrm{Ma}$ ). A justaposição 
destas entidades geotectônicas teria se dado por processos de subducção e colisões ocorridas durante o Proterozóico Superior e o Cambriano relacionado à constituição da porção W do Gondwana: a colisão da Microplaca Curitiba com áreas cratônicas a norte, com geração de arco magmático na borda sul em 700-650 Ma; colisão das Microplacas Luís Alves e Curitiba em 650-600 Ma, e a colisão entre o Cinturão Granitóide Costeiro (Batólito Paranaguá) e a Microplaca Luís Alves em 600-550 Ma.

Machado \& Endo (1993) propõe a designação de Cinturão de Cisalhamento Atlântico em substituição as denominações: Cinturão Paraíba, Faixa Paraibides, Cinturão Atlântico, Cinturão Ribeira, Região de Dobramentos Sudeste e Província Mantiqueira. O Cinturão de Cisalhamento Atlântico é caracterizado como um segmento que se estende da região sudeste da Bahia até o Rio Grande do Sul / Uruguai, com natureza transpressional.

$\mathrm{Na}$ concepção desses autores o Cinturão de Cisalhamento Attântico é constituído por dois sistemas de cisalhamento principais: o Sistema de Cisalhamento Paraíba do Sul e o Sistema de Cisalhamento Dom Feliciano. Entre estes sistemas interpõem-se os Maciços Medianos de Curitiba, Itatins, e Cabo Frio.

As rochas gnáissico-granulíticas que ocorrem na região de Itatins, foram estudadas sob o ponto de vista geocronológico por Picanço (1994). Os dados obtidos pelo autor, indicam para os protólitos dessas rochas charnoquíticas épocas de derivação do manto arqueanas (2.6-2.5 Ga). Os dados $\mathrm{Rb}-\mathrm{Sr}$, embora mal definidos, sugerem a formação dessas rochas no Paleoproterozóico, que sofreram episódios de granulitização e fusão parcial no Neoproterozóico (720-580 Ma). Segundo o autor, os protólitos das rochas da Suíte Itatins foram gerados provavelmente em ambiente de convergência de placas; esta crosta seria constituída por granulitos tipo Guaraú e Azeite (Bloco Peruíbe), que estariam associados a diversos tipos supracrustais (Sequência Cachoeira). Esta crosta arqueana teria sido afetada pelos episódios compressionais do Ciclo Brasiliano, onde foi infracavalgada por sob o Bloco Costeiro (a norte), onde a falha de Itariri teria a expressão de uma subducção do tipo $\mathrm{A}$. Em profundidade, o Maciço Itatins foi granulitizado e granitizado, sendo também submetido a cisalhamento e transporte tectônico ao longo das zonas de cisalhamento Itariri e Cubatão, por até 100 km (Sadowski, 1991). A partir dessas observações, o autor descarta qualquer relação 
com os terrenos granulíticos de Serra Negra e Luís Alves, hipótese aventada por Siga Jr et al., 1994). As idades K-Ar mais antigas obtidas para o Bloco Peruíbe em relação às do Bloco Costeiro, juntamente com as idades de migmatização em fácies anfibolito no Bloco Costeiro, indicam clara diferença de nível crustal entre os dois blocos, hoje tectonicamente justapostos. $\mathrm{O}$ autor apresenta idades $\mathrm{Rb}-\mathrm{Sr}$ para os migmatitos de Mongaguá ( $532 \pm 31 \mathrm{Ma}, \mathrm{Ri}=0.708$ ), bem como datações K-Ar de $512 \mathrm{Ma}$.

Azevedo Sobrinho (1995) com enfoque geoquímico - petrológico, caracteriza no setor meridional do Maciço de Itatins, a predominância de rochas charnoquíticas maciças a bandadas, quartzo-noritos, e enderbitos com variações para quartzo-jotunitos e quartzo-mangeritos. Os dados geoquímicos indicam que as rochas charnoquíticas pertencem a uma sequência cálcio-alcalina bimodal, formada por rochas de composição intermediária a ácida, associadas a enclaves básicos. No setor setentrional, balizado a norte pela falha de Itariri, predominam gnaisses migmatíticos com estrutura estromática. - mesossoma dessas rocha é representado por biotita-gnaisses tonalíticos e anfibolíticos e o leucossoma apresenta normalmente composição sienogranítica. A passagem das rochas charnoquíticas para as migmatíticas é gradativa, sendo delimitada uma região a qual o autor acima citado atribuiu a denominação de Zona de Transição. As caracteristicas geoquímicas (sequência bimodal) que são associadas a ambientes tectônicos compressionais, corroborariam com um modelo de subducção de placa oceânica sob um microcontinente, seguido por colisão de duas placas continentais. A zona de subducção teria ocorrido no Arqueano Médio ou Inferior e retomada em $2.8 \mathrm{Ga}$ (Silva, 1981).

Neste contexto, a Zona de Cisalhamento Itariri constituiria um importante balizamento entre o Maciço de Itatins e os terrenos granito-migmatíticos a norte.

Siga Jr. (1995) discute a evolução dos terrenos Pré-Cambrianos da porção SE do PR e NE de SC, definindo os Domínios Luís Alves, Curitiba e Paranaguá. Apresenta importante contribuição geocronológica e isotópica para a área. A configuração dos terrenos Luís Aves, que se estenderiam para NE em direção ao Maciço Serra Negra e possivelmente até $o$ Maciço Itatins, poderia representar um microcontinente localizado entre os Crátons do Congo (África) e Paraná (Brasil) durante o Neoproterozóico (Siga Jr., et al. 1994) ou até mesmo estar conectado com o Cráton do Congo (Siga Jr, 1995). 
Coloca o Domínio Curitiba, em substituição do termo Microplaca Curitiba (Basei et al., 1992), uma vez que representaria a borda do segmento Luís Alves, intensamente deformada, migmatizada e granitizada. O Domínio Paranaguá faria parte da evolução de um grande cinturão colisional, que balizaria toda porção costeira das regiôes sul e SE do Brasil. Como encaixantes destes granitóides ocorrem gnaisses, por vezes granatiferos, mica-xistos, quartzitos, e anfibolitos que podem se apresentar migmatizados em diferentes graus. Adicionalmente, ocorre importante atividade plutônica de características tardi a pós-tectônicas, representada por corpos graníticos isótropos. As pesquisas geocronológicas realizadas por Siga Jr. (1995) caracterizam o intervalo 620570 Ma para formação de grande parte desses granitóides. Os dados $\mathrm{K}-\mathrm{Ar}$ indicam que o Domínio Paranaguá permaneceu quente (isotermas superiores a $300-250^{\circ} \mathrm{C}$ ) por bem mais tempo que os domínios adjacentes (Luís Alves e Curitiba), acusando idades do intervalo $560-480 \mathrm{Ma}$.

Durante a justaposição do Domínio Paranaguá ocorre no âmbito dos terrenos adjacentes, já relativamente estabilizados, expressiva granitogênese de natureza alcalina-peralcalina (Serra da Graciosa, Marumby, Anhangava, Serra da Igreja, Morro Redondo, Agudos do Sul, Dona Francisca, Piraí, e Corupá - Suíte Serra do Mar, Kaul, 1984; Kaul \& Cordani 1994), bem como intenso vulcanismo ácido - intermediário relacionado à evolução das Bacias de Campo Alegre, Guaratubinha e Corupá. Tais manifestações sugerem uma associação com regimes tectônicos distensivos, produzidos pelos ajustes crustais decorrentes de uma procura de condições de maior estabilidade, após o espessamento provocado pelo tectonismo precedente.

$\mathrm{Na}$ porção sul-sudeste de São Paulo, Campos Neto \& Figueiredo (1995) relacionam a evolução tectônica da orogenia Brasiliano I (>600 Ma) às microplacas Curitiba, Guanhães, Apiaí-Guaxupé, e Sistema de Cavalgamento Juiz de Fora e Terrenos Acrescionários Embu; e a Microplaca Serra do Mar à Orogenia Rio Doce. A área de estudo englobaria a Microplaca Curitiba, Microplaca Serra do Mar, Terrenos Acrescionários Embu, e Fragmentos Exóticos de Ante País do Itatins.

Reconhecem três segmentos crustais na Microplaca Serra do Mar: terrenos supracrustais, gnáissico-migmatítico, e granulito-granítico-migmatítico. Esses terrenos 
apresentam uma evolução entre 590 e $480 \mathrm{Ma}$ (Orogênese Rio Doce), distinta dos terrenos mais ocidentais que parecem ter atingido um estágio pós-orogênico há cerca de $600 \mathrm{Ma}$ (Orogênese Brasiliana).

Batólitos cálcio-alcalinos com componentes geoquímicos de zona de subducção, pertencentes à Microplaca Serra do Mar, são relacionados ao estágio de arco magmático da Orogênese Rio Doce, desenvolvido entre 590 e $570 \mathrm{Ma}$. O estágio colisional (560-530 Ma) foi responsável, na opinião dos autores referidos, pela acresção da Microplaca Serra do Mar aos domínios orogênicos precedentes. Ainda para Campos Neto \& Figueiredo (1995), a fusão parcial de crosta continental, principalmente de metassedimentos, teria produzido migmatitos e granitos peraluminosos, tendo-se iniciado no estágio de arco magmático, culminando, durante o espessamento crustal, com o empilhamento de grandes fatias de cavalgamento para NW. O plutonismo pós colisional (520-480 Ma) caracteriza-se por plútons e diques de granitóides, geralmente álcali-cálcicos, enriquecidos em elementos incompatíveis.

Novos dados U-Pb (shrimp), Sm-Nd e Rb-Sr acerca das rochas do Maciço Granulítico de Itatins são apresentados por Picanço et al., 1998, que confirmam a história evolutiva policíclica do Maciço. Segundo os autores o protólito crustal se diferenciou do Manto Superior em $2.5 \mathrm{Ga}$. As rochas foram afetadas por um metamorfismo granulítico há cerca de 2.2 Ga e um metamorfismo no fácies anfibolito entre 720 e $580 \mathrm{Ma}$.

Basei et al. (1999), em trabalho sobre os cinturões granulíticos da região sulbrasileira, questiona a correlação entre o Maciço Itatins como sendo continuidade da Microplaca Luís Alves. Propõem que os granulitos do Maciço Itatins integrem a Microplaca Curitiba, limitada no estado de São Paulo pela ZC Lancinha-Itariri. O alinhamento Lancinha-Itariri, segundo os autores, representaria uma importante sutura que separa a Microplaca Curitiba dos terrenos a norte desta.

Ainda em 1999, importante trabalho de mapeamento geológico, levantamento geoquímico e geofísico, foi realizado pela CPRM, nas Folhas Topográficas Jacupiranga e Rio Guaraú, escala 1:50.000. A partir deste trabalho, novos dados geocronológicos foram obtidos (Vasconcellos et al., 2000) referentes aos ortognaisses porfiroclásticos $(2.1 \mathrm{Ga})$ correlacionados pelos autores aos terrenos do Cráton Luís Alves, ao granito- 
gnaisse Alto Jacupiranguinha $(0.74 \mathrm{Ga})$ relacionado pelos autores à Suíte Rio Piên, e ao gnaisse Itapeúna $(0.63 \mathrm{Ga})$ associados a granitos tipo $S$ anatético, cujos protólitos estão associados a Sequência Turvo-Cajati.

Novas datações acerca do Complexo Embu (Cordani et al., 2000) foram obtidas em ortognaisses miloníticos próximo a São Lourenço da Serra. Os autores obtiveram idades isocrônicas $\mathrm{Rb}-\mathrm{Sr}(\mathrm{RT})$ de $770 \mathrm{Ma}$ com $\mathrm{Sr}^{87} / \mathrm{Sr}^{86}$ de 0.722 , e idades K-Ar em cerca de $500 \mathrm{Ma}$. As idades U-Pb (shrimp) obtidas revelaram populações de zircão bastante heterogêneas, com cristais herdados com idades próximas a $2.000 \mathrm{Ma}$, um grupo de zircões magmáticos com cerca de $800 \mathrm{Ma}$ e sobrecrescimento em zircões indicando um episódio metamórfico há cerca de $660 \mathrm{Ma}$. Conforme os autores, estas rochas estão associadas a processos anatéticos ocorridos na fase tectônica precoce do Ciclo Brasiliano.

Importantes trabalhos de cunho geotectônico foram desenvolvidos no ano 2000 acerca da evolução tectônica da América do Sul, a saber, Basei et al., que discutem a evolução tectônica do Cinturão Dom Feliciano no Brasil e Uruguai, e sua correlação com províncias similares do Sudoeste Africano; Campos Neto, onde apresenta a evolução geodinâmica do SE do Brasil desde o Rodínia até o Gondwana e Trouw et al., que apresentam um novo modelo tectônico para o segmento central do Cinturão Ribeira baseados na relação entre a evolução estrutural e feições magmático-metamórficas, suportado por dados geoquímicos e geocronológicos. 


\section{COMPARTIMENTAÇÃO TECTÔNICA}

Com intuito de posicionar a área de estudo dentro do quadro geológico regional, será aqui apresentado um esboço da compartimentação tectônica das regiões sudeste do Estado de São Paulo e nordeste do Paraná (Figura 4.1), bem como a compartimentação utilizada para a área em questão (Figura 4.2).

A região de interesse tem importante papel na contexto tectônico da porção sul-sudeste brasileira (Figura 4.1), oferecendo grande oportunidade para se discutir a continuidade dos terrenos, anteriormente estudados, localizados mais a sul, Microplaca Curitiba, Microplaca Luís Alves e Domínio Paranaguá (parte da Microplaca Serra do Mar, e dos terrenos localizados mais a norte, pertencentes a Microplaca Serra do Mar (Campos Neto \& Figueiredo, 1995; Campos Neto, 2000).

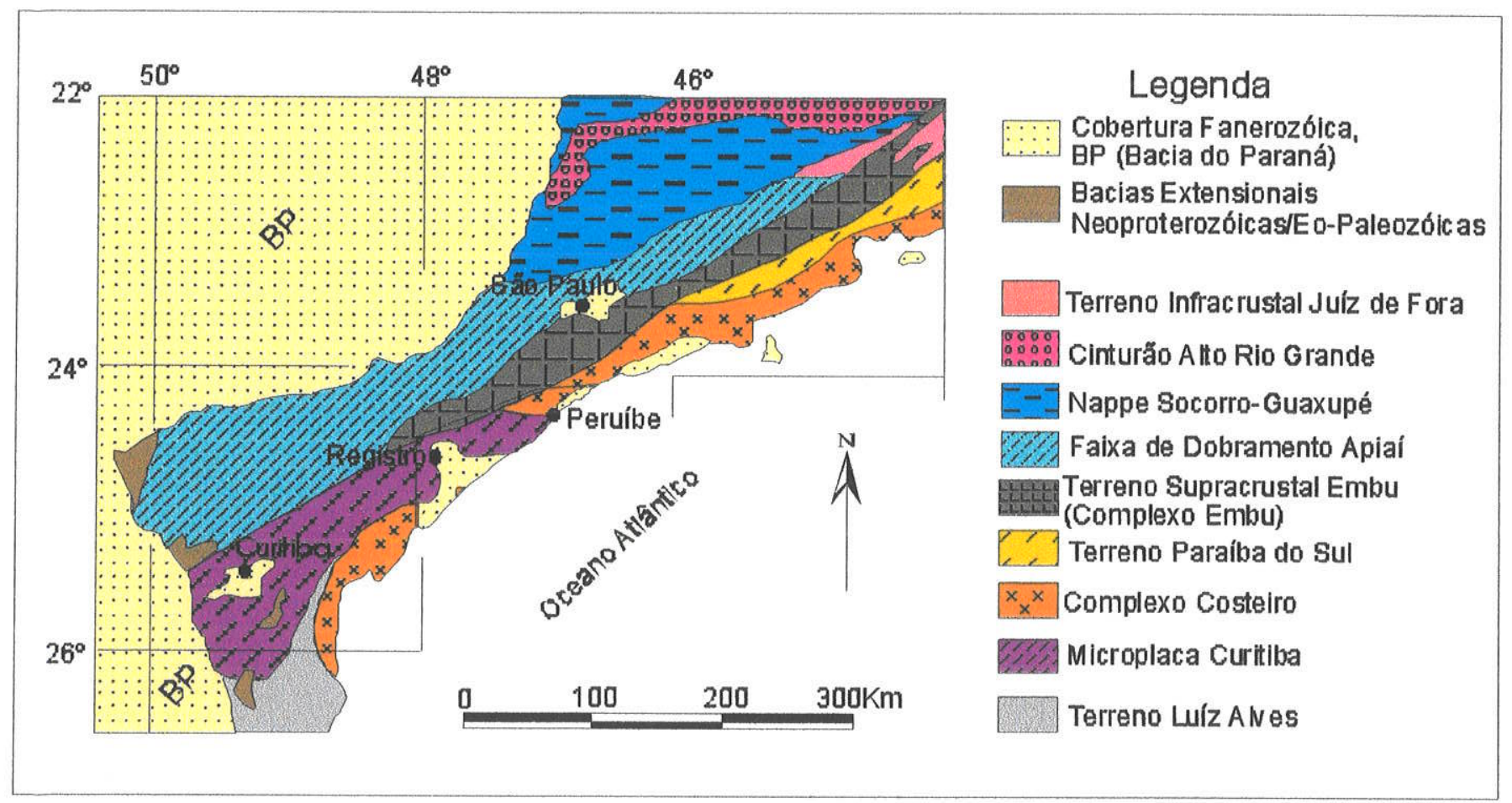

Figura 4.1 - Esboço da compartimentação tectônica das regiôes sudeste do estado de SP e nordeste do PR, e localização da área (Modificado de Campos Neto \& Figueiredo, 1995).

Os compartimentos estudados foram subdivididos em 4 Blocos tectônicos principais: Embu, Mongaguá, Registro e Iguape, cujos limites são determinados por importantes Zonas de Cisalhamento, a saber Zona de Cisalhamento Itariri, Cubatão e Serrinha (Figura 4.2). 
Ressalta-se que a autora não teve a pretensão de abranger toda complexidade de cada compartimento tectônico. Foram pesquisadas áreas específicas e limitadas de cada Bloco, que puderam fornecer informações geológicas necessárias, com base na petrografia, geologia estrutural, geoquímica e geologia isotópica, para posteriores correlações regionais.

Bloco Embu - ocorre a norte da Zona de Cisalhamento Cubatão ZCC (Figura 4.2). correspondente ao Bloco Embu (Dantas et al., 1987b), ao Terreno Acrescido Embu (Campos Neto \& Figueiredo, 1995) e ao Complexo Embu como parte do Terreno Juiz de Fora (Campos Neto, 2000). Abrange rochas metassedimentares (Complexo Embu e Sequência Miracatu) e rochas granitóides peraluminosas (Suite granítica de Fácies Cantareira). Composto por mica-xistos e paragnaisses parcialmente migmatizados e quartzitos (Complexo Embu) e xistos finos, filitos e subordinadamente quartzitos, metabásicas e rochas cálcio-silicáticas (Sequência Miracatu). Ambas unidades são intrudidas por rochas deformadas da Suíte Granítica de Fácies Cantareira, que abrange granitos cálcio-alcalinos de alto potássio e peraluminosos tardi-orogênicos.

Bloco Mongaguá - região entre a Zona de Cisalhamento Cubatão (ZCC) e Zona de Cisalhamento Itariri $(\mathrm{ZCl})$, Figura 4.2, correspondente aos migmatitos indiferenciados do Complexo Costeiro (Gimenez Filho et al., 1987), aos terrenos gnáissico-migmatíticos da Microplaca Serra do Mar (Campos Neto \& Figueiredo, 1995; Campos Neto, 2000) e ao Cinturão Granítico Costeiro (Basei et al., 1999, 2000), correlacionado por estes autores ao Batólito Paranaguá (Basei et al., 1990) Composto por rochas gnáissico - migmatíticas e granitóides associados.

Bloco Registro - ocorre a sul das ZCC e ZCl até a Zona de Cisalhamento Serrinha (ZCS), Figura 4.2, onde predominam rochas migmatíticas. Corresponde ao Bloco Costeiro de Dantas et al., 1987. Inclui Complexo Costeiro (Suíte Itatins, rochas charnockíticas, Suíte ortognáissica (tonalítica a granítica), Seq. Cachoeira (vulcanosedimentar), segundo Bistrichi et al.,1981, apud Dantas et al., 1987), Complexo Gnáissico-Migmatítico (migmatitos de estruturas variadas) e Suíte granítica de fácies migmatítica, intrudido por granitos filonianos, rochas alcalinas do Complexo Juquiá e parcialmente recoberta por sedimentos cenozóicos do Grupo Mar Pequeno 
(Formações Pariquera-Açu e Cananéia). Campos Neto \& Figueiredo (1995) correlacionam o Maciço de Itatins aos Fragmentos exóticos de Ante-País e o restante do bloco à Microplaca Curitiba ou mesmo aos terrenos granulito-granitomigmatíticos da Microplaca Serra do Mar. Segundo Basei et al., 1999, 2000, correlaciona-se ao Complexo Atuba (Siga Jr. et al., 1995).

Bloco Iguape - região a sul da Zona de Cisalhamento Serrinha (ZCS), Figura 4.2. Correlacionado por Campos Neto \& Figueiredo (1995) aos terrenos granulitogranito-migmatíticos da Microplaca Serra do Mar. Abrange rochas graníticas e rochas metassedimentares anteriormente associadas à Sequência Turvo - Cajati (Silva \& Algarte, 1981). Associado ao Cinturão Granítico Costeiro (Basei et al., 1999, 2000), correlacionado por estes autores ao Batólito Paranaguá (Basei et al., 1990).

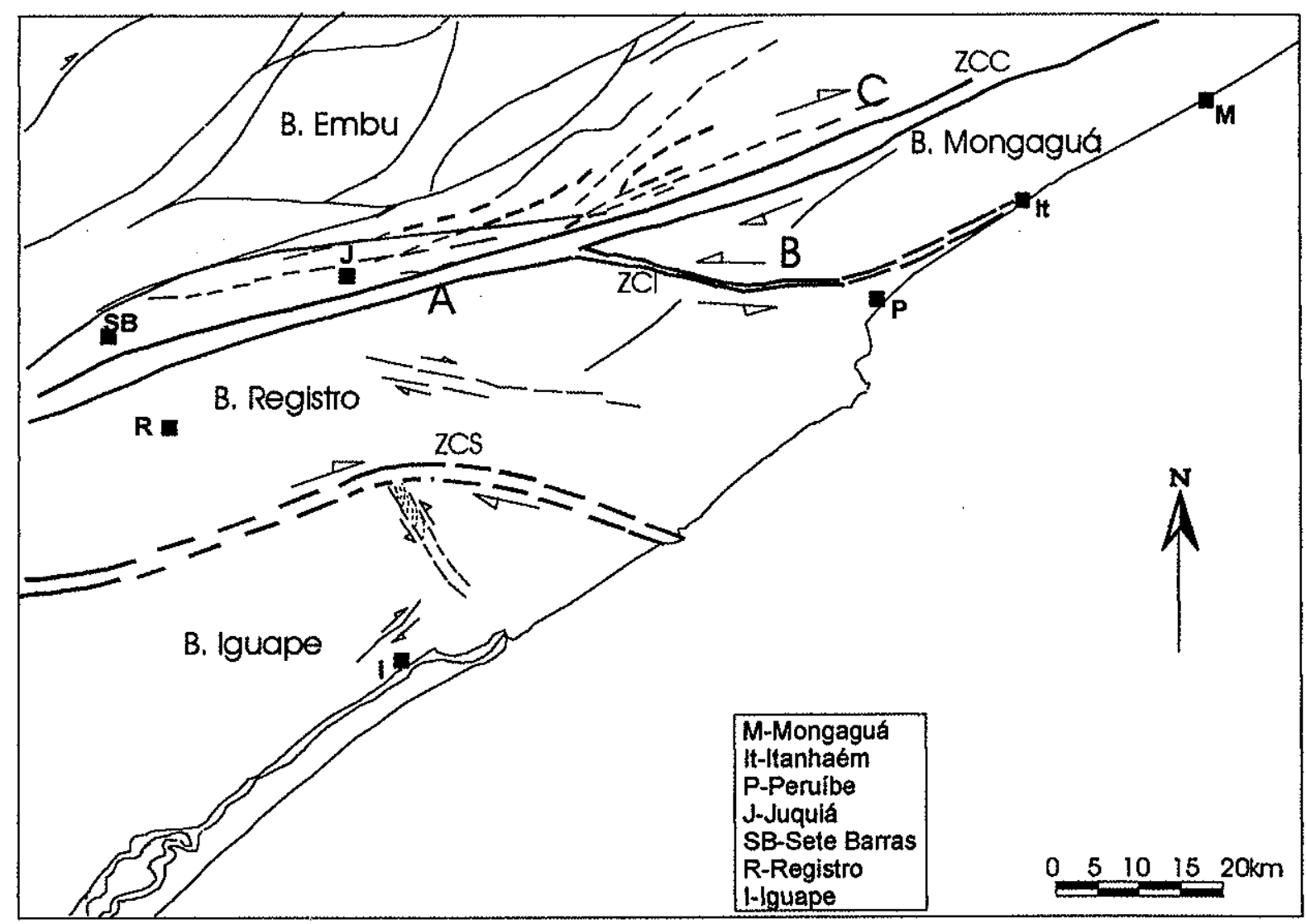

Figura 4.2 - Esboço da compartimentação tectônica da área estudada - região S-SE do Estado de São Paulo. 


\section{BLOCO EMBU}

\subsection{INTRODUÇÃo}

$\mathrm{Na}$ área de estudo, o Bloco Embu, conforme definido por Dantas et al., (1987), é limitado a sul pela Zona de Cisalhamento Cubatão (ZCC), Figura 4.2, e constituido predominantemente por rochas metassedimentares (filitos e xistos) e rochas graníticas. Ressalta-se que os trabalhos desenvolvidos neste bloco referemse às localidades próximas à ZCC, e não pretenderam de forma alguma, abranger a sua diversidade litológica.

No presente trabalho, a investigação geológica do Bloco Embu foi realizada ao longo de um perfil na Rodovia BR-116 entre as localidades de Pedra Larga e Pedro Barros, com ocorrência de rochas metassedimentares; nas proximidades da cidade de Juquiá, com ocorrências de rochas graníticas e metassedimentares; e nas proximidades da cidade de Sete Barras, com ocorrência de rochas graníticas (Mapa Geológico - Anexo 1).

\subsection{CARACTERIZAÇÃo Petrográfica-estrutural.}

\section{METASSEDIMENTOS}

Na região estudada, o pacote de rochas metassedimentares é composto predominantemente por xistos (muscovita - quartzo - xistos e biotita - quartzo xistos) e filitos, caracterizados pela cor de alteração avermelhada a arroxeada, (Prancha 1, Foto 1) e subordinadamente quartzitos.

Próximo a localidade de Pedra Larga, o bandamento composicional $S_{0}$, caracteriza-se pela intercalação rítmica de níveis quartzíticos de até $5 \mathrm{~cm}$, e níveis pelíticos. Ocasionalmente, em meio aos filitos, também ocorrem intercalações centimétricas com rochas cálcio-silicáticas.

Os mica-xistos (biotita/muscovita xistos) podem conter porfiroblastos de cordierita, granada e sillimanita, caracterizando um fácies de alto grau metamórfico.

Migmatitos estromáticos resultantes da anatexia destas rochas metassedimentares também são observados em meios aos mica-xistos, e apresentam-se principalmente em duas formas. Na primeira são caracterizados por camadas centimétricas de leucossoma quartzo-feldspático de granulação grossa em meio aos xistos (Prancha 1, Foto 2). $\mathrm{Na}$ segunda forma caracterizam-se por 
leucossomas graníticos, de granulação grossa, leucocráticos a hololeucocráticos, definindo corpos distintos do tipo pod em meio aos xistos (Prancha 1, Foto 3).

Os xistos possuem uma foliação metamórfica principal, possivelmente $S_{2}$, paralela ao bandamento composicional que apresenta-se levemente dobrada com foliação $S_{3}$ plano axial. As dobras parasitas desta fase, mostram espaçamento centimétrico. Os eixos de dobramento $B_{3}$ têm caimentos intermediários preferencialmente para SWW (Figura 5.2.1).

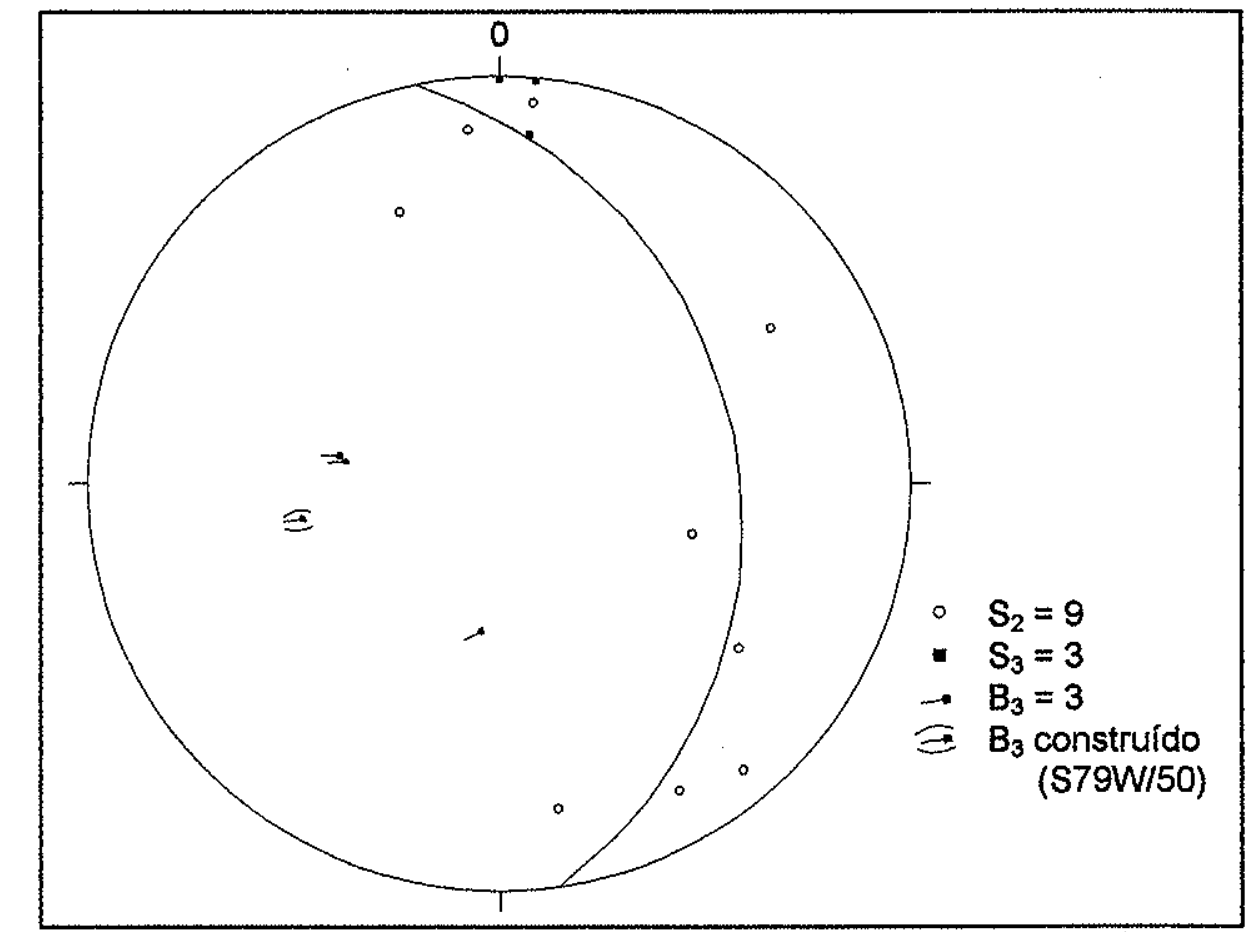

Figura 5.2.1. Bloco Embu - Rochas metassedimentares. Dobramento da superfície $S_{2}$, superfície plano axial $\mathrm{S}_{3}$ e eixos $\mathrm{B}_{3}$ medidos e construído, $\mathrm{S} 79 \mathrm{~W} / 50$.

As rochas metassedimentares estão afetadas por fortes lineamentos (Figura 4.2, Mapa Estrutural - Anexo 2), desenvolvendo uma superfície milonítica bem marcada, paralela à foliação metamórfica principal $S_{2}$. Corpos boudinados de provável rocha cálcio-silicática, com até $40 \mathrm{~cm}$ de espessura, podem ocorrer em meio aos filitos.

A zona de falha que afeta as rochas metassedimentares tem movimentação dextral, caracterizada principalmente por indicadores cinemáticos do tipo pares S-C, e possivelmente está relacionada à área de influência da ZCC.

Superposta a foliação milonítica $(\mathrm{Sm})$ ocorrem dobras decimétricas desenvolvendo uma clivagem de crenulação discreta, correlacionada a $S_{3}$. A foliação 
milonítica dobrada, tem máximos em N72W/70SW e N50E/70NW, e eixo construído em S88W/62 (Figura 5.2.2).

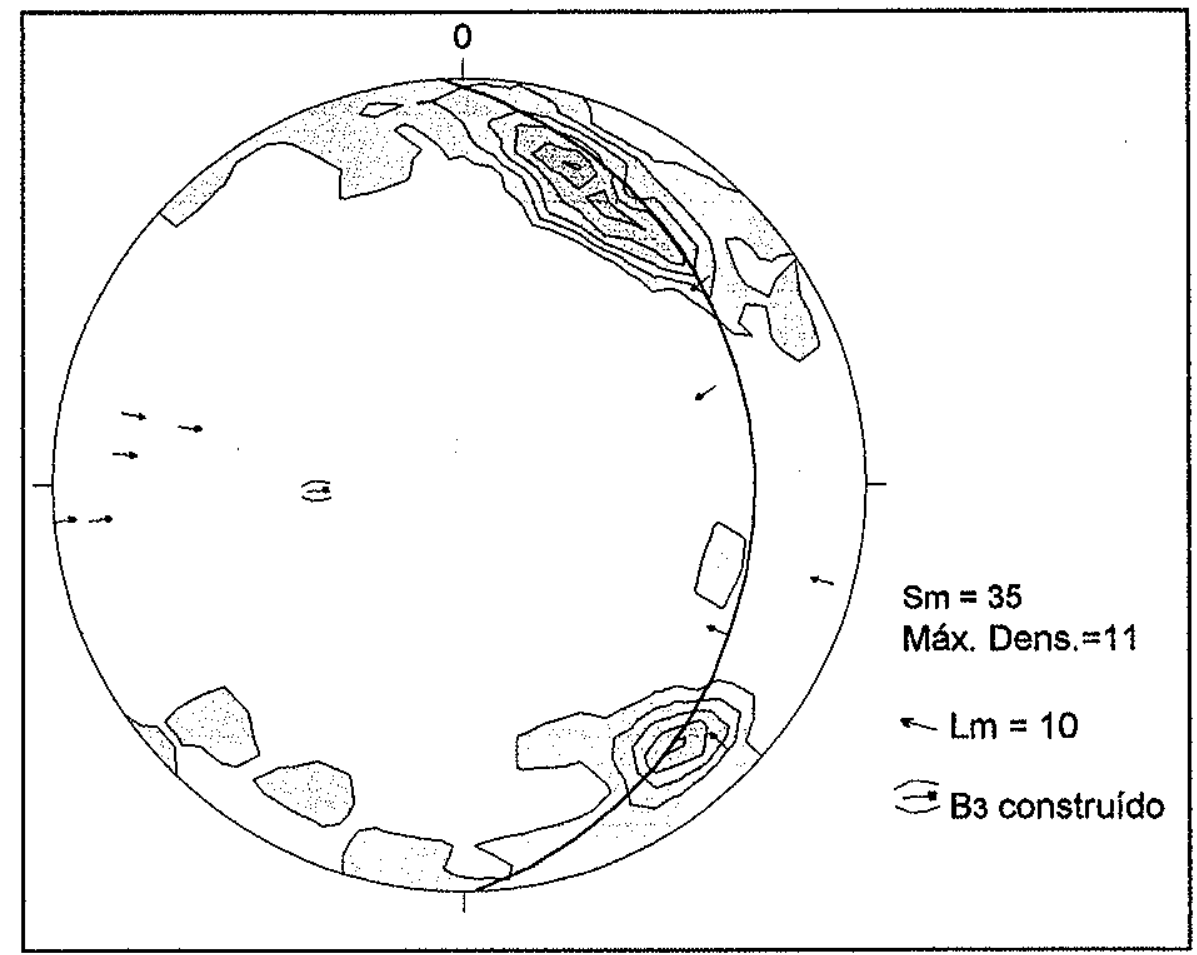

Figura 5.2.2. Bloco Embu - Rochas metassedimentares. Dobramento $D_{3}$ da foliação milonítica, com lineação de estiramento mineral associada. Eixo $B_{3}$ construído: S89W/62.

O paralelismo entre as superfícies $S_{2}$ e a foliação milonítica $\mathrm{Sm}$ é observado (Figuras 5.2.1 e 5.2.2), onde ambas apresentam máximos próximos à orientação $E$ W e mergulhos fortes para $\mathrm{N}$ e $\mathrm{S}$, e são dobradas por uma fase posterior com eixos de dobramento (possivelmente $B_{3}$ ) de caimentos em torno de $60^{\circ}$ para $W$.

Em seções delgadas, os xistos apresentam textura lepidoblástica, sendo a foliação principal, caracterizada provavelmente como $S_{2}$, definida pela orientação dos minerais constituintes principais como muscovita, biotita e quartzo, e também porfiroblastos de sillimanita, ou granada ou cordierita (Prancha 1, Foto 4).

Nas porções afetadas pelo processo de milonitização há o desenvolvimento de bandas de cisalhamento extensionais assimétricas (Hanmer \& Passchier, 1991), indicando movimentação dextral (Prancha 1, Foto 5). Feições de rotação de sombra de pressão em porfiroclastos de muscovita também são observadas (Prancha 1 , Foto 6). A sombra de pressão em uma deformação progressiva de um cisalhamento dextral, é arrastada para os quadrantes de máximo encurtamento (Hanmer \& Passchier, 1991). 


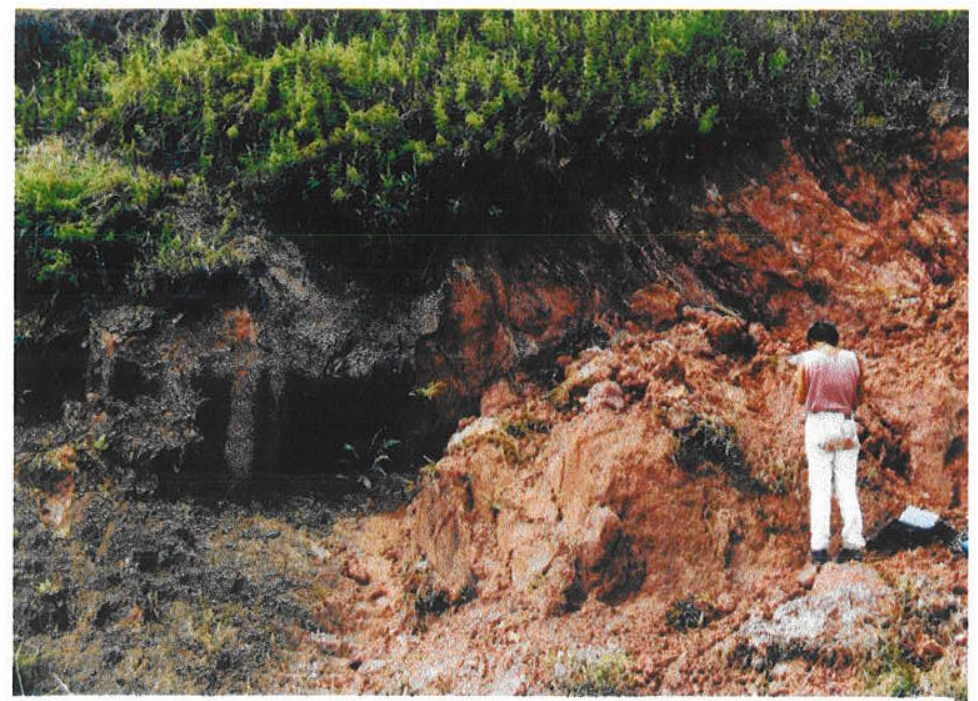

Foto 1 - Mica-xistos intercalados com bandas centimétricas quartzíticas, muito alterado. Foliação principal N50E/81NW. Região de Pedra Larga (K-8).

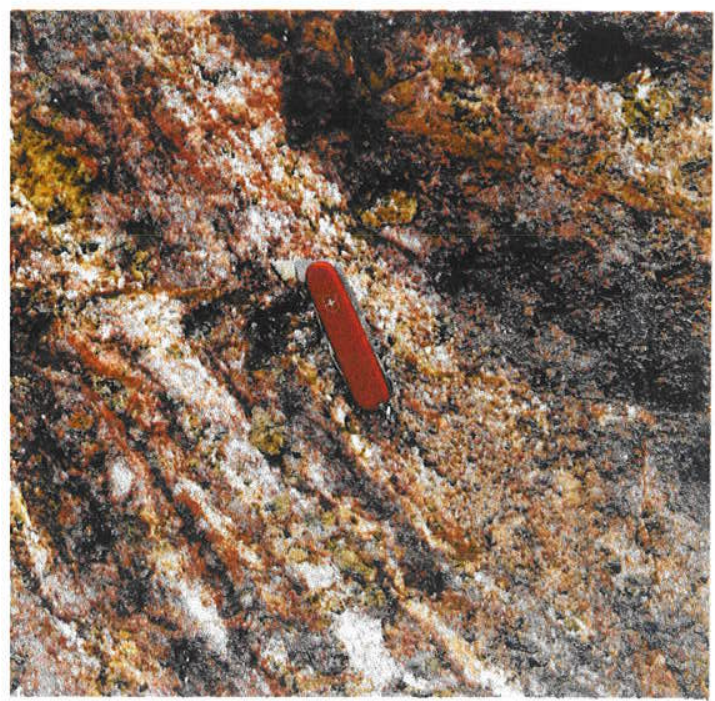

Foto 2 - Granada-biotita-xistos alterados com bandas leucossomáticas centimétricas quartzofeldspáticas. Região de Pedra Larga (K-8).

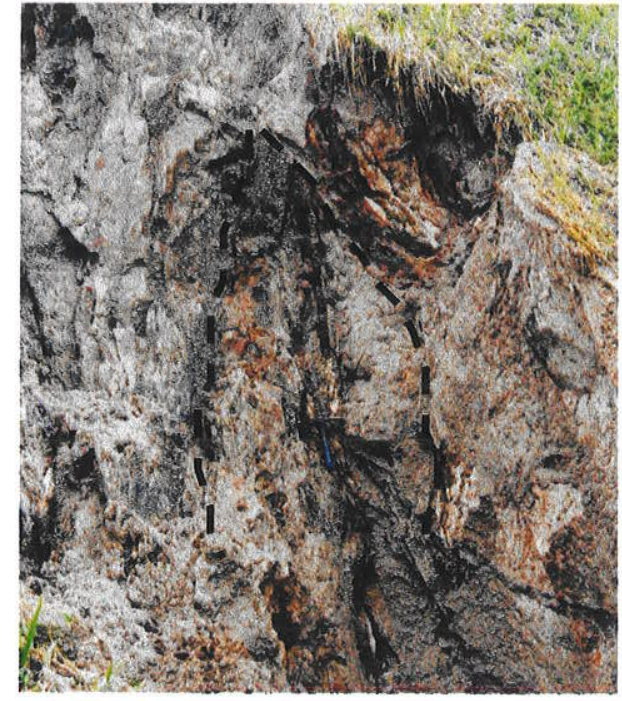

Foto 3 - Leucossoma granítico em forma de pod, em meio a xistos. O conjunto está milonítico (K-10). Foliação milonítica: N70E/60NW; N70E/80SE. Região a norte de Pedro Barros.

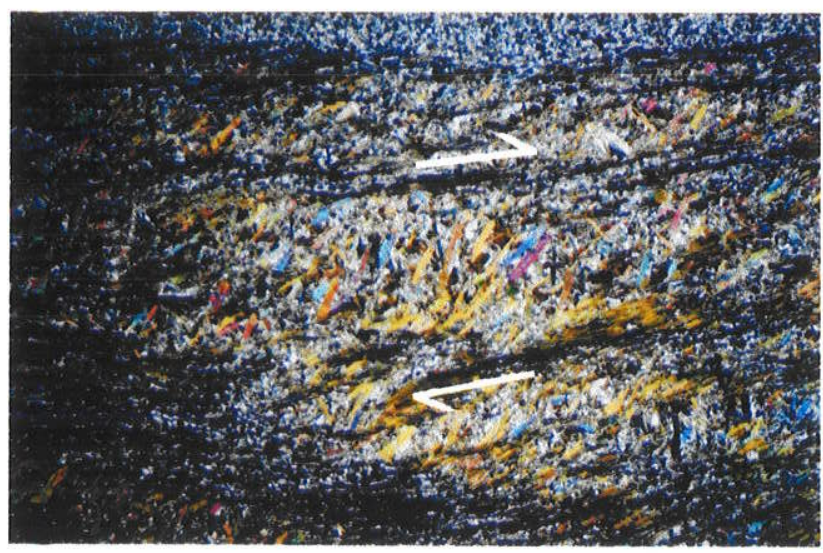

Foto 5 - Fotomicrografia (nicóis $\mathrm{X}$, aumento $7.5 \mathrm{x}$ ). Bandas de cisalhamento extensionais assimétricas desenvolvidas em biotita-muscovita xisto, indicando movimento dextral. Amostra K-19 (corte XZ). Reqiẫo a norte de Juquiá.

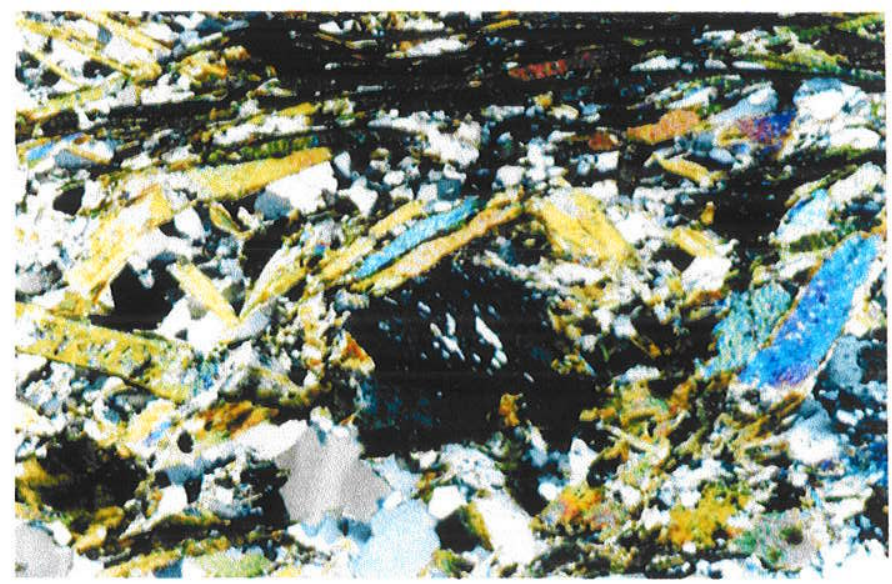

Foto 4 - Fotomicrografia (nicóis $\mathrm{X}$, aumento $50 \mathrm{x}$ ). Cordieritabiotita-muscovita xisto. Porfiroblasto de cordierita poiquiloblástico com inclusões de quartzo. Amostra K-19 (corte XZ).

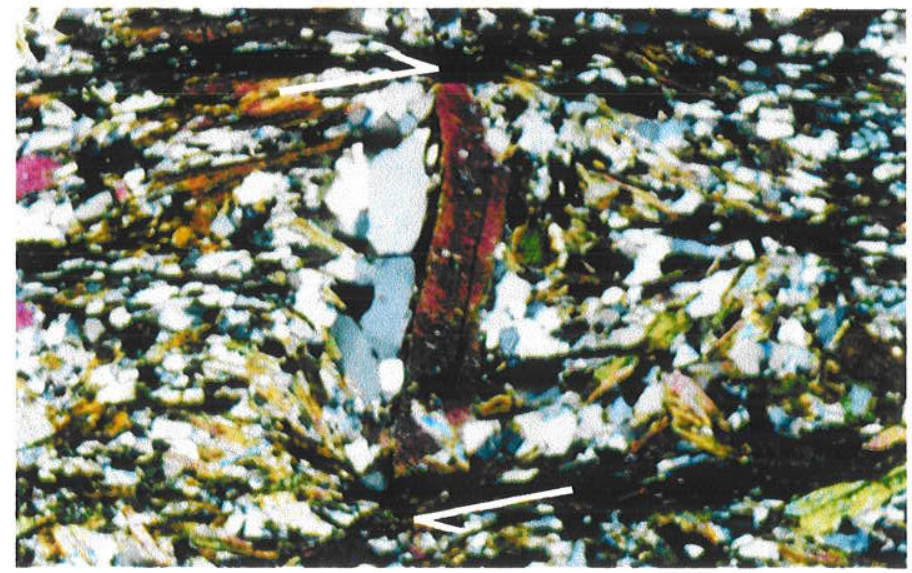

Foto 6 - Fotomicrografia (nicóis $\mathrm{X}$, aumento $50 \mathrm{x}$ ). Rotação de sombra de pressão em porfiroclasto de muscovita, indicando movimentação dextral. Amostra K-19 (corte XZ). 


\section{ROCHAS GRANITICAS}

Associados ao conjunto de rochas metassedimentares, ocorrem na região de Juquiá e a norte de Sete Barras, rochas graniticas deformadas, denominadas informalmente neste trabalho de Granito Sete Barras e Granito Juquiá respectivamente.

O Granito Sete Barras (amostra K-23, Mapa Geológico - Anexo 1), apresenta-se como um stock granítico de aproximadamente $24 \mathrm{~km}^{2}$, de formato estirado, com orientação de seu eixo maior em torno de N60E. São granitos foliados, leucocráticos, de cor acinzentada e granulação média. São inequigranulares, com cristais maiores de feldspato branco, apresentando biotita e muscovita como minerais máficos.

O Granito Juquiá (amostra K-20, Mapa Geológico - Anexo 1), localiza-se no contexto dos Granitóides de Fácies Cantareira (Hasui et al., 1978), mapeado por Dantas et al., 1987. Apresenta, na região estudada, uma área de aproximadamente $45 \mathrm{~km}^{2}$, mostrando-se extremamente estirado na direção em torno de N70E. São granitos deformados, de cor cinza, com porções porfiríticas, a megacristais de feldspato branco retangulares a ocelares, que chegam a $3 \times 1 \mathrm{~cm}$, em matriz cinza escura, ricos em biotita, e com presença de muscovita (Prancha 2, Foto 1).

Os contatos observados com as rochas encaixantes metassedimentares são tectônicos, limitados por faixas miloníticas.

Ambos granitos podem apresentar textura protomilonitica, caracterizada pela orientação de porfiroclastos de feldspato branco com formato sigmoidal e orientação dos minerais máficos.

O Granito Juquiá, localmente está em contato com rocha granitóide de granulação grossa, cor de alteração rósea a megacristais de feldspato branco de até $5 \times 3 \mathrm{~cm}$ (direção de contato N-S/67 E).

A foliação protomilonítica apresenta orientação em torno de E-W, subvertical, e desenvolve uma lineação mineral (estiramento de feldspato branco e orientação de cristais de biotita) com caimento para $W$ (Figura 5.2.3). Os indicadores cinemáticos para os falhamentos que balizam estes corpos graníticos (Mapa Estrutural - Anexo 2), sugerem movimentação dextral. 


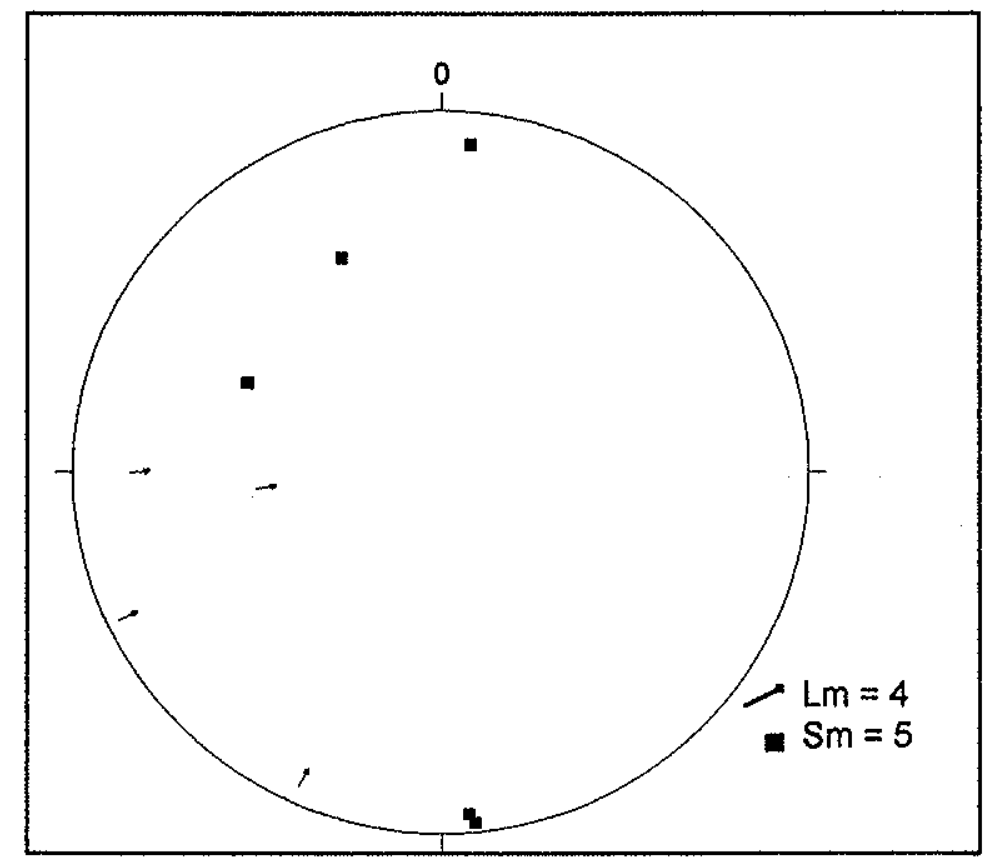

Figura 5.2.3 - Bloco Embu - Biotita Monzogranitos. Foliação milonítica e lineações de estiramento mineral.

Petrograficamente, os Granitos Juquiá e Sete Barras são semelhantes, apresentando apenas algumas diferenças, que serão destacadas a seguir. Caracterizam-se por monzogranitos a duas micas, cujos minerais constituintes principais são quartzo, microclínio, oligoclásio, biotita e muscovita. Como acessórios comuns apresentam granada, zircão e monazita. O Granito Sete Barras também apresenta turmalina e allanita, e o Granito Juquiá presença rara de titanita.

Em seção delgada a foliação protomilonítica é definida pela orientação de porfiroclastos cominuídos de microclínio e plagioclásio, e por bandas contínuas de quartzo (Prancha 2, Foto 2).

Os grãos de quartzo tendem a se segregar em bandas contínuas, bastante estirados. Mostram-se com extinção ondulante e contatos serrilhados (Prancha 2, Foto 3). Também ocorrem como agregados microgranulares, fornecendo à rocha porções localizadas de granulação bem fina.

Os cristais de microclínio formam porfiroclastos, e também estão na matriz. Normalmente são pertíticos (tipo filme, spot e mesopertítico). Apresentam-se fraturados e cominuídos, nos granitos que mostram 
deformação incipiente. Nos granitos mais deformados, com textura protomilonítica, os grãos de microclínio apresentam pequena recristalização nas bordas, desenvolvendo uma textura 'mortar' discreta.

Cristais de oligoclásio formam porfiroclastos, menores que os cristais de microclínio, e também estão presentes na matriz. Estão saussuritizados e normalmente com deformação nas maclas, ondulada ou em cunha. No Granito Juquiá, apresentam formações mirmequíticas nas bordas.

No Granito Juquiá os cristais de biotita apresentam pleocroísmo de amarelo-claro a marrom avermelhado, e alteram-se para cloritas. No Granito Sete Barras, duas gerações de biotitas são reconhecidas. Uma com pleocroísmo de amarelo-claro a marrom escuro avermelhado, normalmente subeuedrais. Outra caracteristicamente com pleocroísmo amarelo-claro a verde-amarronzado, intercrescida com microclínio (Prancha 2, Foto 3), normalmente intersticiais, podendo alterar-se para muscovita.

Os cristais de muscovita mostram-se bastante desenvolvidos, normalmente subeuedrais a euedrais, com forte extinção ondulante (Prancha 2, Foto 4). Podem apresentar alteração para cloritas.

Os cristais de granada normalmente estão fraturados, na matriz associam-se às muscovitas, ou como inclusões em microclínio.

Cristais de turmalina normalmente anedrais ocorrem no Granito Sete Barras, e apresentam cor azulada (Prancha 2, Foto 5).

As indicações cinemáticas observadas em seção delgada referem-se a sigmóides de porfiroclastos de microclínio, de quartzo e muscovita (Prancha 2, Foto 4) e porfiroclastos de granada com sombras de pressão (biotita + quartzo), indicando movimentação dextral (Prancha 2, Foto 6). 


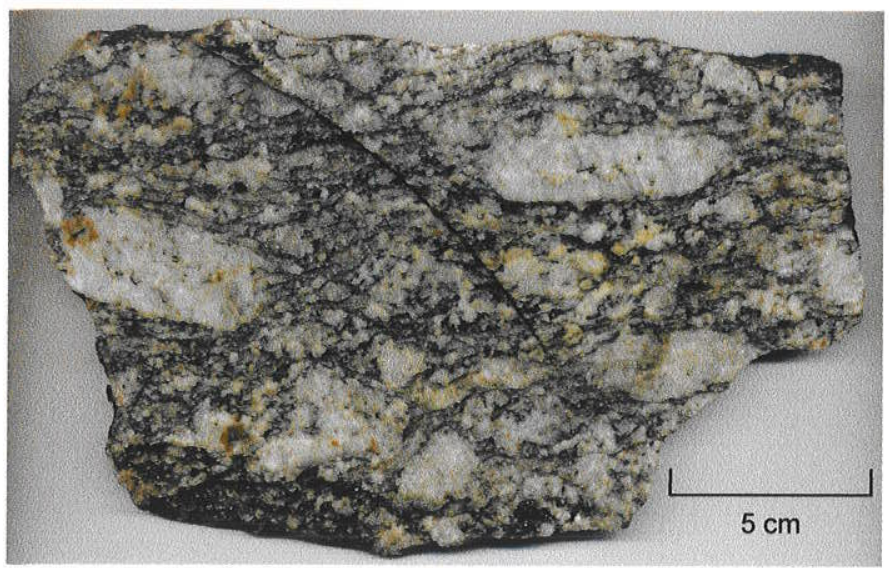

Foto 1 - Fatia de Biotita Monzogranito protomilonítico a megacristais de feldspato branco. Amostra K-20 (corte XZ). Granito Juquiá.

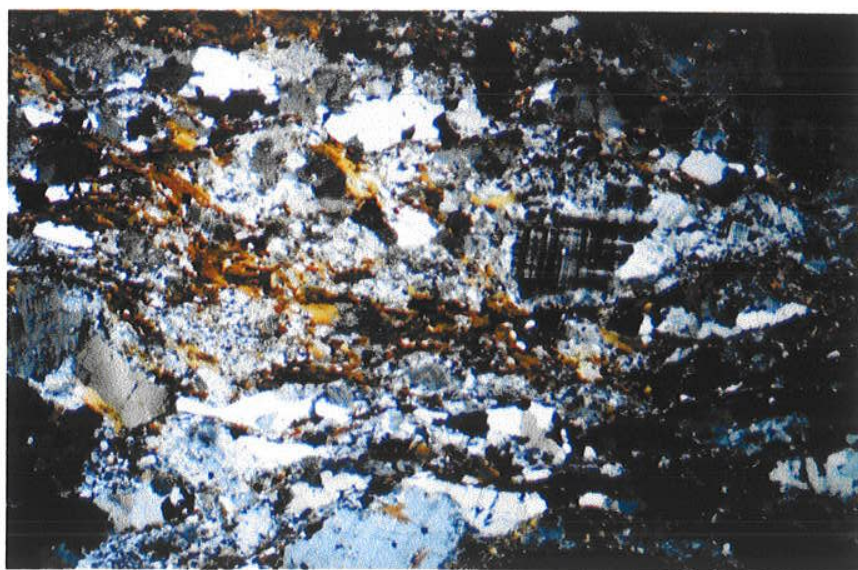

Foto 2 - Fotomicrografia (nicóis $\mathrm{X}$, aumento $7.5 \mathrm{x}$ ). Textura protomilonítica de Biotita monzogranito com granada. Amostra K-20 (corte XZ). Granito Juquiá.

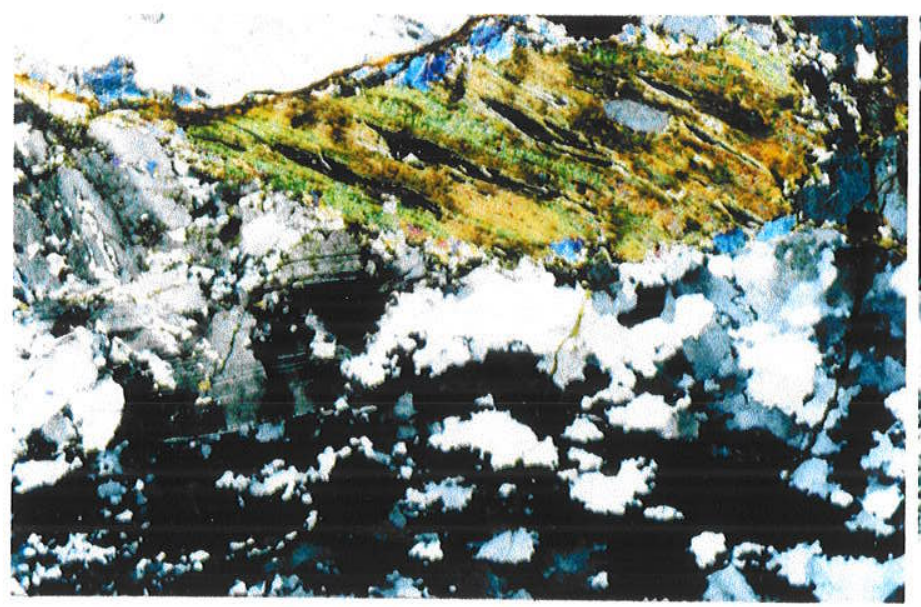

Foto 3 - Fotomicrografia (nicóis $X$, aumento $50 \mathrm{x}$ ). Protomilonito de Biotita monzogranito com granada e turmalina, com presença de biotita intercrescida com feldspato potássico. Amostra K-24 (corte XZ) Granito Sete Barras.

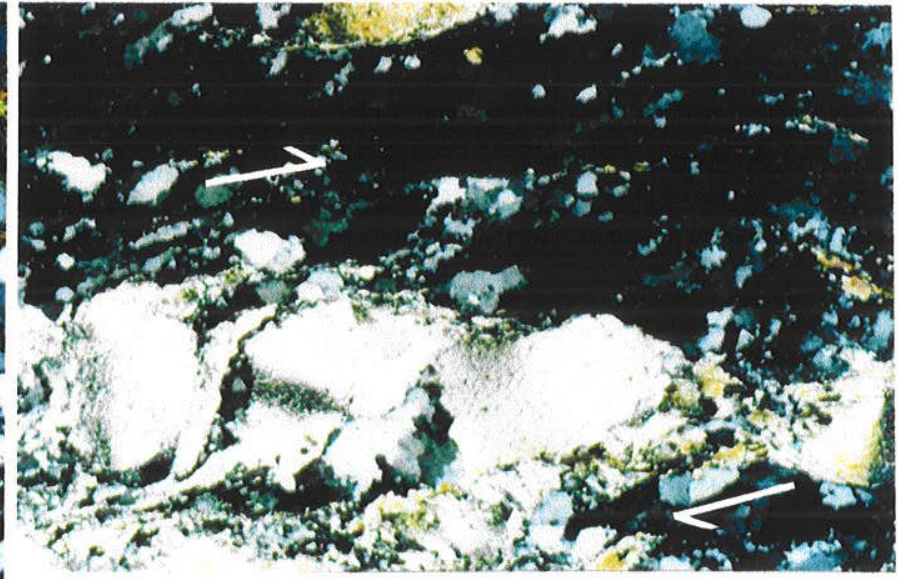

Foto 4 - Fotomicrografia (nicóis $\mathrm{X}$, aumento $50 \mathrm{x}$ ). Protomilonito de Biotita monzogranito com granada e turmalina, com porfiroclastos de muscovitas sigmoidais. Movimentação dextral. Amostra K-24 (corte XZ) Granito Sete Barras.

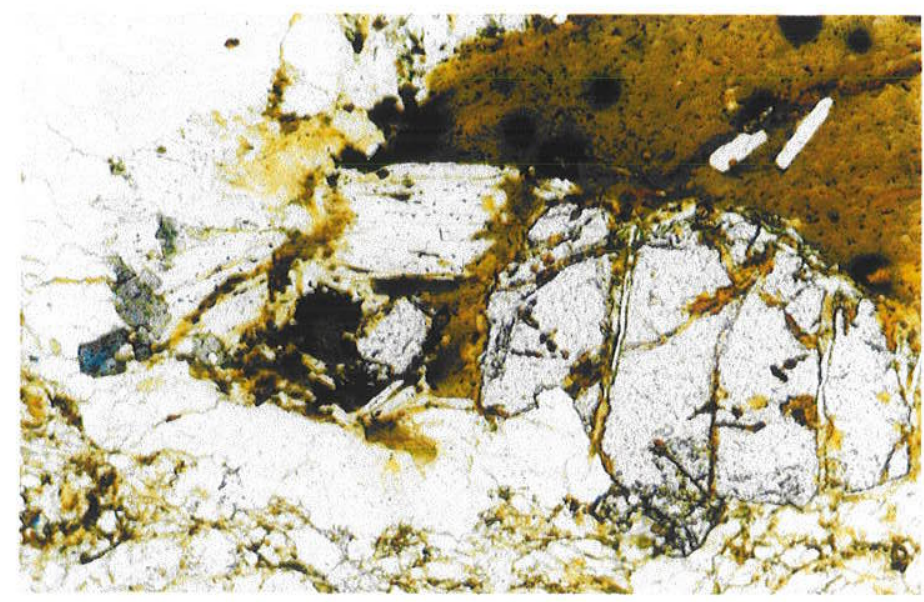

Foto 5 - Fotomicrografia (nicóis //, aumento $100 \mathrm{x}$ ). Protomilonito de Biotita monzogranito. Granada fraturada preenchida por quartzo, turmalina azul anedral, e cristais de monazita em biotita desenvolvendo halos pleocróicos. Amostra K-24 (corte YZ).

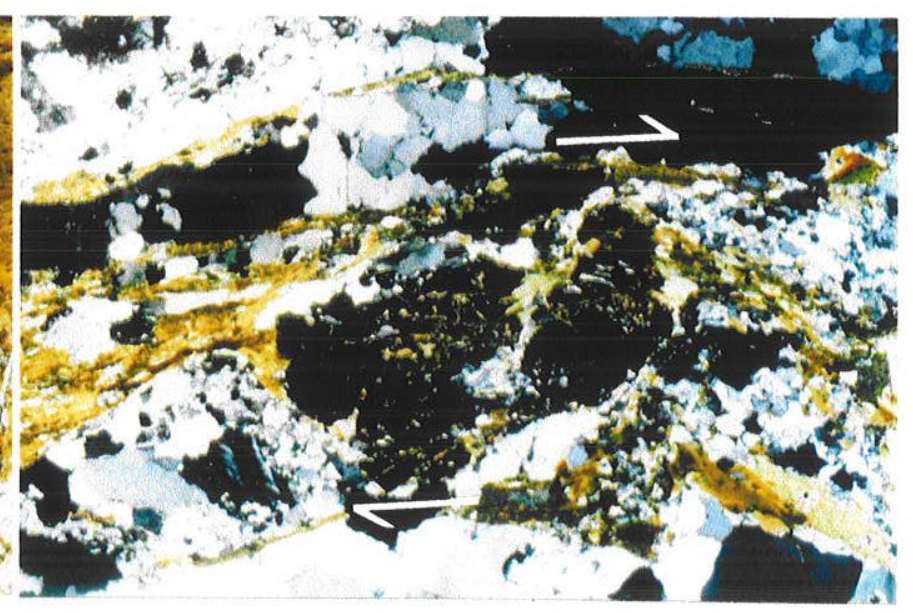

Foto 6 - Fotomicrografia (nicóis $X$, aumento $25 \mathrm{x}$ ). Protomilonito de Biotita monzogranito com porfiroclasto de granada desenvolvendo sombra de pressão composta por quartzo e biotita, indicando movimento dextral. Amostra K-20 (corte XZ). Granito Juquiá. 
Nas rochas graníticas deformadas, foram realizadas análises pelo Método de Fry (Fry, 1979, 1999), em seções delgadas e em fatias de rochas orientadas, nos cortes $X Z$ e YZ do elipsóide de deformação. Uma análise é referente ao corpo granítico de Juquiá $(\mathrm{K}-20)$ e outras duas ao corpo granítico a norte de Sete Barras (K-23; K-24).

Através do Método de Fry obtém-se os valores das elipsidades, ou seja, das razões entre os eixos principais das elipses de cada plano ( $X Z$ e $Y Z$ ), denominadas respectivamente de $R x z$ e Ryz, bem como a orientação dos eixos principais do elipsóide de deformação (Tabela 5.2.1). Através da obtenção destes elementos, juntamente com a orientação da superfície milonítica da amostra analisada pode-se obter a indicação cinemática mais provável.

Este método possibilita principalmente uma análise qualitativa da taxa de deformação obtida nos diferentes litotipos analisados, e a observação do comportamento espacial da taxa de deformação.

\begin{tabular}{|c|c|c|c|c|c|c|c|}
\hline \multirow{2}{*}{ AMOSTRA } & \multirow[b]{2}{*}{ ROCHA } & \multirow{2}{*}{ SM } & \multirow{2}{*}{ LM } & \multicolumn{3}{|c|}{ EIXOS DO ELLIPSÓIDE DE DEFORMAÇĀO } & \multirow[b]{2}{*}{ MOVIMENTO } \\
\hline & & & & EIXoX & EixoY & EixoZ & \\
\hline $\mathrm{K}-20$ & $\begin{array}{c}\text { Protomilonito } \\
\text { granítico }\end{array}$ & N85E/85NW & S85W/52 & S62W/47 & N49E/34 & N28W26 & dextral \\
\hline $\mathrm{K}-23$ & $\begin{array}{c}\text { Granito } \\
\text { deformado }\end{array}$ & N25E/49SE & S57E/48 & S14E/6 & N32E/59 & $576 W / 40$ & dextral \\
\hline $\mathrm{K}-24$ & $\begin{array}{c}\text { Protomilonito } \\
\text { granítico }\end{array}$ & N65E/55SE & $565 \mathrm{~W} / 9$ & S68W/27 & $\mathrm{S} 52 \mathrm{E} / 54$ & $\mathrm{~N} 22 \mathrm{~W} / 23$ & dextral \\
\hline
\end{tabular}

Tabela 5.2.1 - Direção da foliação milonítica e lineação de estiramento mineral das amostras analisadas e orientação dos eixos do elipsóide de deformação obtidos pelo Método de Fry.

Como pode ser observado na Tabela 5.2.1, houve grande concordância nas rochas protomiloníticas entre as orientações do eixo $X$ do elipsóide de deformação (direção de máxima extensão) e as lineações de estiramento minerais medidas nos afloramentos, concentrando-se em torno de $560 \mathrm{~W}$. A direção de máxima compressão (eixo Z) concentrou-se em torno de N25W.

A Figura 5.2.4 mostra as elipses e seus respectivos eixos principais obtidos pelo método de Fry. A posição do traço da foliação milonítica nos cortes $X Z$ e YZ é 
vertical, e a horizontal da direção de cada corte, bem como sua orientação estão indicados na porção superior de cada figura.

O posicionamento das elipses de deformação em relação à foliação milonítica sugere movimentações dextrais em todas amostras analisadas, e razoável deformação associada, devido às elipsidades observadas. A menor taxa deformação associada refere-se à amostra K-23, com valores mais baixos de Rxz. Por tratar-se de rochas pouco deformadas, as elipses podem apresentar uma fraca definição.

O posicionamento espacial das elipses de deformação obtidas, pode ser observado em Mapa Estrutural - Anexo 2.

As elipsidades obtidas pelo Método de Fry, Tabela 5.2.2, consequentemente puderam ser utilizados para obtenção dos parâmetros necessários (Rxy, $K, D)$ para confecção do Diagrama de Flinn (Figura 5.2.5).

\begin{tabular}{|c|c|c|c|c|c|c|c|}
\hline AMOSTRA & $\mathbf{R X Z}$ & $\mathbf{R Y Z}$ & $\mathbf{R X Y}$ & $\mathbf{K}$ & $\mathbf{D}$ & ELIPSÓIDE & DIAGRAMA DE FLINN \\
\hline K-20 & 1.9 & 1.4 & 1.35 & 0.97 & 0.5 & Triaxial & Deformação plana \\
\hline K-23 & 1.5 & 1.2 & 1.25 & 1.25 & 0.32 & Triaxial & Deformação plana \\
\hline K-24 & 2.5 & 1.4 & 1.8 & 2.0 & 0.90 & Prolato & Constricão aparente \\
\hline
\end{tabular}

Tabela 5.2.2 - Dados obtidos pelo método de Fry e aplicação de Diagrama de Flinn.

$\mathrm{O}$ parâmetro $\mathrm{K}$ define a posição geral da plotagem do elipsóide: $\mathrm{K}=(\mathrm{R} x \mathrm{y}$ 1/Ryz-1). Elipsóides com valores $0<K<1$, são oblatos e posicionam-se no campo do achatamento aparente; com valores de $\mathrm{K}=0$, posicionam-se no campo do achatamento uniaxial e valores $1<\mathrm{K}<\infty$ estão relacionados a elipsóides prolatos, do campo da constricção aparente.

O parâmetro $D$ relaciona-se à distância do ponto à origem: $D=\left\{(R x y-1)^{2}+\right.$ $\left.(R y z-1)^{2}\right\}^{1 / 2}$, e pode estar diretamente relacionado à taxa de deformação.

A utilização deste diagrama pode ser de grande utilidade na caracterização do padrão de deformação durante uma deformação progressiva. 

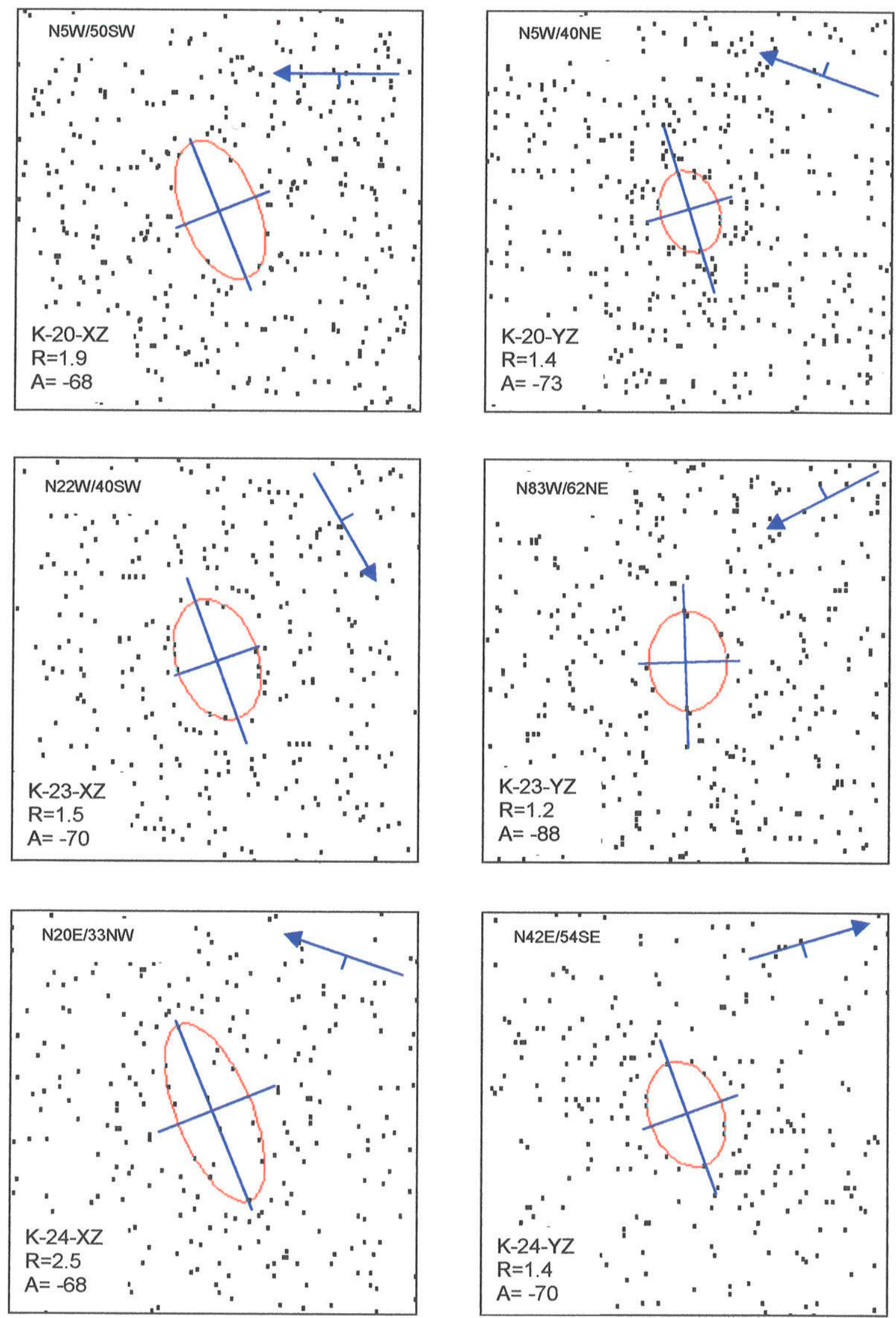

Figura 5.2.4 - Elipses obtidas pelo método de Fry em cortes XZ e YZ. Bloco Embu. 


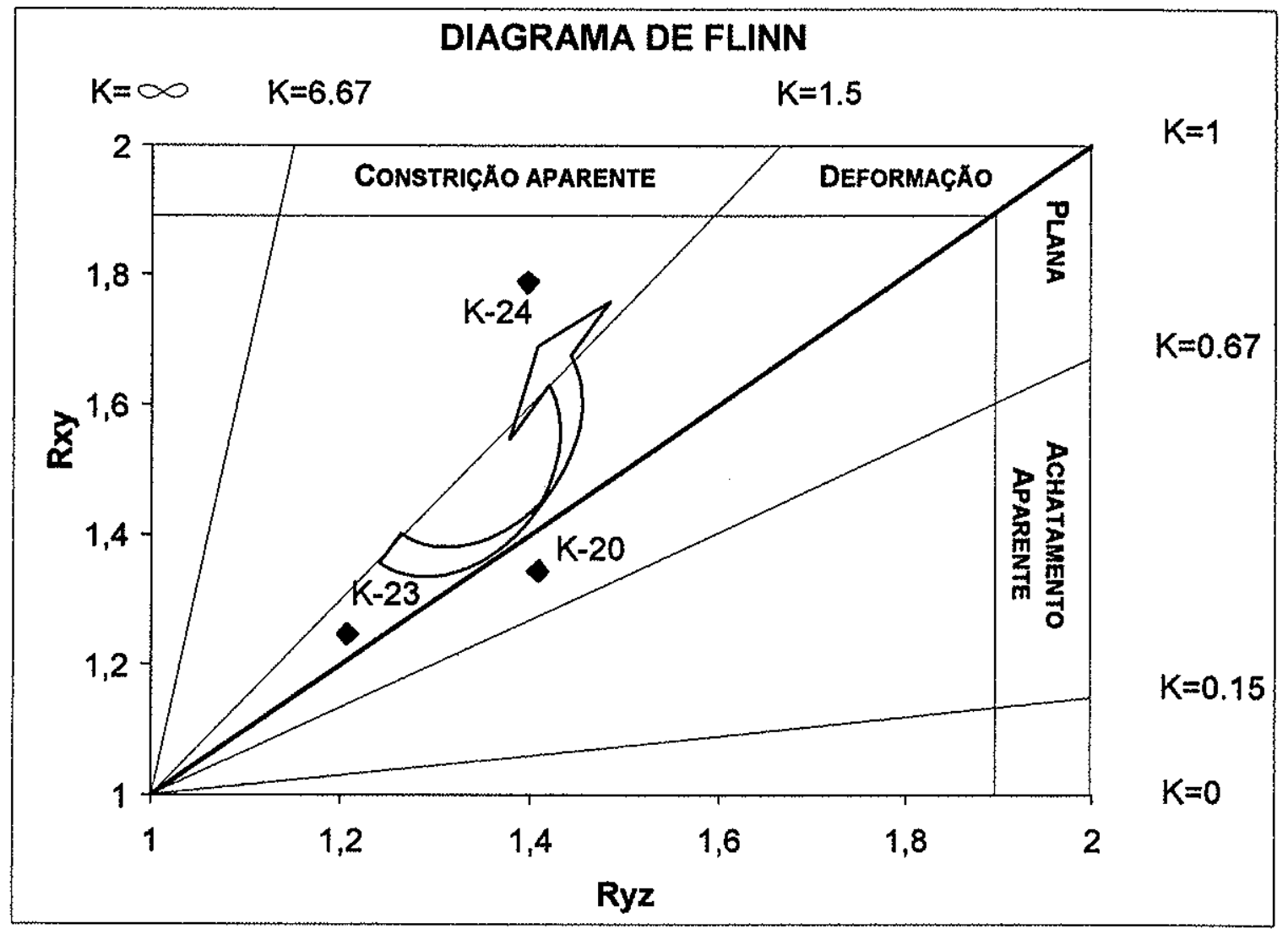

Figura 5.2.5 - Diagrama de Flinn. Granitos deformados Bloco Embu.

Através dos resultados obtidos pode-se sugerir um aumento da taxa deformação acompanhado pelo aumento de volume (campo da constricção aparente).

Um dos granitos a norte de Sete Barras (K-24) mostrou-se mais deformado que os demais (valor maior de $D$, maior elipsidade) e posiciona-se no campo dos elipsóides prolatos. Este campo refere-se ao da constrição aparente, que por sua vez associa-se a deformação acompanhada por aumento de volume.

O granito Sete Barras (K-23), que mostrou-se menos deformado que os demais, e o Granito Juquiá (K-20), apresentam elipsóides triaxiais, no campo da deformação plana, onde não há perda ou ganho no volume. Neste caso o estiramento na direção $X$ é compensado pelo achatamento na direção $Z$, não havendo nenhuma modificação na direção intermediária $Y$.

Tais resultados podem indicar que estas rochas registraram uma deformaçäo associada principalmente a um cisalhamento simples, nas suas taxas mais baixas. 


\subsection{CaRActerização Geoquímica das Rochas Graniticas}

Foram realizadas análises geoquímicas de elementos maiores, traços e Terras Raras (ETR) em apenas duas amostras das rochas graníticas do Bloco Embu, referentes ao Granito Juquiá (biotita-muscovita monzogranito com granada, K-20) e Granito Sete Barras (biotita-muscovita-monzogranito com granada e turmalina, K23). Ressalta-se que as rochas aqui investigadas representam os litotipos graníticos predominantes do Bloco Embu na área estudada. A localização dos afloramentos das amostras quimicamente analisadas, estão plotadas no Mapa Geológico (Anexo 1) e os resultados obtidos encontram-se listados no Apêndice 1.

As rochas analisadas dos Granitos Juquiá e Sete Barras caracterizam-se por granitos com elevado teor de $\mathrm{SiO}_{2}$, respectivamente com 70,43\% e 75,95\%.

Ambos granitos mostram caráter peraluminoso (Figura 5.3.1), com índice de saturação em alumínio entre 1.03 e 1.1 aproximadamente. Petrograficamente, o caráter peraluminoso destes granitos é indicado pela presença de muscovita, granada, turmalina e monazita.

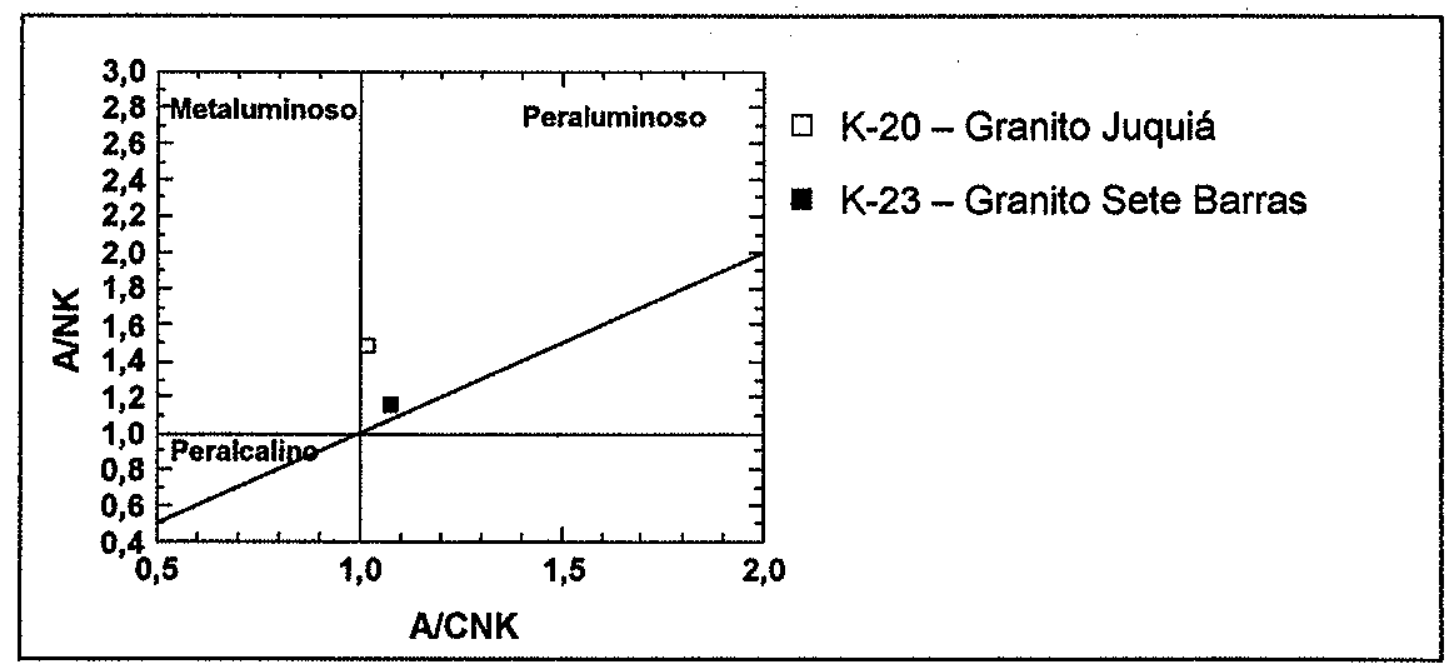

Figura 5.3.1 - Diagrama de razões moleculares A/CNK x ANK (Maniar \& Piccoli, 1989) dos Granitos Juquiá e Sete Barras - Bloco Embu.

Em relação aos principais elementos maiores, observa-se, entre o Granito Juquiá $\left(\mathrm{SiO}_{2}=70,43 \%\right)$ e o Granito Sete Barras $\left(\mathrm{SiO}_{2}=75,95 \%\right)$ respectivamente, uma diminuição esperada dos teores dos óxidos de $\mathrm{Ti}(0,32$ a $0,02 \%)$, Fe (3 a 1\%), $\mathrm{Mg}(0,80$ a 0,04$), \mathrm{P}(0,14$ a 0,03$)$ e $\mathrm{Ca}(2,4$ a 0,4$)$ com o aumento do teor de $\mathrm{SiO}_{2}$ os teores desses elementos diminuem com 0 aumento ambos granitos apresentam 
valores similares de $\mathrm{K}_{2} \mathrm{O}$, em torno de $4.6 \%$, caracterizando-se como rochas pertencentes à séries potássicas $\left(\mathrm{Na}_{2} \mathrm{O} \times \mathrm{K}_{2} \mathrm{O}\right)$ ou de alto potássio $\left(\mathrm{SiO}_{2} \times \mathrm{K}_{2} \mathrm{O}\right)$, e valores distintos de $\mathrm{CaO}(2.41$ e 0.47$)$ e $\mathrm{Na}_{2} \mathrm{O}$ (2.85 e 4.03), para os granitos de Juquiá (K-20) e de Sete Barras (K-23) respectivamente.

O Granito Sete Barras mostra caracteristicamente valores baixos de $\mathrm{Ba}(23$ $\mathrm{ppm})$ e $\mathrm{Sr}(9 \mathrm{ppm})$ e altos de $\mathrm{Rb}(477 \mathrm{ppm})$ e $\mathrm{Pb}(27 \mathrm{ppm})$, enquanto o Granito Juquiá apresenta teores mais elevados de $\mathrm{Ba}(420 \mathrm{ppm}), \mathrm{Sr}(244 \mathrm{ppm})$ e $\mathrm{Pb}(37$ $\mathrm{ppm})$, e menores de $\mathrm{Rb}(211 \mathrm{ppm})$.

Comportamento bastante distinto, das amostras representativas dos granitos analisados, também pode ser observado em Diagramas de perfis de ETR, normalizados aos valores do condrito por Nakamura, 1974.

O Granito Juquiá (K-20) apresenta um razoável enriquecimento e fracionamento de ETRL em relação aos ETRP $[\mathrm{La}(200) / \mathrm{Yb}(7)] \mathrm{N} \sim 29$ (Figura 5.3.2). Padrão totalmente distinto é observado para o Granito Sete Barras (K-23) que mostra uma fracionamento muito fraco de ETRL em relação aos ETRP, $[\mathrm{La}(60) / \mathrm{Yb}(26)$ ]N $\sim 2$, e notável enriquecimento de ETRP, com valores de $\mathrm{Tb} \sim 26$ e Yb $\sim 13$ (Figura 5.3.2), com anomalia negativa marcante de Eu, caracterizando um padrão de rocha mais diferenciada em relação ao K-20.

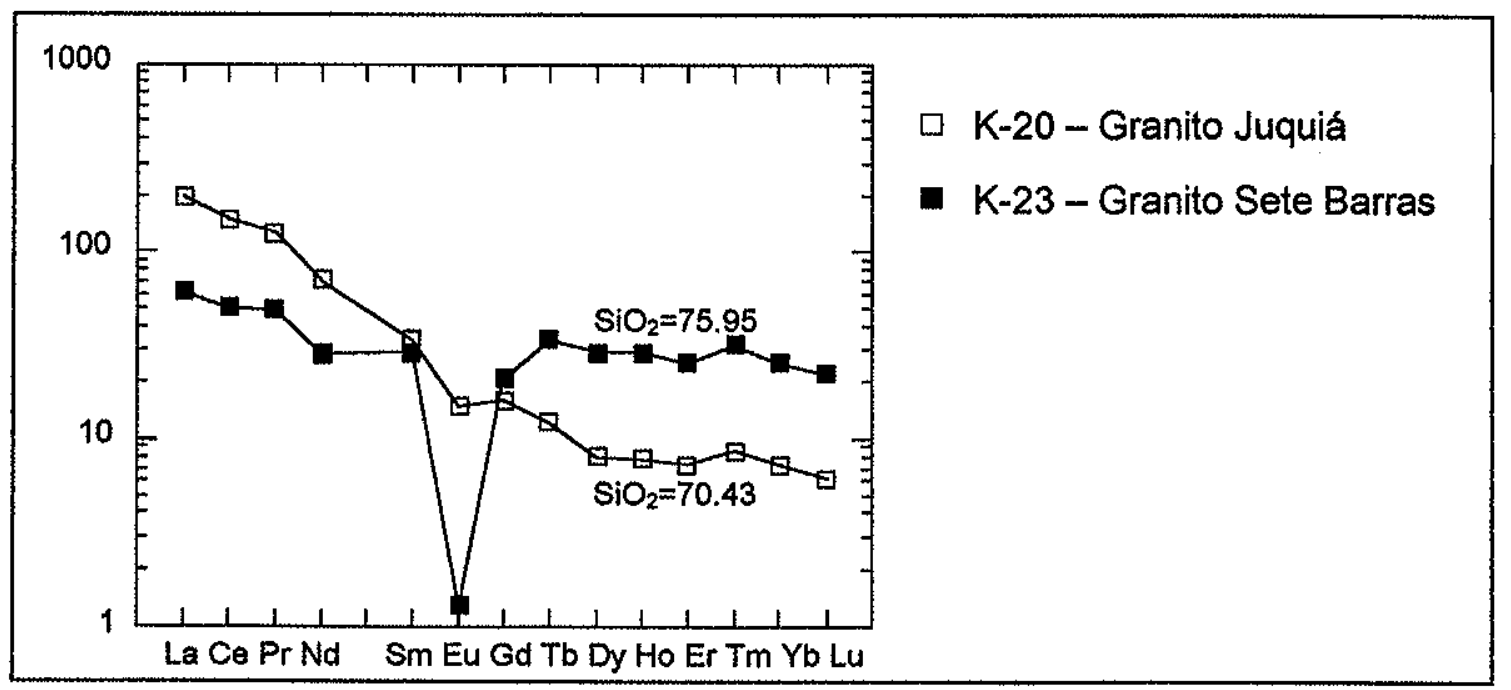

Figura 5.3.2 - Diagrama de ETR normalizado ao condrito (Nakamura, 1974).

Os Granitos Juquiá e Sete Barras, quando analisados em diagrama de variação de multielementos normalizados aos valores hipotéticos de granito de 
cadeia meso-oceânica (ORG), Pearce et al. (1984), apresentam semelhanças aos perfis de granitos sintectônicos (Pearce op. cit, Fig 1e).

Em relação aos granitos estudados pelo autor, o Granito Sete Barras apresenta anomalia negativa mais acentuada de $\mathrm{Ba}$, e teores mais altos de $\mathrm{Y}$, e o Granito Juquiá mostra teores relativamente mais altos em $\mathrm{Hf}$ e $\mathrm{Zr}$ (Figura 5.3.3).

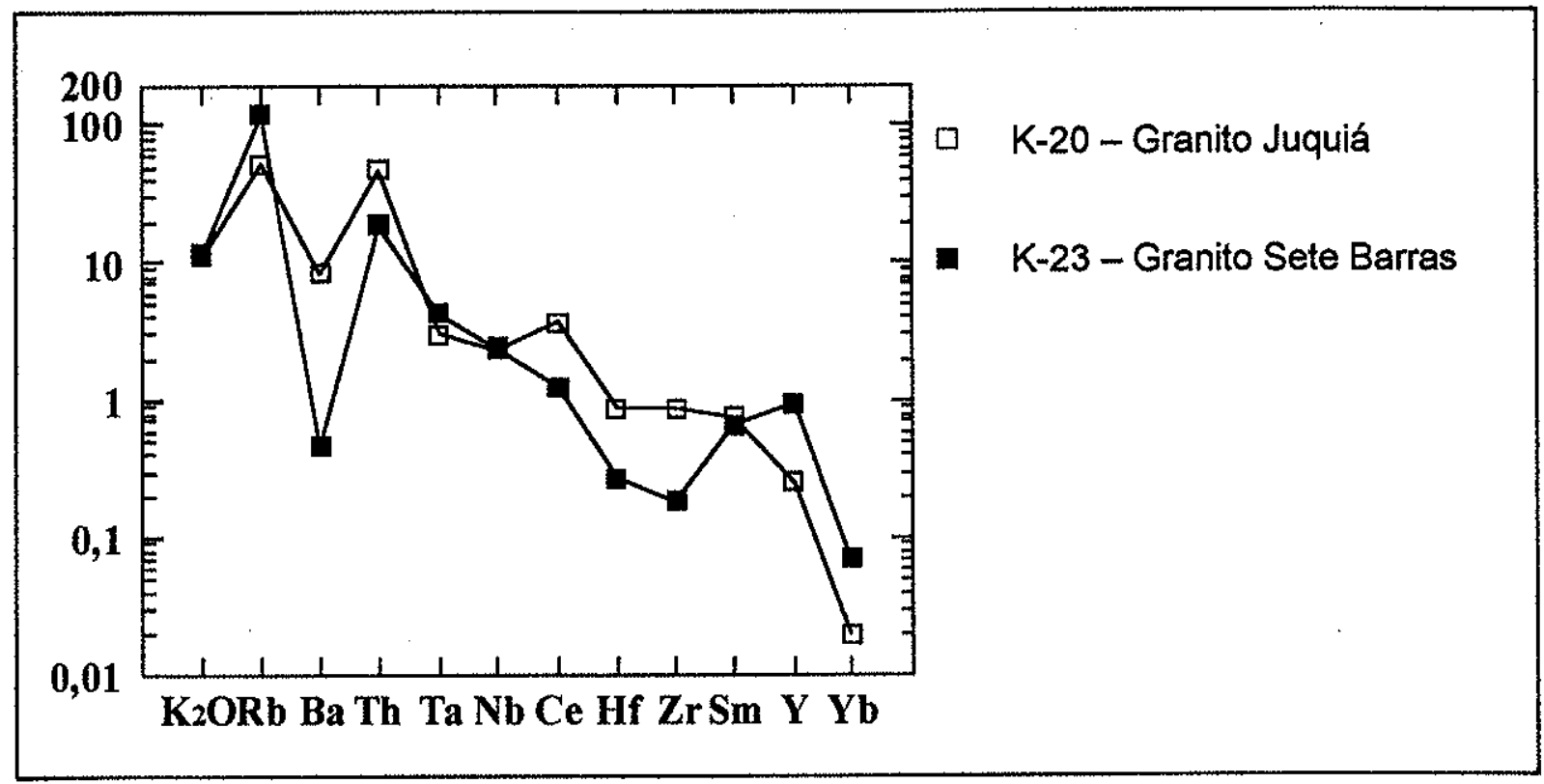

Figura 5.3.3 - Diagrama de variação de multielementos - Granito Juquiá e Sete Barras Bloco Embu, normalizados aos valores do ORG (Pearce et al., 1984).

Fortes indícios da origem destas rochas à partir de fontes supracrustais são encontrados, entretanto algumas diferenças e observações devem ser ressaltadas.

O Granito Sete Barras apresenta baixos valores de $\mathrm{Ba}, \mathrm{Sr}, \mathrm{CaO}$, e altos valores de $\mathrm{K}_{2} \mathrm{O}, \mathrm{Rb}$ e $\mathrm{Pb}$, fatores estes característicos de Granitos Tipo $\mathrm{S}$ (Chappell \& White, 1992), entretanto mostra valores mais elevados de $\mathrm{Na}_{2} \mathrm{O}$ daqueles observados pelos autores. Por outro lado, o Granito Juquiá apresenta baixos teores de $\mathrm{Na}_{2} \mathrm{O}$, e teores elevados de $\mathrm{Pb}$ e relativamente elevados de $\mathrm{Rb}$, condizentes com os valores médios observados em Granitos tipo $\mathrm{S}$, mas mostra teores bem mais elevados de $\mathrm{Ba}$ e $\mathrm{Sr}$. 


\subsection{GEOCRONOLOGIA E GEOLOGIA IsotóPICA}

\subsubsection{RESULTADOS U-PB (ZIRCÕES-MONAZITAS)}

Foram realizadas duas datações U-Pb em zircões referentes ao Granito Juquiá $(\mathrm{K}-20)$ e ao Granito Sete Barras (K-23). Por tratarem-se de granitos peraluminosos, com forte risco de possuírem zircões herdados, também foram realizadas datações U-Pb em monazitas para melhor controle da idade das rochas.

No Granito Juquiá (amostra K-20), biotita-muscovita monzogranito com granada, foram analisadas as frações magnéticas de zircões $M(-3), M(-4)$ e $N M(-5)$, abradadas (AA) e não abradadas (NA), com pesos em torno de $0.08 \mathrm{mg}$. As frações de zircões analisadas constituem-se por cristais euedrais transparentes, normalmente apresentando inclusões e fraturas. A razão média entre comprimento/largura está entre 4 e 6 (Foto 5.4.1.a).

Foram analisadas monazitas da fração magnética M 0.7 (amostra K-20), com peso de $0.009 \mathrm{mg}$. Foram selecionados cristais límpidos de cor amarelada, mas normalmente apresentando formas irregulares, possivelmente devido a 'alteração' do mineral (Foto 5.4.1b). Apresentam dados analíticos ruins, com baixa razão $\mathrm{Pb}^{206} / \mathrm{Pb}^{204}$, em torno de 194 (Tabela 5.4.1).

As razões isotópicas obtidas em zircões e monazitas são apresentadas na Tabela 5.4.1.

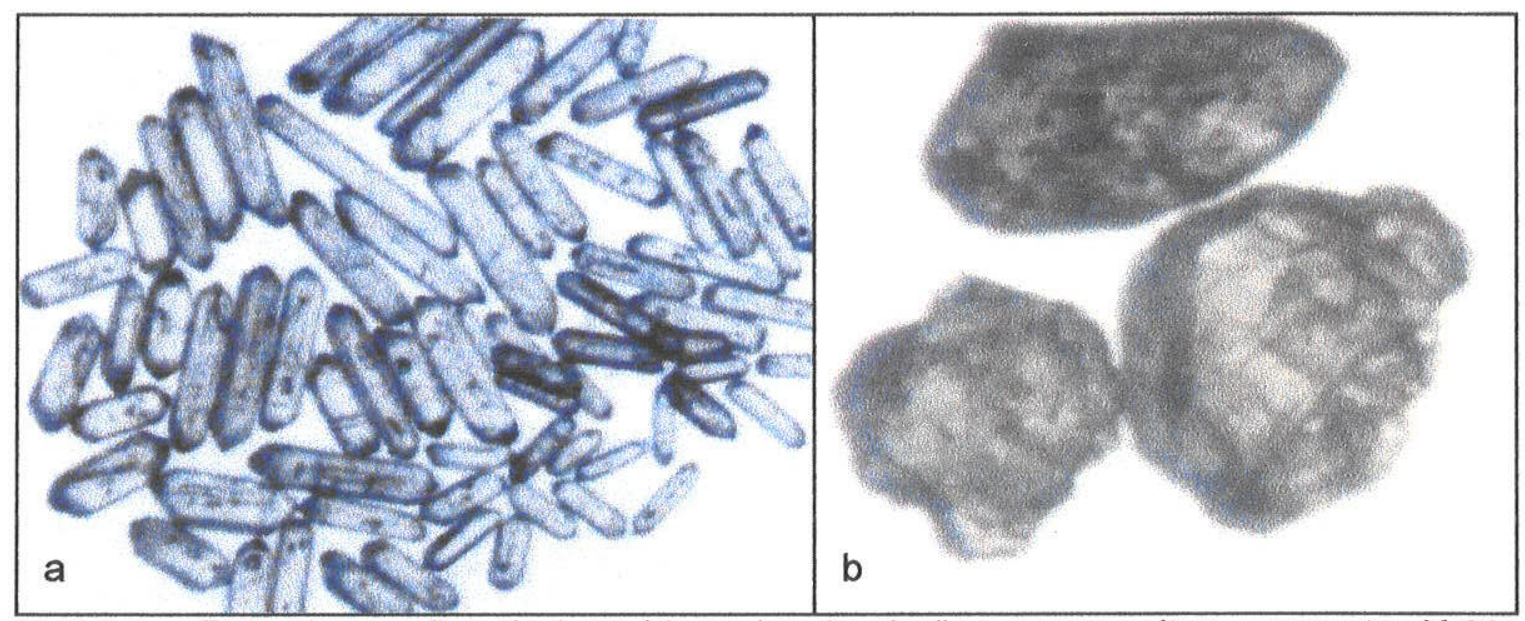

Foto 5.4.1 - Fotomicrografias de lupa binocular de zircões e monazitas - amostra K-20: a) cristais de zircão fração M-4, não abradada (aumento 107X); b) cristais de monazita fração M 0.7 (aumento $220 \mathrm{X}$ ). 
Em Diagrama Concórdia, as frações de zircões analisadas mostraram-se bem alinhadas resultando em idade, intercepto superior, de $761 \pm 2 \mathrm{Ma}$. A fração de monazita analisada, apesar de dados analíticos ruins, mostrou uma idade concordante em $598 \pm 8 \mathrm{Ma}$, interpretada como época de cristalização desta rocha (Figura 5.4.1).

Os resultados obtidos, sugerem que o Granito Juquiá apresenta zircões com heranças isotópicas neoproterozóicas, e provavelmente teve como época de cristalização a idade em torno de $600 \mathrm{Ma}$, obtida em monazitas.

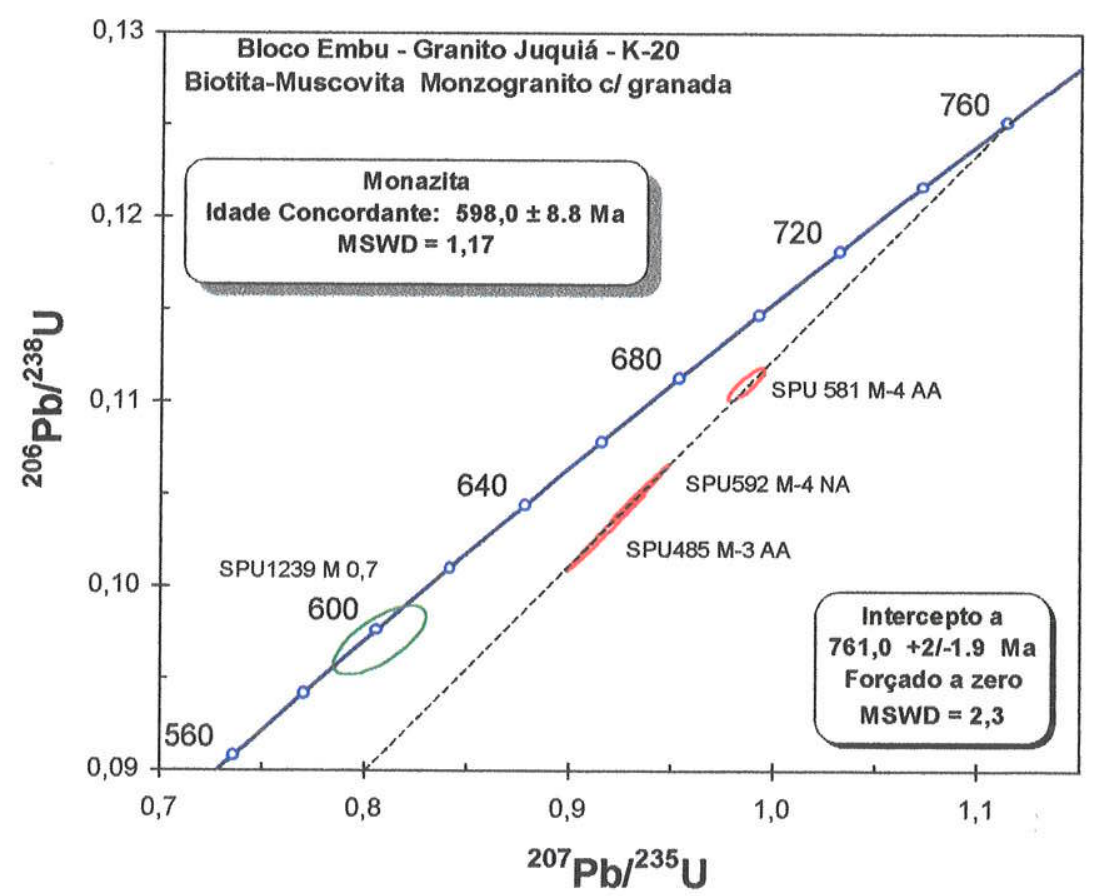

Figura 5.4.1 - Diagrama Concórdia ${ }^{207} \mathrm{~Pb} /{ }^{235} \mathrm{U} \times{ }^{206} \mathrm{~Pb} /{ }^{238} \mathrm{U}$ em zircões (vermelho) e monazita (verde), amostra K-20. Granito Juquiá - Bloco Embu. 
No Granito Sete Barras (amostra K-23), biotita-muscovita monzogranito com granada e turmalina, o conjunto de zircões analisados compreendeu as frações magnéticas $M(-1), M(-2), M(-3), M(-4)$, e $N M(-4) a, N M(-4) b$, não abradadas (NA), com pesos, para cada fração, em torno de $0.05 \mathrm{mg}$. As frações de zircões analisadas possuem cristais idiomórficos normalmente transparentes, por vezes com inclusões e fraturas, e razão média comprimento/largura em torno de 4 (Foto 5.4.2 a).

Foram atacadas monazitas da fração magnética M 0.6 da amostra K-23, com pesos em torno de $0.002 \mathrm{mg}$. Os cristais analisados são límpidos, bem formados e apresentam coloração amarela clara (Foto 5.4 .2 b). Apresentam dados analíticos ruins com razões $\mathrm{Pb}^{206} / \mathrm{Pb}^{204}$ muito baixas, de 33 e 83 (Tabela 5.4.1).

As razões isotópicas das frações magnéticas analisadas de zircões e monazitas utilizadas para o cálculo da idade U-Pb estão listadas na Tabela 5.4.1.

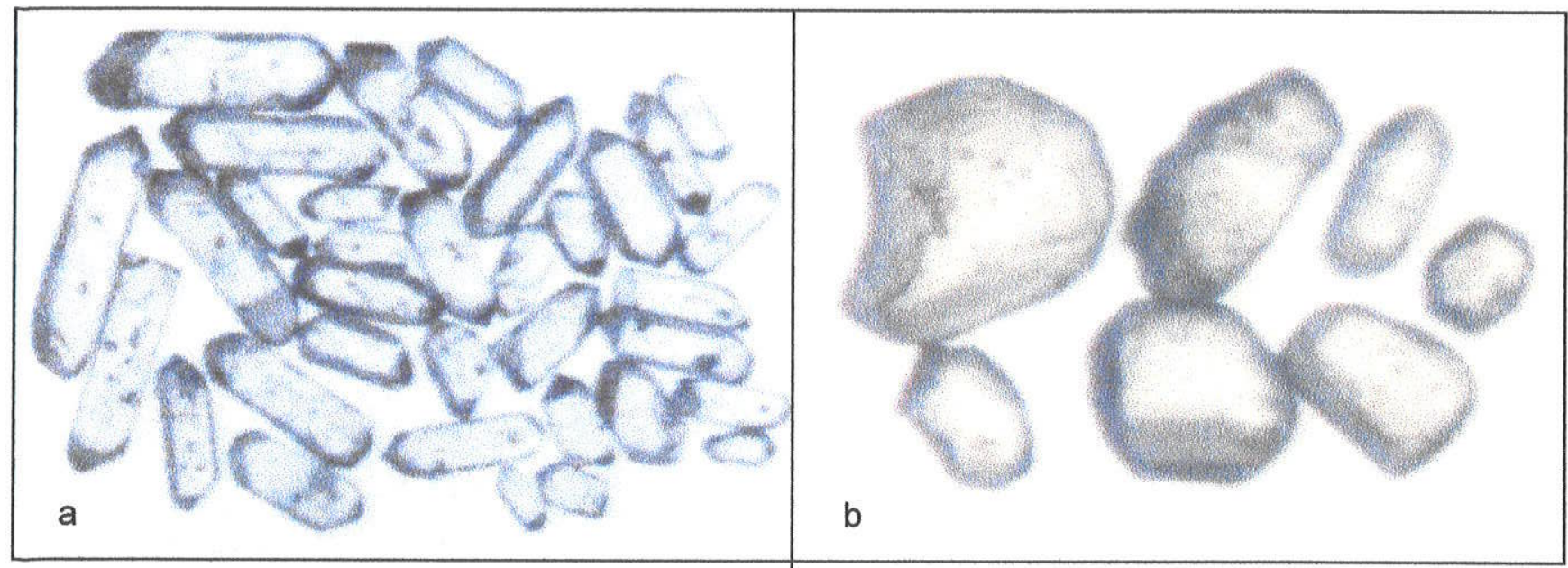

Foto 5.4.2 - Fotomicrografias de lupa binocular de zircões e monazitas - amostra K-23: a) cristais de zircão fração NM-4, não abradada (aumento 135X); b) cristais de monazita fração M0.6 (aumento $275 \mathrm{X}$ ).

Em Diagrama Concórdia (Figura 5.4.2), os pontos analíticos das frações de zircões analisadas, apresentam um alinhamento razoável, indicando uma idade imprecisa, intercepto superior de $739 \pm 63 \mathrm{Ma}$.

A fração NM(-4)b (SPU 1116) mostrou-se muito discordante, Figura 5.4.2, indicando uma forte componente de herança paleoproterozóica, com idade $\mathrm{Pb}^{207} / \mathrm{Pb}^{206}$ de $2.235 \pm 2.5 \mathrm{Ma}$. Esta população é caracteristicamente mais 
arredondada e mais escura, diferindo-se das demais populações de zircões analisadas.

As frações de monazitas analisadas, mostraram uma idade imprecisa, concordante em $631 \pm 23 \mathrm{Ma}$, época aproximada de cristalização desta rocha (Figura 5.4.2). Entretanto, esta idade deve der interpretada com ressalvas devido aos altos erros analíticos envolvidos nesta análise.

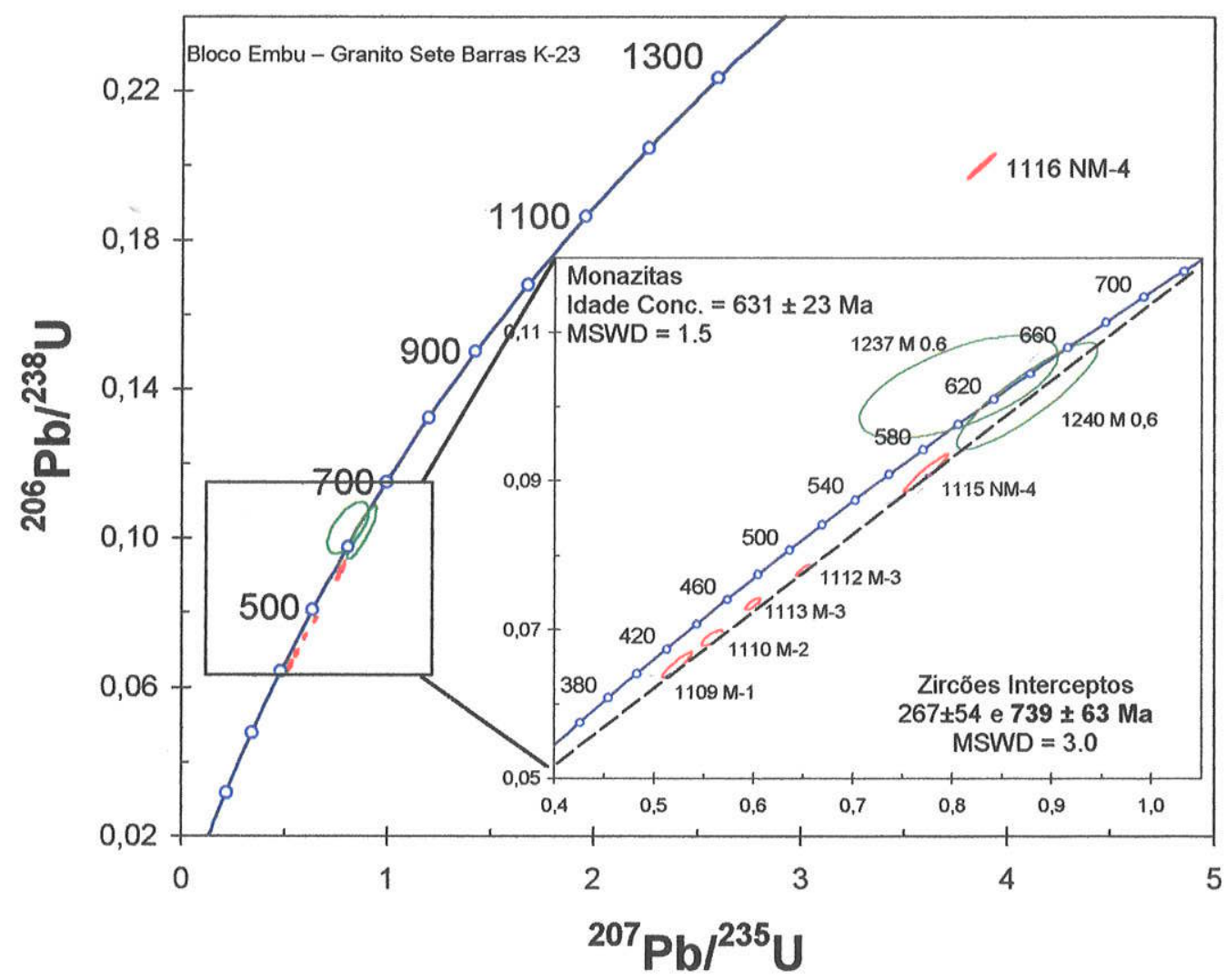

Figura 5.4.2 - Diagrama Concórdia ${ }^{207} \mathrm{~Pb} /{ }^{235} \mathrm{U} \times{ }^{206} \mathrm{~Pb} /{ }^{238} \mathrm{U}$ em zircões da amostra K-23. Granito Sete Barras - Bloco Embu.

Os resultados apresentados, indicam que os granitos peraluminosos do Bloco Embu, mostram importante herança isotópica neoproterozóica e possivelmente paleoproterozóica.

É interpretado aqui para época de cristalização destas rochas graníticas idades em torno de $600 \mathrm{Ma}$, obtidas em monazitas, apesar dos erros analíticos. As idades em torno de 740 - $760 \mathrm{Ma}$, obtidas em zircões, possivelmente refletem a forte herança isotópica presente nestes granitos. 
Tabela 5.4 .1

Dados analíticos referentes à Sistemática U.Pb (zircão e monazita) - Bloco Embu.

\begin{tabular}{|c|c|c|c|c|c|c|c|c|c|c|c|c|c|}
\hline \multicolumn{7}{|c|}{ Bloco Embu } & \multicolumn{4}{|c|}{ Razóes Isotopicas } & \multicolumn{3}{|c|}{ Idades (Ma) } \\
\hline Unidade & Amostra & $\begin{array}{c}\text { Mineral } \\
\text { Analisado }\end{array}$ & $\begin{array}{l}\text { Fraçäo } \\
\text { Magnética }\end{array}$ & $\begin{array}{l}\text { Peso } \\
\text { (mg) }\end{array}$ & $\underset{\text { (ppm }}{\mathbf{U}}$ & $\begin{array}{c}\mathbf{P b} \\
\text { (ppm) }\end{array}$ & $\begin{array}{l}\mathrm{Pb}^{205} \\
\mathrm{~Pb}^{204}\end{array}$ & $\mathrm{~Pb}^{201} \mathrm{~N}^{235}-\mathrm{ErrO} \%$ & $\mathrm{~Pb}^{205} / \mathrm{U}^{238}-\mathrm{Erro} \%$ & $\mathbf{P b}^{207} / \mathrm{PB}^{206}-\mathrm{Erro} \%$ & $\mathrm{~Pb}^{2358}$ & $\begin{array}{c}\mathrm{Pb}^{208} / \\
\mathrm{U}^{238}\end{array}$ & $\begin{array}{l}\mathrm{Pb}^{207} \mathrm{l} \\
\mathrm{Pb}^{206}\end{array}$ \\
\hline \multirow{4}{*}{$\begin{array}{l}\text { Granito } \\
\text { Juquiá }\end{array}$} & \multirow{4}{*}{$\mathrm{K}-20$} & zircäo & M-3aa & 0.084 & 17,20 & 189 & 1240.5 & $0.918054-1.76$ & $0.102949-1.76$ & $0.0646764-0.157$ & 661 & 632 & $764 \pm 3$ \\
\hline & & Zarcão & M-4aa & 0.116 & 519 & 62 & $1249 . B$ & $0.986368-0.746$ & $0.110942-0.646$ & $0.0644826-0.356$ & 697 & 678 & $756 \pm 8$ \\
\hline & & zircăo & $M-4$ & 0.099 & 1216 & 142 & 640.8 & $0.934410-1.26$ & $0.104984-1.25$ & $0.0645523-0.122$ & 670 & 844 & $760 \pm 3$ \\
\hline & & monazita & $M(0.7)$ & 0.009 & 522 & 808 & 193.8 & $0.807472-2.29$ & $0.0970091-1.59$ & $0.060369-1.64$ & 601 & 597 & $617 \pm 35$ \\
\hline \multirow{8}{*}{$\begin{array}{c}\text { Granito } \\
\text { Sete Barras }\end{array}$} & \multirow{8}{*}{$\mathrm{K}-23$} & zircão & $M-1$ & 0.021 & 272 & 20 & 326.8 & $0.523165-2.35$ & $0.0651211-2.19$ & $0.058266-0.827$ & 427 & 407 & $540 \pm 18$ \\
\hline & & 丸̆cāo & $\mathrm{M}-2$ & 0.050 & 226 & 18 & 400.2 & $0.558277-1.58$ & $0.0687619-1.22$ & $0.0588844-0.995$ & 450 & 429 & $563 \pm 22$ \\
\hline & & żrcão & $M-3 A$ & 0.057 & 287 & 24 & 724.9 & $0.650147-0.924$ & $0.0778242-0.829$ & $0.0605893-0.405$ & 509 & 483 & $625 \pm 9$ \\
\hline & & zirca & $\mathrm{M}-3 \mathrm{~B}$ & 0.048 & 420 & 35 & 508.8 & $0.599196-1.08$ & $0.0733012-0.872$ & $0.592865-0.632$ & 477 & 456 & $578 \pm 14$ \\
\hline & & Zircāo & $N M-4$ & 0.025 & 211 & 21 & 688.1 & $0.773066-2.37$ & $0.0909505-2.29$ & $0.0616468-0.603$ & 582 & 561 & $662 \pm 13$ \\
\hline & & zircáo & $N M-4 b$ & 0.063 & 167 & 39 & 1996.1 & $3.872240-1.38$ & $0.1997320-1.37$ & $0.140609-0.155$ & 1608 & 1174 & $2234 \pm 3$ \\
\hline & & monazita & $\mathrm{M}(0,6)$ & 0.0025 & 274 & 913 & 33,487 & $0,8063740-10.1$ & $0.1025730-5.52$ & $0,057017-7.96$ & 600 & 629 & $492 \pm 180$ \\
\hline & & monazita & $M(0,6)$ & 0.0014 & 693 & 1306 & 83,284 & $0.8749220-6.61$ & $0.1013340-5.79$ & $0,06262-3.08$ & 638 & 622 & $695 \pm 66$ \\
\hline
\end{tabular}




\subsubsection{GEOLOGIA ISOTÓPICA Nd-Sr}

Utilizando-se da sistemática Sm-Nd, os resultados obtidos da amostra K-20, Granito Juquiá (Tabela 5.4.2), quando plotados em Diagrama de Evolução de $\mathrm{E} \mathrm{Nd}$, fornecem uma idade modelo TDM de $1.984 \mathrm{Ma}, \varepsilon \mathrm{Nd}(0)=-22.61$ e $\varepsilon \mathrm{Nd}(\mathrm{t}=750 \mathrm{Ma})$ $=-12.73$ (Figura 5.4.3). Os valores negativos de $\varepsilon \mathrm{Nd}(\mathrm{t}$ ) indicam uma origem crustal para os protólitos destes granitos, e negativos de $\varepsilon \mathrm{Nd}(0)$ um tempo relativamente longo de residência crustal destas rochas.

A análise realizada em amostra do Granito Sete Barras mostrou problemas analíticos, impossibilitando o cálculo da idade TDM e obtenção dos valores de $\varepsilon \mathrm{Nd}$.

\begin{tabular}{|l|l|l|l|l|l|l|l|l|l|l|l|l|}
\hline SPS & $\begin{array}{l}\mathrm{N}^{\circ} \\
\text { campo }\end{array}$ & $\begin{array}{l}\mathrm{Sm} \\
(\mathrm{ppm})\end{array}$ & $\begin{array}{l}\mathrm{Nd} \\
(\mathrm{ppm})\end{array}$ & $\begin{array}{l}147 \\
{ }^{14} \mathrm{Sm} /\end{array}$ & Erro & $\begin{array}{l}{ }^{443} \mathrm{Nd} / \\
{ }^{144} \mathrm{Nd}\end{array}$ & Erro & F Sm/Nd & $\begin{array}{l}\text { T De } \\
\text { Paolo }\end{array}$ & Erro & $\varepsilon(0)$ & $\begin{array}{l}\varepsilon \mathrm{Nd}(\mathrm{t}) \\
(600 \mathrm{Ma})\end{array}$ \\
\hline 1746 & $\mathrm{~K}-20$ & 7.852 & 50.816 & 0.0934 & 0.0003 & 0.511479 & 0.000017 & -0.52 & 1983.9 & 20.8 & -22.61 & -14.71 \\
\hline
\end{tabular}

Tabela 5.4.2 -Dados analíticos da sistemática Sm-Nd para o Granito Juquiá.

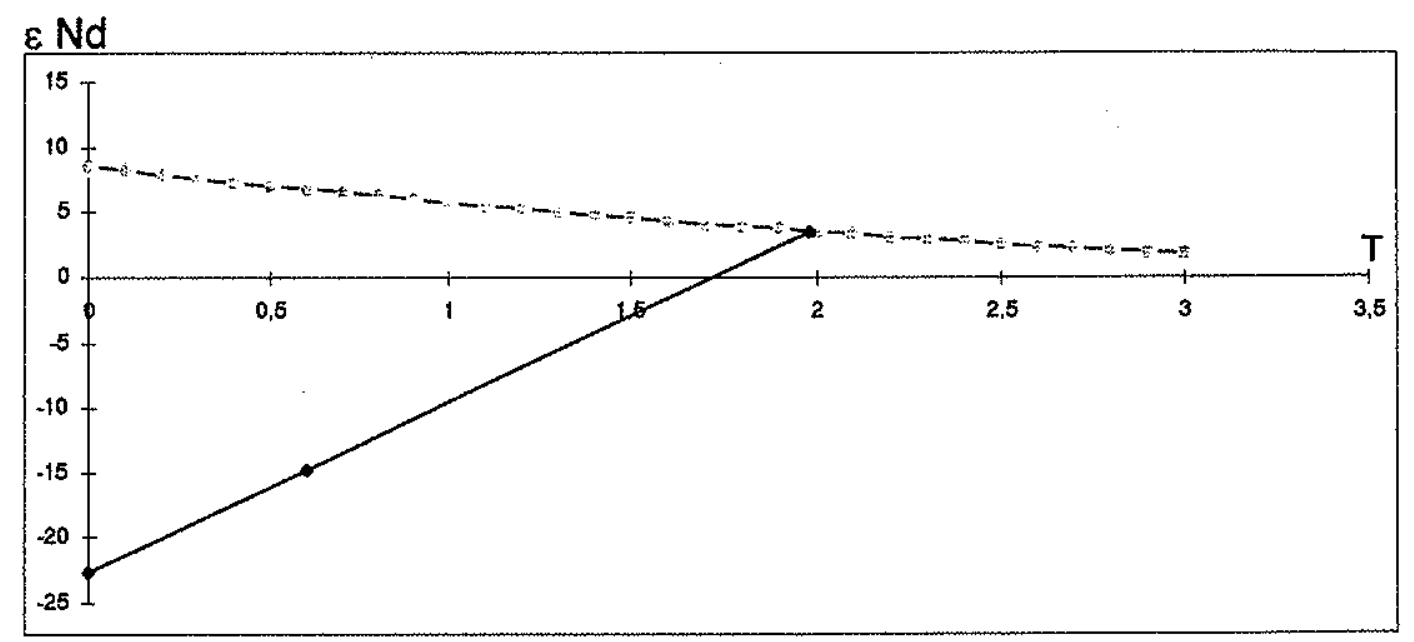

Figura 5.4.3 - Diagrama de evolução $\mathrm{ENd} \times$ tempo $(\mathrm{Ga})$ - Granito Juquiá-Bloco Embu.

As razões isotópicas de $\mathrm{Sr}$ obtidas pela sistemática $\mathrm{Rb}-\mathrm{Sr}$ (Tabela 5.4.3) para o Granito Juquiá, mostram valor de $\left(\mathrm{Sr}^{87} / \mathrm{Sr}^{86}\right) \mathrm{i}_{(600 \mathrm{Ma})}$ de 0.72174 , indicando a origem destas rochas, como observado na assinatura de $\mathrm{Nd}$, a partir de reservatórios crustais. 


\begin{tabular}{|c|c|c|c|c|c|c|c|c|c|c|}
\hline amostra & $\begin{array}{c}\mathrm{Rb} \\
(\mathrm{ppm})\end{array}$ & $\begin{array}{c}\mathrm{Sr} \\
(\mathrm{ppm})\end{array}$ & ${ }^{8 /} \mathrm{Rb}^{86} \mathrm{Sr}$ & ${ }^{8 /} \mathrm{Sr}{ }^{86} \mathrm{Sr}$ & $\varepsilon_{(0)}$ & $\begin{array}{c}\mathrm{T}_{\mathrm{DM}} \\
(\mathrm{Ma})\end{array}$ & $\varepsilon_{(\mathrm{TDM})}$ & $\begin{array}{c}\mathbf{T}_{1} \\
(\mathrm{Ma})\end{array}$ & $\varepsilon_{(\mathrm{r} 1)}$ & $\mathbf{R E}-\mathrm{T1}$ \\
\hline $\mathrm{K}-20$ & 211,0 & 244,0 & 2,513 & 0,748648 & 626,66 & 1312,6 & $-22,68$ & 600,0 & 331.7 & 0,72715 \\
\hline
\end{tabular}

Tabela 5.4.3 -Dados analíticos da sistemática Rb-Sr para o Granito Juquiá.

Adicionalmente, em diagrama de $\varepsilon S r \times$ \&Nd para $t=600 \mathrm{Ma}, \circ$ Granito Juquiá plota na porção inferior do $4^{\circ}$ quadrante (valores negativos de $\varepsilon N d$ e positivos de $\varepsilon S r)$, indicativo de uma vivência crustal longa, confirmando, como observado nos dados isotópicos de $\mathrm{Nd} \mathrm{e} \mathrm{Sr}$, a origem para estas rochas a partir de fontes crustais (Figura 5.4.4).

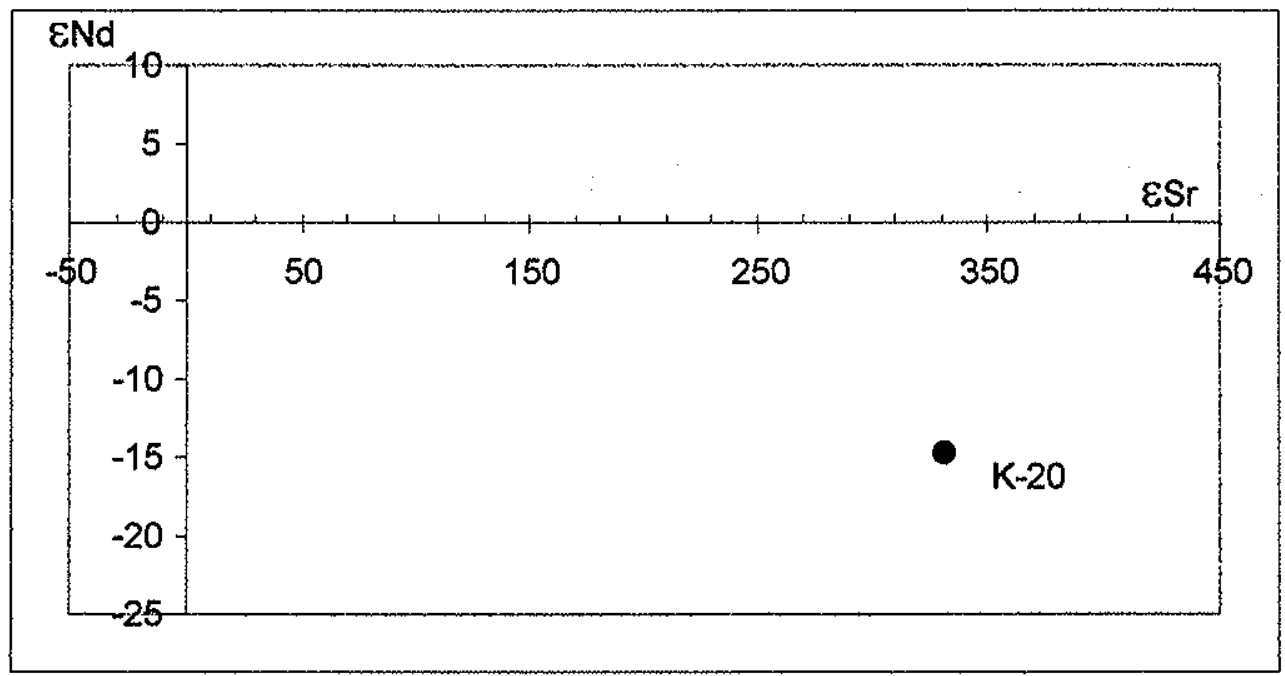

Figura 5.4.4 - Diagrama $\varepsilon \operatorname{Sr} \times \varepsilon N d(t=600 \mathrm{Ma})$ - Granito Juquiá - Bloco Embu. 


\subsection{Discussão dos RESULTAdos OBTIDOS}

No Bloco Embu, foram estudadas rochas metassedimentares correspondentes ao Complexo Embu (Hasui et al., 1981), compreendendo muscovita-xistos, granada-xistos, sillimanita xistos e cordierita xistos $e$, metassedimentos de mais baixo grau correlacionados à Sequência Miracatu (Dantas et al., 1987), e rochas graniticas intrusivas.

As rochas graníticas investigadas, denominadas informalmente de Granito Juquiá e Sete Barras, têm caráter peraluminoso, e apresentam como litotipo principal muscovita-biotita monzogranitos. Apresentam características geoquímicas distintas no comportamento dos ETR, onde o Granito Sete Barras apresenta padrão geoquímico de rocha mais fracionada, com alta anomalia negativa de Eu. Estes granitos apresentam muitas similaridades com Granitos Tipo $S$ (Chappell \& White, 1992) ou mesmo com Granitos Tipo MPG (Muscovite-bearing Peraluminous Granitoids). Estes últimos, conforme discutido por Barbarin (1999), são associados a anatexia de crosta associada a zonas de cisalhamento ou cavalgamento.

As faixas miloníticas que cortam o Bloco Embu, apresentam direçōes em torno de E-W e mergulhos sub-verticais. Estas faixas definem fortes lineamentos que se desenvolvem sub-paralelamente às ZCC e ZCl (Mapa Estrutural - Anexo 2). São falhas transcorrentes de movimentação dextral, $e$ afetam tanto as rochas metassedimentares, como também balizam os diversos corpos de granitos peraluminosos.

Os corpos graníticos, orientados nas faixas de cisalhamento, apresentam formas estiradas, notadamente o Granito Juquiá, e textura protomilonítica.

Idades U-Pb (monazitas) de $598 \pm 8$ Ma para o Granito Juquiá, e $631 \pm 23 \mathrm{Ma}$ para o Granito Sete Barras, são interpretadas como época de formação destas rochas, possivelmente associada à fusão de fontes crustais, e idades U-Pb (zircões) em torno de $750 \mathrm{Ma}$, associadas a heranças isotópicas.

Conforme, Fernandes (1991), a época em torno de $750 \mathrm{Ma}$, pode estar correlacionada à fase metamórfica principal do Complexo Embu, que atingiu grau forte (migmatização in situ) e grau médio (zona da sillimanita). 
A idade obtida em monazitas, apesar dos erros analíticos, para $\circ$ Granito Sete Barras, pode estar associada à fase sin-colisional do Cinturão Ribeira, em torno de $620 \mathrm{Ma}$, (Janasi, 1999; Hackspacher et al., 2000) responsável por importante geração de magmatismo cálcio-alcalino.

Por outro lado, a idade obtida em monazitas para o Granito Juquiá interpretada como época de cristalização desta rocha, possivelmente está associada ao desenvolvimento das zonas de cisalhamento que balizam estes corpos graníticos estudados. Esta idade, em torno de $600 \mathrm{Ma}$, pode estar correlacionada à fase tardicolisional do Cinturão Ribeira, responsável pela tectônica de escape lateral com desenvolvimento de diversas zonas de cisalhamento NE-SW e colocação de corpos graníticos (Hackspacher et al., 2000).

No entanto, devido ao erro analítico observado, as idades de ambos granitos se interpõem, havendo a necessidade de um refinamento nas datações $\mathrm{U}-\mathrm{Pb}$.

Na região de São Lourenço do Sul, ortognaisses miloníticos do Complexo Embu apresentaram idades $\mathrm{Rb}-\mathrm{Sr}$ (RT) de $770 \mathrm{Ma}$, com Ri=0.722 (Cordani et al., 2000 ), semelhantes às idades em U-Pb em zircões, e à $\mathrm{Ri}\left(\mathrm{Sr}^{87} / \mathrm{Sr}^{86}\right)$ obtidas neste trabalho. No entanto, através de análises SHRIMP, os autores observaram populações de zircões bem heterogêneas, com idades em 2.000, 800 e $600 \mathrm{Ma}$, interpretados respectivamente como zircões herdados, magmáticos e metamórficos.

Foi obtida uma idade Sm-Nd TDM de $1.984 \mathrm{Ma}$, interpretada como uma indicação da composição isotópica da área fonte das rochas que originaram estes granitos. Tal interpretação deve-se ao fato de tratarem-se possivelmente de granitos tipo $S$ (mineralogia, química).

Através dos dados aqui obtidos, sugere-se que o magmatismo granítico da porção investigada do Bloco Embu, é proveniente de uma fonte crustal, gerada e intensamente retrabalhada durante o Neoproterozóico, como observado pela herança dos zircões e pelo comportamento dos isótopos de $\mathrm{Nd}$ e $\mathrm{Sr}$.

Preliminarmente sugere-se que o Granito Sete Barras estaria associado à fase tectônica principal na evolução do Cinturão Ribeira e o Granito Juquiá a processos tectônicos relacionados ao desenvolvimento de importantes zonas de cisalhamento (ZCC), responsáveis pela geração de magmatismo granítico cálcioalcalino peraluminoso. 


\section{BLOCO MONGAGUÁ}

\subsection{INTRODUÇÃo}

O Bloco Mongaguá é limitado a sul pela Zona de Cisalhamento Itariri $(\mathrm{ZCl})$ e a norte pela Zona de Cisalhamento Cubatão (ZCC), Figura 4.2, e apresenta como litotipos predominantes rochas gnáissico-migmatíticas e rochas graníticas localmente com feições gnáissicas. Os litotipos estudados pertencentes a este bloco, localizam-se em perfis ortogonais à $\mathrm{ZCl}$, em perfil próximo à região da Vila Peruíbe, na cidade de Itanhaém, e na cidade de Mongaguá (Mapa Geológico - Anexo 1).

Através dos estudos desenvolvidos na área, o referido Bloco foi subdividido em dois grupos principais: 1) Rochas gnáissico migmatíticas aflorantes na região de Mongaguá e Itanhaém; 2) Rochas graníticas, que incluem os Granitos Tipo Itariri (não individualizados no Mapa Geológico das rochas gnáissico-migmatíticas), Granito Tipo Areado e Granito Ribeirão do Óleo.

\subsection{CARACTERIZAÇÃo PETROgRáfica-Estrutural}

\section{ROCHAS GNÁISSICO-MIGMATITICAS}

Os litotipos aflorantes na região de Mongaguá e Itanhaém compreendem rochas granito-gnáissicas com feições migmatíticas, onde pode ser identificado a interação de dois materiais contrastantes, um félsico (granítico) e um máfico (diorítico), na geração destas rochas.

Em Mongaguá, afloram rochas gnáissico-migmatíticas, que representam interação entre material monzogranítico, de granulação média, com bandas félsicas e máficas irregulares, com material máfico, rico em biotita de granulação fina. Analisandose com detalhe, observa-se uma série de estruturas e relaçöes texturais complexas, que serão sucintamente descritas a seguir:

1) Bandamento de material gnáissico monzogranítico leucocrático a mesocrático com material máfico fino. O material máfico observado apresenta-se 
finamente foliado e ocorre como bandas centimétricas a milimétricas, intercalado ao material gnáissico monzogranítico (Prancha 3, Foto 1). Também ocorrem como enclaves métricos (Prancha 3, Foto 2) ovalados ou com formas sigmoidais. É composto principalmente por cristais de anfibólio e biotita, bem orientados, e subordinadamente plagioclásio e quartzo.

2) Material gnáissico monzogranítico, caracteristicamente com cristais esparsos de anfibólio e biotita, intercalados com enclaves máficos decimétricos, de granulação fina, muito semelhantes aos enclaves que representam fragmentos de diques sin-intrusivos, normalmente com lados paralelos, e também deformados com formas sigmoidais (Prancha 3, Foto 3);

3) Feições migmatíticas diversas: a) estruturas dobradas com interação de material gnáissico leucocrático e material gnáissico máfico (Prancha 3, Foto 4); b) estruturas flebíticas ou em veio com predomínio do material máfico sobre o félsico quartzo-feldspático (Prancha 3 , Foto 5 ). É muito comum o predomínio do material máfico sobre o félsico (Prancha 3, Foto 6);

4) Porções monzograníticas, normalmente mesocráticas, de cor cinza e granulação média com bandamento gnáissico irregular, possivelmente representando porções de maior mistura dos materiais. $O$ bandamento gnáissico sub-horizontal caracteriza-se por bandas centimétricas félsicas (quartzo-feldspáticas), não raramente irregulares, onde sobressaem-se cristais de biotita e/ou anfibólio isolados (Prancha 4, Foto 1) intercaladas com bandas máficas milimétricas a centimétricas de granulação fina, ricas em biotita e anfibólio, e também com presença de feldspatos e quartzo.

5) Porções gnáissicas monzograníticas mesocráticas (item 4) em contato magmático irregular em cúspide com material máfico (Prancha 4, Foto 2), com feições de corrosão de megacristais de feldspato potássico.

Segregações ricas em feldspato potássico, de granulação grossa, são bastante comuns, podendo apresentar até $50 \mathrm{~cm}$ de espessura (Prancha 3, Foto 1). Nestas porções ocorrem cristais de turmalina, bem formados, que também podem se 
desenvolver em zonas de fraturas como cristais agregados fibro-radiados (Prancha 4, Foto 3). Há presença de veios graníticos e pegmatíticos que cortam a foliação principal.

Estruturalmente as rochas gnáissico-migmatiticas desenvolvem-se faixas filoníticas sub-horizontais, em torno de $15 \mathrm{~cm}$, e faixas protomiloníticas e miloníticas (Prancha 4, Foto 4) que podem apresentar-se sub-paralelas ao bandamento gnáissico (Figura 6.2.1). Este apresenta direções principais em N30E/20 SE (sub-paralelo à foliação milonítica) e N50E/65SE. Estruturas S-C (Prancha 4, Foto 5), e sigmóides de quartzo e feldspato, sugerem transporte para N30E em uma componente de cavalgamento.

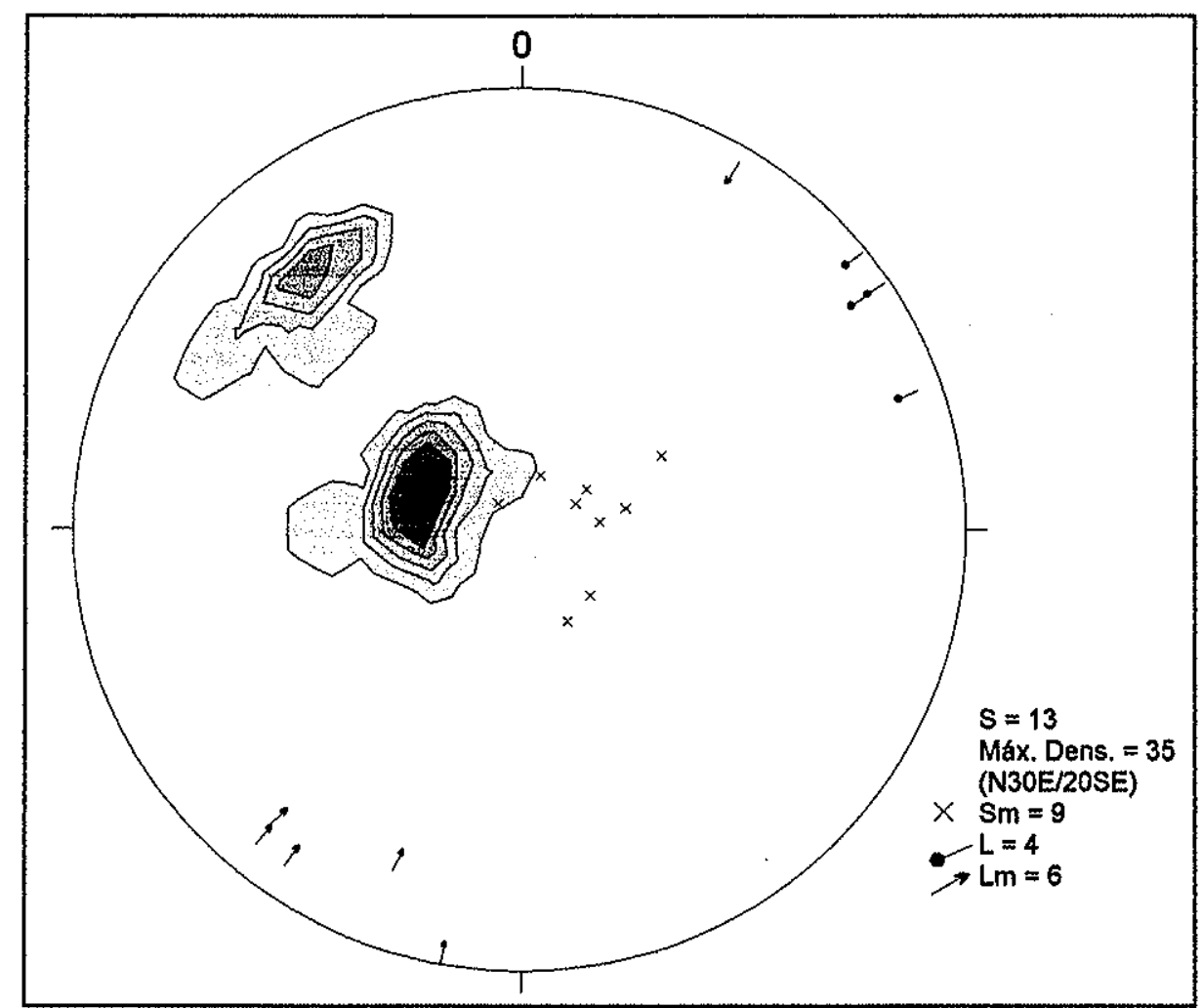

Figura 6.2.1. Bloco Mongaguá - Gnaisses migmatíticos Mongaguá. Bandamento gnáissico (contorno), com concentração principal em N30E/20SE e lineação mineral (L), e foliação milonítica $(\mathrm{Sm})$ com desenvolvimento de lineação de estiramento mineral $(\mathrm{Lm})$.

Petrograficamente, o monzogranito mesocrático a leucocrático apresenta-se foliado, caracterizado principalmente pela orientação dos minerais máficos (Prancha 5, 
Foto 1). Apresenta como mineralogia principal o quartzo, microclínio, oligoclásio, como máficos hornblenda e biotita, e minerais acessórios principais apatita, zircão e titanita.

Os cristais de quartzo normalmente apresentam pouca ou nenhuma extinção ondulante, são intersticiais, podendo apresentar-se em recuperação (sub-grãos) ou totalmente recristalizados com contatos poligonizados.

Cristais de microclínio, constituem fenocristais, normalmente são pertíticos (em filme ou veio, não orientados) sendo comum o desenvolvimento de texturas mirmequíticas, principalmente nas bordas, em contato com plagioclásio. Recristalização de microclínio nas bordas dos fenocristais é encontrada.

Os cristais de plagioclásio (oligoclásio) podem apresentar-se preservados ou saussuritizados com alteração de sericita, epídoto e calcita, podendo conter alguma deformação nas maclas, em forma de cunha. Há indícios de recristalização de plagioclásio nas bordas (Prancha 5, Foto 2). Em contato com microclínio, é comum o desenvolvimento de texturas mirmequíticas.

Cristais de biotita apresentam pleocroísmo de amarelo claro a marrom escuro, normalmente subeuedrais, bastante orientadas. Também ocorrem como alteração de anfibólios, normalmente mal formadas. Podem também apresentar feições 'esponjosas' ou spongy (descritas por Hibbard, 1995 em cristais de plagioclásio), podendo indicar algum tipo de dissolução.

Os cristais de hornblenda, em menor quantidade, podem mostrar-se bem preservados, com pleocroísmo de verde amarelado a verde escuro, ou já bastante alterados para biotitas. Podem conter inclusões de albita.

Em seção delgada realizada na interface entre o material félsico e máfico (Prancha 5, Foto 3), observou-se um contato bem definido, não apresentando-se muito evidentes texturas microscópicas típicas de magma mixing (Hibbard, 1995). Entretanto, a mistura do material diorítico com o granítico, pode ser observada, através da incorporação de cristais de hornblenda isolados e titanitas no material granítico. Tais minerais são bastante comuns nas porções máficas e inexistem nas porções monzograníticas mais afastadas das porções dioríticas. 
Nas faixas miloníticas observam-se bandas concentradas com alta taxa de deformação, caracterizadas pela presença de quartzo microgranular, crescimento de muscovitas e intensa carbonatização de minerais (Prancha 5, Foto 4). Textura mortar em cristais de microclínio é comum, que já tendem a formar porfiroclastos sigmoidais. Os cristais de plagioclásio apresentam deformação nas maclas, sendo comum a ocorrência de alta quantidade de texturas mirmequíticas. Cristais de hornblenda alteram-se para biotitas ao longo de fraturas e das clivagens.

As porções máficas dioríticas, são finamente foliadas e caracterizam-se pela presença de hornblenda e biotita como minerais principais, e também plagioclásio e quartzo, e como acessórios, titanita, e alta quantidade de apatitas.

A rocha é foliada, e caracteriza-se pela forte orientação dos minerais máficos (hornblenda e biotita) (Prancha 5, Foto 5).

Os cristais de hornblenda constituem os maiores minerais da rocha, são subeuedrais a anedrais, e apresentam pleocroísmo amarelo claro e verde oliva escuro, sendo muito comum apresentarem as bordas corroídas pela matriz constituída por quartzo e plagioclásio (Prancha 5, Foto 6). Os cristais de biotita, com pleocroísmo de amarelo claro a marrom, normalmente são bem formados. Observa-se substituição de hornblenda por biotita e calcita.

Plagioclásio e quartzo constituem a granulometria menor da rocha. Os cristais de plagioclásio apresentam extinção ondulante e deformação nas maclas. Os cristais maiores de quartzo apresentam extinção ondulante ou já formam subgrãos, e normalmente os grãos menores mostram-se recristalizados.

$\mathrm{Na}$ localidade de Itanhaém, o conjunto gnáissico-migmatítico mostra interação de material sienogranítico leucocrático, de cor rosada e granulação média, a megacristais de feldspato potássico, protomilonítico e material máfico diorítico de granulação fina, que pode ser observada de três formas principais:

1) gnaisses bandados, caracterizados pela intercalação centimétrica a decimétrica de material félsico sienogranítico e material máfico diorítico em um 
bandamento sub-horizontal (Prancha 6, Foto 1), com desenvolvimento de enclaves microdioríticos ovalados desde centimétricos a métricos (Prancha 6, Foto 2);

2) como feições migmatíticas, com desenvolvimento de estruturas dobradas, onde há predomínio de material félsico sobre máfico ou flebítica, onde há o predomínio do material máfico sobre o félsico (Prancha 6, Foto 3);

3) através de uma rede de veios do material granítico por entre o material máfico, resultando em enclaves magmáticos de diferentes formas, com contatos nítidos desde ovalados até retilíneos, desde centimétricos a métricos (Prancha 6, Foto 4), ocasionalmente com inclusão de fenocristais de feldspato potássico.

Paralelamente ao bandamento gnáissico sub-horizontal, desenvolve-se uma foliação milonítica (Figura 6.2.2), caracterizada pelo estiramento de porfiroclastos de feldspato potássico e orientação de biotitas. Importantes feições distensivas, boudins métricos (Prancha 6, Foto 5) são observadas indicando uma direção importante de extensão E-W/sub-horizontal.

Todo conjunto é cortado por veios de quartzo, veios pegmatíticos e graníticos, de direção a cerca de N50E/ sub-vertical. Estes últimos são isótropos de granulação média-grossa, e composição monzogranítica. Têm biotita como máfico principal e apatita como mineral acessório. 


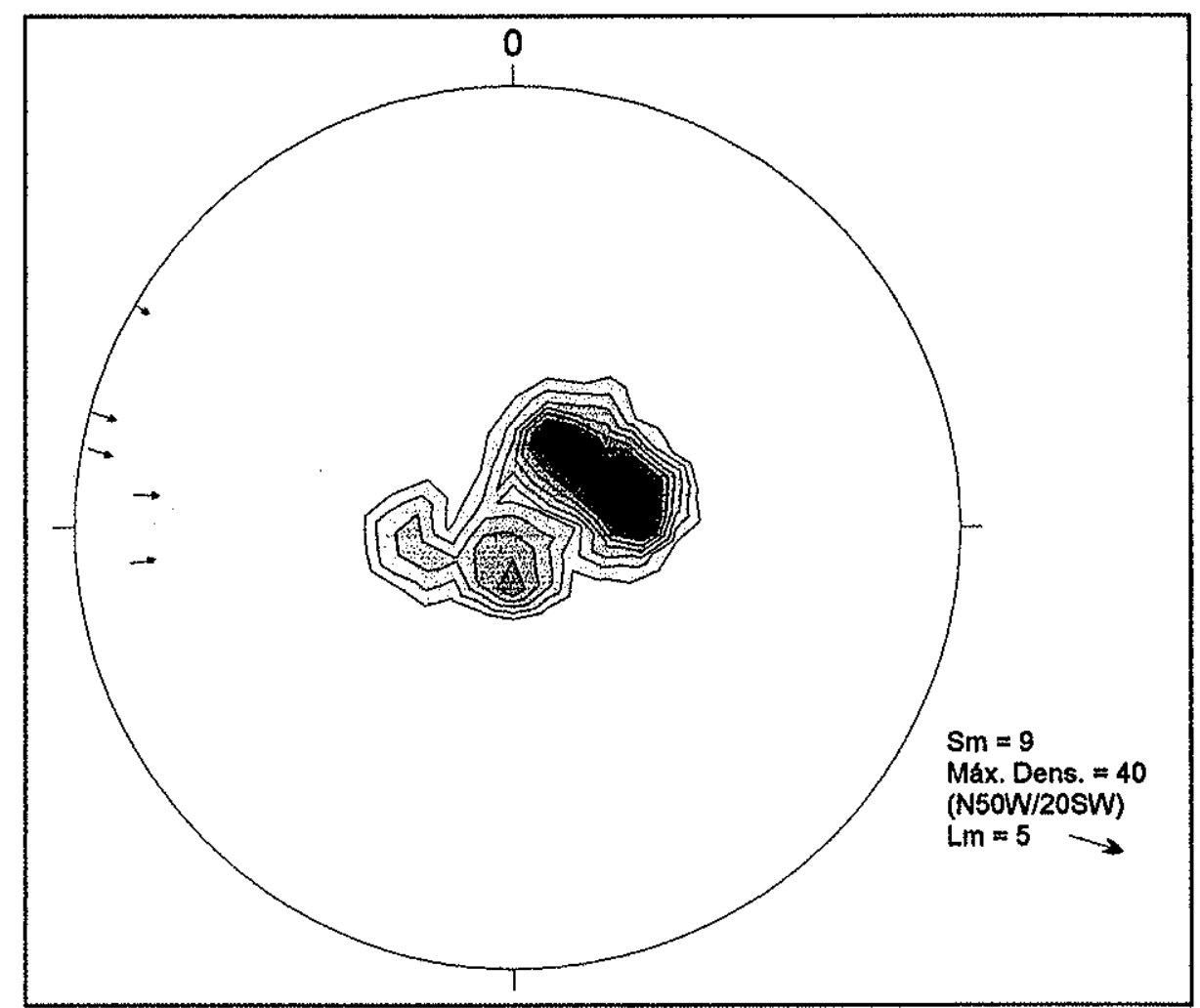

Figura 6.2.2. Bloco Mongaguá - Gnaisses migmatíticos Itanhaém. Foliação milonítica (Sm) paralela ao bandamento gnáissico com concentração principal em N50W/20SW, e desenvolvimento de lineação de estiramento mineral $(\mathrm{Lm})$.

Através de indicadores cinemáticos como par S-C, e porfiroclastos de feldspato potássico assimétricos, juntamente com as relações planares, foliação protomilonítica com mergulho para SW, e lineares, lineação de estiramento mineral com caimento para NW, há sugestão de transporte para SEE, em uma componente de cavalgamento. Tais feições serão novamente discutidas no Capítulo 9 , referente às zonas de cisalhamento.

As porções leucocráticas sienograníticas apresentam-se foliadas, normalmente desenvolvendo uma textura protomilonítica, com forte orientação dos minerais máficos (principalmente a biotita) que se intercalam com bandas félsicas, onde os feldspatos normalmente apresentam-se bastante fraturados (Prancha 6, Foto 6). Caracterizam-se pela mineralogia: quartzo, microclínio, oligoclásio, como máficos hornblenda e biotita, e acessórios principais apatita, zircão, allanita, turmalina verde, muscovita e minerais opacos. 
Os grãos de quartzo normalmente apresentam pouca extinção ondulante, em recuperação, ou formando sub-grãos, com tendência a formar contatos poligonizados.

Cristais de microclínio, constituem os cristais maiores, normalmente pertíticos, podendo-se dividir duas gerações de pertitas, uma em filme ou veio, e outra tipo maculada. É comum o desenvolvimento de texturas mirmequíticas, principalmente nas bordas, em contato com plagioclásio. Recristalização de microclínio nas bordas é encontrada.

Os cristais de plagioclásio (oligoclásio), normalmente estão saussuritizados com alteração de sericita, epídoto e calcita, podendo conter alguma deformação nas maclas, em forma de cunha. Em contato com microclínio, é muito comum o desenvolvimento de mirmequitas. Localmente podem ocorrer antipertitas.

Cristais de biotita apresentam pleocroismo de amarelo claro a marrom escuro, normalmente subeuedrais, bastante orientadas, definindo filmes. Apresentam intercrescimento com feldspato.

Cristais de hornblenda, em menor quantidade, podem mostrar-se bem preservados, com pleocroísmo de verde amarelado a verde escuro, ou já bastante alterados para biotita e óxidos de Fe, ao longo de fraturas e clivagens (Prancha 6, Foto 7).

As porções máficas, finamente foliadas, microdioritos, caracterizam-se pela presença de hornblenda, biotita, plagioclásio e quartzo, e como acessórios, apatita, titanita, e opacos.

A rocha apresenta uma foliação caracterizada pela orientação dos minerais máficos hornblenda e biotita, normalmente subeuedrais, formando filmes máficos intercalados com filmes félsicos tonalíticos (Prancha 6, Foto 8).

Os cristais de hornblenda, com pleocroísmo amarelo claro e verde oliva escuro, apresentam forte substituição por biotita. Cristais de biotita, normalmente estão bem formados, têm pleocroísmo amarelo claro a marrom.

Os cristais de plagioclásio, estão bem preservados, com pouca sericitização, e apresentam extinção ondulante com leve deformação nas maclas. Cristais de quartzo intersticial, normalmente mostram extinção ondulante. 
PRANCHA 3

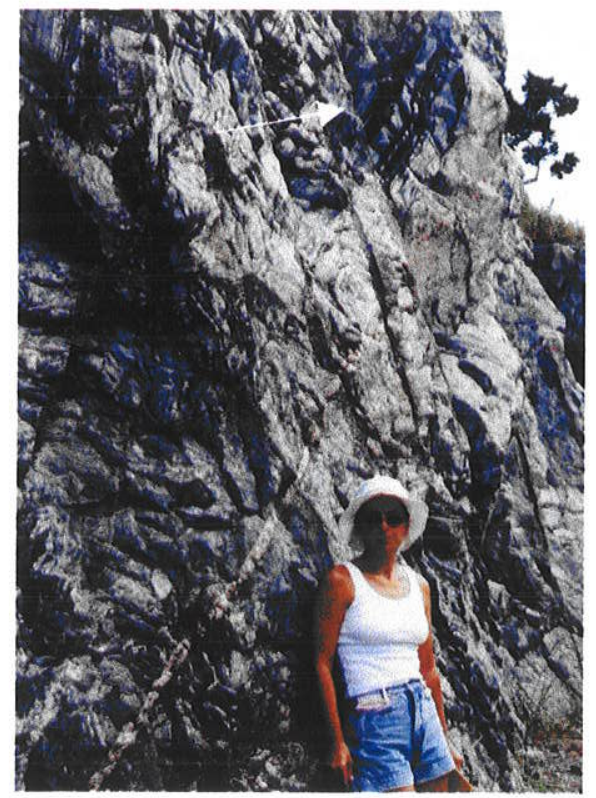

Foto 1 - Rochas gnáissico-migmatíticas Mongaguá. Bandamento gnáissico (seta) S: N55E/65SE. Afloramento K-103.

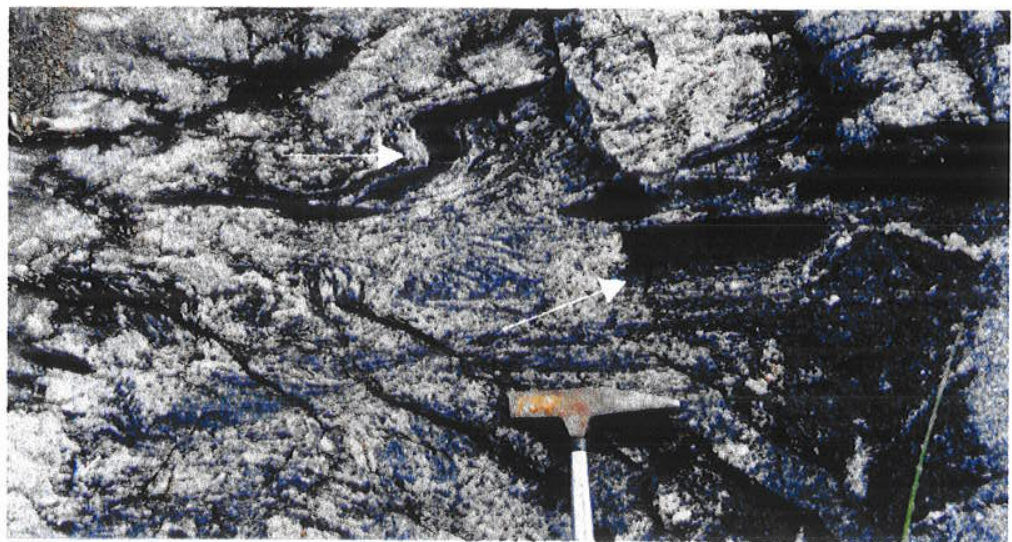

Foto 3 - Enclaves máficos com lados paralelos (setas). Rochas gnáissicomigmatíticas Mongaguá. Afloramento K-103.

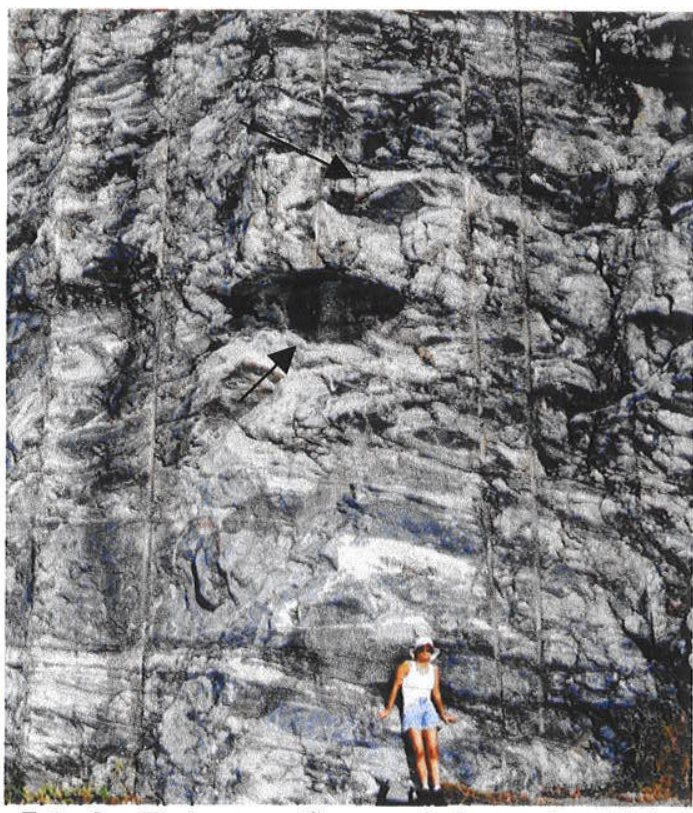

Foto 2 - Enclaves máficos ovalados e sigmoidais (setas). Rochas gnáissico-migmatíticas Mongaguá. Afloramento K-103.

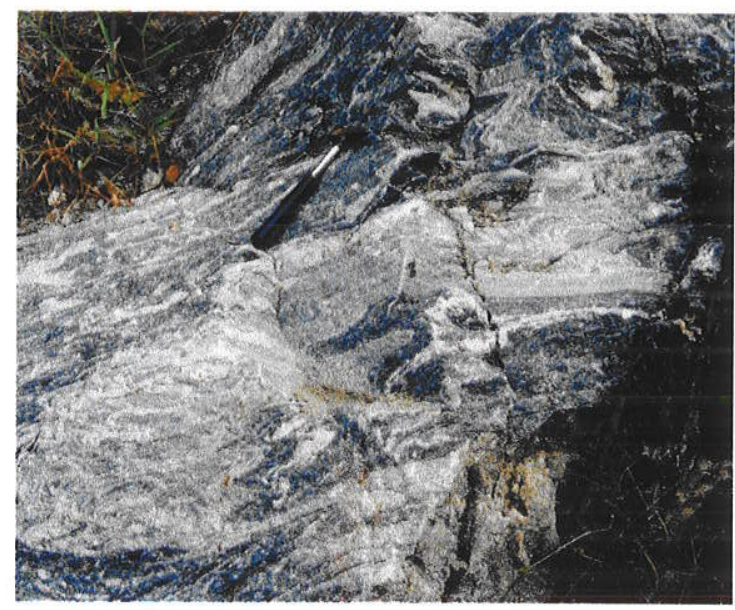

Foto 4 - Estruturas migmatíticas dobradas. Rochas gnáissico-migmatíticas Mongaguá. Afloramento K-103.

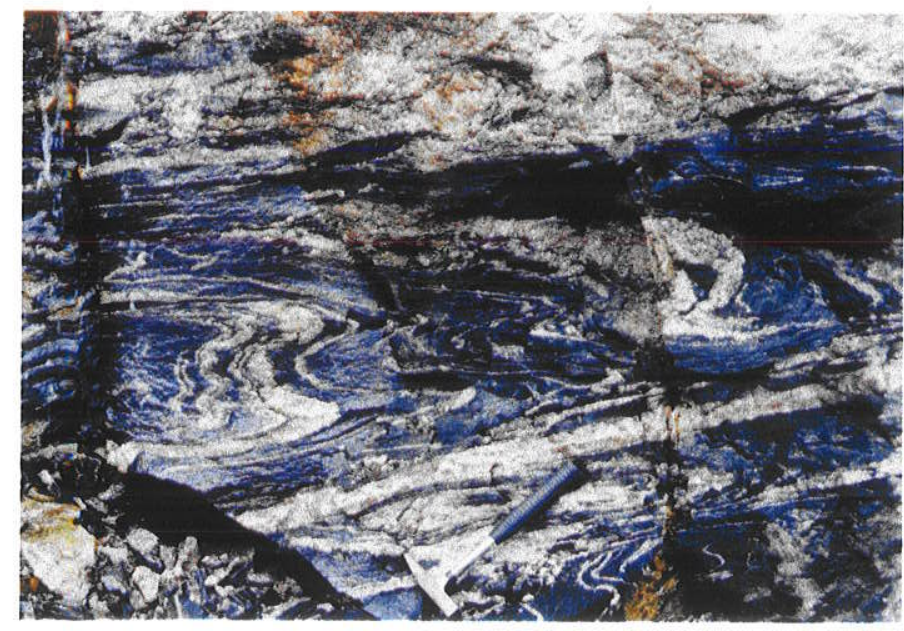

Foto 5 - Estruturas migmatíticas dobradas. Rochas gnáissicomigmatíticas Mongaguá. Afloramento K-3.

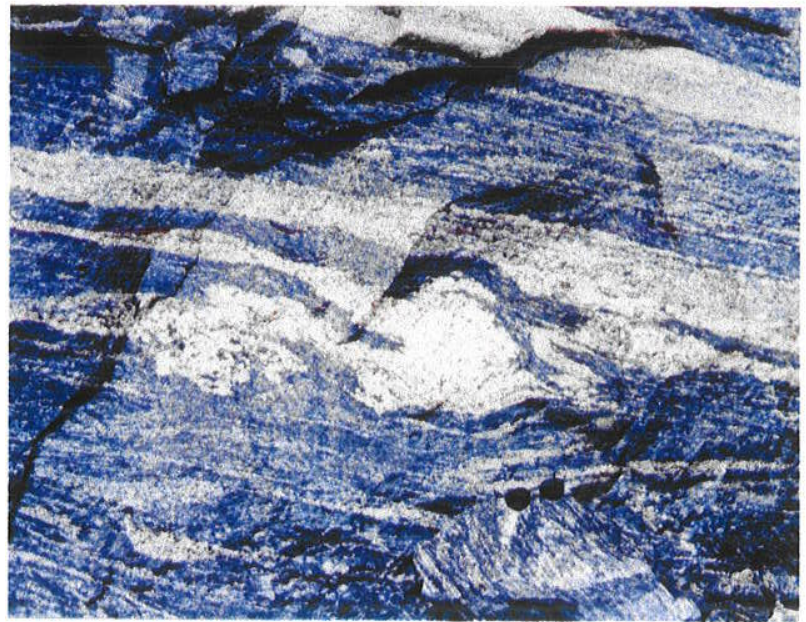

Foto 6 - Estruturas bandadas irregulares, localmente flebíticas, com predomínio de material máfico. Rochas gnáissico-migmatíticas Mongaguá. Afloramento K-3. 
PRANCHA 4

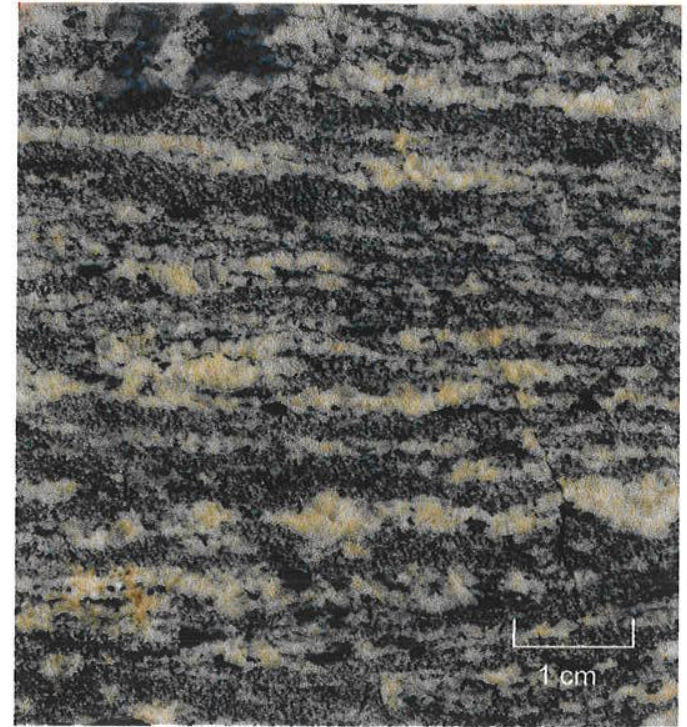

Foto 1 - Bandamento gnáissico irregular, notar minerais máficos em meio às bandas quartzofeldspáticas. Amostra K-3 (corte XZ). Mongaguá.

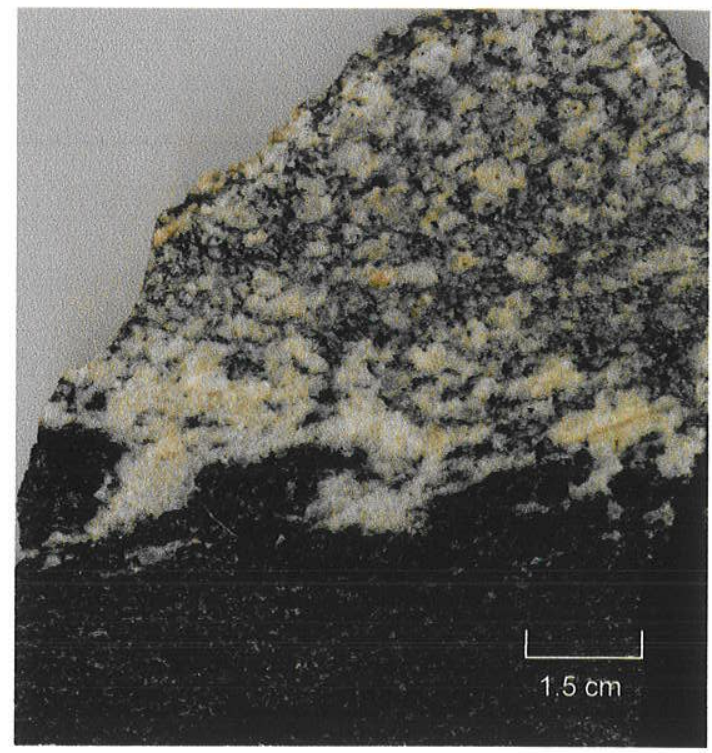

Foto 2 - Contato magmático irregular em cúspide, com corrosão de feldspato potássico. Amostra K-3. Mongaguá.

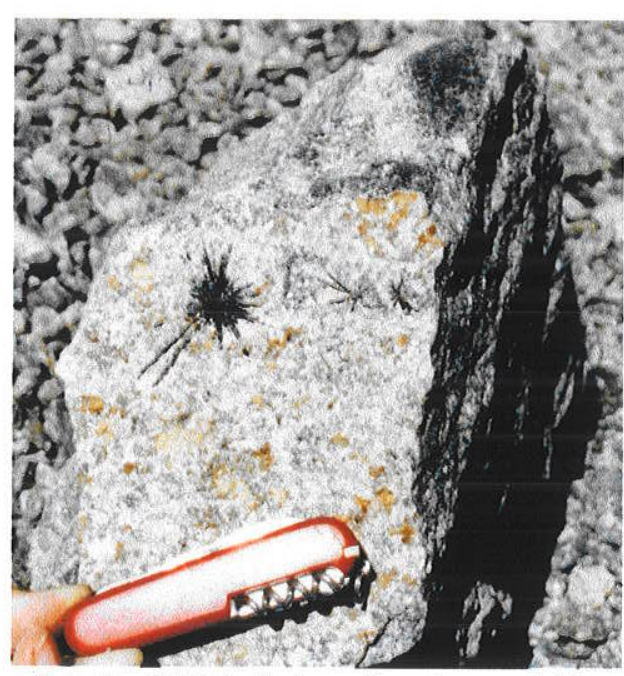

Foto 3 - Cristais de turmalinas desenvolvidos em fraturas. Amostra K-3. Mongaguá.

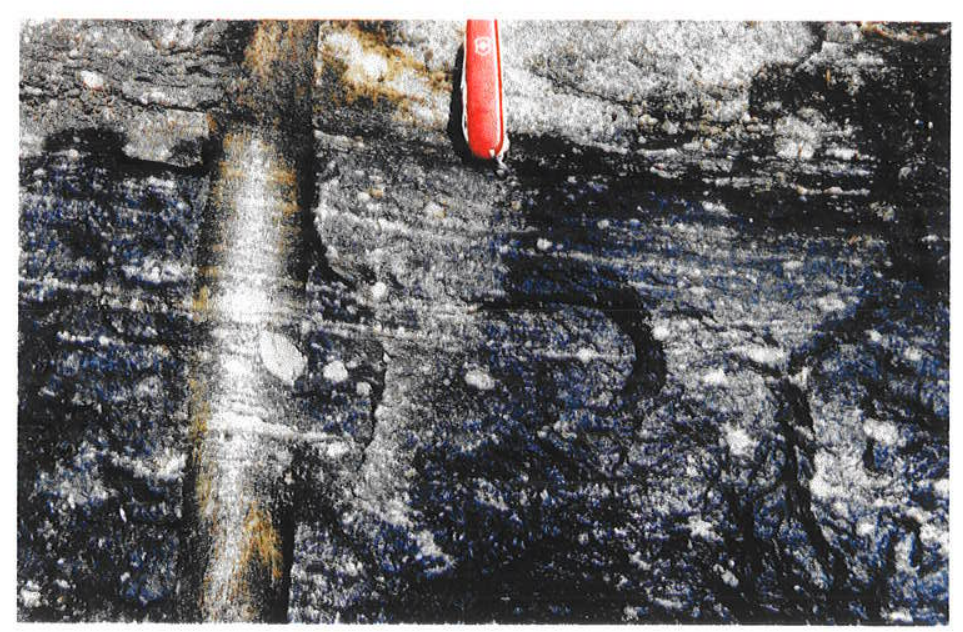

Foto 4 - Faixas miloníticas centimétricas. Rochas gnáissicomigmatíticas. Afloramento K-103 (corte XZ). Mongaguá.

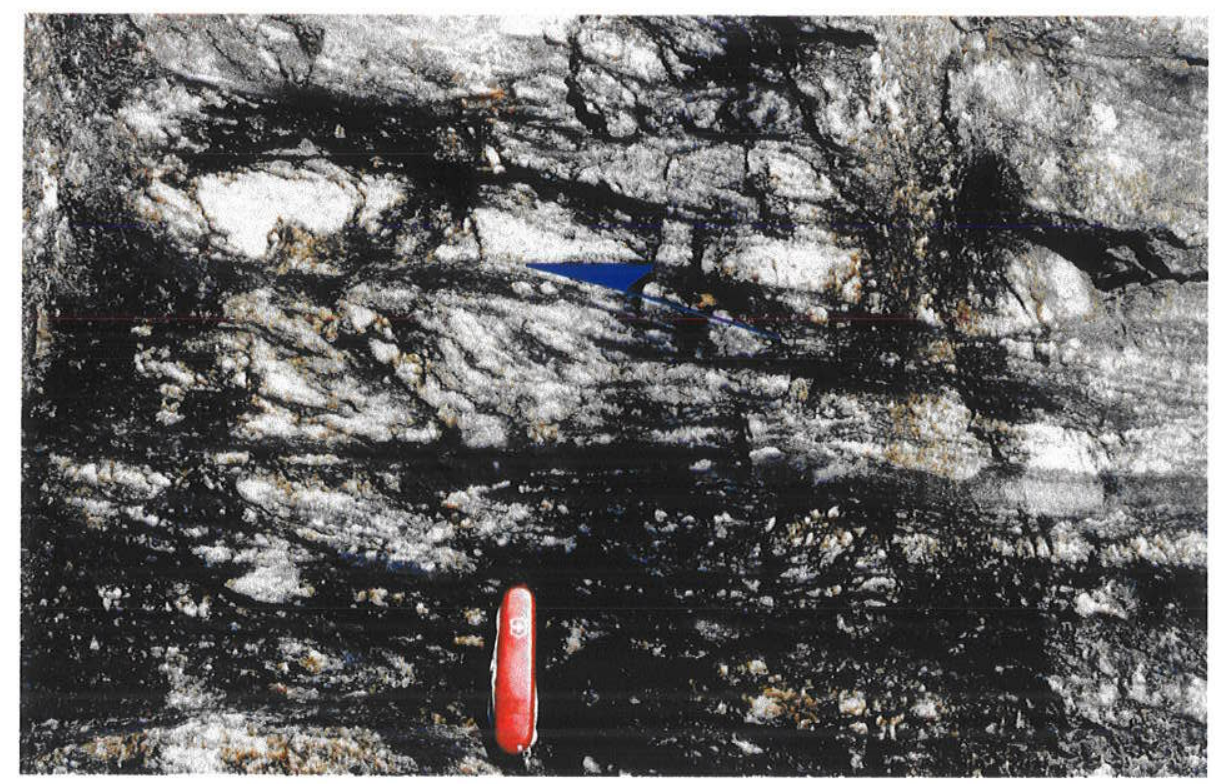

Foto 5 - Esruturas S-C em faixas miloníticas (Sm: N35W/15SW; Lm: S40W/15) com indicação de transporte para NE. Afloramento K-103 (corte XZ). Mongaguá. 


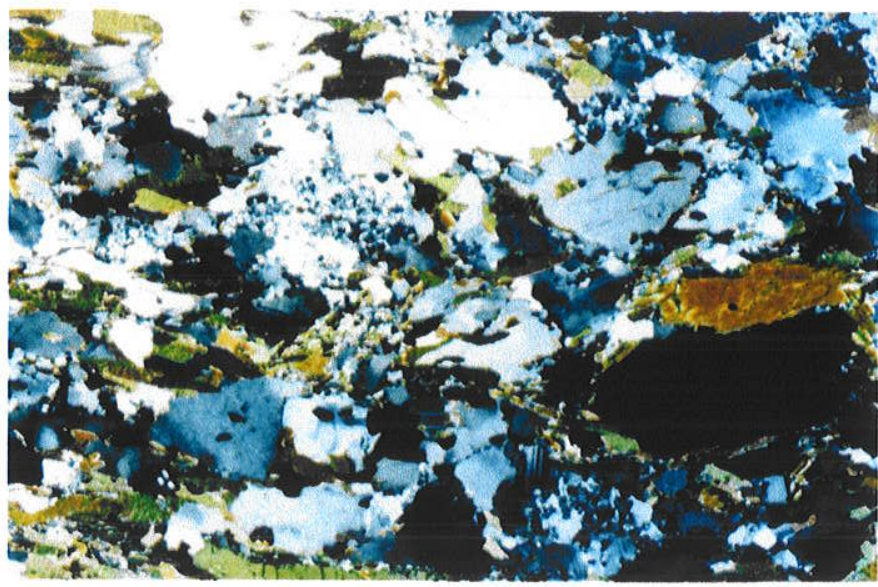

Foto 1 - Fotomicrografia (nicóis X, aumento 25x). Anfibólio-biotita monzogranito com foliação incipiente caracterizada principalmente pela orientação dos máficos. Amostra K-3 (corte $\mathrm{XZ}$.

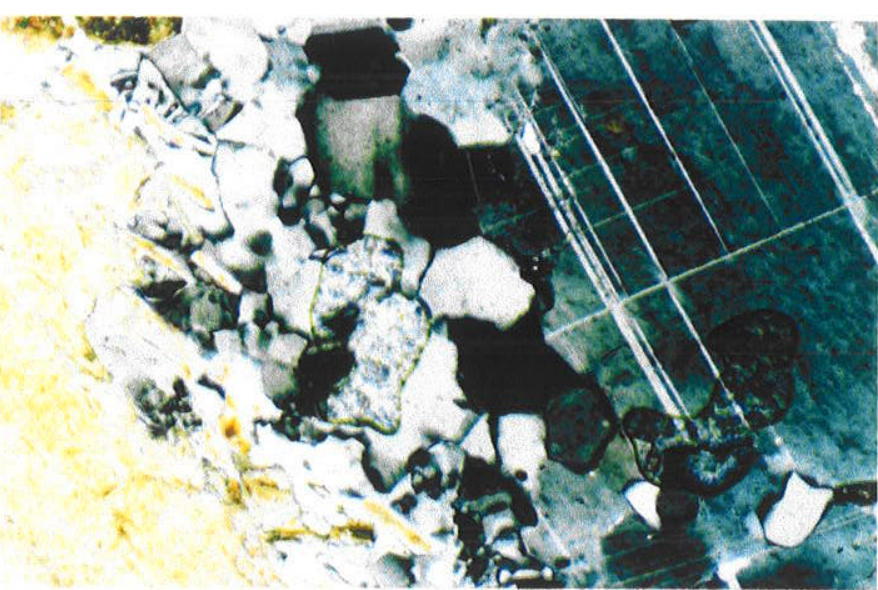

Foto 2 - Fotomicrografia (nicóis X, aumento 200x). Anfibólio-biotita monzogranito. Recristalização de plagioclásio. Amostra K-3 (corte $\mathrm{XZ}$ )

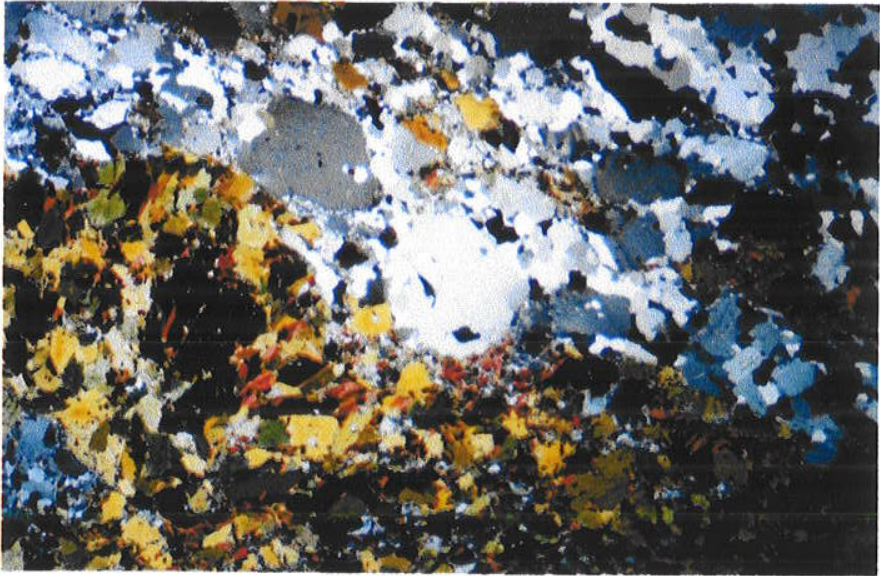

Foto 3 - Fotomicrografia (nicóis $\mathrm{X}$, aumento $7.5 \mathrm{x}$ ). Interface entre material máfico e monzogranito Notar cristais de minerais máficos isolados em meio ao monzogranito. Amostra K-3.

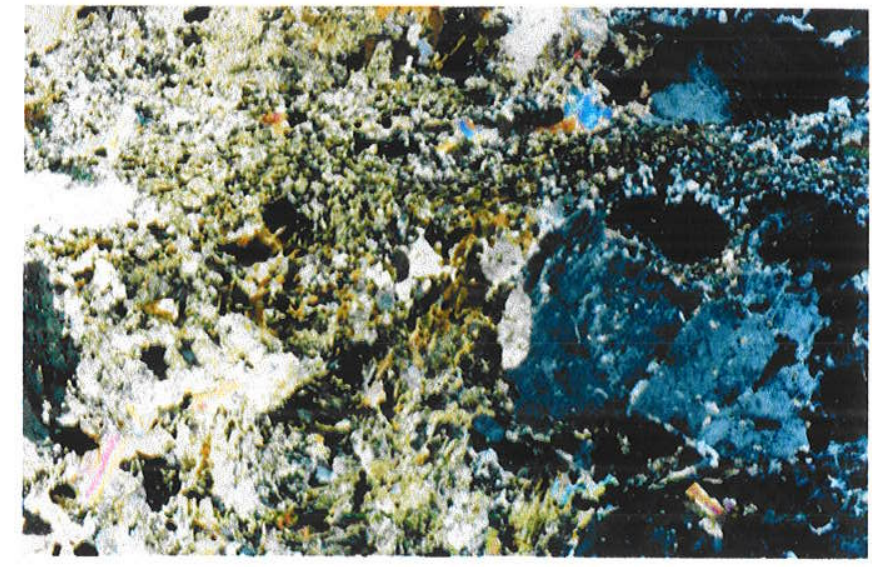

Foto 4 - Fotomicrografia (nicóis $\mathrm{X}$, aumento 25x). Faixa milonítica caracterizada pela intensa alteração dos minerais. Amostra K-3 (corte YZ).

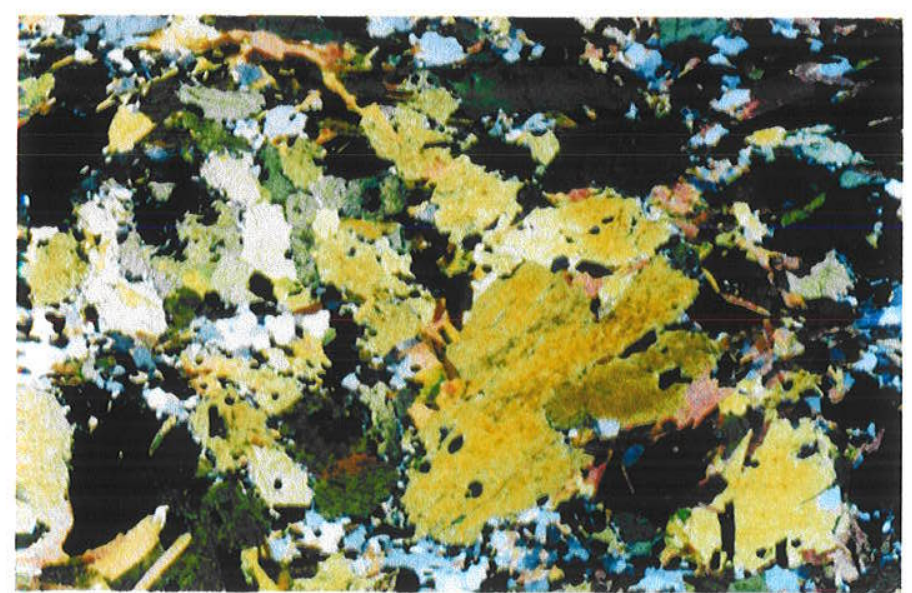

Foto 5 - Fotomicrografia (nicóis X, aumento 25x). Porção máfica, foliação principal dada pela orientação de anfibólio e biotita. Amostra K-3b.

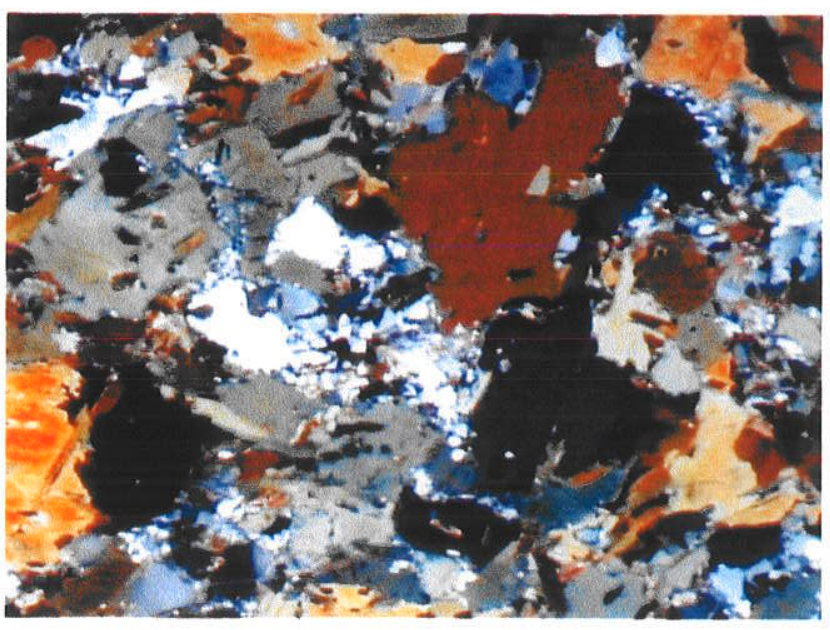

Foto 6 - Fotomicrografia (nicóis $X$, aumento 15x). Cristais de hornblenda com bordas corroídas pela matriz constituída por quartzo e plagioclásio. Amostra K-3b. 
PRANCHA 6

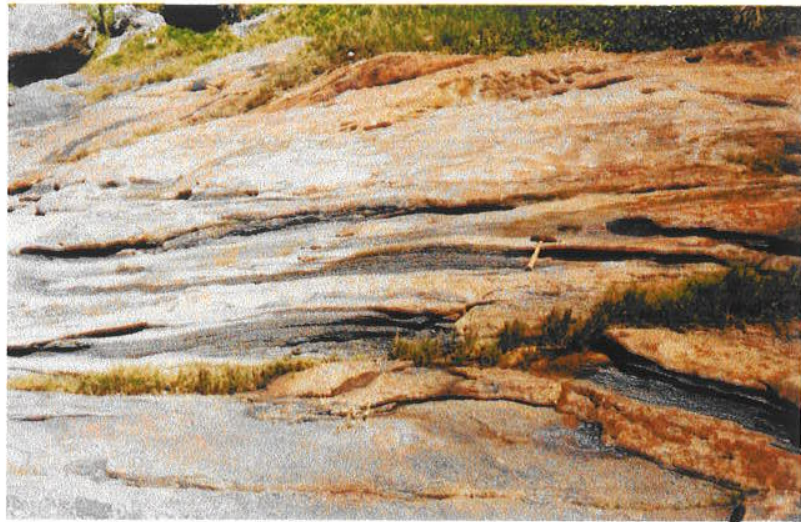

Foto 1 - Bandamento gnáissico irregular sub-horizontal. Afloramento K-5, Itanhaém.

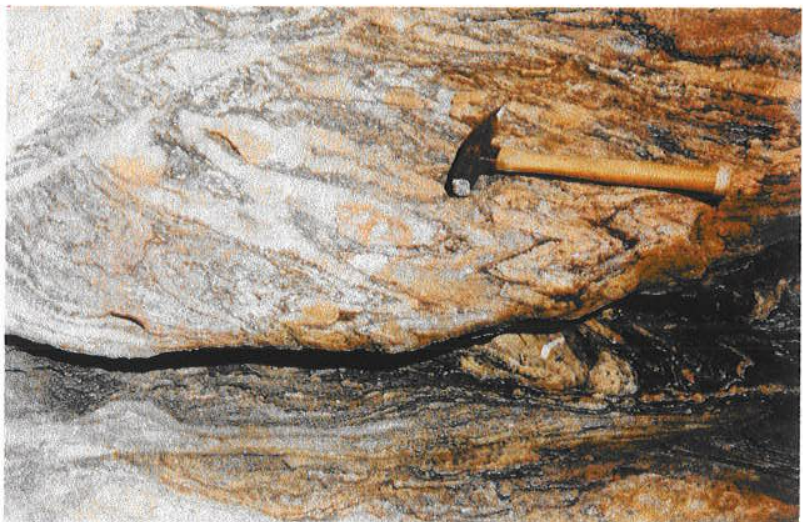

Foto 3 -Estruturas migmatíticas dobradas/flebítica. Itanhaém.

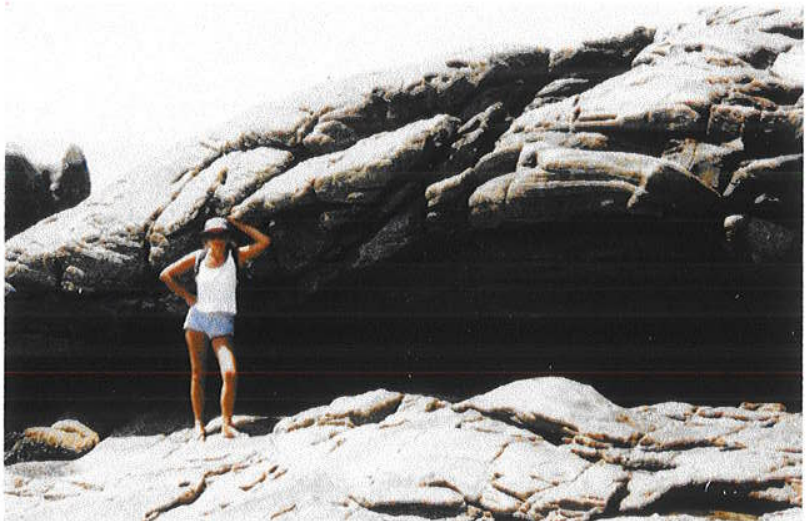

Foto 5 - Boudin métrico com eixo maior sub-horizontal. Afloramento K-5, Itanhaém.

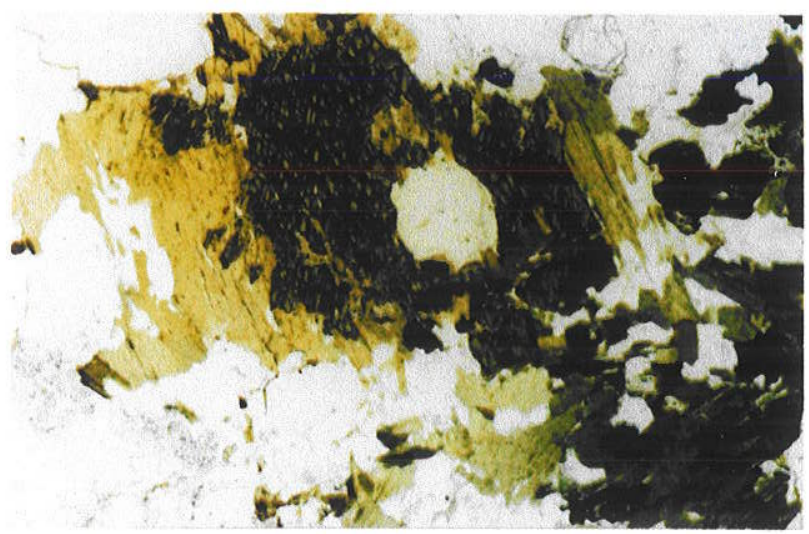

Foto 7 - Fotomicrografia (nicóis X, aumento 50x). Sienogranito foliado. Cristal de hornblenda alterado para biotita. Amostra K-5 (corte YZ).

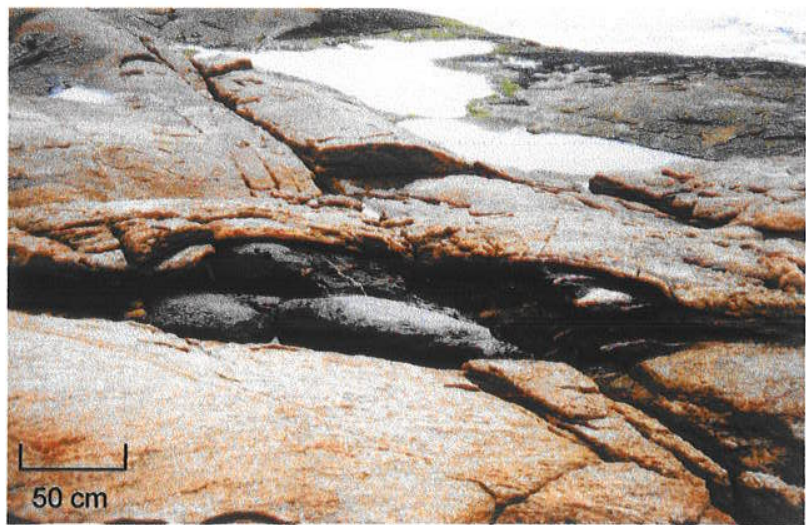

Foto 2 - Enclave máfico métrico de formato oblato. Afloramento K-5, Itanhaém.

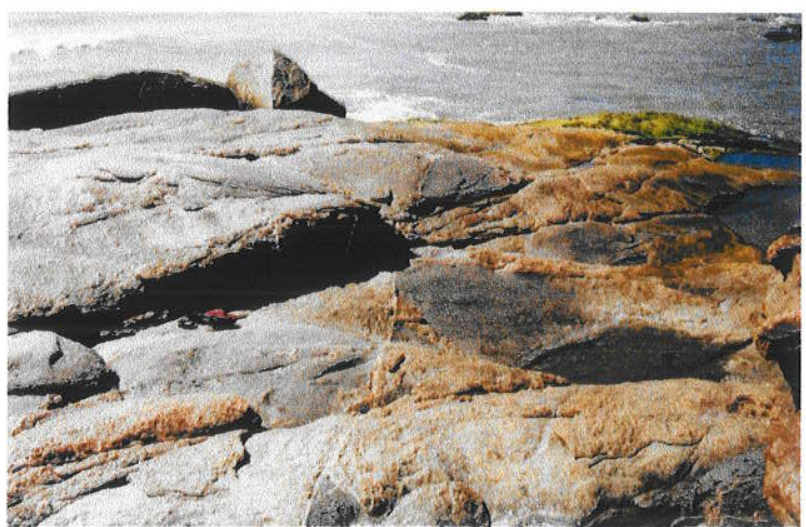

Foto 4 - Estruturas tipo Net Veined. Itanhaém.

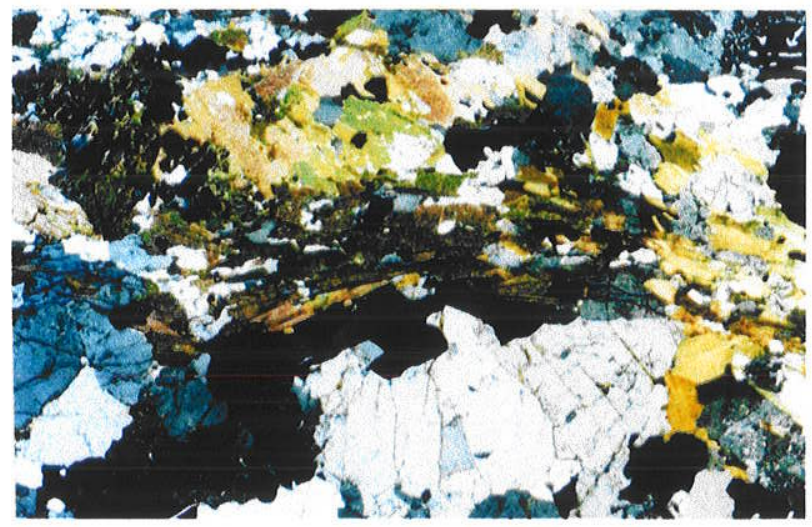

Foto 6 - Fotomicrografia (nicóis $X$, aumento 25x). Sienogranito foliado: forte orientação dos cristais de biotita. Amostra K-5 (corte XZ).

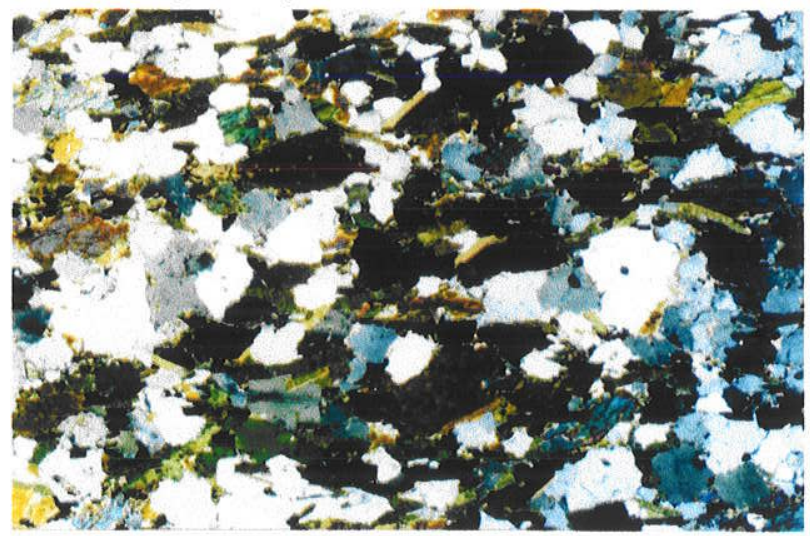

Foto 8 - Fotomicrografia (nicóis X, aumento 25x). Microdiorito: Foliação caracterizada pela intercalação de filmes máficos e félsicos. Amostra K-5b (corte XZ) 


\section{ROCHAS GRANITICAS}

$\mathrm{Na}$ porção mais oeste do Bloco Mongaguá, ocorrem granitos foliados, com feições gnáissicas ou protomiloníticas, subdivididos em três associações principais: 1) Granitos Tipo Itariri, de maior expressão em área, não diferenciado em mapa das rochas gnáissico- migmatíticas de Mongaguá e Itanhaém; 2) Granito Areado, corpo granítico limitado a norte pela $\mathrm{ZCC}$ e a sul pela $\mathrm{ZCl}$, com orientação em torno de $\mathrm{N} 40 \mathrm{E}$ e N70E nas proximidades da ZCC (Mapa Geológico - Anexo 1) com aproximadamente $42 \mathrm{~km}^{2}$ de área; e 3) Granito Ribeirão do Óleo, de menor expressão em área, em torno de $4 \mathrm{~km}^{2}$, ocorre nas proximidades da $\mathrm{ZCl}$, com orientação aproximada $\mathrm{E}-\mathrm{W}$. Os contatos entre os diferentes litotipos não foram identificados, sendo inferidos e fotointerpretados.

\section{GRANITO TIPO ITARIRI}

Tratam-se de biotita Monzogranitos (localmente tonalitos), de granulação finamédia, cor cinza médio, foliados, a megacristais de feldspato branco (Prancha 7, Foto 1). Localmente apresentam camadas ou filmes quartzo-feldspáticos, ou mesmo remobilizados quartzo-feldspáticos de granulação mais grossa, intercalados com bandas máficas, desenvolvendo um bandamento gnáissico com direção $E / 76 \mathrm{~N}$, localmente apresentando feições migmatíticas (Prancha 7, Foto 2).

A foliação ígnea caracteriza-se principalmente pela orientação dos megacristais de feldspatos e de biotitas, com orientaçōes em N85W/87NE e N30W/35NE, e desenvolve uma lineação mineral caracterizada pela orientação de feldspato com direção N85E/10.

Petrograficamente apresentam textura normalmente xenomórfica e caracterizamse pela mineralogia: quartzo, microclínio, plagioclásio, como máfico, biotita e os acessórios mais comuns são zircão, muscovita, apatita, opacos, e também, allanita e granada.

Os cristais de quartzo normalmente formam agregados (Prancha 7, Foto 3), com sub-grãos recristalizados e grãos maiores com extinção ondulante, mas em recuperação. 
Cristais de microclínio são normalmente mesopertíticos, subeuédricos a euédricos, e podem apresentar feiçőes mirmequíticas nas bordas ou no centro do cristal.

Os cristais de oligoclásio, subeuedrais a euedrais, normalmente apresentam-se saussuritizados, fraturados e com pouca deformação nas maclas.

A biotita normalmente é intersticial, com pleocroísmo de amarelo claro a marrom escuro avermelhado, podendo alterar para clorita.

Cristais de muscovita ocorrem como traços, normalmente associadas às biotitas, e também ocorrem como alteração de plagioclásio.

Os termos miloníticos dos Granitos Tipo Itariri, ocorrem tanto na porção sul, como na porção central do Bloco Mongaguá (Mapa Geológico - Anexo 1).

As rochas miloníticas da porção sul, afetadas pela $\mathrm{ZCl}$ (limite com o Bloco Registro), apresentam uma foliação milonítica principal com orientação em torno de N70W/53NE, e serão oportunamente descritas no Capítulo 9 referente à ZCI.

As rochas miloníticas presentes no interior do Bloco Mongaguá, ocorrem a norte da cidade de Peruibe, na região de Vila Peruíbe e Piraquara. Os litotipos identificados nesta região variam composicionalmente desde monzogranitos a tonalitos. Tratam-se de protomilonitos a milonitos (Prancha 7, Foto 4), com foliação milonítica de direções N80E/65SE e N80W/60NE, e lineações de estiramento mineral, caracterizadas pelo notável estiramento de feldspatos, com orientações S75E/28 e N85E/23 respectivamente. Através das indicações cinemáticas sinistrais observadas, predomina uma componente compressiva para $\mathrm{W}$.

Os granodioritos-monzogranitos apresentam uma textura protomilonítica definida pela orientação de biotitas, porfiroclastos de microclínio e plagioclásio e sigmóides de agregados de quartzo (Prancha 7, Foto 5), com indicação de movimento sinistral.

Os cristais de quartzo apresentam-se bem segregados em bandas ou em sigmóides, com grãos com pouca extinção ondulante, normalmente já recuperados ou recristalizados. 
Cristais de microclínio formam porfiroclastos sigmoidais, com textura mortar, recristalização nas bordas, (Prancha 7, Foto 6) e formação de feições mirmequíticas nas bordas. Cristais de oligoclásio mostram-se bastante fraturados, com alguma deformação nas maclas. As biotitas têm pleocroísmo amarelo claro a marrom escuro.

Os biotita-tonalitos, com minerais acessórios principais, zircão e granada, são protomiloníticos cuja foliação é caracterizada pela orientação das biotitas, envolvendo o plagioclásio e o quartzo já segregado em bandas e formas sigmoidais, com indicação de movimento sinistral (Prancha 7, Foto 7).

Cristais de plagioclásio apresentam textura mortar (Prancha 7, Foto 8) com recristalização de pequenos grãos nas bordas. Podem apresentar maclas ligeiramente encurvadas, e desenvolvem mirmequitas nas bordas.

Os cristais de biotita estão bem orientados e apresentam pleocroísmo de amarelo a marrom escuro. O mineral acessório em abundância é a granada, que apresenta-se bastante fraturada, com fraturas preenchidas por biotitas.

\section{GRANITO TIPO AREADO}

As rochas graníticas definidas como tipo Areado, afloram ao longo do Ribeirão do Areado e nas proximidades da cidade de Pedro de Toledo (Mapa Geológico - Anexo 1). São compostos predominantemente por biotita-monzogranitos de granulação finamédia, leucocráticos (Prancha 8, Foto 1), a megacristais de feldspato potássico de $3 \times$ $1.5 \mathrm{~cm}$. Apresentam foliação caracterizada pela disposição preferencial de cristais de feldspato e biotita, com orientação em torno de N20E/80NW e N-S/82W.

Localmente (afloramento K-84) podem apresentar feições atribuídas a uma deformação rúptil superimosta.

Nas proximidades da cidade de Pedro de Toledo, o Granito Tipo Areado encontra-se afetado pela $\mathrm{ZCl}$. Apresentam foliação milonítica N65W/60NE, e lineação de estiramento mineral (estiramento de feldspato e orientação de muscovitas) com orientação N55W/15, e indicação cinemática sinistral, com uma componente distensiva para NW. 
Os monzogranitos são compostos por quartzo, microclínio, plagioclásio e biotitas verdes como máfico, e como acessórios: titanita, epídoto, allanita, zircão e opacos (Prancha 8, Foto 2).

Os cristais de quartzo são normalmente intersticiais, os maiores com extinção ondulante ou tendendo a formar sub-grãos, e os grãos menores são recristalizados e com contatos poligonais (Prancha 8, Foto 3).

Cristais de microclínio, normalmente subeuedrais, mostram feições mirmequíticas nas bordas, e cristais de plagioclásio (oligoclásio), normalmente subeuedrais, estão pouco sericitizados.

Cristais de biotita, subeuedrais ou intersticiais, têm pleocroísmo amarelo claro a verde escuro, e alteram para clorita.

Cristais de titanita ocorrem sempre associadas às biotitas e manteando minerais opacos. Allanitas ocorrem manteadas por epídoto.

Estes granitos apresentam variações composicionais, gradualmente tornando-se mais tonalíticos, de granulação mais fina e com maior porcentagem de máficos, apresentando-se mesocráticos. Nestes locais é frequente o desenvolvimento de feições gnáissicas (Prancha 8, Foto 4).

Ao microscópio, onde a textura gnáissica é bastante proeminente, desenvolvemse bandas quartzo-feldspáticas, onde o quartzo tende a se segregar em ribbons (Prancha 8, Foto 5) e as bandas máficas apresentam alta quantidade de biotitas subeuedrais bem orientadas.

Nas porções onde ocorre deformação rúptil, a rocha apresenta-se bastante sericitizada e epidotizada. Ocorrem fraturas nos cristais de microclínio e plagioclásio preenchidas por quartzo microgranular (Prancha 8, Foto 6). Cristais de quartzo também apresentam-se fraturado, ou recristalizados com contatos poligonais.

\section{GRANITO RIBEIRÃO DO ÓLEO}

A norte da localidade de Raposo Tavares, ao longo do Ribeirão do Óleo, ocorrem biotita-monzogranitos de coloração cinza médio azulado, finamente foliado, com porções porfiríticas bem definidas, a megacristais de feldspato potássico euedrais 
centimétricos. Este granito apresenta, na região de estudo, uma particularidade que é a interação nítida com um material máfico, de coloração cinza escuro, finamente foliado.

Nesta interação, as rochas (félsica e máfica) apresentam estruturas de fluxo magmático bem definidas (Prancha 9 , Foto 1). O conjunto mostra-se finamente foliado, apresentando foliação com direção preferencial E-W/60 N, e lineação mineral N50W/54, caracterizada principalmente pela orientação de cristais de biotita.

Próximo ao contato entre os materiais félsico e máfico, há forte concentração de fenocristais de feldspato potássico (Prancha 9, Foto 2), euedrais, centimétricos (Prancha 9, Foto 3), caracterizando verdadeiros cumulatos. Notadamente, os cumulatos de feldspatos concentram-se próximo à rocha máfica, que por sua vez pode apresentarse como enclaves em meio ao monzogranito, com formas bastante alongadas e irregulares (Prancha 9, Foto 1). Nota-se também a presença de enclaves duplos, ou seja, enclaves de fenocristais de feldspato potássico do material monzogranítico, nos enclaves máficos (xenocristais) (Prancha 9, Foto 1).

É comum a presença de segregados quartzo-feldspáticos de granulação grossa, que podem apresentar-se paralelos ou cortando a foliação (Prancha 9, Foto 4).

Tais feições são características da existência de magma mingling, onde pode ser observada a interação entre dois materiais bastante distintos, que ainda são perfeitamente individualizados.

Petrograficamente a porção félsica caracteriza-se por um biotita-monzogranito, de granulação fina, foliado, composto por quartzo, microclínio, plagioclásio, biotita, e como acessórios titanita, zircão e apatita.

A foliação é caracterizada pela orientação das biotitas e das faixas segregadas de quartzo (Prancha 9, Foto 5).

Os cristais de quartzo normalmente ocorrem em agregados policristalinos, com contatos poligonizados, sem extinção ondulante, tendendo a se segregar em faixas.

Cristais de microclínio são raramente micropertíticos, e não raramente mostramse recristalizados (Prancha 9, Foto 6). Cristais de plagioclásio normalmente estäo saussuritizados.

Os cristais de biotita têm pleocroísmo amarelo-claro a marrom forte avermelhado, e alteram-se para cloritas. Cloritas e muscovitas também ocorrem bem formadas. 
PRANCHA 7

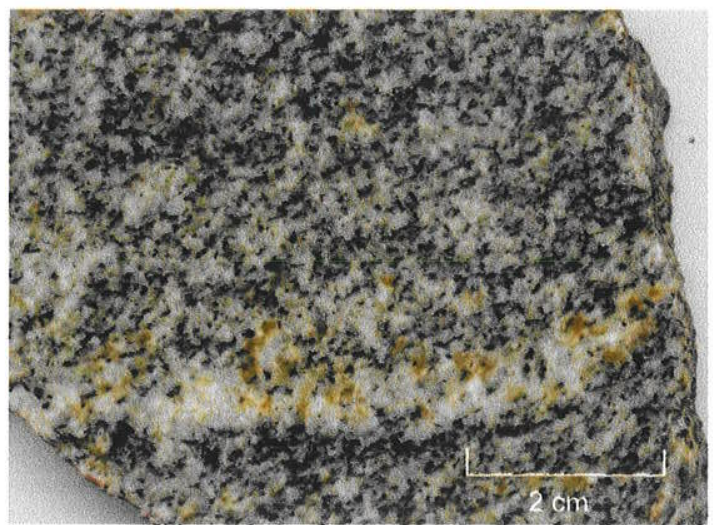

Foto 1 - Biotita monzogranito - Tipo Itariri. Norte de Itariri. Amostra K-78.

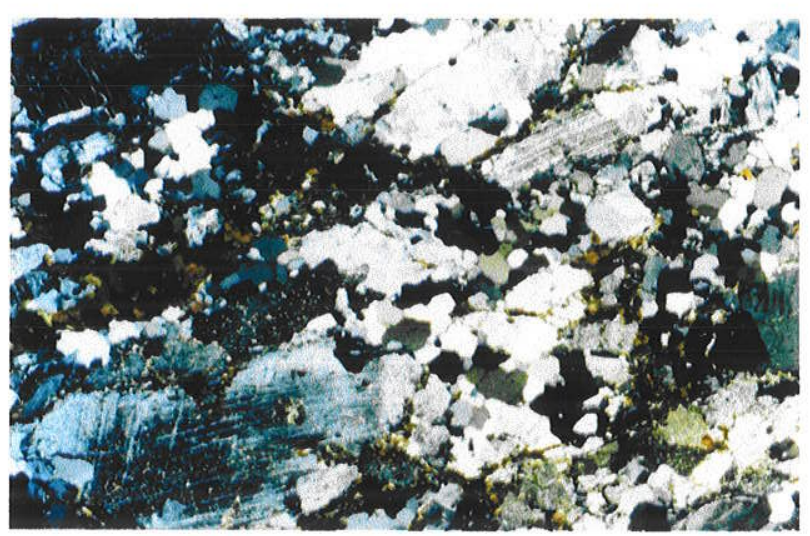

Foto 3 - Fotomicrografia (nicóis $X$, aumento 25x). Biotitamonzogranito foliado - Tipo Itariri. Agregados de quartzo, FK mesopertíticos. Amostra K-52 (corte XZ).

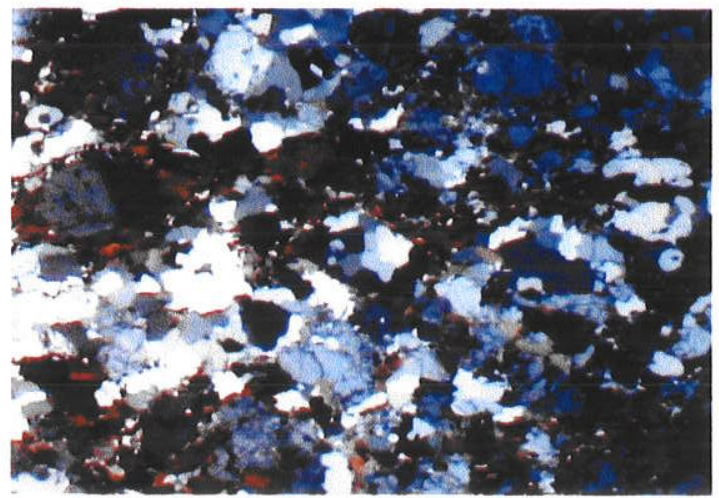

Foto 5 - Fotomicrografia (nicóis $X$, aumento 10x). Textura protomilonítica em granodiorito: porfiroclastos de plagioclásio e agregados de quartzo sigmoidais. Amostra K-69 (corte XZ).

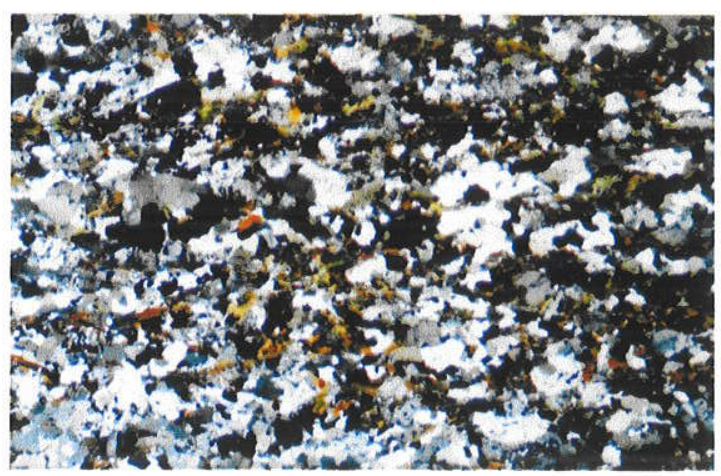

Foto 7 - Fotomicrografia (nicóis $X$, aumento 10x). Biotita tonalito. Textura protomilonítica. Amostra K68 (corte XZ).

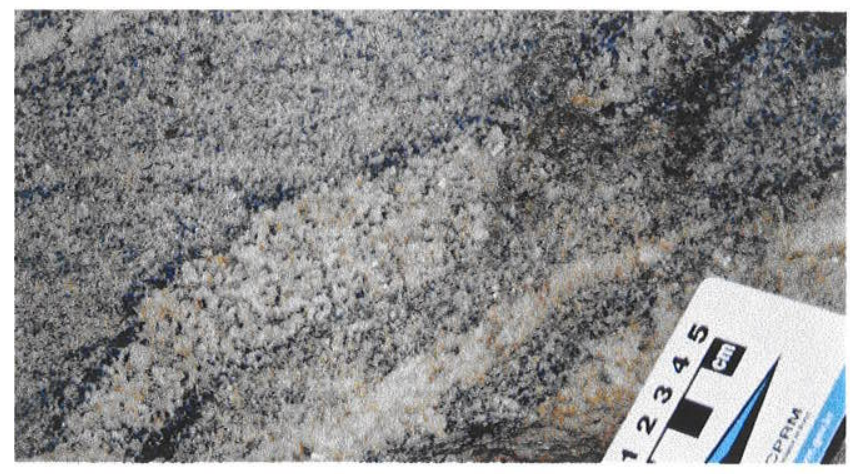

Foto 2 - Biotita-monzogranito - Tipo Itariri com feições gnáissico-migmatíticas localizadas. Amostra K-78.

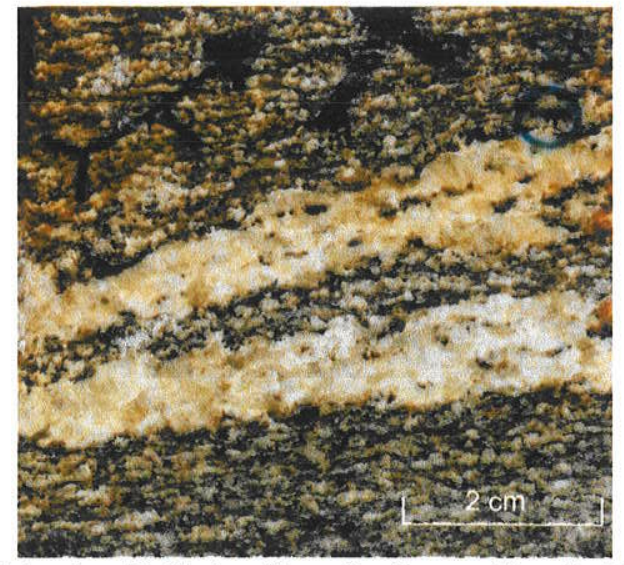

Foto 4 - Biotita-tonalito milonítico - Tipo Itariri. Região de Piraquara. Amostra K-68 (corte XZ).

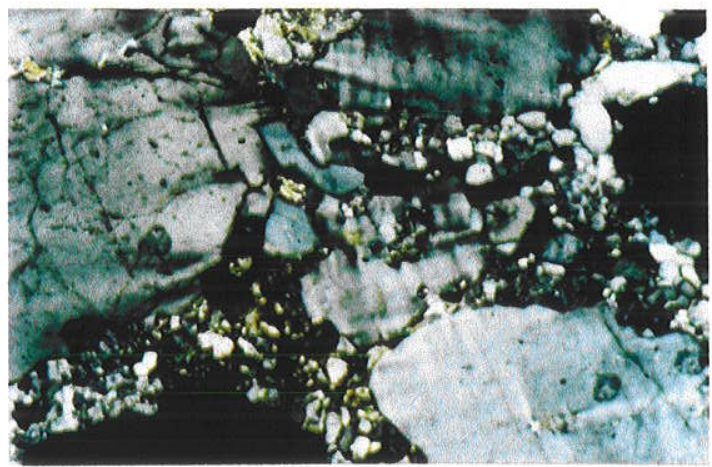

Foto 6 - Fotomicrografia (nicóis $\mathrm{X}$, aumento 100x). Biotita-monzogranito milonítico. Recristalização de microclínio. Amostra K-69 (corte XZ).

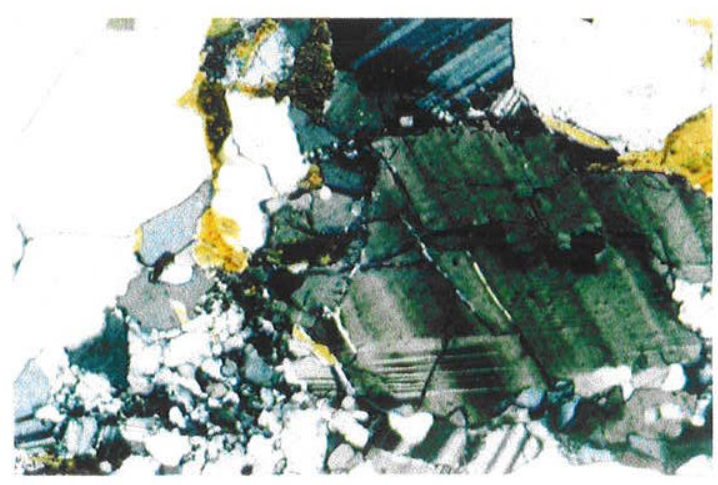

Foto 8 - Fotomicrografia (nicóis $X$, aumento 100x). Biotita tonalito protomilonítico. Início de recristalização de plagioclásio. Amostra K-68 (corte XZ). 


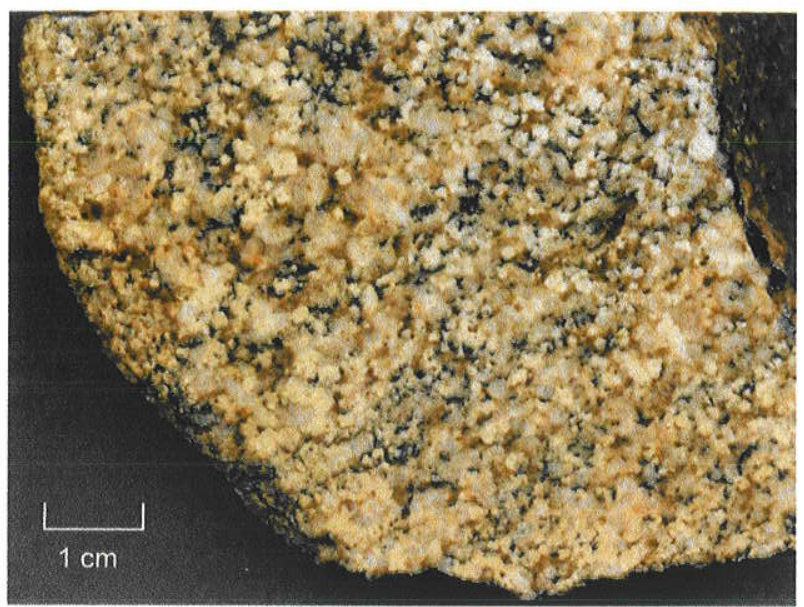

Foto 1 - Biotita monzogranito - Tipo Areado. Amostra K-83.

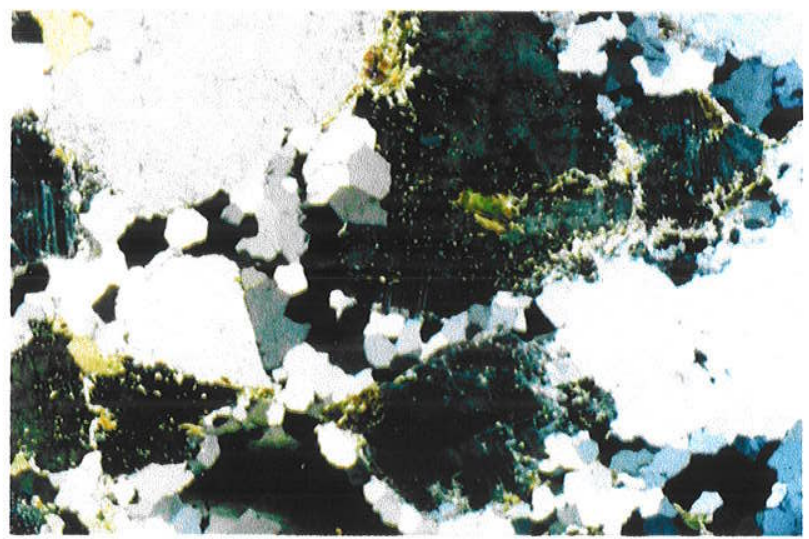

Foto 3 - Fotomicrografia (nicóis $X$, aumento 25x). Biotitamonzogranito - Tipo Areado. Recristalização de quartzo. Amostra K-82.

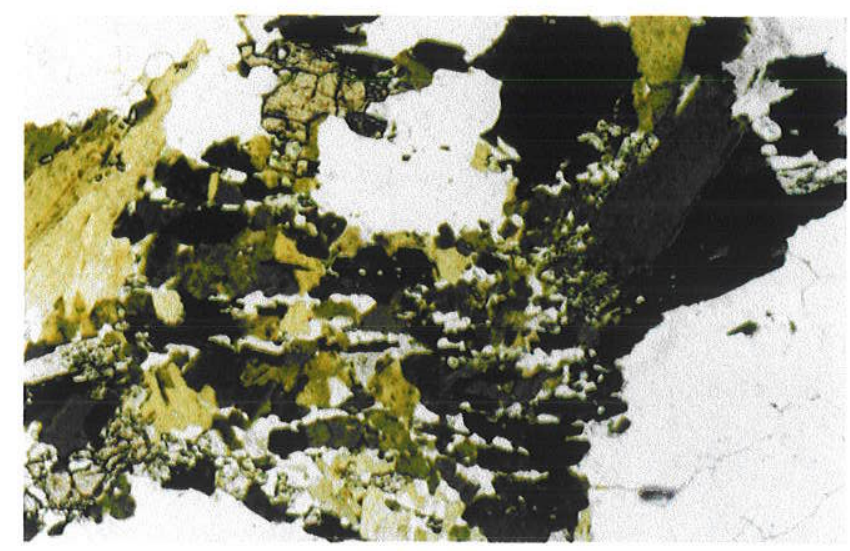

Foto 2 - Fotomicrografia (nicóis /I, aumento 50x). Biotitamonzogranito - Tipo Areado. Máfico principal biotita verde, mineral acessório titanita. Amostra K-81.

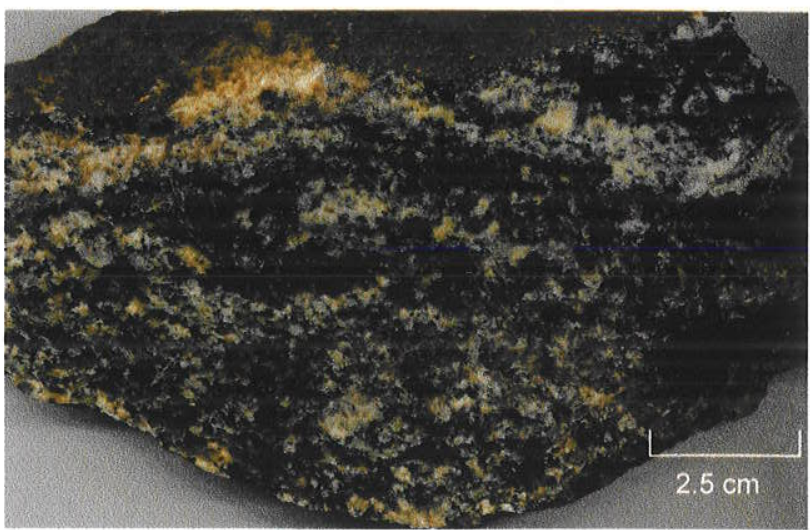

Foto 4 - Biotita-tonalito mesocrático - Tipo Areado. Feições gnáissicas localizadas. Amostra K-81.

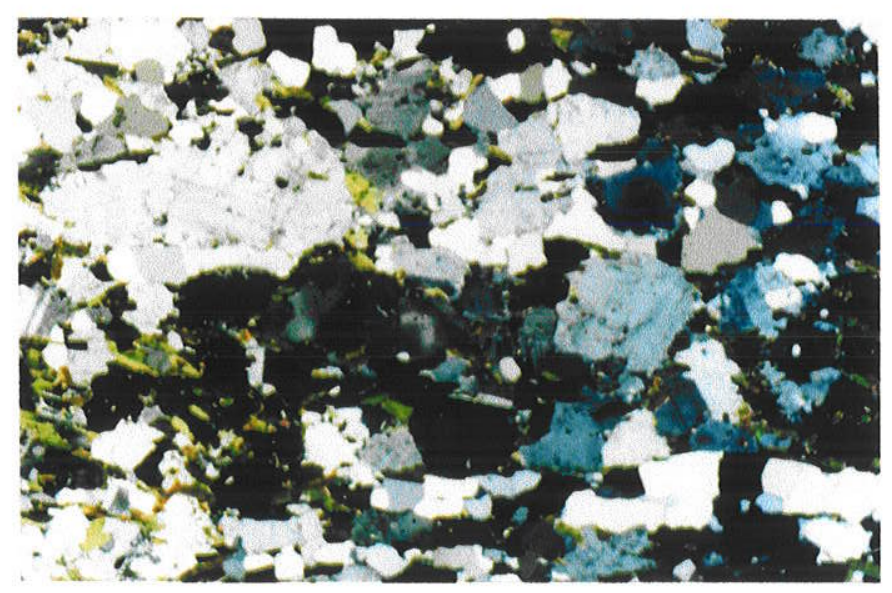

Foto 5 - Fotomicrografia (nicóis X, aumento 25x). Biotita monzogranito deformado - Tipo Areado. Tendência a formar ribbons de quartzo. Amostra K-84 (corte XZ).

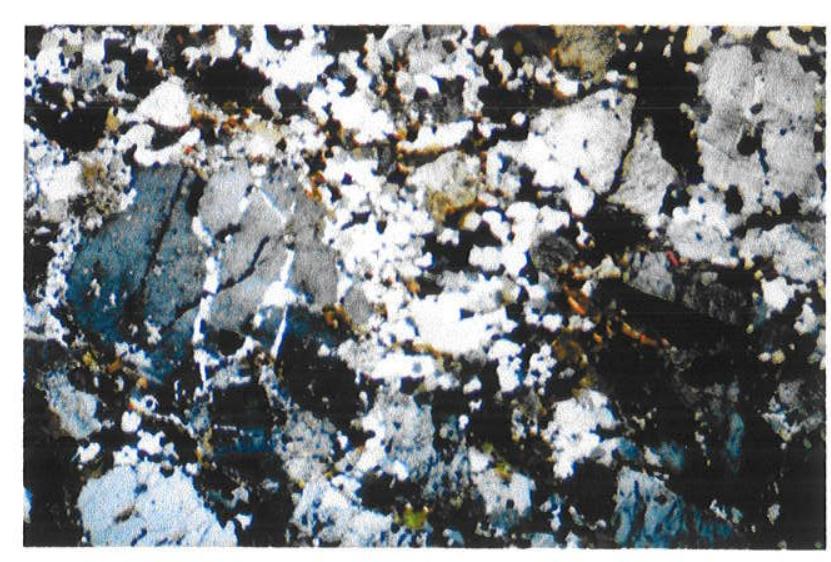

Foto 6 - Fotomicrografia (nicóis $\mathrm{X}$, aumento $7.5 \mathrm{x}$ ). Biotita monzogranito deformado - Tipo Areado. Fraturamento em cristais de FK e plagioclásio preenchidos por quartzo. Amostra K-84. 


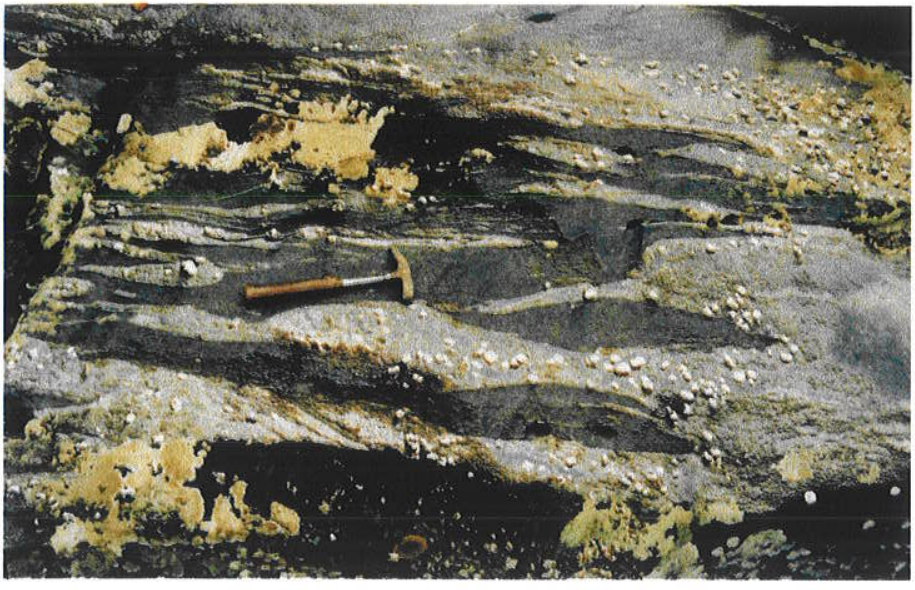

Foto 1 - Magma mingling de material monzogranítico e máfico. Granito Ribeirão do Óleo. Maior concentração de fenocristais de FK nas proximidades do material máfico. Afloramento K-54.

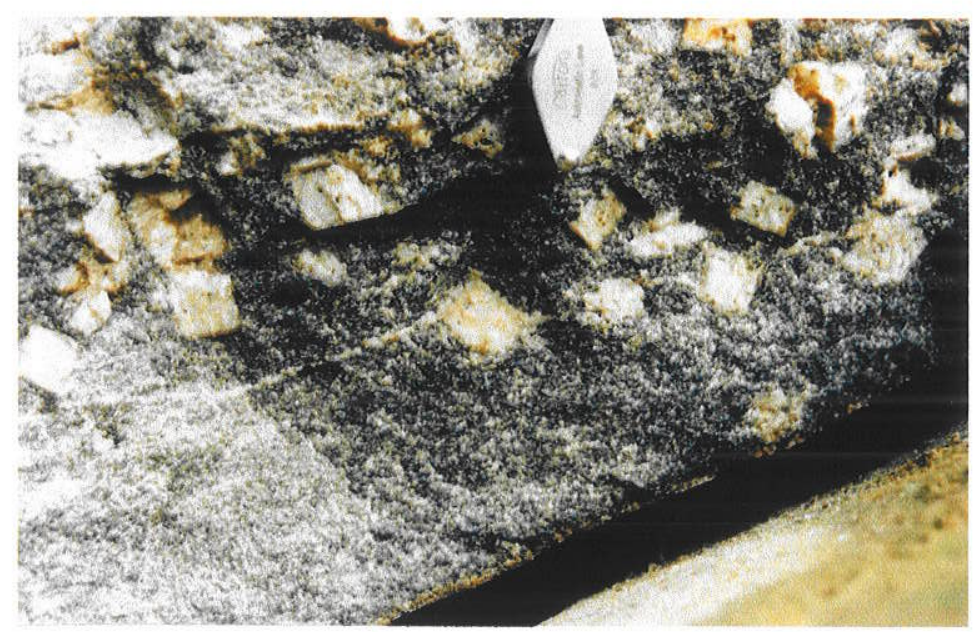

Foto 3 - Granito Ribeirão do Óleo. Fenocristais de FK euedrais centimétricos.

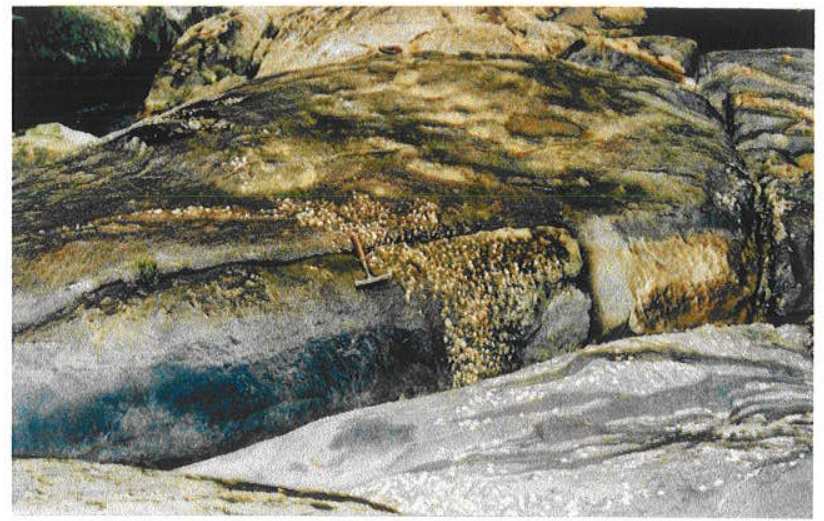

Foto 2 - Granito Ribeirão do Óleo. 'Cachoeira' de fenocristais de FK

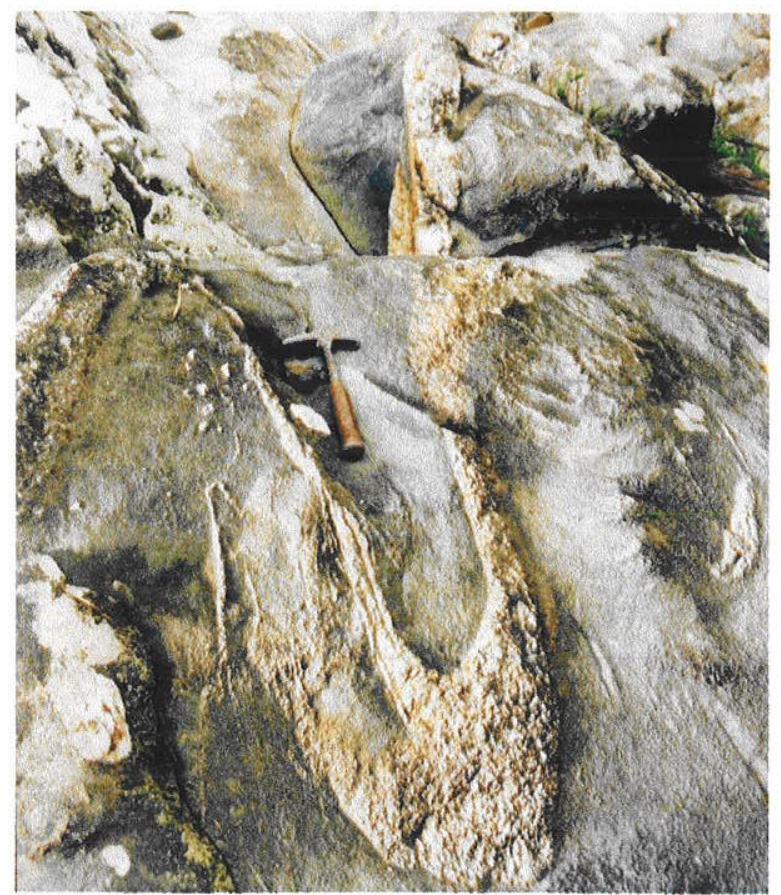

Foto 4 - Granito Ribeirão do Óleo. Segregados quartzo-feldspáticos de granulação grossa.

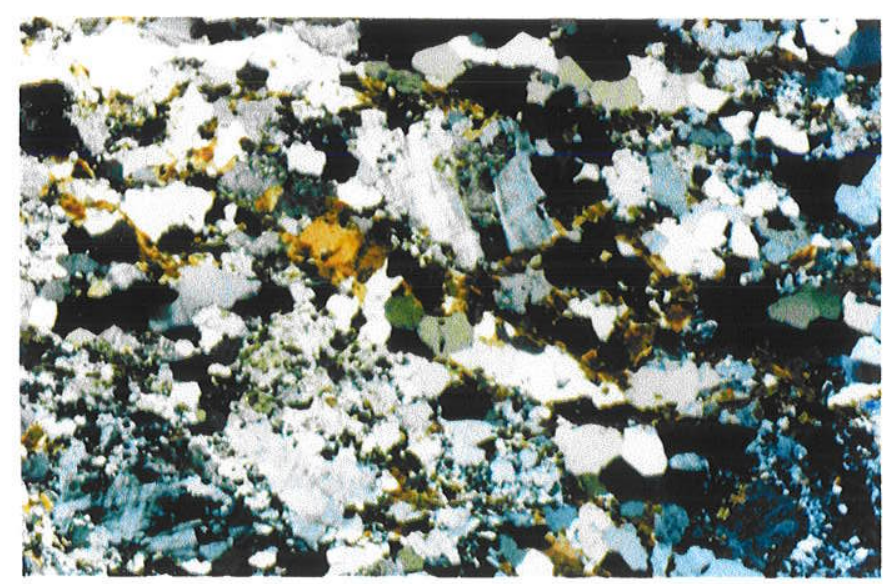

Foto 5 - Fotomicrografia (nicóis X, aumento 25x). Biotitamonzogranito-Ribeirão do Óleo. Foliação caracterizada pela orientação de faixas segregadas de quartzo. Amostra K-54 (corte $\mathrm{XZ}$ ).

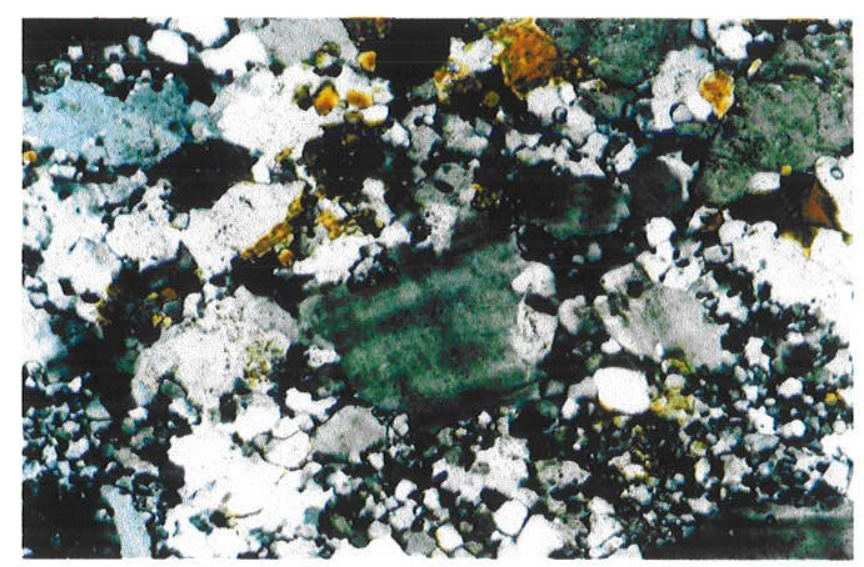

Foto 6 - Fotomicrografia (nicóis X, aumento 100x). Biotitamonzogranito-Ribeirão do Óleo. Recristalização de microclínio. Amostra K-54 (corte XZ). 
Análises pelo Método de Fry (Fry, 1979, 1999), em cortes XZ e YZ de seções delgadas foram realizadas em rochas graníticas Tipo Itariri, da porção mais interior do Bloco Mongaguá, a norte da localidade de Pedro de Toledo e a norte de Peruíbe. As análises realizadas referem-se ao biotita-monzogranito (amostra K-52) e ao biotita-tonalito com granada (amostra K-68), ver Mapa Geológico - Anexo 1.

O biotita monzogranito (K-52) apresenta-se finamente foliado, com foliação caracterizada pela orientação de feldspatos e biotita, e a lineação mineral desenvolvida definida pelo alinhamento dos feldspatos. Em seção delgada, a rocha apresenta-se pouco deformada, com fraturamento dos cristais de plagioclásio e fraturas preenchidas por quartzo microgranular.

O biotita tonalito (K-68) mostra-se protomilonítico, com foliação caracterizada por filmes e camadas quartzo-feldspáticas estiradas, intercaladas com bandas máficas. Apesar do seu posicionamento no interior do Bloco Mongaguá, esta rocha mostra forte influência da $\mathrm{ZCl}$, apresentando indicações cinemáticas sinistrais, e orientação da foliação milonítica em torno de E-W.

A orientação dos eixos principais do elipsóide de deformação estão listados na Tabela 6.2.1, juntamente com as orientações da foliação principal da rocha e lineação mineral.

\begin{tabular}{|c|c|c|c|c|c|c|c|}
\hline \multirow[b]{2}{*}{ AMOSTRA } & \multirow[b]{2}{*}{ ROCHA } & \multirow[b]{2}{*}{$\mathbf{S} / \mathbf{S M}$} & \multirow[b]{2}{*}{ L/LM } & \multicolumn{3}{|c|}{ EIXOS DO ELIPSÓIDE DE DEFORMAÇAO } & \multirow[b]{2}{*}{ MOVIMENTO } \\
\hline & & & & EixoX & EixoY & EixoZ & \\
\hline $\mathrm{K}-52$ & Granito foliado & N85W/87NE & N85E/10 & $\mathrm{S} 88 \mathrm{E} / 16$ & N30W/65 & $\mathrm{S} 2 \mathrm{~W} / 30$ & \\
\hline K-68 & Protomilonito granítico & E/76N & N85E/23 & S74E/32 & $\mathrm{N} 15 \mathrm{~W} / 15$ & $S 16 \mathrm{~W} / 38$ & sinistral \\
\hline
\end{tabular}

Tabela 6.2.1 - Direção da foliação e lineação mineral principal das amostras analisadas e orientação dos eixos do elipsóide obtidos pelo Método de Fry .

Como pode ser observado na Tabela 6.2.1, houve razoável concordância entre a orientação do eixo $X$ do elipsóide de deformação (direção de máxima extensão) e a lineação de estiramento mineral medida na rocha protomilonítica (K68). Adicionalmente, também houve concordância entre as orientações obtidas na rocha protomilonítica com às obtidas no granito foliado $(\mathrm{K}-52)$. Tal fato pode ser sugestivo de que o fluxo magmático associado ao Granito Tipo Itariri estava condicionado pela deformação associada à $\mathrm{ZCl}$. A direção de máxima compressão 
(eixo Z) concentrou-se em torno de SW, e a direção de estiramento próximo a $\mathrm{E}$ (ver Mapa Estrutural - Anexo 2).

A Figura 6.2.3 mostra as elipses e seus respectivos eixos principais obtidos pelo método de Fry. A posição do traço da foliação principal (magmática e protomilonítica) nos cortes $X Z$ e YZ é vertical, e a horizontal da direção de cada corte, bem como sua orientação estão indicados na porção superior de cada figura.

O posicionamento da elipse de deformação na amostra K-68, em relação à foliação protomilonítica sugere movimentação sinistral, e as elipsidades observadas indicam razoável deformação associada a estas rochas.
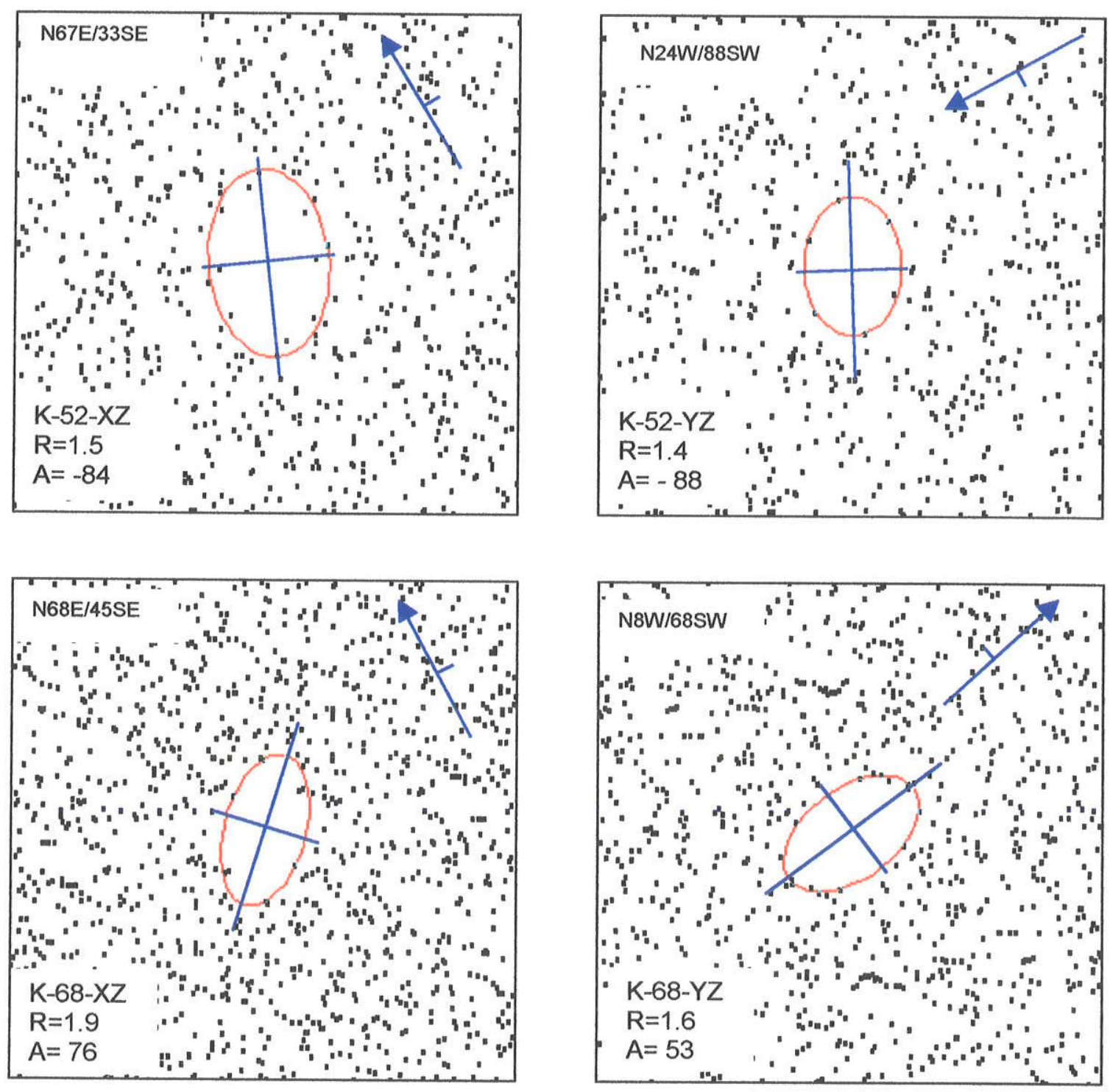

Figura 6.2.3 - Método de Fry aplicado às rochas do Bloco Mongaguá. 
As elipsidades obtidas pelo Método de Fry, Tabela 6.2.2, consequentemente foram utilizados para obtenção dos parâmetros necessários (Rxy, K, D - Capítulo 2) para o conhecimento da forma do elipsóide de deformação (Diagrama de Flinn).

\begin{tabular}{|c|c|c|c|c|c|c|c|}
\hline AMOSTRA & $\mathbf{R X Z}$ & $\mathbf{R Y Z}$ & $\mathbf{R X Y}$ & $\mathbf{K}$ & $\mathbf{D}$ & ELIPSOIDE & DIAGRAMA DE FLINN \\
\hline K-52 & 1.5 & 1.4 & 1.1 & 0.25 & 0.4 & Oblato & Achatamento aparente \\
\hline K-68 & 1.9 & 1.6 & 1.2 & 0.33 & 0.6 & Oblato & Achatamento aparente \\
\hline
\end{tabular}

Tabela 6.2.2 - Dados obtidos pelo método de Fry e aplicação de Diagrama de Flinn.

Em diagrama de Flinn (Figura 6.2.4), o granito foliado K-52, plotou no campo de achatamento aparente, próximo ao campo do achatamento uniaxial, com valor de $\mathrm{K}$ muito baixo. Por tratar-se de rocha muito pouco deformada, a geração de elipsóides oblatos possivelmente relaciona-se ao fluxo magmático. Este, por sua vez, poderia estar condicionado à movimentação da $\mathrm{ZCl}$.

Do mesmo modo, o protomilonito K-68 plotou no campo do achatamento uniaxial (Figura 6.2.4), com geração de elipsóides oblatos, registrando portanto, uma deformação associada a um evento transpressional, de movimentação sinistral (Figura 6.2.3).

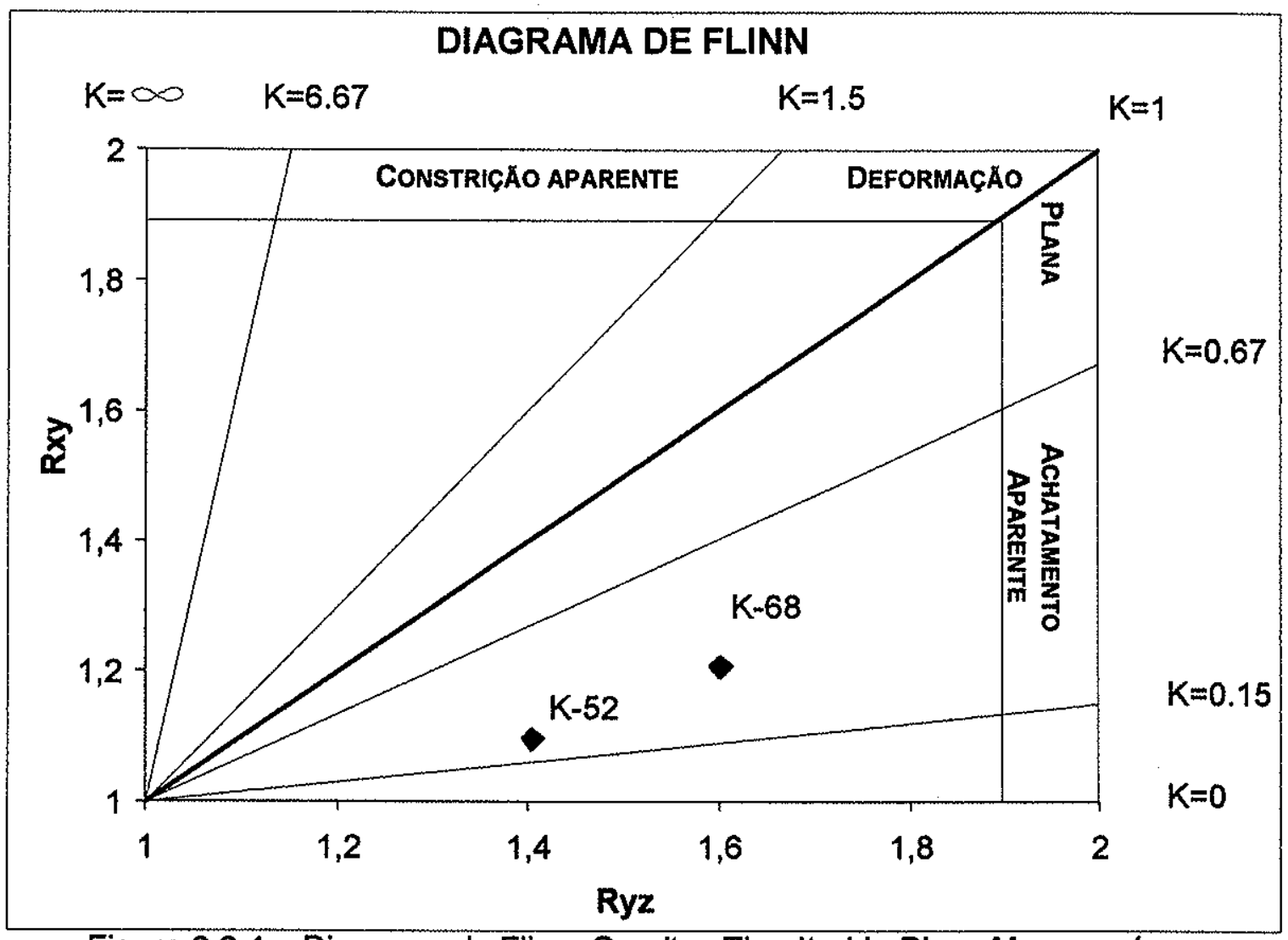

Figura 6.2.4 - Diagrama de Flinn. Granitos Tipo Itariri - Bloco Mongaguá. 


\subsection{ANÁLISE GeOQUIMICA}

As amostras selecionadas para as análises químicas dos elementos maiores, traços e Terras Raras (ETR) do Bloco Mongaguá, procuraram representar os principais litotipos existentes na área estudada deste Bloco. A localização dos afloramentos das amostras quimicamente investigadas, encontram-se assinalados no Mapa Geológico - Anexo 1, e os resultados analíticos obtidos estão listados no Apêndice 1. A relaçăo dos litotipos analisados, via química rocha total, compreende:

1) Rochas gnáissico migmatíticas de Mongaguá e Itanhaém: porção félsica, anfibólio-biotita monzogranito (amostras $\mathrm{K}-3, \mathrm{~K}-3 \mathrm{~A}$ ), anfibólio-biotita sienogranito (amostra K-5), com teores de 60 a $70 \%$ de $\mathrm{SiO}_{2}$; porção máfica, gnaisses dioríticos (amostras K-3B, K-5B) com teores de $\mathrm{SiO}_{2}$ entre 44 e $52 \%$;

2) Granitos Tipo Itariri: biotita monzogranitos (amostras K-4, K-52, K-78) e biotitatonalito, (amostra K-68) com teores de $\mathrm{SiO}_{2}$ entre 70 e $77 \%$;

3) Granito Tipo Areado: biotita monzogranitos (amostras $\mathrm{K}-81, \mathrm{~K}-82$ ) com teores de $\mathrm{SiO}_{2}$ em torno de $70 \%$;

4) Granito Ribeirão do Óleo: biotita-monzogranito (amostra K-54) com teor de $70.5 \%$ de $\mathrm{SiO}_{2}$.

O tratamento geoquímico das rochas pertencentes ao Bloco Mongaguá é aqui apresentado de modo simplificado, devido o número reduzido de análises realizadas para as amostras representativas de cada grupo de rochas do Bloco Mongaguá, que envolve uma grande variedade de litotipos.

Em Diagrama $\mathrm{Na}_{2} \mathrm{O}+\mathrm{K}_{2} \mathrm{O} \times \mathrm{SiO}_{2}$, de Irvine \& Baragar (1971), Figura 6.3.1, as rochas graníticas analisadas do tipo Itariri, Areado e Ribeirão do Óleo, plotam no campo sub-alcalino (cálcio-alcalino de alto potássio). Estas diferenciam-se das amostras representativas das porções graníticas e dioríticas do contexto gnáissicomigmatítico de Mongaguá e Itanhaém, que plotam no campo das rochas alcalinas. 


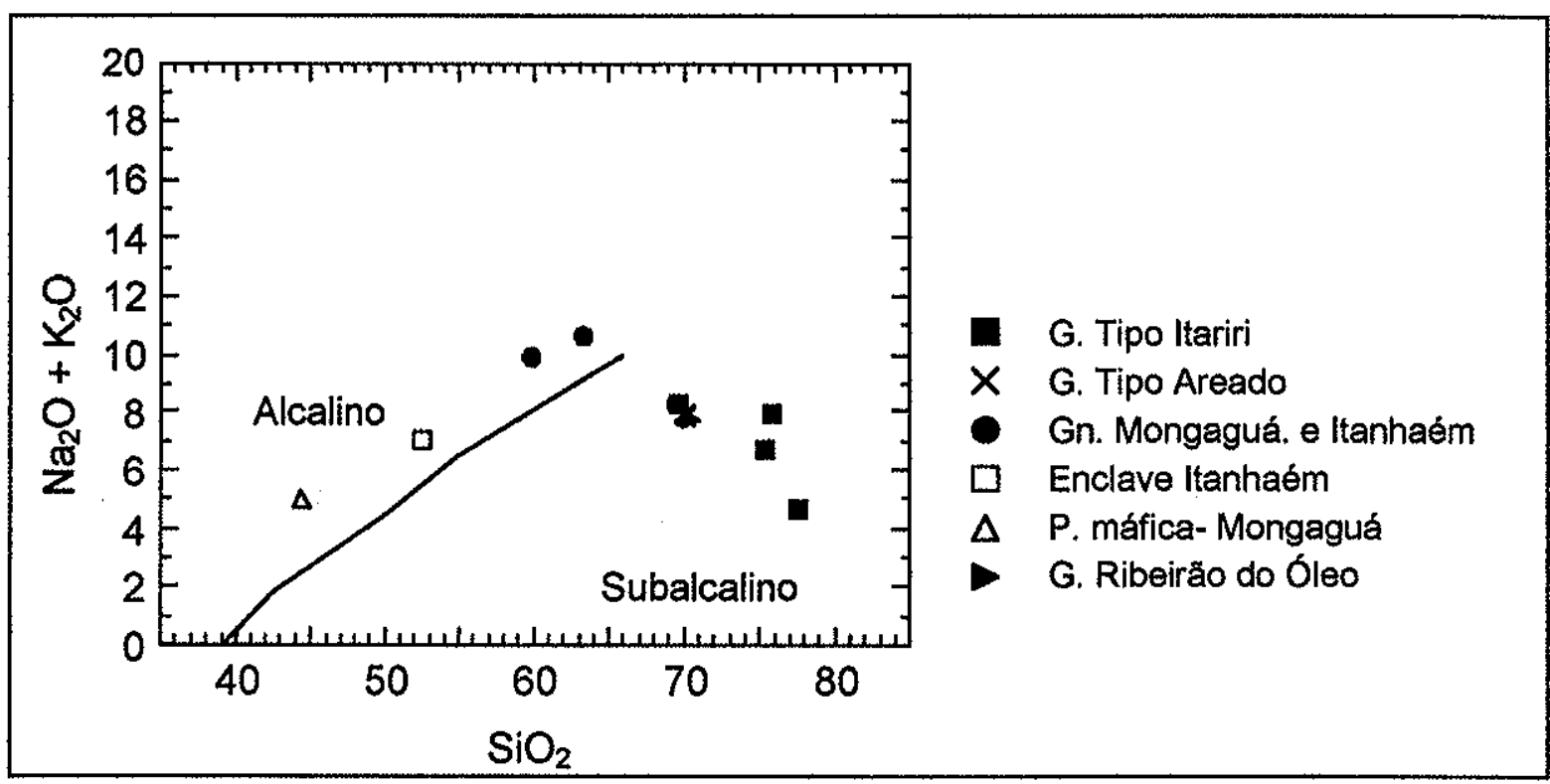

Figura 6.3.1 - Diagrama $\mathrm{SiO}_{2} \times \mathrm{Na}_{2} \mathrm{O}+\mathrm{K}_{2} \mathrm{O}$ - Irvine \& Baragar (1971) - Bloco Mongaguá.

As rochas do Bloco Mongaguá apresentam características metaluminosas a peraluminosas (Figura 6.3.2), como pode ser observado em Diagrama de Maniar \& Piccoli (1989).

As porções graníticas e dioríticas de Mongaguá e Itanhaém, se posicionam no campo das rochas metaluminosas, onde as porções dioríticas se diferenciam das demais, por apresentarem valores bem mais elevados de $\mathrm{CaO}$.

Os granitóides tipo Itariri se posicionam preferencialmente no campo das rochas peraluminosas. Destacam-se a amostra representativa de um biotita-tonalito com granada protomilonítico (K-68), próximo a Peruíbe, por apresentar valores bem mais elevados de A/NK, e a amostra do muscovita-biotita monzogranito a norte de Itariri (K-52), por mostrar valores bem mais baixos principalmente de $\mathrm{CaO}$, e consequente elevada razão de AVCNK.

Apenas duas amostras dos granitóides Tipo Areado foram analisadas, e posicionam-se no campo das rochas peraluminosas, próximo ao campo das metaluminosas.

A única amostra representativa do Granito Ribeirão do Óleo, posicionou-se no campo das rochas peraluminosas, próximo ao campo das metaluminosas. 


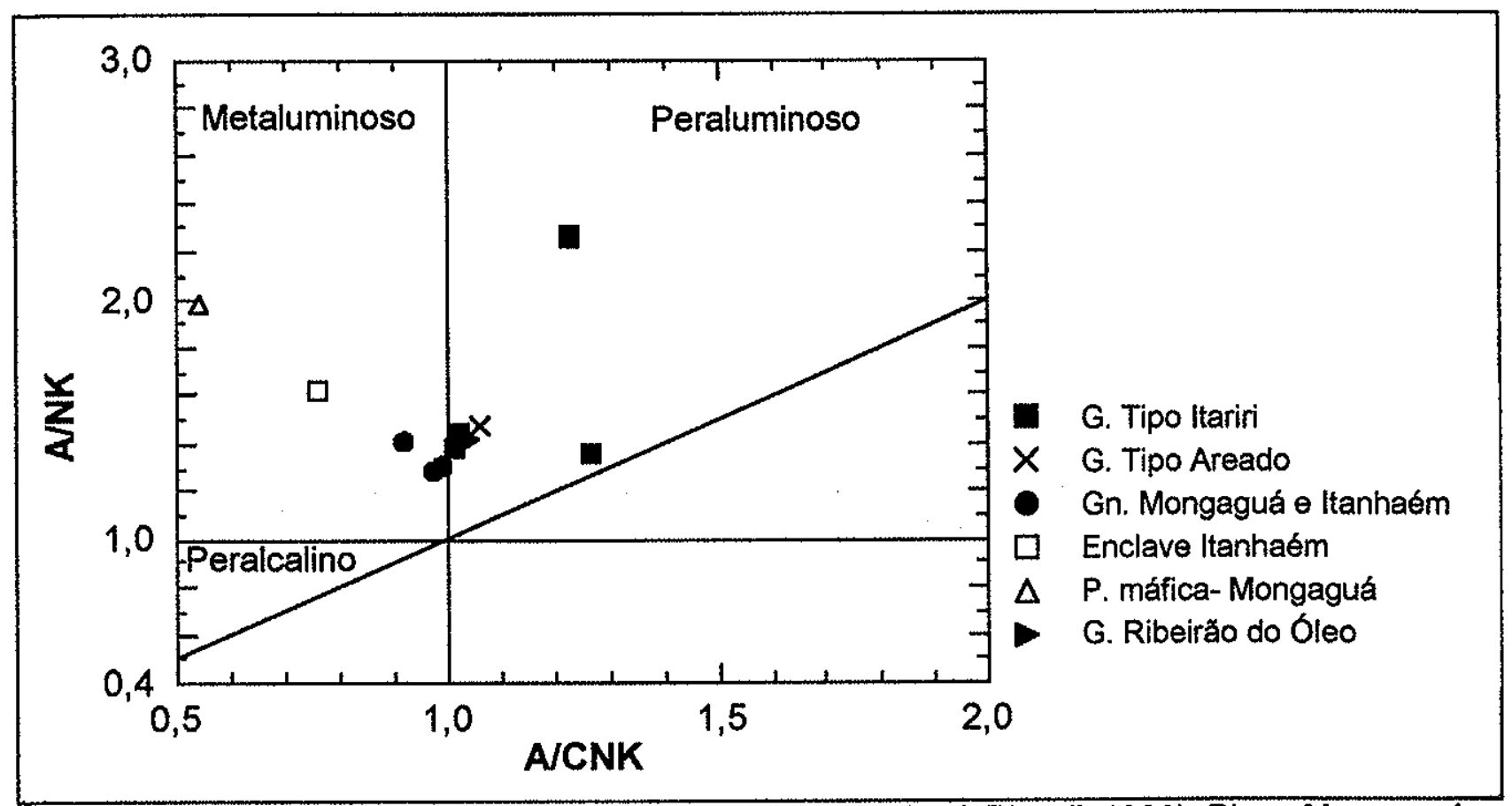

Figura 6.3.2-Diagrama de razóes A/CNK x A/NK (Maniar \& Piccoli, 1989)-Bloco Mongaguá.

Em diagrama $\mathrm{Na}_{2} \mathrm{O} \times \mathrm{K}_{2} \mathrm{O}$ (Figura 6.3.3), observa-se um comportamento bastante variável entre as rochas gnáissicas (Mongaguá e Itanhaém) e entre as rochas graníticas tipo Itariri, Areado e Ribeirão do Óleo.

Os gnaisses monzograníticos da região de Mongaguá distribuem-se no campo das séries de alto potássio e das séries potássicas, sendo sua porção máfica, pertencente ao campo das séries potássicas. Distribuição distinta é observada para a rocha gnáissica sienogranítica de Itanhaém, que plota no campo das rochas pertencentes a séries potássicas, sendo a amostra representativa do enclave máfico, pertencente às séries sódicas.

As rochas graníticas tipo Itariri apresentam uma variação de rochas desde séries de mais baixo potássio até rochas pertencentes à séries de alto potássio. Mostram uma tendência no aumento do teor de $\mathrm{K}_{2} \mathrm{O}$ da porção mais a leste do Bloco Mongaguá, amostra K-4, que plota no limite das série potássica e sódica, para a porção mais oeste, amostra K-52, que plota no campo das série de alto potássio.

Os granitos tipo Areado pertencem a séries de alto potássio, e a única amostra do Granito Ribeirão do Óleo plota no campo das séries potássicas. 


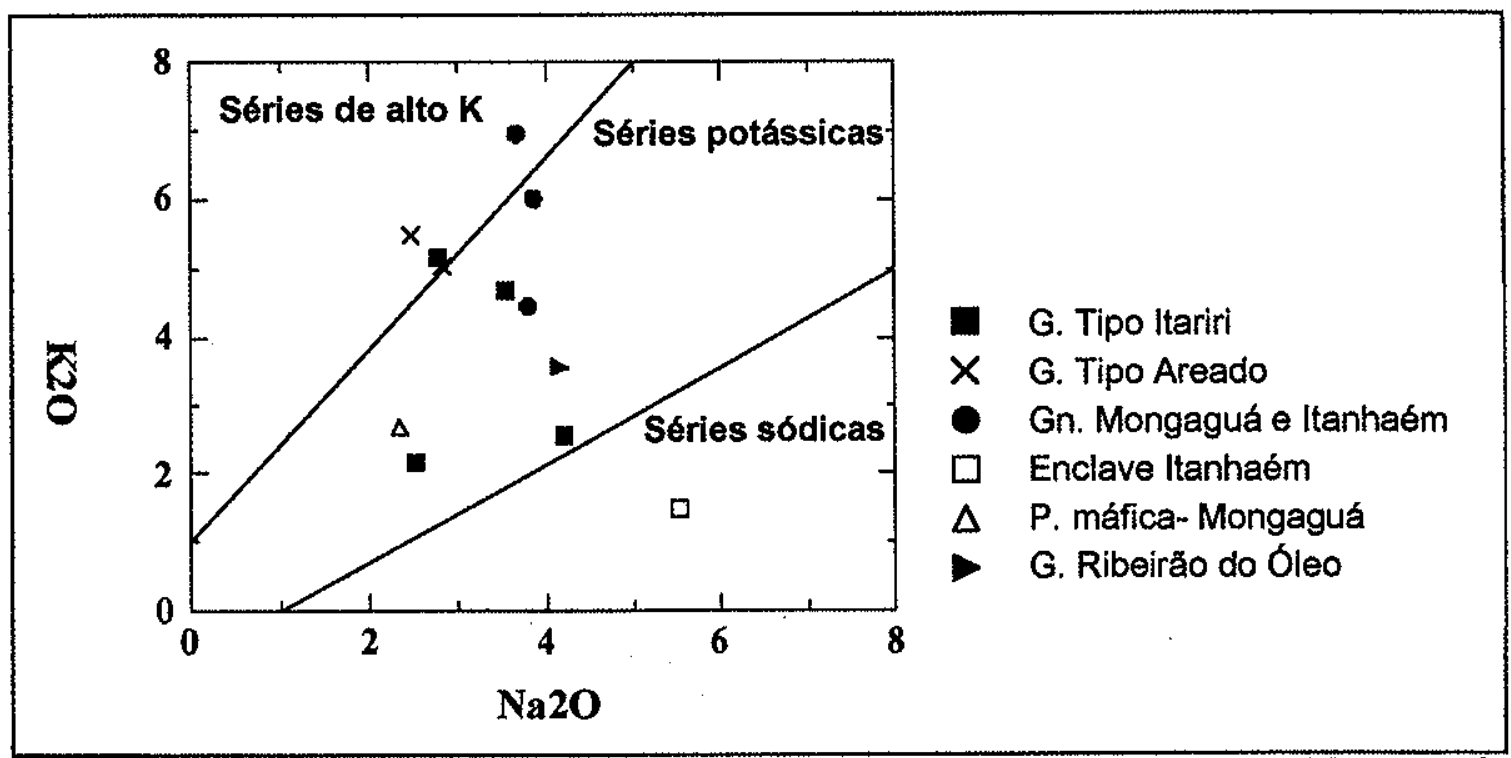

Figura 6.3.3 - Diagrama $\mathrm{Na}_{2} \mathrm{O} \times \mathrm{K}_{2} \mathrm{O}$, Middlemost (1975). Rochas do Bloco Mongaguá.

Em diagramas de $\mathrm{SiO}_{2} \times$ óxidos, para os Granitos Tipo Itariri, não observa-se uma coerência geoquimica constante em relação aos coeficientes de correlação entre os teores de óxidos de $\mathrm{Ti}, \mathrm{Fe}, \mathrm{Mg}, \mathrm{Mn}, \mathrm{Ca}$ e $\mathrm{P}$ e $\mathrm{SiO}_{2}$ (Figura 6.3.4). Nota-se que as amostras com teores semelhantes de $\mathrm{SiO}_{2}$, entre 75 e $77 \%$, (amostras $\mathrm{K}-4$, $\mathrm{K}-52$ e K-68) apresentam um comportamento distinto principalmente em relação aos teores de óxidos de $\mathrm{Ti}$ e $\mathrm{Ca}$, onde, a amostra K-52 mostra-se mais empobrecida nestes elementos em relação às demais. Diferença marcante também pode ser observada nos teores de $\mathrm{Na}_{2} \mathrm{O}$, onde as amostras com teores similares de $\mathrm{SiO}_{2}$ mostram teores bastante distintos neste óxido. Os teores de $\mathrm{Al}_{2} \mathrm{O}_{3}$ se mantém praticamente constantes nos granitos Tipo Itariri.

As amostras representativas dos Granitos Areado e Ribeirão do Óleo, com teores em $\mathrm{SiO}_{2}$ de cerca de 70\%, apresentam comportamento bastante similar na distribuição dos óxidos, com exceção do $\mathrm{Na}_{2} \mathrm{O}$, que está mais enriquecido no Granito Ribeirão do Óleo (Figura 6.3.4).

As rochas gnáissico-migmatíticas de Mongaguá e Itanhaém (porções graníticas e respectivas porções dioríticas) apresentam uma tendência na diminuição dos óxidos de $\mathrm{Ti}, \mathrm{Fe}, \mathrm{Mg}, \mathrm{Ca}$ e $\mathrm{P}$ com o aumento da $\mathrm{SiO}_{2}$. Porém, observa-se um enriquecimento nos teores dos óxidos de $\mathrm{Ti}, \mathrm{Fe}$ e $\mathrm{Mn}$ no sienogranito de Itanhaém em relação aos monzogranitos de Mongaguá. Diferenças importantes são observadas nos teores de óxidos de $\mathrm{Al}$ e $\mathrm{Na}$ nas porções dioríticas, onde apresentam-se empobrecidos em Mongaguá em relação à Itanhaém (Figura 6.3.4). 

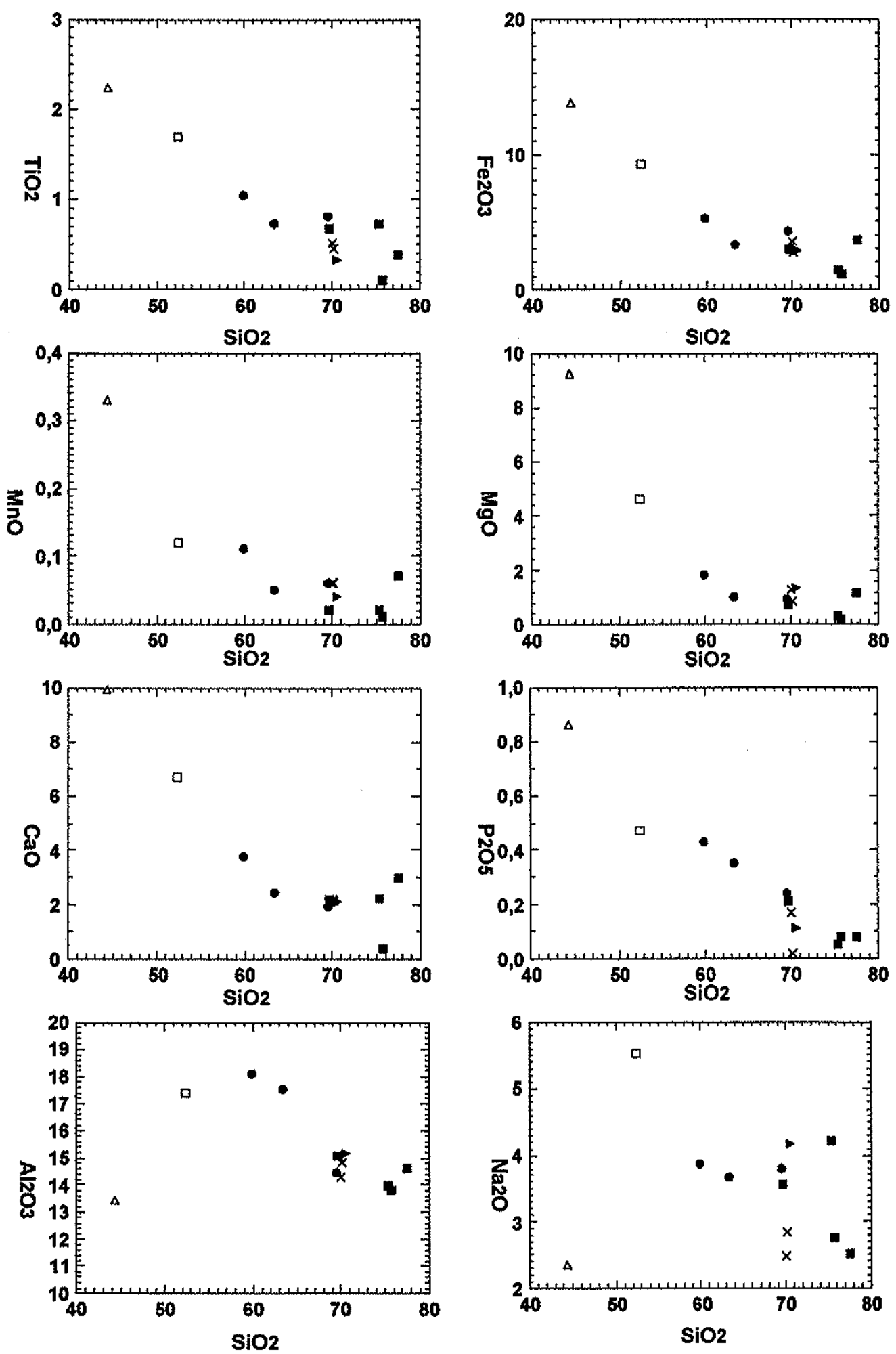

- G. Tipo Itariri

$\times$ G. Tipo Areado

- Gn. Mongaguá e Itanhaém $\triangle P$. máfica Mongaguá

- G. Ribeirão do Óleo $\square$ Enclave Itanhaém

Figura 6.3.4 - Diagramas de $\mathrm{SiO}_{2} \times$ óxidos - Bloco Mongaguá. 
Comportamento heterogêneo das rochas do Bloco Mongaguá também se observa em Diagramas de $\mathrm{SiO}_{2} \times$ elementos traços (Figura 6.3.5).

Nos Granitos tipo Itariri as amostras K-52 $\left(75.7 \% \mathrm{SiO}_{2}\right)$ e K-78 $\left(70 \% \mathrm{SiO}_{2}\right)$ mostram padrões distintos na distribuição dos teores de elementos traços, que também se distinguem das demais amostras $\left(\mathrm{K}-4,75.3 \% \mathrm{SiO}_{2}\right.$ e $\left.\mathrm{K}-68,77.5 \% \mathrm{SiO}_{2}\right)$. A amostra K-78 mostra-se bastante enriquecida em Ba (1473 ppm), $\mathrm{Sr}(512 \mathrm{ppm}$ ) e $\mathrm{Zr}(389 \mathrm{ppm})$ em relação às demais que possuem valores em torno de (450-550 $\mathrm{ppm})$ de $\mathrm{Ba},(160-180 \mathrm{ppm})$ de $\mathrm{Sr}$ e (100-140 ppm) de $\mathrm{Zr}$. Diferenças marcantes também são observadas nos teores de $\mathrm{Rb}$, muito mais enriquecido na amostra K-52 (401 ppm) em relação às demais (100-170 ppm), esta por sua vez, mais empobrecida em Ba (170 ppm) e Sr (57 ppm).

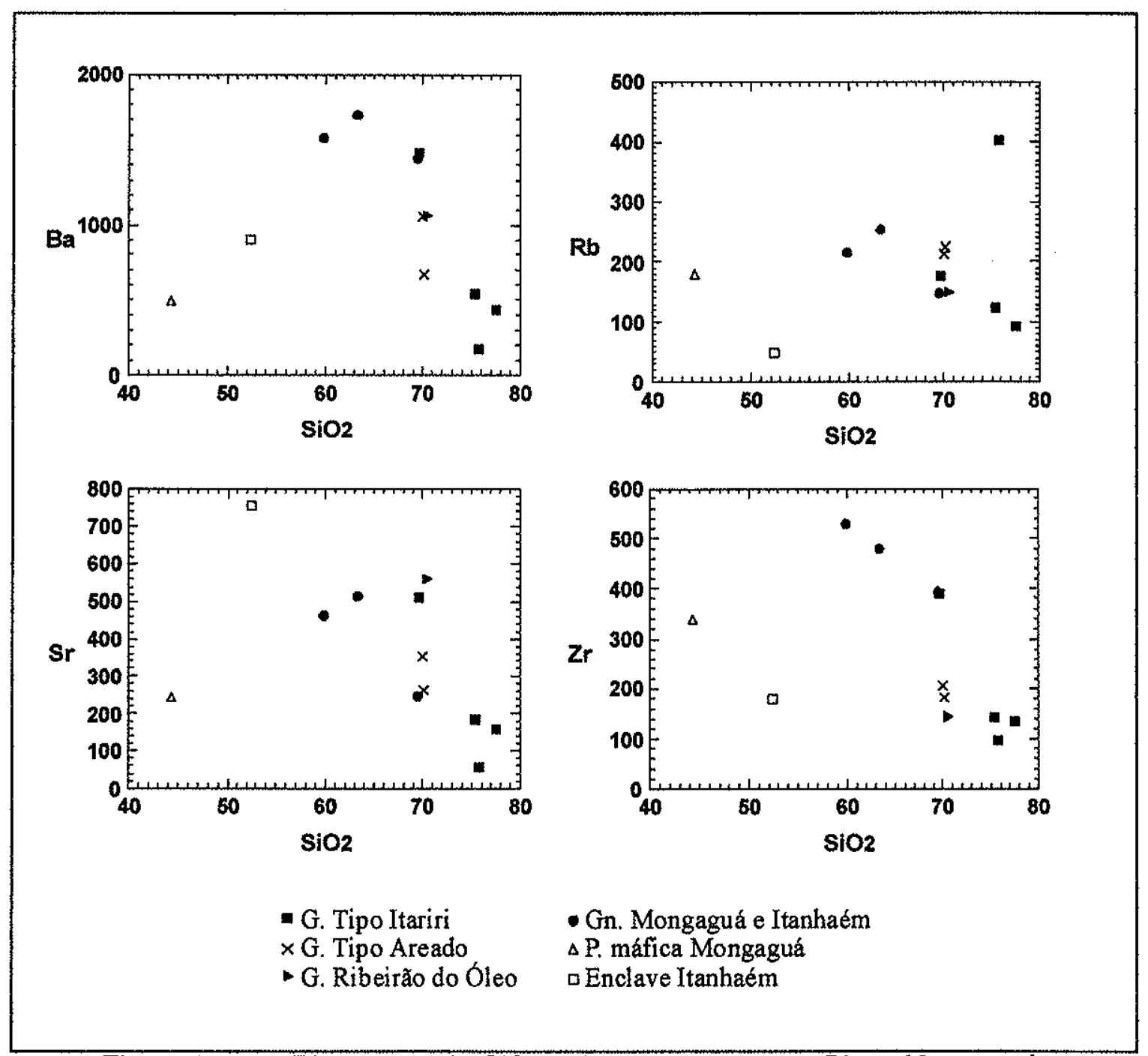

Figura 6.3.5 - Diagramas de $\mathrm{SiO}_{2} \times$ elementos traços - Bloco Mongaguá. 
Em Diagramas de perfis de ETR, normalizados aos valores do condrito por Nakamura, 1974, as rochas do Bloco Mongaguá também mostraram um padrão bastante distinto e heterogêneo entre si.

As rochas gnáissico-migmatíticas e suas respectivas porções máficas da região de Mongaguá e Itanhaém, mostram um fracionamento similar de ETRL em relação aos ETRP de $[\mathrm{La}(80-180) / \mathrm{Yb}(8-16.5)] \mathrm{N} \sim 8$ 8-13 (Figura 6.3.6). Em Mongaguá a porção máfica mostra-se mais enriquecido em ETRL em relação ao monzogranito. Nas rochas gnáissico-migmatíticas de Itanhaém, o enclave mostra teores mais baixos de ETRL e ETRP em relação ao leucossoma, e ausência de anomalia negativa de Eu, suavemente presente nas porções sienograníticas.

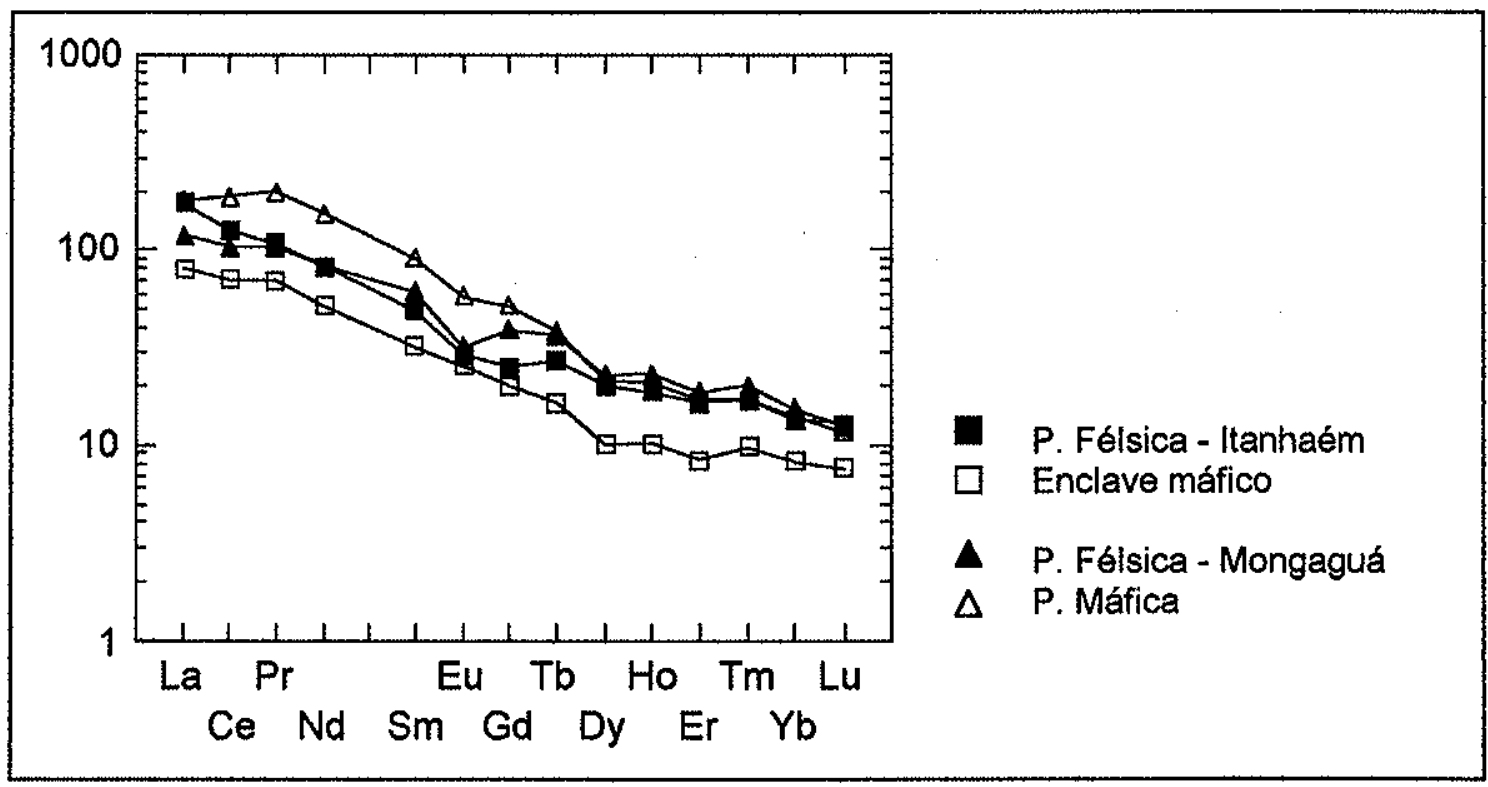

Figura 6.3.6 - Diagrama de ETR normalizado ao condrito (Nakamura, 1974). Rochas gnáissico-migmatíticas da região de Mongaguá-Itanhaém - Bloco Mongaguá.

As demais rochas analisadas, granitóides Tipo Itariri e Areado, bem como o Granito Ribeirão do Óleo, apresentaram um padrão de distribuição dos ETR bastante heterogêneo (Figura 6.3.7).

Nos granitóides Tipo Itariri, as três amostras analisadas apresentam caráter totalmente distinto das demais e entre si. A amostra K-52 (biotita-monzogranito), a 
norte de Pedro Toledo apresenta anomalias muito acentuadas de $\mathrm{Eu}$ e de $\mathrm{Ce}$, mostrando um fracionamento de. Comportamento bastante distinto é observado em rocha protomilonítica de composição tonalítica, a norte de Peruíbe, que apresenta fraco fracionamento de ETRL em relação aos ETRP de $[\mathrm{La}(60) / \mathrm{Yb}(17)] \mathrm{N} \sim 3.5$. A amostra de biotita-monzogranito, a norte de Itariri, mostrou maior fracionamento de ETRL em relação aos ETRP, em relação às demais rochas, mas provavelmente superestimado por apresentar teores muito baixos de $\mathrm{Yb}=0.22$, provavelmente refletindo erros analíticos.

O biotita-monzogranito (K-54), Granito ribeirão do Óleo, apresenta um padrão bastante característico com valores continuamente decrescentes de ETRL para ETRP, com fracionamento de $[\mathrm{La}(75) / \mathrm{Yb}(1.8)] \mathrm{N} \sim 41$.

As rochas graníticas Tipo Areado (K-81 e 82), apresentam padrão similar mostrando anomalias de Eu acentuadas, e forte fracionamento de ETRL em relação aos ETRP entre [La(200-350)/Yb(4-3.2) ]N 50 e 109.

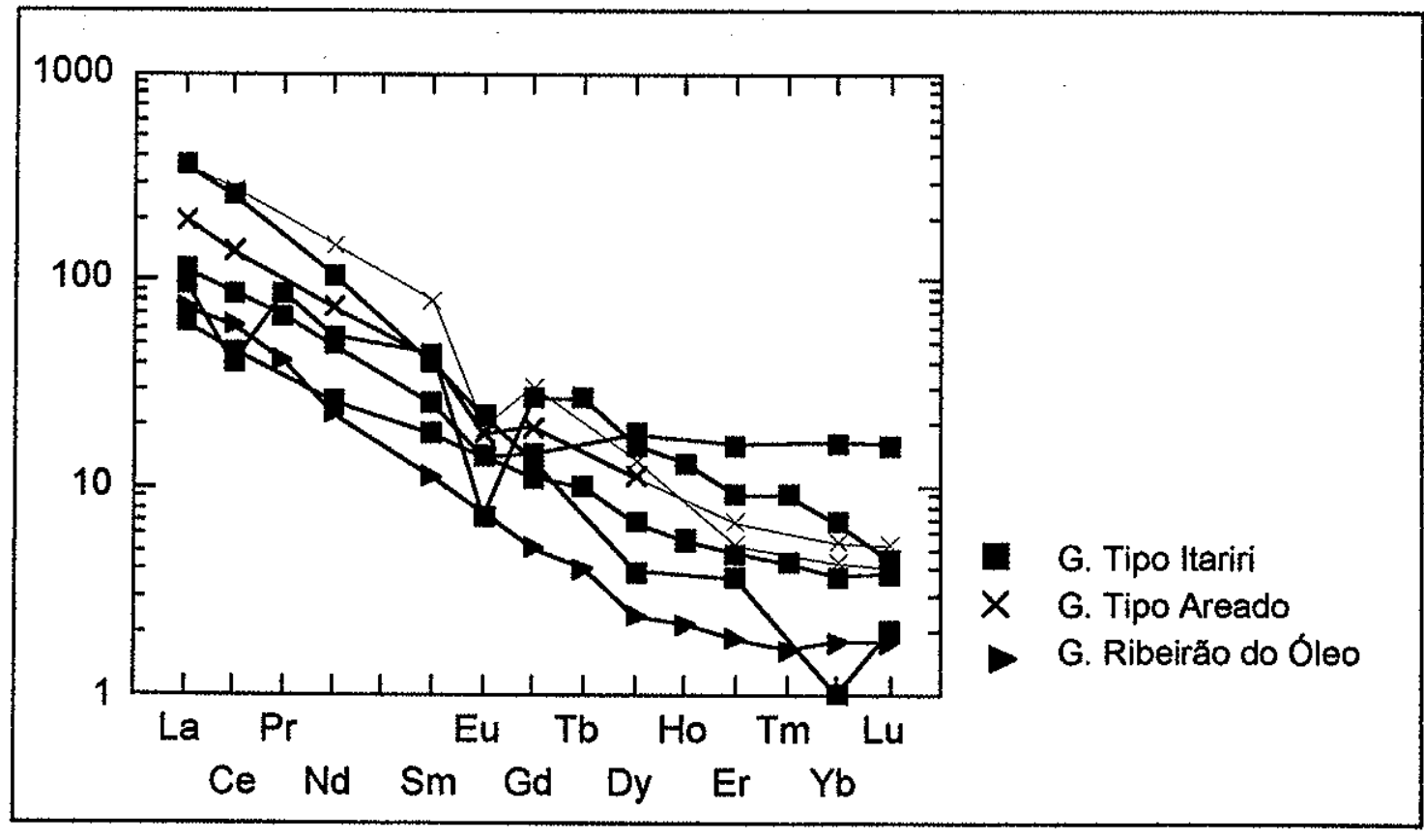

Figura 6.3.7 - Diagrama de ETR normalizado ao condrito (Nakamura, 1974). Rochas graníticas Tipo Itariri, Areado e Ribeirăo do Óleo. Bloco Mongaguá. 


\subsection{GEOCRONOLOgIA E GEOLOGIA IsotóPICA}

\subsubsection{RESULTADOS U-PB (ZIRCÕES)}

Foram realizadas cinco datações U-Pb em zircões de rochas graníticas do Bloco Mongaguá.

A amostra K-3, representativa das rochas híbridas gnáissico-migmatíticas de Mongaguá, representa uma porção mais homogênea dos migmatitos. Apresenta composição monzogranítica, textura gnáissica, caracterizada por bandas irregulares félsicas quartzo-feldspáticas, intercaladas com bandas máficas (Prancha 4, Foto 1).

Foram analisadas frações magnéticas $M(-4)$ e $M(-5)$, abradadas (AA), com pesos em torno de $0.09 \mathrm{mg}$. As frações de zircão analisadas são idiomórficas, límpidas, bipiramidais, isentas de inclusões ou fraturas com razão comprimento/largura em torno de 2 (Foto 6.4.1 a). A fração $M(-4)$ foi abradada por uma hora, ocasionando no arredondamento dos cristais, que são normalmente límpidos sem inclusões ou fraturas (Foto 6.4.1b), apresentando os melhores resultados analíticos (Tabela 6.4.1).

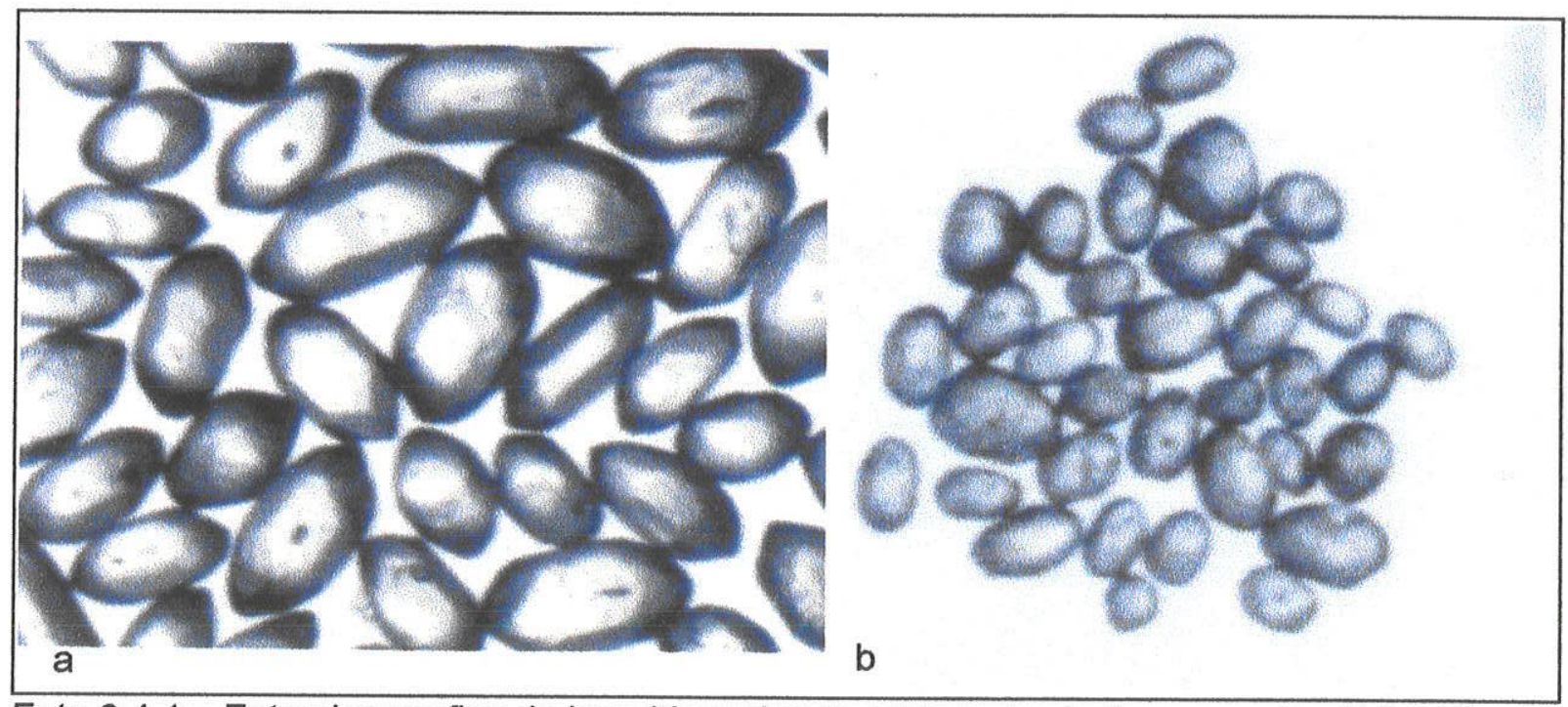

Foto 6.4.1 - Fotomicrografias de lupa binocular de cristais de zircão - amostra K-3. a) fração M-5, abradada 15 min (aumento $165 \mathrm{X}$ ); b) fração M-4, abradada 1 hora, (aumento $54 \mathrm{X}$ )

Em Diagrama Concórdia, apresentaram idades concordantes em $599 \pm 3 \mathrm{Ma}$ (M-5) e $612 \pm 3 \mathrm{Ma}$ (M-4). Ambas frações, com intercepto inferior forçado a zero, indicaram idade de $613 \pm 2 \mathrm{Ma}$ (Figura 6.4.1). A idade em torno de $612 \mathrm{Ma}$ é interpretada como época mais provável para formação destas rochas, devido ao maior erro analítico associado à fração $\mathrm{M}(-5)$, e seus baixos valores de ${ }^{206} \mathrm{~Pb} /{ }^{204} \mathrm{~Pb}$. 


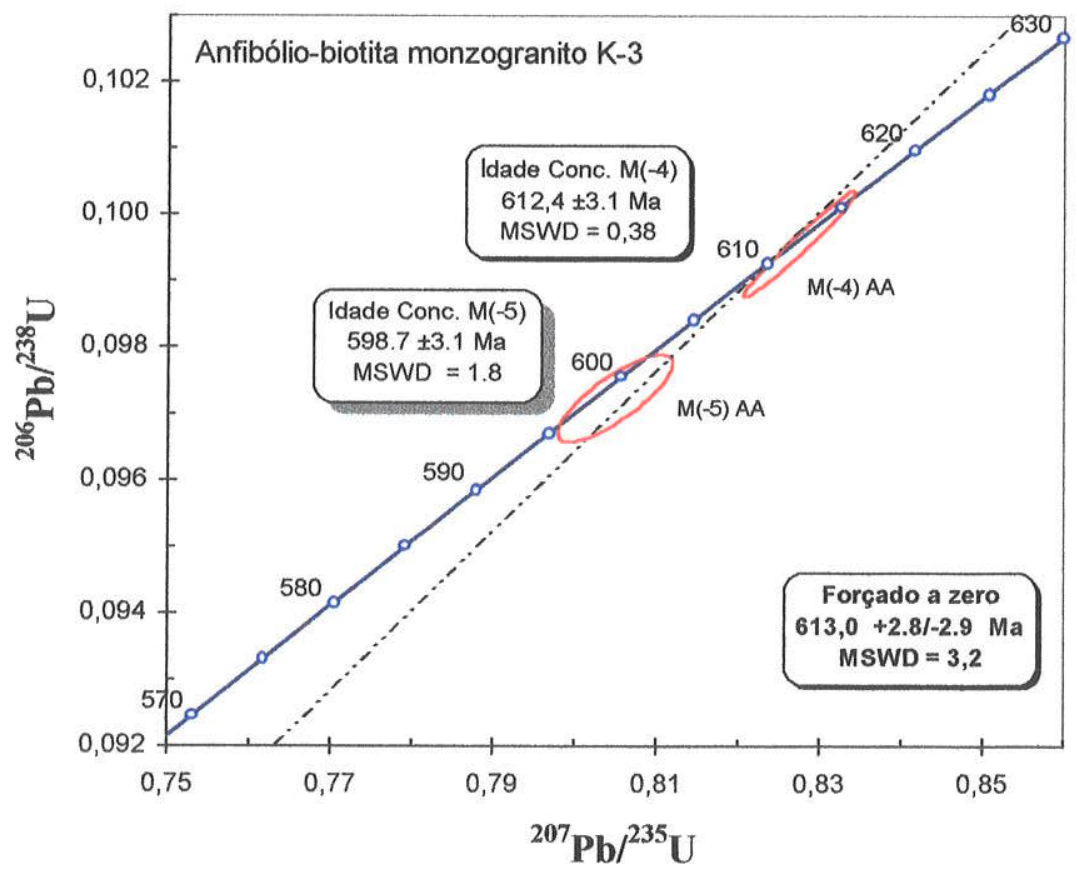

Figura 6.4.1 - Diagrama Concórdia ${ }^{207} \mathrm{~Pb} /{ }^{235} \mathrm{U} \mathrm{x}^{206} \mathrm{~Pb} /{ }^{238} \mathrm{U}$ em zircões da amostra K-3.

$\mathrm{Na}$ amostra K-52, biotita-monzogranito foliado Tipo Itariri, localizado a norte da cidade de Itariri, foram analisadas frações magnéticas $M(-2), M(-3)$ e $M(-4)$, abradadas (AA) e não abradadas (NA), com pesos entre 0.09 e $0.1 \mathrm{mg}$. As frações atacadas constituem-se por cristais idiomórficos, límpidos, bipiramidais e transparentes, com razão média comprimento/largura entre 2 e 3 (Foto 6.4.2).

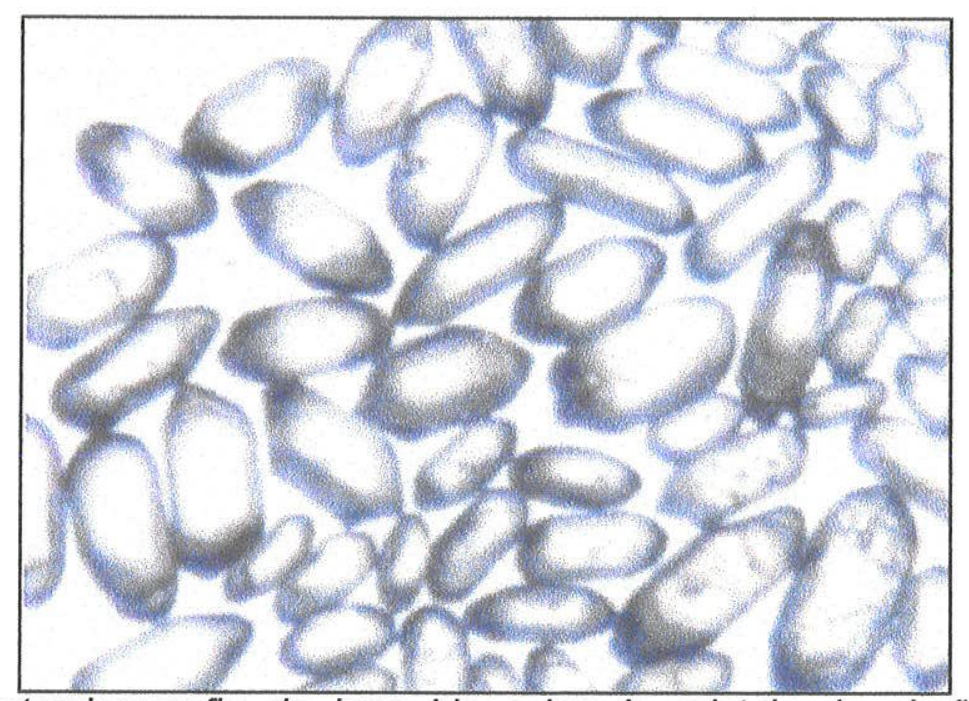

Foto 6.4.2 - Fotomicrografia de lupa binocular de cristais de zircão fração $M-3$, não abradada (aumento $162 \mathrm{X}$ ) - amostra K-52. 
As frações analisadas apresentaram resultados analíticos muito bons, e os dados obtidos encontram-se listados na Tabela 6.4.1.

Quando plotadas em Diagrama Concórdia, as frações analisadas mostraramse bastante discordantes indicando forte herança isotópica, fornecendo uma idade, intercepto inferior de $578 \pm 12 \mathrm{Ma}$, interpretada com ressalvas, como uma idade mínima de formação desta rocha. O intercepto superior ofereceu uma idade bastante imprecisa de $2.137 \pm 100 \mathrm{Ma}$. Assim sendo, pode-se apenas afirmar que estas rochas foram formadas no Neoproterozóico a partir de protólitos paleoproterozóicos (Figura 6.4.2).

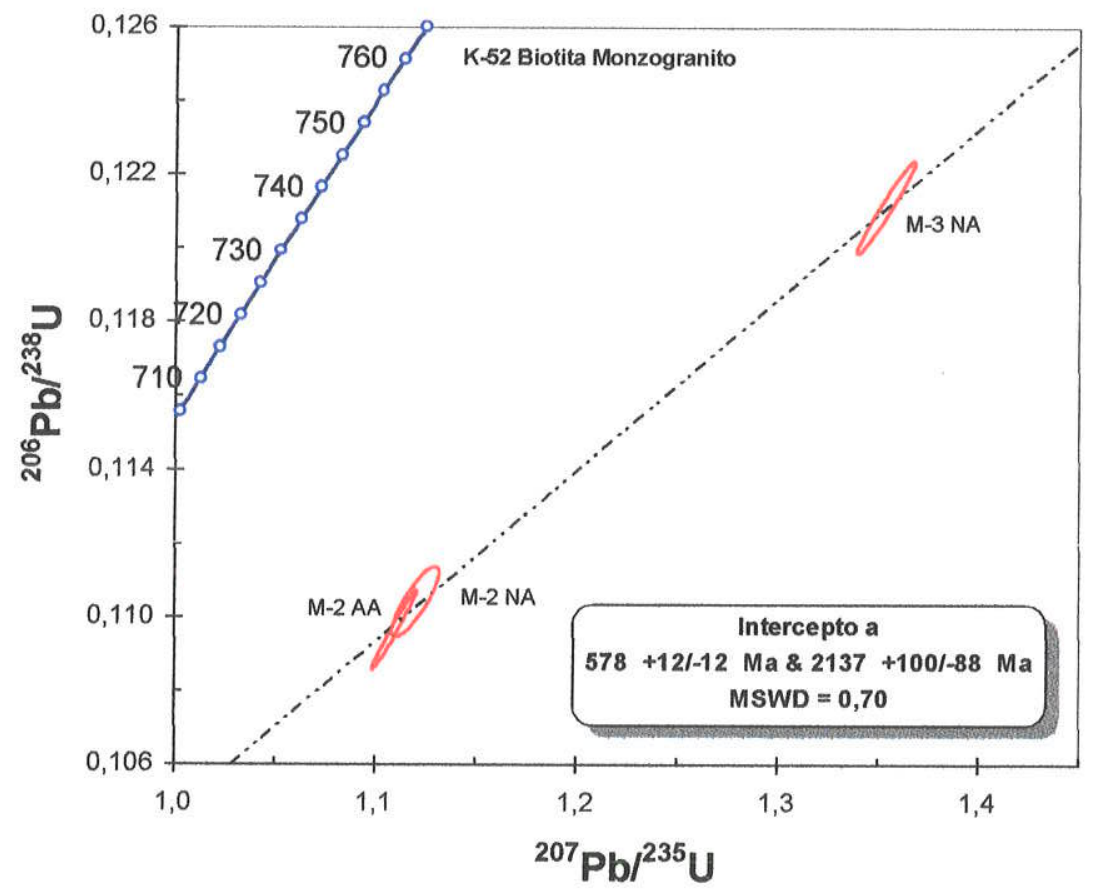

Figura 6.4.2 - Diagrama Concórdia ${ }^{207} \mathrm{~Pb} /{ }^{235} \mathrm{U} \mathrm{x}^{206} \mathrm{~Pb} \mathrm{f}^{238} \mathrm{U}$ em zircões da amostra K-52.

Em biotita-tonalito Tipo Itariri protomilonítico, localizado a norte de Peruíbe, amostra $K-68$, foram analisadas as frações magnéticas $M(-2), M(-4)$ e $N M(-4)$, não abradadas (NA), com pesos entre 0.08 e $0.1 \mathrm{mg}$. As frações analisadas possuem cristais transparentes, límpidos, livres de inclusões e fraturas, com bordas arredondadas, e razão média comprimento/largura entre 2.5 e 4 (Foto 6.4.3). 


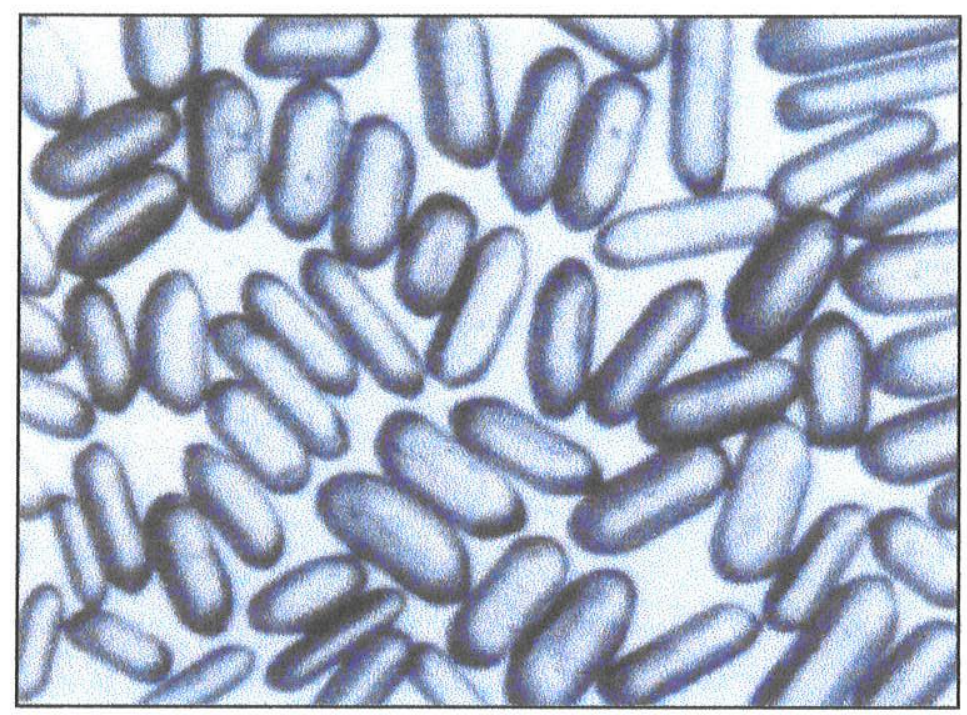

Foto 6.4.3 - Fotomicrografia de lupa binocular de cristais de zircão fração $M-4$, não abradada (aumento $135 \mathrm{X}$ ) - amostra K-68.

As frações magnéticas apresentaram resultados analíticos muito bons, listados na Tabela 6.4.1.

Quando plotadas em Diagrama Concórdia, as frações mostraram-se bastante discordantes e com forte herança isotópica, fornecendo uma idade, intercepto inferior de $647 \pm 8 \mathrm{Ma}$. Esta idade pode não possuir significado geológico, por tratarse de idade intercepto inferior, sendo interpretada, com ressalvas, como idade máxima para a formação destas rochas. O intercepto superior ofereceu uma idade bastante imprecisa de $1.972+200 /-170 \mathrm{Ma}$. Pode-se interpretar, como no caso precedente, que estas rochas apresentam forte herança crustal de rochas paleoproterozóicas (Figura 6.4.3). 


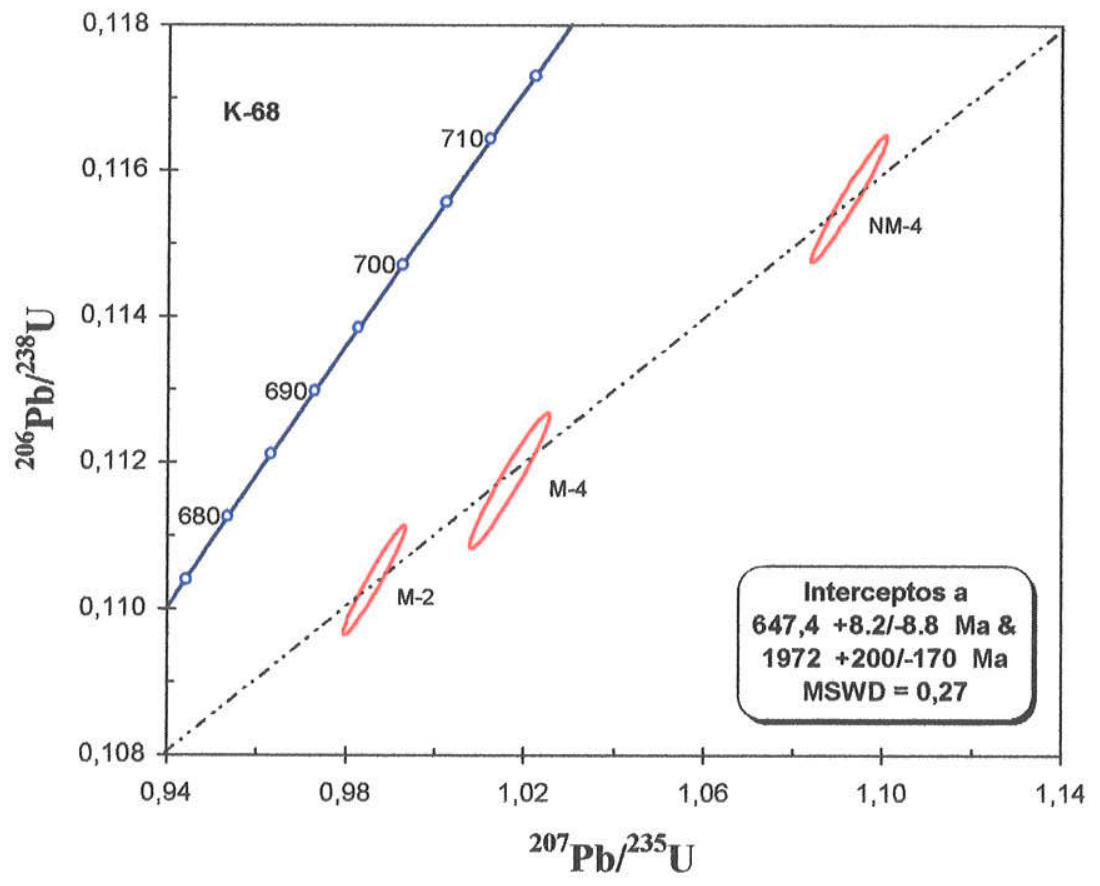

Figura 6.4.3 - Diagrama Concórdia ${ }^{207} \mathrm{~Pb} /{ }^{235} \mathrm{U} \times{ }^{206} \mathrm{~Pb} /{ }^{238} \mathrm{U}$ em zircões da amostra K-68.

No Biotita monzogranito Ribeirão do Óleo (K-54) localizado a norte de Itariri, foram analisadas uma fração $A$ (sem split) e as frações magnéticas, $M(-3)$ e $M(-4)$, abradadas (AA) e não abradadas (NA), com pesos entre 0.035 e 0.08 mg. Os cristais de zircão analisados apresentam-se normalmente idiomórficos, normalmente límpidos, transparentes, podendo apresentar inclusões e fraturas (Foto 6.4.4).

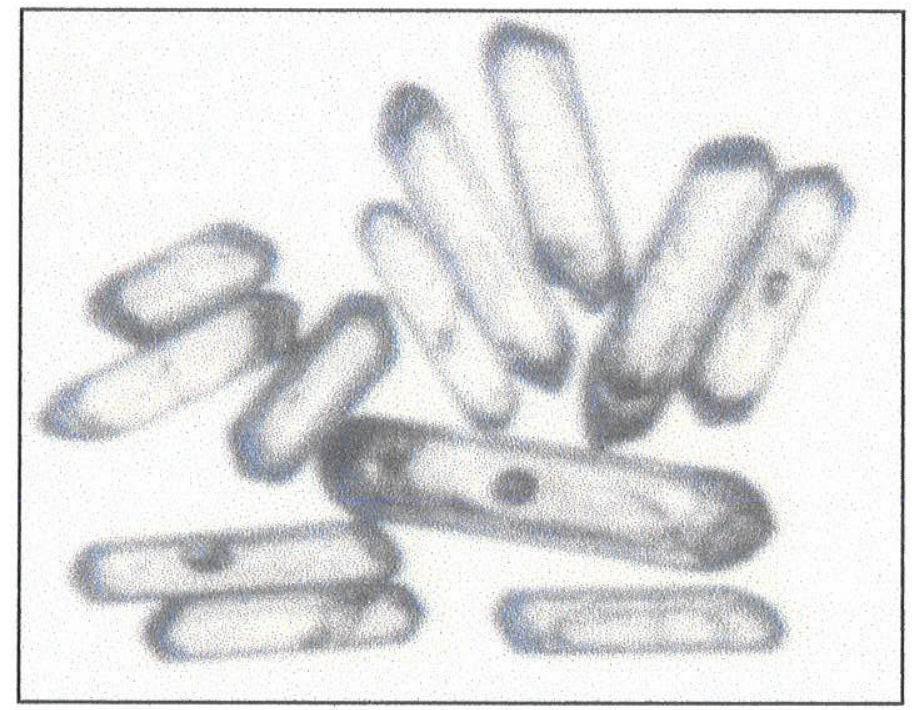

Foto 6.4.4 - Fotomicrografia de lupa binocular de cristais de zircão fração $M-3$, não abradada (aumento 275 X) - amostra K-54. 
As frações magnéticas apresentaram resultados analíticos razoáveis, com exceção da fração $\mathrm{M}(-3) \mathrm{AA}$ que apresentou valores muito baixos de $\mathrm{Pb}^{206} / \mathrm{Pb}^{204}$. No entanto, devido ao bom alinhamento entre elas, foram utilizadas para cálculo da idade todas frações atacadas (Tabela 6.4.1).

Quando plotadas em Diagrama Concórdia, as frações mostraram-se bastante discordantes, com exceção da fração $M(-4)$, e com forte herança isotópica, fornecendo uma idade, intercepto inferior de $579 \pm 110 \mathrm{Ma}$.

A fração $\mathrm{M}(-4)$, relativamente mais concordante que as demais, apresentou uma idade ${ }^{206} \mathrm{~Pb} /{ }^{238} \mathrm{U}$ de $599 \mathrm{Ma}$, podendo-se interpretar esta idade como a melhor estimativa da época de formação da rocha. $O$ intercepto superior ofereceu uma idade bastante imprecisa de $2.350 \pm 370 \mathrm{Ma}$.

Os altos erros destas idades, não permitem precisar a época de cristalização destas rochas, mas pode-se sugerir, como parece ser comum nas rochas graníticas do Bloco Mongaguá, que estas rochas têm idades em torno de 580 Ma e heranças crustais paleoproterozóicas (Figura 6.4.4).

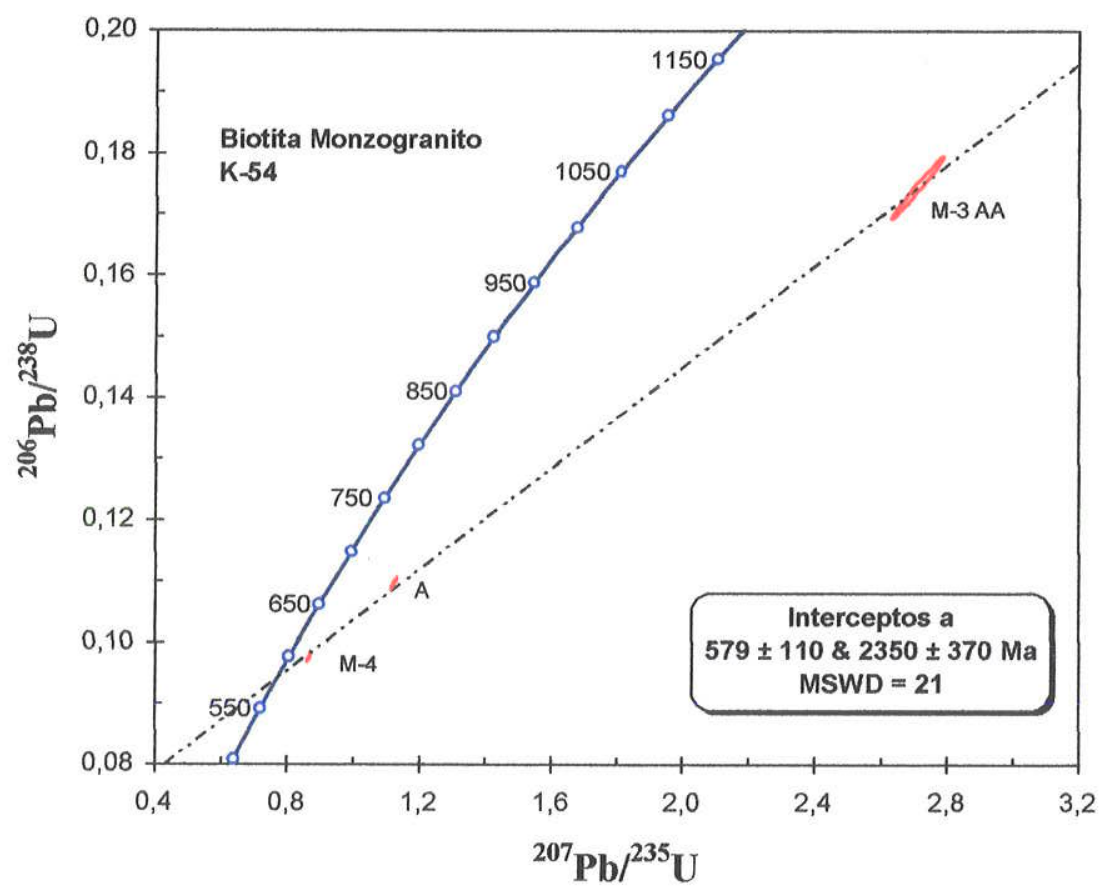

Figura 6.4.4 - Diagrama Concórdia ${ }^{207} \mathrm{~Pb} /{ }^{235} \cup \mathrm{x}^{206} \mathrm{~Pb} /{ }^{238} \mathrm{U}$ em zircôes da amostra K-54. 
Tabela 6.4.1

Dados analíticos referentes à Sistemática U-Pb (zircäo) - Bloco Mongaguá.

\begin{tabular}{|c|c|c|c|c|c|c|c|c|c|c|c|c|c|}
\hline \multicolumn{7}{|c|}{ Bloco Mongaguá } & \multicolumn{4}{|c|}{ Razōes Isotopicas } & \multicolumn{3}{|c|}{ Idades (Ma) } \\
\hline Unidade & Amostra & $\begin{array}{c}\text { Mineral } \\
\text { Analisado }\end{array}$ & $\begin{array}{c}\text { Fração } \\
\text { Magnética }\end{array}$ & $\begin{array}{l}\text { Peso } \\
\text { (mg) }\end{array}$ & $\begin{array}{c}U \\
\text { (ppm) }\end{array}$ & $\begin{array}{c}\mathrm{Pb} \\
\text { (ppm) }\end{array}$ & $\begin{array}{l}\mathrm{Pb}^{206} \mathrm{I} \\
\mathrm{Pb}^{204}\end{array}$ & $\mathrm{~Pb}^{20} / \mathrm{U}^{236}-\mathrm{ErrO} \%$ & $\mathrm{~Pb}^{206} \mathrm{~N}^{238}-\mathrm{ErTO} \%$ & $\mathrm{~Pb}^{201} / \mathrm{Pb}^{206}-\mathrm{ErrO} \%$ & $\begin{array}{c}\mathrm{Pb}^{207} \mathrm{I} \\
\mathrm{U}^{235}\end{array}$ & $\begin{array}{c}\mathrm{Pb}^{2016} \mathrm{I} \\
\mathrm{U}^{238}\end{array}$ & $\begin{array}{l}\mathrm{Pb}^{207} \mathrm{I} \\
\mathrm{Pb}^{206}\end{array}$ \\
\hline & & zircão & M-4AA & 0.086 & 211 & 24 & 1152 & $0.827404-0.674$ & $0.0995404-0.658$ & $0.602861-0.142$ & 612 & 612 & $614 \pm 3$ \\
\hline Gn. Mongaguá & $K-3$ & zircão & M-5 AA & 0.023 & 171 & 20 & 630 & $0,804876-0,714$ & $0,0972167-0,552$ & $0,0600463-0,425$ & 599.5 & 598 & $605 \pm 9$ \\
\hline \multirow{3}{*}{ Gr. Itarisi } & \multirow{3}{*}{ K-52 } & zircão & $\mathrm{M}-2$ & 0.099 & 378 & 42 & 1210.2 & $1.12002-0.84$ & $0.110379-0.703$ & $0.0735932-0.451$ & 763 & 675 & $1030 \pm 9$ \\
\hline & & zincão & M-2aa & 0.087 & 747 & 85 & 920.5 & $1.10951-0.823$ & $0.109611-0.812$ & $0.0734133-0.135$ & 758 & 670 & $1025 \pm 3$ \\
\hline & & zircão & M-3 & 0.082 & 343 & 43 & 911.2 & $1.35383-0.871$ & $0.121103-0.847$ & $0.0810789-0.199$ & 869 & 737 & $1223 \pm 4$ \\
\hline & & & & & & & & & & & & & \\
\hline \multirow{3}{*}{ Gr. Itariri } & \multirow{3}{*}{$\mathrm{K}-68$} & zircão & $M-2$ & 0.099 & 319 & 36 & 1199.2 & $0.986403-0.58$ & $0.110379-0.56$ & $0.064814-0.149$ & 697 & 675 & $768 \pm 3$ \\
\hline & & zircâo & $M-4$ & 0.095 & 244 & 29 & 597.1 & $1.0166-0.708$ & $0.111739-0.68$ & $0.0659852-0.195$ & 712 & 683 & $806 \pm 4$ \\
\hline & & zircão & $\mathrm{NM}-4$ & 0.079 & 311 & 36 & 1715.9 & $1.0923-0.635$ & $0.115613-0.617$ & $0.0685228-0.149$ & 750 & 705 & $884 \pm 3$ \\
\hline \multirow{3}{*}{ Gr. R. Óleo } & \multirow{3}{*}{ K-54 } & zircão & NM(1.5) & 0.034 & 406 & 45 & 1318.9 & $1.12216-0.738$ & $0.109383-0.724$ & $0.0744053-0.138$ & 764 & 669 & $1053 \pm 3$ \\
\hline & & zircão & M-3aa & 0.054 & 37 & 9 & 152.9 & $2.70985-2.43$ & $0.174292-2.42$ & $0.112763-0.337$ & 1331 & 1036 & $1844 \pm 6$ \\
\hline & & zircão & $M-4$ & 0.085 & 423 & 44 & 903.3 & $0.865788-0.585$ & $0.0973552-0.567$ & $0.0644987-0.141$ & 633 & 599 & $758 \pm 3$ \\
\hline
\end{tabular}




\subsubsection{RESULTADOS K-AR (BIOTITA)}

$\mathrm{O}$ método $\mathrm{K}-\mathrm{Ar}$ foi aplicado ao biotita-tonalito com granada (amostra K-68) protomilonítico (Tipo Itariri), localizado na porção central do Bloco Mongaguá, a norte da cidade de Peruíbe, apresentando forte influência da $\mathrm{ZCl}$.

Forneceu, em concentrado de biotitas, dados analíticos bons (Tabela 6.4.2) e a idade de $485 \pm 10.6 \mathrm{Ma}(1 \sigma)$, cerca de $160 \mathrm{Ma}$ mais jovem que a obtida através da metodologia U/Pb em zircões, de $647 \mathrm{Ma}$, Figura 6.4.3.

A idade obtida indica a época de resfriamento dessa rocha (colocação a niveis com temperaturas inferiores a $250^{\circ} \mathrm{C}$ ).

Esta idade é interpretada como referente a época de resfriamento associada à movimentação da $\mathrm{ZCl}$. A idade de resfriamento em torno de $500 \mathrm{Ma}$ é caracteristica de toda regiäo estudada, tanto em rochas miloniticas como em rochas pouco ou não deformadas.

\begin{tabular}{|c|c|c|c|c|c|c|c|}
\hline Amostra & Material & $\%$ de K & Erro & $\begin{array}{c}\text { Ar }^{40} \operatorname{Rad} \\
\operatorname{CosTP} / g\left({ }^{* 10^{-6}}\right)\end{array}$ & Ar $^{40}$ Atm & $\begin{array}{c}\text { Idade } \\
\text { (Ma) }\end{array}$ & $\begin{array}{c}\text { Erro Máx. } \\
\text { (Ma) }\end{array}$ \\
\hline K-68 & Biotita & 7.2351 & 0.8620 & 156.46 & 4.20 & 485.3 & 10.6 \\
\hline
\end{tabular}

Tabela 6.4.2 - Dados analíticos K-Ar - Bloco Mongaguá. 


\subsubsection{GEOL.OGIA ISOTÓPICA Nd-Sr}

Utilizaram-se as sistemáticas $\mathrm{Sm}-\mathrm{Nd}$ e $\mathrm{Rb}-\mathrm{Sr}$, para o gnaisse monzogranítico de Mongaguá (K-3A), e sua porção diorítica (K-3B); porção diorítica de Itanhaém (K5B), e dos granitos Tipo Itariri (biotita-monzogranitos K-52 e K-78 e biotita-tonalito K68), Areado (biotita-monzogranitos K-81 e K-82) e Ribeirão do Óleo (biotitamonzogranito, K-54). Os resultados obtidos apresentam-se listados nas Tabelas 6.4.3 e 6.4.4.

$O$ gnaisse monzogranítico de Mongaguá (K-3A) mostra idade modelo TDM de $2.25 \mathrm{Ga}$ e $\varepsilon \mathrm{Nd}(0)=-10.65$ (Figura 6.4.5). Estes valores, provavelmente, não possuem significado geológico por esta rocha apresentar razão $\mathrm{Sm}^{147} / \mathrm{Nd}^{144}$ de 0.1510, muito acima do intervalo admitido para as rochas graníticas que não sofreram um fracionamento adicional entre $\mathrm{Sm}$ e $\mathrm{Nd}$ (Sato, 1998).

No caso acima referido, assim como mencionado por (Pimentel, 1992; Sato et al., 1995 e Sato, 1998), as idades TDM e os valores de $\varepsilon N d(0)$ calculados em estágio único não possuem significado geológico. Por este motivo optou-se por recalcular as idades modelo destes gnaisses pelo método de estágio duplo, como recomendado por Sato (1998). Para tal procedimento utilizou-se a razão $\mathrm{Sm}^{147} / \mathrm{Nd}^{144}$ de 0.11 , média das razões para rochas graníticas (Sato, op.cit), obtendo-se o valor TDM de $1.70 \mathrm{Ga}$ e $\mathrm{ENd}(0) \sim-13.5$ como apresentado na Tabela 6.4.3.

A amostra representativa da porção máfica das rochas migmatíticas de Mongaguá (K-3B, gnaisse de composição diorítica) mostra idade modelo TDM de $1.800 \mathrm{Ma}$, e da porção diorítica de Itanhaém (K-5B), de 1.765 Ma (Tabela 6.4.3).

Tais idades podem indicar que os precursores dos materiais félsico e máfico das rochas aflorantes em Mongaguá, e da porção máfica de Itanhaém se diferenciaram do manto durante o paleoproterozóico. Entretanto, tal afirmação deve ser interpretada com ressalvas, pois, tratando-se de rochas híbridas, fenômenos de misturas de diferentes fontes podem estar envolvidos na sua geração, podendo resultar idades TDM sem significado geológico.

Em Diagrama de Evolução de $\varepsilon N d x$ tempo (Figura 6.4.5), notam-se valores muito próximos de $\varepsilon \mathrm{Nd}(0)=-12.89$ e -13.81 , bem como valores muito semelhantes de $\varepsilon N d(t=600 \mathrm{Ma})$ de -7.15 e -7.91 . Novamente, tais dados devem ser 
interpretados com cuidado pois podem representar uma homogeneização isotópica ocorrida com a mistura destes materiais e não necessariamente que ambos tenham tido um tempo relativamente longo de residência crustal $\left(\varepsilon \mathrm{Nd}_{(0)}\right.$ bastante negativos), ou tido contribuição de fontes crustais na sua geração ( $\left(E \mathrm{Nd}_{(t=600 \mathrm{Ma})}\right.$ negativos).

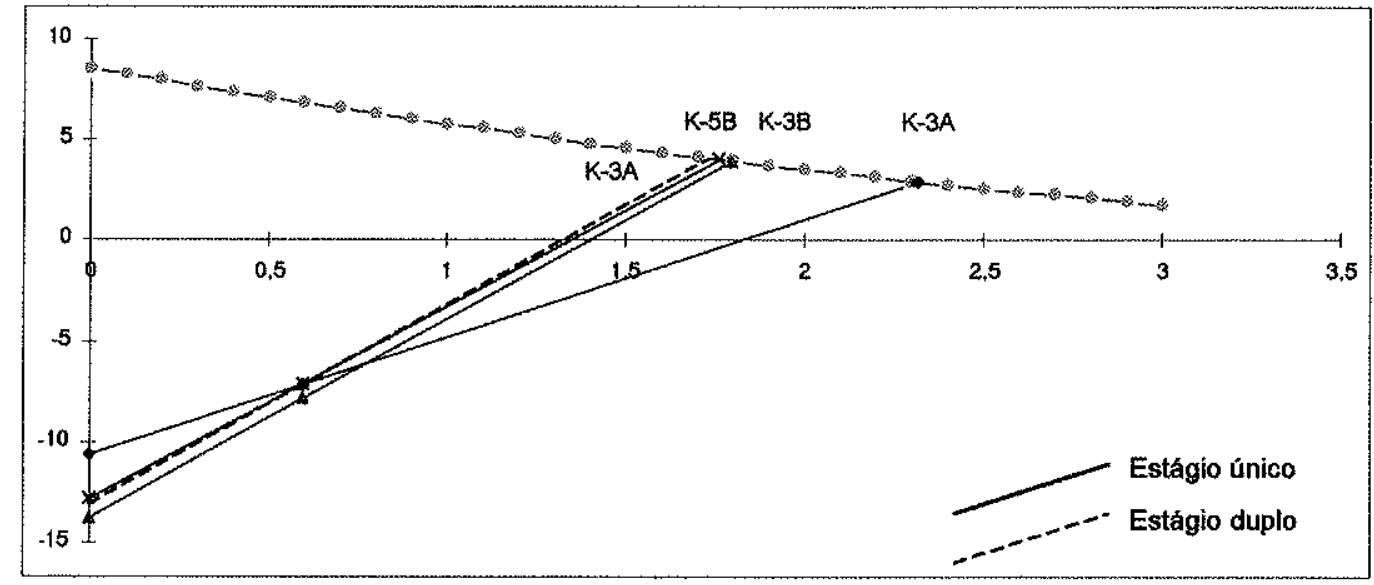

Figura 6.4.5 - Diagrama de evolução $\varepsilon N d x$ tempo (Ga). Gnaisses migmatíticos. Material monzogranítico $(\mathrm{K}-3 \mathrm{~A})$ e materiais diorítico (K-3B, K-5B) - Bloco Mongaguá.

Com relação aos isótopos de $\mathrm{Sr}$ (Tabela 6.4.4), as razöes iniciais de $\left(\mathrm{Sr}^{87} / \mathrm{Sr}^{86}\right)_{(600}$ Ma) 0.708 para ambos materiais também podem indicar a homogeneização isotópica ocorrida quando do evento de mistura 'magma mixing'. No entanto, também sugerem, a influência, na origem destas rochas, de reservatórios crustais.

Os Granitos Tipo Itariri (K-68, K-52, K-78) mostram idades modelo TDM de 2.2 $\mathrm{Ga}, 3.85 \mathrm{Ga}$, e $1.7 \mathrm{Ga}$ e, $\varepsilon N d(0)$ de $-16.21,-17.79$ e -24.38 respectivamente (Figura 6.4.6). As duas últimas idades e valores de $\varepsilon N d(0)$, provavelmente, não possuem significado geológico por estas rochas apresentarem razões $\mathrm{Sm}^{147} / \mathrm{Nd}^{144}$ de 0.1628 (K-52), e 0.0694 (K-78). Como verificado nos gnaisses de Mongaguá, estas rochas graníticas Tipo Itariri, provavelmente sofreram um fracionamento adicional entre Sm e Nd.

Recalculando-se as idades modelo destes granitos Tipo Itariri pelo método de estágio duplo, como recomendado por Sato (1998), foram obtidos os valores TDM de $2.25 \mathrm{Ga}(\mathrm{K}-52)$ e $2.24 \mathrm{Ga}(\mathrm{K}-78)$, e valores de $\varepsilon \mathrm{Nd}(0)$ em torno de -21 e -22.5 , respectivamente, como apresentado na Tabela 6.4.3. 


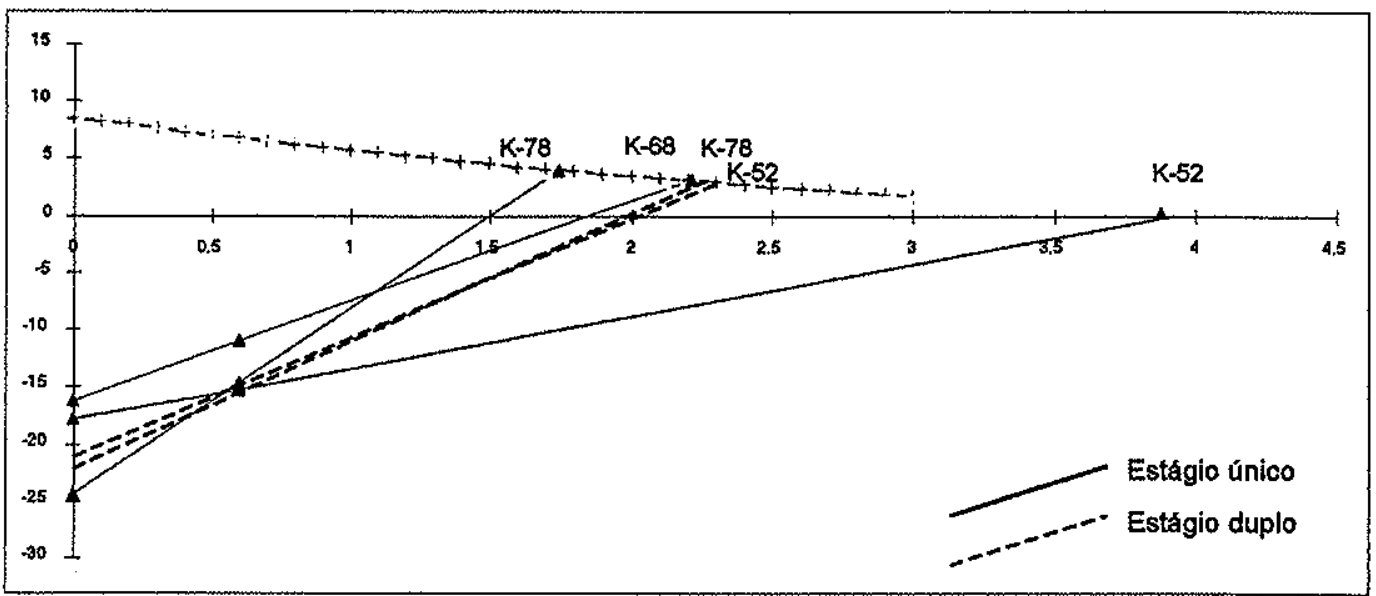

Figura 6.4.6 - Diagrama de evolução $\varepsilon N d \times$ tempo (Ga). Granitos Tipo Itariri - Bloco Mongaguá.

Os valores obtidos de $\varepsilon N d$ (0) e $\varepsilon N d$ ( $t=600 \mathrm{Ma}$ ), negativos são respectivamente entre -16.21 a -22.5 e -11 a -15 (Tabela 6.4.3 e Figura 6.4.6). Esses dados aliados aos resultados obtidos pelos isótopos de $\mathrm{Sr}$ (Tabela 6.4.4) que indicam valores de $\mathrm{Sr}^{87} / \mathrm{Sr}^{86}$ (i=600 Ma) entre 0.711 a 0.730 (1), sugerem longo período de residência crustal e forte contribuição de fontes crustais na geração dos litotipos graníticos Itariri, cujos protólitos se diferenciaram do manto em épocas paleoproterozóicas semelhantes.

Em diagrama de evolução $\varepsilon N d \times$ tempo (Figura 6.4.7) e Tabela 6.4.3, os monzogranitos Tipo Areado ( $\mathrm{K}-81$ e 82) mostram idades modelo TDM de $1.681 \mathrm{Ga}$ e $1.730 \mathrm{Ga}$, respectivamente, e o monzogranito Ribeirão do Óleo (K-54), idade modelo TDM de $1.728 \mathrm{Ga}$. Tais resultados indicam que os precursores desses granitóides se diferenciaram do manto em épocas paleoproterozóicas próximas.

Os valores de $\varepsilon N d$ obtidos (Figura 6.4.7) foram de: $\varepsilon N d(0)=-17.42$ e -17.34 , e $\varepsilon N d(t=600 \mathrm{Ma})=-9.72$ e -9.92 para os Granitos Areado, e $\varepsilon N d(0)=-18.47$ e $\varepsilon N d(t=600 \mathrm{Ma})=-10.66$ para o monzogranito Ribeirão do Óleo.

As razões isotópicas de $\mathrm{Sr}$ (Tabela 6.4.4) mostram valores de $\mathrm{Sr}^{87} / \mathrm{Sr}^{86}$ (i=600 Ma) de 0.708 (Granito Ribeirão do Óleo) e 0.714 (Granito Areado).

$\mathrm{O}$ conjunto dos dados isotópicos de $\mathrm{Nd}$ e $\mathrm{Sr}$ sugerem para os granitóides tipo Areado e Ribeirão do Óleo analisados, um longo período de residência crustal e fontes crustais na geração destas rochas, evidenciado pelos valores negativos de $\varepsilon N d$ e razões iniciais de $\mathrm{Sr}$ altas. 


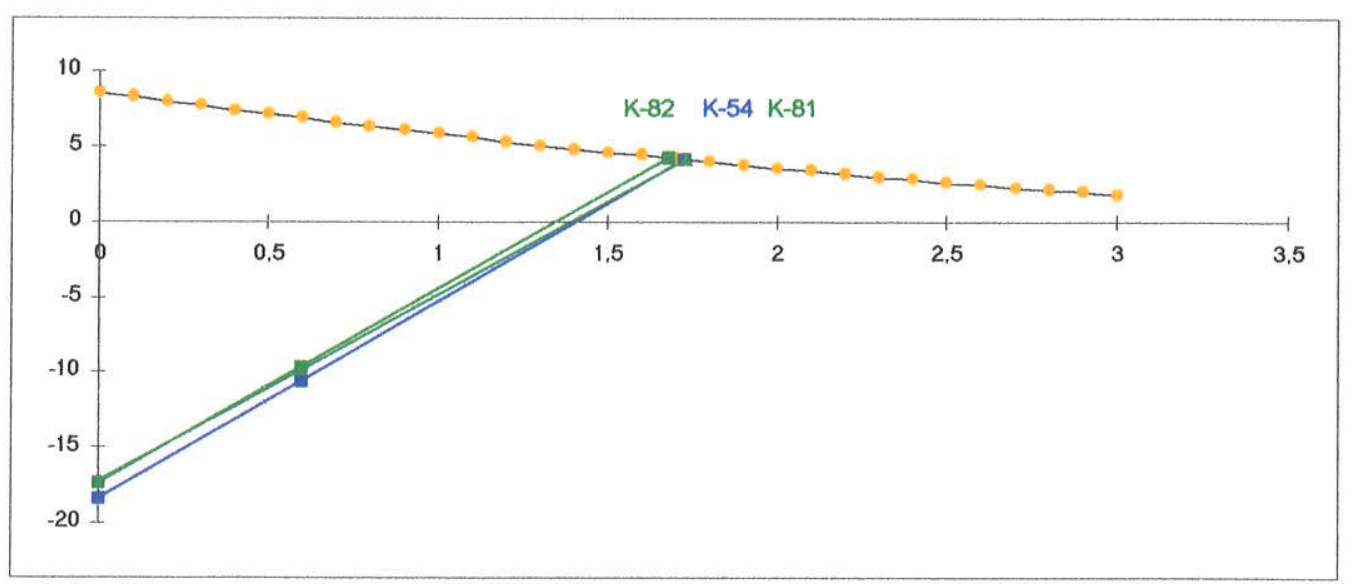

Figura 6.4.7 - Diagrama de evolução $\varepsilon N d x$ tempo (Ga). Granitos Tipo Areado e Ribeirão do Óleo - Bloco Mongaguá.

Pelos dados isotópicos de $\mathrm{Nd}$ e $\mathrm{Sr}$ obtidos dos litotipos graníticos do Bloco Mongaguá, sugere-se, preliminarmente, que os protólitos das rochas gnáissicomigmatíticas, dos Granitos Tipo Areado e Ribeirão do Óleo se diferenciaram do manto em épocas paleoproterozóicas próximas (entre 1.7 e $1.8 \mathrm{Ga}$ ) distintas dos Granitos Tipo Itariii $(2.2 \mathrm{Ga})$.

Em diagrama $\varepsilon S r \times \varepsilon N d(t=600 \mathrm{Ma})$, Figura 6.4.8, nota-se um comportamento distinto para os litotipos aqui analisados, o que pode ser sugestivo de fontes distintas na geração desses granitóides. Essas fontes teriam características de reservatórios crustais, evidenciado pelo comportamento dos isótopos de $\mathrm{Nd}$ e $\mathrm{Sr}$ e pelas heranças observadas nos zircões.

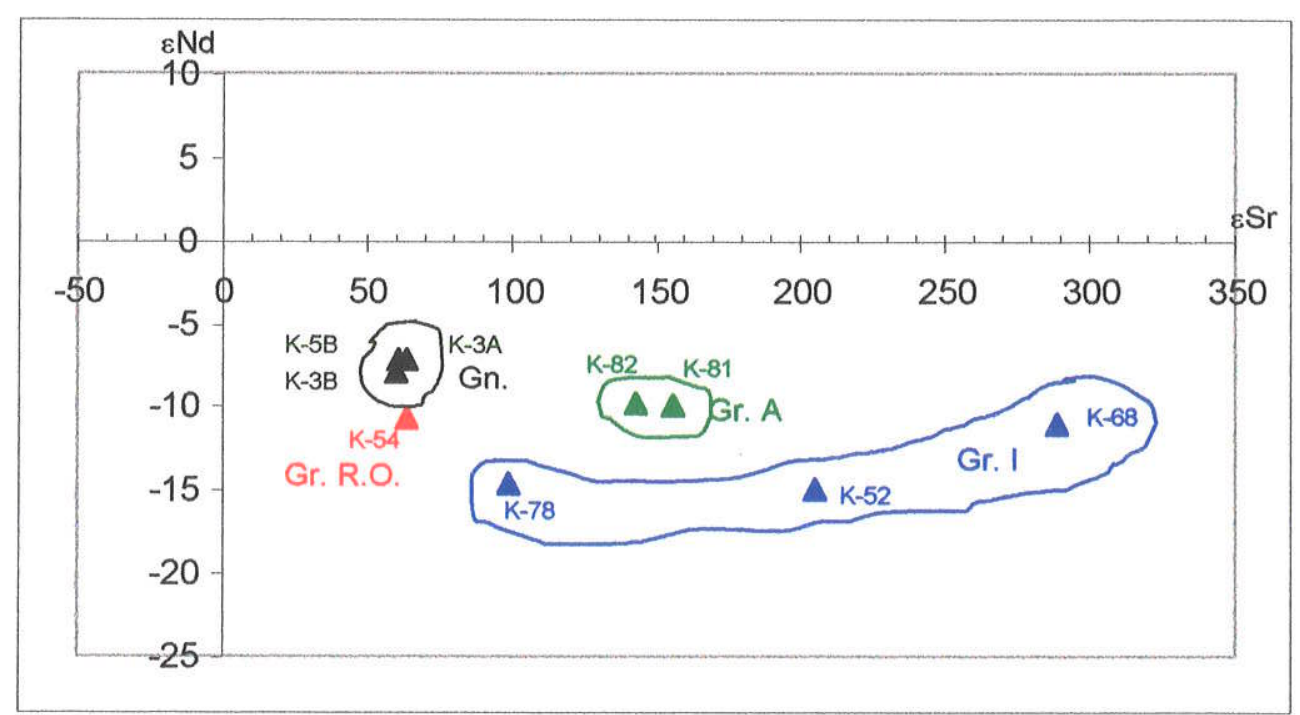

Figura 6.4.8 - Diagrama $\varepsilon S r \times \varepsilon N d(t=600 \mathrm{Ma})$ - Bloco Mongaguá. 
Tabela 6.4.3 - Dados analíticos da sistemática Sm-Nd para rochas Bloco Mongaguá.

\begin{tabular}{|c|c|c|c|c|c|c|c|c|c|c|c|}
\hline $\begin{array}{c}N^{\circ} . \\
\text { Campo }\end{array}$ & $\begin{array}{c}\mathrm{Sm} \\
(\mathrm{ppm})\end{array}$ & $\begin{array}{c}\mathrm{Nd} \\
\text { (ppm) }\end{array}$ & $\begin{array}{l}147 \mathrm{Sm} / \\
{ }^{144} \mathrm{Nd}\end{array}$ & $\begin{array}{l}745 \mathrm{NdI} \\
{ }^{144} \mathrm{Nd}\end{array}$ & Erro & $e_{(0)}$ & $f_{\text {Sm/Nd }}$ & $\begin{array}{l}\text { ToM } \\
(\mathrm{Ma})\end{array}$ & $\mathbf{e}_{\text {(TDM) }}$ & $\begin{array}{c}T_{1} \\
(\mathrm{Ma})\end{array}$ & $e_{(T 1)}$ \\
\hline $\mathrm{K}-3 \mathrm{~A}$ & 12,017 & 48,125 & 0,1510 & 0,512092 & 0.000010 & $-13.5^{\star}$ & $-0,23$ & $1700^{*}$ & 2,88 & 600 & $-7,15$ \\
\hline $\mathrm{K}-3 \mathrm{~B}$ & 25.447 & 128.675 & 0.1196 & 0.511930 & 0.000009 & -13.81 & -0.39 & 1800.7 & 3.90 & 600 & -7.91 \\
\hline $\mathrm{K}-5 \mathrm{~B}$ & 6.820 & 33.872 & 0.1218 & 0.511977 & 0.000009 & -12.89 & -0.38 & 1764.9 & 3.98 & 600 & -7.16 \\
\hline $\mathrm{K}-52$ & 9.200 & 34.934 & 0.1593 & 0.511726 & 0.000015 & $-21^{\star}$ & -0.19 & $2.250^{*}$ & 0.64 & 600 & -14.92 \\
\hline $\mathrm{K}-68$ & 2.766 & 13.019 & 0.1285 & 0.511807 & 0.000011 & -16.21 & -0.35 & $2.215,7$ & 3.07 & 600 & -10.99 \\
\hline K-78 & 6.990 & 60.936 & 0.0694 & 0.511388 & 0.000010 & $-22.5^{*}$ & -0.65 & $2.240^{*}$ & 4.01 & 600 & -14.64 \\
\hline $\mathrm{K}-54$ & 2,527 & 16,162 & 0,0945 & 0,511691 & 0.000014 & $-18,47$ & $-0,52$ & 1728,7 & 4,05 & 600 & $-10,66$ \\
\hline $\mathrm{K}-81$ & 8.208 & 49.765 & 0.0997 & 0.511749 & 0.000010 & -17.34 & -0.49 & 1729.6 & 4.05 & 600 & -9.92 \\
\hline $\mathrm{K}-82$ & 14,564 & 91,672 & 0,0961 & 0,511745 & 0.000011 & $-17,42$ & $-0,51$ & 1680,8 & 4,16 & 600 & $-9,72$ \\
\hline
\end{tabular}

${ }^{*} \varepsilon N d(0)$ e idade TDM recalculados pelo método do estágio duplo (Sato, 1998).

Tabela 6.4.4 - Dados analíticos da sistemática Rb-Sr para as rochas do Bloco Mongaguá.

\begin{tabular}{|c|c|c|c|c|c|c|c|c|c|c|c|}
\hline $\begin{array}{c}N^{\circ} . \\
\text { Campo }\end{array}$ & $\begin{array}{c}\mathrm{Rb} \\
\mathrm{ppm}\end{array}$ & $\begin{array}{c}\mathrm{Sr} \\
(\mathrm{ppm})\end{array}$ & ${ }^{87} \mathrm{Rb} /{ }^{86} \mathrm{Sr}$ & $\left.{ }^{81} \mathrm{Sr}\right)^{86} \mathrm{Sr}$ & Erro & $\varepsilon_{(0)}$ & $\begin{array}{l}\text { ToM } \\
\text { (Ma) }\end{array}$ & $\varepsilon_{\text {(TOM) }}$ & $\begin{array}{c}T_{1} \\
\text { (Ma) }\end{array}$ & $\overline{\varepsilon(\mathrm{TI})}$ & RE - T1 \\
\hline $\mathrm{K}-3 \mathrm{~A}$ & 216,0 & 463,0 & 1,352 & 0,719837 & 0.000072 & 217,70 & 941,9 & $-25,11$ & 600 & 63.49 & 0,70827 \\
\hline$k-3 B$ & 180,0 & 244,0 & 2,139 & 0,726401 & 0.000058 & 310,87 & 807,6 & $-25,99$ & 600 & 59.94 & 0,70802 \\
\hline K-5B & 49 & 755 & 0.188 & 0.709698 & 0.000142 & 73.78 & 3665.4 & -6.85 & 600 & 60.94 & 0.70809 \\
\hline $\mathrm{K}-52$ & 401,0 & 57,0 & 18,940 & 0.895650 & 0.000030 & 2713.27 & 655.1 & -26.99 & 600 & 204.68 & 0.71821 \\
\hline$K-68$ & 94,0 & 157,0 & 1,612 & 0.739020 & 0.000025 & 489.99 & 1514.8 & -21.34 & 600 & 289.08 & 0.72415 \\
\hline K-78 & 175,0 & 510,0 & 0,924 & 0.719289 & 0.000020 & 209.92 & 1255.0 & -23.06 & 600 & 99.18 & 0.71078 \\
\hline $\mathrm{K}-54$ & 149,0 & 559,0 & 0,772 & 0,714874 & 0.000021 & 147,25 & 1214,9 & $-23,32$ & 600 & 63.47 & 0,70827 \\
\hline K-81 & 213.0 & 354.0 & 1.745 & 0.729698 & 0.000073 & 357.67 & 1128.7 & -23.89 & 600 & 155.78 & 0.71477 \\
\hline $\mathrm{K}-82$ & 225,0 & 260,0 & 2,511 & 0,735365 & 0.000037 & 438,11 & 939,5 & $-25,13$ & 600 & 143.15 & 0,71388 \\
\hline
\end{tabular}




\subsection{Discussão dos REsultados OBTIDOS}

No Bloco Mongaguá, que apresenta uma área de cerca de $780 \mathrm{~km}^{2}$ na região estudada, foram identificadas rochas gnáissico-migmatíticas e rochas graníticas com feições gnáissicas localizadas.

As rochas gnáissico-migmatíticas de Mongaguá e Itanhaém, se diferenciam das demais rochas graníticas (Tipo Itariii, Areado e Ribeirão do Óleo) por apresentarem como minerais máficos hornblenda e também biotita, apresentando um caráter cálcio-alcalino metaluminoso.

No presente trabalho, é sugerida, através de uma série de feições texturais, uma íntima associação entre materiais totalmente distintos, um granítico (mais frio) e um básico (mais quente) na geração destas rochas. Assim sendo, a coexistência de magmas que podem ter se cristalizado concomitantemente, permitiram a formação de rochas híbridas, que foram intensamente deformadas (gnaisses bandados).

A presença de enclaves máficos microgranulares, comuns em granitos híbridos (Wernick, 1983) também podem indicar a íntima associação entre material granítico mais frio e material mantélico básico mais quente.

Em Mongaguá, o contato irregular em cúspide (Prancha 4, Foto 2) é indicativo da coexistência de magmas contemporâneos que apresentam diferenças marcantes de viscosidade (Smith, 2000), onde o material máfico mostra uma viscosidade muito mais baixa em relação ao magma granítico.

Estruturas bandadas irregulares, localmente flebiticas observadas nas rochas de Mongaguá e Itanhaém (Prancha 3, Foto 6 , Prancha 6 , Fotos 1 e 3 ), onde há alternância de bandas mutualmente contaminadas do granito e do material máfico, podem indicar que o magma máfico foi colocado no granito antes que este estivesse cristalizado o suficiente para fraturar. Enclaves típicos de fragmentos de diques sinintrusivos, frequentes em rochas híbridas, ocorrem nas rochas gnáissicas de Mongaguá.

Feições observadas em Itanhaém onde ocorrem enclaves magmáticos apresentando contatos bastante nítidos com o material granítico (Prancha 6, Foto 4), são denominadas de 'net veined complexes' (Marshall \& Sparkes, 1984). Tais feições podem ocorrer devido ao alto conteúdo de cristais no material máfico em 
relação ao granítico. Neste caso, o material máfico tem um comportamento mais rúptil em relação ao magma granítico (Neves \& Vauchez, 1995).

Enclaves máficos centimétricos a métricos apresentam desde formas ovaladas ou arredondadas, ou mesmo apresentam-se fortemente deformados, com formas sigmoidais. Tal deformação, também evidenciada pelas estruturas gnáissicas, pode ter sido originada devido ao fluxo marginal formado pela ascenção destes corpos através de diápiros (Wernick, 1983).

O Granito Ribeirão do Óleo já havia sido diferenciado por Silva (1981) como pertencente às "rochas gnáissicas incipientemente migmatizadas" a NNE de Itariri. Neste granito, o magma mingling é bem evidente, identificando-se nitidamente a participaçäo de magmas bastante distintos, um monzogranítico e outro máfico. Nesta interação entre os materiais, possivelmente em zonas profundas, observamse cumulatos de feldspato potássico, caracterizados pela forte concentração destes megacristais euedrais nas imediações dos enclaves máficos (Prancha 9, Fotos 1 e 2).

As lineações minerais magmáticas com forte caimento encontradas no Granito Ribeirão do Óleo (N50W/54), também podem indicar que o nível de erosão afetou zonas bem profundas deste plúton granítico.

Nos Granitos Tipo Itarii, predominam biotita monzogranitos foliados, caracterizados pelo mineral máfico biotita marrom avermelhada, e minerais acessórios muscovita e granada. São desde fracamente peraluminosos a peraluminosos. Os resultados obtidos pelo método de Fry, indicam que pelo menos os estágios finais do fluxo magmático destes granitos foram condicionados pela deformação associada a movimentação da Zona de Cisalhamento Itariri. Suas lineações minerais magmáticas de baixo caimento, indicam que se trata de porções mais rasas deste plúton granítico.

Os Granitos Tipo Areado, monzogranitos a granodioritos, mostram localmente feições gnáissicas e caracterizam-se por possuir como mineral máfico biotita-verde e como mineral acessório titanita. Estes granitos são correlacionados ao Granito Caepupu (Silva et al., 1978), ou "Granitos geralmente embrechíticos" Silva (1981) e Batolla Jr. et al., 1981, e ao Granito Ribeirão Braço Grande (Janasi \& Ulbrich, 1992). 
A ocorrência de granitos híbridos, com presença de enclaves microgranulares, indicam, possivelmente, a origem profunda destas rochas, e sua colocação em regimes tensionais. O regime extensional associado à geração das rochas do Bloco Mongaguá também pode ser corroborado pelas feições estruturais observadas. Entretanto, para melhor caracterizar o regime deformacional associado a geração destas rochas, se faz necessário o estudo sistemático das formas dos enclaves máficos e de suas orientaçōes, definidas pelos seus eixos maiores, conforme sugerido por Smith (2000).

Característica comum aos Granitos Tipo Itariri e Ribeirão do Óleo (não foram analisadas amostras do Granito Tipo Areado), é a herança isotópica paleoproterozóica, observada nas análises U-Pb em zircões. Desse modo, as idades obtidas no intercepto inferior são ainda imprecisas.

No entanto, a idade em torno de $580 \mathrm{Ma}$ pode ser considerada como importante fase magmática deste bloco, com a geração de rochas graníticas (Tipo Areado e Ribeirão do Óleo). Neste contexto, os granitos Tipo Itariri, podem representar um magmatismo um pouco mais antigo, em relação aos Granitos Areado e Ribeirão do Óleo.

A idade $\mathrm{U}-\mathrm{Pb}$ (zircão) concordante de $612 \mathrm{Ma}$ obtida nos gnaisses monzograníticos de Mongaguá, mostrou-se bem mais antiga que a obtida pela metodologia Rb-Sr (RT) por Picanço (1994) de $532 \pm 31 \mathrm{Ma}$.

As análises isotópicas parecem corroborar com as diferenças químicas e geocronológicas entre os Granitos Tipo Itariri e Areado (Caepupu). Os Granitos Tipo Itariri provavelmente sofreram um fracionamento adicional entre Sm-Nd, e apresentam idades TDM de $2.2 \mathrm{Ga}$. Os Granitos Tipo Areado e Ribeirão do Óleo, bem como as rochas gnáissico-migmatíticas de Mongaguá, mostraram idades TDM mais jovens, entre 1.7 e $1.8 \mathrm{Ga}$.

Através da análise dos isótopos de $\mathrm{Nd}$ e $\mathrm{Sr}$, pode-se sugerir, apesar da pequena quantidade de dados, que as rochas do Bloco Mongaguá tiveram origens a partir de fontes distintas, com características de reservatórios crustais. 


\section{BLOCO REGISTRO}

\subsection{INTRODUÇÃO}

O Bloco Registro foi definido na área de estudo, para as rochas que afloram a sul das Zonas de Cisalhamento de Cubatão (ZCC) e Itariri (ZCl), e a norte da Zona de Cisalhamento Serrinha (ZCS). A ZCC e ZCl limitam este bloco com o Bloco Embu e Mongaguá, e a ZCS faz o limite com o Bloco Iguape (Mapa Geológico - Anexo 1).

Foram investigadas, no Bloco Registro, rochas gnáissico-migmatíticas e rochas graníticas associadas, e paragnaisses do Maciço da Juréia.

Os trabalhos desenvolvidos neste compartimento abrangeram as regiões entre Pedro Barros e Registro, ao longo da Rodovia BR-116; perfil em trecho do Rio dos Morais, a SW de Pedro Barros; perfil de Miracatu rumo a sul até o vilarejo de Paraíso Mirim, pela Rodovia SP 222; redondezas da Serra do Votupoca, a oeste da cidade de Registro; e a borda sul do Maciço da Juréia. Neste trabalho não foram investigadas as rochas referentes ao Maciço do Itatins, tema das Dissertações de Mestrado de Picanço (1994) e Azevedo Sobrinho (1995).

\subsection{CARACTERIZAÇÃo PETROgráfica-ESTRUTURAL}

Através dos estudos realizados, o Bloco Registro foi subdividido em três grupos litológicos principais, definidos pelos respectivos litotipos predominantes.

O primeiro grupo, refere-se às rochas granito-gnáissicas complexamente interrelacionadas com material diorítico, desenvolvendo estruturas migmatíticas heterogêneas e relações texturais diversas, interpretadas como produtos de magma mingling $t$ mixing. Termos miloníticos destas rochas são encontrados nas área de influência das $\mathrm{ZCC}$ e $\mathrm{ZCl}$, bem como na porção central do Bloco, próxima a Serra de Timirim.

O segundo grupo refere-se às rochas metassedimentares, que incluem os paragnaisses aflorantes no Maciço da Juréia (extremo SE do Bloco Registro), com aproximadamente $47 \mathrm{~km}^{2}$ de área, onde apresentam-se miloníticos, afetados pela ZCS; e mica-xistos afetados pela ZCl, aflorantes próximo à localidade de Ana Dias. 
O terceiro grupo refere-se ao Granito da Serra do Votupoca, que apresentase, na área estudada, como um stock granítico com aproximadamente $14 \mathrm{~km}^{2}$ de área.

\section{ROCHAS GRANITO-GNÁISSICO MIGMATITICAS}

As rochas deste contexto ocorrem de duas maneiras principais:

1) onde a mistura de materiais ocorre (mixing), sendo ainda comum o reconhecimento de ambos materiais envolvidos (mingling). Os afloramentos-Tipo localizam-se na região de Oliveira Barros;

2) onde a mistura de materiais é mais intensa (mixing), raramente reconhecendo-se ambas porções envolvidas. Os afloramentos-Tipo localizam-se nas Serras do Taquaruçu e de Timirim.

Esta subdivisão fundamenta-se apenas para efeito de descrição destes litotipos, devido a complexidade das estruturas observadas. Não há uma divisão estanque entre o modo de ocorrência (itens 1 e 2 ) destas rochas, onde os processos de mistura estão intrinsecamente relacionados.

1) Região de Oliveira Barros

A 'mistura' (mingling) entre material granítico e diorítico, onde ambos materiais são ainda perfeitamente individualizados, pode ser observada em afloramento na Rodovia BR-116, a cerca de $10 \mathrm{~km}$ a sul da cidade de Miracatu, região de Oliveira Barros.

O afioramento caracteriza-se por diques dioríticos, em material granodioritico, que podem mostrar-se rompidos, gerando enclaves (Prancha 10, Foto 1). Os enclaves métricos, apresentam formatos desde ovalados a irregulares, com pequena borda de reação caracterizada por uma camada feldspática que envolve todo enclave (Prancha 10, Foto 2). Enclaves decimétricos são muito comuns em meio ao material granodiorítico, apresentando formas estiradas (Prancha 10, Foto 3). Interessante notar 0 contato entre o material granodiorítico e diorítico em detalhe (Prancha 10, Foto 4 ) onde pode-se observar a foliação no granodiorito a altos ângulos da foliação do material diorítico, caracterizada pela intercalação de filmes feldspáticos irregulares e filmes máficos. 
Em determinadas porções, no contato entre os dois materiais, pode-se observar a foliação no enclave diorítico rotacionada pelo fluxo magmático granodiorítico (Prancha 10, Foto 5).

Em outras localidades, muito próximas às anteriores, a mistura (mixing) entre os dois materiais apresenta-se mais evidente. A rocha mostra feições migmatíticas bastante heterogêneas, mas preservando ainda enclaves máficos com formatos irregulares, de dimensões normalmente decimétricas, que não foram totalmente assimilados (Prancha 10, Foto 6). Nestes locais a rocha apresenta um bandamento gnáissico irregular (Prancha 11, Foto 1), e comumente observa-se uma das feições mais características de magma mixing: fenocristais de feldspato branco do material granítico assimilado pelas porções mais dioríticas (Prancha 11, Foto 2). Outras feições de assimilação também podem ser observadas, como enclaves com borda de reação bastante marcante, e intensa 'feldspatização' em forma de vênulas e presença de cristais esparsos de microclínio branco (Prancha 11, Foto 3).

Em alguns locais, é possivel observar a passagem das porções mais hibridas, onde a mistura entre os materiais granítico e diorítico é intensa, para as porções onde se identificam claramente as duas rochas em interação, onde há o predomínio do material diorítico (Prancha 11, Foto 4).

Nestes locais de maior mistura, há o predomínio de material gnáissico, bandado, fortemente segregado (Prancha 11, Foto 5), caracterizado pela intercalação de faixas máficas centimétricas de granulação fina, com bandas decimétricas definidas pela intercalação de filmes máficos com faixas félsicas. $O$ material mostra-se bastante deformado, onde o enclave máfico comporta-se como um porfiroclasto sigmoidal, em meio ao material gnáissico bandado, apresentando uma sombra de pressão constituída por material granítico não deformado (Prancha 11, Foto 6).

A passagem entre as porções mais e menos híbridas não se mantém, ou seja, analisando-se o afloramento como um todo há diversas passagens irregulares e heterogêneas entre as porções de maior mistura (mixing) e de menor mistura (mingling).

Nas áreas de grande mistura, também desenvolvem-se diversas estruturas migmatíticas, do tipo agmatítica, flebítica, surreítica, schiliren e shollen (Prancha 12, Fotos 1 a 5$)$. 
$\mathrm{Na}$ localidade de Oliveira Barros, desenvolvem-se camadas miloníticas irregulares sub-horizontais (Prancha 10, Foto 2), podendo apresentar um padrão anastomosado métrico (Prancha 12, Foto 6).

Nas proximidades da $\mathrm{ZCl}$, as rochas gnáissico-migmatíticas mostram-se mais foliadas, onde observam-se os enclaves mais deformados, de formato mais ovalado (Prancha 13, Foto 1) até porções totalmente miloníticas, com enclaves máficos totalmente estirados (Prancha 13, Foto 2). Apresentam foliação milonítica com orientação principal em torno de E-W/75 $\mathrm{N}$, que desenvolve uma lineação de estiramento mineral $\mathrm{N} 80 \mathrm{~W} / 25$, caracterizada pelo estiramento de feldspatos. Estruturas S-C indicam movimentação sinistral (Prancha 13, Foto 3).

Não raramente as rochas gnáissico-migmatíticas apresentam-se extremamente alteradas, apenas identificando-se prováveis estruturas migmatíticas (Prancha 13, Foto 4) ou mesmo enclaves com bordas feldspatizadas de formas sigmoidais (Prancha 13, Foto 5).

O material félsico, ou 'leucossomático' caracteriza-se pela cor cinza claro e granulação fina a média, textura inequigranular, com megacristais de feldspato branco euedrais de até $7 \times 3 \mathrm{~cm}$. Apresentam-se normalmente foliados, cuja foliação caracteriza-se pelo alinhamento dos feldspatos e dos minerais máficos (anfibólio e/ou biotita). Podem variar de anfibólio-biotita granodioritos (Prancha 14, Foto 1) a biotita-monzogranitos. Localmente (Prancha 13, Foto 3) apresentam composição sienogranítica, tendo como máfico a biotita e minerais acessórios principais o zircão e apatita.

Petrograficamente os granodioritos e monzogranitos caracterizam-se pelos minerais principais: quartzo, microclínio, plagioclásio e máfico principal biotita. Anfibólio também ocorre nos granodioritos. Como acessórios mais comuns, zircão, allanita, apatita e epídoto.

Em seção delgada, observa-se a foliação caracterizada pela forte orientação dos cristais de homblenda e biotita, e dos cristais de plagioclásio subeuedrais a euedrais (Prancha 14, Foto 2).

Cristais de quartzo normalmente têm forte extinção ondulante, tendendo a recuperação, formando sub-grãos. Localmente apresentam-se totalmente recristalizados. 
Os cristais de microclínio são normalmente subeuedrais e pertíticos (tipo veio, macula ou filme). Comumente no contato com plagioclásio há desenvolvimento de mirmequitas. Ocorre pequena recristalização de microclínio nas bordas.

Os cristais de oligoclásio, podem apresentar-se bastante saussuritizados ou mais preservados. Raramente apresentam deformação nas maclas. Podem ocorrer como anti-pertitas.

Nos granodioritos, cristais de biotita euedrais a subeuedrais apresentam pleocroísmo amarelo-claro a verde, podendo alterar-se para clorita. Nos monzogranitos a biotita tem pleocroísmo amarelo-claro marrom avermelhado, normalmente intersticial (Prancha 14, Foto 3). Por vezes mostra-se intercrescida com feldspato, ou como inclusões em microclínio e plagioclásio, onde estão subeuedrais a euedrais e podem alterar para muscovita.

Cristais de anfibólio, presentes nos granodioritos, do grupo das hornblendas, têm pleocroísmo amarelo claro a verde azulado, e altera para biotita e calcita.

Feições características destas rochas é a presença de epídoto bem desenvolvido, associados a plagioclásio e biotita, e presença de cristais de allanita manteados por epídoto (Prancha 14, Foto 4).

Demais acessórios frequentes são zircão, apatita e opacos. Ocasionalmente, nos biotita-monzogranitos ocorre granada inclusa em cristal de microclínio.

O material félsico sienogranítico, de granulação mais grossa que os granodioritos e monzogranitos (Prancha 14, Foto 5), tem como máfico a biotita, intersticial, ou evedral quando inclusa em cristais de microclínio ou quartzo.

A interface entre o material granítico e diorítico é caracterizada por forte corrosão dos cristais de plagioclásio (Prancha 14, Foto 6).

O material diorítico que ocorre como enclave tem granulação fina, é foliado e tem textura lepi-nematoblástica (Prancha 15, Foto 1). A rocha apresenta clivagem de crenulação, cortada por foliação milonítica. Neste processo o anfibólio se comporta de maneira rúptil e o quartzo de maneira dúctil (Prancha 15, Foto 2). Porfiroclastos de hornblenda apresentam-se totalmente substituídos por biotita, epídoto e calcita, com sombra de pressão constituída por quartzo. Os cristais de biotita e anfibólio formam a grande massa fina da rocha.

A mineralogia principal constitui-se por anfibólio, biotita, plagioclásio, quartzo e epídoto, e os principais minerais acessórios são titanita, apatita e opacos. 
Cristais de hornblenda, normalmente anedrais a subeuedrais, possuem pleocroísmo de amarelo claro a verde escuro. Alteram para biotita, epídoto e calcita sendo o início da alteração observado ao longo das clivagens. Localmente para actinolita (Prancha 15, Foto 1).

Cristais de biotitas são normalmente anedrais, com pleocroísmo amarelo claro a marrom.

O processo de saussuritização do plagioclásio é bastante intenso, não sendo possível determinar sua provável composição. Em alguns enclaves, apresenta-se intersticial, mirmequítico, provavelmente tratando-se de andesina.

Os cristais de quartzo estão segregados em pequenos ribbons e em sigmóides. Apresentam formas sigmoidais com extinção ondulante, recristalizados nas bordas, em recuperação ou totalmente recristalizados (Prancha 15, Foto 3 ).

As titanitas normalmente estão concentradas em faixas, manteando opacos (Prancha 15, Foto 4).

Cristais de epidoto ocorrem em grande quantidade, principalmente da alteração dos anfibólios e plagioclásio.

Nos locais onde o material félsico é sienogranítico, a porção máfica é muito rica em biotita (Prancha 13, Foto 3). Petrograficamente caracteriza-se pela presença de biotita, quartzo e granada (Prancha 15, Foto 5). Apresenta foliação caracterizada pela orientação das biotitas, granadas, epídotos e sericitas, ocorrendo segregação de bandas ricas em quartzo, que tendem a formar ribbons com extinção ondulante, ou em recuperação. As granadas mostram-se estiradas e apresentam fraturas preenchidas por sericitas.

Estruturalmente as rochas deste contexto apresentam uma foliação caracterizada pelo alinhamento de feldspatos e de minerais máficos, mostrando-se bastante dobrada, apresentando máximo em N47W/42NE (Figura 7.2.1). Nos locais onde a rocha mostra-se mais deformada, a foliação caracteriza-se por um bandamento gnáissico, definido pela intercalação de faixas centimétricas quartzofetdspáticas e máficas. Este bandamento (Sb, em vermelho no estereograma), apresenta direção principal em N40E/42NW (Figura 7.2.1). A foliação principal observada nos enclaves máficos, mostra-se sub-vertical. As faixas miloníticas irregulares observadas (Prancha 10, Foto 2; Prancha 12, Foto 6) apresentam-se 
sub-horizontais ou com mergulhos intermediários, por vezes apresentando-se paralelas à foliação principal. As lineações minerais mostram-se dispersas.

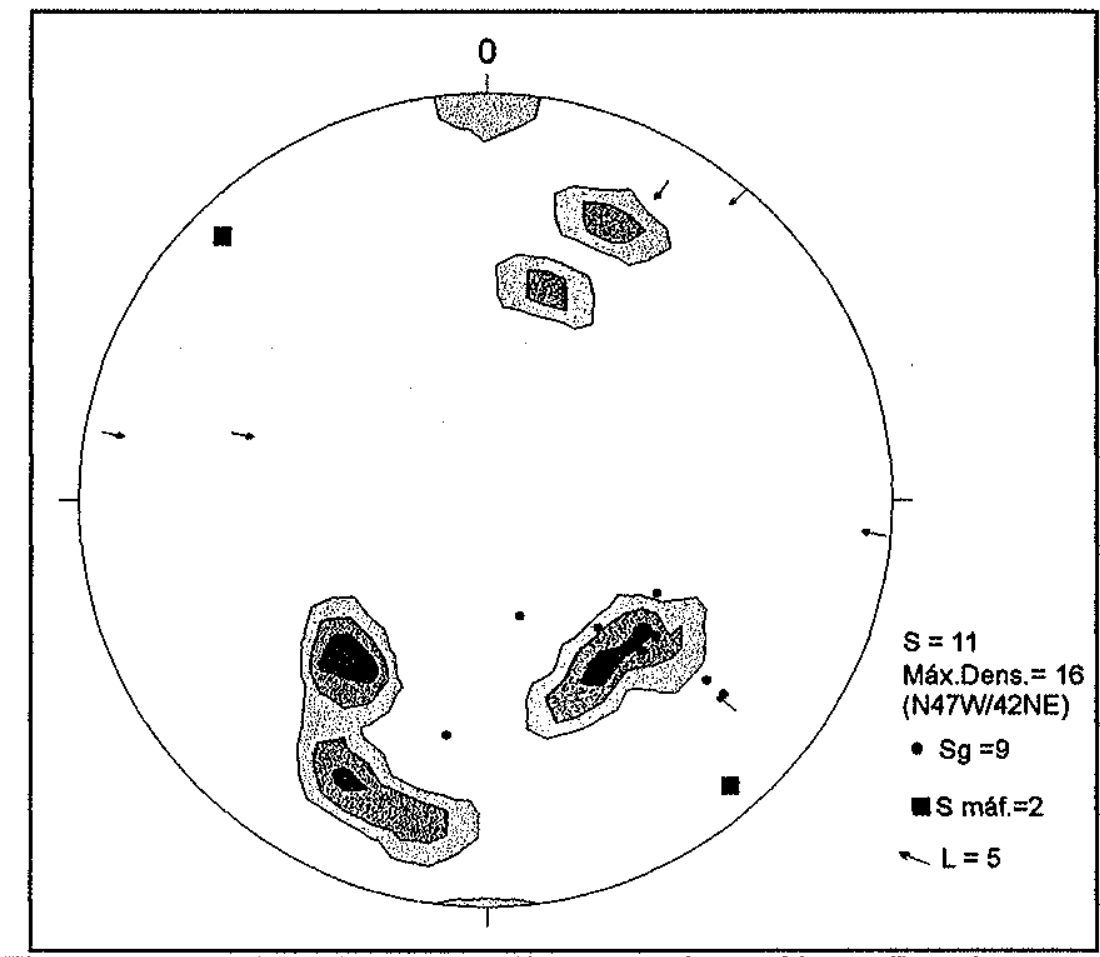

Figura 7.2.1. Bloco Registro - Rochas migmatíticas. Bandamento.

2) Região das Serras do Taquaruçu e de Timirim

Predominam rochas granito-gnáissicas leucocráticas a mesocráticas, localmente com feições migmatíticas, representando as porções de maior mistura (mixing) entre os materiais granítico e máfico. Localmente (Serra do Timirim) apresentam texturas miloníticas.

As rochas gnáissicas, têm composição granodiorítica a monzogranítica, representados por anfibólio-biotita granodioritos e biotita-monzogranitos.

Suas porções mesocráticas, são muito semelhantes àquelas porções de maior mistura encontradas próximo a localidade de Oliveira Barros, onde apresentam bandamento gnáissico irregular e predomínio de material máfico (Prancha 16, Foto 1), comparar com Foto 1, Prancha 11. O bandamento gnáissico é caracterizado pela orientação dos minerais máficos, biotita e anfibólio, intercalados com bandas quartzo-feldspáticas. Caracterizam-se pela textura inequigranular com 
megacristais de feldspato potássico euedrais de até $5 \times 4 \mathrm{~cm}$. Feições localizadas migmatíticas comuns são do tipo ptigmáticas (Prancha 16, Foto 2).

As porções miloníticas mesocráticas apresentam uma foliação protomilonítica, caracterizada pela orientação dos cristais de biotita e início do estiramento dos porfiroclastos de feldspato (Prancha 16, Foto 3 ).

A mineralogia principal constitui-se de quartzo, microclínio, plagioclásio, biotita e ocasionalmente anfibólio. Os acessórios principais são zircão, apatita, allanita e epídoto.

Os cristais maiores de quartzo mostram extinção ondulante, sendo que a maioria dos cristais tendem a recuperação, formando sub-grãos, ou recristalizados com contatos poligonais. Em rocha onde há presença de uma fraca deformação, os grãos de quartzo mostram contatos irregulares ou serrihados e bastante fraturados. Nos termos miloníticos estão segregados, podendo formar faixas sigmoidais com cristais totalmente recristalizados.

Nos monzogranitos os cristais de microclínio são pertíticos, tipo veio, e podem apresentar crescimentos mirmequíticos. Ocorre pequena recristalização nas bordas, e ao longo de fraturas. Nos granodioritos os cristais de microclínio são límpidos, não pertíticos, e também desenvolvem mirmequitas em contato com plagioclásio.

Os cristais de oligoclásio nos monzogranitos são desde límpidos até bastante saussuritizados, e nos termos mais deformados mostram alguma deformação nas maclas tipo em cunha. Também observa-se um padrão de fraturamento bastante constante. Podem ocorrer anti-pertitas.

Nos granodioritos o plagioclásio é normalmente pouco alterado e mostra normalmente ondulação nas maclas. Também ocorrem anti-pertitas.

As biotitas têm pleocroísmo de amarelo claro a verde escuro, normalmente subeuedrais e podem alterar para clorita.

Nos granodioritos, cristais de hornblenda alteram para biotita e epídoto ao longo das clivagens (Prancha 16, Foto 4).

Nos monzogranitos apenas observam-se pseudomorfos de anfibólio, totalmente substituídos por biotita e epidoto.

Característica comum nestas rochas é a presença de allanita como mineral acessório mais comum, manteada por epídoto (Prancha 16, Foto 6). 
Os termos miloníticos podem apresentar texturas protomiloníticas (Prancha 16, Foto 5), observando-se textura mortar bem desenvolvida em microclínio, onde apresenta importante recristalização nas bordas e feições mirmequíticas. A sul da Serra de Timirim, milonitos apresentam foliação caracterizada pelo estiramento de porfiroclastos de feldspatos, e forte orientação dos cristais de biotita. Porfiroclastos sigmoidais e estruturas S-C sugerem movimentação dextral (Prancha 16, Foto 6).

Estruturalmente, as rochas deste contexto podem apresentar-se miloníticas, com uma direção principal em torno de N50W e mergulhos intermediários predominantes para NE, paralela ao bandamento gnáissico, que mostra-se dobrado. Desenvolve lineação de estiramento mineral, com caimentos intermediários a baixos para NE e SE. Onde o bandamento gnáissico apresenta direção NE com mergulhos para SE (em azul no estereograma), apresenta lineação mineral com caimentos para SW (Figura 7.2.2).

Foliação protomilonítica também se desenvolve preferencialmente em torno na direção de $E-W$ com mergulhos para $S$ (em vermelho no estereograma), desenvolvendo lineação de estiramento mineral com caimento preferencial para SEE (Figura 7.2.2).

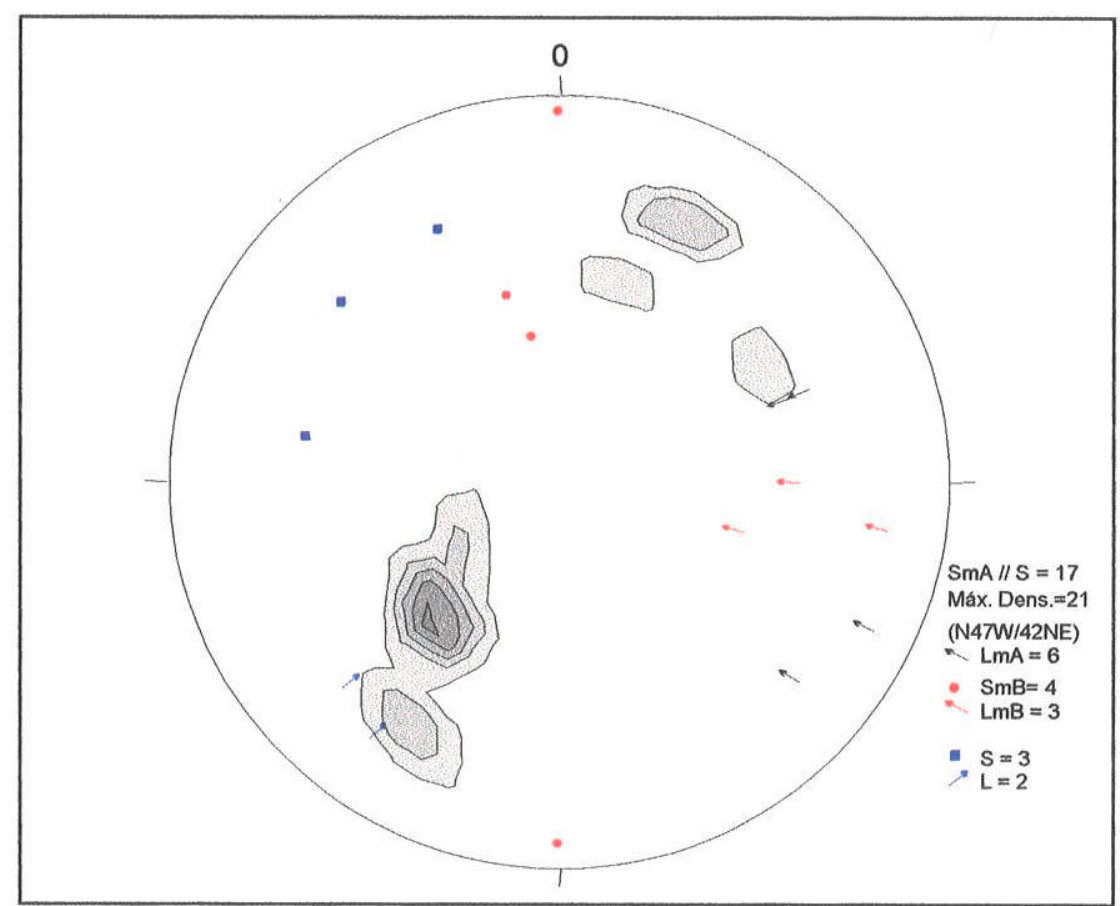

Figura 7.2.2. Bloco Registro - Rochas gnáissicas miloníticas. 
A partir dos dados obtidos, observa-se que estas rochas apresentam um bandamento gnáissico extremamente variável, possivelmente dobrado. Há presença de duas direções principais de faixas miloníticas, uma NW e outra E-W. Como observado por indicadores cinemáticos ambas faixas miloníticas apresentam movimentação dextral.

\section{ROCHAS METASSEDIMENTARES}

Na porção extremo NE do Bloco Registro ocorrem rochas metassedimentares miloníticas, afetadas pela $\mathrm{ZCl}$, representadas por granada-sillimanita-biotita xistos, tendo como mineral acessório principal o zircão.

Apresentam biotita e sillimanita em alta quantidade, sendo compostos também por quartzo, granada e microclínio (Prancha 17, Foto 1).

A rocha apresenta uma foliação milonítica predominante caracterizada pela orientação de ribbons de quartzo, biotitas e sillimanitas, que circundam os porfiroclastos de agregados de quartzo, de granada e de agregados de microclínio. A matriz é muito fina e composta por quartzo, biotita e sillimanita, com cristais muito pequenos de zircão

Os ribbons de quartzo intercalam-se com a matriz bem orientada, são policristalinos e cristalograficamente bem orientados.

Os cristais de sillimanita (pré-cinemáticos) estão bem preservados e bem formados, euedrais a subeuedrais, por vezes rotacionados, indicando movimentação sinistral (Prancha 17, Foto 2). Os cristais de granada (pré-cinemáticos) não apresentam inclusões, estão bem fraturados e bastante alterados por óxidos de Fe. Formam porfiroclastos com sombras de pressão compostas por quartzo e biotita.

Cristais de microclínio, em pequena quantidade, estão agregados e raramente formam porfiroclastos.

Estruturalmente os xistos apresentam uma foliação milonitica $E-W$, com merguthos intermediários para norte e lineação mineral (estiramento de quartzo e orientação de biotita) com caimento intermediário para N40W (Figura 7.2.3). 


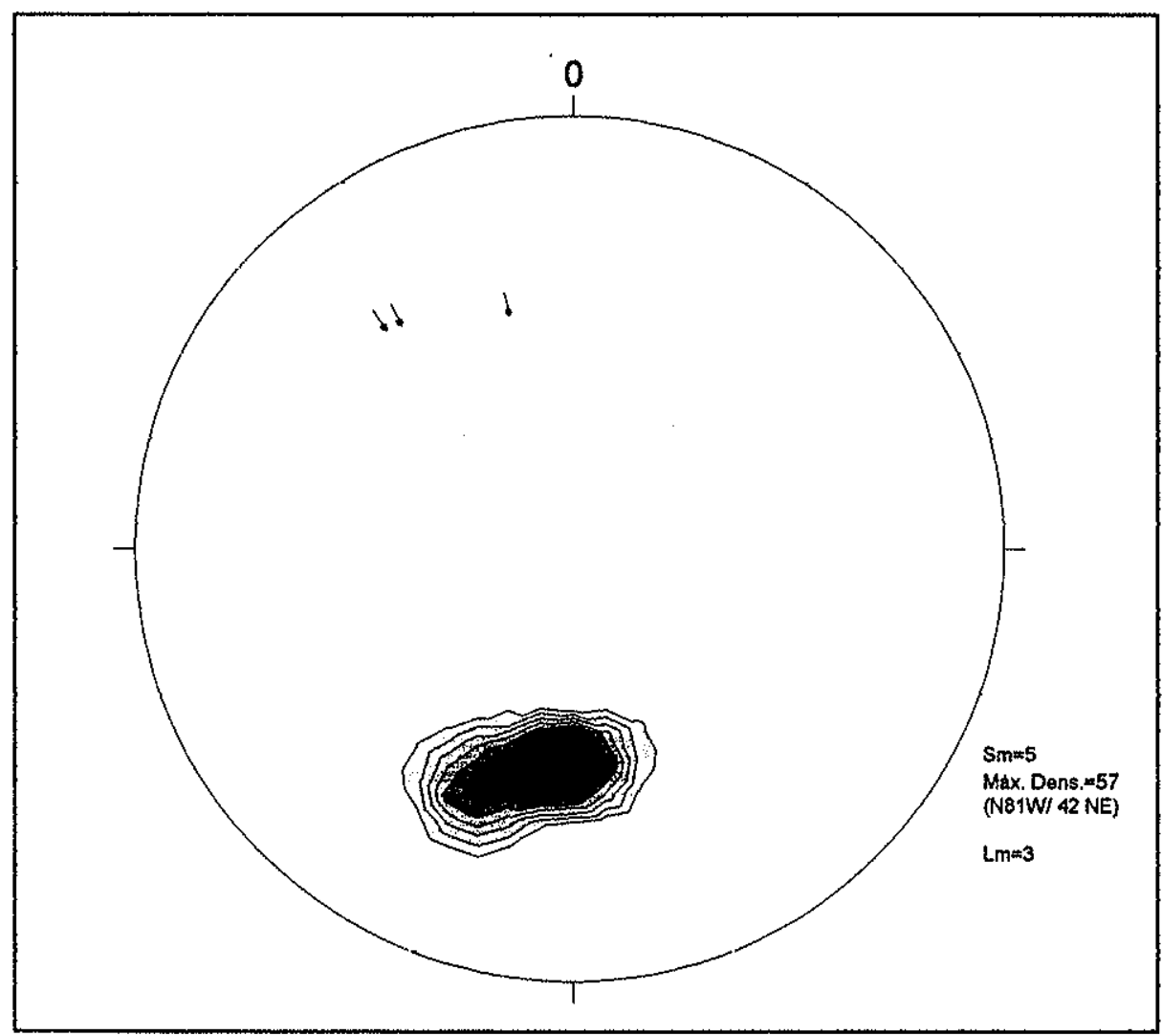

Figura 7.2.3. Bloco Registro/ZCl - Granada-sillimanita-biotita xistos miloníticos. Foliação milonítica $(\mathrm{Sm})$ e lineação mineral $(\mathrm{Lm})$.

Através de indicações cinemáticas sinistrais definidas por porfiroclastos assimétricos e porfiroclastos rotacionados observados em seção delgada (Prancha 17, Foto 2) e relação com as estruturas planares e lineares, observa-se uma componente distensiva para NW nos milonitos de rochas metassedimentares.

Os paragnaisses que afloram na porção extremo SE do Bloco Registro, sustentam o Maciço da Juréia, e apresentam-se afetados pela ZCS.

Possuem coloração cinza-azulada, bandamento caracterizado por faixas centimétricas quartzo-feldspáticas intercaladas com bandas porfiroclásticas predominantes, ricas em biotita. A foliação milonítica é caracterizada pelo estiramento de porfiroclastos (feldspatos e granadas), em matriz finamente foliada, caracterizada pela forte orientação dos cristais de biotita. 
A foliação milonítica possui mergulhos intermediários a baixos (Prancha 17, Foto 3), e a relação entre a foliação milonítica, lineação de estiramento mineral e indicação cinemática, sugere transporte distensivo predominantemente para $\mathrm{E}$. Os dados estruturais referentes aos paragnaisses da Juréia serão oportunamente tratados no capítulo referente ao setor leste da ZCS.

Os paragnaisses, apresentam predomínio de material máfico, rico em biotita e muscovita, sendo comum o desenvolvimento de remobilizados quartzo-feldspáticos (Prancha 17, Foto 4). São ricos em granada, e seus cristais (porfiroblastos I porfiroclastos) atingem até $3 \times 3 \mathrm{~cm}$ (Prancha 17, Foto 5).

Não raramente, em planos sub-paralelos ao corte $X Z$, os remobilizados apresentam formas bastante achatadas e estiradas (Prancha 17, Foto 6 ), sugerindo a influência de uma deformação com forte componente de cisalhamento puro.

É bastante comum os porfiroclastos de feldspato, ou mesmo remobilizados quartzo feldspáticos apresentarem formas bastante simétricas nos cortes $X Z$ do elipsóide de deformação, com sugestão de movimentação dextral em estruturas do tipo S-C (Prancha 18, Foto 1).

No entanto, sugestões de movimentação dextral em porfiroclastos rotacionados de plagioclásio do tipo $\delta$ (Hanmer \& Passchier, 1991), são observadas em cortes aproximadamente paralelos ao corte YZ (Prancha 18, Foto 2).

Petrograficamente, os paragnaisses são caracterizados pela mineralogia principal: quartzo, biotita, muscovita, plagioclásio, como traços granada e microclínio e acessórios, monazita, zircão, e turmalina.

A foliação é definida pela orientação das biotitas/muscovitas e estiramento do quartzo e feldspatos. É caracterizada pela forte segregação das bandas quartzofeldspáticas, das bandas ricas em biotitas. Porfiroclastos de plagioclásio sugerem movimentação dextral (Prancha 18, Foto 3).

Os cristais de quartzo tendem a se segregar em ribbons policristalinos. Normalmente apresentam-se recristalizados, ou em recuperação, formando subgrãos. Os grãos maiores podem preservar extinção ondulante.

Os cristais maiores de oligoclásio formam porfiroclastos com formas sigmoidais, que mostram-se fraturados, com inclusões de quartzo e muscovita, por 
vezes mostrando-se recristalizados (Prancha 18, Foto 4). Os cristais menores da matriz são subeuedrais e limpos. Também mostram-se segregados com quartzo.

Segregados em faixas ocorrem os cristais de biotita, que apresentam pleocroísmo amarelo claro a marrom avermelhado escuro, e são subeuedrais.

Cristais de granada também formam porfiroclastos, e normalmente apresentam-se fraturadas, bem arredondadas. Apresentam inclusões de biotita, quartzo e muscovita; também podem desenvolver sombras de pressão constituídas por quartzo, biotita e muscovita.

\section{SERRA DO VOTUPOCA}

No extremo oeste da área, há ocorrência de corpo granítico, denominado de Granito Votupoca, representado por biotita-monzogranitos, de granulação fina, predominantemente equigranular, de cor marrom claro, desenvolvendo foliação incipiente (Prancha 18, Foto 5).

Apresenta como mineralogia principal: quartzo, microclínio, plagioclásio e biotita. Como acessórios ocorrem allanita, epídoto e zircão.

Os cristais de quartzo normalmente apresentam extinção ondulante ou forma sub-grãos (em recuperação), anedrais.

Cristais de microclínio, geralmente anedrais, são pertíticos, em veios. Os cristais de plagioclásio, subeuedrais a anedrais, encontram-se muito saussuritizados (Prancha 18, Foto 6).

Dois tipos de biotita são observadas e apresentam-se quase que totalmente substituídas por clorita. A distinção se dá pela diferença do pleocroísmo que varia entre amarelo a marrom, e amareto esverdeado claro a verde escuro. 


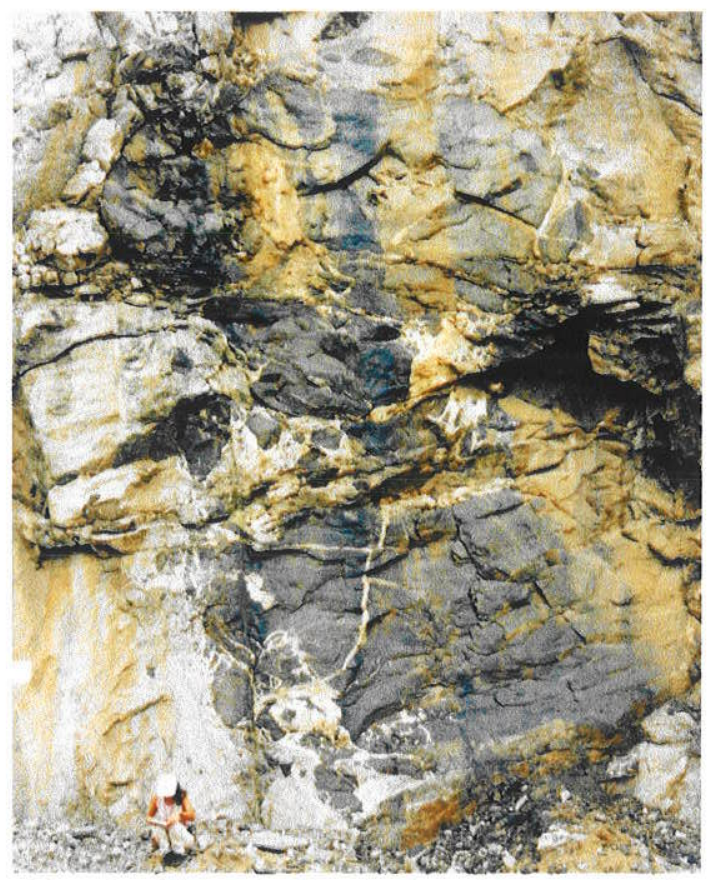

Foto 1 - Dique diorítico sin intrusivo em material granodiorítico. Região próxima a Oliveira BarrosRodovia BR-116. Afloramento K-16.

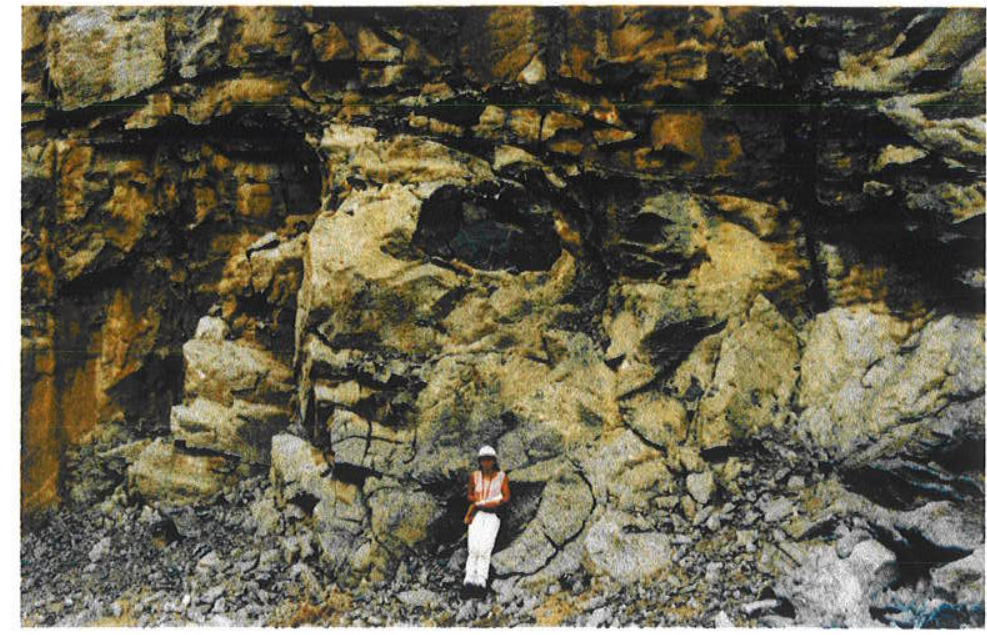

Foto 2 - Enclave diorítico de formato oval, em granodiorito. Apresenta pequena borda de reação feldspática. $\mathrm{O}$ material apresenta faixas miloníticas sub-horizontais. Afloramento K-16.

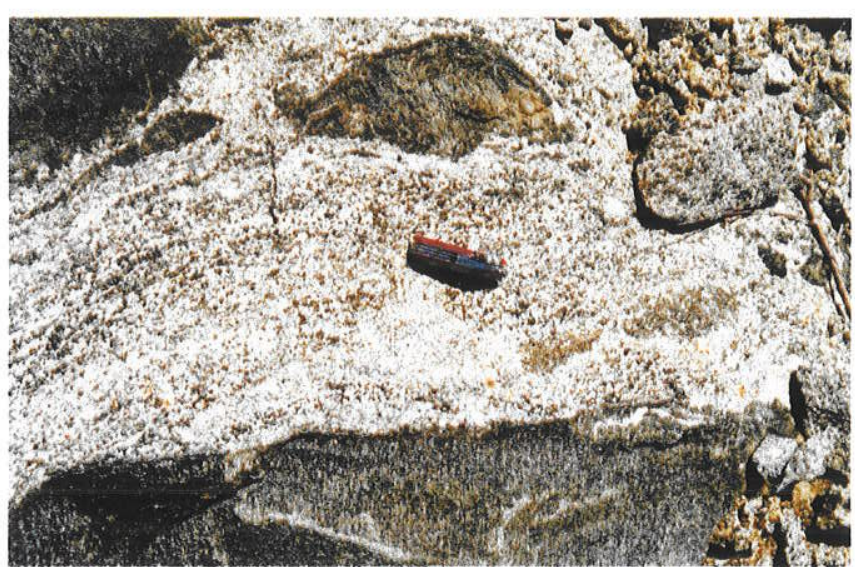

Foto 3 - Enclave decimétrico deformado em material granodiorítico foliado. Parte inferior da foto, porção de enclave métrico de material diorítico. Afloramento K-16.

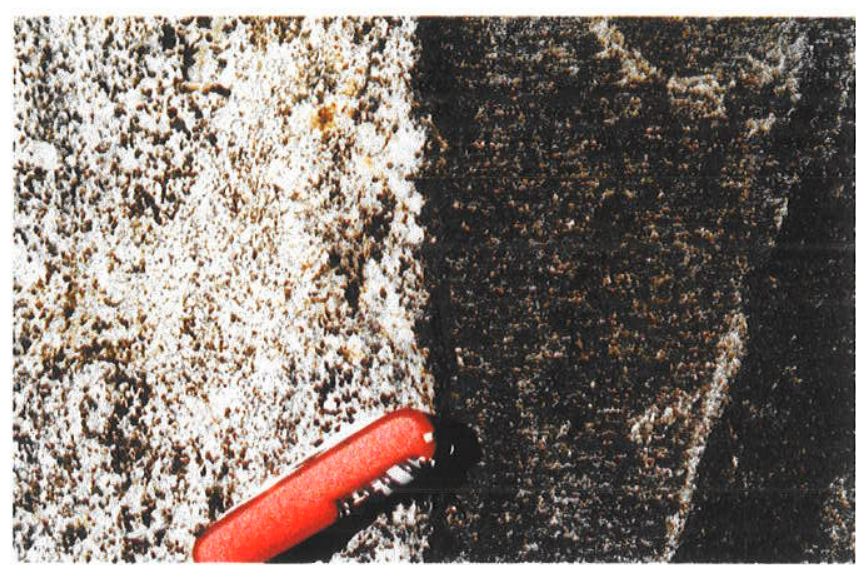

Foto 4 - Detalhe do contato entre granodiorito e enclave diorítico. Notar foliações de ambos materiais dispostas perpendicularmente. Afloramento K-16.

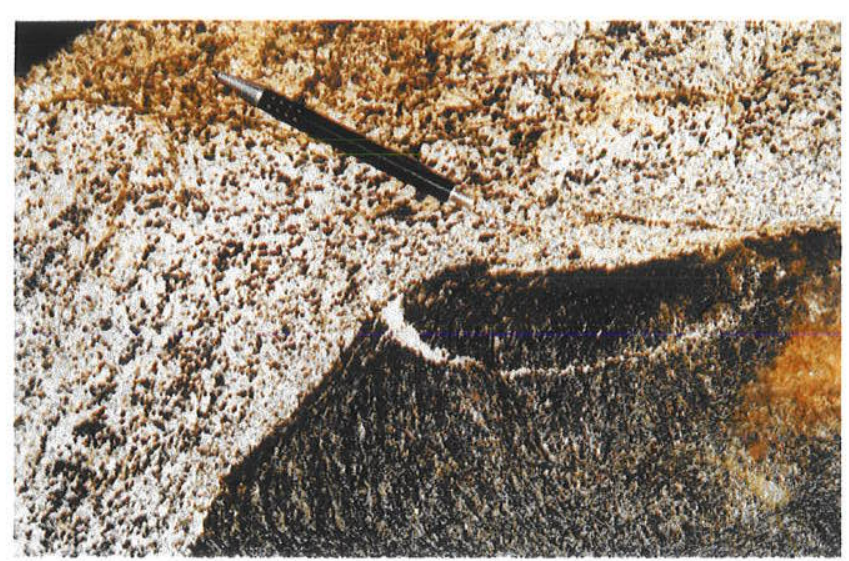

Foto 5 - Foliação no enclave diorítico rotacionada pelo fluxo magmático granodiorítico. Afloramento K-16.

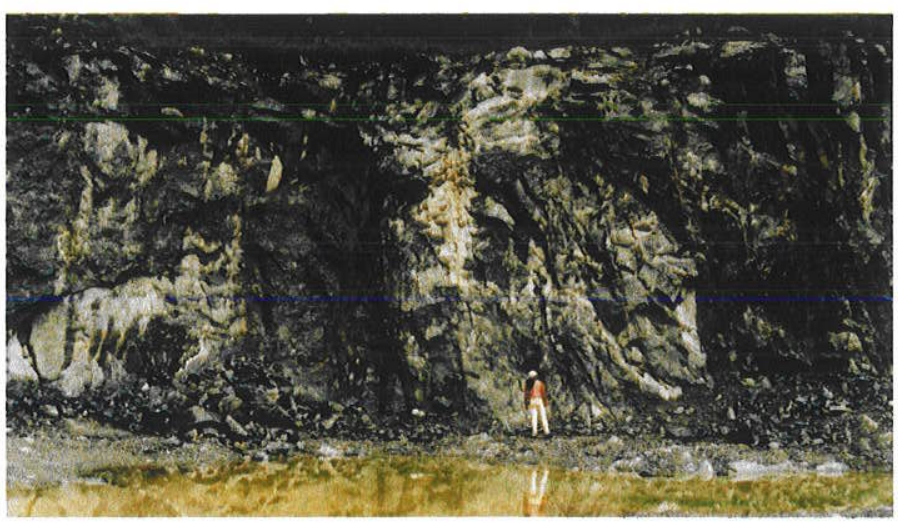

Foto 6 - Magma mixing entre material granítico e diorítico. Proximidades de Oliveira Barros. Afloramento K-17. 


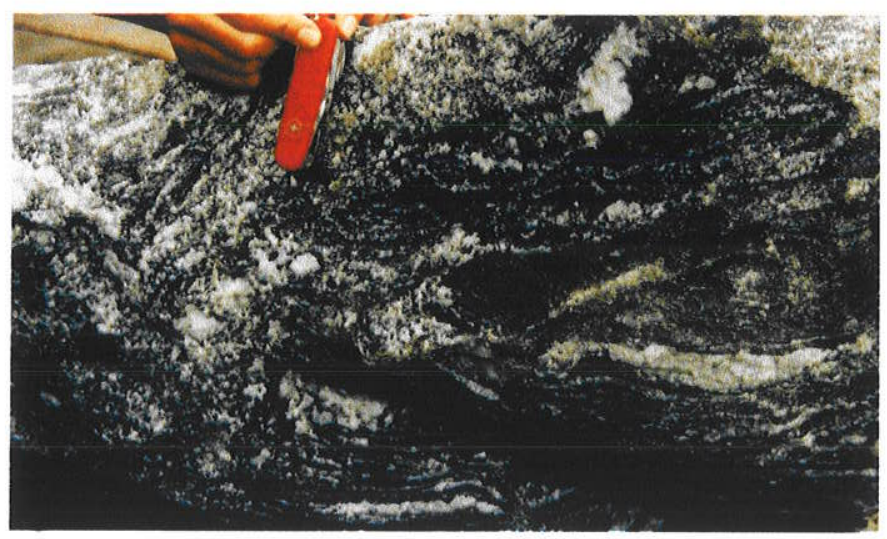

Foto 1 - Material híbrido com bandamento gnáissico irregular. Afloramento K-17.

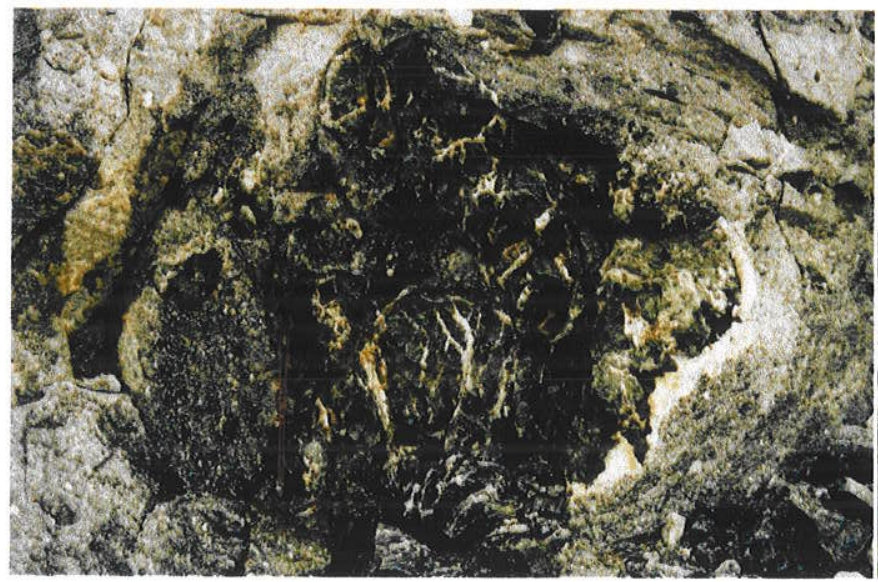

Foto 3 - Enclave diorítico parcialmente assimilado, com borda de reação feldspática bastante desenvolvida, e presença de grande quantidade de vênulas feldspáticas. Afloramento K-17.

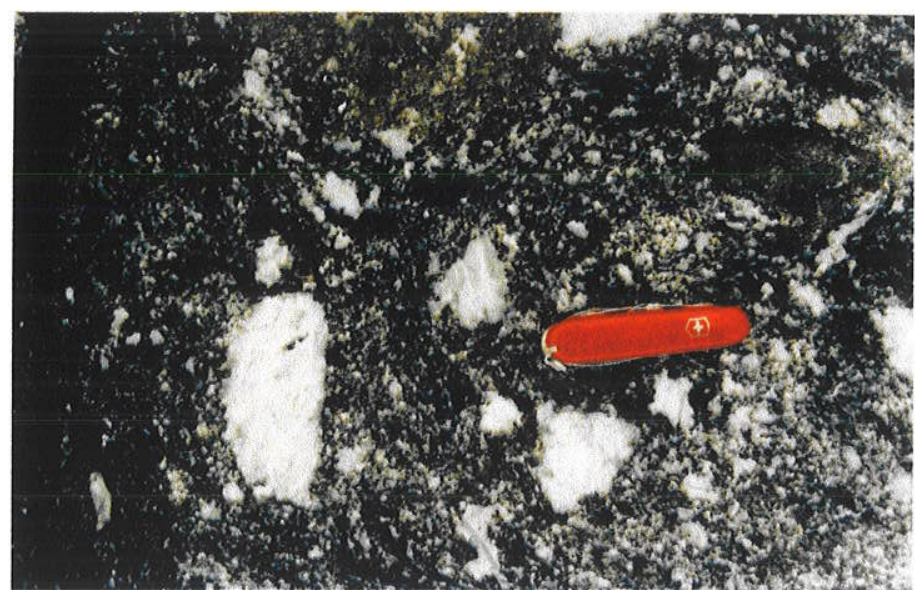

Foto 2 - Assimilação de fenocristais de feldspato do material granodiorítico pelo material diorítico (feição característica de magma mixing). Afloramento K-17.

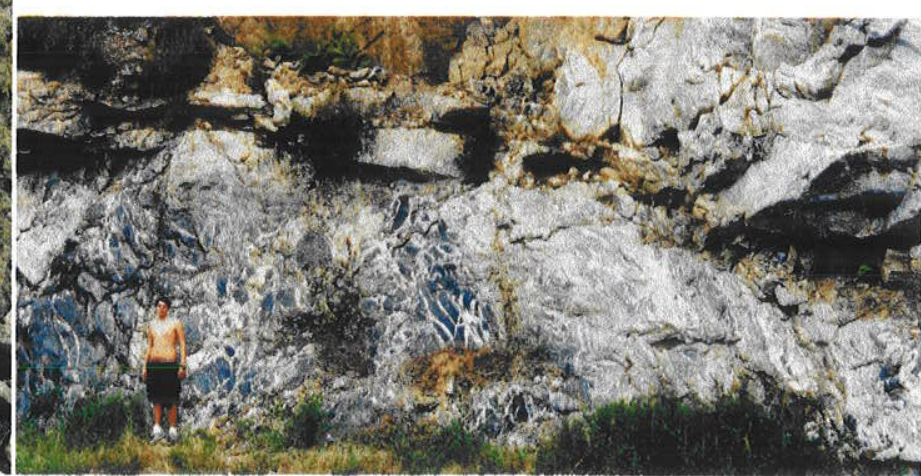

Foto 4 - Gradação entre porções com predomínio de material máfico rompido e porções mais híbridas gnáissico-migmatíticas. Região próxima a Oliveira Barros. Afloramento K-15.

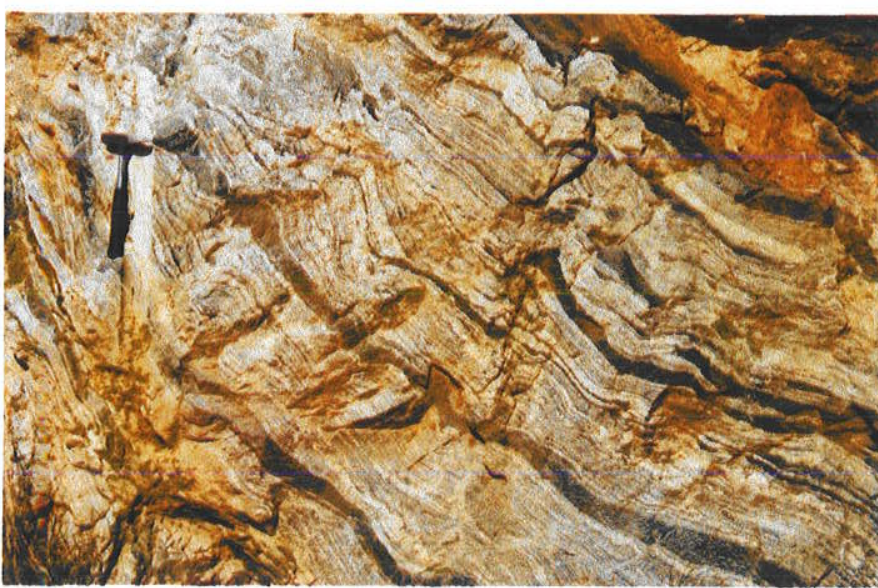

Foto 5 - Material gnáissico, bandado, caracterizado pela intercalação de faixas máficas centimétricas de granulação fina, com bandas decimétricas definidas pela intercalação de filmes máficos com faixas félsicas. Afloramento K-15

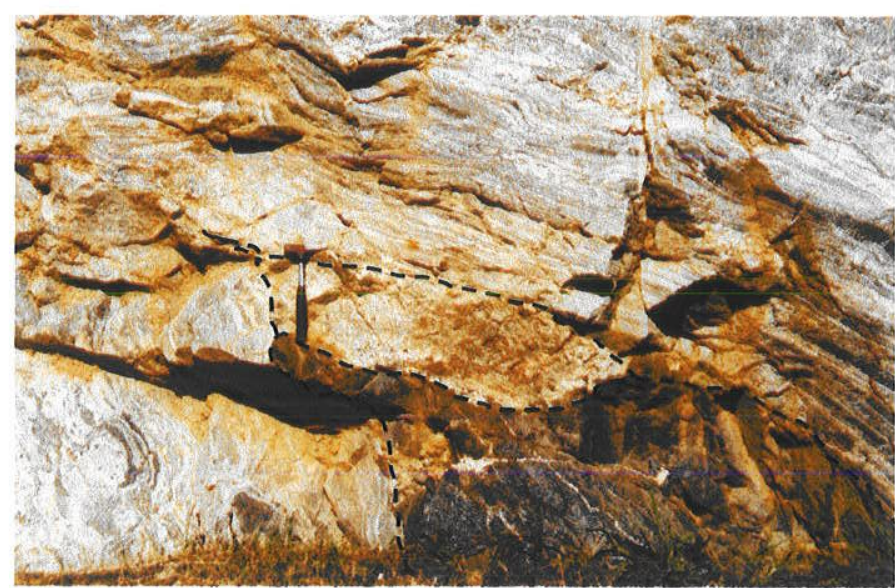

Foto 6- Enclave diorítico sigmoidal, em meio ao material gnáissico bandado, apresentando uma sombra de pressão constituída por material granítico não deformado. Afloramento K-15. 
PRANCHA 12
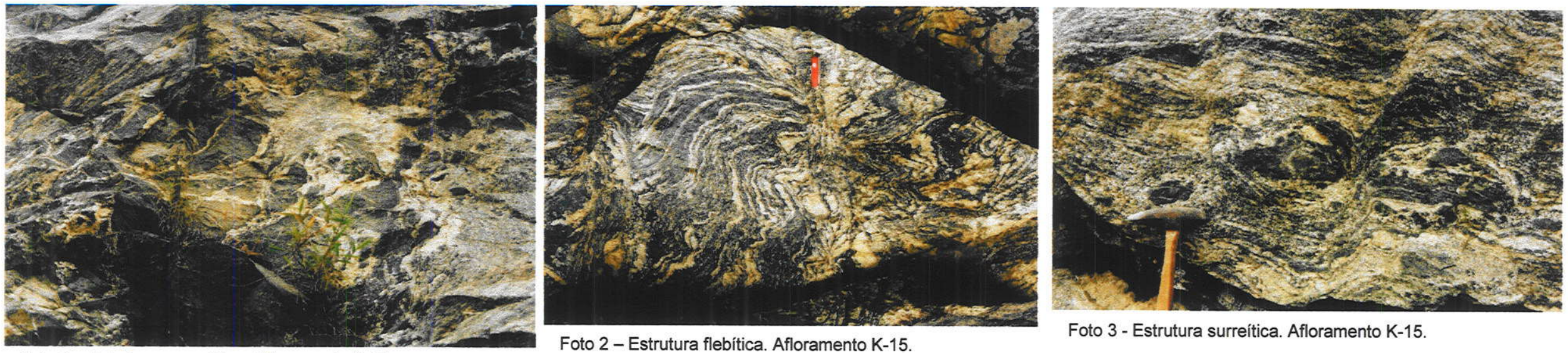

Foto 1 - Estrutura agmatítica. Afloramento K-15.

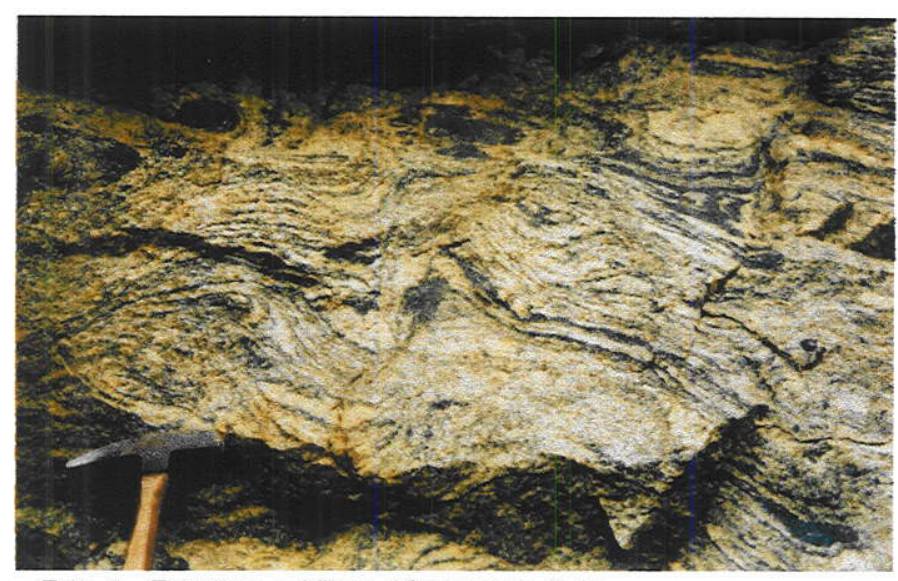

Foto 4 - Estrutura schiliren. Afloramento K-15.
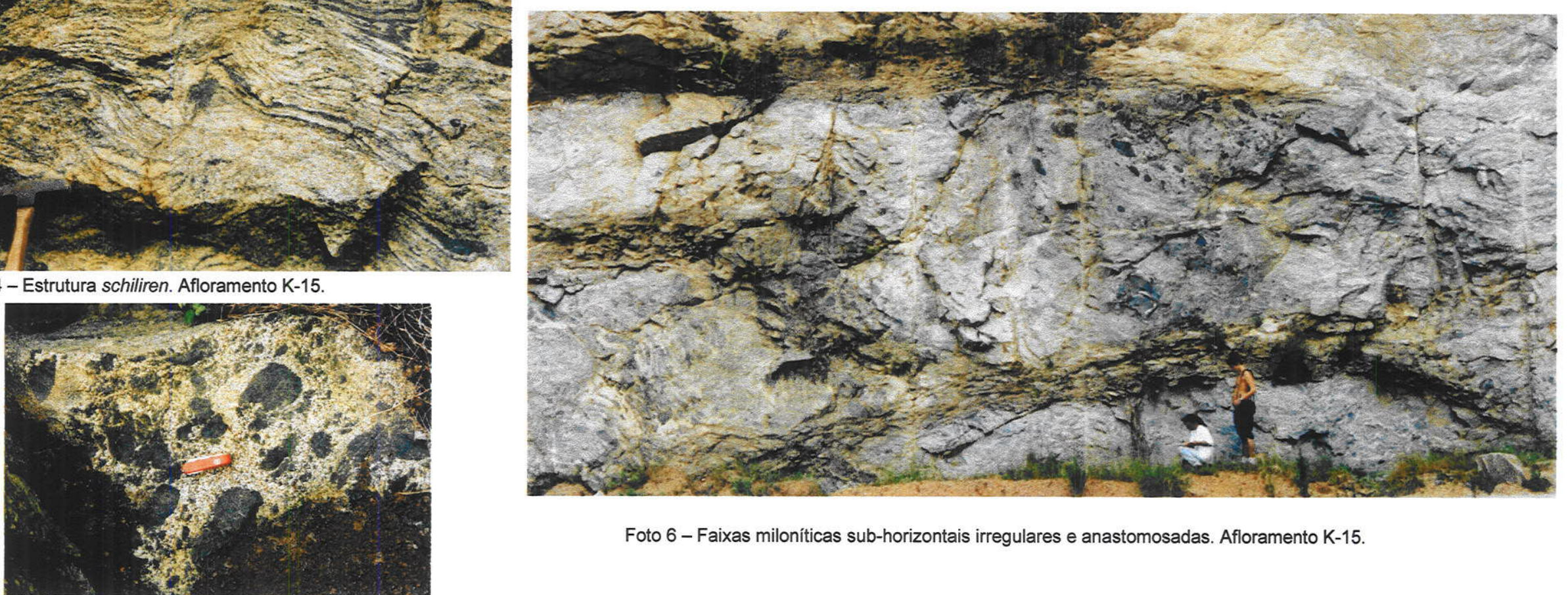

Foto 6 - Faixas miloníticas sub-horizontais irregulares e anastomosadas. Afloramento K-15. 


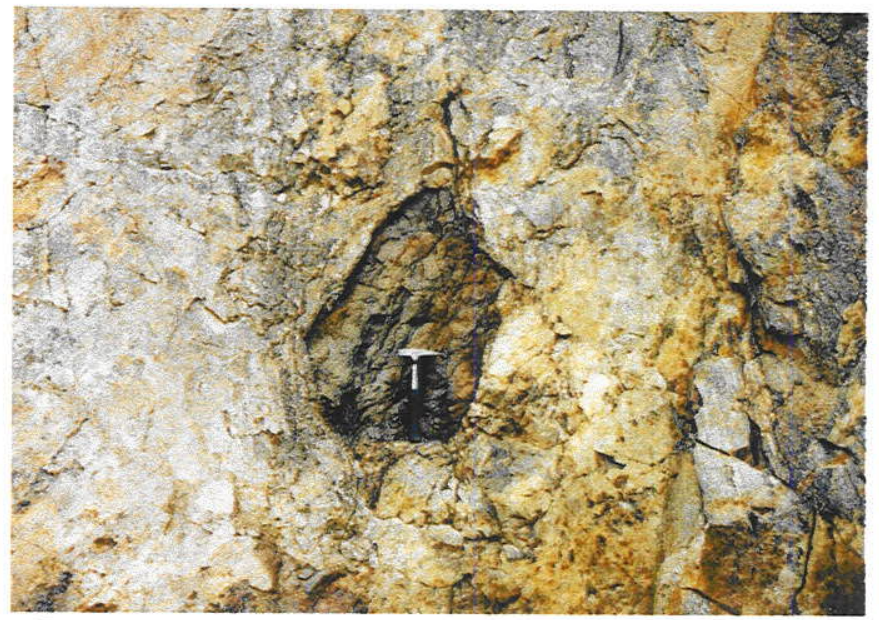

Foto 1 - Enclave máfico ovalado em material granítico deformado. Afloramento K-88. Região próxima a Miracatu - ZC

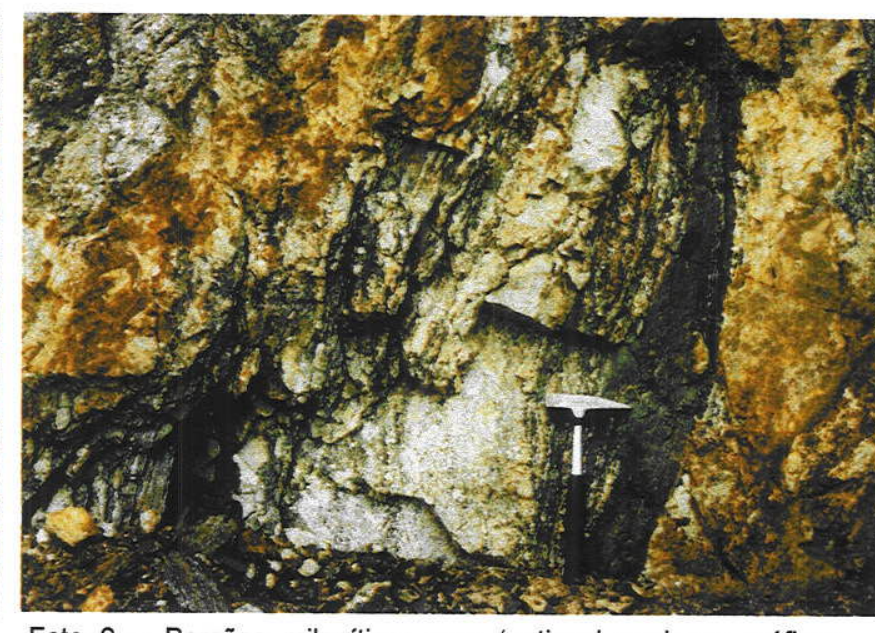

Foto 2 - Porções miloníticas com 'antigos' enclaves máficos totalmente estirados. Afloramento K-88.

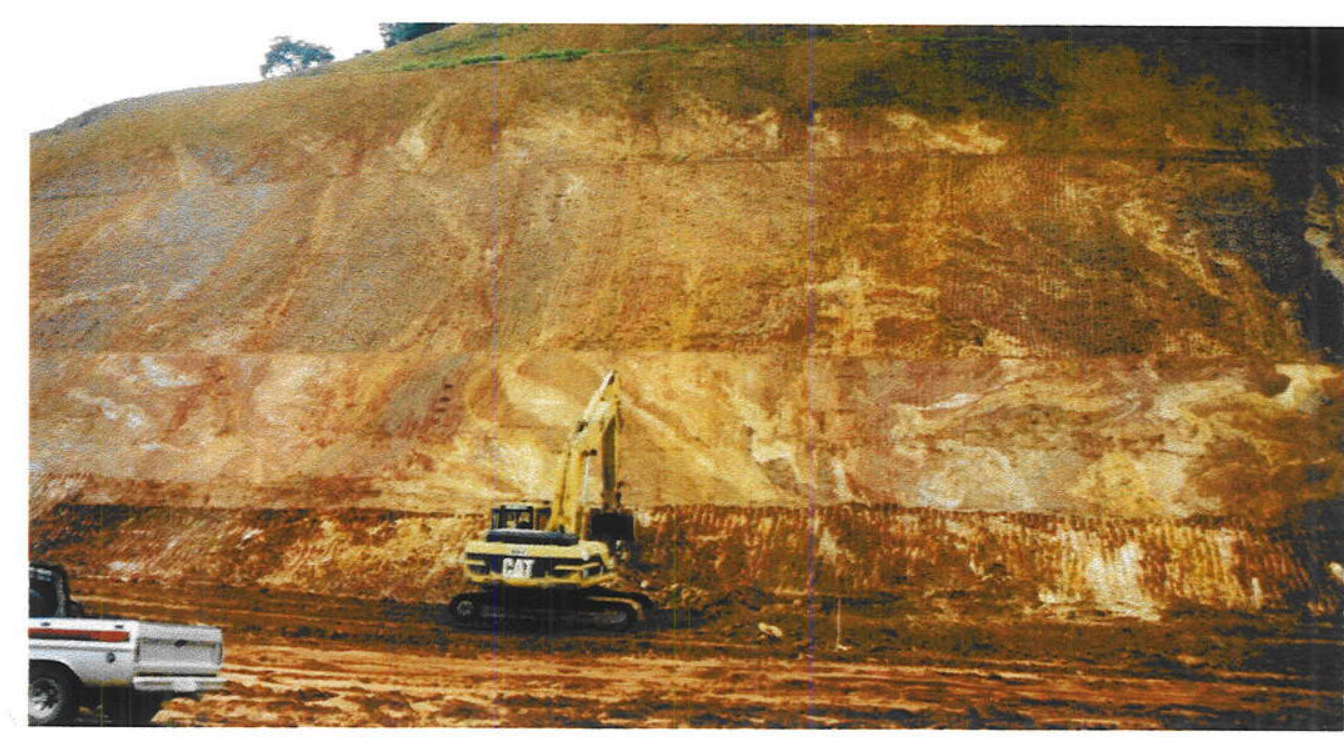

Foto 4 - Corte de estrada (BR-116) aproximadamente $10 \mathrm{~km}$ a sul de Juquiá. Rochas migmatíticas com estruturas diversas, extremamente alteradas.

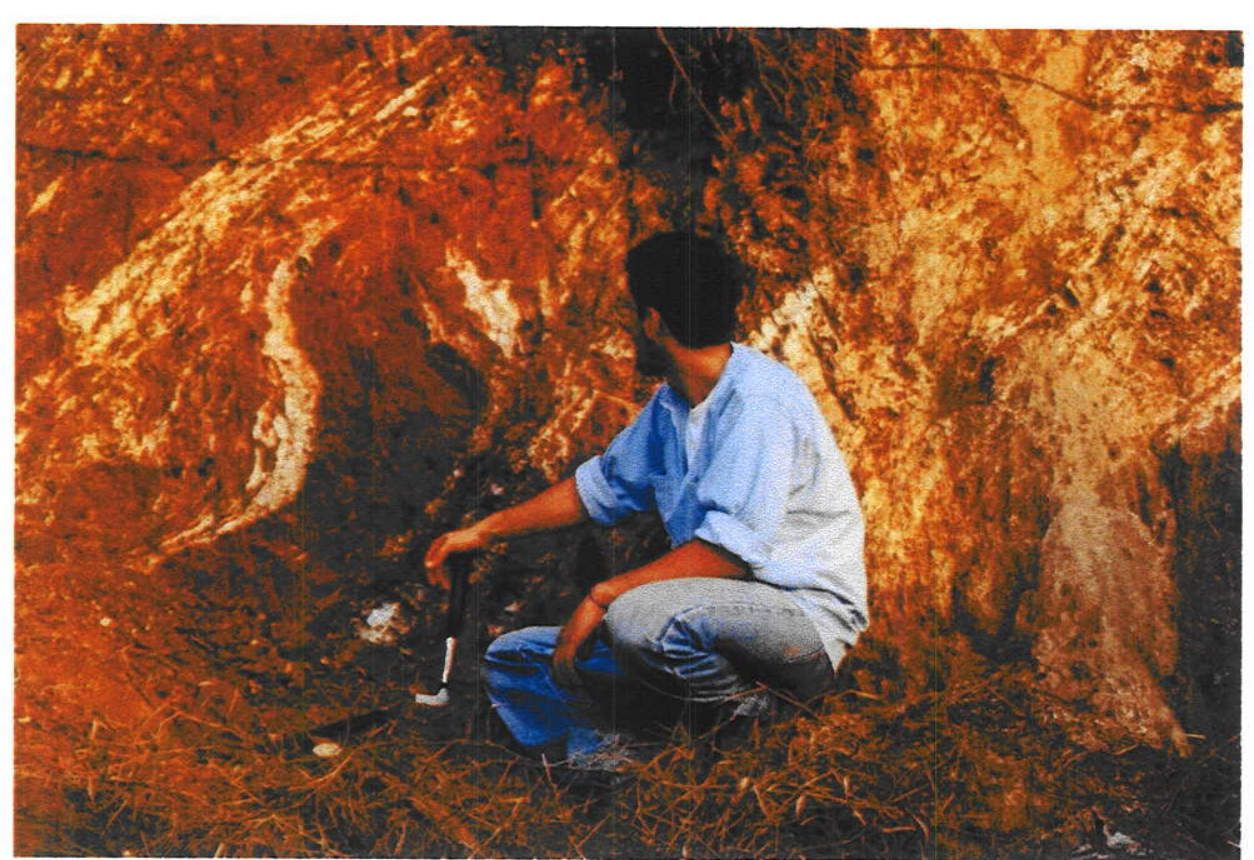

Foto 5 - Rochas migmatíticas extremamente alteradas da região do Ribeirão dos Morais. Os enclaves máficos apresentam formas sigmoidais.
Foto 3 - Material máfico rico em biotita e material sienogranítico desenvolvendo estruturas $\mathrm{S}-\mathrm{C}$, indicando movimentação sinistral. Região do Ribeirão dos Morais. Próximo a ZCl. 


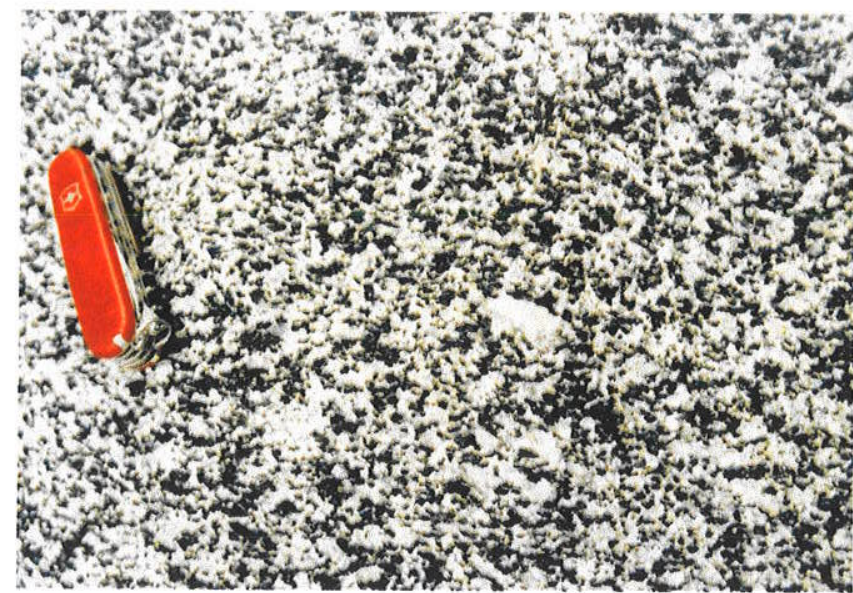

Foto 1 - Anfibólio-biotita granodiorito foliado. Amostra K-16. Região de Oliveira Barros.

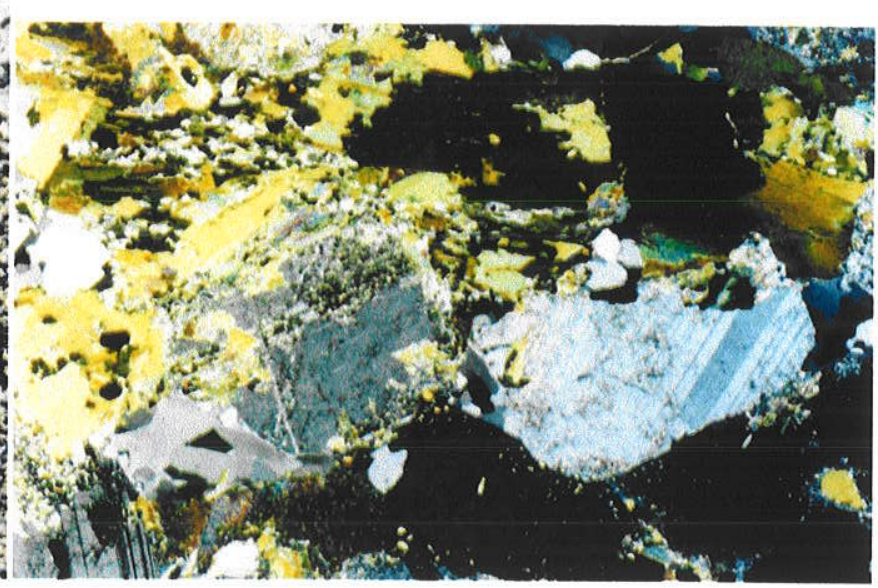

Foto 2- Fotomicrografia (nicóis $X$, aumento 25x). Anfibóliobiotita granodiorito, apresentando textura hipidiomórfica. Amostra K-16 (corte XZ)

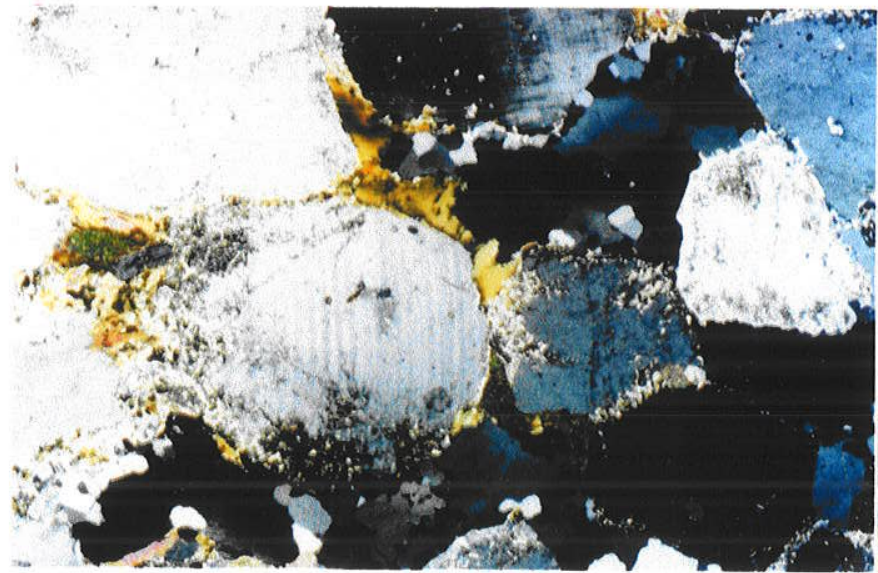

Foto 3 - Fotomicrografia (nicóis $\mathrm{X}$, aumento 25x). Biotitamonzogranito. Textura hipidiomórfica, com cristais de biotita intersticiais. Amostra K-17(corte XZ)

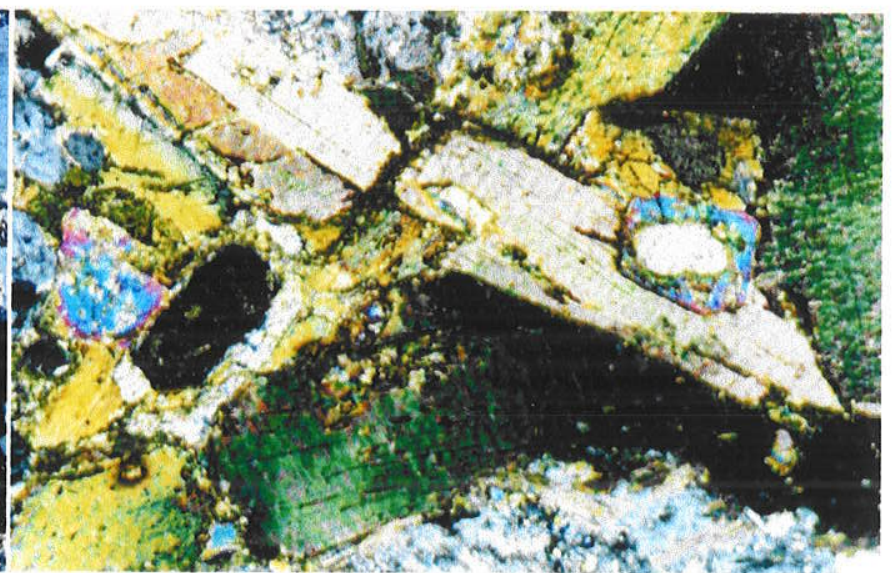

Foto 4 - Fotomicrografia (nicóis $\mathrm{X}$, aumento 100x). Anfibóliobiotita granodiorito com cristais de biotita euedrais e alanitas manteadas por epídoto. Amostra K-16 (corte YZ).

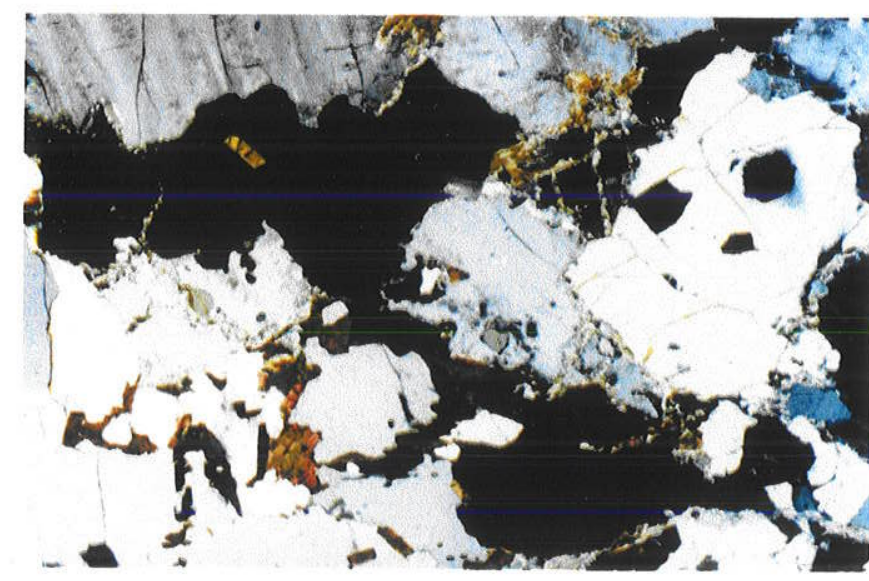

Foto 5 - Fotomicrografia (nicóis $X$, aumento 25x). Textura xenomórfica de biotita sienogranito. Amostra K-87. Região do Ribeirão dos Morais.

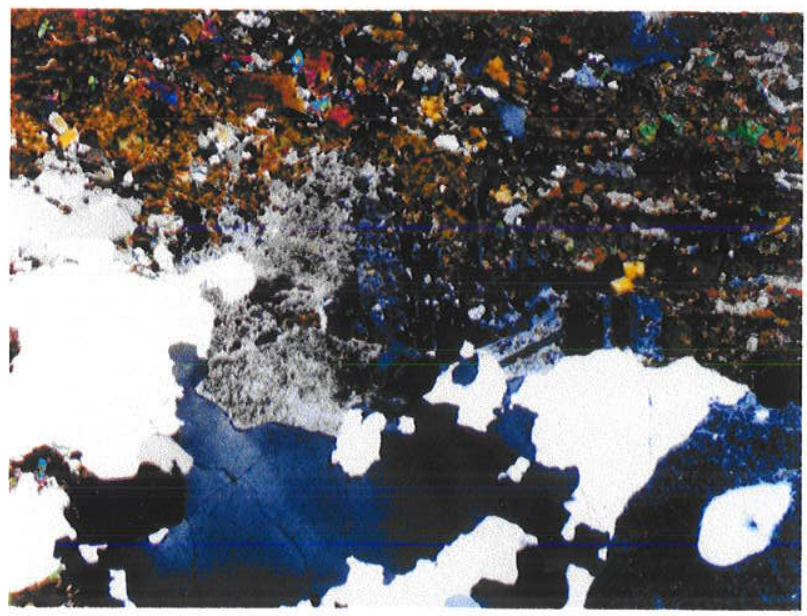

Foto 6 - Fotomicrografia (nicóis X, aumento 25x). Interface entre material diorítico (parte superior da foto) e material granodiorítico, com forte corrosão dos cristais de plagioclásio. Amostra K-16C. 


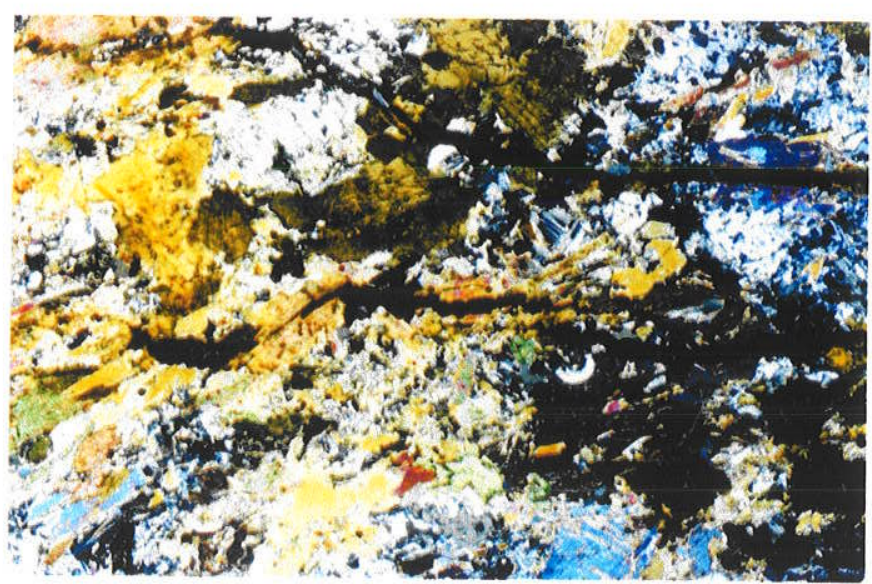

Foto 1 - Fotomicrografia (nicóis $X$, aumento 25x). Enclave diorítico com foliação definida pela orientação de cristais de anfibólio e biotita. Amostra K-85E.

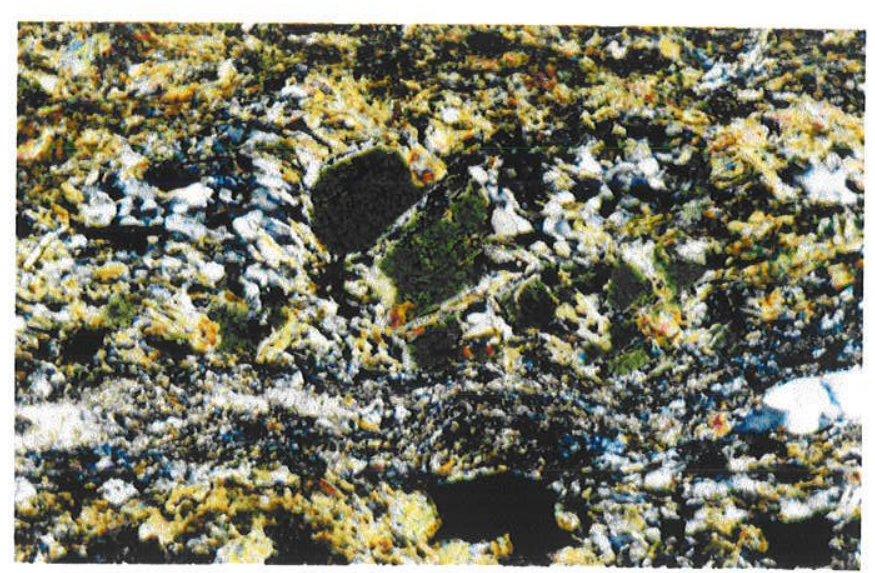

Foto 2 - Fotomicrografia (nicóis X, aumento 100x). Rocha diorítica deformada apresentando cristais de hornblenda com comportamento rúptil. Amostra K-16b (corte XZ).

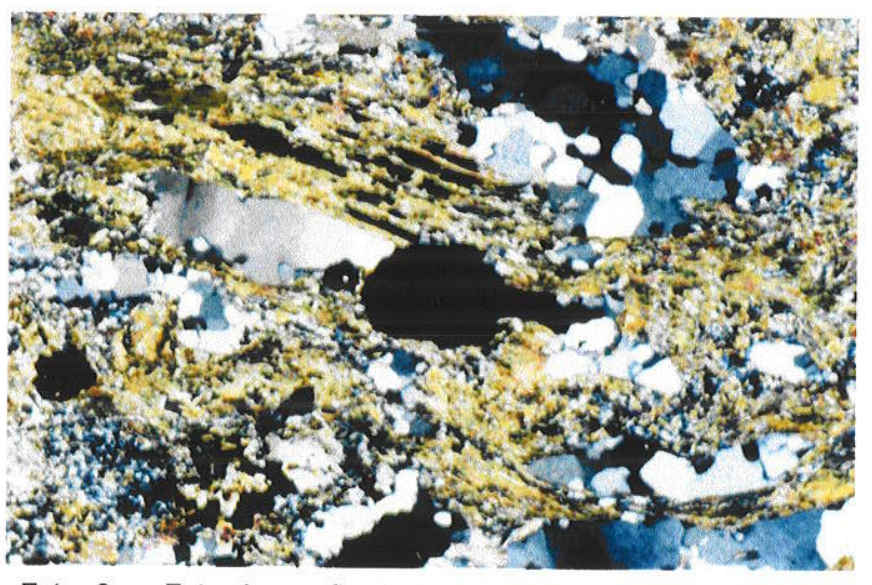

Foto 3 - Fotomicrografia (nicóis $X$, aumento 25x). Rocha diorítica deformada apresentando cristais de quartzo normalmente em agregados ou formando ribbons. Amostra K-
$16 \mathrm{~b}$ (corte XZ).

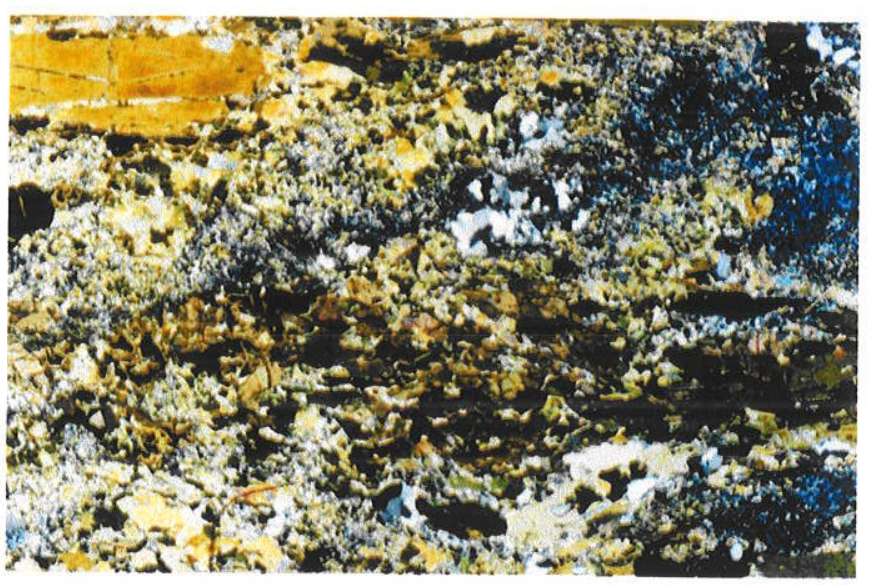

Foto 4 - Fotomicrografia (nicóis $X$, aumento 25x). Rocha diorítica deformada com faixas ricas em titanitas manteando opacos. Amostra K-16c (corte XZ).

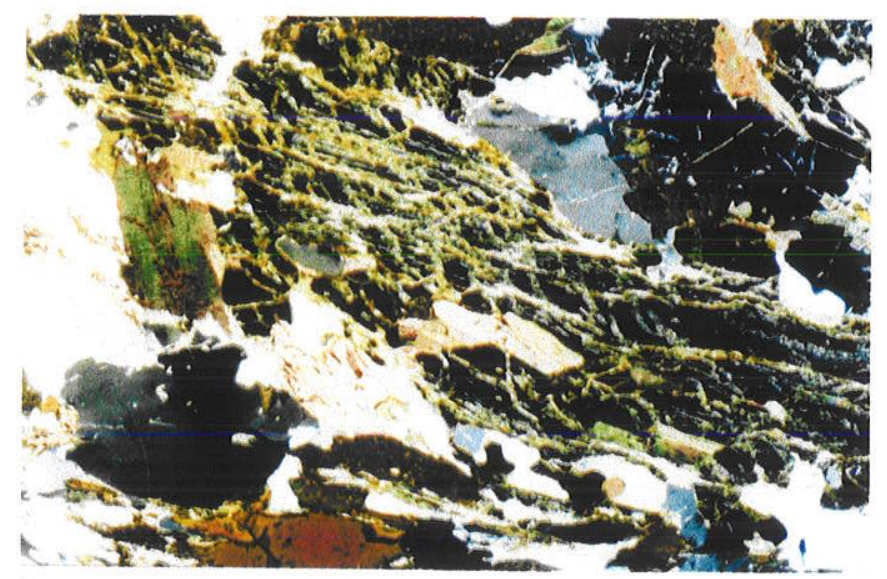

Foto 5 - Fotomicrografia (nicóis $X$, aumento 25x). Faixa de porção mesossomática rica em cristais de granada, estirados, com fraturas preenchidas por sericita, com biotita e quartzo. Amostra K-87A. 


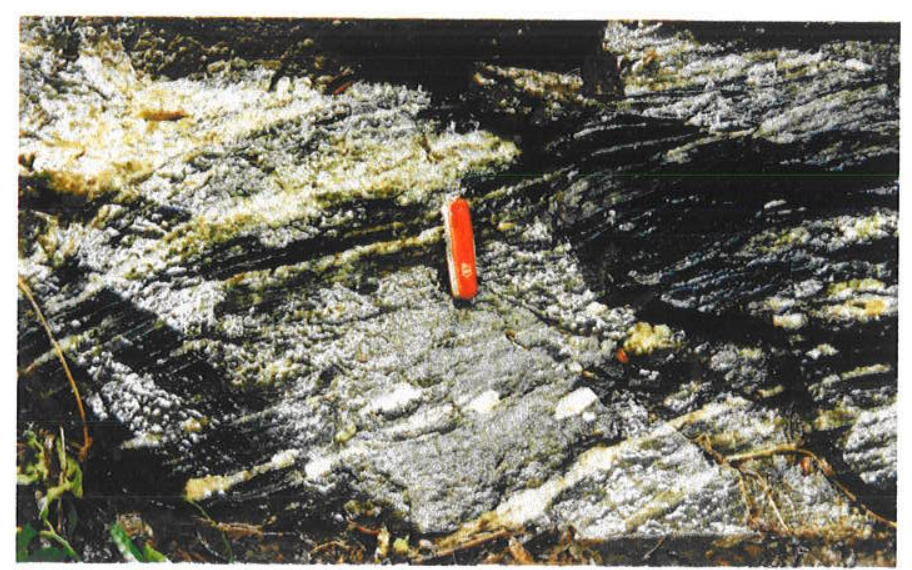

Foto 1 - Bandamento irregular de material quartzo-feldspático com material máfico predominante. A rocha apresenta-se protomilonítica. Afloramento K-48. Serra do Taquaruçu.

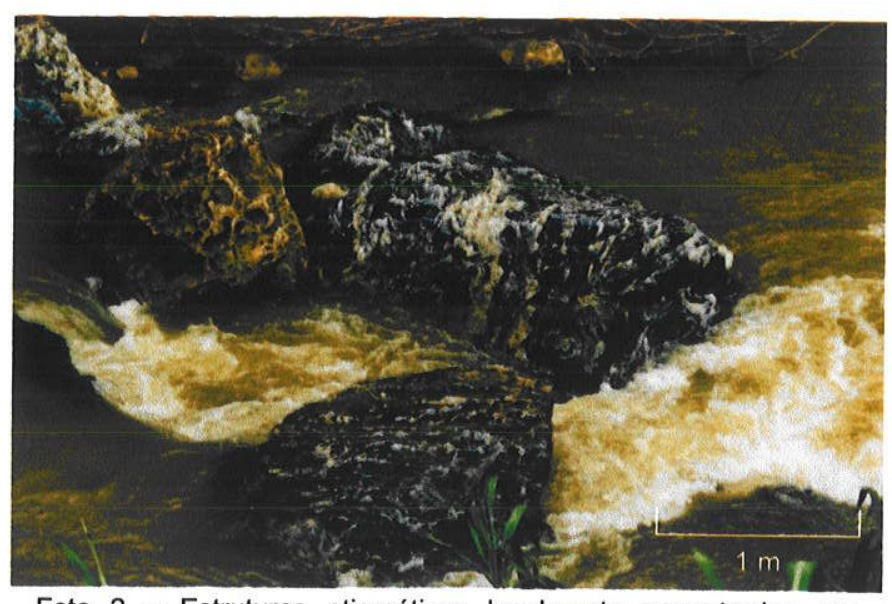

Foto 2 - Estruturas ptigmáticas localmente encontradas em rochas gnáissicas com predomínio de material máfico. Afloramento K-48. Serra do Taquaruçu.

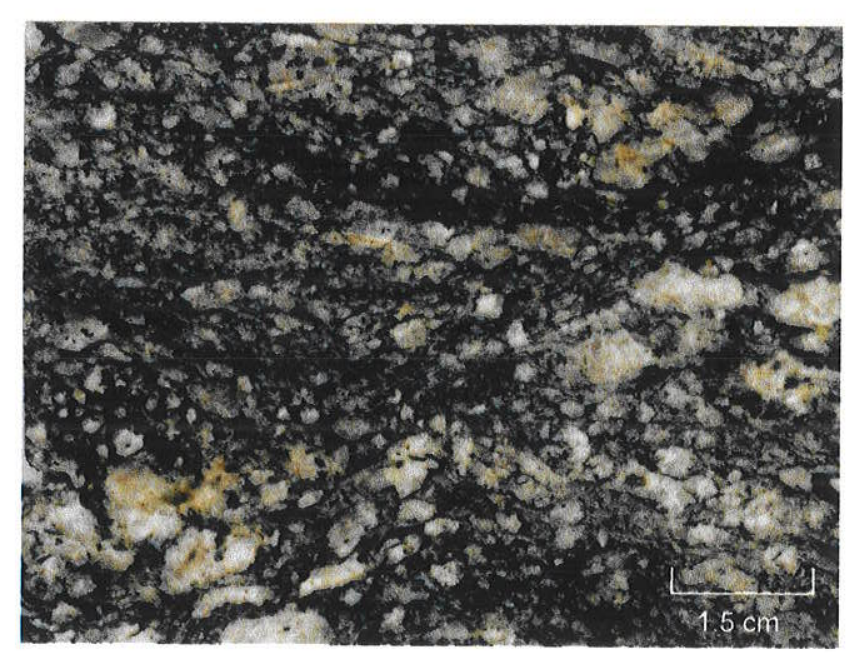

Foto 3 - Textura protomilonítica em biotita - monzogranito mesocrático. Amostra K-44 (corte XZ). Sul da Serra de Timirim.

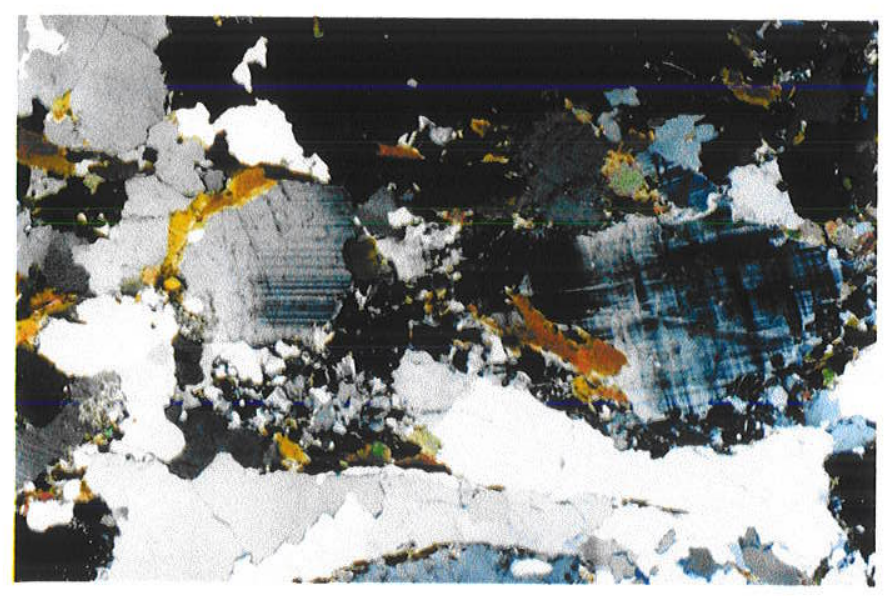

Foto 5 - Fotomicrografia (nicóis $X$, aumento 25x). Biotitamonzogranito protomilonítico, com porfiroclastos de microclínio apresentando pequena recristalização nas bordas e feições mirmequíticas. Amostra K-47 (corte XZ).

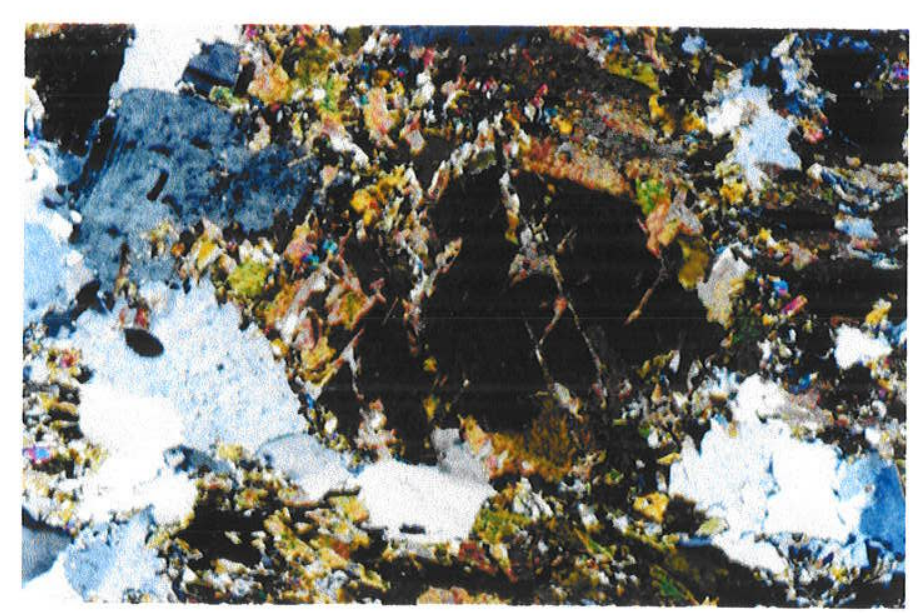

Foto 4 - Fotomicrografia (nicóis X, aumento 50x). Anfibólio-biotita granodiorito com cristais de hornblenda alterados ao longo das clivagens por biotita e epídoto. Amostra K-45 (corte XZ).

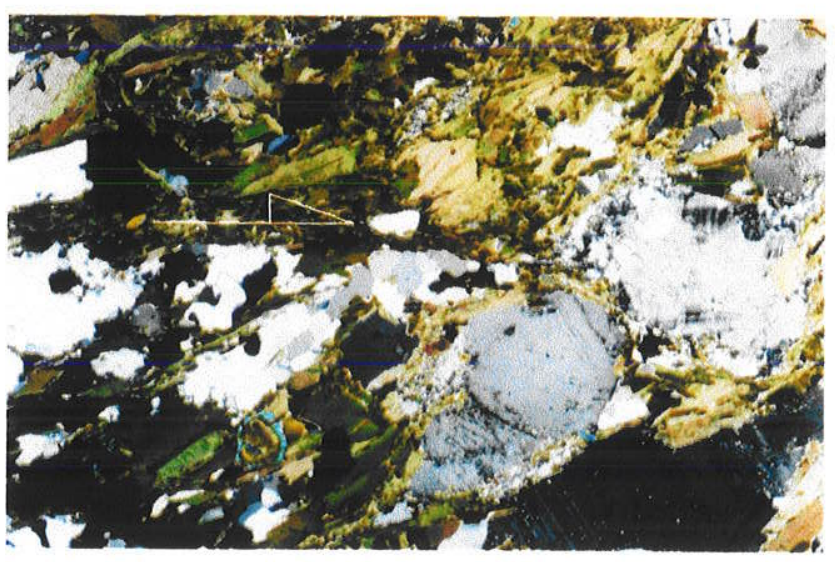

Foto 6 - Fotomicrografia (nicóis X, aumento 25x). Biotitamonzogranito mesocrático com textura protomilonítica. Estruturas S-C Indicando movimento dextral. Amostra K-44 (corte $\mathrm{XZ}$ ). 


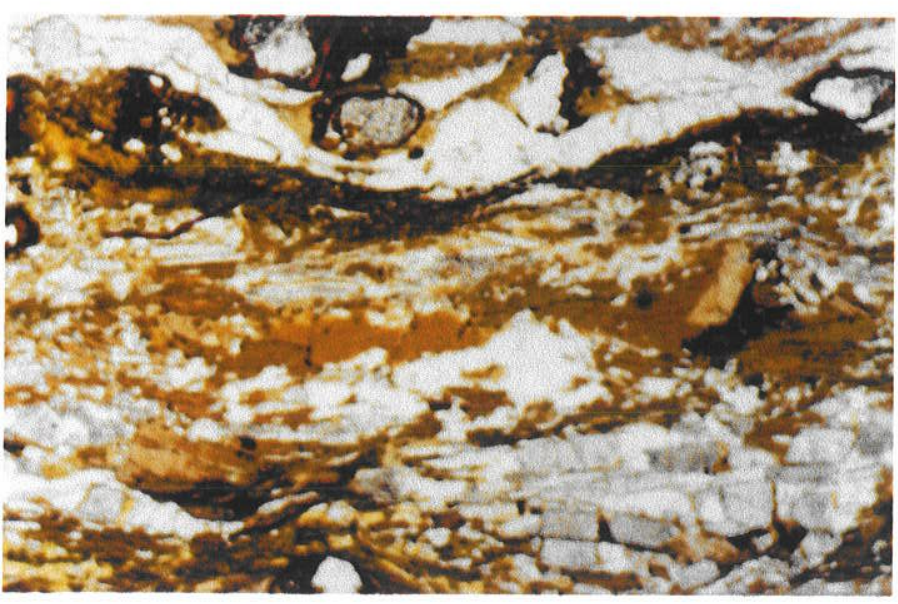

Foto 1 - Fotomicrografia (nicóis //, aumento 12.5x). Sillimanitagranada biotita xisto. Foliação caracterizada pela orientação dos ribbons de quartzo, cristais de biotita e sillimanita. Amostra K-56 (corte XZ). Reaião de Ana Dias.

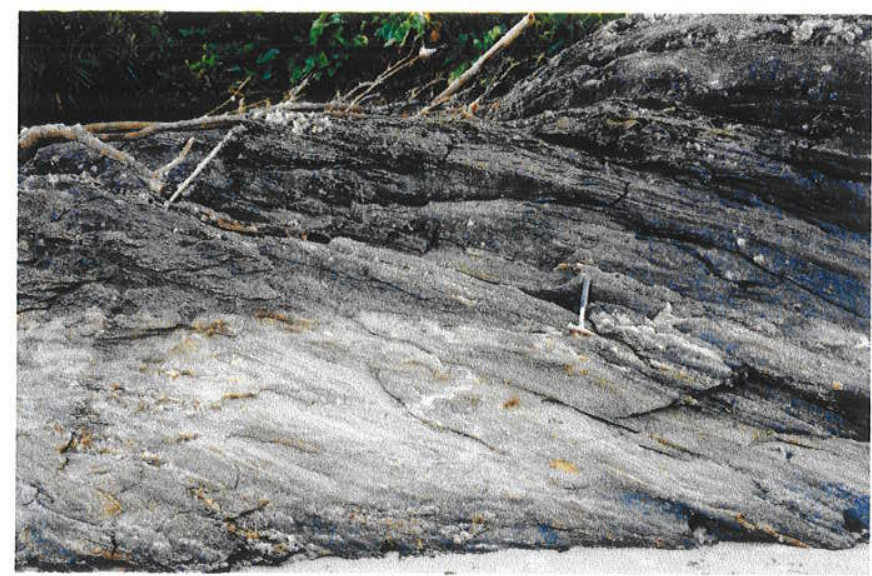

Foto 3 - Paragnaisse Juréia apresentando foliação milonítica N45W/40 NE. Afloramento K-96.

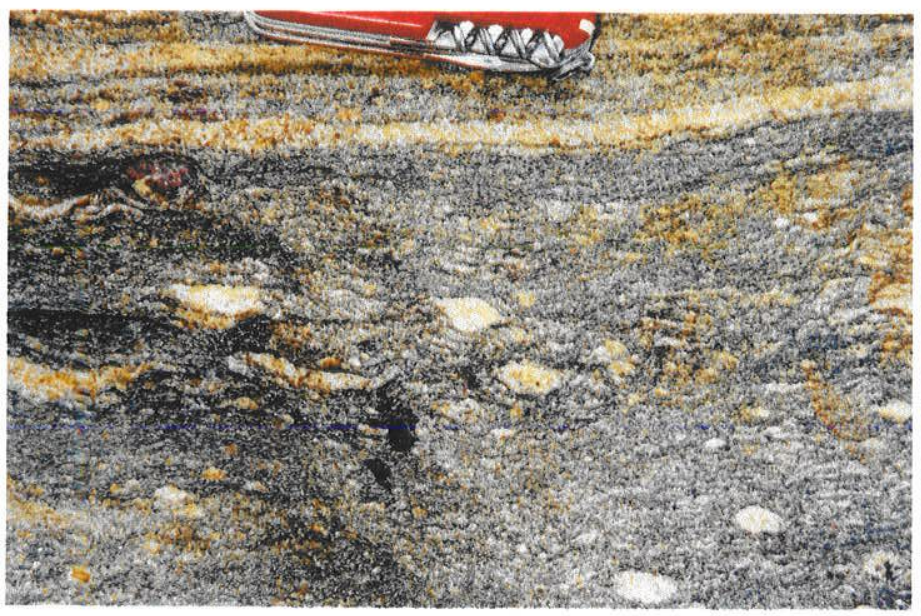

Foto 5 - Porfiroblastos / porfiroclastos de granada centimétricos, nornalmente arredondados. Paragnaisse Juréia.

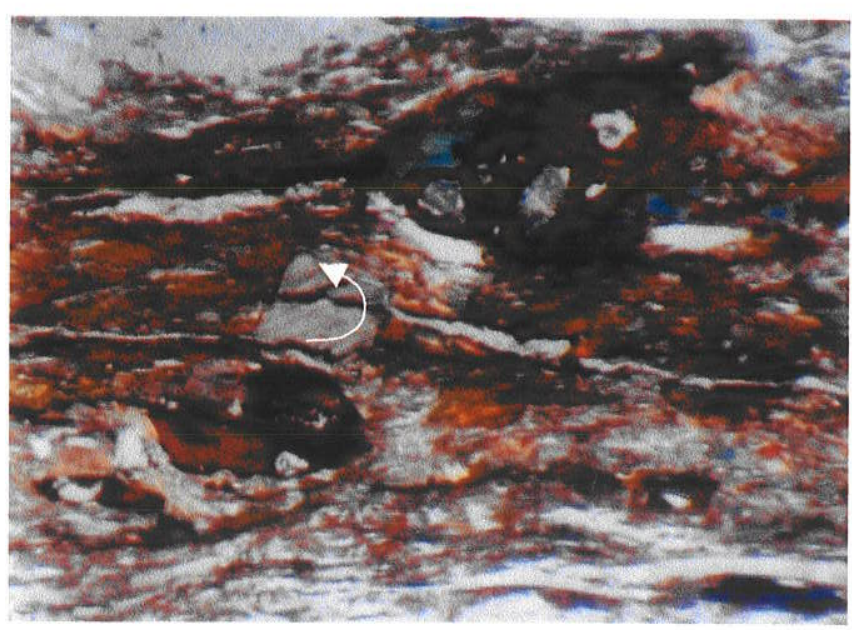

Foto 2 - Fotomicrografia (nicóis //, aumento 35.5x). Sillimanitagranada biotita xisto. Pseudomorfos de granada e detalhe de porfiroclasto de sillimanita rotacionado com sombra de pressão constituída por quartzo, sugerindo movimentação sinistral. Amostra K-56 (corte XZ).

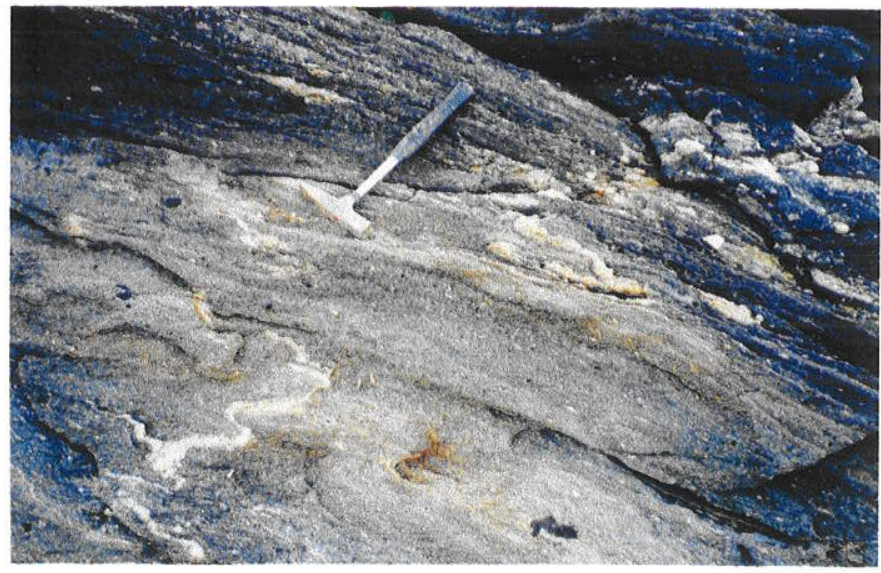

Foto 4 - Remobilizados quartzo-feldspáticos ocorrem paralelos ou cortam o bandamento principal. Paragnaisse Juréia.

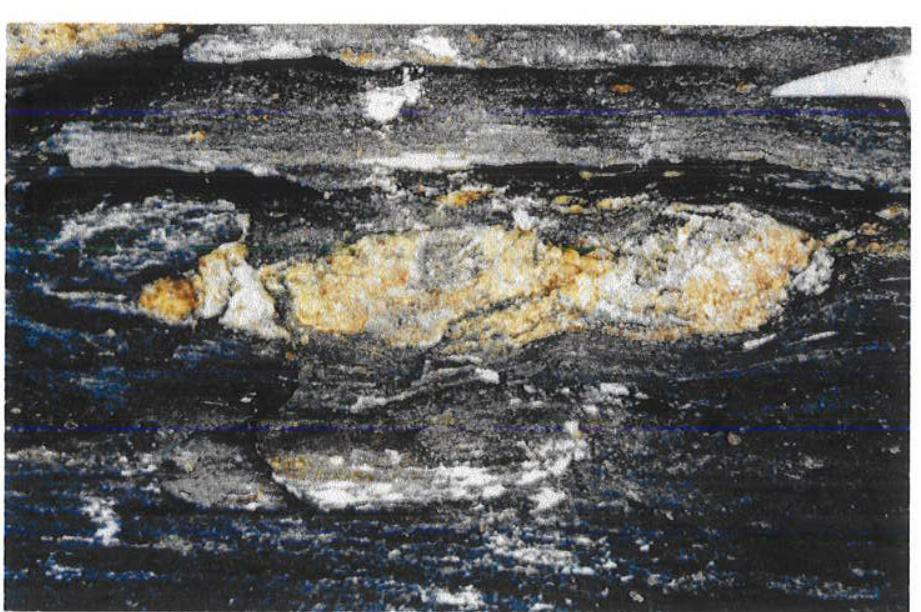

Foto 6 - Remobilizados quartzo-feldspáticos com formas achatadas e estirados. Corte XZ. Paragnaisse Juréia. 


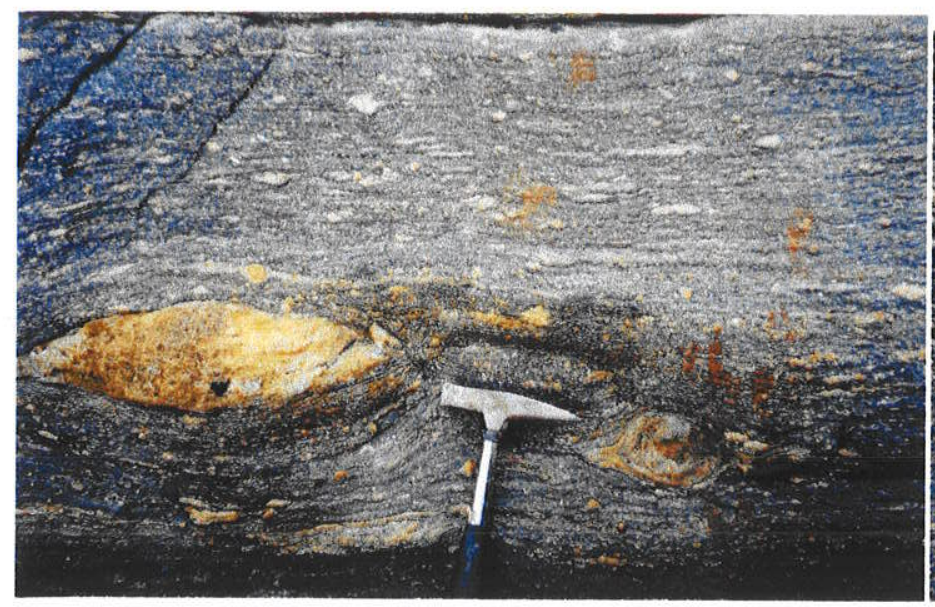

Foto 1 - Corte $X Z$ com porfiroclastos maiores simétricos, e estruturas S-C e porfiroclastos sigmoidais, sugerindo movimentação dextral. Afloramento K-96. Paragnaisse Juréia.

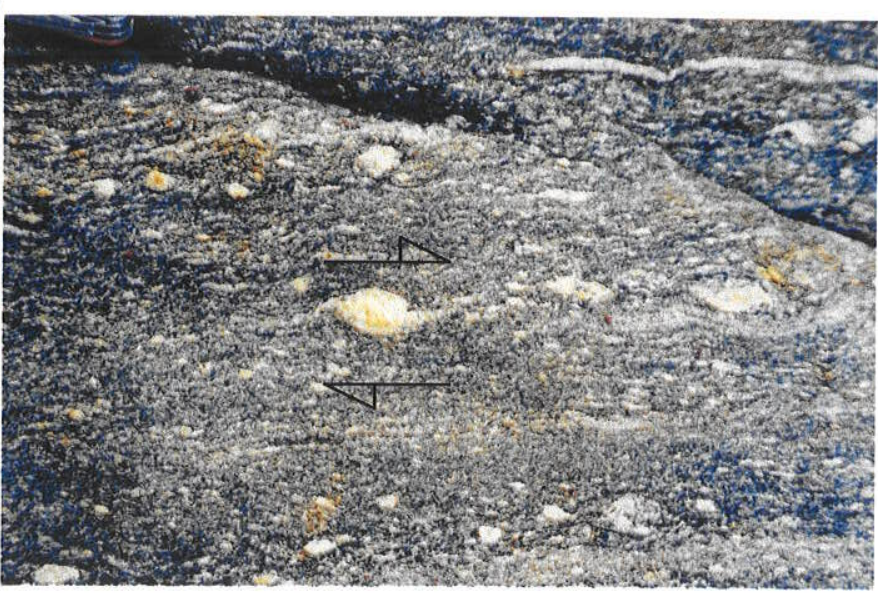

Foto 2 - Corte $\mathrm{YZ}$ com porfiroclasto de plagioclásio rotacionado tipo $\delta$, indicando movimento dextral. Afloramento K-96. Paragnaisse Juréia.

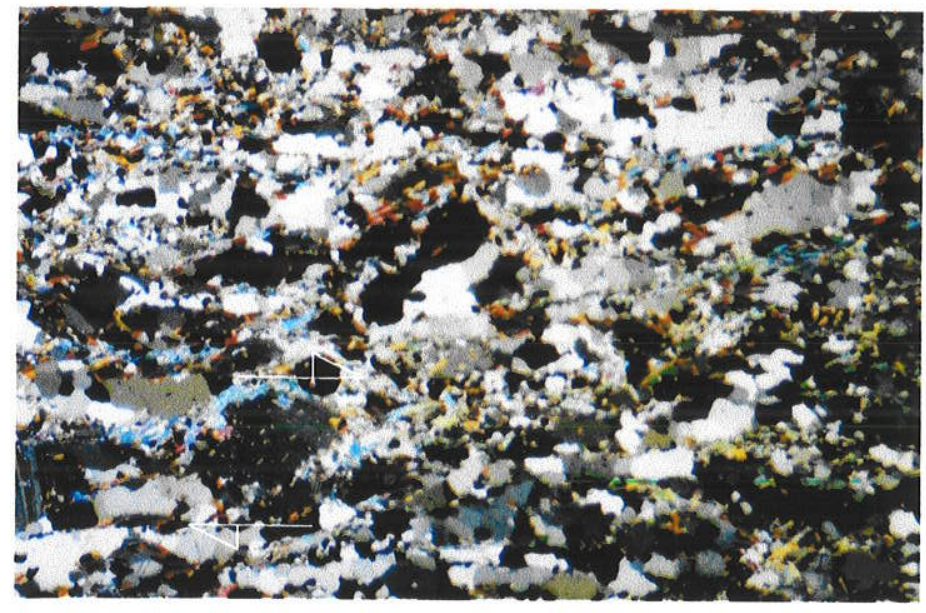

Foto 3 - Fotomicrografia (nicóis X, aumento 10x). Granada-biotitagnaisse com foliação caracterizada pela tendência de intercalação dos minerais máficos com bandas quartzo-feldspáticas estiradas Sugestão de movimentação dextral por porfiroclasto assimétrico de plagioclásio. Amostra K-97 (corte XZ).

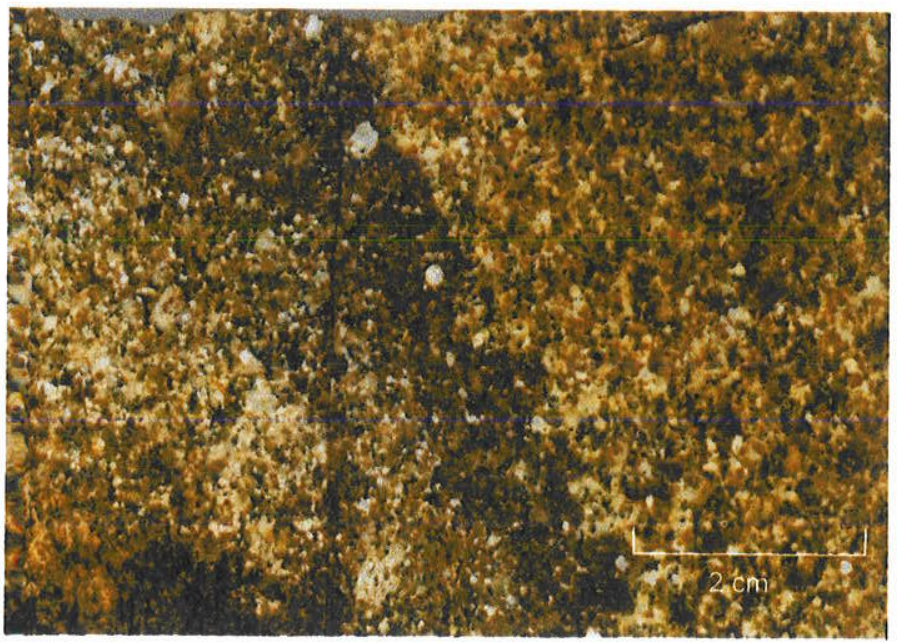

Foto 5 - Granito Votupoca. Biotita monzogranito. Afloramento K-92.

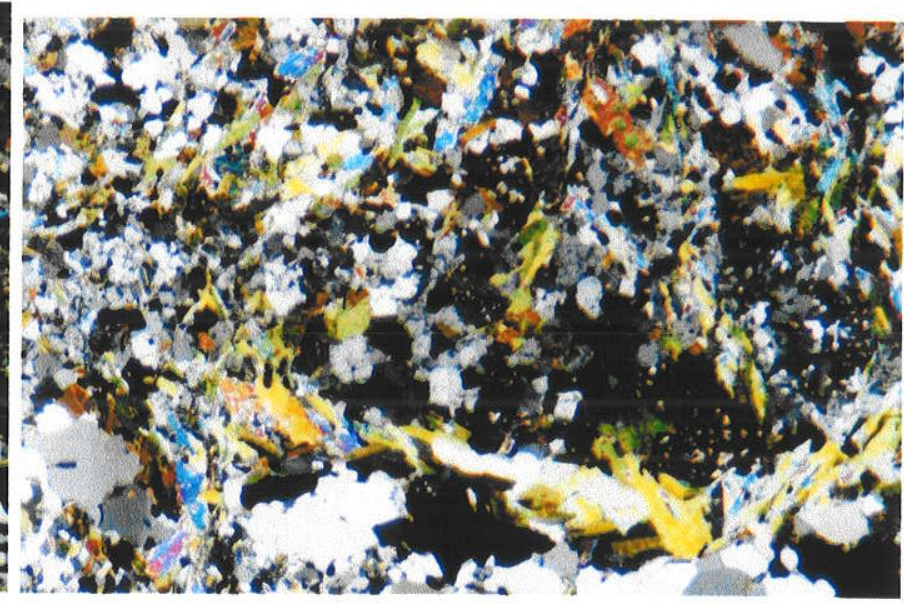

Foto 4 - Fotomicrografia (nicóis $X$, aumento 25x). Granadabiotita-gnaisse com recristalização de porfiroclasto de plagioclásio. Amostra K-99 (corte YZ).

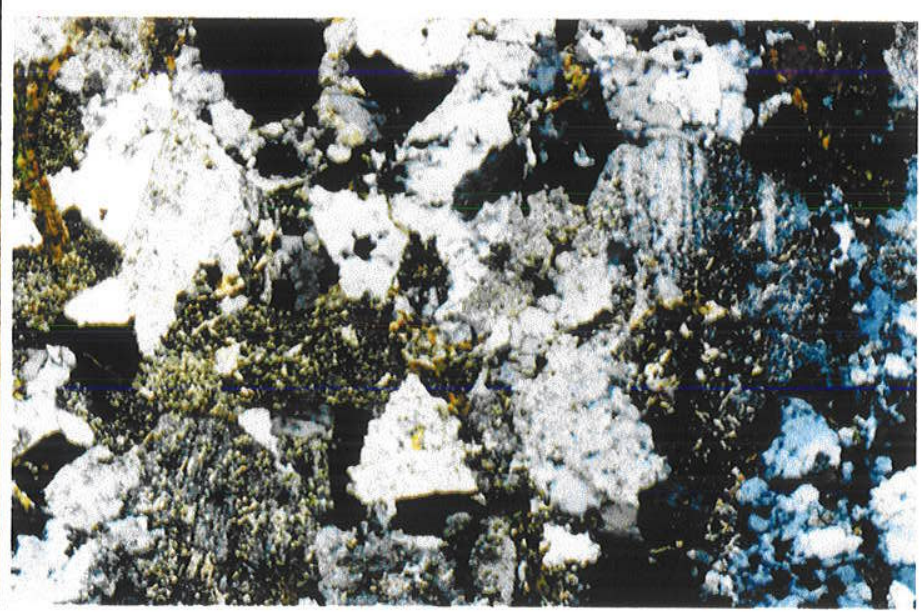

Foto 6 - Fotomicrografia (nicóis $X$, aumento 25x). Textura xenomórfica de biotita-monzogranito, com cristais de plagioclásio extremamente saussuritizados. Amostra K-92. 
Para utilização do Método de Fry (Fry, 1979, 1999), foram selecionadas amostras foliadas e homogêneas, com quantidade razoável de porfiroclastos ou fenocristais de feldspatos, suficientes para utilização do método.

Assim sendo, foram realizadas análises em seções delgadas de cortes $X Z$ e $\mathrm{YZ}$ de três amostras do Bloco Registro. As análises referem-se ao anfibólio biotitagranodiorito foliado (K-16 A) e aos biotita-monzogranitos (K-17 e K-46).

Os resultados obtidos pelo método de Fry (Figura 7.2.4) para as amostras K16 A e K-17 mostram um vazio esférico, que sugere a inexistência de deformação. No entanto, em corte $X Z$ da amostra K-16 A nota-se a formação de um vazio eliptico externo à esfera, podendo estar associado a foliação magmática presente na rocha.

A amostra K-46 mostra-se pouco deformada, e os resultados obtidos pelo Método de Fry mostram o início da formação de vazios elípticos. O corte YZ apresentou vazios elípticos diversos, sendo imprudente a determinação da orientação do eixo $Y$ do elipsóide de deformação.

A orientação dos eixos $X$ e $Z$ do elipsóide de deformação das amostras K-16 e K-46 estão listados na Tabela 7.2.1, juntamente com as orientações da foliação principal da rocha e lineação mineral.

\begin{tabular}{|c|c|c|c|c|c|}
\hline \multirow[b]{2}{*}{ AMOSTRA } & \multirow[b]{2}{*}{ ROCHA } & \multirow[b]{2}{*}{$\mathbf{s}$} & \multirow[b]{2}{*}{ L } & \multicolumn{2}{|c|}{ EIXOS DO ELIPSÓIDE DE DEFORMAÇAO } \\
\hline & & & & EIxoX & EIxoZ \\
\hline K-16 & Granito foliado & N50E/40NW & $\mathrm{N} 75 \mathrm{~W} / 40$ & S52W/44 & $\mathrm{S} 38 \mathrm{E} / 48$ \\
\hline $\mathrm{K}-17$ & Granito foliado & N8OW/71NE & S85E/6 & & 8 \\
\hline $\mathrm{K}-46$ & Granito deformado & N75E/41SE & $\mathrm{S} 82 \mathrm{E} / 20$ & N68W/4 & N22E/46 \\
\hline
\end{tabular}

Tabela 7.2.1 - Direção da foliação e lineação mineral principal das amostras analisadas e orientação dos eixos do elipsóide obtidos pelo Método de Fry . 
Os resultados obtidos para o granodiorito foliado (K-16) são interpretados como referentes ao fluxo magmático, ou seja, condicionamento do fluxo magmático a uma direção de maior compressão em torno de $S 40 E$, e maior estiramento em torno de S60W.

Os resultados obtidos para o biotita monzogranito (K-46) referem-se a uma deformação incipiente sofrida por esta rocha. Esta observada pela própria análise da amostra através de seções delgadas, bem como pela fraca definição do vazio elíptico formado e sua baixa elipsidade.

Como pode ser observado na Tabela 7.2.1, houve discordância entre a orientação dos eixos $X$ do elipsóide de deformação (direção de máxima extensão) e as lineações minerais medidas no granito foliado $(\mathrm{K}-16)$ e no granito deformado ( $\mathrm{K}$ 46). Entretanto observa-se uma tendência de maior extensão em torno de $E-W$, e maior encurtamento em torno de N-S.

Os resultados obtidos pelo Método de Fry para as rochas graníticas pertencentes ao Bloco Registro foram insuficientes para determinação da forma do elipsóide de deformação, não sendo possivel o estabelecimento dos parâmetros necessários para plotagem em Diagrama de Flinn. 

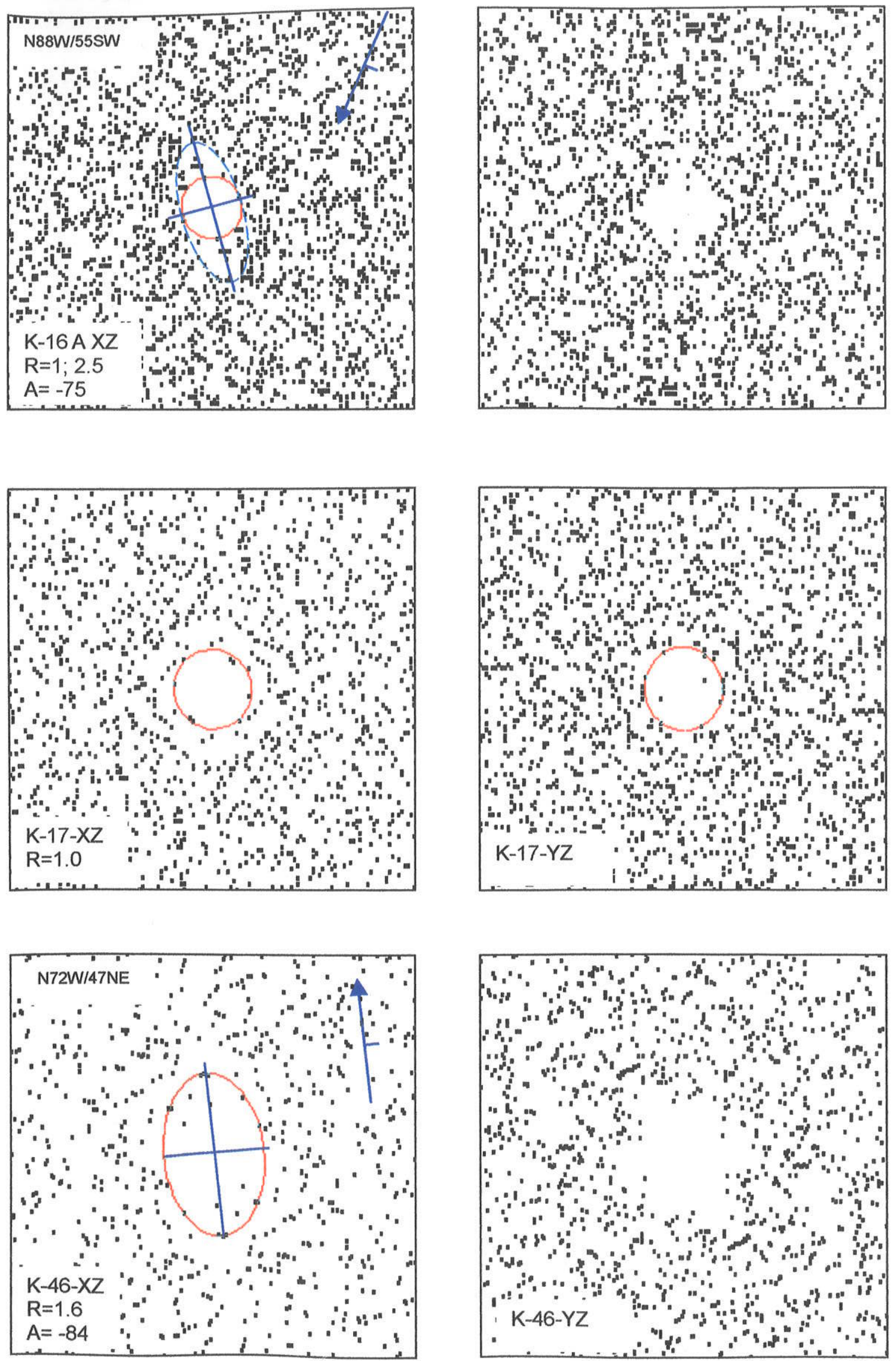

Figura 7.2.4 - Método de Fry aplicado às rochas do Bloco Registro. 


\subsection{Caracterização Geoquímica}

Neste capítulo serão apresentadas características geoquímicas gerais de alguns litotipos que constituem o Bloco Registro. A dificuldade de amostragem das rochas deste bloco deu-se pelo alto grau de alteração dos afloramentos $e$, principalmente, pela característica das rochas que afloram neste bloco, que possivelmente representam mistura de materiais.

A investigação geoquímica de rochas migmatíticas, torna-se complexa, devido a problemática que envolve a geração destas rochas. As diversas feições observadas nos litotipos que compõem este Bloco, indicam a grande possibilidade de tratarem-se de rochas hibridas, ou seja originárias da mistura de materiais diferentes. No entanto, esta mistura não mantém um padrão homogêneo.

Nas porções onde a mistura é menor, em rochas da região de Oliveira Barros, foram amostradas as porções máficas (dioríticas) que apresentam-se como enclaves (amostras $\mathrm{K}-16 \mathrm{~b}$ e $\mathrm{K}-17 \mathrm{~b}$ ), com valores de $\mathrm{SiO}_{2}$ de $45.96 \%$ e $48.22 \%$, respectivamente, e as porções graníticas, amostra K-16A (anfibólio-biotita granodiorito $-65.02 \% \mathrm{SiO}_{2}$ ) e amostra $\mathrm{K}-17 \mathrm{~A}$ (biotita-monzogranito com granada $65.27 \% \mathrm{SiO}_{2}$ ).

Nas porções onde predominam as rochas híbridas, onde possivelmente a mistura dos materiais pode ter sido mais intensa, foi analisada uma amostra de biotita-monzogranito mesocrático que apresenta-se protomilonítico (amostra K-44 $68.03 \% \mathrm{SiO}_{2}$ ). Foi também analisada amostra de biotita gnaisse protomilonítico, afetado pela $\mathrm{ZCl}$ (amostra $\mathrm{K}-11-65.95 \% \mathrm{SiO}_{2}$ ).

Adicionalmente, foram analisadas amostras do Paragnaisse Juréia (K-97), e do Granito Votupoca (amostra K-92 - $71.5 \% \mathrm{SiO}_{2}$ ), representado por biotitamonzogranito.

Para o adequado tratamento geoquímico, seja de elementos maiores, menores ou elementos terras raras (ETR) em rochas ambientadas em áreas complexas que envolvem rochas migmatíticas, faz-se necessário um estudo sistemático das porções félsicas e máficas envolvidas.

A sistemática envolveria dois procedimentos principais:

1) Análise das porções migmatíticas, ou seja, de diversas porções mesossomáticas, leucossomáticas, melanossomáticas e neossomáticas 
(melanossoma + leucossoma), conforme descrito por Johannes et al. (1995).

2) Análise de diversas amostras representativas das rochas graníticas e dioríticas (ambas não contaminadas) e de amostras de rochas possivelmente híbridas, podendo então ser qualificada a variação na composição química dos dois membros opostos (granítico e diorítico), conforme apresentado por Silva et al. (2000).

Tal estudo sistemático colaboraria para investigação dos possíveis processos magmáticos que envolvem a gênese destas rochas.

A sistemática não foi objeto deste trabalho, onde apenas foram amostradas rochas graníticas e seus respectivos enclaves máficos, bem como rochas gnáissicas, que podem representar porções mesossomáticas.

Como pode ser observado em Diagrama de Irvine \& Baragar (1971), as rochas posicionam-se no campo das rochas sub-alcalinas, sendo os enclaves dioríticos pertencentes ao campo de rochas alcalinas (Figura 7.3.1).

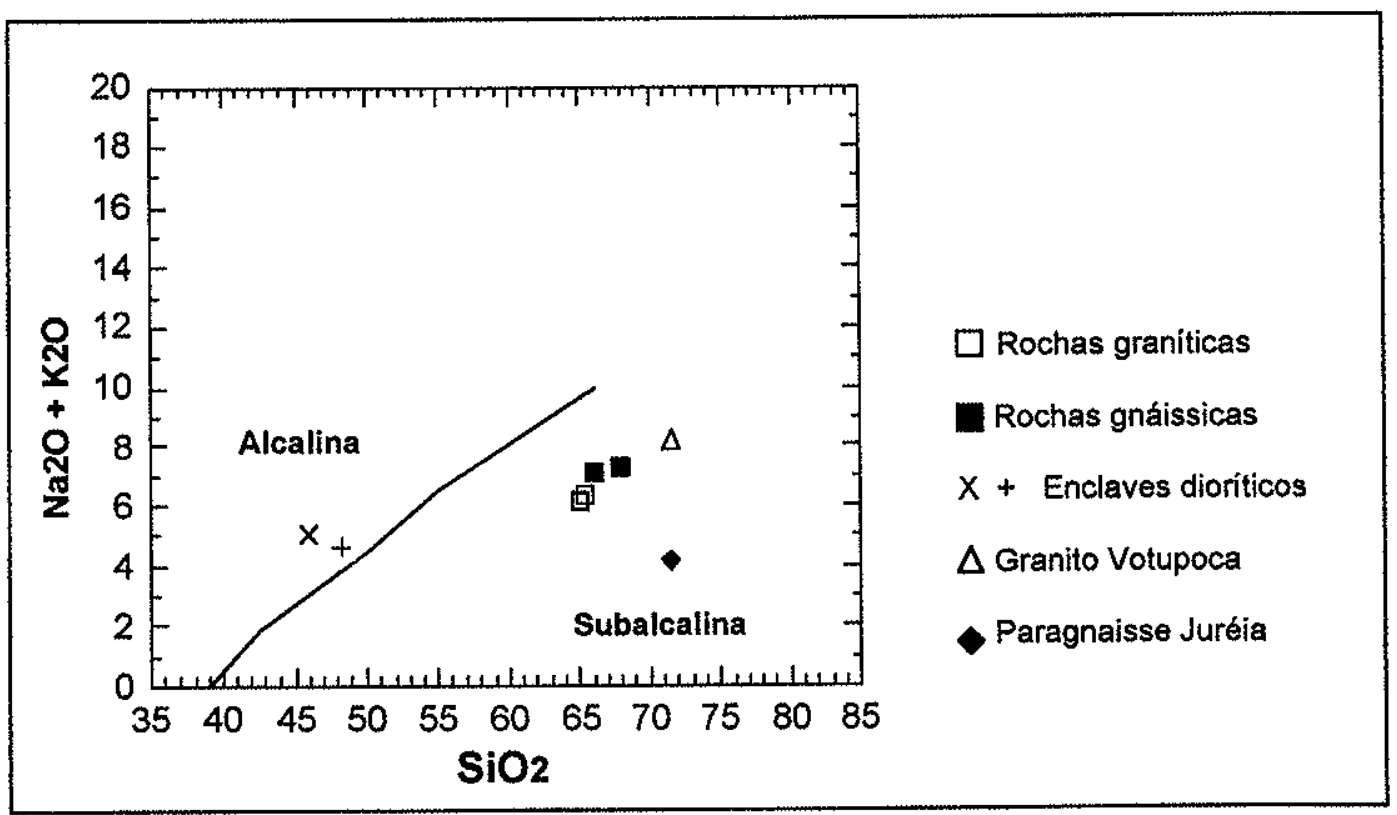

Figura 7.3.1 - Diagrama $\mathrm{SiO}_{2} \times \mathrm{Na}_{2} \mathrm{O}+\mathrm{K}_{2} \mathrm{O}$ Irvine \& Baragar (1971). Bloco Registro. 
Em diagrama $\mathrm{SiO}_{2} \times \mathrm{K}_{2} \mathrm{O}$ (Figura 7.3.2), observa-se uma clara diferenciação entre as rochas graníticas e gnáissicas. As rochas graníticas representadas por anfibólio-granodiorito (K-16) e biotita-monzogranito (K-17) plotam no campo das rochas de médio potássio, enquanto as rochas gnáissicas (K-11 e K-44) plotam no campo das rochas de alto potássio, juntamente com os enclaves dioríticos e o Granito Votupoca.

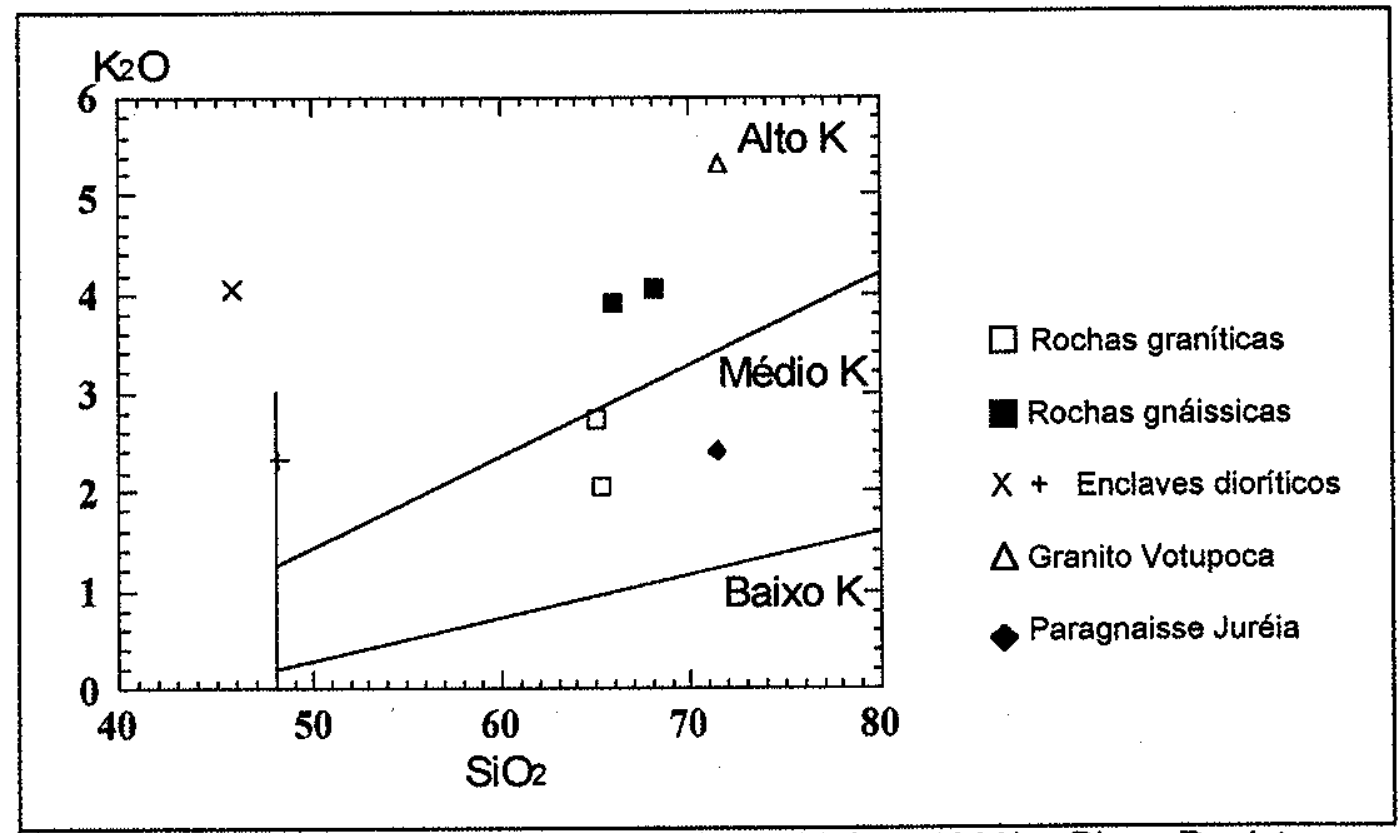

Figura 7.3.2 - Diagrama $\mathrm{SiO}_{2} \times \mathrm{K}_{2} \mathrm{O}$ (Le Maitre, 1989)-Bloco Registro.

As rochas graníticas ( $\mathrm{K}-16$ e $\mathrm{K}-17)$ apresentam caráter metaluminoso, onde 0 biotita-monzogranito (K-17) apresenta índice de saturação em alumínio próximo a 1. Os respectivos enclaves máficos, também posicionam-se no campo das rochas metaluminosas, mas diferenciam-se de suas rochas hospedeiras por seus altos valores de A/NK.

As rochas gnáissicas são metaluminosas a peraluminosas (K-44). Amostra do Granito Votupoca posiciona-se no campo das rochas peraluminosas e os paragnaisses da Juréia mostram caráter extremamente peraluminoso (Figura 7.3.3). 


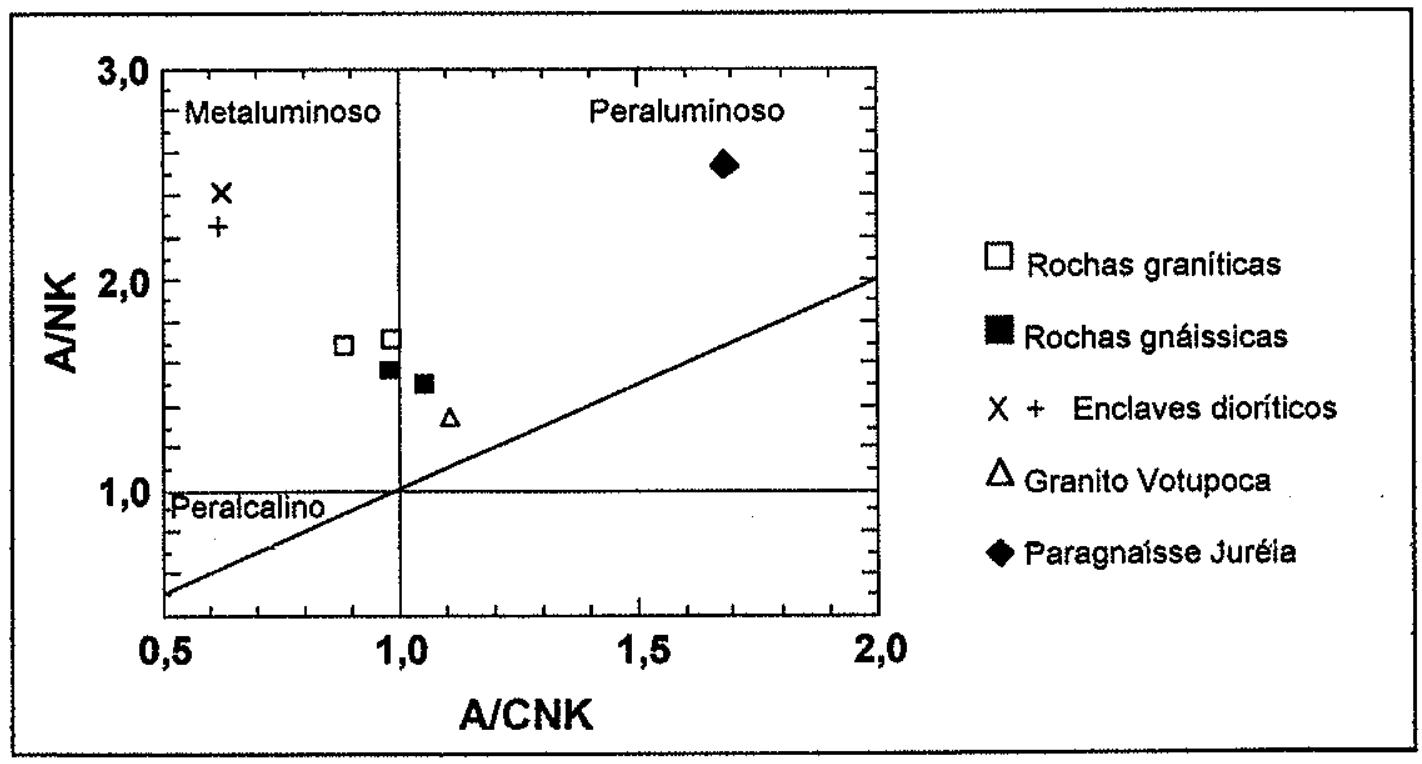

Figura 7.3.3 - Diagrama de razões moleculares A/CNK x A/CNK (Maniar \& Piccoli, 1989). Bloco Registro.

$\mathrm{Em}$ diagramas de $\mathrm{SiO}_{2} \times$ óxidos, para as rochas graníticas e gnáissicas do Bloco Registro, observa-se uma coerência geoquímica constante, onde observa-se a tendência de uma correlação negativa entre os teores de óxidos de $\mathrm{Ti}, \mathrm{Fe}, \mathrm{Mn}, \mathrm{Mg}$, $\mathrm{Mn}, \mathrm{Ca}$ e $\mathrm{P}$ e $\mathrm{SiO}_{2}$ (Figura 7.3.4). Os enclaves dioríticos apresentam sempre os teores mais elevados nestes óxidos, havendo diferenças marcantes principalmente em relação aos teores de óxidos de $\mathrm{Ti}, \mathrm{Mn}$, e $\mathrm{P}$.

As amostras graníticas e dioríticas analisadas apresentaram teores semelhantes de $\mathrm{Al}_{2} \mathrm{O}_{3}$ e $\mathrm{Na}_{2} \mathrm{O}$, com exceção da amostra $\mathrm{K}-17$ (biotita-monzogranito com granada) que mostra-se mais enriquecida nestes óxidos em relação às demais. Nestes óxidos observam-se também diferenças marcantes entre os enclaves dioríticos (Figura 7.3.4). 


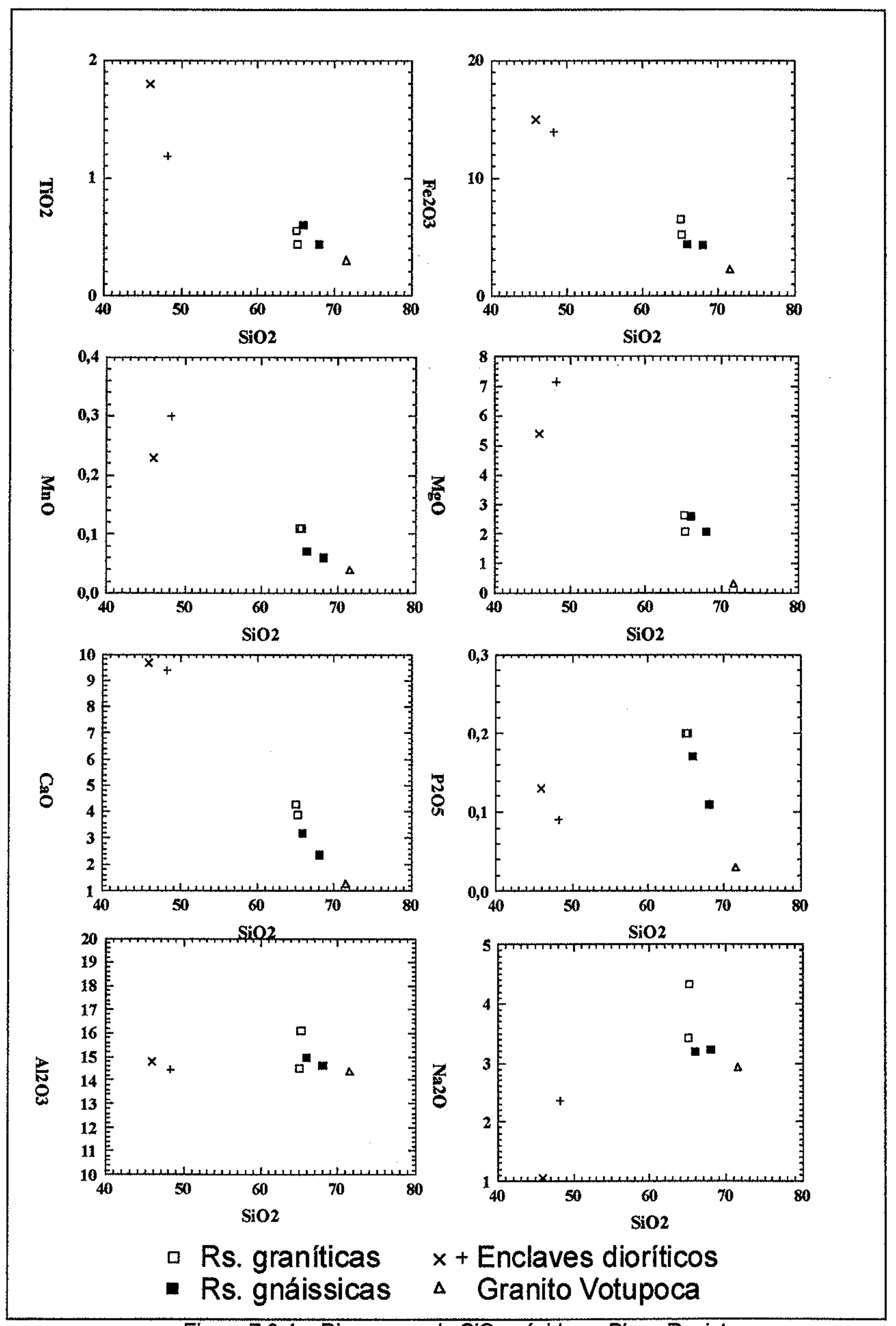

Figura 7.3.4 - Diagramas de $\mathrm{SiO}_{2} \times$ óxidos - Bloco Registro. 
As rochas graníticas e gnáissicas, que apresentam teores semelhantes de $\mathrm{SiO}_{2}(65-68 \%)$ possuem um comportamento heterogêneo na distribuição dos elementos traços (Figura 7.3.5), onde normalmente as rochas gnáissicas mostramse mais enriquecidas em $\mathrm{Ba}, \mathrm{Rb}, \mathrm{Sr}$ e $\mathrm{Zr}$ em relação às rochas graníticas correlatas.

Os enclaves dioríticos apresentam entre si teores semelhantes em Ba (448 e $255 \mathrm{ppm}), \mathrm{Sr}(247$ e $271 \mathrm{ppm})$ e $\mathrm{Zr}$ (91 e $73 \mathrm{ppm}$ ), com teores normalmente mais baixos nestes elementos em relação às rochas graníticas hospedeiras 627 e 217 ppm de $\mathrm{Ba}$ ), (381 e $395 \mathrm{ppm}$ de $\mathrm{Sr}$ ) e (180 e $158 \mathrm{ppm}$ de $\mathrm{Zr}$ ). Comportamento distinto é observado em relação aos teores de $R b$, onde o enclave (K-16b) apresenta teores bem mais elevados (216 ppm) em relação ao granito hospedeiro (K-16, 135 ppm) e em relação ao outro enclave diorítico (K-17b, 113 ppm), Figura 7.3.5.

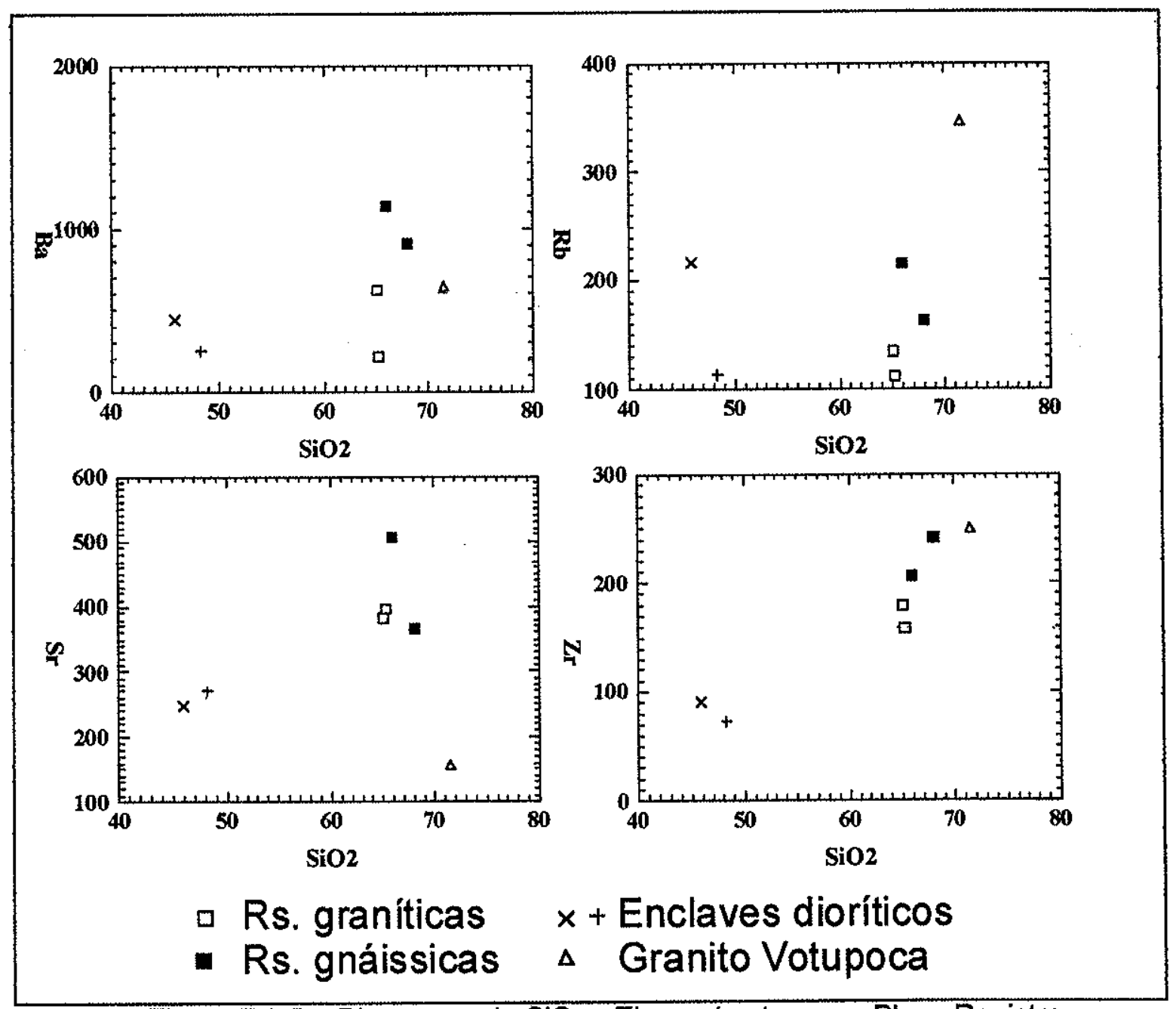

Figura 7.3.5 - Diagramas de $\mathrm{SiO}_{2} \times$ Elementos traços - Bloco Registro. 
Em Diagramas de perfis de ETR, normalizados aos valores do condrito por Nakamura, 1974, as rochas graníticas mostraram padrão distinto na distribuição dos ETR (Figura 7.3.6 a). O anfibólio-biotita granodiorito, apresentou razoável enriquecimento de ETRP (TbN 19; Y Y $\sim 13$ ), e fraca anomalia negativa de Eu, enquanto o biotita-monzogranito mostrou-se empobrecido em todos os ETR em relação ao anterior, sem anomalias de Eu. Ambos apresentam um fracionamento de ETRL em relação aos ETRP próximos de [La(125-60)/Yb(12.5-4) ]N 10 e 15.

Comportamento distinto é observado nos respectivos enclaves máficos (Figura 7.3.6 b), que não apresentam fracionamento de ETRL em relação aos ETRP de $[\mathrm{La}(400) / \mathrm{Yb}(5)] \mathrm{N}=\sim 1.5$, e mostram um padrão muito semelhante entre si.

As rochas gnáissicas mostram um fracionamento de ETRL em relação aos ETRP diferente do grupo anterior, $[\mathrm{La}(200-100) / \mathrm{Yb}(5-2.3)] \mathrm{N}$ em torno de 40 , não apresentando anomalias de Eu, ou apenas suave anomalia positiva (amostra K-44).

O Granito Votupoca mostra um razoável fracionamento de ETRL em relação aos ETRP de $[\mathrm{La}(300) / \mathrm{Yb}(10)] \mathrm{N}=30$, e apresenta anomalia negativa de Eu bem marcada (Figura 7.3.6 a).

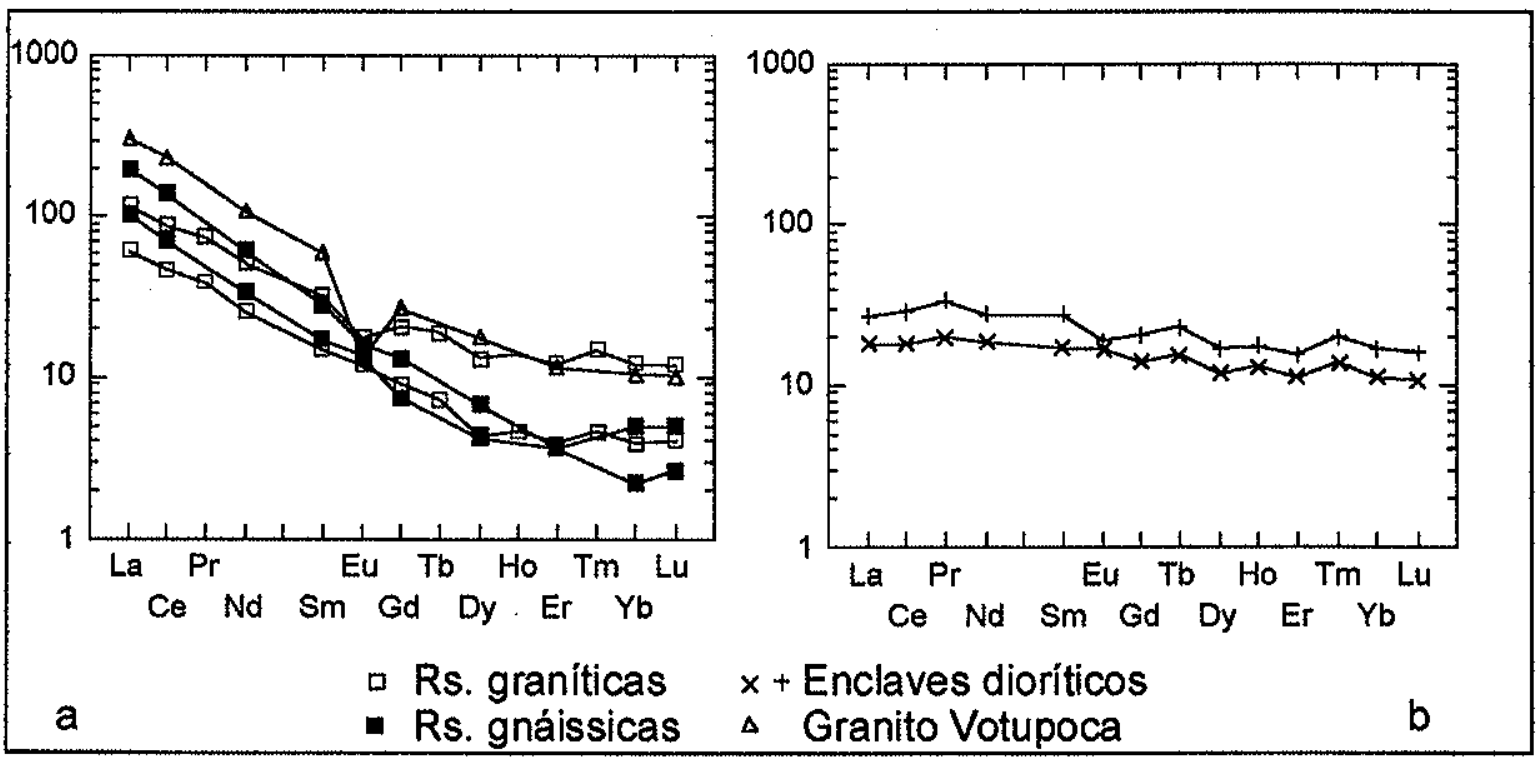

Figura 7.3.6 - Diagrama de ETR normalizado ao condrito (Nakamura, 1974) Bloco Registro.

Apesar da escassez de dados, nota-se um comportamento similar entre as rochas graníticas e entre as rochas gnáissicas na distribuição dos ETR. Comportamento geoquímico totalmente distinto é observado entre as rochas graníticas e seus respectivos enclaves. 


\subsection{GEOCRONOLOGIA E GEOLOGIA ISOTÓPICA}

\subsubsection{RESULTADOS U-PB (ZIRCÕES)}

Foram realizadas seis datações pela metodologia U-Pb, cinco em zircões, sendo uma em rocha gnáissica afetada pela $\mathrm{ZCl}$ (K-11), duas em rochas graníticas que apresentam enclaves dioríticos (K-16, K-17), uma em monzogranito mesocrático milonítico, da região a sul da Serra de Timirim (K-44), e uma em biotita-monzogranito da Serra do Votupoca (K-92); e uma datação em monazitas do Paragnaisse da Juréia (K-96). A localização das amostras encontra-se no Mapa Geológico-Anexo 1.

$\mathrm{Na}$ amostra K-11, gnaisse protomilonítico de composição monzogranítica, afetado pela $\mathrm{ZCl}$ (Mapa Geológico-Anexo 1), foram analisadas as frações magnéticas $M(-2), M(-3), M(-4)$ e $M(-5)$, não abradadas (NA), com pesos em torno de 0.08 . mg. As frações constituem-se por cristais euedrais, transparentes, normalmente com inclusões e fraturas, e com razão média comprimento/largura entre 4 e 6 (Foto 7.4.1).

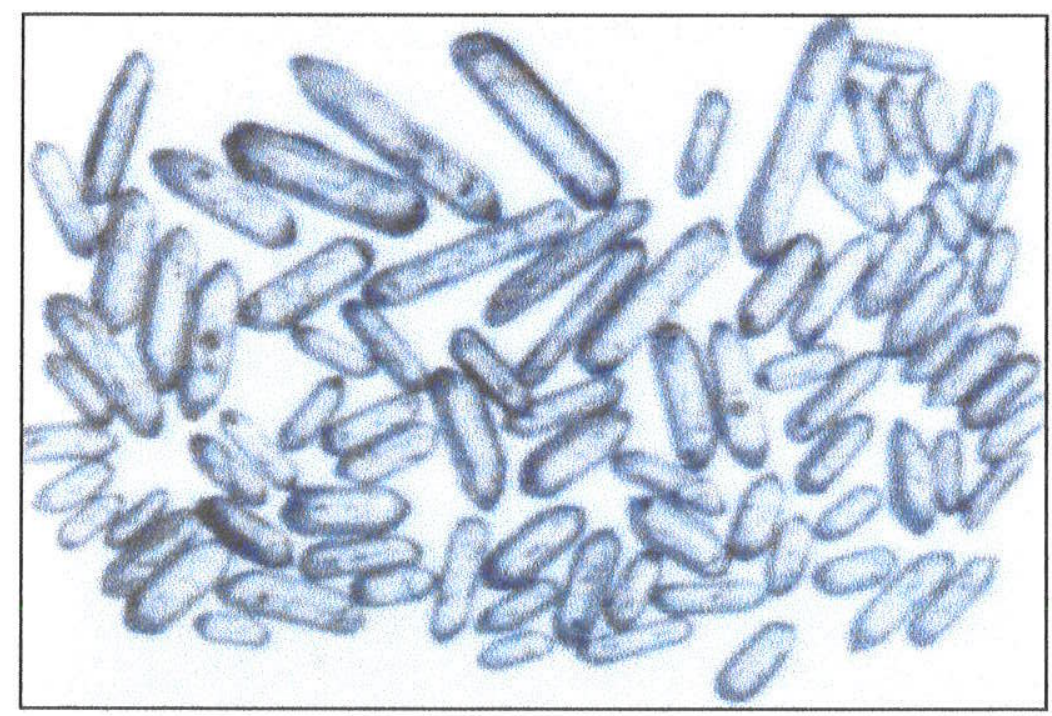

Foto 7.4.1 - Fotomicrografia de lupa binocular de cristais de zircão fração $M-3$, não abradada (aumento $108 \mathrm{X}$ ) - amostra K-11. 
Em Diagrama Concórdia, as frações $\mathrm{M}(-2), \mathrm{M}(-4)$ e $\mathrm{M}(-5)$ posicionaram-se discordantes, porém com um bom alinhamento, que define a idade, intercepto superior, de $606 \pm 19$ Ma interpretada como época mais provável de cristalização desta rocha. Adicionalmente, a fração $\mathrm{M}(-3)$ plotou acima da Curva Concórdia, indicando uma idade $\mathrm{Pb}^{206} / \mathrm{U}^{238}$ de $589 \mathrm{Ma}$ (Tabela 7.4.1).

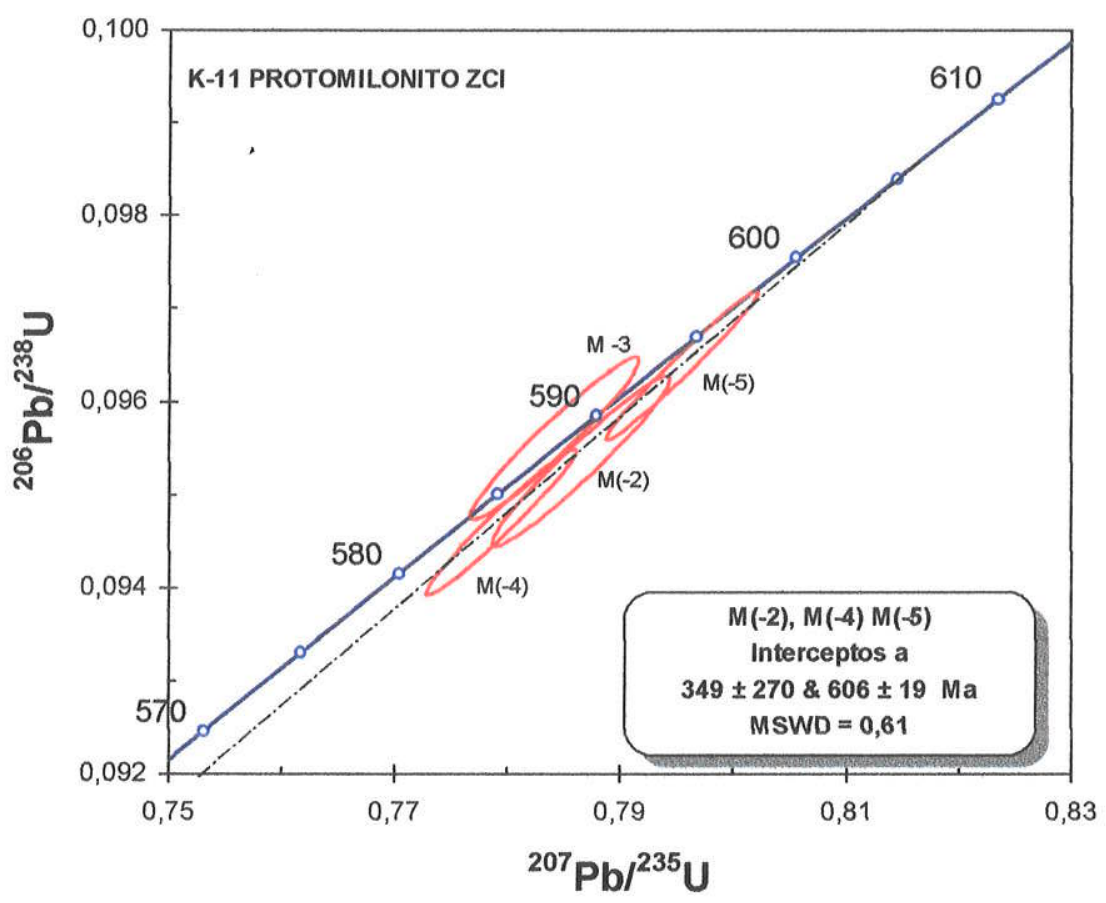

Figura 7.4.1 - Diagrama Concórdia ${ }^{207} \mathrm{~Pb} /{ }^{235} \mathrm{U} x^{206} \mathrm{~Pb} /{ }^{238} \mathrm{U}$ em zircões amostra K-11.

No anfibólio-biotita granodiorito aflorante na região de Oliveira Barros (Prancha 10, Foto 2; Prancha 14, Foto 1), amostra K-16, foram analisados zircões sem a realização de split, de 3 a 5 cristais, frações com split incompleto $N M(-1)$ e frações magnéticas $M(-3), M(-4)$ e $N M(-4)$ abradadas (AA) e não abradadas (NA), com utilização dos spikes $\mathrm{Pb}^{208} \mathrm{e} \mathrm{Pb}^{205}$. Os pesos das frações variaram entre $0.06 \mathrm{e}$ $0.08 \mathrm{mg}$. As frações caracterizam-se por cristais transparentes, normalmente prismáticos, apesar de apresentarem faces e arestas arredondadas, por vezes com inclusões e fraturas, e razão média comprimento/largura em torno de 2 (Foto 7.4.2). 


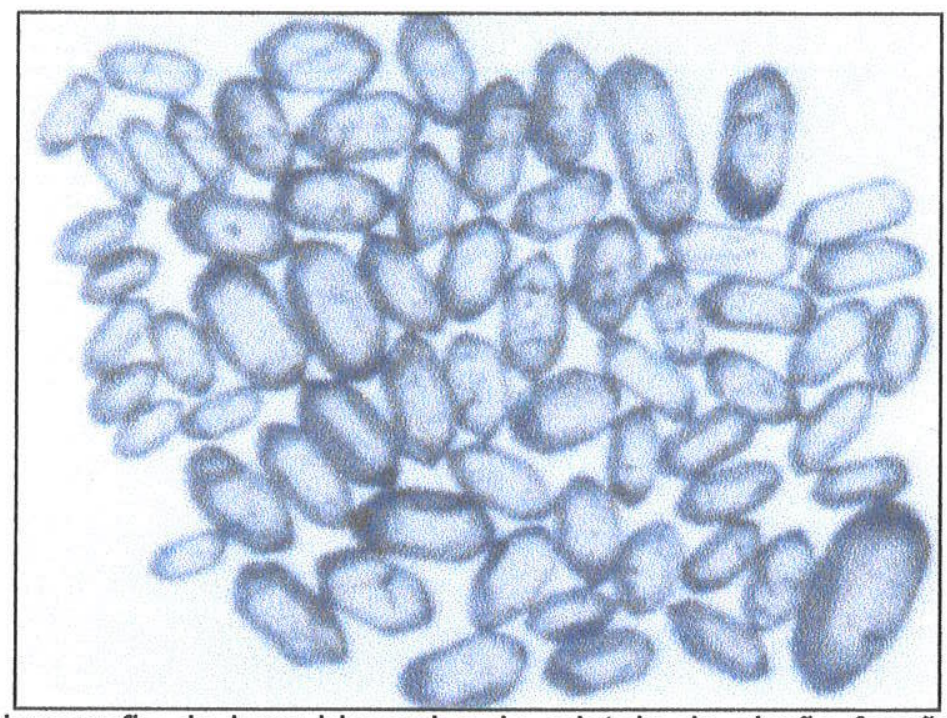

Foto 7.4.2 - Fotomicrografia de lupa binocular de cristais de zircão fração NM-4, abradada por 1 hora (aumento $108 \mathrm{X}$ ) - amostra K-16.

Os resultados obtidos encontram-se listados na Tabela 7.4.1, e quando plotados em Diagrama Concórdia, encontram-se extremamente discordantes, cujo alinhamento mostra uma idade, intercepto superior, de $1.894 \pm 26 \mathrm{Ma}$. O posicionamento intermediário das frações, entre os interceptos, pode refletir zircões que apresentam porções neoformadas e núcleos herdados. Esta idade pode representar uma época aproximada para os protólitos desta rocha (Figura 7.4.2).

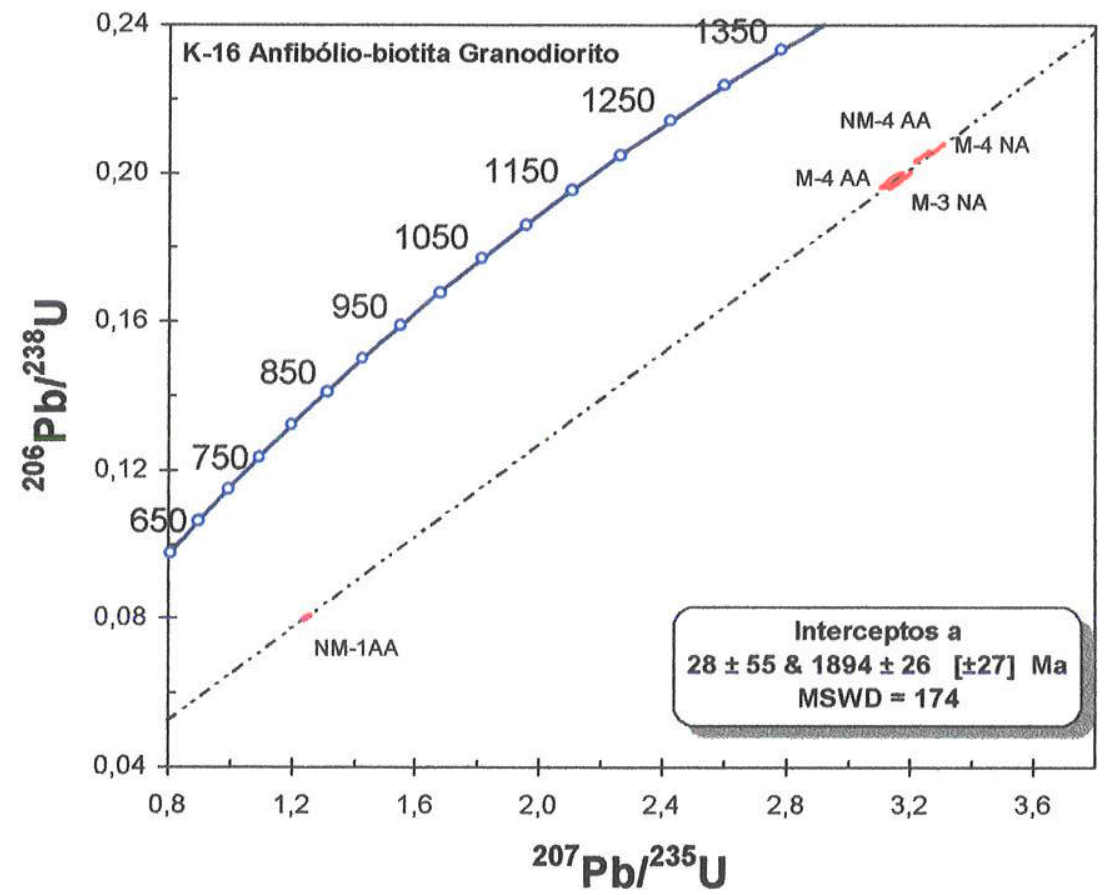

Figura 7.4.2 - Diagrama Concórdia ${ }^{207} \mathrm{~Pb} /{ }^{235} \mathrm{U} \times{ }^{206} \mathrm{~Pb} /{ }^{238} \mathrm{U}$ em zircões da amostra K-16. 
$\mathrm{Na}$ amostra K-17, biotita-monzogranito aflorante na região de Oliveira Barros (Prancha 10, Foto 6), foram analisadas frações magnéticas $M(-4), M(-5)$ e $N M(-5)$, não abradadas (NA), e abradadas (AA) com pesos em torno de $0.08 \mathrm{mg}$. As frações constituem-se por cristais euedrais transparentes normalmente límpidos, por vezes com inclusões e raramente com fraturas, com razão média comprimento/largura entre 2 e 4.5 (Foto 7.4.3).

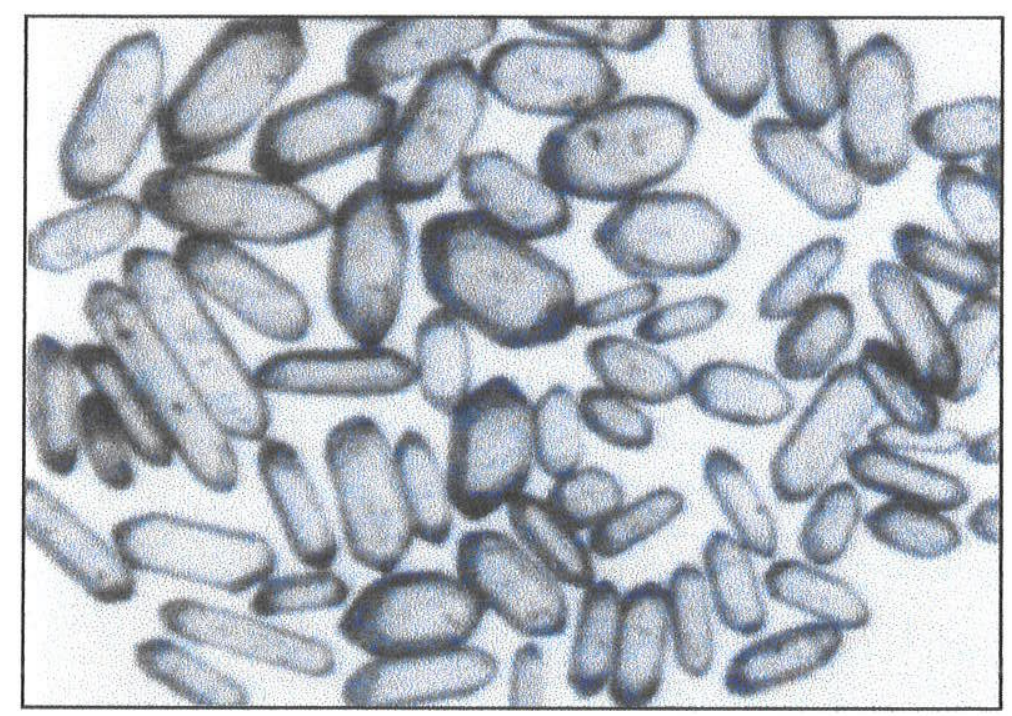

Foto 7.4.3 - Fotomicrografia de lupa binocular de cristais de zircão fração $M-4$, não abradada (aumento $135 \mathrm{X}$ ) - amostra K-17.

Todas as frações analisadas apresentaram valores bons de $\mathrm{Pb}^{206} / \mathrm{Pb}^{204}$ (entre 1800 e 5900), e os resultados obtidos encontram-se listado na Tabela 7.4.1.

Em Diagrama Concórdia, as frações de zircão apresentaram uma idade, intercepto superior de $2.151 \pm 62 \mathrm{Ma}$, idade esta interpretada como possível época de cristalização do protólito desta rocha (Figura 7.4.3).

A idade em torno de $510 \mathrm{Ma}$, sugerida no intercepto inferior, pode representar uma idade mínima para o evento tectono-termal (migmatítico) gerador destas rochas. 


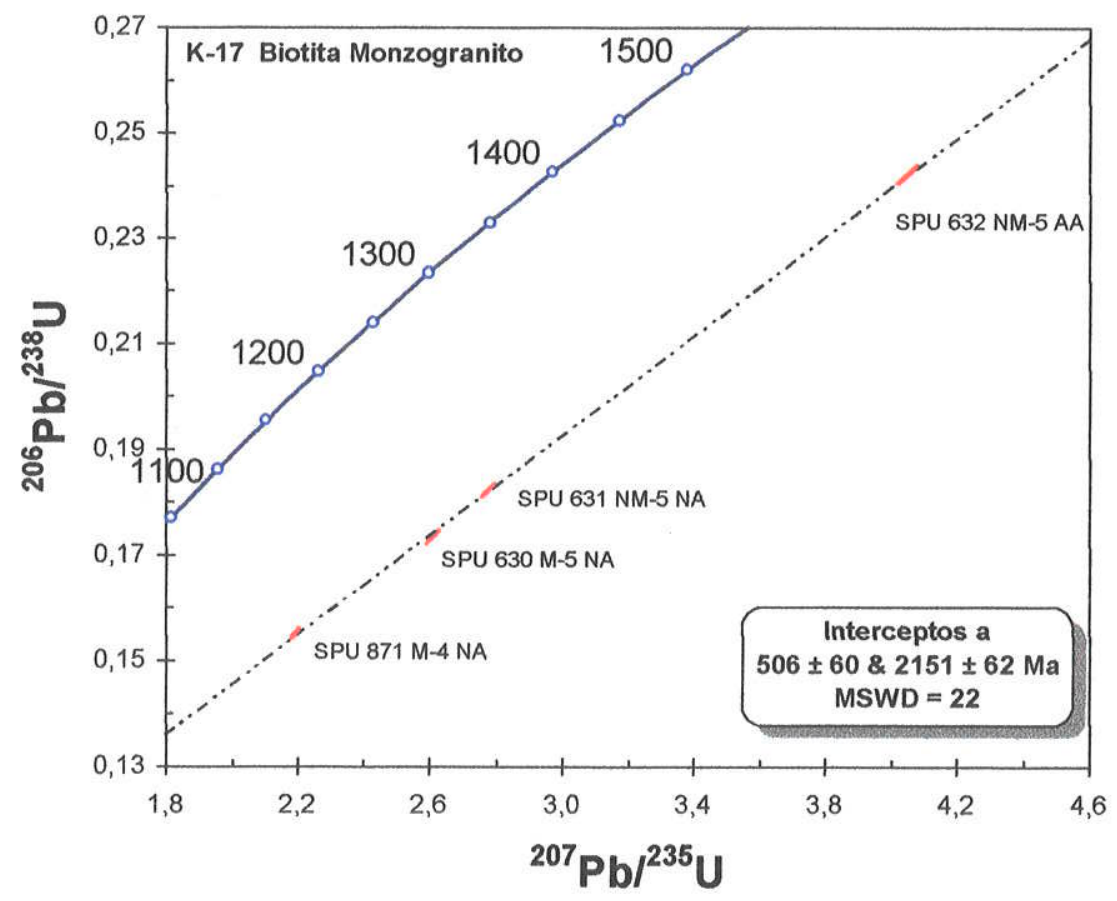

Figura 7.4.3 - Diagrama Concórdia ${ }^{207} \mathrm{~Pb} /{ }^{235} \mathrm{U} \mathrm{x}^{206} \mathrm{~Pb} /{ }^{238} \mathrm{U}$ em zircões da amostra K-17.

Em biotita-monzogranito mesocrático protomilonítico (amostra K-44) foram analisadas as frações magnéticas $M(-3), M(-4), M(-5)$ e $N M(-5)$, não abradadas (NA), e abradadas (AA) com pesos em torno de $0.08 \mathrm{mg}$. As frações analisadas mostram cristais euedrais, bipiramidais, transparentes, por vezes límpidos, mas normalmente com inclusões e fraturas, com razão média comprimento/largura em torno de 3 (Foto 7.4.4).

A grande maioria das frações analisadas apresentaram dados analíticos muito bons, como pode ser observado na Tabela 7.4.1. 


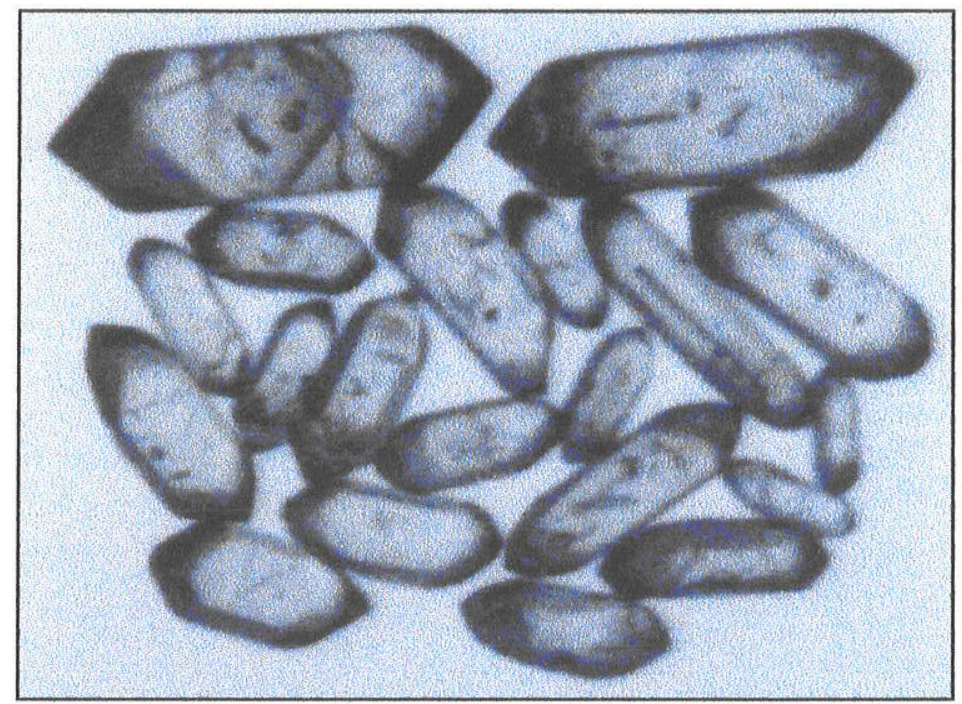

Foto 7.4.4 - Fotomicrografia de lupa binocular de cristais de zircão fração M-4, abradada por 1 hora (aumento $162 \mathrm{X}$ ) - amostra K-44.

Em Diagrama Concórdia, apresentou uma idade, intercepto superior de 2.197 $\pm 41 \mathrm{Ma}$, idade esta interpretada como provável época de cristalização do protólito desta rocha (Figura 7.4.4). Foi obtida idade do intercepto inferior de $580 \pm 24 \mathrm{Ma}$ que, apesar de imprecisa, é interpretada como época de importante evento térmico/migmatítico que afetou a região, e propiciou a neoformação de cristais de zircão.

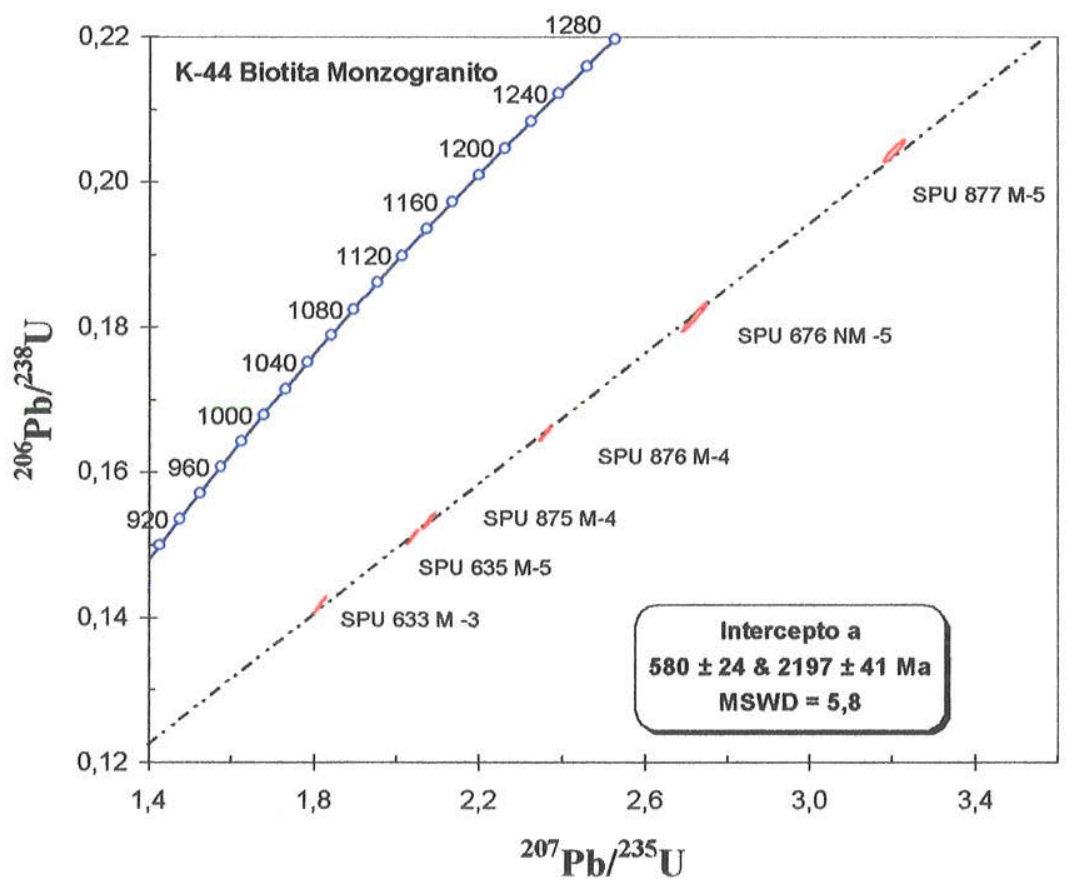

Figura 7.4.4 - Diagrama Concórdia ${ }^{207} \mathrm{~Pb} /{ }^{235} \mathrm{U} x{ }^{206} \mathrm{~Pb} /{ }^{238} \mathrm{U}$ em zircões da amostra K-44. 
$\mathrm{Na}$ amostra K-92, biotita-monzogranito (Granito Votupoca), foram analisadas frações magnéticas $M(-2), M(-3)$ e $M(-4)$, não abradadas (NA) com pesos em torno de $0.080 \mathrm{mg}$. As frações analisadas mostram cristais euedrais, bipiramidais, transparentes, normalmente com inclusões e fraturas, com razão média comprimento/largura entre 4 e 6 (Foto 7.4.5).

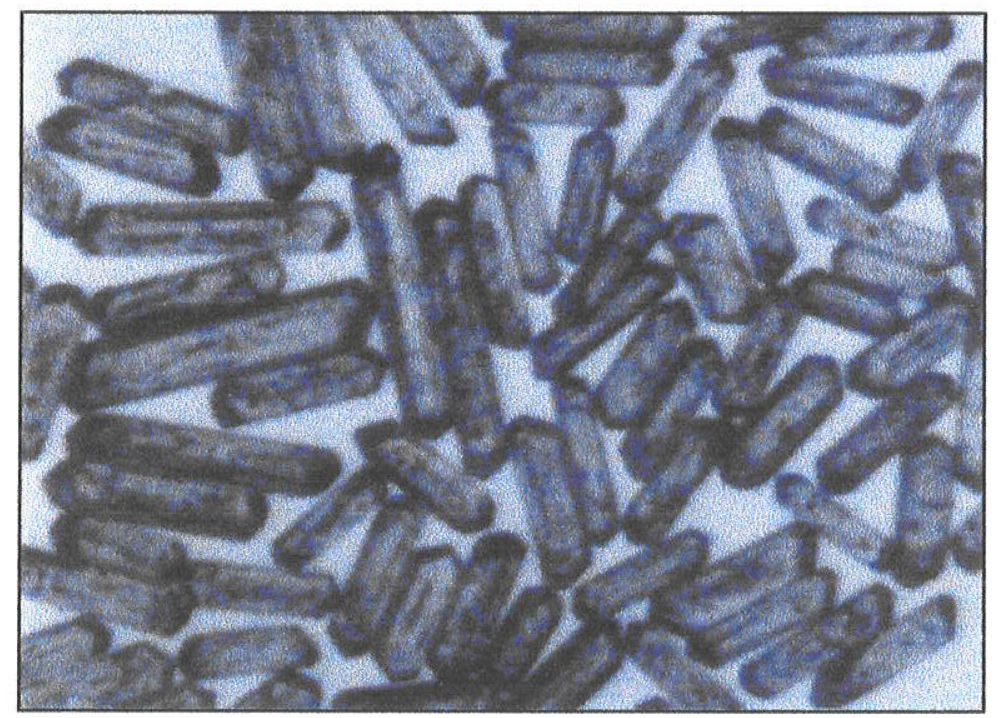

Foto 7.4 .5 - Fotomicrografia de lupa binocular de cristais de zircão fração $M-3$, não abradada (aumento $162 \mathrm{X}$ ) - amostra K-92.

Todas as frações atacadas apresentaram dados analíticos muito bons, sendo utilizadas no cálculo da idade (Tabela 7.4.1).

Em Diagrama Concórdia, apresentou uma idade, intercepto superior de $582 \pm$ $9 \mathrm{Ma}$, idade esta interpretada como época de cristalização desta rocha (Figura 7.4.5). 


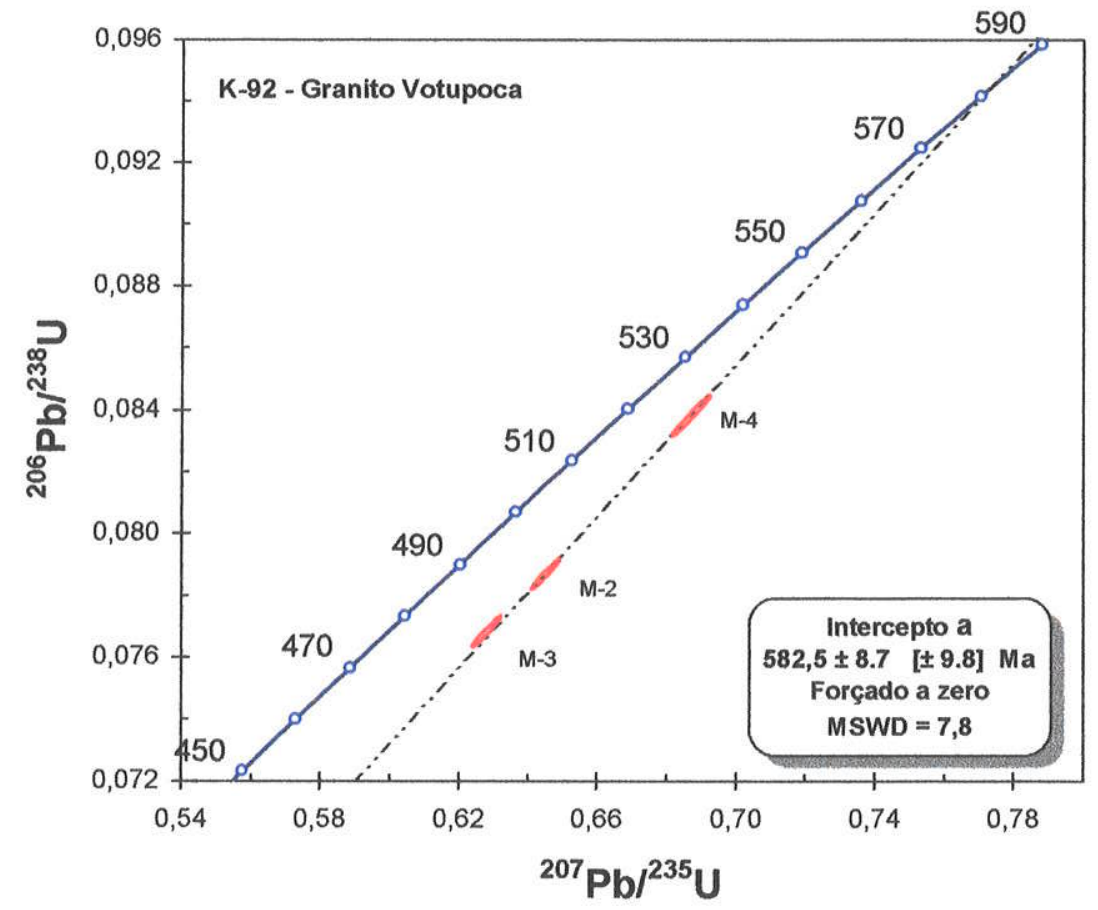

Figura 7.4.5 - Diagrama Concórdia ${ }^{207} \mathrm{~Pb} /{ }^{235} \mathrm{U} \mathrm{x}^{206} \mathrm{~Pb} /{ }^{238} \mathrm{U}$ em zircões da amostra K-92.

$\mathrm{Na}$ amostra representativa dos paragnaisses aflorantes no Maciço da Juréia (K-96) foram analisadas monazitas das frações $M(0.6)$ e $M(0.7)$, com pesos entre 0.002 e $0.006 \mathrm{mg}$. Foram selecionados cristais límpidos, normalmente apresentando cor amarelada (Foto 7.4.6).

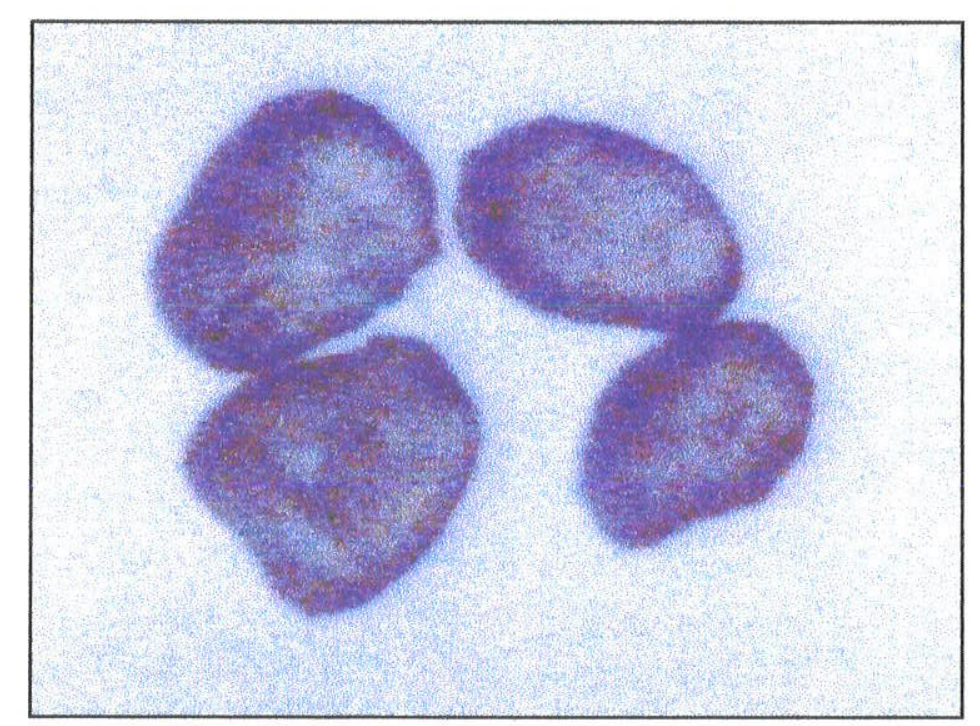

Foto 7.4.6 - Fotomicrografia de lupa binocular de cristais de monazita fração M 0.6 (aumento $275 \mathrm{X})$ - amostra K-96. 
As duas frações de monazitas analisadas mostraram-se concordantes e com idades bastante próximas: $M(0.7)$, com idade concordante em $741 \pm 7 \mathrm{Ma}$; e M (0.6), com idade concordante em $752 \pm 4 \mathrm{Ma}$ (Figura 7.4.6).

Apesar da proximidade das idades obtidas, considera-se a idade obtida pela fração $M(0.6), 752 \pm 4 \mathrm{Ma}$, como a de maior significado geológico, por possuir resultados analíticos melhores (Tabela 7.4.1).

Esta idade é interpretada como época de importante evento metamórfico que afetou as rochas metassedimentares situadas a SE do Bloco Registro, possivelmente associado a uma paragênese de alto grau, atingindo temperaturas suficientes para geração de monazitas.

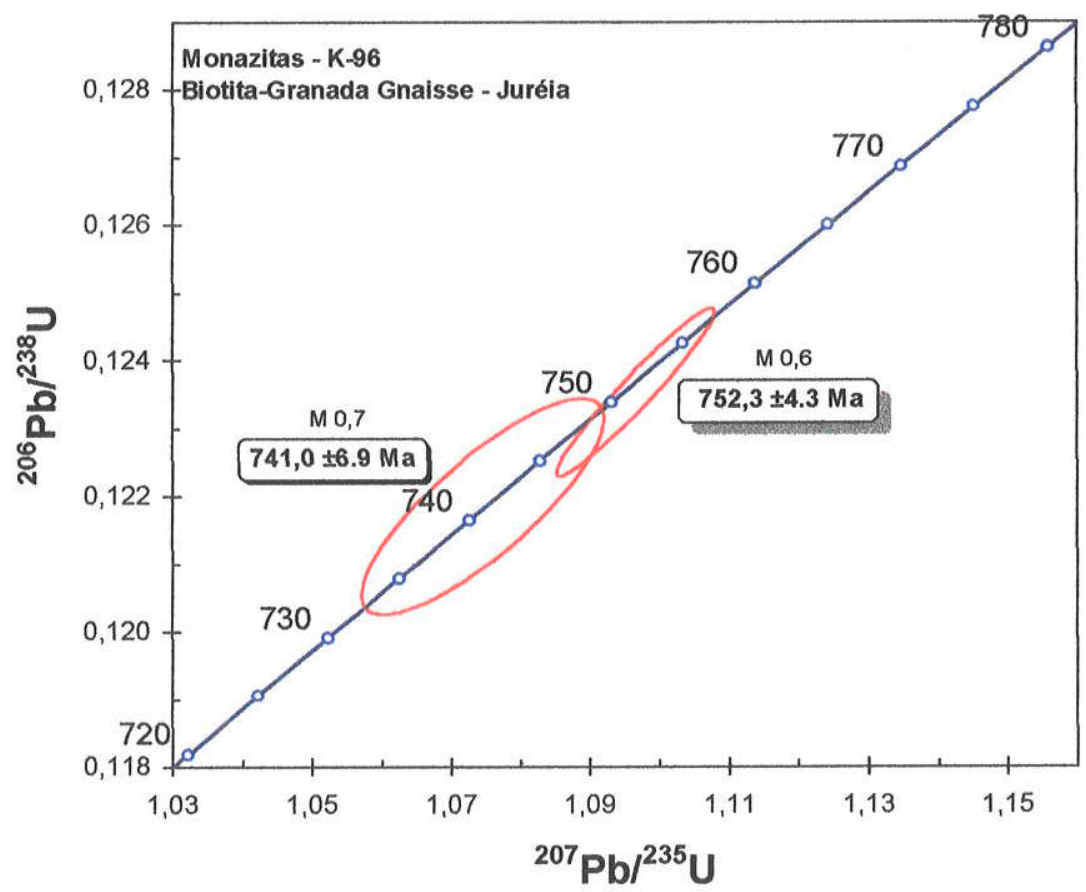

Figura 7.4.6 - Diagrama Concórdia ${ }^{207} \mathrm{~Pb} /{ }^{235} \mathrm{U} x^{206} \mathrm{~Pb} /{ }^{238} \mathrm{U}$ (monazitas) - K-96. 
Tabela 7.4.1

Dados analíticos referentes à Sistemática U-Pb (zircão e monazita) - Bloco Registro.

\begin{tabular}{|c|c|c|c|c|c|c|c|c|c|c|c|c|c|}
\hline \multicolumn{7}{|c|}{ Bloco Registro } & \multicolumn{4}{|c|}{ Razões Isotópicas } & \multicolumn{3}{|c|}{ Idades (Ma) } \\
\hline Unidade & Amostra & $\begin{array}{c}\text { Mineral } \\
\text { Analisado }\end{array}$ & $\begin{array}{c}\text { Fraçäo } \\
\text { Magnética }\end{array}$ & $\begin{array}{l}\text { Peso } \\
\text { (mg) }\end{array}$ & $\begin{array}{c}U \\
(\mathrm{ppm})\end{array}$ & $\begin{array}{c}\mathrm{Pb} \\
\text { (ppm) }\end{array}$ & $\begin{array}{l}\mathrm{Pb}^{206} \mathrm{I} \\
\mathrm{Pb}^{204}\end{array}$ & $\mathrm{~Pb}^{207} \mathrm{~N}^{235}-\mathrm{ErrO} \%$ & $\mathrm{~Pb}^{206} / \mathrm{U}^{238}-$ Erro\% & $\mathrm{Pb}^{201} \mathrm{~Pb}^{206}$-Erro\% & $\begin{array}{c}\mathrm{Pb}^{201} \mathrm{I} \\
\mathrm{U}^{236}\end{array}$ & $\begin{array}{c}\mathrm{Pb}^{206} I \\
\mathrm{U}^{238}\end{array}$ & $\begin{array}{l}\mathrm{Pb}^{207} \mathrm{I} \\
\mathrm{Pb}^{206}\end{array}$ \\
\hline \multirow{4}{*}{$\begin{array}{c}\text { Gnaisse } \\
\text { protomilonitico }\end{array}$} & \multirow{4}{*}{$\mathrm{K}-11$} & zircáo & $\mathrm{M}-2$ & 0.066 & 196 & 22 & 408,4 & $0,786509-0,817$ & $0,0953448-0,786$ & $0,0598282-0,214$ & 589 & 587 & $597 \pm 4$ \\
\hline & & zircāo & $\mathrm{M}-3$ & 0.068 & 206 & 22 & 777.2 & $0.784213-0.78$ & $0.0955932-0.749$ & $0.0594985-0.21$ & 588 & 589 & $585 \pm 5$ \\
\hline & & zircāo & $M-4$ & 0.074 & 233 & 24 & 1028.4 & $0.779489-0.699$ & $0.0946926-0.682$ & $0.0597025-0.148$ & 585 & 583 & $593 \pm 3$ \\
\hline & & zircão & M-5 & 0.071 & 231 & 25 & 1456.5 & $0.795459-0.691$ & $0.0963766-0.679$ & $0.0598611-0.124$ & 594 & 593 & $599 \pm 3$ \\
\hline & & & & & & & & & & & & & \\
\hline \multirow{5}{*}{$\begin{array}{c}\text { Gr. Reg. } \\
\text { Oliveira Barros }\end{array}$} & \multirow{5}{*}{$K-16$} & zircäo & $N M-1$ & 0.36 & 1263 & 107 & 3642.9 & $1.24414-1.1$ & $0.0799312-0.948$ & $0.112889-0.496$ & 821 & 496 & $1846 \pm 9$ \\
\hline & & zircäo & $\mathrm{M}-3$ & 0.091 & 444 & 93 & 5203.3 & $3.16498-0.946$ & $0.197853-0.943$ & $0.116018-0.0756$ & 1449 & 1164 & $1896 \pm 1$ \\
\hline & & zircảo & M-4aa & 0.50 & 529 & 114 & 1583.3 & $3.13836-1$ & $0.197998-0.931$ & $0.114958-0.325$ & 1442 & 1165 & $1879 \pm 6$ \\
\hline & & zircão & $M-4$ & 0.086 & 393 & 87 & 3115.2 & $3.28181-0.653$ & $0.206296-0.65$ & $0.115378-0.056$ & 1477 & 1209 & $1886 \pm 1$ \\
\hline & & zircão & NM-4aa & 0.091 & 395 & 87 & 2082.3 & $3.234-0.628$ & $0.204367-0.625$ & $0.11477-0.0621$ & 1465 & 1199 & $1876 \pm 1$ \\
\hline & & & & & & & & & & & & & \\
\hline \multirow{4}{*}{$\begin{array}{c}\text { Gr. Reg. } \\
\text { Oliveira Barros }\end{array}$} & \multirow{4}{*}{$\mathrm{K}-17$} & zircäo & $M-4$ & 0.058 & 468 & 75 & 1794.7 & $2.19235-0.576$ & $0.155023-0.568$ & $0.102568-0.0913$ & 1179 & 929 & $1671 \pm 2$ \\
\hline & & zircão & $M-5$ & 0.088 & 509 & 91 & 2635.6 & $2.60815-0.634$ & $0.17322-0.632$ & $0.109202-0.0578$ & 1303 & 1030 & $1786 \pm 1$ \\
\hline & & zircāo & $\mathrm{NM}-5$ & 0.093 & 462 & 88 & 2150.3 & $2.77276-0.597$ & $0.182131-0.593$ & $0.110415-0.0642$ & 1348 & 1079 & $1806 \pm 1$ \\
\hline & & zircão & NM-5aa & 0.092 & 199 & 50 & 3875.1 & $4.04566-0.607$ & $0.241953-0.603$ & $0.121271-0.0713$ & 1643 & 1397 & $1975 \pm 1$ \\
\hline & \multirow{7}{*}{$\mathrm{K}-44$} & & & & & & & & & & & & \\
\hline \multirow{6}{*}{$\begin{array}{c}\text { Gnaisse } \\
\text { protomilonitico }\end{array}$} & & zircāo & $\mathrm{M}-3$ & 0.081 & 350 & 52 & 1343 & $1.81545-0.709$ & $0.141662-0.705$ & $0.092946-0.0761$ & 1051 & 854 & $1487 \pm 1$ \\
\hline & & zircāo & M-5 & 0.103 & 436 & 71 & 917 & $2.0383-0.593$ & $0.150883-0.587$ & $0.0979772-0.083$ & 1128 & 906 & $1586 \pm 2$ \\
\hline & & zircăo & NM-5aa & 0.075 & 206 & 39 & 3218.1 & $2.72011-0.953$ & $0.181266-0.934$ & $0.108835-0.191$ & 1334 & 1074 & $1780 \pm 4$ \\
\hline & & zircāo & M-4aa & 0.051 & 328 & 58 & 394.1 & $2.07808-0.623$ & $0.153161-0.611$ & $0.098404-0.117$ & 1142 & 919 & $1594 \pm 2$ \\
\hline & & zircão & $M-4 a a$ & 0.073 & 288 & 51 & 882.6 & $2.36001-0.557$ & $0.165276-0.547$ & $0.103563-0.101$ & 1231 & 986 & $1689 \pm 2$ \\
\hline & & zircão & M-5aa & 0.083 & 155 & 35 & 705.3 & $3.20363-0.649$ & $0.204125-0.618$ & $0.113827-0.197$ & 1458 & 1197 & $1861 \pm 4$ \\
\hline & & & & & & & & & & & & & \\
\hline \multirow{3}{*}{ Gr. Votupoca } & \multirow{3}{*}{ K-92 } & zircão & M-2 & 0.084 & 753 & 73 & 1247.9 & $0.644946-0.543$ & $0.0786439-0.531$ & $0.0594781-0.111$ & 505 & 488 & $585 \pm 2$ \\
\hline & & zircão & $M-3$ & 0.078 & 667 & 63 & 1482.0 & $0.627909-0.563$ & $0.0767868-0.551$ & $0.0593074-0.115$ & 495 & 477 & $578 \pm 3$ \\
\hline & & zircăo & $M-4$ & 0.076 & 766 & 79 & 1331.7 & $0.686814-0.678$ & $0.0837716-0.669$ & $0.0594622-0.108$ & 531 & 519 & $584 \pm 2$ \\
\hline \multirow{2}{*}{$\begin{array}{l}\text { Paragnaisse } \\
\text { Juréia }\end{array}$} & \multirow[t]{2}{*}{ K-96 } & monazita & $M(0.6)$ & 0.0024 & 4218 & 2024 & 1149.4 & $1.09655-0.855$ & $0.123517-0.822$ & $0.0643876-0.228$ & 752 & 751 & $754 \pm 5$ \\
\hline & & monazita & $M(0.7)$ & 0.0054 & 2396 & 1159 & 470 & $1.07455-1.33$ & $0.121831-1.07$ & $0.0639689-0.762$ & 741 & 741 & $741 \pm 16$ \\
\hline
\end{tabular}




\subsubsection{RESULtAdOS K-AR (BIOTITA)}

No Bloco Registro o método K-Ar foi aplicado aos paragnaisses miloníticos da Juréia (discutido no Capítulo 10, referente a ZCS) e ao biotita-monzogranítico mesocrático (K-44), aflorante próximo à Serra de Timirim.

A amostra (K-44) apresenta-se protomilonítica, afetada por faixa milonítica na porção central do Bloco Registro (Mapa Geológico - Anexo 1). Os resultados analíticos mostraram-se bons (Tabela 7.4.2), e forneceram, em concentrado de biotitas, idade de $504 \pm 9 \mathrm{Ma}(1 \sigma)$.

Esta rocha mostrou uma idade U-Pb (zircões), intercepto superior de $2.197 \pm$ $41 \mathrm{Ma}$, interpretada como época de cristalização do protólito desta rocha e idade intercepto inferior de $580 \pm 24 \mathrm{Ma}$, interpretada como um evento térmico que afetou a região.

A idade K-Ar obtida, de cerca de $505 \mathrm{Ma}$, pode representar a época final de movimentação de pequenas zonas de cisalhamento associadas às $\mathrm{ZCC}$ e $\mathrm{ZCl}$, indicando o resfriamento dessas rochas (temperaturas inferiores a $250^{\circ} \mathrm{C}$ ).

\begin{tabular}{|c|c|c|c|c|c|c|c|}
\hline Amostra & Material & $\%$ de K & Erro & $\begin{array}{c}\text { Ar }{ }^{40} \text { Rad } \\
\operatorname{CcsTP} / g\left({ }^{\left.* 10^{8}\right)}\right.\end{array}$ & Ar $^{40}$ Atm & $\begin{array}{c}\text { Idade } \\
\text { (Ma) }\end{array}$ & $\begin{array}{c}\text { Erro máx. } \\
\text { (Ma) }\end{array}$ \\
\hline Kn44 & Biotita & 7.4823 & 0.5007 & 168.92 & 4.12 & 503.8 & 9.3 \\
\hline
\end{tabular}

Tabela 7.4.2 - Dados analíticos K-Ar - Bloco Registro.

\subsubsection{GEOLOGIA ISOTÓPICA ND-SR}

As sistemáticas $\mathrm{Sm}-\mathrm{Nd}$ e $\mathrm{Rb}-\mathrm{Sr}$ foram utilizadas nas rochas granitognáissicas migmatíticas, no Granito Votupoca e nos paragnaisses da Juréia.

As rochas granito-gnáissicas migmatíticas estão representadas:

1) na região de Oliveira Barros: por anfibólio-biotita granodiorito (K-16), e seu enclave máfico diorítico (K-16D), por biotita monzogranito (amostra K-17A) e seu enclave máfico diorítico (K-17B);

2) na região a sul da Serra do Timirim: por biotita monzogranito deformado mesocrático, afetado por faixa milonítica interna ao Bloco Registro (K-44); 
3) na região a NE de Miracatu: por rocha gnáissica protomilonítica de composição monzogranítica afetada pela $\mathrm{ZCl}(\mathrm{K}-11)$.

Adicionalmente, foram analisadas amostras do Biotita monzogranito da Serra do Votupoca (amostra K-92), e do paragnaisse do Maciço da Juréia (K-97). Os resultados obtidos apresentam-se listados na Tabela 7.4.3.

Quando plotados em Diagrama de Evolução de $\varepsilon N d x$ tempo (Figura 7.4.7; 7.4.8), nota-se padrões distintos em relação às idades modelo TDM dos litotipos estudados no Bloco Registro, sugerindo que a derivação do manto dos protólitos dessas rochas se deu em épocas diferentes.

O período arqueano está registrado nas rochas da região de Oliveira Barros (Figura 7.4.7), onde o anfibólio-biotita granodiorito (K-16) apresentou idade TDM de $2.930 \mathrm{Ma}$ calculada pelo método de estágio duplo, por apresentar razão ${ }^{147} \mathrm{Sm} /{ }^{144} \mathrm{Nd}=0.1236$, e seu enclave máfico (K-16D) uma idade TDM de $2.809 \mathrm{Ma}$. O biotita-monzogranito (K-17A) apresentou idade TDM de $2.717 \mathrm{Ma}$, e a análise do enclave associado a esta rocha apresentou problemas analíticos.

Duas épocas distintas de derivação do manto dos protólitos das demais rochas deste bloco estão registradas (Figura 7.4.8): o Mesoproterozóico, $1.581 \mathrm{Ma}$ para o gnaisse protomilonítico (amostra K-11) e o Paleoproterozóico, 2.4 Ga para o granito mesocrático (amostra K-44) e Granito Votupoca (amostra K-92).

Os valores de $\varepsilon N d_{(t)}$ foram calculados para uma idade média de $600 \mathrm{Ma}$ e de 1.9 Ga para amostra K-16. Para os enclaves máficos, que não possuem datações U$\mathrm{Pb}$, considerou-se uma idade menor ou igual ao valor obtido para as rochas graníticas associadas.

O conjunto das rochas analisadas apresentaram valores de ENd distintos, (Tabela 7.4.3), indicando contribuição a partir de fontes distintas na geração destas rochas, bem como, períodos de residência crustal distintos.

As rochas da região de Oliveira Barros, apresentaram-se resultados bastante distintos. O granodiorito (amostra K-16) apresenta valor de $\varepsilon \mathrm{Nd}_{(T)}$ de -10.06 e seu

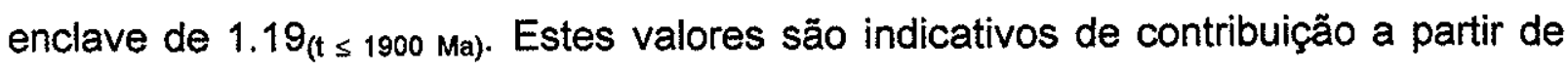
fontes crustais e mantélicas, respectivamente. A amostra de enclave diorítico (K$17 \mathrm{D})$, apresentou valor de $\varepsilon \mathrm{Nd}_{(\mathrm{t})}$ de -12.54 e o granito associado $(\mathrm{K}-17) \mathrm{de}-19.84$. 
O monzogranito mesocrático da Serra de Timirim (K-44) apresentou valor de $\varepsilon N d_{(T)}$ de -21.65 , semelhante aos obtidos para as rochas graníticas da região de Oliveira Barros. Para o Granito Votupoca (K-92) obteve-se o valor de $\varepsilon N d_{(T)}$ de 21.03.

$\mathrm{O}$ gnaisse afetado pela $\mathrm{ZCl}(\mathrm{K}-11)$ apresentou valor de $\mathrm{eNd}(\mathrm{t})$ distinto das demais rochas, de -8.42 .

Os paragnaisses da Juréia (Figura 7.4.8), apresentam idade modelo TDM de $2.293 \mathrm{Ma}$, e valor de $\varepsilon N d(0)$ de -22.04 e de $\varepsilon N d(t)$ de -13.88 (t=750 Ma) (K-97) calculado para época do evento metamórfico determinado pelas datações U-Pb (monazitas). A idade TDM obtida pode representar uma média ponderada das composições isotópicas de suas rochas-fonte, sendo considerada uma idade híbrida.

As idades TDM obtidas para os granitos da região de Oliveira Barros, o granito mesocrático e Granito Votupoca (Tabela 7.4.3,), indicam duas épocas principais de diferenciação dos protólitos destas rochas do manto, entre $2.7-2.9 \mathrm{Ga}$ e $2.4 \mathrm{Ga}$ (Figuras 7.4.7, 7.4.8). Os valores de $\varepsilon \mathrm{Nd}_{(\mathrm{T})}$ entre $-10 \mathrm{e}-22$, indicam contribuição a partir de fontes crustais.

Características bastante diversas estão relacionadas aos enclaves máficos dos dois afloramentos da região de Oliveira Barros (Figura 7.4.7). Apresentam valores díspares, onde o enclave K-16D mostra ter origem mantélica, e o enclave K17B, forte contribuição crustal, ou mesmo importante contaminação da rocha granítica associada.

O gnaisse protomilonítico ( $\mathrm{K}-11$ ) mostra um comportamento totalmente distinto das demais rochas do Bloco Registro, apresentando uma idade TDM muito mais jovem, e valor de $\varepsilon N d_{(T)}$ bem menos negativo, sugerindo uma fonte distinta para geração desta rocha. 


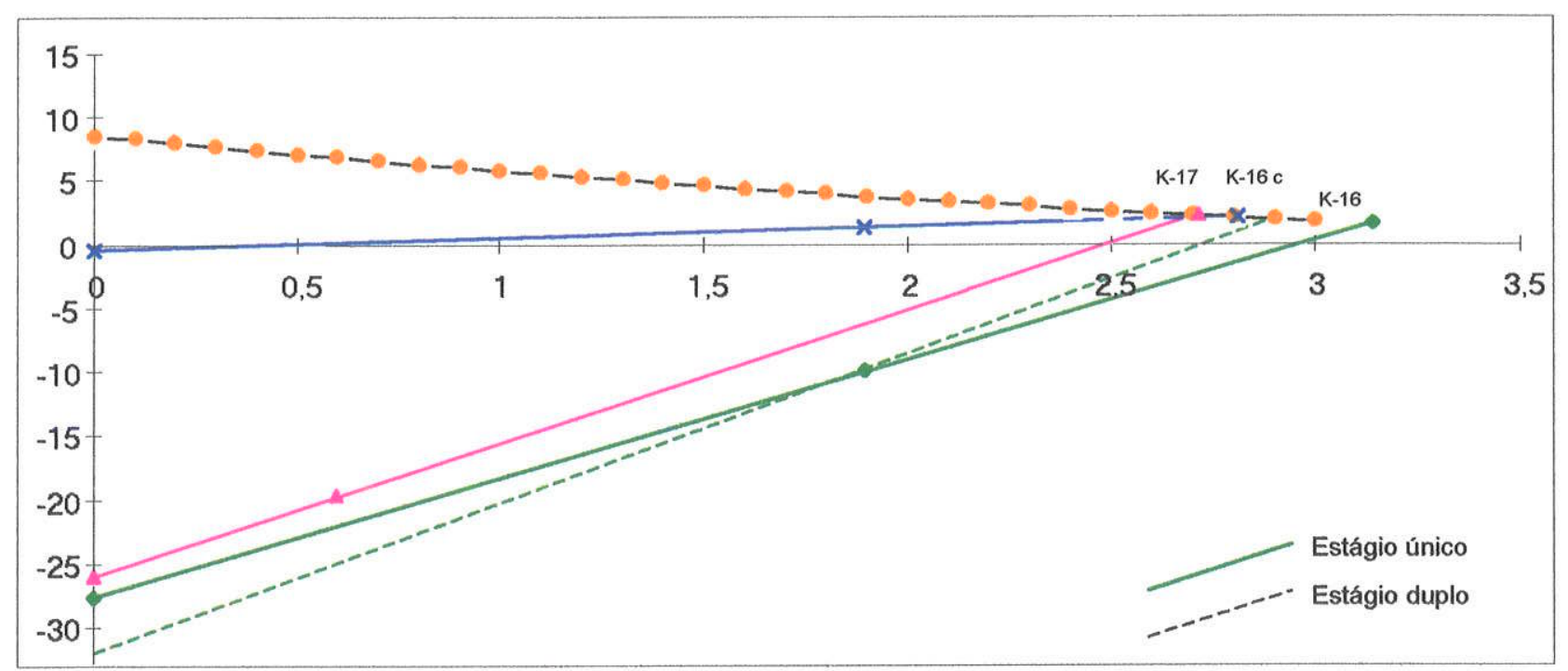

Figura 7.4.7 - Diagrama de evolução \&Nd x tempo (Ga). Oliveira Barros - Bloco Registro.

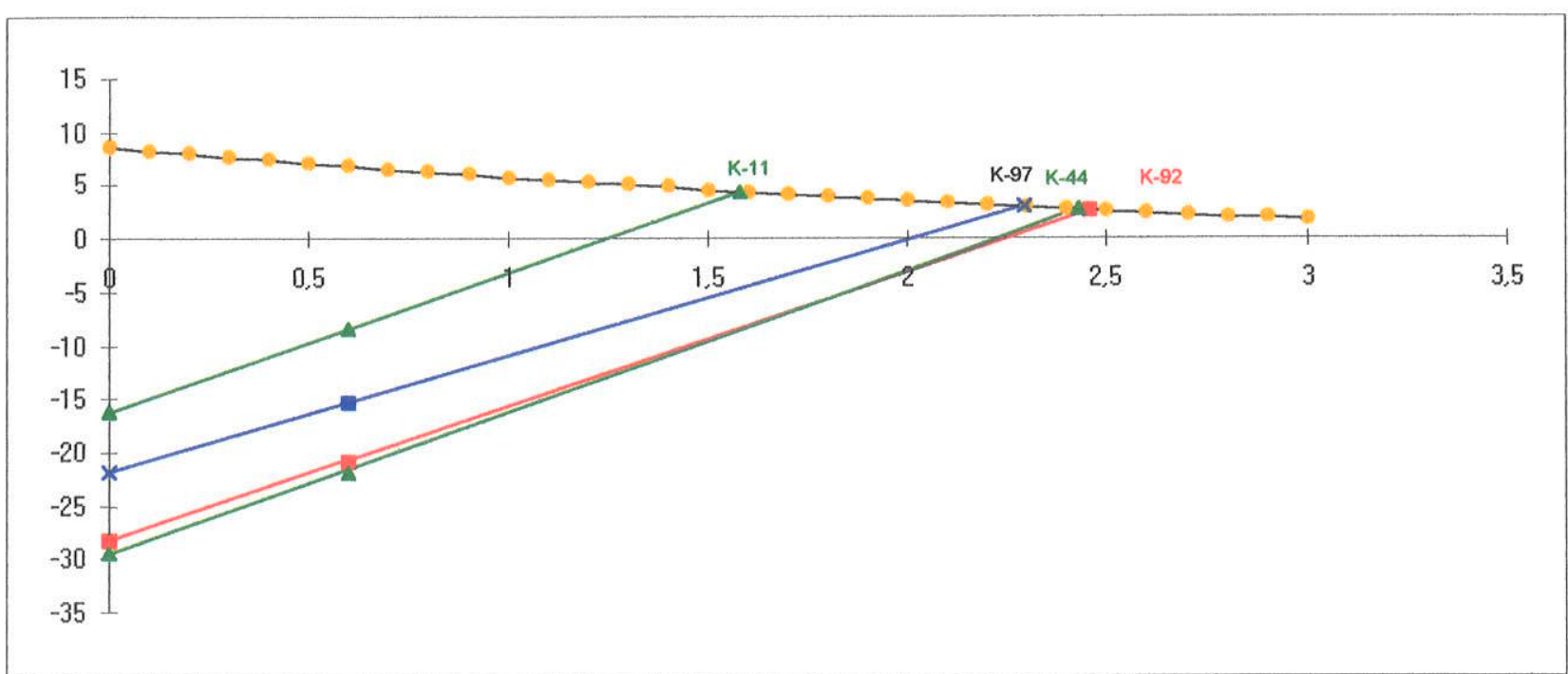

Figura 7.4.8 - Diagrama de evolução $£ N d$ x tempo (Ga). Rs. Gnáissicas, Granito Votupoca e Paragnaisses da Juréia - Bloco Registro.

A razões isotópicas de $\left(\mathrm{Sr}^{87} / \mathrm{Sr}^{86}\right) \mathrm{i}$ obtidas pela sistemática $\mathrm{Rb}-\mathrm{Sr}$ (Tabela 7.4.4) para as rochas granito gnáissicas da região de Oliveira Barros, foram entre 0.712 e 0.721 , e para a rocha gnáissica da Serra de Timirim, 0.723 . Tais valores sugerem a origem destas rochas, adicionada às informações obtidas pela assinatura dos isótopos de $\mathrm{Nd}$, possivelmente a partir de reservatórios crustais. 
O protomilonito afetado pela $\mathrm{ZCl}(\mathrm{K}-11)$ apresentou razão inicial $\mathrm{Sr}^{87} / \mathrm{Sr}^{86}$ relativamente mais baixa, de 0.71078 e o Granito Votupoca de 0.71676 .

Os paragnaisses da Juréia apresentam razão inicial $\mathrm{Sr}^{87} / \mathrm{Sr}^{86}$ bem mais elevada de 0,72996 .

Em diagrama de $\varepsilon S r \times \varepsilon N d$, pata $\mathrm{t}=600 \mathrm{Ma}$ (Figura 7.4.9), as rochas do Bloco Registro tendem a formar um trend no quadrante inferior direito, indicativo de uma longa vivência crustal, com valores negativos de ENd e positivos de ESr, com exceção da amostra representativa do enclave diorítico (K-16D) que apresentou valor de eNd próximo a zero, sugerindo importante contribuição mantélica na sua formação.

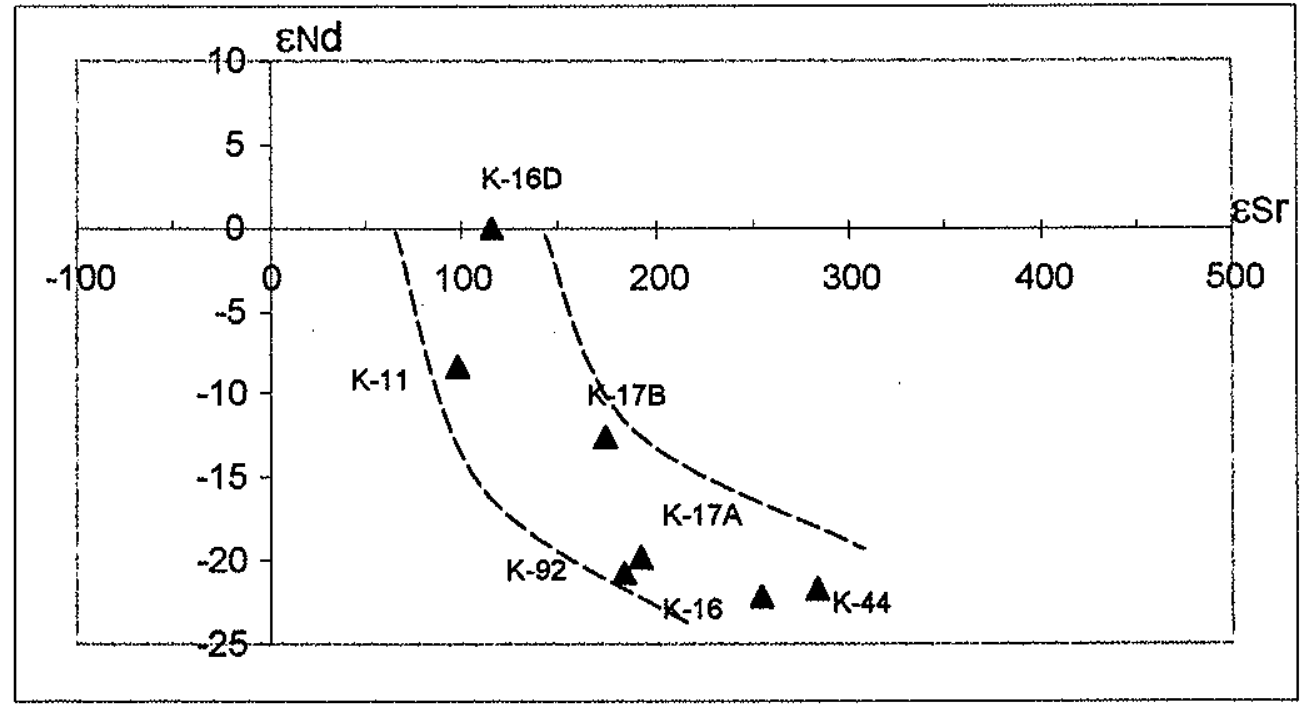

Figura 7.4.9 - Diagrama $\varepsilon \operatorname{Sr} \times \varepsilon \mathrm{Nd}(600 \mathrm{Ma})$ - Bloco Registro. 
Tabela 7.4.3 -Dados analíticos da sistemática Sm-Nd para rochas Bloco Registro.

\begin{tabular}{|c|c|c|c|c|c|c|c|c|c|c|c|}
\hline $\begin{array}{c}\text { No. } \\
\text { Campo }\end{array}$ & $\begin{array}{c}\mathrm{Sm} \\
(\mathrm{ppm})\end{array}$ & $\begin{array}{c}\mathrm{Nd} \\
(\mathrm{ppm})\end{array}$ & $\begin{array}{l}{ }^{74 /} \mathrm{Sm} / \\
{ }^{144} \mathrm{Nd}\end{array}$ & $\begin{array}{l}{ }^{743} \mathrm{Nd} / 1 \\
{ }^{144} \mathrm{Nd}\end{array}$ & Erro & $e_{(0)}$ & f $_{\text {Smind }}$ & $\begin{array}{l}\text { ToM } \\
(\mathrm{Ma})\end{array}$ & $e_{\text {(TDM) }}$ & $\begin{array}{l}T_{1} \\
\text { (Ma) }\end{array}$ & $e_{(71)}$ \\
\hline $\mathrm{K}-11$ & 5,335 & 34,159 & 0,0944 & 0,511805 & 0.000012 & $-16,25$ & $-0,52$ & 1581,1 & 4,37 & 600 & -8.42 \\
\hline $\mathrm{K}-16$ & 7,020 & 34,351 & 0,1236 & 0,511214 & 0.000015 & $-33^{*}$ & $-0,37$ & $2.930^{*}$ & 1,53 & 1900 & -10.06 \\
\hline $\mathrm{K}-16 \mathrm{D}$ & 3,594 & 11,480 & 0,1893 & 0,512607 & 0.000015 & -0.60 & $-0,04$ & 2809,7 & 2,04 & $<1900$ & $<1.19$ \\
\hline $\mathrm{K}-17 \mathrm{~A}$ & 3,285 & 17,251 & 0,1151 & 0,511301 & 0.000010 & $-26,08$ & $-0,41$ & 2717,1 & 2,18 & 600 & -19.84 \\
\hline $\mathrm{K}-17 \mathrm{~B}$ & 5,357 & 16,686 & 0,1941 & 0,511985 & 0.000010 & $-12,74$ & $-0,01$ & 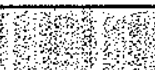 & Wry & 600 & -12.54 \\
\hline $\mathrm{K}-44$ & 3,398 & 22,240 & 0,0924 & 0,511119 & 0.000011 & $-29,63$ & $-0,53$ & 2428,2 & 2,68 & 600 & -21.65 \\
\hline K-92 & 10,960 & 67,849 & 0,0977 & 0,511183 & 0.000013 & $-28,38$ & $-0,50$ & 2455,3 & 2,63 & 600 & -20.80 \\
\hline K-97 & 4,623 & 25,106 & 0,1113 & 0,511508 & 0.000016 & $-22,04$ & $-0,43$ & 2293,4 & 2,92 & 600 & -15.51 \\
\hline
\end{tabular}

${ }^{\star} \varepsilon N d(0)$ e idade TDM recalculados pelo método do estágio duplo (Sato, 1998).

Tabela 7.4.4 - Dados analíticos da sistemática Rb-Sr para as rochas do Bloco Registro.

\begin{tabular}{|c|c|c|c|c|c|c|c|c|c|c|c|}
\hline No. Campo & $\begin{array}{c}\mathrm{Rb} \\
\mathrm{ppm}\end{array}$ & $\begin{array}{c}\mathrm{Sr} \\
(\mathrm{ppm})\end{array}$ & ${ }^{87} \mathrm{Rb} /{ }^{86} \mathrm{Sr}$ & ${ }^{81} \mathrm{Sr} r^{86} \mathrm{Sr}$ & Erro & $\varepsilon_{(0)}$ & $\begin{array}{l}\text { TDM } \\
\text { (Ma) }\end{array}$ & E(TDM) & $\begin{array}{c}T_{1} \\
\text { (Ma) }\end{array}$ & $\overline{\varepsilon(11)}$ & RE-TI \\
\hline $\mathrm{K}-11$ & 215,0 & 507,0 & 1,229 & 0,721299 & 0.000036 & 238,45 & 1125,3 & $-23,91$ & 600 & 99.2 & 0,71078 \\
\hline $\mathrm{K}-16$ & 135,0 & 381,0 & 1,028 & 0,730460 & 0.000029 & 368,49 & 1998,3 & $-18,13$ & 600 & 253.8 & 0.72167 \\
\hline $\mathrm{K}-16 \mathrm{D}$ & 216,0 & 247,0 & 2,537 & 0,733728 & 0.000059 & 414,88 & 884,0 & $-25,49$ & 600 & 116.7 & 0.71202 \\
\hline $\mathrm{K}-17 \mathrm{~A}$ & 112,0 & 395,0 & 0,822 & 0,724396 & 0.000036 & 282,41 & 1985,9 & $-18,22$ & 600 & 192.7 & 0.71736 \\
\hline $\mathrm{K}-17 \mathrm{~B}$ & 113,0 & 271,0 & 1,209 & 0,726446 & 0.000036 & 311,51 & 1451,3 & $-21,76$ & 600 & 174.8 & 0.71610 \\
\hline$K-44$ & 163,0 & 365,0 & 1,296 & 0,734826 & 0.000037 & 430,46 & 1814,0 & $-19,36$ & 600 & 283.3 & 0.72374 \\
\hline$K-92$ & 346,0 & 156,0 & 6,460 & 0,772035 & 0.000023 & 958,62 & 761,9 & $-26,29$ & 600 & 184.2 & 0.71676 \\
\hline K-97 & 86,0 & 180,0 & 1,388 & 0,744815 & 0.000037 & 572,25 & 2202,2 & $-16,77$ & 600 & 414.0 & 0,72996 \\
\hline
\end{tabular}




\subsection{DISCUSSÃO DOS RESULTADOS OBTIDOS}

As rochas granito-gnáissicas migmatíticas investigadas neste bloco, correspondem cartograficamente ao Complexo Gnáissico-Migmatítico e Suíte Granítica de fácies migmatítica de Dantas et al. (1987).

Os paragnaisses do Maciço da Juréia, correspondem cartograficamente ao Complexo Granito-migmatítico indiferenciado de Silva (1981) e Campanha (1991), e - Granito Votupoca, correlacionado ao granito de mesmo nome cartografado na Folha 1: 50.000 de Jacupiranga, por Vasconcellos et al. (1999).

As rochas granito-gnáissicas migmatíticas, ocupam a maior porção da área do Bloco Registro, e oferecem uma grande oportunidade de investigação de diques sinplutônicos, onde há coexistência de magmas félsico e máfico, produzida por commingling destes dois diferentes tipos de magmas. Processo esse, responsável pela formação dos enclaves máficos observados.

As estruturas diversas observadas em campo, como os diques máficos rompidos e presença de enclaves (Prancha 10, Fotos 1, 2 e 6) sugerem que houve a intrusão de um magma básico em fraturamentos iniciais formados em um hospedeiro granítico ainda em processo de cristalização.

O tipo de interação entre os magmas, dependerá das viscosidades relativas (Pitcher, 1991; Smith, 2000). Conforme os autores, um magma máfico quente só poderá reter seu calor, e consequentemente sua baixa viscosidade, se estiver em volume consideravelmente maior que o magma félsico mais frio, e ainda a mistura (mixing) só ocorrerá enquanto as viscosidades dos dois materiais forem compativeis.

Neste aspecto, na área estudada, observam-se locais onde houve o predomínio do magma félsico sobre o máfico, sendo a diferença reológica tão grande que apenas o fenômeno mingling pode ocorrer (Prancha 10, Fotos 1 e 2 , afloramento $\mathrm{K}-16$ ). Os locais onde a mistura (mixing) dos materiais é mais evidente, (Prancha 10, Foto 6, Prancha 11 Fotos 1, 2 e 3) pode ser indicativo então, de volumes maiores de magma máfico. 
Uma das dificuldades encontradas, para confirmação do processo aventado, refere-se a diversas relações texturais observadas os materiais félsico e máfico, como a presença de enclaves com nítida foliação metamórfica, em posições espaciais diversas, em meio aos granitóides (Prancha 10, Fotos 4 e 5 , afloramento K-16). Tal feição pode ser explicada pelo rápido resfriamento do material diorítico, em virtude da pequena quantidade em relação ao material granítico e deformação em estado sólido ou sub-plástico associada à própria colocação do material.

A presença de enclaves formados pelo desmembramento de diques sinintrusivos, relacionados a processos de mingling e mixing de magmas félsico e máfico, pode estar associada a regiōes profundas e colocação destes corpos em áreas distensionais.

As rochas gnáissico-migmatíticas $(\mathrm{K}-17, \mathrm{~K}-44)$ apresentam idades Neoproterozóicas, obtidas em intercepto inferior de Diagrama Concórdia. Tal idade não é registrada na amostra do afloramento $\mathrm{K}-16$, podendo refletir uma maior preservação do sistema isotópico desde o processo de magma mingling. Ressaltase que neste afloramento, não são observadas feições gnáissico-migmatíticas. A rocha granitóide preserva a foliação magmática e, o dique sin-intrusivo máfico é bem evidenciado, mostrando-se rompido e gerando enclaves arredondados. Adicionalmente, ressalta-se que neste afloramento observa-se nítida diferença isotópica entre o enclave máfico e a rocha granitóide associada, $\varepsilon N d,\left(\mathrm{Sr}^{87} / \mathrm{Sr}^{86}\right) \mathrm{i}$, diferença esta não mantida nas demais rochas, talvez por processos de re homogeneização isotópica devida ao evento térmico/migmatítico.

A influência neoproterozóica também pode ser observada na estruturação destas rochas, que desenvolvem bandamento gnáissico, muitas vezes sub-paralelo às foliações miloníticas associadas ao Sistema de Cisalhamento Cubatão e Itariri. Localmente, pode ser observado o total estiramento dos enclaves máficos presentes nestas rochas.

Assim sendo, o processo distensional responsável pela geração destas rochas, teria ocorrido em épocas paleoproterozóicas (1.9 - 2.2 Ga), conforme sugerido pelas idades obtidas pelo método $\mathrm{U}-\mathrm{Pb}$ em zircões em granodiorito e monzogranitos (interceptos superiores), que apresentam interação com material máfico. 
Estas rochas apresentaram idades TDM entre 2.7 e $2.9 \mathrm{Ga}$, com exceção de monzogranito mesocrático aflorante a sul da Serra de Timirim, que apresentou idade TDM de $2.4 \mathrm{Ga}$, como épocas principais de diferenciação dos seus protólitos do manto.

A amostra referente ao gnaisse milonítico da $\mathrm{ZCl}$, mostrou padrão isotópico bastante distinto, apresentando idade TDM Mesoproterozóica, \&Nd bem menos negativo e $\left(\mathrm{Sr}^{87} / \mathrm{Sr}^{86}\right) \mathrm{i}$ mais baixa $(0.710)$ que os valores observados nas demais rochas deste Bloco.

As rochas que ocorrem na porção sudeste de São Paulo, a sul das ZCC e $\mathrm{ZCl}$, já foram correlacionadas às rochas do Domínio Curitiba (Siga Jr., 1995) ou a Microplaca Curitiba, em trabalhos regionais (Campos Neto \& Figueiredo, 1995; Basei et al., 1999).

Neste trabalho, é sugerida a correlação entre as rochas do Bloco Registro, ou seja, dos litotipos aflorantes a sul das ZCC e ZCl, e a norte da ZCS, com as rochas gnáissicas bandadas do Complexo Atuba do Domínio Curitiba (Siga Jr., 1995), por apresentarem características litológicas e geocronológicas semelhantes.

Os dois conjuntos litológicos, representados por rochas granito-gnáissicas migmatíticas, apresentam idades U-Pb (zircões) entre 1.9 e $2.2 \mathrm{Ga}$, com forte retrabalhamento Neoproterozóico, e mostram idades TDM entre 2.8 e $2.7 \mathrm{Ga}$ e localmente $2.4 \mathrm{Ga}$ (Bloco Registro - Gnaisses Serra de Timirim; Complexo Atuba, Gnaisses Mandirituba).

As rochas granito-gnáissicas do Bloco Registro tendem a apresentar $\left(\mathrm{Sr}^{87} / \mathrm{Sr}^{86}\right) \mathrm{i}$ mais elevadas, entre 0.716 e 0.723 , que às razões observadas nas rochas gnáissicas do Complexo Atuba, entre 0.713 e 0.716 (Siga Jr., 1995).

Adicionalmente, rochas gnáissico-granulíticas ocorrem no Domínio Curitiba, a norte da cidade de Curitiba (Siga Jr., op cit.), assim como, no Bloco Registro, as rochas granito gnáissicas migmatíticas estão associadas às rochas granulíticas do Complexo Itatins.

Apesar de não estudado neste trabalho, as rochas granulíticas do Complexo Itatins, podem estar relacionadas a esta importante fase distensiva 
paleoproterozóica, que além de gerar diques sin-intrusivos, pode ter acarretado no metamorfismo do fácies granulito destas rochas, ocorrido próximo a 2.1-2.2 Ga (Picanço et al., 1998).

Os paragnaisses aflorantes no Maciço da Juréia, são aqui correlacionados aos paragnaisses da Sequência Cachoeira (Silva et al., 1981; Dantas et al., 1987), que compreendem kinzigitos e gnaisses kinzigíticos aflorantes na região do Maciço de Itatins, petrograficamente caracterizados por sillimanita-biotita-granada gnaisses (Picanço et al., 1998). A idade U-Pb obtida em monazitas dos paragnaisses da Juréia, em torno de 750 Ma pode esta associada à importante fase de deformação, iniciada em torno de $720 \pm 30 \mathrm{Ma}$ (Picanço 1994), que atingiu até o fácies anfibolito alto (Azevedo Sobrinho, 1995) as rochas do Complexo Itatins e Sequência Cachoeira.

O Granito Votupoca, intrusivo nas rochas gnáissicas migmatíticas, já foi correlacionado por Vasconcellos et al. (1999) aos granitos pós-tectônicos da Suíte Granítica Serra do Mar (Kaul \&Cordani, 1994). Apresentou idade U-Pb em zircões de $582 \mathrm{Ma}$ e idade TDM em torno de $2.3 \mathrm{Ga}$. 


\section{BLOCO IGUAPE}

\subsection{INTRODUÇÃo}

O Bloco Iguape, definido na área de estudo, é limitado a norte pela Zona de Cisalhamento Serrinha (ZCS) e a sudeste pelo Oceano Atlântico. Os litotipos estudados são representados por rochas metassedimentares e rochas graníticas.

Foram investigadas as rochas aflorantes na região próxima a Pariquera-Açu, Serra do Itapitangui, Serra do Cordeiro e Paratiú, Morro do Espia na região de Iguape e região da Serrinha, sendo grande parte da área recoberta por sedimentos recentes (Mapa Geológico - Anexo 1).

\subsection{Características Petrográficas-Estruturais}

\section{ROCHAS METASSEDIMENTARES}

As rochas metassedimentares aflorantes apresentam-se bastante alteradas, com bandamento composicional, normalmente sub-vertical, caracterizado pela alternância de metarenitos finos, homogêneos, e metassiltitos. As cores de alteração variam de cinza-esverdeado a vinho (Prancha 19, Foto 1).

O pacote metassedimentar mostra-se bastante monótono, havendo apenas ora o predomínio de termos mais sílticos ora de termos areníticos finos, caracterizando rochas de baixo grau metamórfico. Comumente os metassedimentos são cortados por inúmeros veios de quartzo.

Localmente apresentam-se cortados por diques básicos, bastante alterados, com cor de alteração verde, onde destacam-se ripas de plagioclásio. Mostram direção preferencial N7OW/sub-verticais, possivelmente associados ao magmatismo Cretáceo.

$\mathrm{Na}$ ZCS, que faz o limite deste bloco com o Bloco Registro, os metassedimentos mostram-se imbricados com milonitos de rochas graníticas, que serão descritos no Capítulo 10.

Estruturalmente apresentam uma foliação principal sub-paralela ao bandamento composicional, com orientação bastante variável, com direções NEE/ com mergulhos fortes para SE e NW, e N2OE/ com mergulhos fortes para SE e 
intermediários para NW (Figura 8.2.1). Os diques de diabásio apresentam orientação preferencial NW e mergulhos sub-verticais.

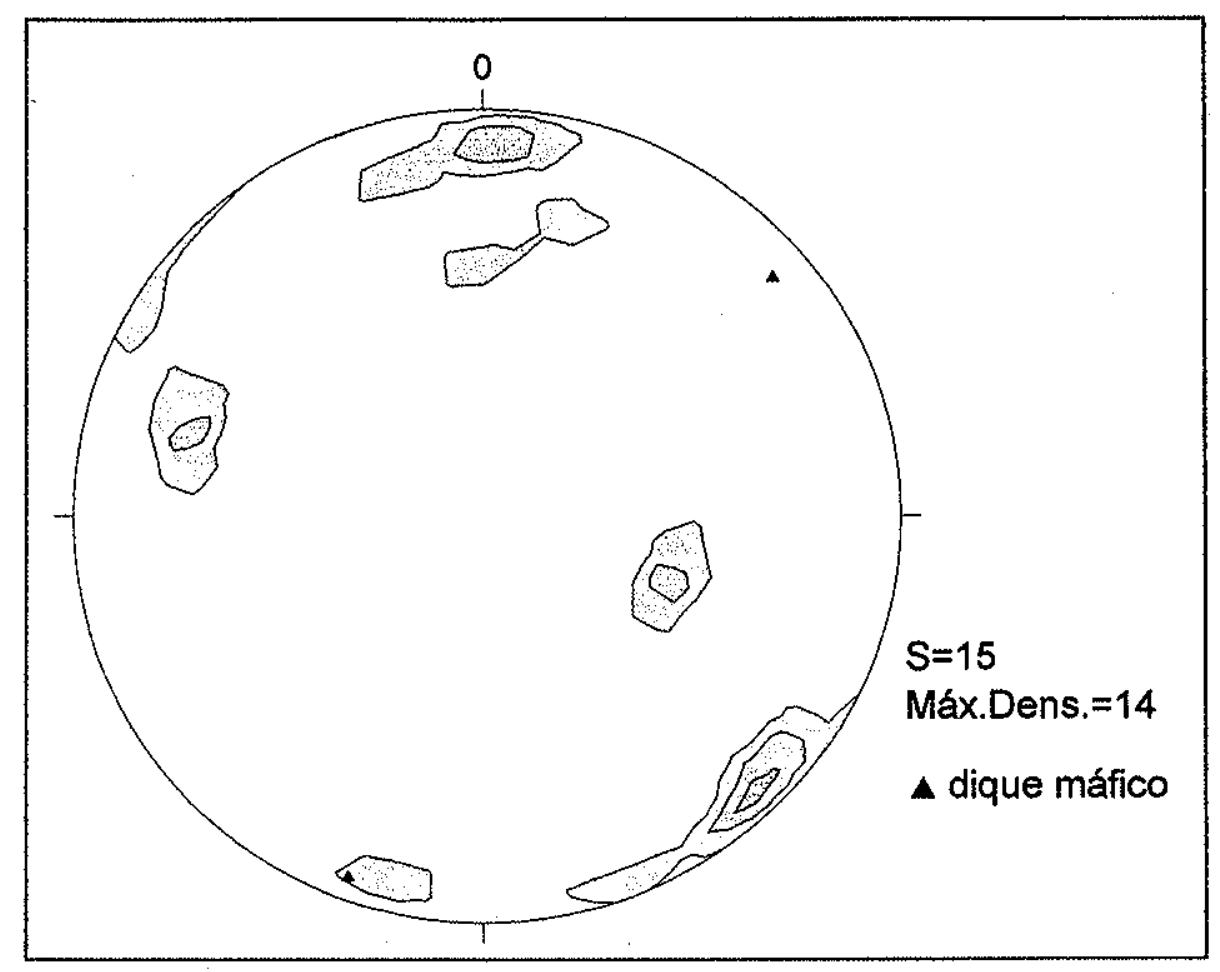

Figura 8.2.1. Bloco Iguape - Metassedimentos. Foliação principal paralela ao bandamento composicional.

\section{ROCHAS GRANITICAS}

As rochas graníticas que ocorrem neste Bloco afloram em três Maciços principais, definidos pela Serra do Itapitangui (extremo sudoeste da área), Serras do Cordeiro/Paratiú e Morro do Espia, na região de Iguape.

\section{Serra do Itapitangui}

A Serra de Itapitangui, apresenta na região investigada $10 \mathrm{~km}^{2}$ de área e eixo maior com orientação N45E. Ocorre no extremo SW da área de estudo, onde afloram biotita-sienogranitos, de granulação fina-média, inequigranulares, foliados, e anfibólio granitos, muito alterados, de granulação média, foliados, com cor de alteração esbranquiçada a avermelhada (Prancha 19, Foto 2). 
Apresentam-se foliados, e levemente deformados. A foliação, caracterizada principalmente pela orientação dos minerais máficos, tem direções principais de N65E/89NW e N52E/70SE, desenvolvendo lineação mineral, com orientação dos máficos em N55E/34. Localmente, a foliação apresenta-se como faixas miloníticas centimétricas.

Os granitos aflorantes na Serra do Itapitangui, foram denominados de Granito Serra de Itapitangui por Morgental et al. (1975) ou Granito Mandira (Oliveira, 1989). Os litotipos investigados podem corresponder às unidades Mandira e Mandira 1 (Oliveira, op cit.).

Petrograficamente os biotita-sienogranitos apresentam textura xenomórfica e os minerais principais quartzo, microclínio e plagioclásio. Como acessórios ocorrem zircão, allanita, apatita e opacos. Muscovita e epídoto ocorrem como minerais de alteração (Prancha 19, Foto 3).

Os grãos de quartzo apresentam-se com extinção ondulante, e recristalizados nas bordas, com contatos serrilhados. Cristais de microclínio formam os maiores cristais da rocha, podem estar fraturados e com pequena recristalização nas bordas, formando textura mortar. São normalmente pertíticos, pertitas em veios, maculados ou tipo spot. Cristais de oligoclásio, são límpidos e ocorrem na matriz.

Biotita apresenta pleocroísmo amarelo-claro a verde, e normalmente é intersticial, geralmente em agregados, associada com epídoto e minerais opacos.

\section{Serras do Paratiú e Cordeiro}

As Serras do Paratiú e do Cordeiro constituem um maciço com aproximadamente $20 \mathrm{~km}^{2}$ de área. Afloram biotita-monzogranitos, normalmente isótropos, de granulação média-grossa, equi a inequigranulares, com megacristais de feldspato potássico centimétricos em matriz média rica em quartzo, com presença de biotita (Prancha 19, Foto 4).

Petrograficamente são constituídos por quartzo, microclínio, plagioclásio e biotita. Como minerais acessórios comuns, ocorrem apatita, allanita, zircão e na Serra do Cordeiro, adicionalmente ocorrem granada e turmalina, muscovita é comum como mineral de alteração. 
Os grãos de quartzo têm forte extinção ondulante, por vezes em recuperação formando sub-grãos, ou recristalizados nas bordas.

Cristais de microclínio formam megacristais, são normalmente subeuédricos, pertíticos (tipo veio, maclas ou spots) e, mais raramente, mesopertíticos.

Cristais de oligoclásio formam megacristais menores, são normalmente subeuédricos, normalmente zonados e saussuritizados na sua porção central.

Biotitas subeuedrais mostram pleocroísmo amarelo-claro a marrom avermelhado. Biotitas esverdeadas apresentam-se normalmente poiquilíticas e mal formadas.

Feição característica deste tipo de granito é a textura formada por biotita e quartzo recristalizado, (Prancha 19, Foto 5), sendo comum ocorrerem como bordas de reação das biotitas sub-euedrais, com contatos bastante irregulares.

Cristais de turmalina apresentam pleocroísmo de incolor a azul, e estão bem formadas, euedrais. Cristais de granada e turmalina podem apresentar-se como inclusões em cristais maiores de microclínio.

\section{Morro do Espia}

$\mathrm{Na}$ região de Iguape, afloram monzogranitos de cor cinza, quando frescos, e cor alaranjada quando alterados, a megacristais brancos de feldspato potássico centimétricos, comumente euedrais, em matriz cinza média rica em quartzo com biotita.

Normalmente estão foliados, e deformados, podendo desenvolver foliação protomilonítica e localmente faixas miloníticas. Nas rochas protomiloníticas apresentam porfiroclastos de microclínio e oligoclásio, em matriz de granulaçãa média (Prancha 20, Foto 1). A lineação mineral é bastante desenvolvida, sendo caracterizada pelo forte estiramento dos feldspatos e quartzo, e orientação de biotita e muscovita, caracterizando tectonitos do tipo $\mathrm{L}$.

As rochas protomiloníticas, localmente com faixas miloníticas, afloram próximas à região da cidade de lguape, e desenvolvem foliações miloníticas com duas direções principais distintas, uma de direção geral NE e outra NW. 
No diagrama da Figura 8.2.2 estão representados os polos e os respectivos grande-círculos de dois grupos de foliações miloníticas: 1) um com direção em torno de N60E, e mergulhos intermediários a fracos para SE e NW (preto), desenvolvendo lineação de estiramento mineral com caimentos para NE e SW; 2) outro com direção em torno de N15W/24SW (azul), desenvolvendo lineações de estiramento mineral com caimentos fracos para SW.

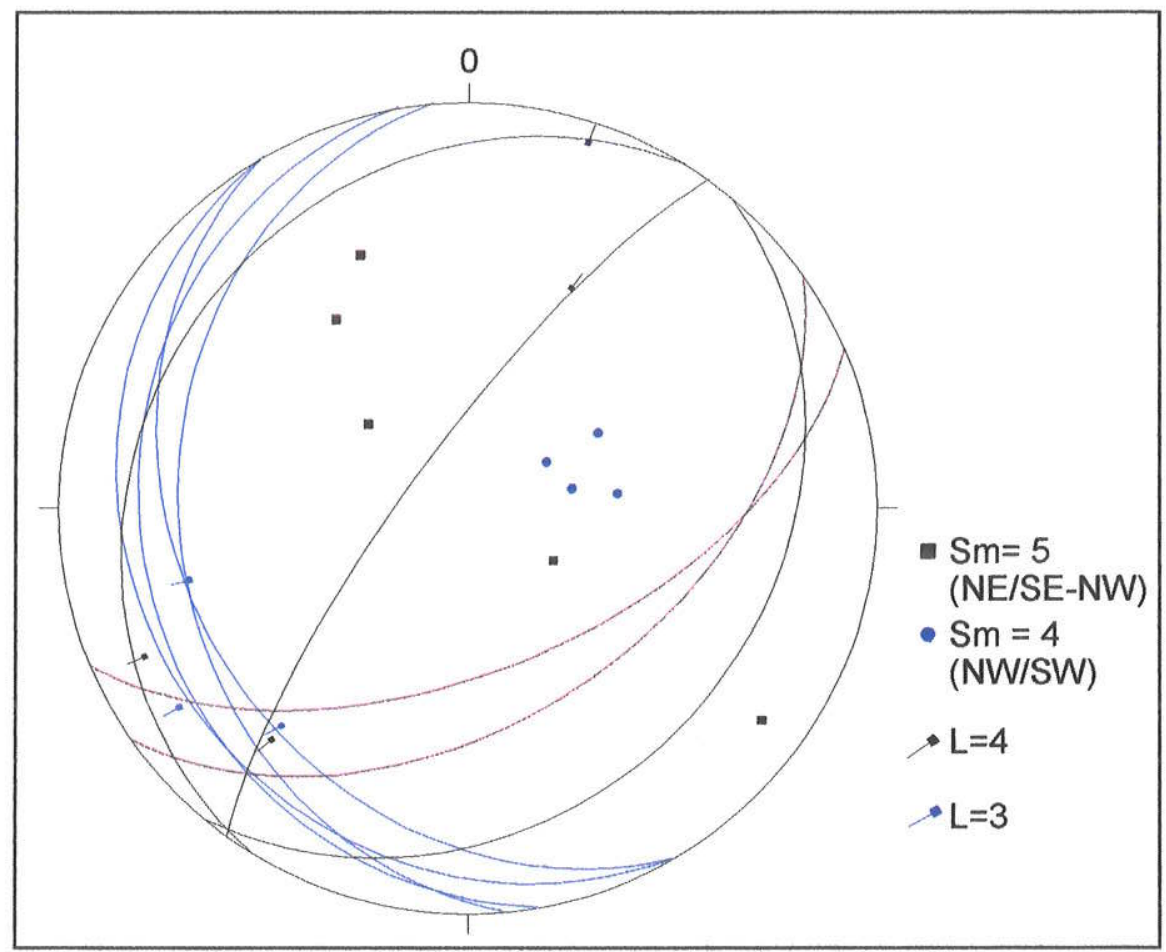

Figura 8.2.2. Bloco Iguape - Granitos miloníticos.

1) As rochas protomiloníticas que apresentam orientação NE e mergulhos intermediários para SE, ocorrem a norte da cidade de Iguape, e apresentam movimentação dextral (Prancha 20, Foto 2). Desenvolvem lineações de estiramento mineral com caimentos para SW (S40W/26, S65W/14). Assim sendo, apresentam componentes distensivas, com transporte para SW.

Protomilonitos que ocorrem próximo a cidade de Iguape, desenvolvem foliação NE, com mergulhos para NW, e lineação de estiramento mineral com caimentos intermediários a fracos para NE. Também mostram numa movimentação dextral, uma componente de distensão para SW.

2) Rochas miloníticas apresentam direções em torno de N20W com mergulhos fracos para SW, desenvolvendo lineação mineral caracterizada pelo 
estiramento de quartzo e orientação de micas, com caimentos fracos a intermediários para SW. Através de estruturas dobradas em remobilizados quartzofeldspáticos e pares S-C, há sugestão de transporte para SW, numa componente normal (Prancha 20, Foto 3).

No extremo leste do Maciço de Iguape, as rochas monzograníticas mostramse foliadas, porém não desenvolvem foliação protomilonítica. Apresentam granulação fina, e foliação magmática sub-horizontal caracterizada principalmente pela orientação de biotitas (Prancha 20, Foto 4). Apresentam como direções principais N46E/24 NW e N30E/20SE.

Petrograficamente, as rochas graníticas aflorantes na região de Iguape, caracterizam-se pela mineralogia principal: quartzo, microclínio, oligoclásio, e como máfico a biotita. Acessórios comuns são: zircão, apatita, muscovita, granada e. ocasionalmente turmalina.

A textura protomilonítica caracteriza-se pelo padrão anastomosado, com porfiroclastos de microclínio e plagioclásio sigmoidais e, segregação de quartzo e orientação de biotita (Prancha 21, Foto 1).

Os porfiroclastos de microclínio são pertíticos (maclas e veios), mostram textura mortar, caracterizada pela recristalização nas bordas de pequenos grãos (Prancha 21, Foto 2).

Os cristais de plagioclásio formam porfiroclastos menores, normalmente saussuritizados. Podem apresentar-se zonados com inclusões de biotitas dispostas paralelamente ao zoneamento.

Na matriz ocorrem cristais de feldspatos menores, quartzo e biotita.

Os cristais maiores de quartzo apresentam forte extinção ondulante, ou em recuperação, tendendo a formar sub-grãos. Onde a foliação protomilonítica é bem desenvolvida, mostram-se bastante segregados, normalmente bem recristalizados com contatos poligonizados (Prancha 21, Foto 1) e cristalograficamente bem orientados.

Os cristais de biotita maiores, com pleocroísmo amarelo claro a marrom avermelhado, podem apresentar extinção ondulante e cristais menores constituem a matriz, juntamente com quartzo, muscovita e minerais opacos, mostrando contatos irregulares. Podem alterar-se para biotita verde e clorita. 
Muscovitas, quando bem desenvolvidas podem apresentar extinção ondulante.

Cristais de granada normalmente apresentam-se fraturadas, e podem conter inclusões de quartzo. As fraturas normalmente estão preenchidas por sericita e biotita (Prancha 21, Foto 3).

Nos granitos onde a foliação protomilonítica não está bem desenvolvida, observa-se uma textura rúptil-dúctil, definida pelo forte fraturamento e cominuição dos feldspatos. Os cristais maiores "proto-porfiroclastos' de feldspato potássico e. plagioclásio, muito fraturados e cominuídos, apresentam fraturas preenchidas por quartzo e muscovita (Prancha 21, Foto 4).

Os cristais de microclínio são pertíticos (em filmes, veios e maclas), sendo comum a presença de inclusões de plagioclásio, com desenvolvimento de feições. mirmequíticas. Não raramente mostram-se mesopertíticos.

Cristais de plagioclásio normalmente estão saussuritizados e zonados, podendo apresentar deformação nas maclas. Na matriz é comum apresentarem feições antipertíticas.

Os cristais de biotita mostram pleocroísmo amarelo-claro a marrom avermelhado, e podem apresentar extinção ondulante. Alteram para muscovita e biotita verde.

A norte da regiấo de Iguape ocorrem biotita-monzogranitos leucocráticos a mesocráticos, que encontram-se afetados pela ZCS. Apresentam textura protomilonítica caracterizada principalmente pelo estiramento dos cristais de feldspato potássico e quartzo, e orientação das biotitas. Como minerais acessórios apresentam zircão, granada, muscovita e monazitas. Estas rochas serão oportunamente descritas e discutidas no Capítulo 10, referente à ZCS. 


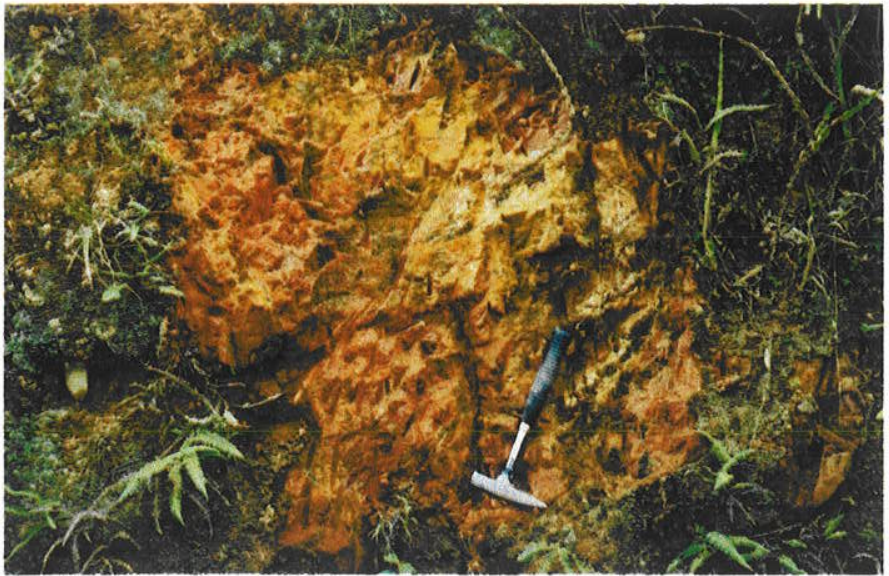

Foto 1 - Metarenitos finos, homogêneos, maciços. Região de Pariquera- Açu. Afloramento K-93.

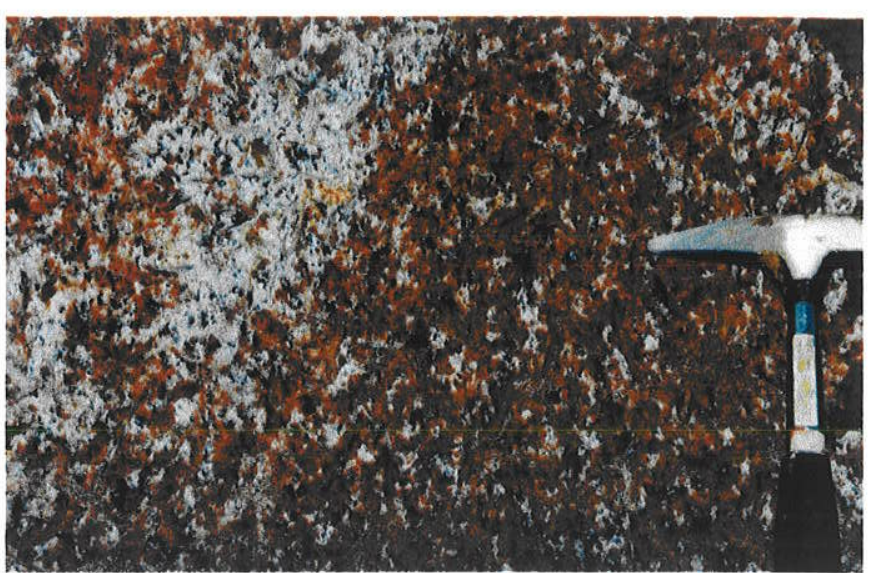

Foto 2 - Anfibólio sienogranito alterado foliado, de granulação média. Serra do Itapitangui. Afloramento K-31.

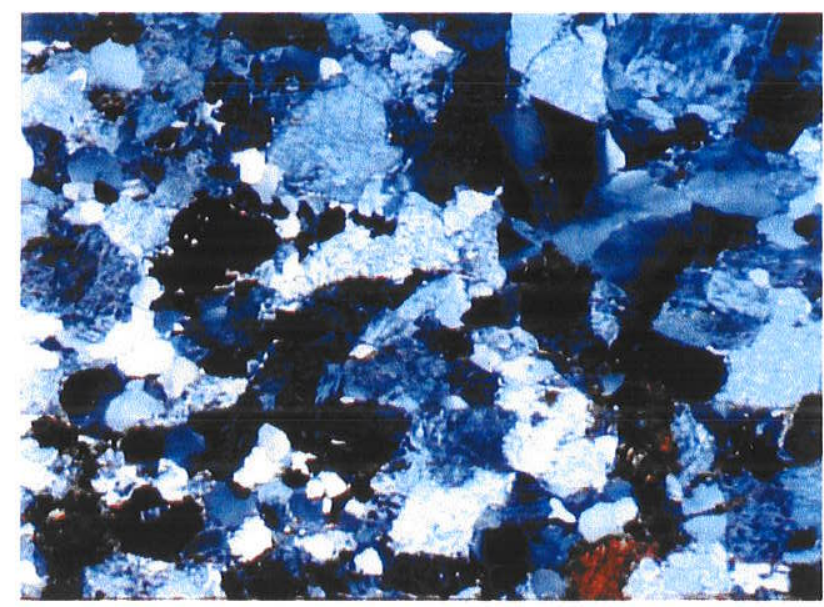

Foto 3 - Fotomicrografia (nicóis $X$, aumento 10.5x). Textura xenomórfica de biotita-sienogranito. Amostra K-31 (corte XZ).

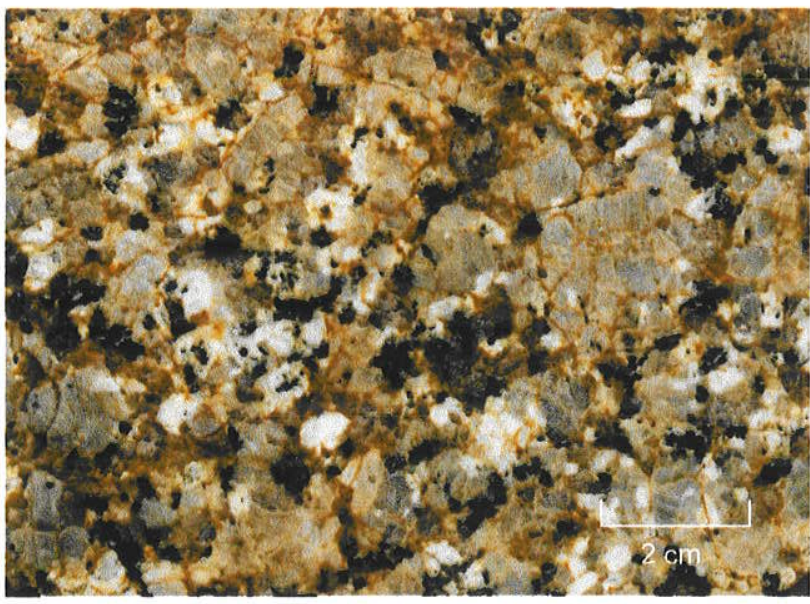

Foto 4 - Biotita monzogranito de granulação grossa, inequigranular. Serra do Cordeiro. Afloramento K-34.

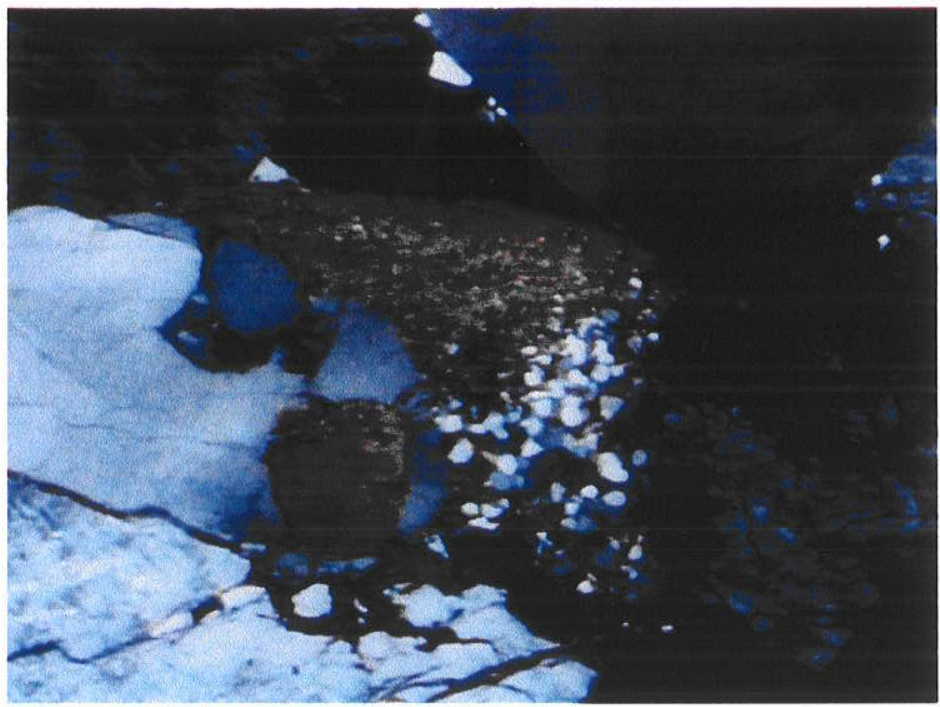

Foto 5 - Fotomicrografia (nicóis $\mathrm{X}$, aumento $35.5 \mathrm{x}$ ). Biotitamonzogranito. 'Borda de reação' entre biotita e quartzo recristalizado. Amostra K-34. 


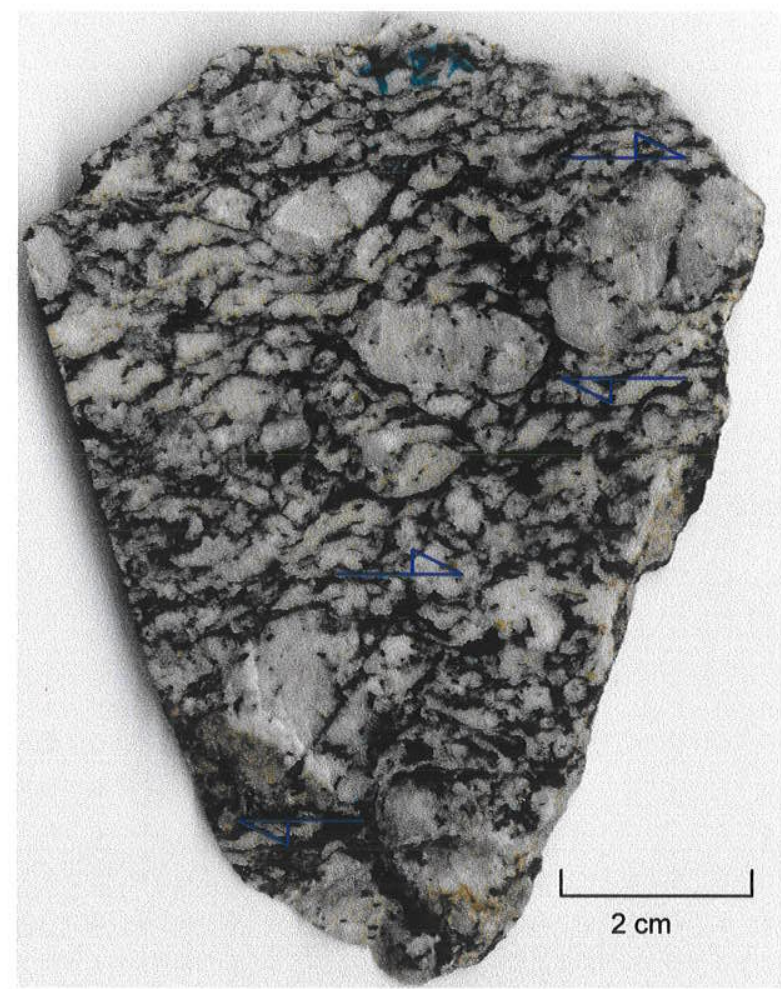

Foto 1 - Corte $X Z$ de protomilonito granítico. Porfiroclastos de feldspatos sugerem movimentação dextral. Morro do Espia. Afloramento K-100.

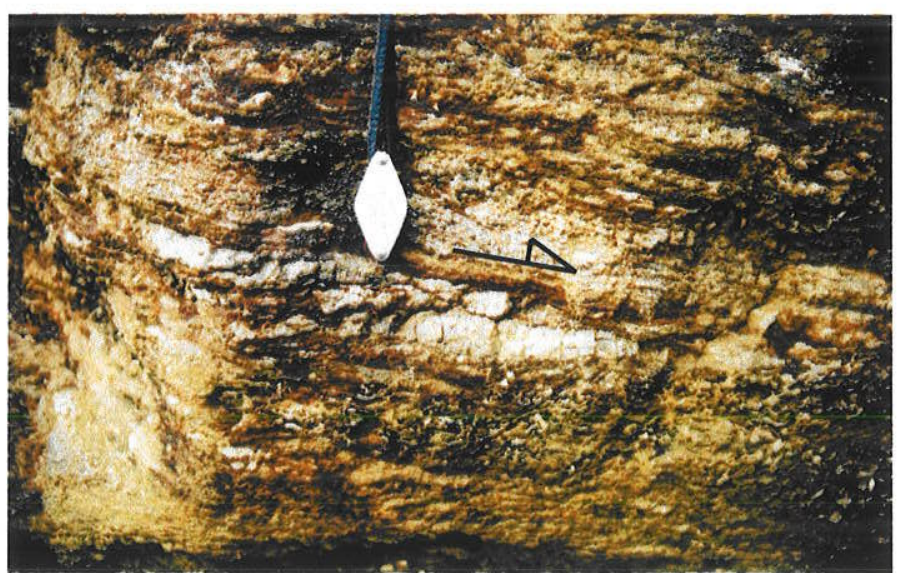

Foto 3 - Remobilizados quartzo-feldspáticos em protomilonito granítico com estruturas dobradas sugerindo transporte para SW, componente normal. Foliação N10W/21 SW. Extremo NE do Maciço de Iguape. Afloramento K-38.

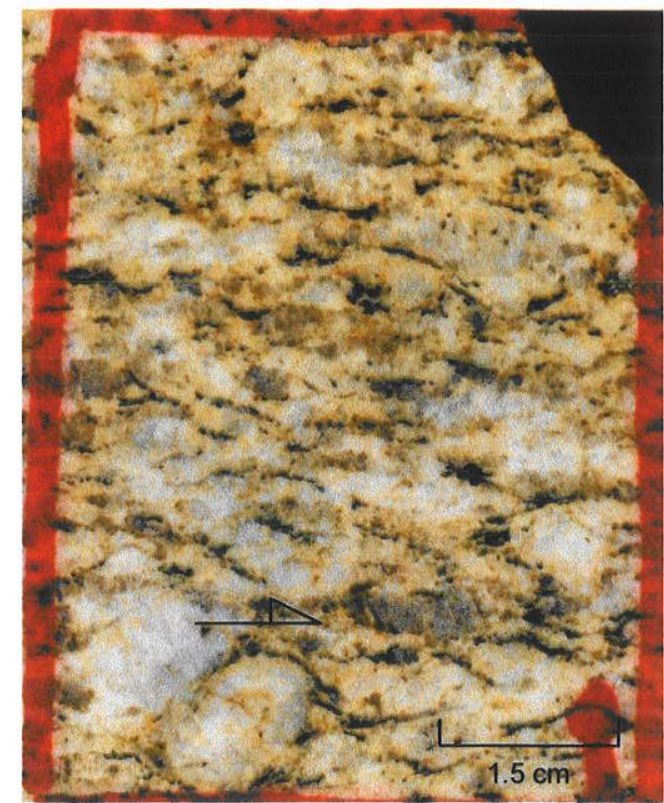

Foto 2 - Corte $X Z$ de protomilonito granítico. Porfiroclasto de feldspato sugere indicação dextral. Norte de Iguape. Afloramento K-37.

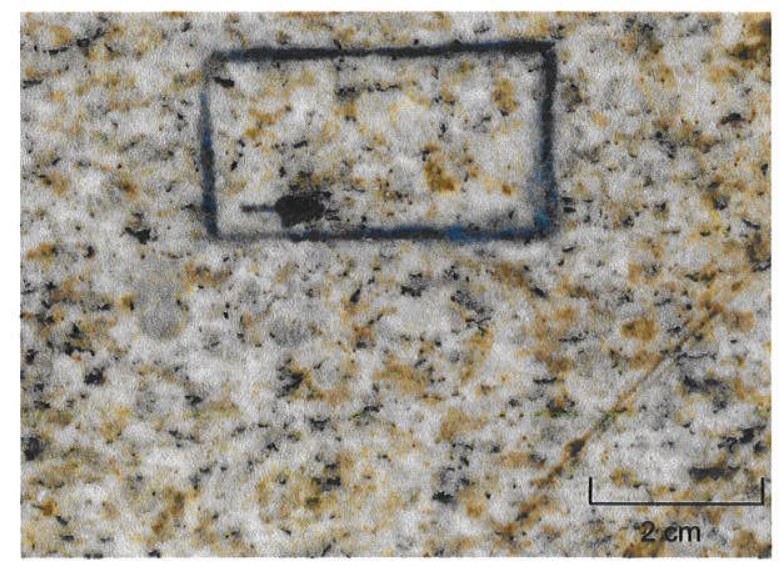

Foto 4 - Biotita-monzogranito apresentando foliação caracterizada pela orientação de biotitas. Leste do Maciço de iguape. Afloramento K-66. 


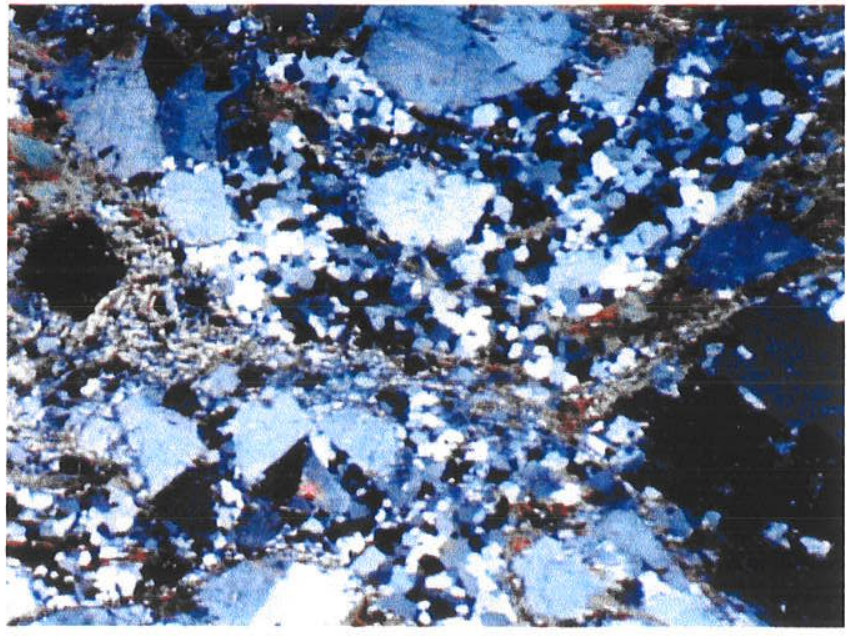

Foto 1 - Fotomicrografia (nicóis $\mathrm{X}$, aumento 10.5 x). Foliação milonítica anastomosada em protomilonito granítico. Porfiroclastos de microclínio e plagioclásio e segregação de cristais de quartzo recristalizados, com contatos poligonais. Amostra K-100 (corte XZ).

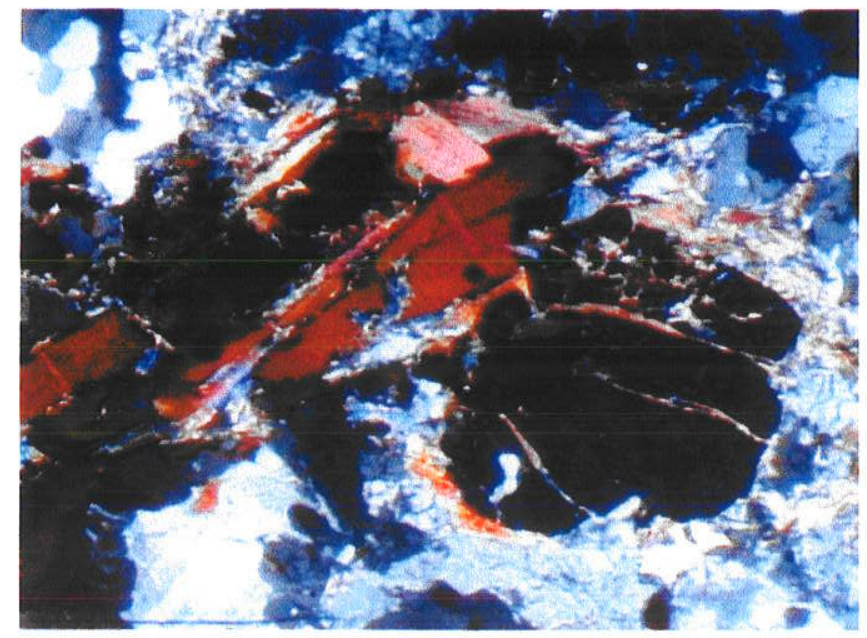

Foto 3 - Fotomicrografia (nicóis $\mathrm{X}$, aumento $35.5 \mathrm{x}$ ). Porfiroclasto de granada com fraturas preenchidas por sericita e biotita em protomilonito granítico. Amostra K-36 (corte XZ).

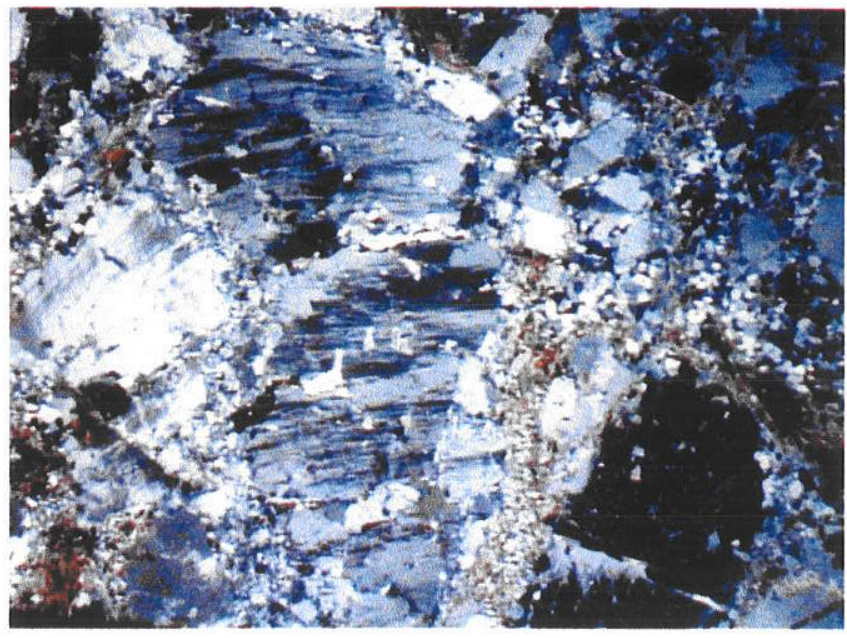

Foto 2 - Fotomicrografia (nicóis $\mathrm{X}$, aumento $5.5 \mathrm{x}$ ). Textura mortar em porfiroclastos de microclínio em protomilonito granítico. Amostra K-100 (corte XZ).

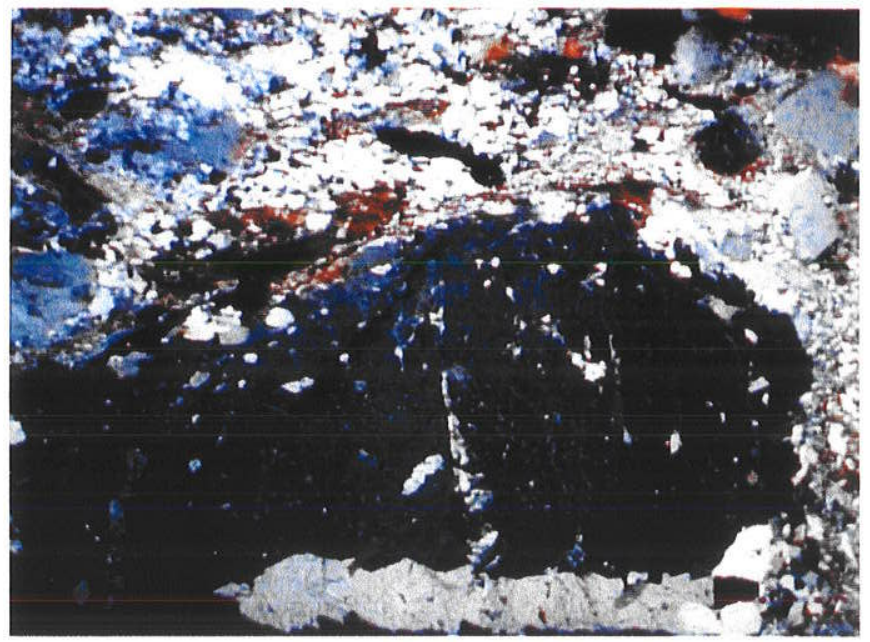

Foto 4 - Fotomicrografia (nicóis $\mathrm{X}$, aumento $5.5 \mathrm{x}$ ). Textura em granito deformado caracterizada pelo forte fraturamento dos minerais com início da formação de porfiroclastos e matriz. Amostra K-64 (corte XZ). 
Foram realizadas análises pelo método de Fry (Fry, 1979, 1999), em seções delgadas de cortes $X Z$ e $Y Z$, em quatro rochas graníticas das Serras do itapitangui e da região de Iguape. Não foram analisadas amostras graníticas da Serra do Cordeiro e Paratiú, pois estas apresentam-se isótropas.

Uma análise é referente ao biotita-sienogranito (K-31) foliado de Itapitangui (Prancha 19, Foto 2). A amostra refere-se à sua porção mais representativa, que apresenta-se levemente deformado, de granulação fina a média.

Duas análises referem-se a granitos protomiloníticos (K-100 e K-37) da região de Iguape (Prancha 20, Fotos 1 e 2), que apresentam indicações cinemáticas dextrais.

Uma análise refere-se a um biotita-monzogranito foliado que ocorre no extremo leste do Maciço de Iguape (K-66), que apresenta uma foliação caracterizada pela orientação de feldspatos e biotita.

A orientação dos eixos principais do elipsóide de deformação estão listados na Tabela 8.2.1, juntamente com as orientações da foliação principal da rocha e lineação mineral.

\begin{tabular}{|c|c|c|c|c|c|c|c|}
\hline \multirow[b]{2}{*}{ AMOSTRA } & \multirow[b]{2}{*}{ ROCHA } & \multirow[b]{2}{*}{$\mathbf{s}$} & \multirow[b]{2}{*}{ L } & \multicolumn{3}{|c|}{ EIXOS DO ELIPSÓIDE DE DEFORMAÇÁO } & \multirow[b]{2}{*}{ MOVIMENTO } \\
\hline & & & & EixoX & EIxOY & Eixo Z & \\
\hline K-31 & Granito foliado & N52E/70SE & N55E/34 & N53E/32 & $S 12 W / 48$ & N37W/4 & \\
\hline K-37 & Protomilonito & N67E/57SE & $\mathrm{S} 65 \mathrm{~W} / 14$ & S58W/8 & S35E/25 & $\mathrm{N} 32 \mathrm{~W} / 50$ & Dextral \\
\hline $\mathrm{K}-66$ & Granito foliado & $\mathrm{N} 30 \mathrm{E} / 20 \mathrm{SE}$ & $S 46 E / 20$ & $\mathrm{~N} 30 \mathrm{~W} / 27$ & $\mathrm{~N} 3 \mathrm{~W} / 43$ & N60E/70 & \\
\hline $\mathrm{K}-100$ & Protomilonito & N32E/20NW & N18E/6 & N17E/0 & N75W/45 & S72E $/ 70$ & Dextral \\
\hline
\end{tabular}

Tabela 8.2.1 - Direção da foliação e lineação mineral principal das amostras analisadas $e$ orientação dos eixos do elipsóide obtidos pelo Método de Fry.

Como pode ser observado na Tabela 8.2.1, houve concordância entre a orientação do eixo $X$ do elipsóide de deformação (direção de máxima extensão) e a lineação de estiramento mineral medidas nas rochas protomiloníticas. Adicionalmente, também houve concordância entre a orientação da lineação mineral medida no granito foliado, levemente deformado, K-31, com a orientação obtida do eixo $X$ do elipsóide de deformação, característica esta, não observada no granito foliado $\mathrm{K}-66$. 
Observa-se que a direção de maior estiramento (NW-SE) nas rochas protomiloníticas, apresentou, apesar da diferença no caimento dos eixos $X$ valores sub-horizontais, e a direção de maior encurtamento (NE-SW) valores altos a subverticais.

As direções dos eixos $\mathrm{X}$ e $\mathrm{Z}$, obtidas para os granitos foliados, apesar de concordar com os valores das respectivas lineações minerais, não apresentaram concordância entre si.

A Figura 8.2.3 mostra as elipses e seus respectivos eixos principais obtidos pelo método de Fry. A posição do traço da foliação principal (magmática e protomilonítica) nos cortes $X Z$ e $Y Z$ é vertical, e a horizontal da direção de cada corte, bem como sua orientação estão indicados na porção superior de cada figura.

O posicionamento das elipses de deformação nas rochas protomiloníticas (K37 e K-100) em relação à foliação indicam movimentação dextral, de acordo com as indicações cinemáticas observadas em campo e seções delgadas. Observa-se razoável deformação associada a estas rochas, devido às elipsidades observadas.

As elipsidades obtidas pelo método de Fry para os granitos foliados indicaram pouca deformação associada. No entanto nota-se uma maior deformação no biotita sienogranito (K-31) em relação ao biotita-monzogranito (K-66), que mostra-se praticamente não deformado.

As orientações dos eixos do elipsóide de deformação obtidas para os granitos foliados possivelmente apresentam forte influência do fluxo magmático. Entretanto, ressalta-se que podem ser orientações imprecisas devido às baixas elipsidades observadas (Figura 8.2.3), ver Mapa Estrutural - Anexo 2.

As elipsidades obtidas pelo Método de Fry, Tabela 8.2.2, consequentemente foram utilizados para obtenção dos parâmetros necessários ( $R x y, K, D)$ para o conhecimento da forma do elipsóide de deformação (Diagrama de Flinn).

\begin{tabular}{|c|c|c|c|c|c|c|c|}
\hline AMOSTRA & $\mathbf{R X Z}$ & $\mathbf{R Y Z}$ & $\mathbf{R X Y}$ & $\mathbf{K}$ & $\mathbf{D}$ & ELIPSÓIDE & DIAGRAMA DE FLINN \\
\hline K-31 & 1.4 & 1.2 & 1.17 & 0.85 & 0.26 & Triaxial & Deformaçăo plana \\
\hline K-37 & 2.1 & 1.3 & 1.6 & 0.5 & 0.45 & Prolato & Constricçăo aparente \\
\hline K-66 & 1.2 & 1.1 & 1.09 & 0.9 & 0.13 & Triaxial & Deformaçăo plana \\
\hline K-100 & 1.9 & 1.2 & 1.58 & 2.9 & 0.61 & Prolato & Constriccăo aparente \\
\hline
\end{tabular}

Tabela 8.2.2 - Dados obtidos pelo método de Fry e aplicação de Diagrama de Flinn. 

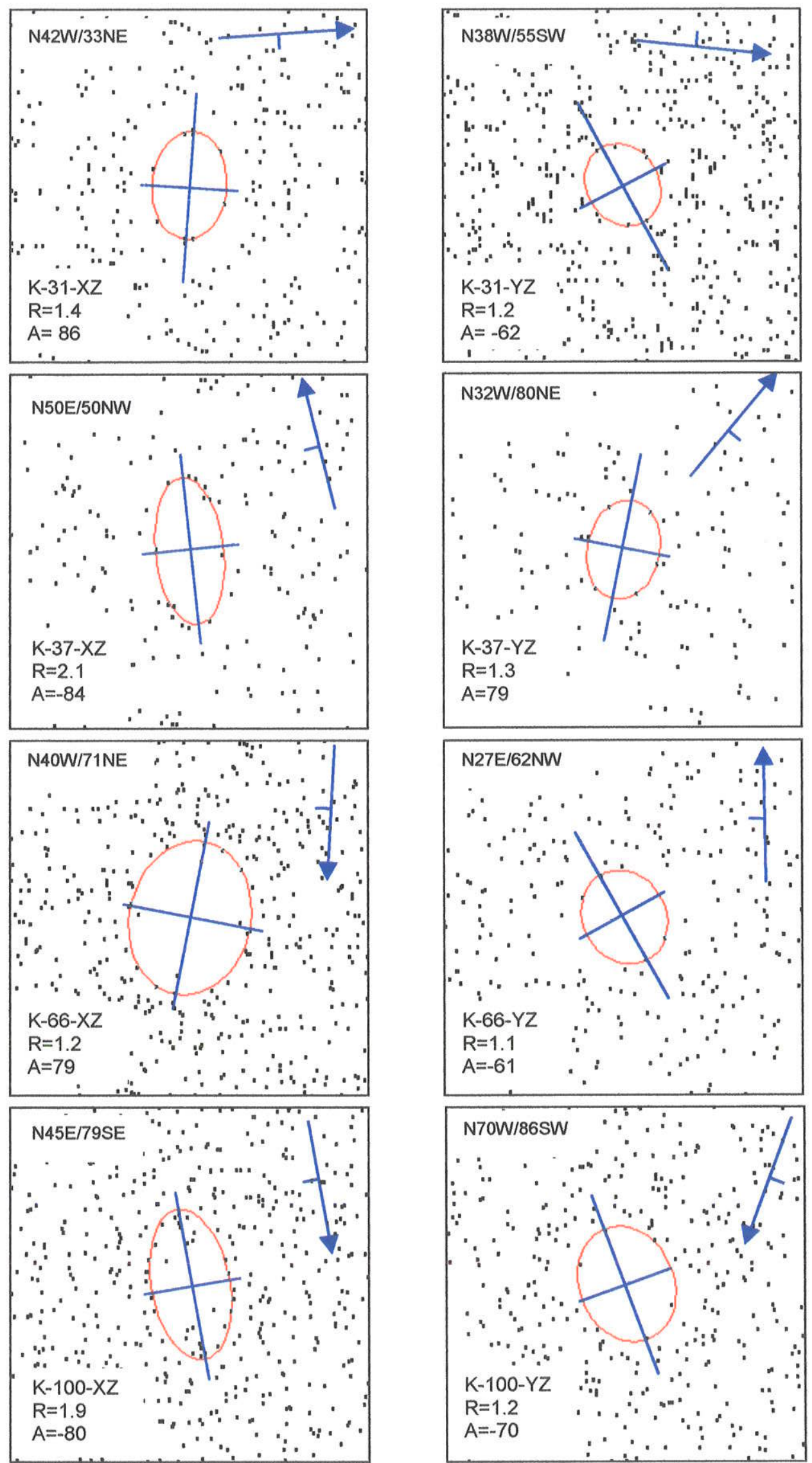

Figura 8.2.3 - Método de Fry aplicado às rochas graníticas do Bloco Iguape. 
Em diagrama de Flinn (Figura 8.2.4), os granitos foliados, plotaram no campo da deformação plana, com valores de $K$ próximos a 1. Por tratarem-se de rochas muito pouco deformadas, a geração de elipsóides compatíveis com deformação sem perda ou ganho de volume, possivelmente relaciona-se ao fluxo magmático.

0 protomilonitos aflorantes na região de lguape (K-37, K-100), estão relacionados a uma constriç̧ão geral com geração de elipsóides prolatos. Estas rochas devem ter registrado momentos extensionais dentro do mesmo processo de deformação, associada a uma movimentação dextral. Tal fato, corrobora com as observações de campo, por tratarem-se de rochas miloníticas forte estiramento mineral, caracterizando tectonitos do tipo $L$.

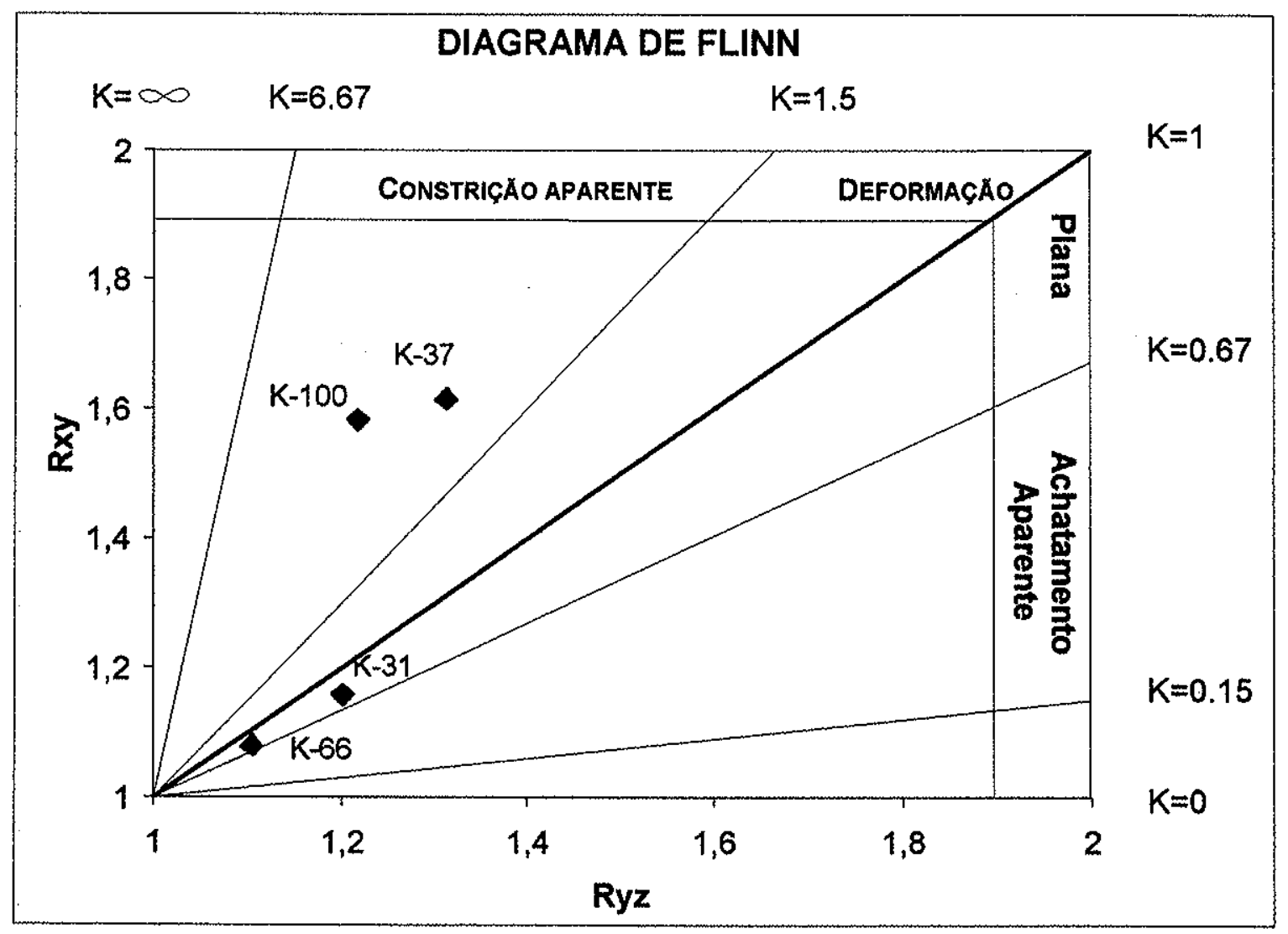

Figura 8.2.4 - Diagrama de Flinn. Granitos Bloco Iguape. 


\subsection{Caracterização Geoquímica}

Foram realizadas análises geoquímicas de elementos maiores, traços e Terras Raras das rochas graníticas do Bloco Iguape. As rochas graníticas referemse a Serra do Itapitangui (K-31), Serra do Paratiú (K-60 e K-61), aos granitos aflorantes próximo a cidade de Iguape (K-36, K-37, K-64 e K-100), e ao granito afetado pela ZCS (K-102). Os afloramentos cujas amostras foram quimicamente investigadas, encontram-se assinalados no Mapa Geológico - Anexo 1, e os resultados analíticos obtidos estão listados no Apêndice 1.

Em Diagrama de Maniar \& Piccoli (1989), a amostra representativa do sienogranito Itapitangui $\left(\mathrm{SiO}_{2}=77.07 \%\right)$, mostra uma tendência peralcalina, os monzogranitos da Serra do Paratiú (71.38 e $75.24 \%$ de $\mathrm{SiO}_{2}$ ), apresentam caráter metaluminoso a peraluminoso. Os demais granitos, da região de lguape (valores de $\mathrm{SiO}_{2}$ entre $68 \%$ e $\left.76 \%\right)$ e o granito afetado pela $\mathrm{ZCS}\left(\mathrm{SiO}_{2}=70 \%\right)$, apresentam características peraluminosas (Figura 8.3.1). Este último, protomilonito - ZCS (K-102) diferencia-se das demais rochas, possuindo um caráter mais peraluminoso, tendo em sua mineralogia acessórios como granada e monazita.

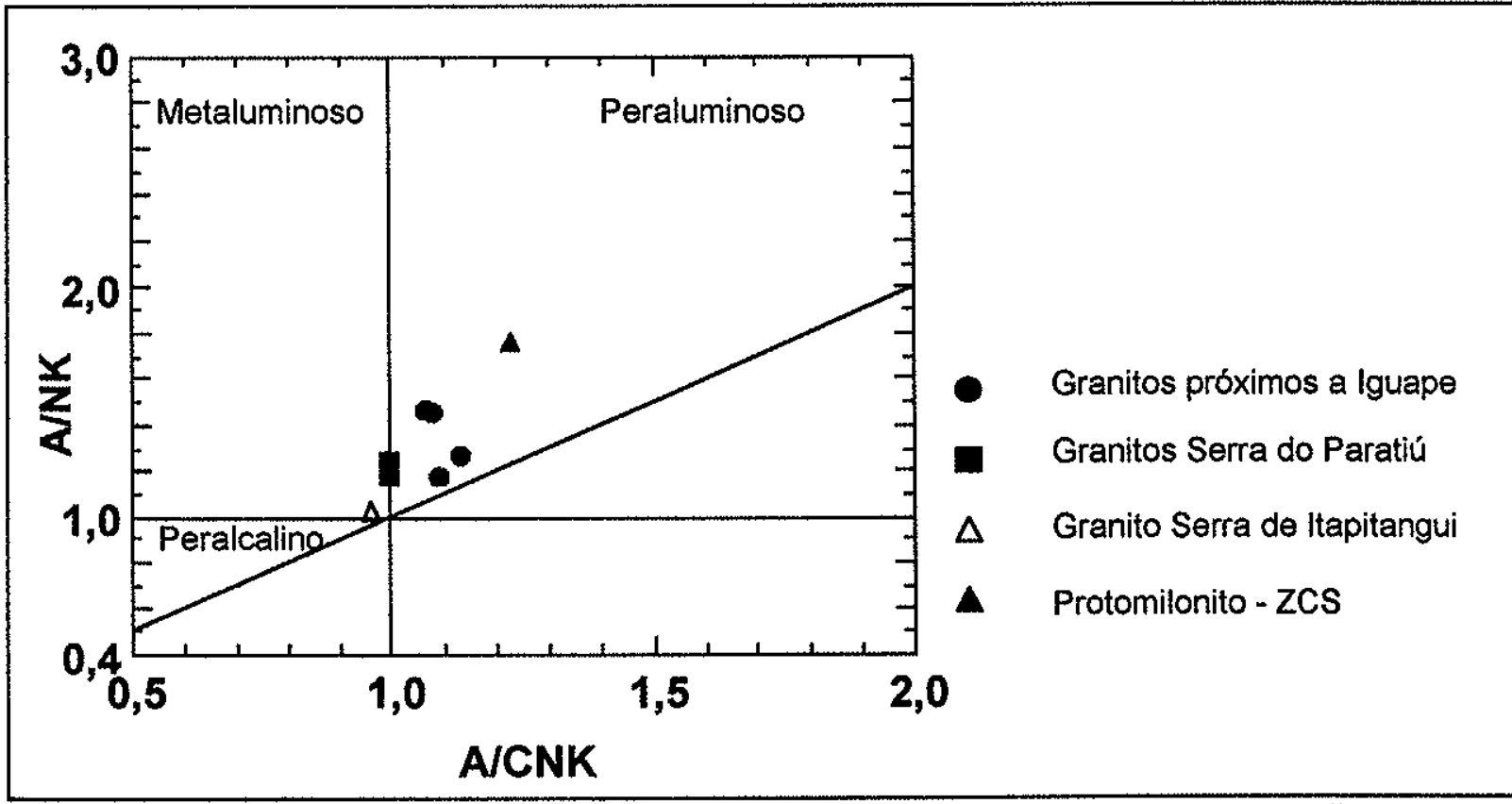

Figura 8.3.1 - Diagrama de razóes moleculares A/CNK $\times$ A/CNK (Maniar \& Piccoli, 1989). Granitos - Bloco Iguape. 
Como pode ser observado em Diagrama $\mathrm{Na}_{2} \mathrm{O} \times \mathrm{K}_{2} \mathrm{O}$ (Figura 8.3.2), a maioria das rochas graníticas que compõem o Bloco Iguape, pertencem a séries potássicas, incluindo as rochas do Maciço de Iguape, o protomilonito - ZCS e o sienogranito da Serra do Itapitangui. Os granitos da Serra do Paratiú se destacam um pouco dos demais por conterem teores um pouco mais elevados de $K$, posicionando-se no campo das séries de alto $K$.

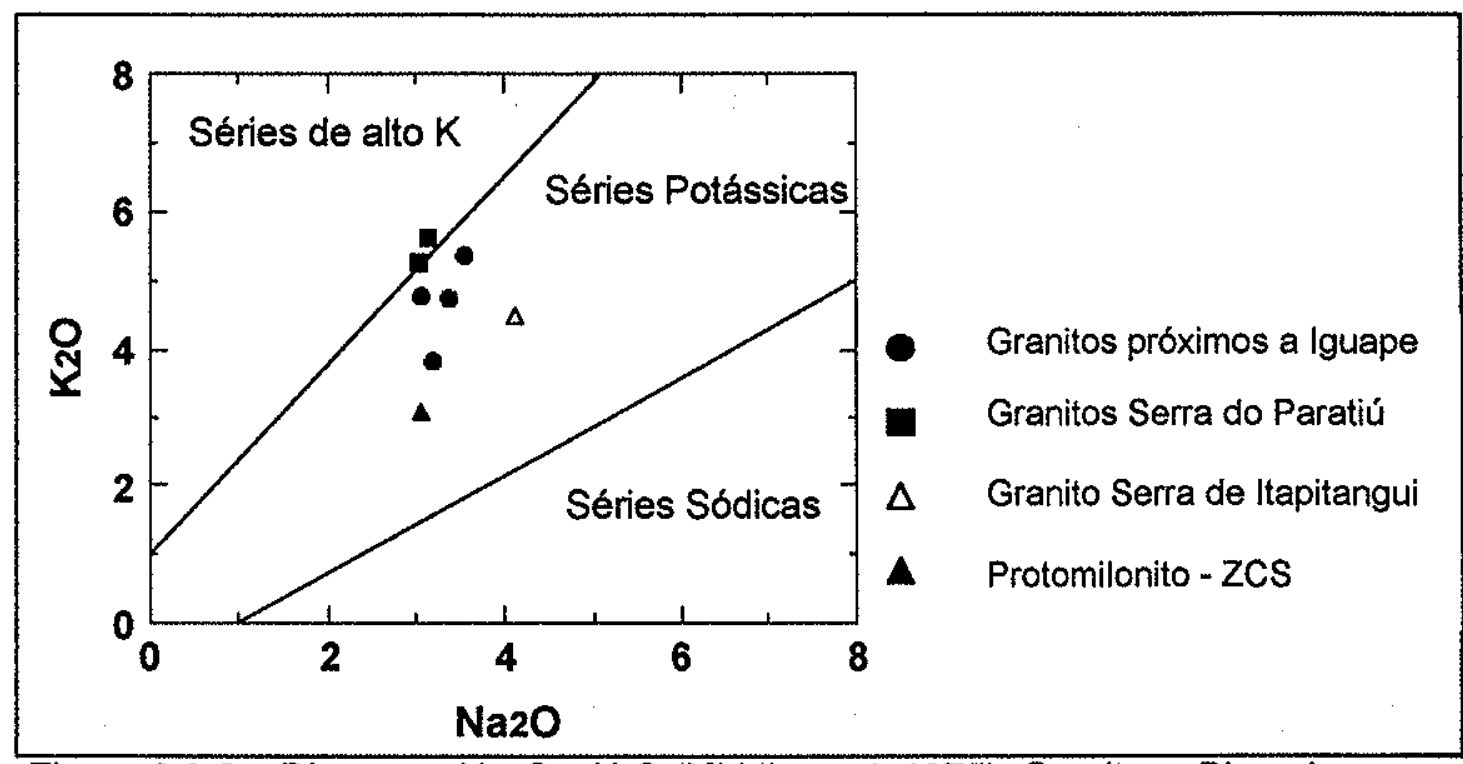

Figura 8.3.2 - Diagrama $\mathrm{Na}_{2} \mathrm{O} \times \mathrm{K}_{2} \mathrm{O}$ (Middlemost, 1975). Granitos - Bloco Iguape.

Em diagrama discriminante de Pearce et al. (1984), $(\mathrm{Y}+\mathrm{Nb}) \times \mathrm{Rb}$, Figura 8.3.3, observa-se que as rochas das Serras do Paratiú e Itapitangui, plotam no campo definido para granitos do tipo intra-placas. As rochas aflorantes no Maciço de Iguape, se dividem em dois grupos. Um grupo é representado pelas amostras (K-36 e K-37), afloramentos situados mais a norte da cidade de Iguape (Mapa Geológico Anexo 1), que plotam no campo dos granitos sin-colisionais. Outro, representado, neste diagrama, pela amostra (K-64), situado próximo à cidade de Iguape plota no campo de granitos característicos de arco vulcânico.

A diferença observada nos granitos do Maciço Iguape, também é observada em diagrama ternário $\mathrm{Rb} \times \mathrm{Ba} \times \mathrm{Sr}$ (Figura 8.3.4). As rochas situadas próximas à cidade de Iguape, apresentam-se mais enriquecidas em Ba (K-64, 462 ppm; K-100, 1002 ppm) em relação aos granitos situados mais a norte da cidade de Iguape (K36, $115 \mathrm{ppm} ; \mathrm{K}-37,229 \mathrm{ppm}$ ). O granito da Serra de Itapitangui mostra os teores mais baixos de $\mathrm{Ba}$ (102 ppm) e $\mathrm{Sr}$ (17 ppm) e o teor mais elevado em Rb (338 ppm) 
em relação aos demais granitos. Os granitos da Serra de Paratiú, apresentam, por sua vez, teores semelhantes de $\mathrm{Ba}$ (K-60, 968 ppm; K-61, 432 ppm) em relação aos granitos aflorantes próximos à cidade de lguape $(K-64, K-100)$, mas com teores bem mais baixos de $\mathrm{Sr}$ (K-60, 102 ppm; K-61, 63 ppm).

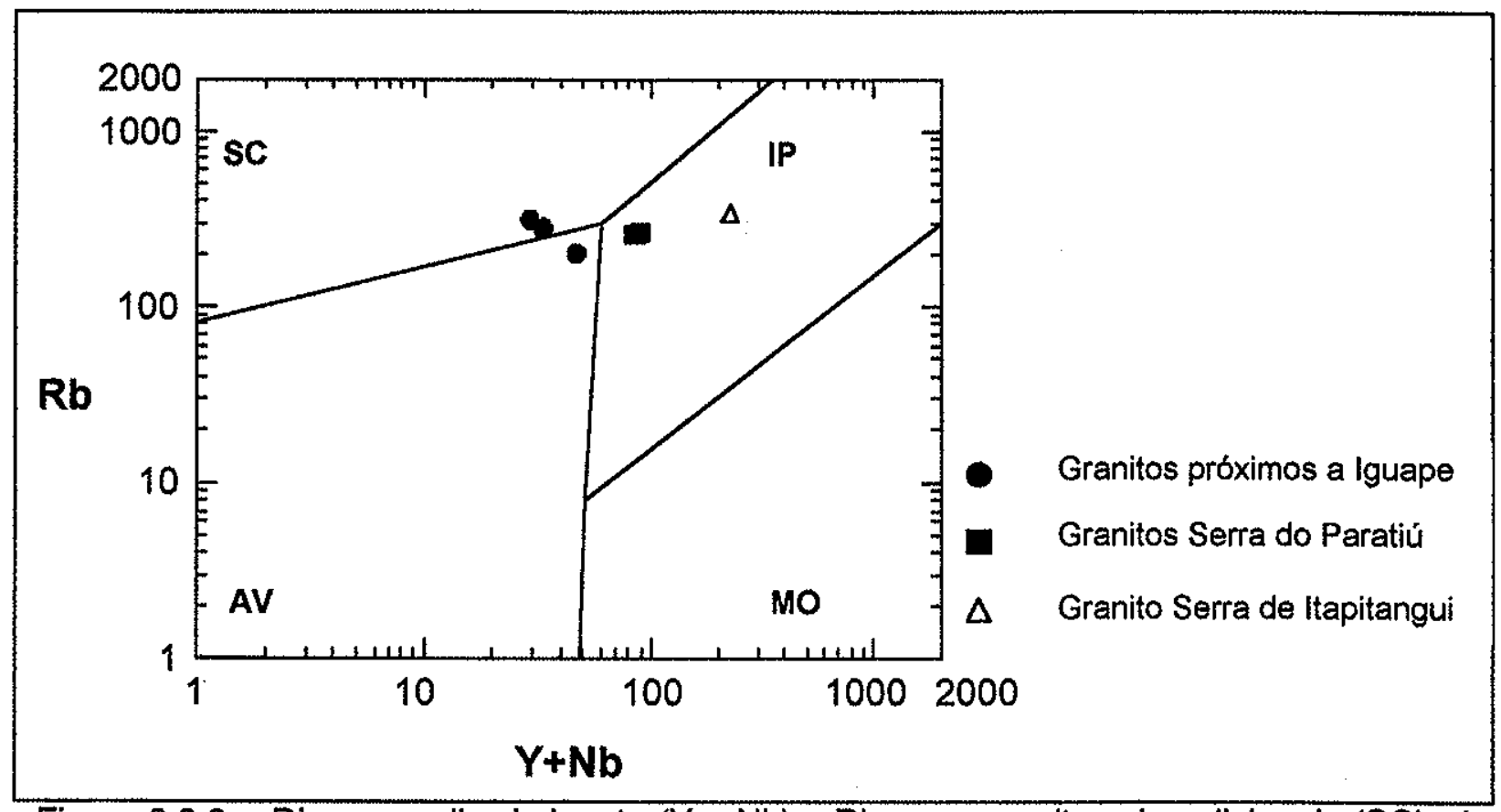

Figura 8.3.3 - Diagrama discriminante $(\mathrm{Y}+\mathrm{Nb}) \times \mathrm{Rb}$, para granitos sin-colisionais $(\mathrm{SC})$, de arcos vulcânicos (AV), intra-placas (IP) e granitos de cadeias meso-oceânicas (MO), conforme Pearce et al. (1984).

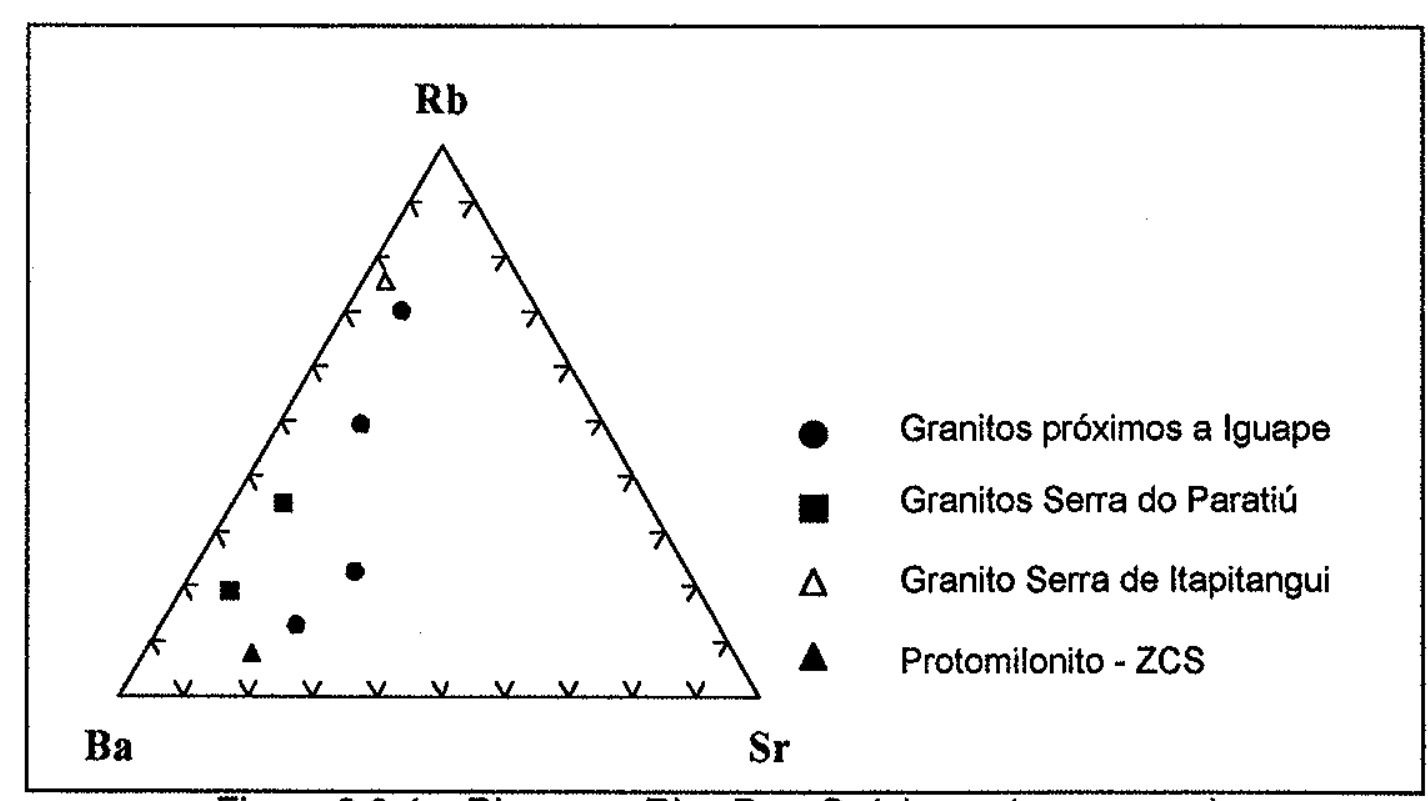

Figura 8.3.4 - Diagrama $\mathrm{Rb} \times \mathrm{Ba} \times \mathrm{Sr}$ (elementos em ppm). 
A distinção entre os diferentes tipos de granitos do Bloco Iguape, também pode ser observada em diagrama de variação de multielementos normalizados aos valores hipotéticos de granito de cadeia meso-oceânica (ORG), Pearce et al. (1984).

Os Granitos do Maciço de Iguape, apresentam semelhanças com os perfis definidos por granitos de arcos vulcânicos ou sin-colisionais (Figura 8.3.5a), enquanto os Granitos das Serras de Paratiú e Itapitangui, mostram semelhanças aos granitos intra-placas (Figura 8.3.5b).

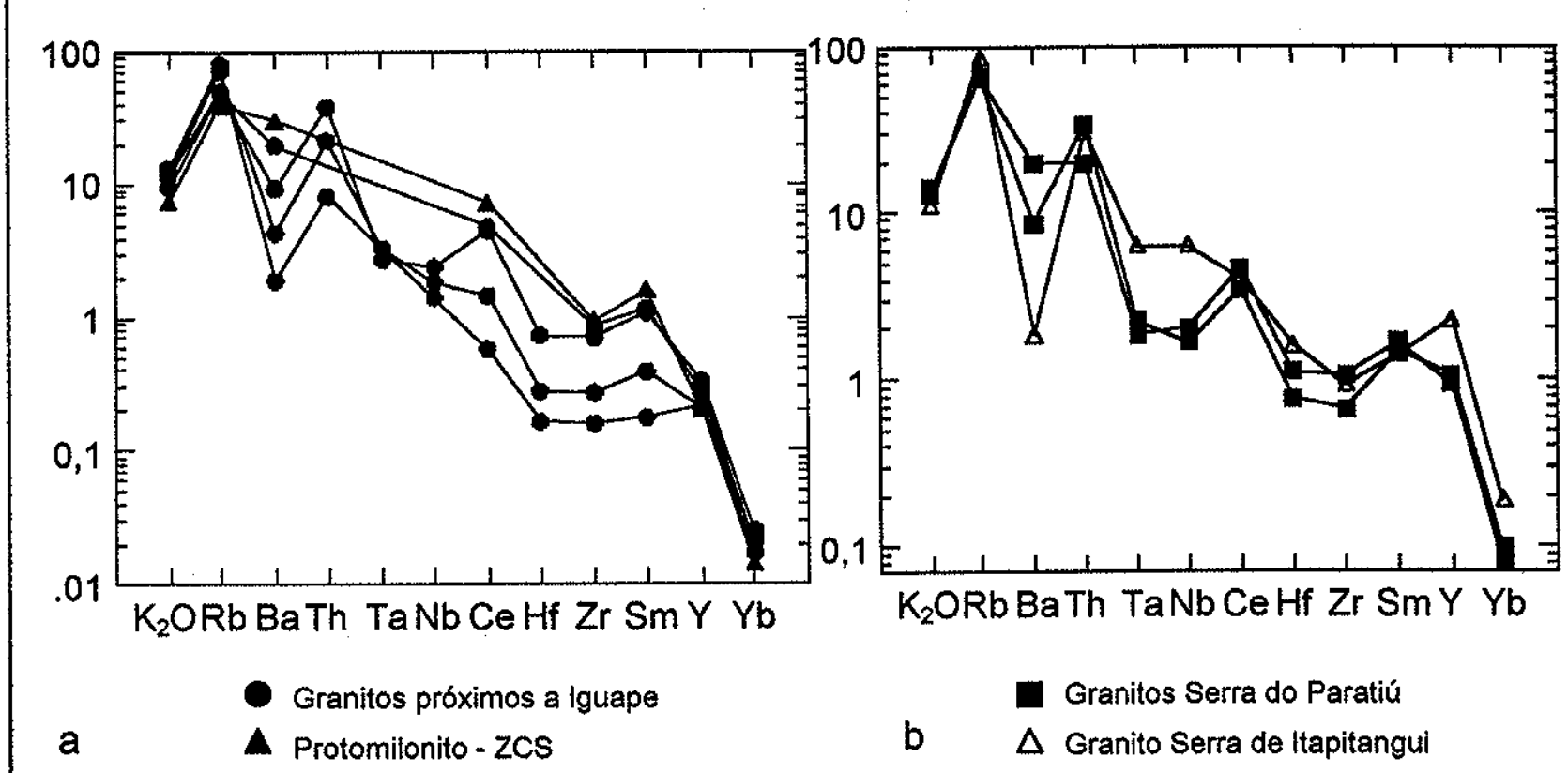

Figura 8.3.5 - Diagramas de variação multielementar normalizados aos valores hipotéticos de granito de cadeia meso-oceânica (ORG), Pearce et al. (1984).

Em Diagramas de perfis de ETR, normalizados aos valores do condrito por Nakamura, 1974, as amostras representativas dos granitos peraluminosos, da regiäo de Iguape, mostraram comportamento similar (Figura 8.3.6). Os granitos próximos à cidade de Iguape (K-64; K-100) mostraram um fracionamento de ETRL em relação aos ETRP de $[\mathrm{La}(250) / \mathrm{Yb}(8-9)] \mathrm{N} \sim 30$ e suaves anomalias negativas de Eu. Comportamento similar é observado em granito afetado pela ZCS, a norte de lguape (K-102), no entanto apresenta maior fracionamento de ETRL em relação aos ETRP de $[\mathrm{La}(400) / \mathrm{Yb}(5)] \mathrm{N}=80$. Comportamento um pouco distinto observa-se nos granitos aflorantes a NE da cidade de Iguape (K-36; K-37), que mostram um menor 
fracionamento de ETRL em relação aos ETRP $[\operatorname{La}(30-80) / Y b(8-6)] N \sim 4-13$, e anomalias negativas de Eu mais pronunciadas.

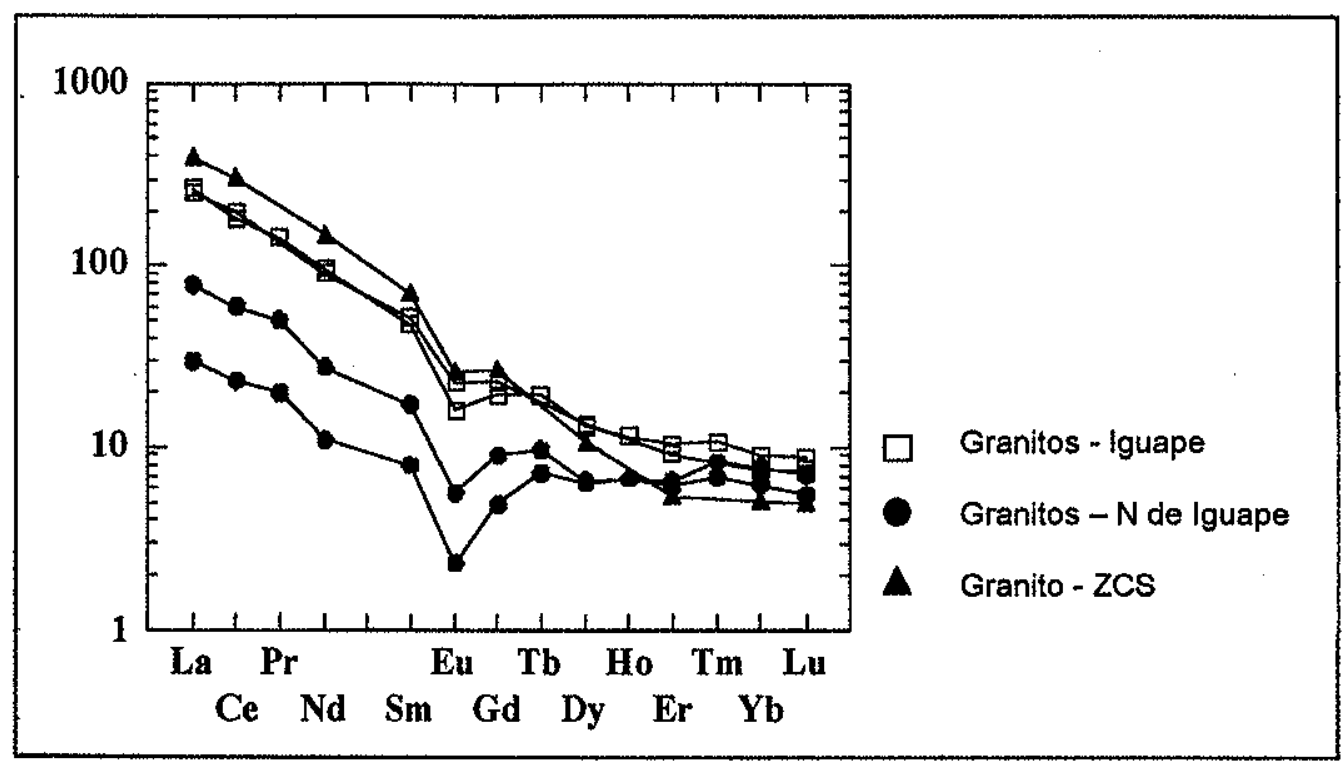

Figura 8.3.6 - Diagrama de ETR normalizado ao condrito (Nakamura, 1974).

Padrões distintos são observados para os granitos de Itapitangui e da Serra do Paratiú, que apresentam fracionamento muito fraco de ETRL em relação aos ETRP, [La(170-225)/ $\mathrm{Yb}(35-70)] \mathrm{N} \sim 3-8$, com notável enriquecimento de ETRP em relação aos demais granitos. O Granito Itapitangui, mostra anomalia negativa de Eu bastante pronunciada, e uma amostra da Serra do Paratiú mostra anomalia negativa de Nd, padrão distinto das demais (Figura 8.3.7).

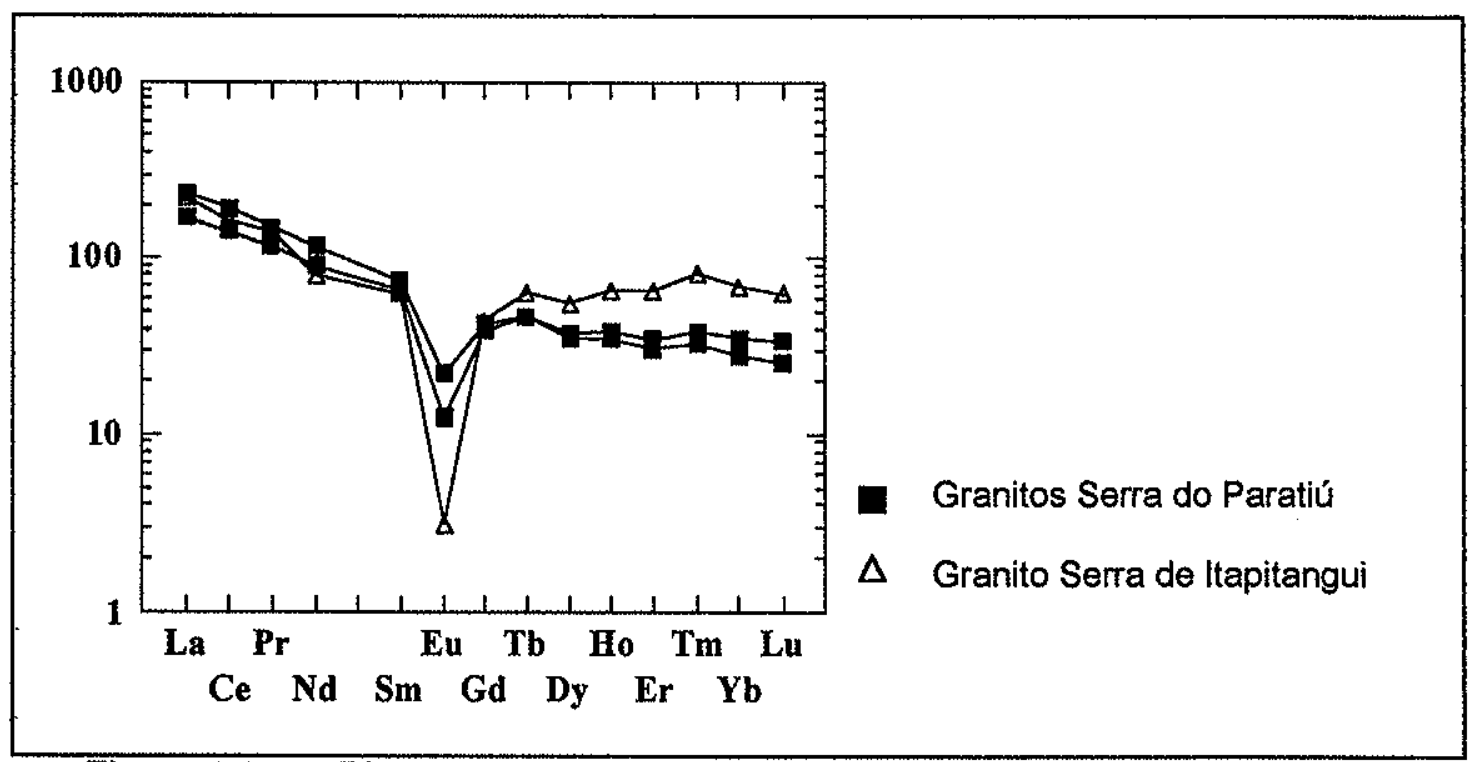

Figura 8.3.7 - Diagrama de ETR normalizado ao condrito (Nakamura, 1974). 


\subsection{GEOCRONOLOGIA E GEOLOGIA IsotópICA}

\subsubsection{RESULTADOS U-PB (ZIRCÕES/MONAZITAS)}

Foram realizadas três datações pela metodologia U-Pb em zircões em rochas graníticas do Bloco Iguape, e uma datação U-Pb em monazitas em rocha granítica protomilonítica da ZCS.

No biotita-monzogranito isótropo - Serra do Cordeiro (amostra K-34) foram analisadas frações magnéticas $\mathrm{M}(-3), \mathrm{M}(-4), \mathrm{M}(-5)$ e $\mathrm{NM}(-5)$, todas abradadas, com pesos em torno de $0.09 \mathrm{mg}$. Os resultado analíticos estão relacionados na Tabela 8.4.1.

As frações analisadas constituem-se por cristais idiomórficos, límpidos, bipiramidais e transparentes, com razão média comprimento/largura entre 3 e 5 (Foto 8.4.1).

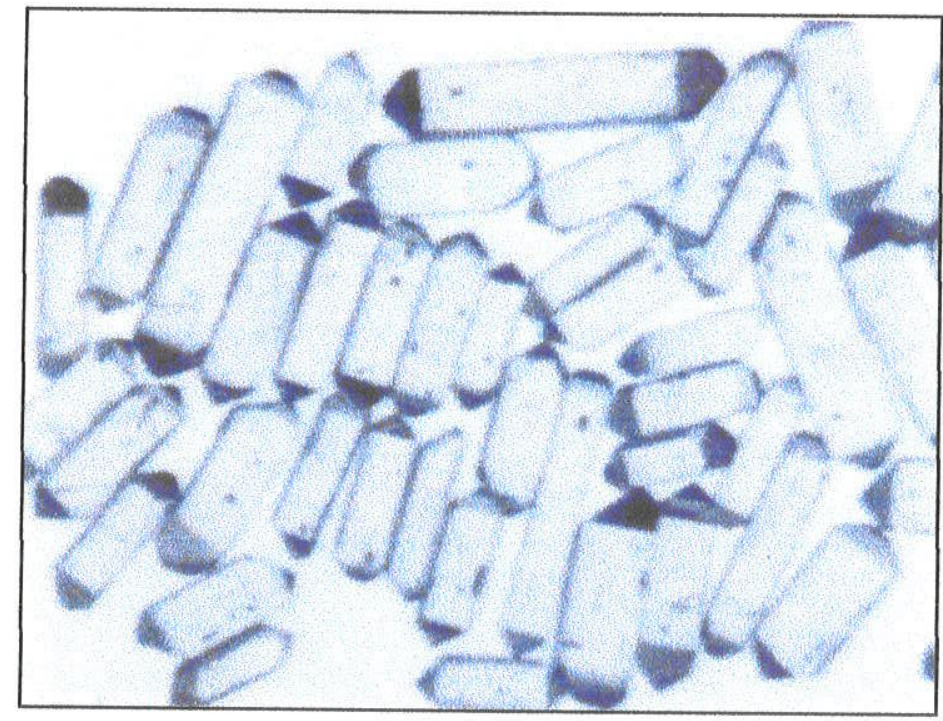

Foto 8.4.1 - Fotomicrografia de lupa binocular de cristais de zircão fração NM-5, abradada por 1 hora (aumento $135 \mathrm{X}$ ) - amostra K-34.

Em Diagrama Concórdia (Figura 8.4.1), as frações $M(-3)$ e $M(-4)$ mostraramse pouco discordantes, e alinharam-se fornecendo uma idade intercepto inferior de $582 \pm 4 \mathrm{Ma}$, idade esta interpretada como época de cristalização desta rocha. As frações M(-5) e NM(-5) mostraram-se fortemente discordantes, indicando a presença nestes zircões de herança crustal. 
O alinhamento de todas frações analisadas fornece uma idade de intercepto superior em torno de $2.745 \mathrm{Ma}$ e idade intercepto inferior de cerca de $550 \mathrm{Ma}$ (Figura 8.4.1). Tais idades devem ser interpretadas com ressalvas, sendo extremamente imprecisas, podendo-se afirmar que estes granitos registram em seus zircões, principalmente nas frações menos magnéticas, fortes heranças isotópicas.

Adicionalmente as frações $M(-3)$ e $M(-4)$ apresentaram um alinhamento razoável, indicando idade, intercepto superior, de cerca de $580 \mathrm{Ma}$, sendo interpretada como a época mais provável para geração desta rocha.

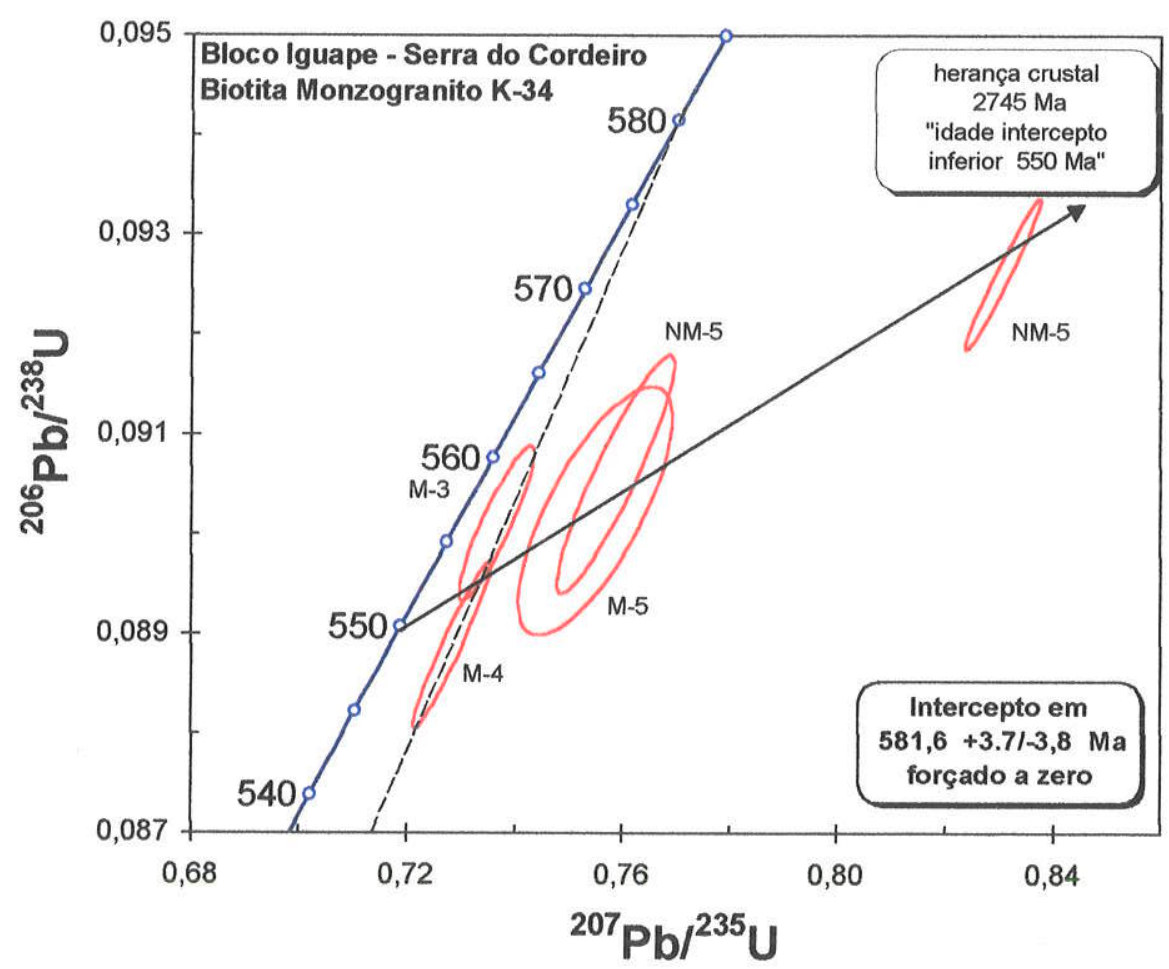

Figura 8.41 - Diagrama Concórdia ${ }^{207} \mathrm{~Pb} /{ }^{235} \mathrm{U} \mathrm{x}^{206} \mathrm{~Pb} /{ }^{238} \mathrm{U}$ em zircões da amostra K-34.

Em biotita-monzogranito, localizado a nordeste de Iguape (amostra K-67), foram analisadas frações magnéticas $M(-2), M(-3)$, e $N M(-4)$, não abradadas, e $M(-4)$ abradada (AA) e com pesos entre 0.07 e $0.125 \mathrm{mg}$. Os resultado analíticos estão relacionados na Tabela 8.4.1.

As frações analisadas são constituídas por cristais idiomórficos, normalmente límpidos e transparentes, comumente com bordas arredondadas, e razão média comprimento/largura entre 6 e 8 (Foto 8.4.2). 


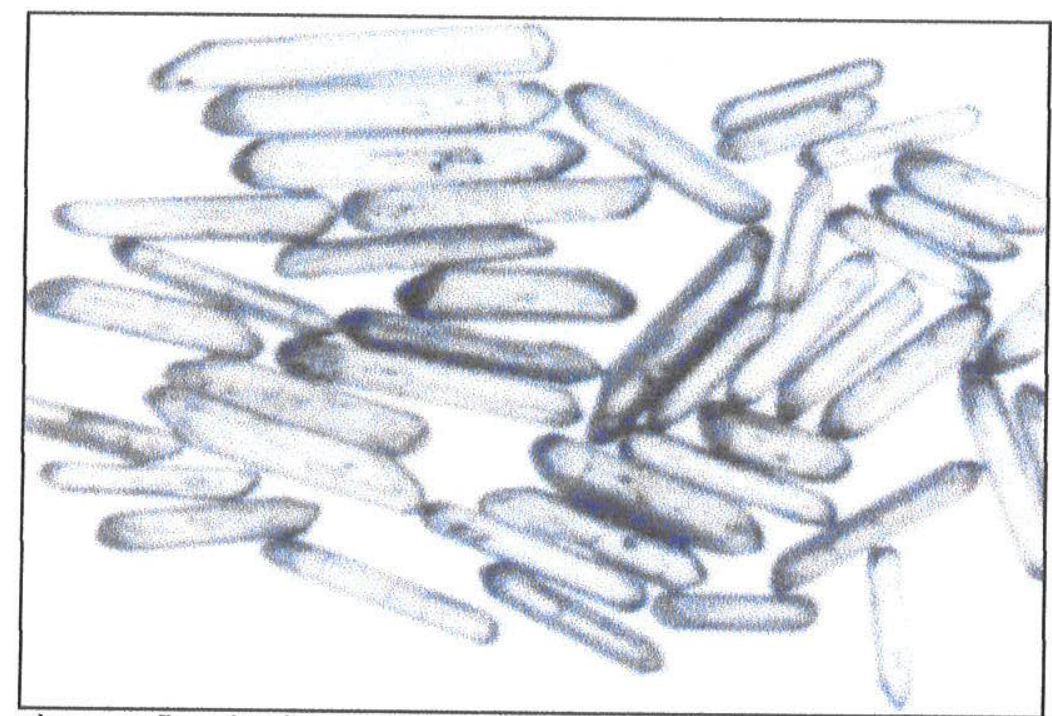

Foto 8.4.2 - Fotomicrografia de lupa binocular de cristais de zircão fração $\mathrm{M}-3$, não abradada (aumento $108 \mathrm{X}$ ) - amostra K-67.

Quando plotadas em Diagrama Concórdia (Figura 8.4.2), as frações de zircões mostraram um bom alinhamento, fornecendo uma idade, intercepto superior de $599 \pm 15 \mathrm{Ma}$, interpretada como época de cristalização desta rocha.

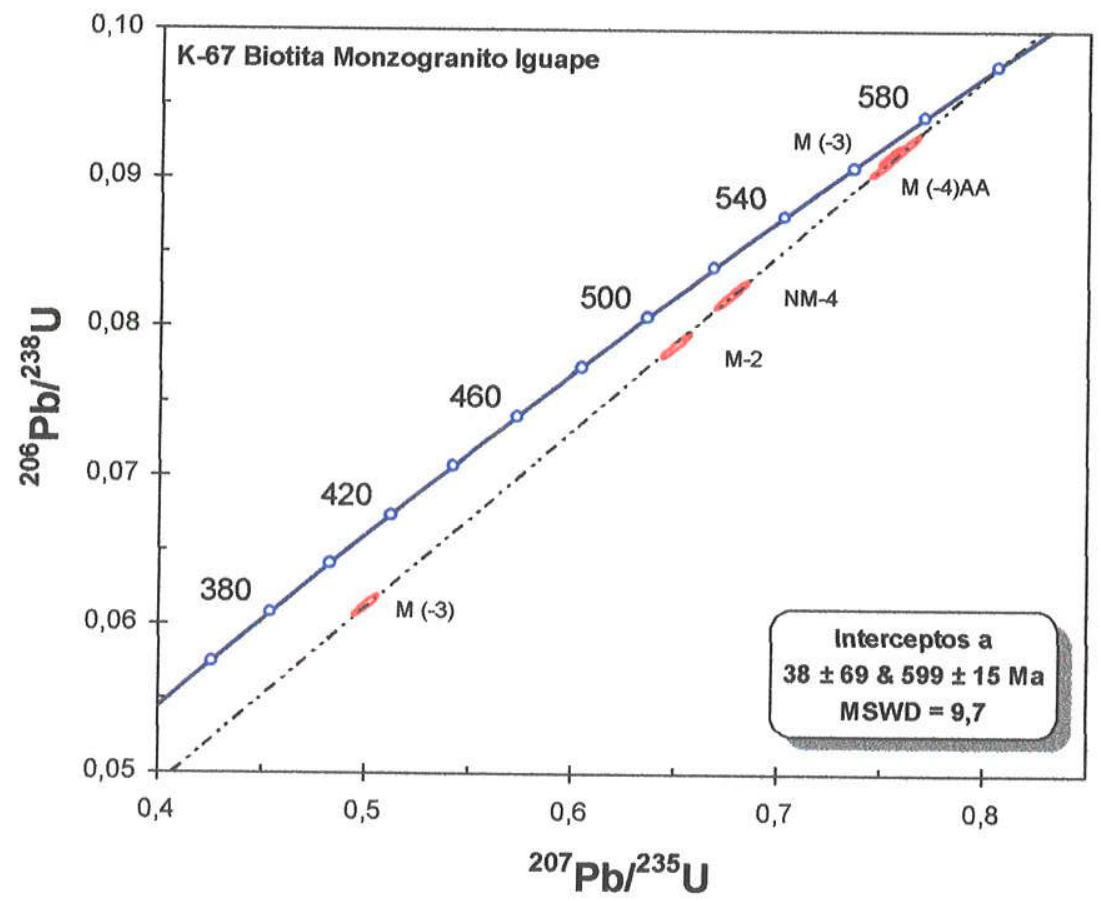

Figura 8.4.2 - Diagrama Concórdia ${ }^{207} \mathrm{~Pb} /{ }^{235} \mathrm{U} \mathrm{x}^{206} \mathrm{~Pb} /{ }^{238} \mathrm{U}$ em zircões da amostra K-67. 
Em protomilonito granítico afetado pela ZCS (amostra K-102), foram analisadas as frações magnéticas, $M(-2), M(-3)$ e $M(-5)$, não abradadas (NA), que apresentaram pesos entre 0.036 e $0.076 \mathrm{mg}$. As frações magnéticas apresentaram diferentes populações de zircão. A população do tipo â, mais abundante, caracteriza-se por cristais de zircão com feições próximas a bastonetes, com bordas arredondadas, normalmente fraturados, com razão média comprimento/largura entre 2 e 3 (Foto 8.4 .3 a). A população $\underline{b}$, caracteriza-se por cristais de zircão prismáticos maiores em relação à população $\underline{a}$ e com razões comprimento/largura relativamente menores. A população $\underline{c}$ caracteriza-se por zircões esféricos, límpidos, e a população tipo $\underline{\mathrm{d}}$, por zircões rosados de formato mais achatado. As populações foram devidamente separadas em cada uma das frações e posteriormente analisadas.

Os resultados analíticos das frações analisadas mostraram-se razoáveis e apresentam-se na Tabela 8.4.1.

Foram atacadas monazitas das frações magnéticas $M(0.6)$ e $M(0.7)$ com pesos em torno de $0.035 \mathrm{mg}$, com dados analíticos muito bons (Tabela 8.4.1). Os cristais de monazita analisados, mostram-se relativamente bem formados, límpidos e com coloração castanho-claro (Foto 8.4.3 b).

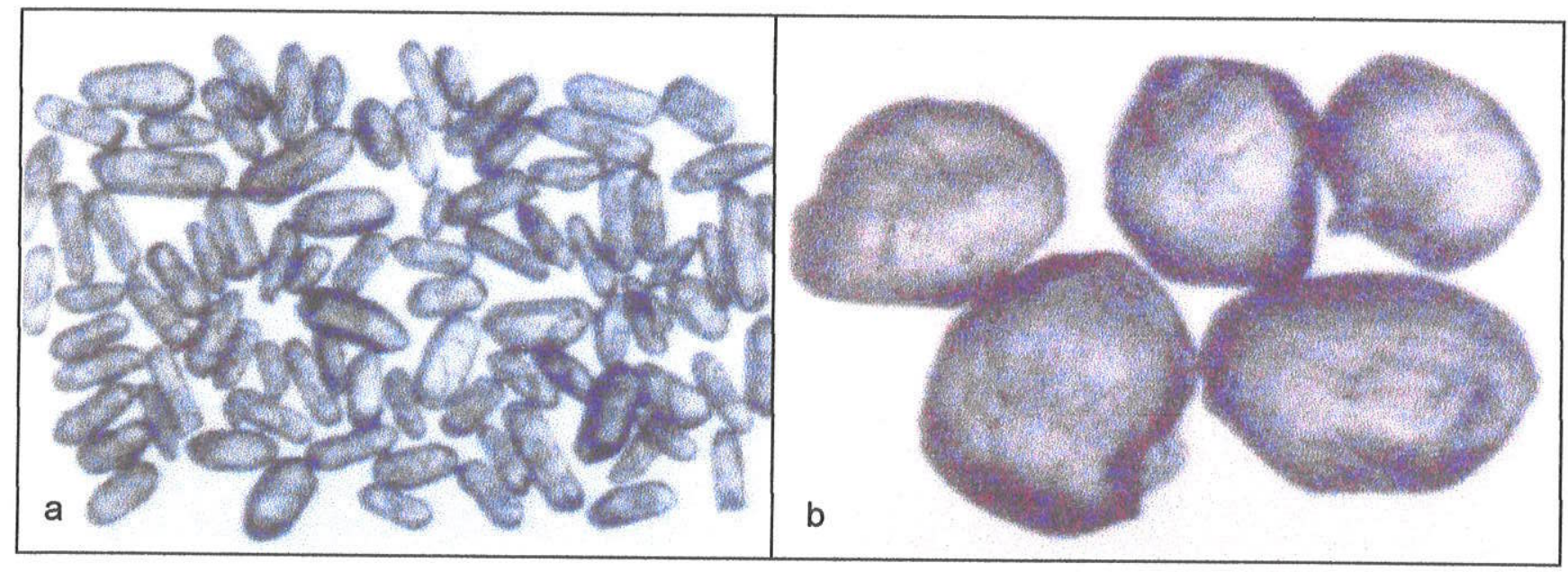

Foto 8.4.3 - Fotomicrografias de lupa binocular de zircões e monazitas - amostra K-102: a) cristais de zircão - população tipo a , fração M-2, não abradada (aumento 135X); b) cristais de monazita fração M 0.7 (aumento 208 X). 
Em Diagrama Concórdia (Figura 8.4.3), observa-se que não houve coerência entre os tipos de população de zircões e seu posicionamento em relação à Curva Concórdia (grau de discordância).

As diferentes populações de zircão da fração magnética $\mathrm{M}(-2)$ alinharam-se e forneceram uma idade intercepto superior de 616 +19/-16 Ma, interpretada como a época mais provável para a formação desta rocha. Populações de zircões das frações magnéticas $M(-3)$ e $M(-5)$ mostraram-se bastante discordantes e com forte herança isotópica (Figura 8.4.3).

As frações de monazitas apresentaram idades concordantes em torno de 570$580 \mathrm{Ma}$. Esta idade é interpretada como importante época de evento metamórfico, que propiciou a geração destes minerais (Figura 8.4.3).

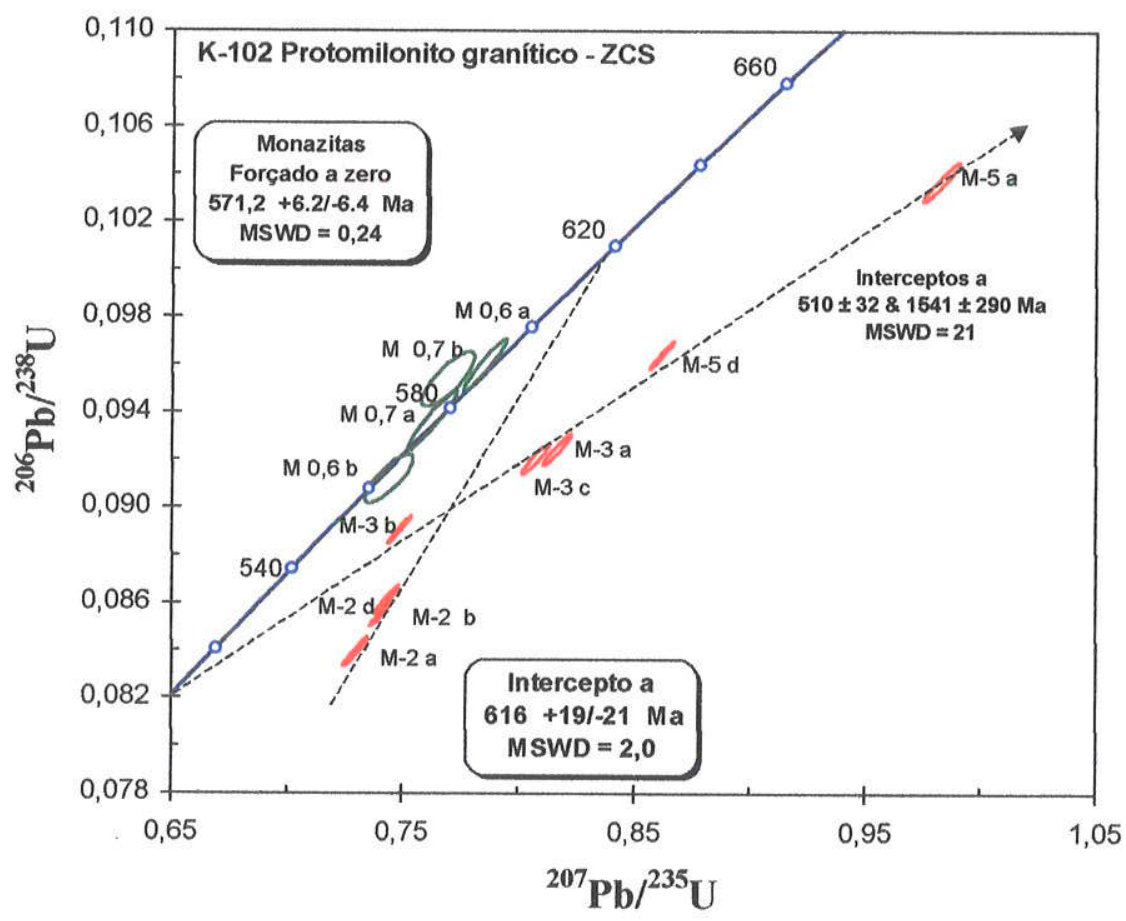

Figura 8.4.3 - Diagrama Concórdia ${ }^{207} \mathrm{~Pb} /{ }^{235} \mathrm{U} \times{ }^{206} \mathrm{~Pb} /{ }^{238} \mathrm{U}$ (zircões e monazitas) - K-102. 
Tabela $8,4.1$

Dadoș analíticos referentes à Siștemática U-Pb (zircão/monazita) - Bloco Iguape

\begin{tabular}{|c|c|c|c|c|c|c|c|c|c|c|c|c|c|}
\hline \multicolumn{7}{|c|}{ Bloco lguape } & \multicolumn{4}{|c|}{ Razöes Isatópicas } & \multicolumn{3}{|c|}{ Idades (Ma) } \\
\hline Localização & Amostra & $\begin{array}{c}\text { Mineral } \\
\text { Analisado }\end{array}$ & $\begin{array}{c}\text { Fração } \\
\text { Magnética }\end{array}$ & $\begin{array}{l}\text { Peso } \\
\text { (mg) }\end{array}$ & $\begin{array}{c}\mathrm{U} \\
\text { (ppm) }\end{array}$ & $\begin{array}{c}\mathrm{Pb} \\
(\mathrm{ppm})\end{array}$ & $\begin{array}{l}\mathrm{Pb}^{206} \mathrm{I} \\
\mathrm{Pb}^{204}\end{array}$ & $\mathrm{~Pb}^{20 r} \mathrm{~N}^{235}-$ Erro\% & $\mathrm{Pb}^{206} / \mathrm{U}^{238}-\mathrm{ErTQ} \%$ & $\mathrm{~Pb}^{201} / \mathrm{Pb}^{205}-$ ErTo $\%$ & $\begin{array}{l}\mathrm{Pb}^{207} \mathrm{l} \\
\mathrm{U}^{235}\end{array}$ & $\begin{array}{c}\mathrm{Pb}^{206} \mathrm{I} \\
\mathrm{U}^{238}\end{array}$ & $\begin{array}{l}\mathrm{Pb}^{201 /} \\
\mathrm{Pb}^{206}\end{array}$ \\
\hline \multirow{5}{*}{$\begin{array}{l}\text { Serra do } \\
\text { Cordeiro }\end{array}$} & \multirow{5}{*}{$k-34$} & zircâo & $M-3$ & 0.101 & 144 & 14 & 1958 & $0.736622-0.774$ & $0.0900979-0.701$ & $0.0592964-0.327$ & 560 & 556 & $578 \pm 7$ \\
\hline & & zircāo & $M-4$ & 0.087 & 180 & 18 & 978 & $0.728341-0.803$ & $0.0888711-0.772$ & $0.0594392-0.214$ & 556 & 549 & $583 \pm 5$ \\
\hline & & zircão & $M-5$ & 0.055 & 157 & 18 & 272.6 & $0.754983-1.55$ & $0.0902191-1.13$ & $0.0606928-1.05$ & 571 & 557 & $628+23$ \\
\hline & & zircāo & NM-5 & 0.240 & 117 & 12 & 1241 & $0.830643-0.691$ & $0.0925935-0.676$ & $0.0650627-0.142$ & 614 & 571 & $776 \pm 3$ \\
\hline & & zircão & $\mathrm{NM}-5$ & 0.139 & 76 & 7 & 1020 & $0.758818-1.18$ & $0.0905854-1.08$ & $0.0607545-0.457$ & 573 & 559 & $630 \pm 10$ \\
\hline & & & & & & & & & & & & & \\
\hline \multirow{5}{*}{$\begin{array}{l}\text { Maciço de } \\
\text { Iguape }\end{array}$} & \multirow{5}{*}{$K-67$} & zircão & $\mathrm{M}-2$ & 0.125 & 710 & 56 & 2243 & $0.650236-0.918$ & $0.0787538-0.882$ & $0.0598822-0.253$ & 509 & 489 & $599 \pm 5$ \\
\hline & & zircão & $\mathrm{NM}-4$ & 0.119 & 527 & 42 & 3441 & $0,677245-1,01$ & $0,0821936-0,977$ & $0,0597595-0,257$ & 525 & 509 & $595 \pm 6$ \\
\hline & & zircão & $M-3$ & 0.093 & 1019 & 60 & 5438 & $0.499978-1.01$ & $0.0611903-0.937$ & $0.0592607-0.363$ & 412 & 383 & $577 \pm 8$ \\
\hline & & zircão & $M-3$ & 0.070 & 659 & 58 & 6134 & $0.753293-0.564$ & $0.0916075-0.552$ & $0.0596392-0.115$ & 570 & 565 & $591 \pm 3$ \\
\hline & & zircão & M-4aa & 0.091 & 896 & 79 & 5773 & $0.756132-1.32$ & $0.0915594-1.31$ & $0.0598955-0.209$ & 572 & 565 & $600 \pm 5$ \\
\hline \multirow{13}{*}{$\mathrm{ZCS}$} & \multirow{13}{*}{$K-102$} & & & & & & & & & & & & \\
\hline & & zircäo & $\mathrm{M}-2 \mathrm{a}$ & 0.052 & 877 & 72 & 946 & $0.729677-0.621$ & $0.0838789-0.606$ & $0.0630923-0.13$ & 556 & 519 & $711 \pm 3$ \\
\hline & & zircão & $\mathrm{M}-2 \mathrm{~b}$ & 0.061 & 1234 & 100 & 2144 & $0.741106-0.543$ & $0.0855100-0.533$ & $0.0628583-0.101$ & 563 & 529 & $703 \pm 2$ \\
\hline & & zircão & $M-2 d$ & 0.077 & 567 & 47 & 1485 & $0.743330-0.587$ & $0.0860585-0.572$ & $0.062645-0.13$ & 564 & 532 & $696 \pm 3$ \\
\hline & & zircão & M-3a & 0.059 & 456 & 40 & 2191 & $0.816558-0.606$ & $0.0923676-0.586$ & $0.0641159-0.155$ & 606 & 570 & $745 \pm 3$ \\
\hline & & zircâo & M-3b & 0.067 & 1045 & 90 & 1084 & $0.748726-0.546$ & $0.0889936-0.538$ & $0.0610187-0.086$ & 567 & 550 & $640+2$ \\
\hline & & zircão & $M-3 c$ & 0.035 & 895 & 91 & 335 & $0.807276-0.621$ & $0.0919912-0.590$ & $0.0636465-0.187$ & 601 & 567 & $730 \pm 4$ \\
\hline & & zircão & $M-5 a$ & 0.032 & 544 & 61 & 420 & $0.982786-0.676$ & $0.1036420-0.656$ & $0.0687739-0.155$ & 695 & 636 & $892 \pm 3$ \\
\hline & & zircão & $M-5 d$ & 0.056 & 1030 & 95 & 2023 & $0.861853-0.520$ & $0.0963631-0.515$ & $0.0648666-0.070$ & 631 & 593 & $770 \pm 2$ \\
\hline & & monazita & $M(0.6) A$ & 0.038 & 2446 & 906 & 1633 & $0.785492-0.982$ & $0.0959579-0.944$ & $0.0593690-0.260$ & 589 & 591 & $581 \pm 6$ \\
\hline & & monazita & $M(0.6) B$ & 0.037 & 1568 & 651 & 733 & $0.744205-1.140$ & $0.0911851-0.921$ & $0.0591926-0.639$ & 565 & 563 & $574 \pm 14$ \\
\hline & & monazita & $M(0.7) A$ & 0.022 & 1977 & 809 & 381 & $0.762747-1.140$ & $0.0936227-1.090$ & $0.0590878-0.337$ & 576 & 577 & $570 \pm 7$ \\
\hline & & monazita & $\mathrm{M}(0.7) \mathrm{B}$ & 0.027 & 1446 & 754 & 263 & $0.769515-1.22$ & $0.0953594-0.986$ & $0.0585264-0.705$ & 579 & 587 & $550 \pm 15$ \\
\hline
\end{tabular}




\subsubsection{RESULtAdOS K-AR (BIOTITA)}

O método K-Ar foi aplicado a 3 rochas graníticas pertencentes ao Bloco Iguape, sendo duas delas em milonitos graníticos, pertencentes à ZCS. Estas serão discutidas no Capítulo 10.

A terceira amostra analisada, refere-se ao Biotita-monzogranito isótropo da Serra do Cordeiro (K-34), cujos resultados analíticos apresentam-se listados na Tabela 8.4.2. Forneceu, em concentrado de biotitas, idade de $505 \pm 16 \mathrm{Ma}(1 \sigma)$, cerca de $80 \mathrm{Ma}$ mais jovem que o obtido através do método U/Pb (582 Ma).

A idade obtida indica a época de resfriamento dessa rocha, ou seja, sua colocação a níveis superiores, com temperaturas inferiores a $250^{\circ} \mathrm{C}$.

A idade em torno de $500 \mathrm{Ma}$ pode representar a época de cessação do aquecimento regional, associado a cinemática dos Blocos tectônicos envolvidos.

\begin{tabular}{|c|c|c|c|c|c|c|c|}
\hline Amostra & Material & \% de K & Erro & $\begin{array}{c}\mathbf{A r}^{\mathbf{4 0}} \mathbf{R a d} \\
\text { CcSTP/g( }\left(^{*} \mathbf{1 0} \text { ) }\right.\end{array}$ & Ar $^{40}$ Atm & $\begin{array}{c}\text { Idade } \\
\text { (Ma) }\end{array}$ & $\begin{array}{c}\text { Erro máx. } \\
\text { (Ma) }\end{array}$ \\
\hline K-34 & Biotita & 7.0165 & 1.8786 & 158.74 & 6.67 & 505.0 & 15.7 \\
\hline
\end{tabular}

Tabela 8.4.2 - Dados analíticos K-Ar Granito Cordeiro - Bloco Iguape. 


\subsubsection{GEOLOGIA ISOTÓPICA ND-SR}

Utilizando-se da sistemática $\mathrm{Sm}-\mathrm{Nd}$, foram analisados protomilonitos graníticos do Maciço Iguape, Morro do Espia (porção extremo SW do Maciço amostras K- 64 e K-100), duas amostras da região mais a NE da cidade de lguape (amostras K-36 e K-37), de protomilonito da ZCS (K-102) e dos granitos da Serra do Paratiú (K-61) e da Serra de Itapitangui (K-31). Os resultados analíticos apresentamse listados na Tabela 8.4.3.

Foram recalculadas as idades modelo por estágio duplo, conforme Sato (1998), de amostras representativas dos granitos aflorantes a NE de Iguape (amostra K-36), das Serras de Itapitangui (amostra K-31) e de Paratiú (amostra K61), que apresentaram razões $S m^{147} / \mathrm{Nd}^{144}$ de $0.1371, \quad 0.1552$ e 0.1357 respectivamente. Antes do cálculo pelo estágio duplo, o granito K-36 apresentou idade modelo TDM de $2.696 \mathrm{Ga}$ e $\varepsilon N d(0)=-18.28$, o granito $\mathrm{K}-31$ de $3.813 \mathrm{Ga}$ e $\varepsilon N d$ $(0)=-19.49$ e $\circ$ granito $\mathrm{K}-61$ de $2.893 \mathrm{Ga}$ e $\varepsilon \mathrm{Nd}(0)=-20.6$. Estas rochas, provavelmente sofreram um fracionamento adicional entre $\mathrm{Sm}$ e $\mathrm{Nd}$, sendo as idades TDM recalculadas pelo método de estágio duplo de, $2.17 \mathrm{Ga}, 2.34 \mathrm{Ga}$ e 2.32 $\mathrm{Ga}$, e $\varepsilon N d(0)$ de $\sim-20,-22.8$ e -22.3 respectivamente (Tabela 8.4.3).

Os granitos do Bloco Iguape, apresentaram uma grande variação nas idades TDM obtidas, bem como nos valores de $\varepsilon N d$. Quando plotados em diagrama de evolução de $\varepsilon N d$, nota-se a evolução distinta entre as rochas graníticas da região de Iguape (Morro do Espia e NE de Iguape), do protomilonito - ZCS a N de Iguape e das Serras do Paratiú e Itapitangui.

$\mathrm{Na}$ região de lguape (Figura 8.4.4), as amostras analisadas do Morro do Espia (K-64 e 100) apresentam idades TDM muito próximas, em torno de $1.8 \mathrm{Ga}, \varepsilon \mathrm{Nd}$ (0) $\sim-20$ e $\varepsilon N d_{(t=600)} \sim-12$ (Tabela 8.4.3). O protomilonito $\mathrm{K}-102$, por sua vez, apresentou idade TDM bem mais antiga, $\sim 2.5 \mathrm{Ga}$ e valores bem mais negativos de $\varepsilon N d 0=\sim-33$, e $\varepsilon N d_{(t=600)} \sim-24$. 


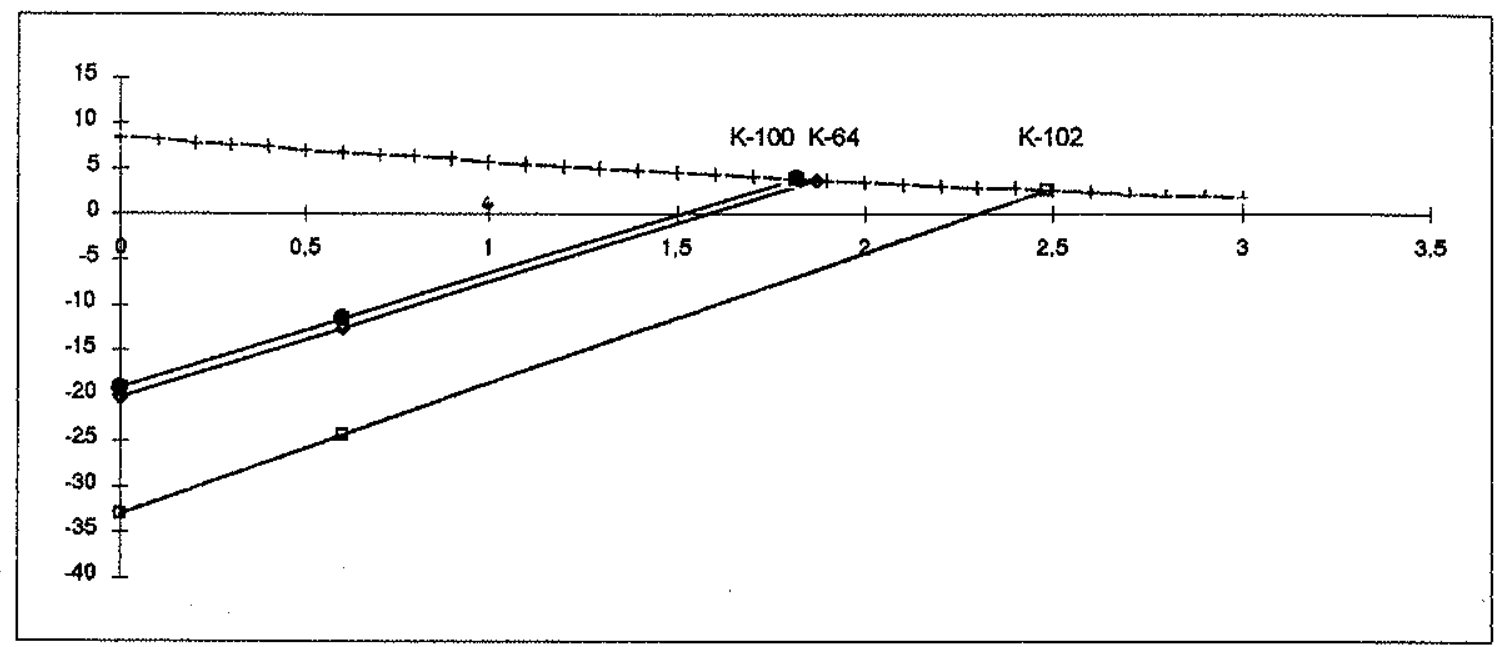

Figura 8.4.4 - Diagrama de evolução $\varepsilon$ Nd x tempo (Ga). Granitos Iguape e ZCS.

Na região a NE Iguape, as amostras $\mathrm{K}-36$ e K-37 apresentaram idades TDM próximas, de $2.17 \mathrm{Ga}$ e $2.2 \mathrm{Ga}$, valores de $\varepsilon \mathrm{Nd}_{(\mathrm{t})} \sim-13$, e de $\varepsilon \mathrm{Nd}(0)$ de $\sim-20$ e 18.6, respectivamente (Figura 8.4.5).

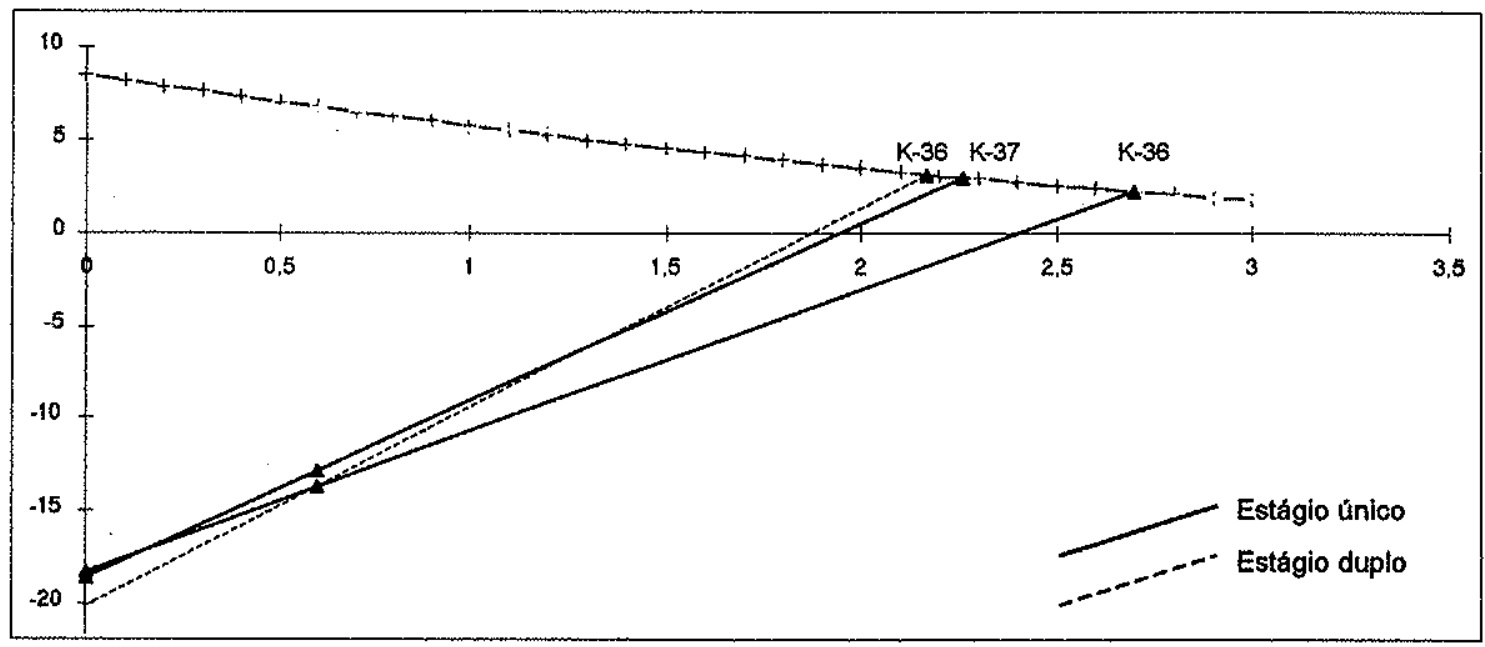

Figura 8.4.5 - Diagrama de evolução \& Nd x tempo (Ga). Granitos NE de lguape.

As rochas graníticas da Serra do Itapitangui (K-31) e Paratiú (K-61) mostraram idades TDM muito próximas de $2.34 \mathrm{Ga}$ e $2.32 \mathrm{Ga}$, bem como valores semelhantes de $\varepsilon N d$ (Figura 8.4.6): $\varepsilon N d(0) \sim-22.8$ e -22.3 , e $\varepsilon N d_{(t)}$ de -16.42 e 16.09, respectivamente (Tabela 8.4.3). 


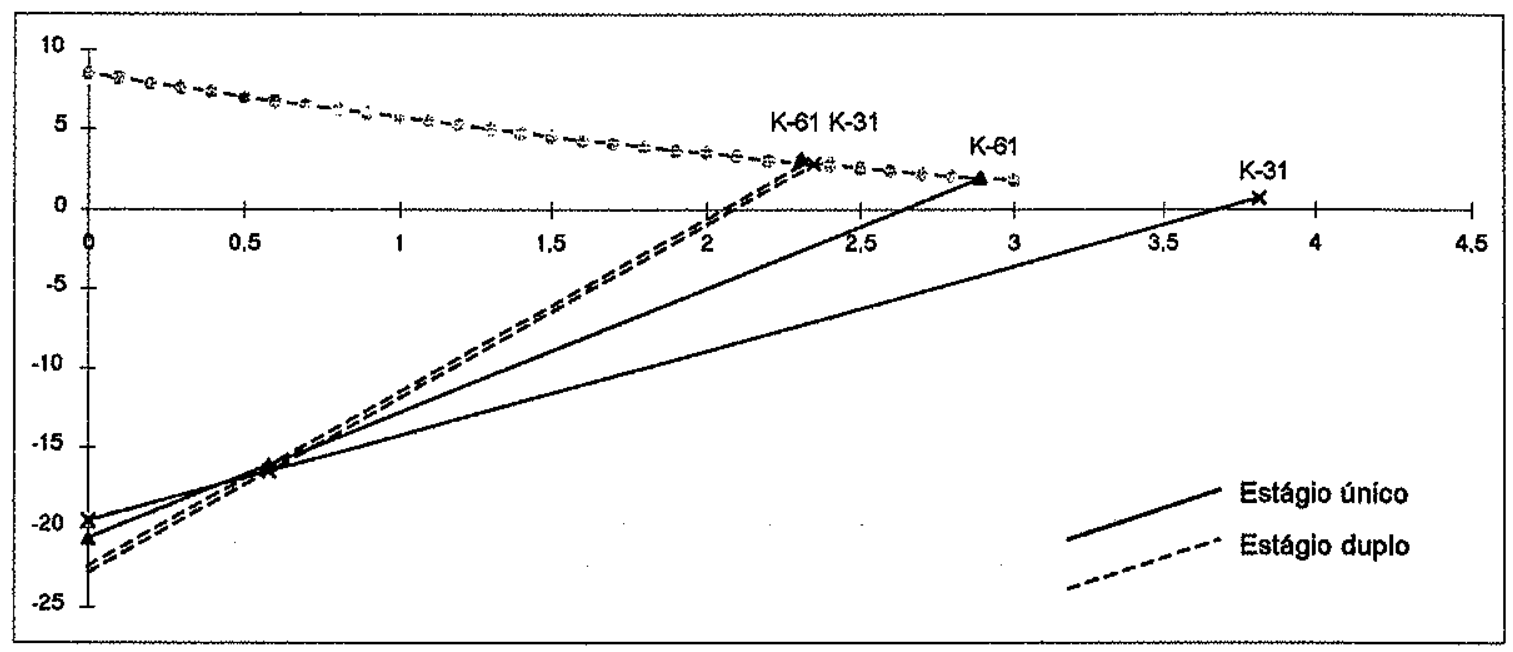

Figura 8.4.6 - Diagrama de evoluçăo $\varepsilon$ Nd x tempo (Ga). Granitos Itapitangui e Paratiú.

Os dados apresentados sugerem que os protólitos destes granitos se diferenciaram do manto em épocas paleoproterozóicas distintas: Granitos Morro do Espia ( 1.8 Ga), Granitos a NE de Iguape (2.1-2.2 Ga), Granitos Serras do Itapitangui e Paratiú $(\sim 2.3 \mathrm{Ga})$ e Protomilonito ZCS $(\sim 2.5 \mathrm{Ga})$.

As rochas referentes à região de Iguape (Morro do Espia e NE de lguape), bem como das Serras de Itapitangui e Paratiú, podem ter contribuição a partir de fontes crustais com características não muito distintas, pelo valores próximos de $\varepsilon \mathrm{Nd}$ (t). A amostra representativa dos protomilonitos graníticos afetados pela ZCS, mostra comportamento bastante distinto das demais, apresentando valor de $\varepsilon N d(t)$ bem mais negativo.

Tais resultados podem representar participação de níveis ou fontes crustais distintos na geração das rochas graníticas do Bloco Iguape, bem como um longo período de residência crustal, pelos valores altamente negativos de $\varepsilon \mathrm{Nd}(0)$. 
As razōes isotópicas de $\mathrm{Sr}$ obtidas pela sistemática $\mathrm{Rb}-\mathrm{Sr}$ para as rochas graníticas do Bloco Iguape estão listadas na Tabela 8.4.4.

Os granitos do Morro do Espia, apresentaram razōes $\left(\mathrm{Sr}^{87} / \mathrm{Sr}^{86}\right) \mathrm{i}$ de 0.710 e 0.712 , do NE de Iguape de 0.713 e da ZCS razão inicial bastante elevada de 0.732 ! (Tabela 8.4.4).

Em diagrama $\varepsilon \operatorname{Sr} \times \varepsilon \mathrm{Nd}(t=600 \mathrm{Ma})$, Figura 8.4.7, nota-se um comportamento distinto para estes litotipos, sugestivo de fontes distintas na geração desses granitóides, apesar de plotarem no quadrante inferior direito. Essas fontes teriam características de reservatórios crustais, fato este sugerido pelo comportamento observado dos isótopos de $\mathrm{Nd}$ e $\mathrm{Sr}$.

Corroborando com os resultados obtidos pela sistemática Sm-Nd, a amostra de protomilonito da ZCS apresenta comportamento bastante distinto das demais rochas graníticas do Bloco Iguape.

As amostras representativas da Serra do Itapitangui (K-31), Serra do Paratiú (K-61) e do protomilonito a NE da cidade de Iguape (K-36) mostraram valores de $\left(\mathrm{Sr}^{87} / \mathrm{Sr}^{86}\right) \mathrm{i}$ muito baixos, entre 0.633 e 0.699 , e consequentemente valores altamente negativos de $\varepsilon \mathrm{Sr}(\mathrm{t}=600 \mathrm{Ma})$. Tais dados são incompatíveis com os resultados obtidos pela sistemática $\mathrm{Sm}-\mathrm{Nd}$, e possivelmente indicam erros analíticos (Tabela 8.4.4).

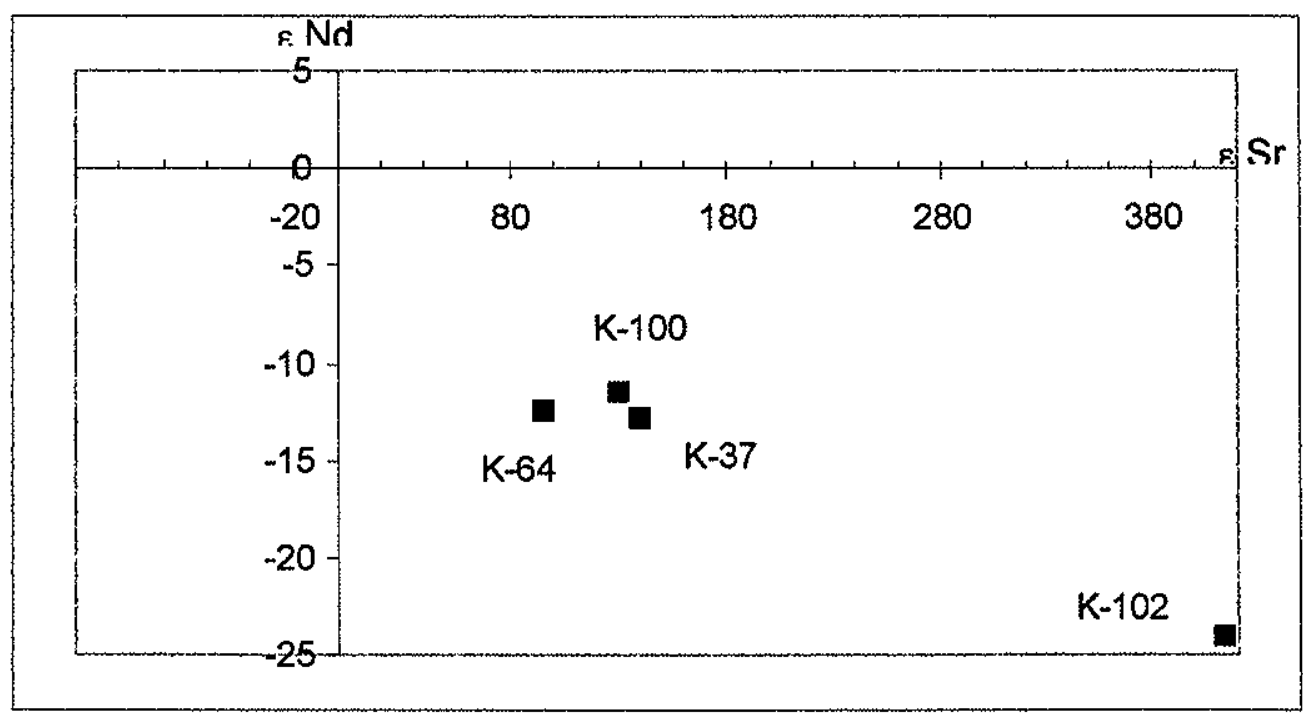

Figura 8.4.7 - Diagrama $\varepsilon \operatorname{Sr} \times \varepsilon N d(t=600 \mathrm{Ma})$ - Rochas graníticas - Bloco lguape. 
Tabela 8.4.3 - Dados analíticos da sistemática Sm-Nd para rochas Bloco Iguape.

\begin{tabular}{|c|c|c|c|c|c|c|c|c|c|c|c|c|}
\hline Região & $\begin{array}{c}\text { No. } \\
\text { Campo }\end{array}$ & $\begin{array}{c}\mathrm{Sm} \\
(\mathrm{ppm})\end{array}$ & $\begin{array}{c}\text { Nd } \\
\text { (ppm) }\end{array}$ & $\begin{array}{l}{ }^{141} \mathrm{Sm} / \\
{ }^{144} \mathrm{Nd}\end{array}$ & $\begin{array}{l}{ }^{143} \mathrm{Nd} / \\
{ }^{144} \mathrm{Nd}\end{array}$ & Erro & $e_{(0)}$ & $f_{S m / N d}$ & $\begin{array}{c}T_{\mathrm{DM}} \\
\text { (Ma) }\end{array}$ & $\mathrm{e}_{(\mathrm{TDM})}$ & $\begin{array}{c}T_{1} \\
\text { (Ma) }\end{array}$ & $e_{(11)}$ \\
\hline \multirow{2}{*}{$\begin{array}{l}\text { Morro do } \\
\text { Espia }\end{array}$} & $\mathrm{K}-64$ & 9.635 & 60.464 & 0.0964 & 0.511601 & 0.000029 & -20.23 & -0.51 & 1873.3 & 3.75 & 600 & -12.55 \\
\hline & $\mathrm{K}-100$ & 8,687 & 53,747 & 0,0977 & 0,511657 & 0.000010 & $-19,14$ & $-0,50$ & 1821,4 & 3,86 & 600 & $-11,56$ \\
\hline ZCS & $\mathrm{K}-102$ & 11,826 & 84,594 & 0,0845 & 0,510949 & 0.000037 & $-32,95$ & $-0,57$ & 2483,0 & 2,58 & 600 & $-24,36$ \\
\hline \multirow{2}{*}{ NE Iguape } & $\mathrm{K}-36$ & 1,581 & 6,974 & 0,1371 & 0,511701 & 0.000014 & $-20^{*}$ & $-0,30$ & $2.170^{*}$ & 2,22 & 600 & $-13,72$ \\
\hline & $\mathrm{K}-37$ & 4.552 & 22.608 & 0.1218 & 0.511684 & 0.000011 & -18.61 & -0.38 & 2.259 .4 & 2.99 & 600 & -12.87 \\
\hline Sa.Itapitangui & $\mathrm{K}-31$ & 13.243 & 51.591 & 0.1552 & 0.511639 & 0.000011 & $-22.8^{*}$ & -0.21 & $2.340^{*}$ & 0.69 & 580 & -16.42 \\
\hline Sa. Paratiú & $\mathrm{K}-61$ & 11,449 & 51,015 & 0,1357 & 0,511582 & 0.000010 & $-22.3^{*}$ & $-0,31$ & $2.320^{*}$ & 1,90 & 580 & $-16,09$ \\
\hline
\end{tabular}

${ }^{*} \varepsilon N d(0)$ e idade TDM recalculados pelo método do estágio duplo (Sato, 1998).

Tabela 8.4.4 - Dados analíticos da sistemática $\mathrm{Rb}-\mathrm{Sr}$ para as rochas do Bloco lguape.

\begin{tabular}{|c|c|c|c|c|c|c|c|c|c|c|c|c|}
\hline Regiāo & $\begin{array}{c}\text { No. } \\
\text { Campo }\end{array}$ & $\begin{array}{l}\mathbf{R b} \\
\mathrm{ppm}\end{array}$ & $\begin{array}{c}\mathrm{Sr} \\
\text { (ppm) }\end{array}$ & ${ }^{87} \mathrm{Rb} /{ }^{86} \mathrm{Sr}$ & ${ }^{81} \mathrm{Sr} f^{56} \mathrm{Sr}$ & Erro & $\varepsilon(0)$ & $\begin{array}{l}\text { ToM } \\
\text { (Ma) }\end{array}$ & $\varepsilon(T D M)$ & $\begin{array}{c}T_{1} \\
(M a)\end{array}$ & $\varepsilon(T 1)$ & RE - TI \\
\hline \multirow[b]{2}{*}{$\begin{array}{c}\text { Morro do } \\
\text { Espia }\end{array}$} & $K-64$ & 202.0 & 221.0 & 2.652 & 0.733248 & 0.000029 & 408.06 & 832.5 & -25.83 & 600 & 95.97 & 0.71056 \\
\hline & $\mathrm{K}-100$ & 197,0 & 318,0 & 1,797 & 0,728321 & 0.000019 & 338,13 & 1041,1 & $-24,46$ & 600 & 129,97 & 0,71295 \\
\hline $\mathrm{ZCS}$ & $\mathrm{K}-102$ & 160,0 & 345,0 & 1,347 & 0,744400 & 0.000037 & 566,36 & 2248,4 & $-16,46$ & 600 & 413,07 & 0,73287 \\
\hline \multirow[b]{2}{*}{ NE Iguape } & $\mathrm{K}-36^{*}$ & 316,0 & 41,0 & 22,703 & 0,887946 & 0.000027 & 2603,92 & 574,8 & $-27,51$ & 600 & -143.64 & 0,69369 \\
\hline & K-37 & 283.0 & 75.0 & 11.029 & 0.808069 & 0.000057 & 1470.11 & 675.2 & -26.85 & 600 & 140.68 & 0.71370 \\
\hline Sa.Itapitangui & $\mathrm{K}-31^{*}$ & 338.0 & 16.0 & 63.874 & 1.161380 & 0.000081 & 6485.17 & 504.7 & -27.96 & 580 & -1004.3 & 0.63314 \\
\hline Sa. Paratiú & $\mathrm{K}-61^{*}$ & 264,0 & 61,8 & 12,479 & 0,802685 & 0.000036 & 1393,68 & 566,5 & $-27,56$ & 580 & -61.71 & 0,69948 \\
\hline
\end{tabular}

* amostras com problemas analíticos. 


\subsection{DiscussÃo dos REsultados OBTIDOS}

Os litotipos investigados no Bloco Iguape englobam rochas graníticas e metassedimentares.

Os metassedimentos aflorantes na área de estudo, de baixo grau metamórfico anteriormente foram correlacionados à Sequência Turvo-Cajati (Silva, 1981). Esta correlação não se mantém neste trabalho por esta Sequência apresentar continuidade para norte, não restrita aos limites do Bloco Iguape. Os metassedimentos compreendem principalmente metaritmitos, com intercalações de metarenitos finos e metasiltitos, informalmente denominados de Metassedimentos Iguape. Apresentam uma foliação principal de direção em torno de E-W/ sub-vertical, paralela ao bandamento composicional. É sugerido neste trabalho a sua correlação com os metassedimentos de baixo grau aflorantes na porção setentrional da llha do Cardoso, definidos por Weber (1998), podendo ser correlacionados com os metassedimentos Rio das Cobras (Lopes, 1987).

As rochas graníticas aflorantes foram subdivididas em três grupos principais. Os sienogranitos da Serra de Itapitangui, biotita-monzogranitos da Serra de Paratiú I Cordeiro e os granitos que ocorrem no Maciço de Iguape. Através dos estudos desenvolvidos, pode ser observado que os granitos aflorantes no Bloco lguape, apresentaram características petrográficas, geoquímicas e isotópicas distintas.

Os Granitos da Serra de Paratiú e de Itapitangui são metaluminosos, este último com tendência peralcalina. Ambos apresentam características de rochas graníticas do tipo intra-placa.

Os granitos do Maciço do Iguape e aqueles afetados pela ZCS, são peraluminosos e apresentam características similares aos granitos do tipo arcovulcânico ou sin-colisionais. Entretanto nota-se uma diferença entre os granitos aflorantes no Morro do Espia daqueles que afloram a NE da cidade de Iguape.

Os granitos do Morro do Espia são mais enriquecidos em ETR em relação aos afiorantes a NE de Iguape, e apresentam teores bem mais elevados em $\mathrm{Ba}$ e bem mais baixos em $\mathrm{Rb}$ em relação àqueles.

$\mathrm{Na}$ região de Iguape os granitos apresentam textura protomilonítica, afetados por falhamento de movimentação dextral, indicando uma componente normal com 
transporte para SW. A deformação associada a fases distensionais também pode ser caracterizada pelos elipsóides de deformação prolatos obtidos.

O granito do Maciço de Iguape (K-67) e o protomilonito da ZCS (K-102) apresentaram idades U-Pb (zircões) em torno de $600 \mathrm{Ma}$, um pouco mais antigas que a obtida para o Granito da Serra do Cordeiro (K-34), em torno de $580 \mathrm{Ma}$. As frações de zircão analisadas do protomilonito da ZCS e da Serra do Cordeiro apresentaram heranças isotópicas, não observadas no Granito do Maciço de Iguape.

Foram obtidas idades U.Pb em monazitas no protomilonito ZCS, em torno de 570-580 Ma. Tais idades podem refletir um importante período termal que afetou a região, podendo estar associada a própria movimentação da ZCS, e mesmo da colocação de rochas graníticas como as da Serra do Cordeiro / Paratiú.

As rochas graníticas do Bloco Iguape mostraram grande variação nas idades modelo TDM, granitos do Morro do Espia ( 1.8 Ga), granitos a NE de Iguape (2.1 $2.2 \mathrm{Ga}$ ), Granitos das Serras de Itapitangui e Paratiú $(\sim 2.3 \mathrm{Ga})$ e protomilonito - ZCS $(\sim 2.5 \mathrm{Ga})$, e nos valores de $\varepsilon \mathrm{Nd}$ obtidos. Tais dados sugerem que os protólitos destas rochas se diferenciaram do manto em épocas paleoproterozóicas distintas, bem como que estes granitos apresentaram evolução isotópica bastante distinta.

O Granito da Serra do Itapitangui (K-31) ou Granito Mandira estudado, de tendências peralcalinas, pode ser correlacionado à Unidade Mandira 1, definida por Oliveira (1989), principalmente por suas caraterísticas petrográficas. As rochas graníticas aflorantes na Serra do Paratiú, já foram correlacionadas por Kaul \& Cordani (1994) à Suíte Granítica Intrusiva Serra do Mar.

Os biotita-monzogranitos a megacristais que ocorrem no Maciço de Iguape, normalmente protomiloníticos, através de suas características petrográficas, geoquímicas e geocronológicas, são aqui correlacionados aos granitos pertencentes ao Domínio Paranaguá (Siga Jr., 1995). Apresentam heranças isotópicas em zircões, como observado nos Granitóides tipo Morro Inglês, e idades TDM bastante variáveis, como também caracterizado nos Granitóides tipo Canavieira, Estrela e Morro Inglês, no Domínio Paranaguá (Siga Jr., op. cit.). 


\section{ZONAS DE CISALHAMENTO ITARIRI (ZCI) E CUBATÃO (ZCC)}

\subsection{INTRODUÇÃo}

A região sudeste do Estado de São Paulo apresenta-se recortada por inúmeros lineamentos de direção preferencial NE e E-W. Dentre eles, na área estudada, destacam-se em relação aos demais, a Zonas de Cisalhamento Cubatão (ZCC) e Zona de Cisalhamento Itariri (ZCl).

Para facilidade no tratamento dos dados estruturais, o Sistema de Cisalhamento Cubatão - Itariri ( $\mathrm{SCCl}$ ), foi subdividido em três domínios principais $A$, $B$ e $C$ (Figura 9.1.1). O ramo $A$, faz o limite entre o Bloco Embu e Registro, o ramo $B$ entre o Bloco Mongaguá e Registro e o ramo $\mathrm{C}$ entre o Bloco Embu e Mongaguá.

$O$ tratamento estrutural foi realizado conforme as diferentes movimentações (fases dentro de um mesmo processo deformacional), discriminadas ao longo destas ramificações ou faixas miloníticas.

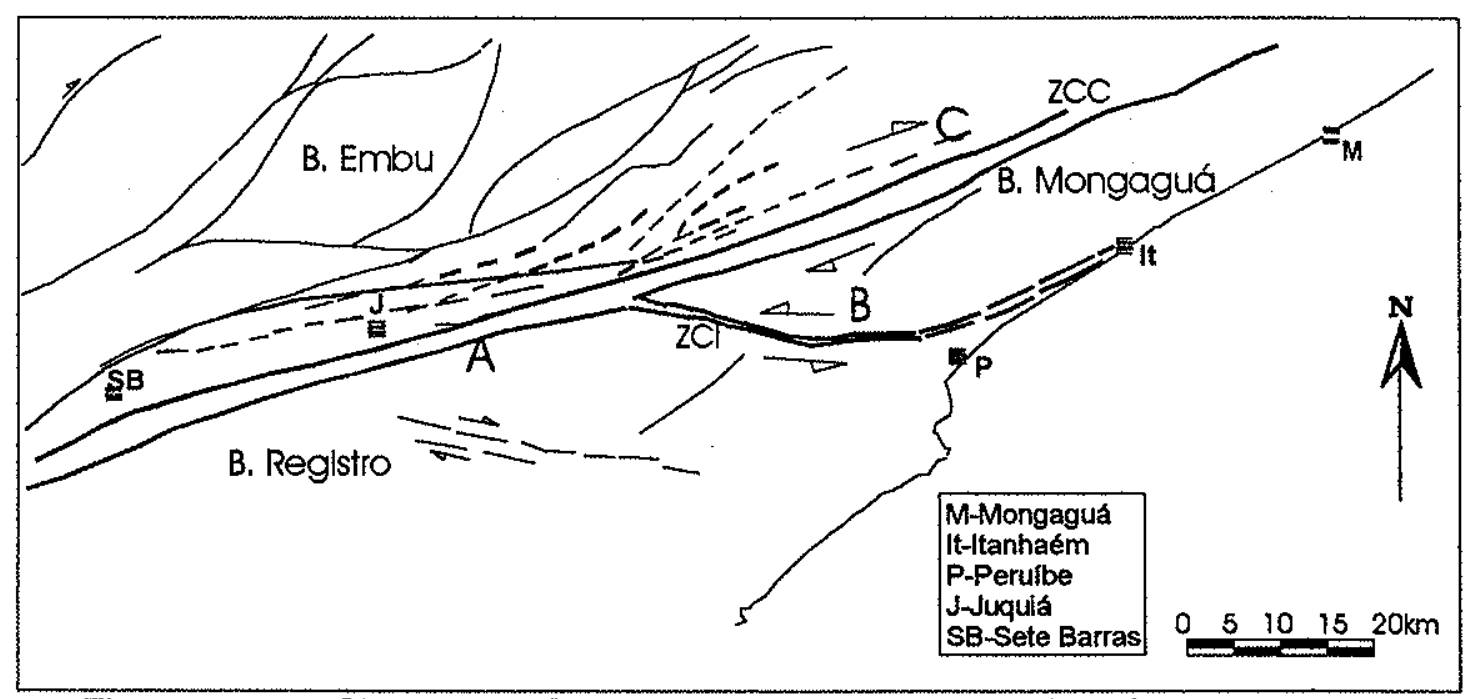

Figura 9.1.1 - Sistema de Cisalhamento Cubatão - Itariri na área de estudo. 


\subsection{CARACTERIZAÇÃo PETROGRÁFICA-ESTRUTURAL}

\section{CARACTERÍSTICAS MESOSCÓPICAS E MACROSCÓPICAS}

Duas importantes fases de deformação foram identificadas nos domínios estudados do $\mathrm{SCCl}$, através do estudo sistemático das rochas miloníticas aflorantes ao longo das ramificações $A, B$ e $C$.

$O$ estudo das estruturas planares e lineares observadas em trabalhos de campo, posteriormente foram analisadas e comparadas com os resultados obtidos pelo tratamento dos dados em estereogramas, em seções delgadas orientadas, bem como com as análises realizadas pelo Método de Fry e posterior posicionamento em Diagrama de Flinn.

$1^{A}$ FASE

A primeira fase, bem caracterizada nos ramos $A-B$, está relacionada a uma movimentação sinistral associada a uma componente de abatimento (extensão) para NWW. Esta fase foi responsável pela geração de boudins e dobras associadas ao cisalhamento, consequente de um forte extensão N80W (sigma 3). Para melhor caracterização desta primeira fase, realizou-se a subdivisão do ramo A-B em 2 setores principais.

O setor centro-oeste do domínio A-B (Figura 9.2.1) apresenta rochas protomiloníticas e miloníticas de rochas granitóides.

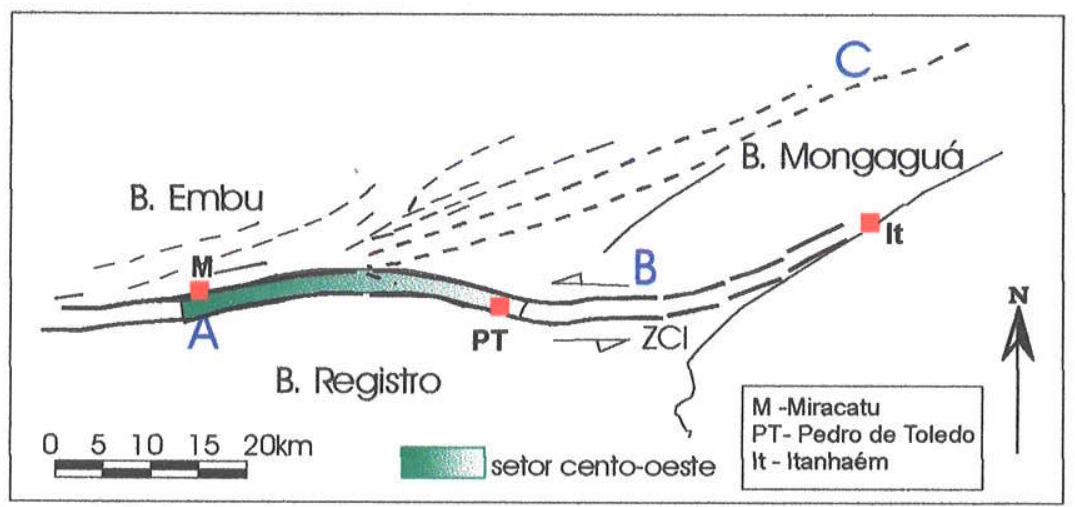

Figura 9.2.1 - Setor centro-oeste da ramificação A-B do SCCI. 
São rochas granitóides miloníticas, destacando-se porfiroclastos de feldspato branco em matriz de granulação fina média, e cor cinza escura, rica em biotita. Podem estar cortados por veios aplíticos, de direção N35E/65SE. A lineação mineral é caracterizada pelo estiramento dos porfiroclastos de feldspatos e cristais de quartzo. Não raramente a foliação protomilonítica apresenta-se anastomosada, dificultando a observação dos indicadores cinemáticos.

Neste setor, também observam-se rochas gnáissico-migmatíticas com enclaves máficos, apresentando porções afetadas pelo cisalhamento, onde mostram-se bastante orientadas, com enclaves máficos totalmente estirados (Prancha 13, Fotos 1 e 2). Caracterizam-se pela intercalação de faixas ricas em porfiroclastos de feldspato branco ou faixas de feldspato totalmente estirado, em uma matriz cinza escura, muito fina, rica em biotita (Prancha 22, Foto 1).

$\mathrm{Na}$ região próxima a junção das ramificações $\mathrm{A}, \mathrm{B}$ e $\mathrm{C}$, ocorrem rochas ultramiloníticas, apresentando escassos porfiroclastos de feldspato branco milimétricos em uma matriz cinza escura, muito fina.

As indicações cinemáticas foram obtidas a partir de porfiroclastos de feldspato sigmóides (Prancha 22, Foto 2) e de estruturas do tipo S-C, observando-se um rejeito sinistral oblíquo, com componente de abatimento (Figura 9.2.2).

Figura 9.2.2 - Croqui esquemático de movimentação sinistral com componente oblíqua para NW.

Caracteriza-se por uma foliação milonítica, de direção preferencial N85W/66N e lineação de estiramento mineral com caimentos baixos a intermediários para $\mathrm{W}$ (Figura 9.2.3). 


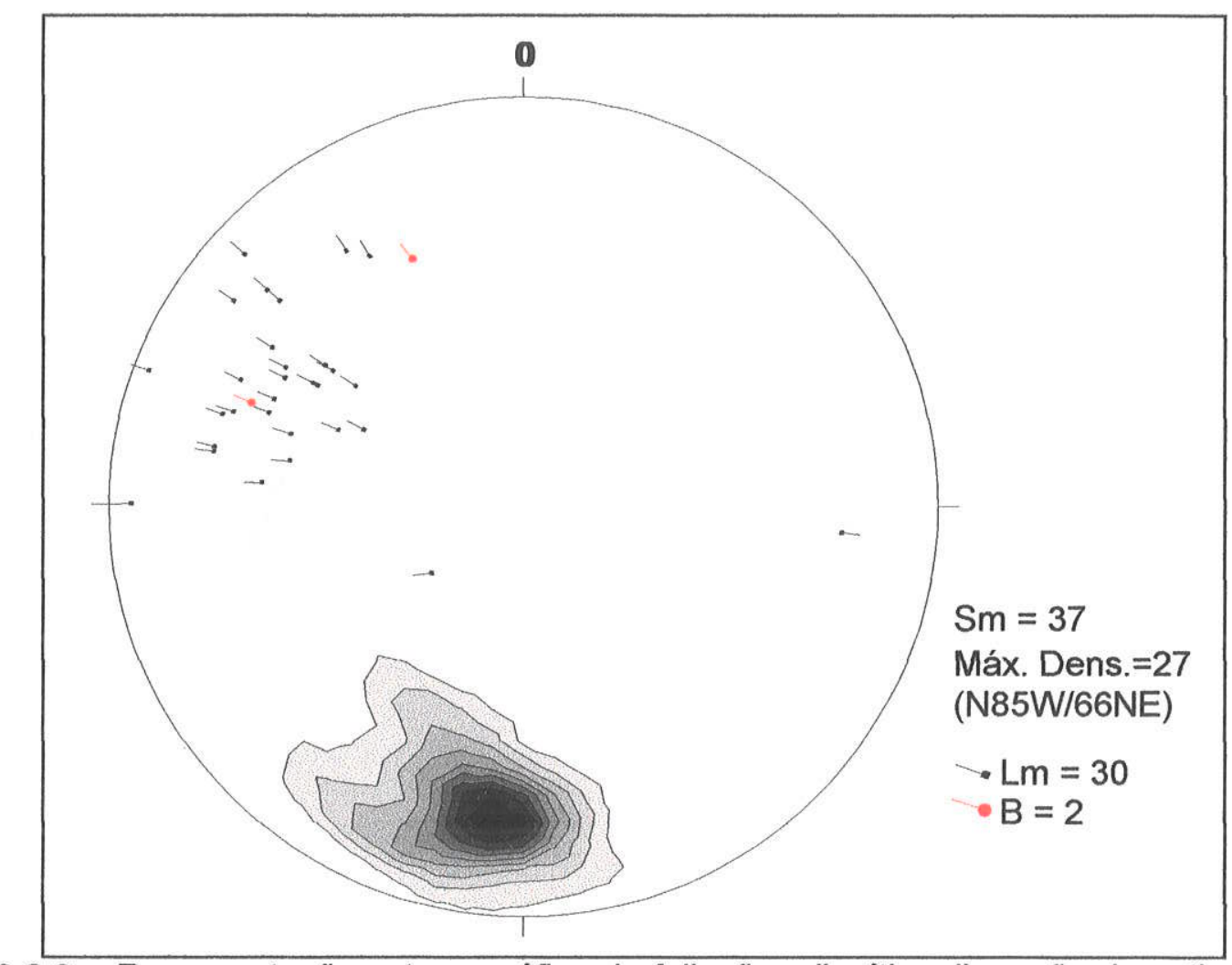

Figura 9.2.3 - Representação estereográfica de foliação milonítica, lineação de estiramento mineral e eixo de dobras de zona de cisalhamento sinistral - ramo A-B - setor centro-oeste.

Neste setor observam-se dobramentos associados a esta primeira fase (Figura 9.2.4), cujos planos axiais são paralelos à foliação milonítica. São dobras assimétricas, corroborando com a componente distensiva do cisalhamento, cujos eixos encontram-se sub-paralelos à lineação de estiramento mineral (Figura 9.2.3). As indicações cinemáticas sinistrais adicionadas aos dados planares e lineares indicam uma componente oblíqua distensiva para NW.

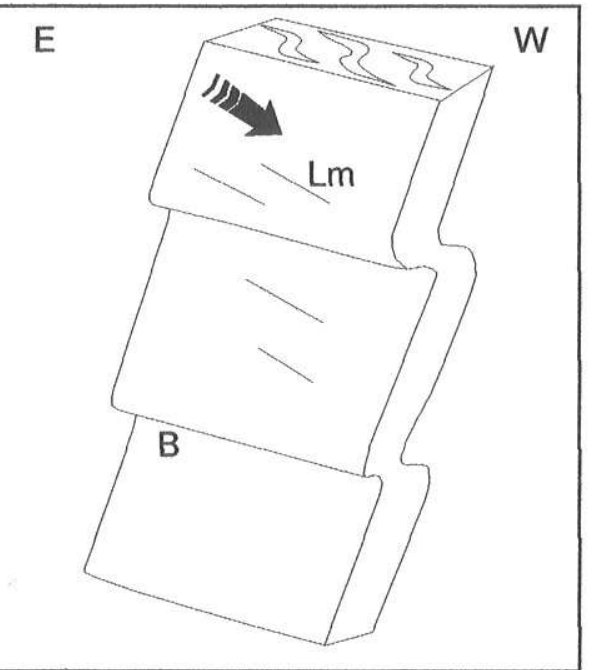

Figura 9.2.4 - Croqui de dobras assimétricas associadas à $1^{\text {a }}$ fase - ramo A-B. 
O setor centro-leste (Figura 9.2.5) caracteriza-se por apresentar menor mergulho da foliação milonítica e razoável variação na direção e caimento da lineação de estiramento mineral, apresentando milonitos e protomilonitos de rochas granitóides e metassedimentares.

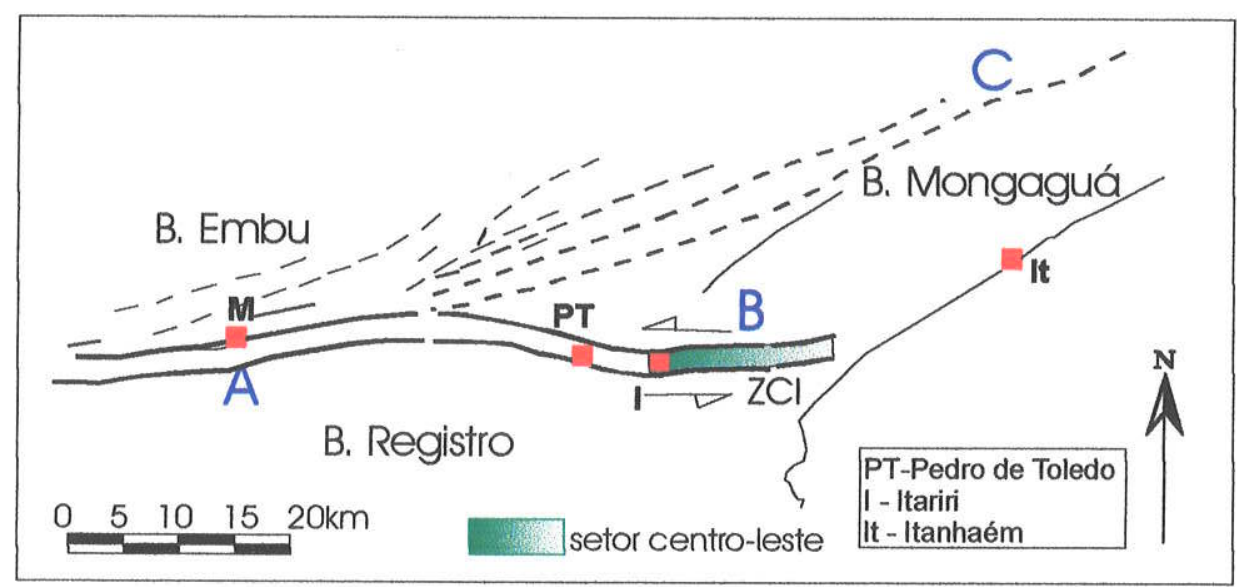

Figura 9.2.5 - Setor centro-leste da ramificação A-B do SCCI.

Os protomilonitos de rochas granitóides, caracterizam-se por porfiroclastos centimétricos de feldspato branco e menores de quartzo, muitas vezes sigmoidais, em uma matriz fina rica em biotita (Prancha 22, Foto 3).

Também ocorrem milonitos, com faixas ultramiloníticas, apresentando porfiroclastos de feldspato branco arredondados ou sigmoidais, de até $1 \mathrm{~cm}$, em matriz fina de cor marrom escura, com faixas totalmente estiradas compostas por feldspatos e quartzo (Prancha 22, Foto 4).

Localmente, próximo a região de Ana Dias, ocorrem sillimanita-granada biotita xistos miloníticos.

As indicações cinemáticas sinistrais observadas, foram obtidas principalmente em porfiroclastos sigmoidais de protomilonitos de rochas granitóides.

Apresentam foliação milonítica com direção geral em torno de N70W/48NE, desenvolvendo lineações de estiramento mineral com caimentos fracos a intermediários para direções variáveis preferencialmente no quadrante NW (Figura 9.2.6). 


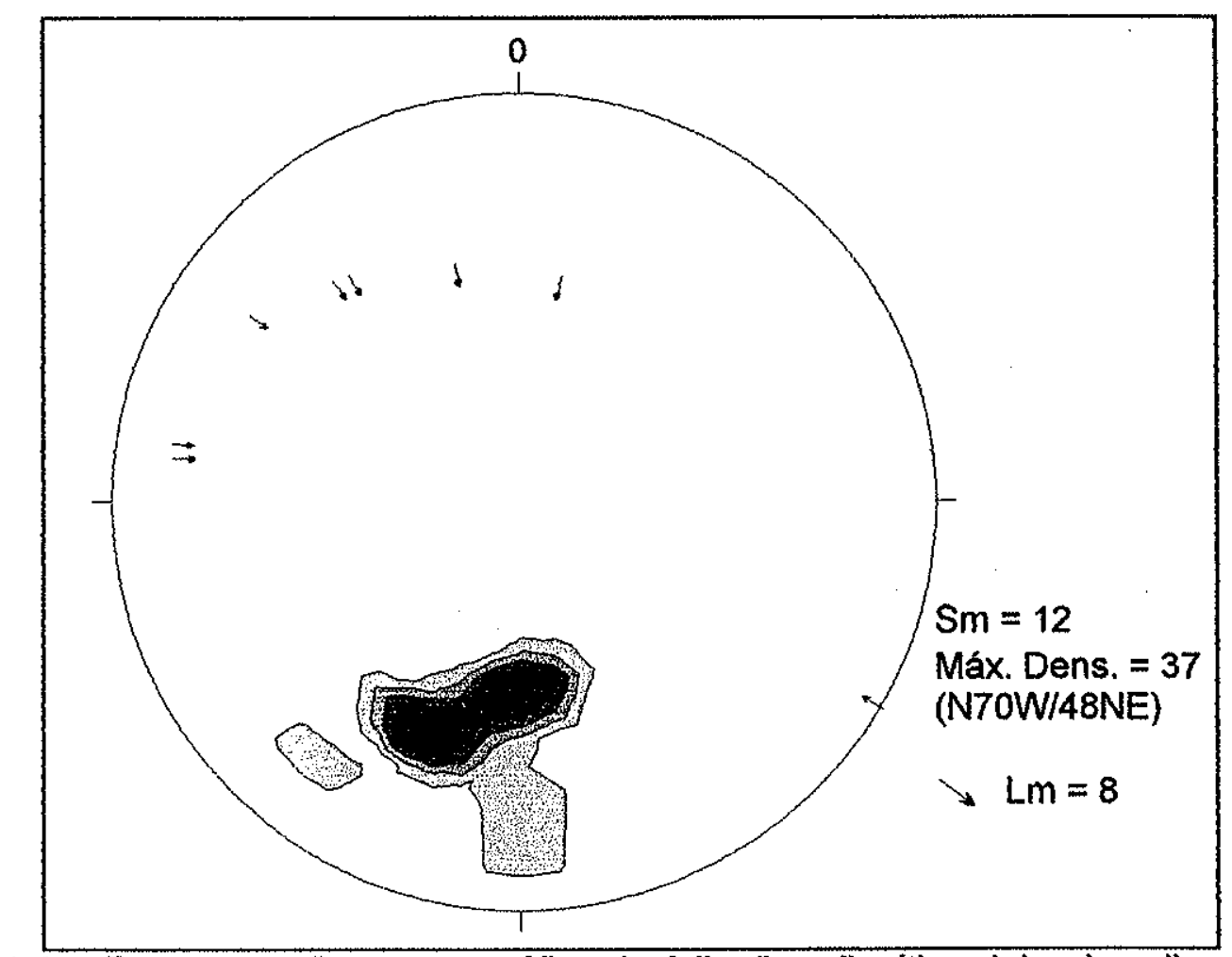

Figura 9.2.6 - Representação estereográfica de foliaçāo milonítica dobrada e lineaçäo de estiramento mineral de zona de cisalhamento sinistral - ramo A-B - setor leste.

$\mathrm{Na}$ área estudada, o ramo $\mathrm{C}$ não mostra registro desta primeira fase de movimentação sinistral, com componente de abatimento para NW.

\section{$2^{A}$ FASE}

A segunda fase de movimentação identificada no $\mathrm{SCCl}$, refere-se a uma compressão em torno de $\mathrm{E}-\mathrm{W}$, promovendo uma movimentação dextral no ramo $\mathrm{C} e$ sinistral no ramo A-B (Figura 9.2.7).

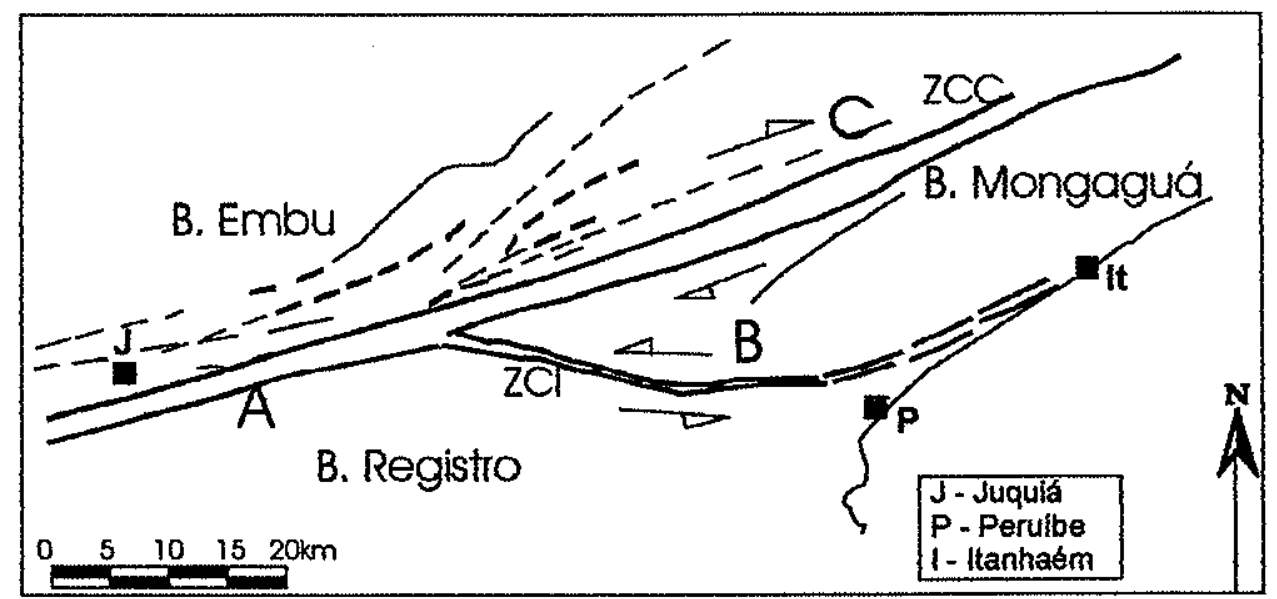

Figura 9.2.7 - Sistema de Cisalhamento Cubatão - Itariri na área de estudo. 
Na área investigada do ramo $C_{1}$ próximo à junção das três ramificações, ocorrem biotita gnaisses miloníticos, localmente ultramiloníticos, bandados, de cor cinza médio, com porfiroclastos de feldspato potássico entre 0.5 e $1 \mathrm{~cm}$, em matriz fina. Apresentam bandas de material hololeucocrático, intensamente deformados, ressaltando o bandamento. As indicaçöes cinemáticas dextrais, foram obtidas principalmente por porfiroclastos sigmoidais.

Também ocorrem filonitos alterados, de granulação muito fina, intensamente foliados, preservando-se lentes de material quartzo-feldspático com feiçōes sigmoidais. Podem apresentar estruturas do tipo S-C, indicando movimentação dextral.

A movimentaçăo transcorrente dextral, registrada na ramificação $C$, é caracterizada por uma foliação milonítica orientada preferencialmente em N70E com mergulhos sub-verticais para NW e SE, associada a lineações de estiramento mineral com caimentos baixos a intermediários predominantemente para $N E$, promovendo também uma componente distensiva para NE (Figura 9.2.8).

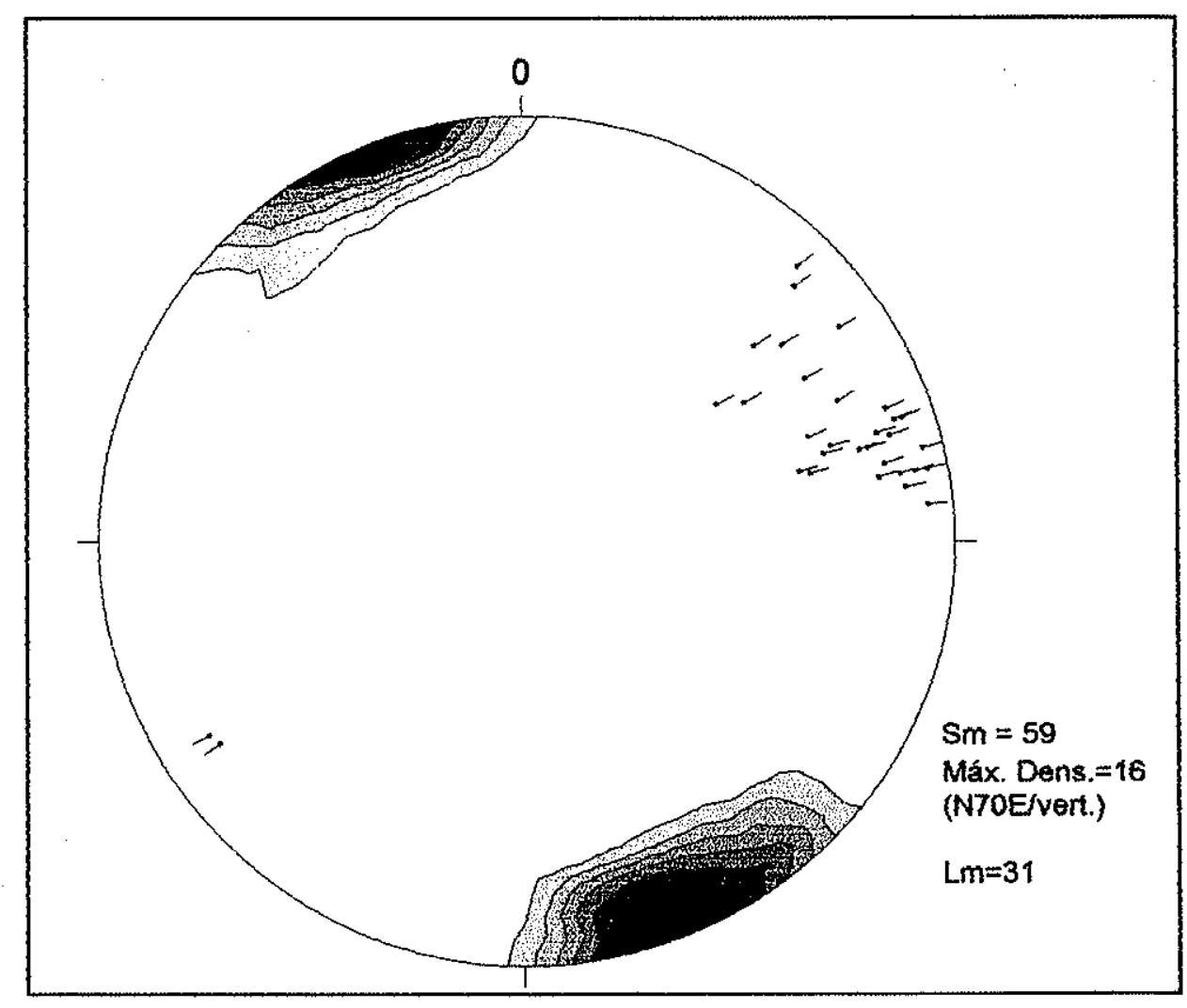

Figura 9.2.8 - Representação estereográfica de foliaçăo milonítica e lineação de estiramento mineral de zona de cisalhamento dextral - ramo $\mathrm{C}$. 
Esta mesma fase acarretou em uma movimentação sinistral na ramificação A$B$, onde predominam granitóides protomiloníticos e miloníticos que afloram em grandes paredões (Prancha 22, Foto 5).

Caracterizam-se por biotita gnaisses miloníticos, de composição granodiorítica a monzogranítica, granulação média a grossa, muitas vezes com predomínio de porções mesossomáticas, com porfiroclastos de feldspato branco de até $2 \mathrm{~cm}$, estirados e sigmoidais. A rocha apresenta faixas centimétricas hololeucocráticas, bastante estirada, intercaladas com faixas ricas em biotitas (Prancha 22, Foto 6). Apresentam estruturas do tipo S-C indicando movimentação sinistral.

Também ocorrem biotita granitos porfiroclásticos, com megacristais de feldspato branco, em matriz muito fina, de cor cinza, rica em biotita, com presença de filmes estirados de quartzo e feldspato (Prancha 23, Foto 1). Estas rochas podem apresentar remobilizados quartzo-feldspáticos bastante estirados, com formas sigmoidais, indicando movimentação sinistral (Prancha 23, Foto 2).

Esta movimentação sinistral no ramo $A-B$, desenvolveu uma foliação milonítica com máximo em N84E/60 NW, e lineação de estiramento mineral com caimentos baixos a intermediários para NE (Figura 9.2.9). Consequentemente, acarretou em uma movimentação com componente oblíqua compressiva para SW.

$\mathrm{Em}$ alguns afloramentos é possivel observar a foliação Ss, com direção preferencial N46W/45NE, que desenvolve uma lineação de estiramento mineral (LS) com caimento de $15^{\circ}$ para S45E (Figura 9.2.9).

Associadas a esta movimentação, ocorrem dobras (Figura 9.2.10) cujos eixos mostram caimentos preferenciais para NW, a cerca de $90^{\circ}$ da lineação de estiramento mineral (Figura 9.2.9). As foliações plano axiais apresentam direção geral NW, com mergulhos sub-verticais para NE e SW (Figura 9.2.9). 


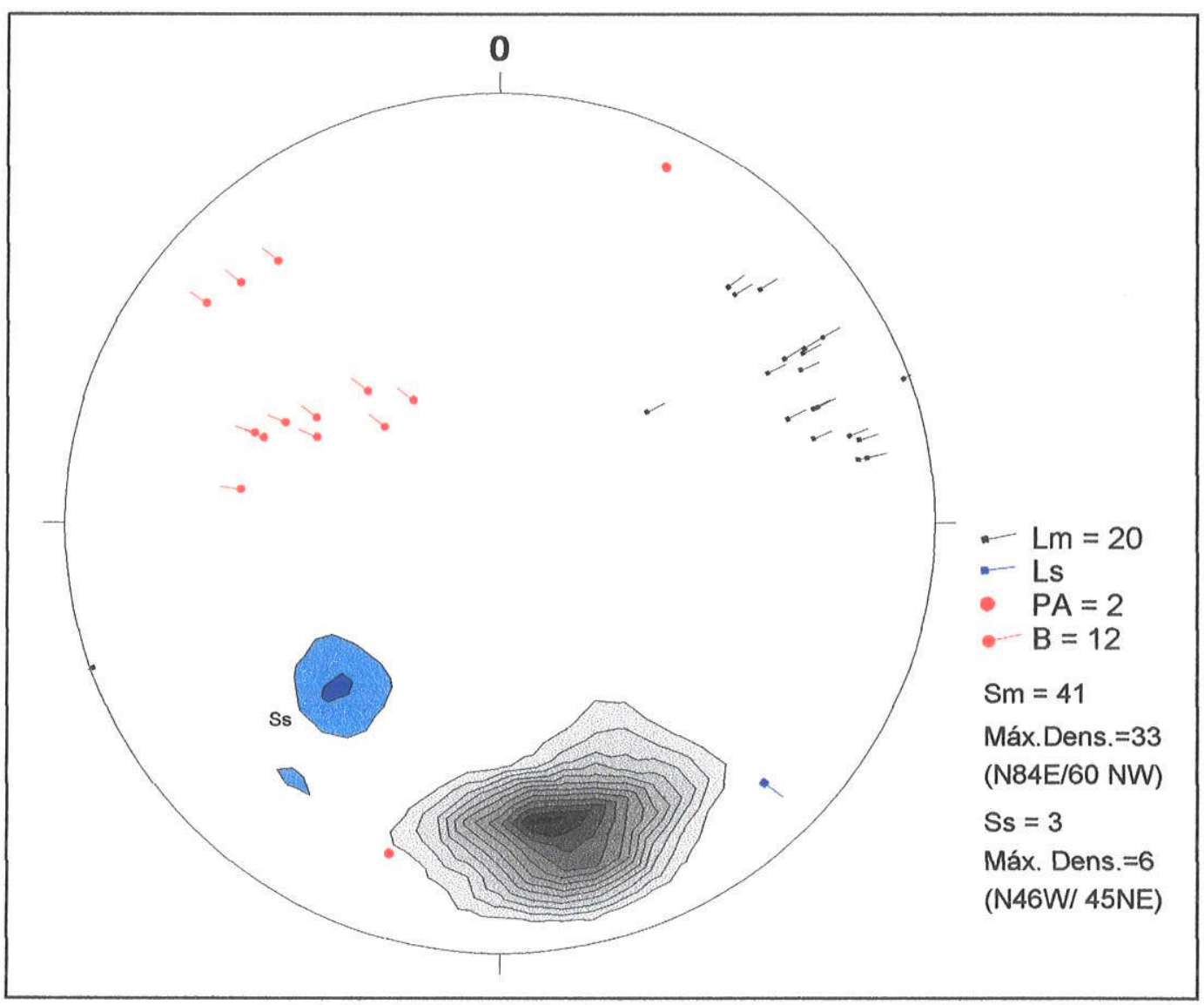

Figura 9.2.9 - Representação estereográfica de foliação milonítica e lineação de estiramento mineral de zona de cisalhamento sinistral - ramo A-B.

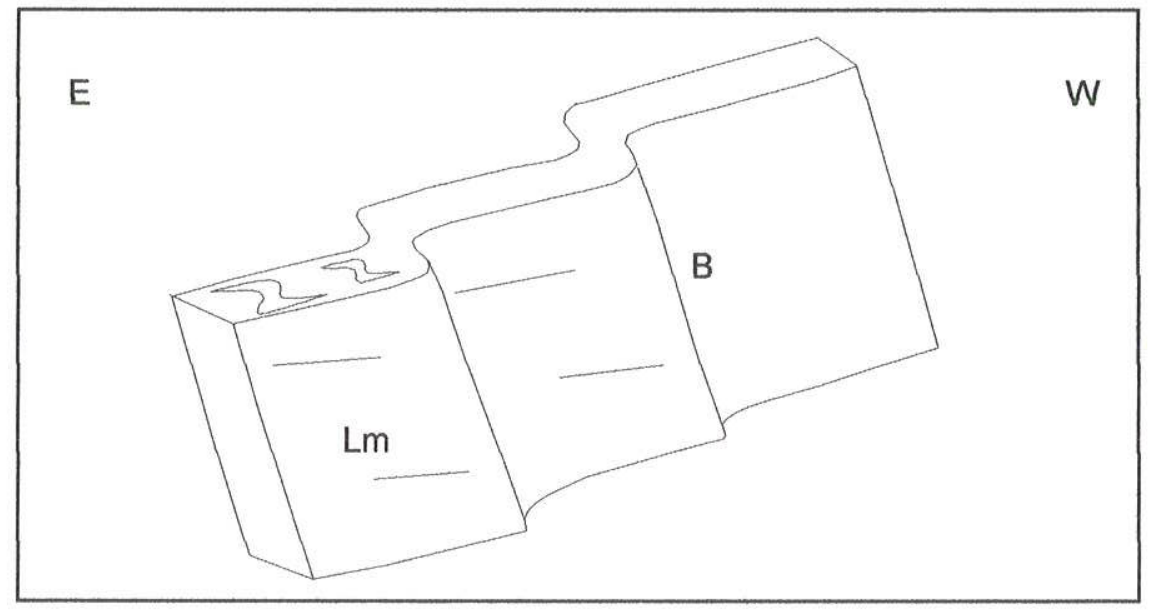

Figura 9.2.10 - Croqui de dobras assimétricas associadas à $2^{\mathrm{a}}$ fase - ramo $A-B$ 
Estrias presentes na foliação milonítica, com caimentos fracos a intermediários para NWW, e fendas de tração $T(N 13 E / 40 N W)$ provavelmente estão associadas a movimentações transcorrentes posteriores mais rúpteis da ramificação A-B.

A superposição das fases 1 e 2, pode ser identificada em milonitos graníticos da ramificação B. São biotita-granitos miloníticos, de cor cinza, com porfiroclastos de feldspato branco de até $1 \mathrm{~cm}$, apresentando alternância com bandas hololeucocráticas estiradas, sub-centimétricas. Apresentam o registro de uma foliação milonítica de caráter mais dúctil, associada a forte estiramento e recristalização de feldspatos, e outra sub-paralela a esta, relacionada à geração de dobras, de características menos dúcteis, com orientação de cristais de biotita. Ambas fases apresentam movimentação sinistral.

Localmente, os milonitos apresentam boudins, possivelmente formados na $1^{\text {a }}$ fase distensiva, que agora mostram-se comprimidos (Figura 9.2.11).

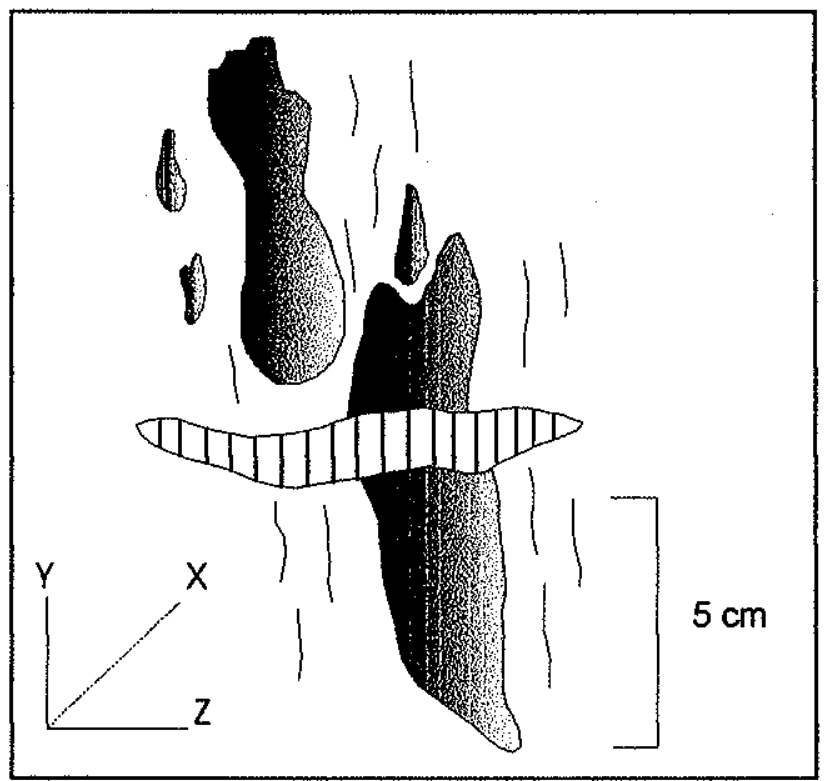

Figura 9.2.11 - Acavalamento de boudins.

Nota-se que as foliações miloniticas associadas a ambas as fases são praticamente paralelas, com máximo concentrado em N84W/60NE (Figura 9.2.12). Lineações de estiramento mineral com caimentos para NW, estão associadas a movimentação sinistral, com geração de dobras com eixos sub-paralelos a $\mathrm{Lm}$ e planos axiais sub-paralelos a $\mathrm{Sm}_{1}$, com componente oblíqua distensiva. As lineações 
de estiramento mineral com caimentos para NE, estão associadas a uma movimentação sinistral, com componente compressiva para SW, e geração de dobras com eixos NW e planos axiais sub-paralelos a $\mathrm{Sm}_{2}$.

Ambas fases estão associadas a dobramentos com planos axiais subparalelos às foliações miloníticas e eixos com caimentos para NW.

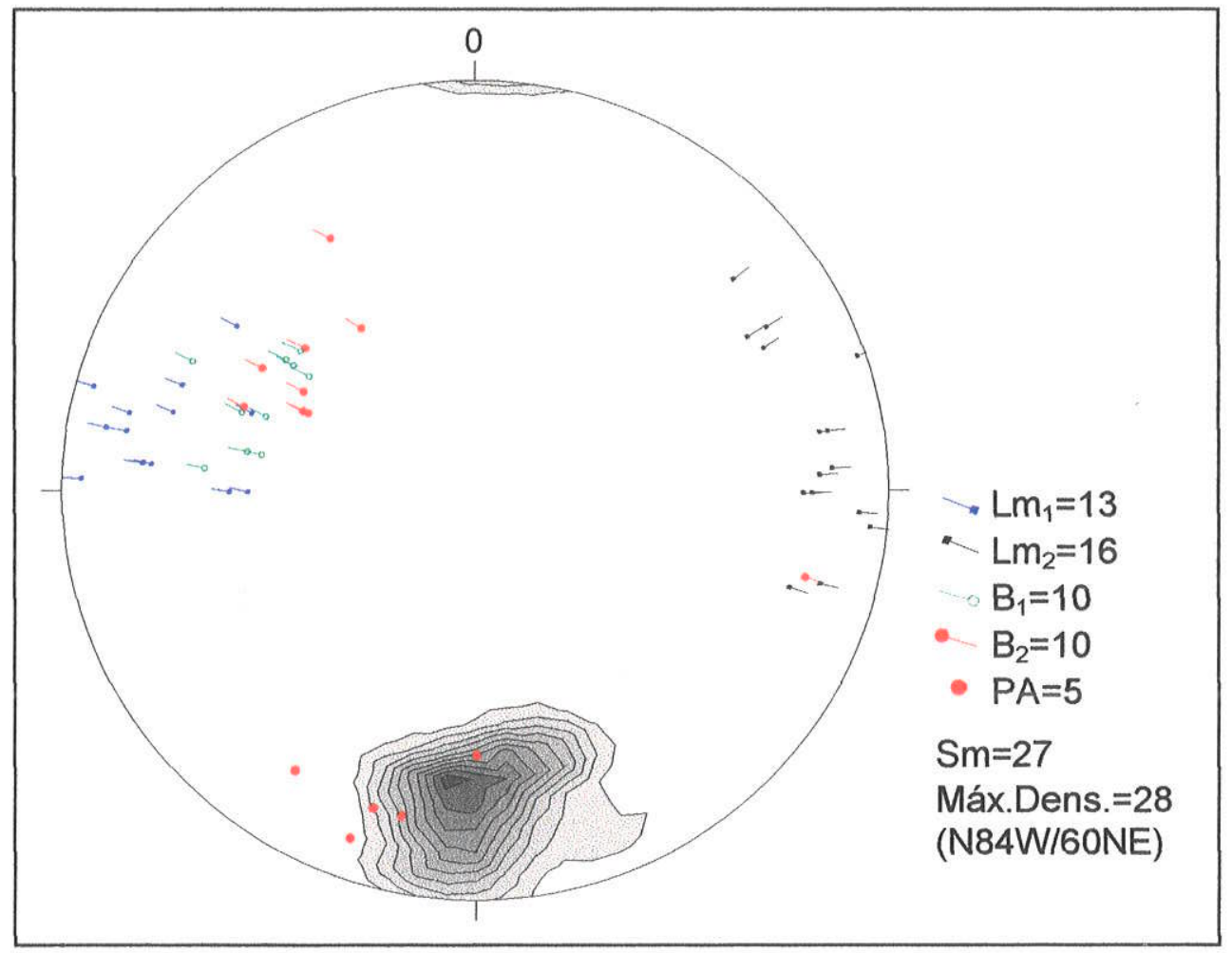

Figura 9.2.12 - Representação estereográfica de foliação milonítica e lineação de estiramento mineral $\left(\mathrm{Sm}_{1}, \mathrm{Lm}_{1}\right)$ associadas a movimentação sinistral distensiva e $\left(\mathrm{Sm}_{2}\right.$ e $\mathrm{Lm}_{2}$ ) associadas a movimentação sinistral compressiva - ramo B.

Certamente posterior à fase de abatimento NW (fase 1) e concomitante ou posterior à fase com componente de cavalgamento para SW no ramo B (fase 2), está registrada, na porção central e extremo leste do ramo $B$, uma componente oblíqua de cavalgamento para SE, denominada de fase $2 \mathrm{~A}$.

$\mathrm{Na}$ porção central da ramificação $\mathrm{B}$, esta fase afeta rochas granitóides e rochas metassedimentares, que mostram-se como lentes dentro do domínio das 
rochas graníticas. Tratam-se de rochas cálcio-silicáticas e xistos miloníticos intercalados com milonitos bandados de rochas granitóides.

O conjunto apresenta dobras associadas ao cavalgamento, com eixos N25W/33, sub-paralelos a lineação de estiramento mineral.

Nesta região central da ramificação $B$, esta fase está associada tanto a uma movimentação dextral, com foliação milonítica em torno de E-W e mergulhos intermediários para norte, como a uma movimentação sinistral, com foliação milonítica em torno de NWW e mergulhos fortes para SW, ambas com lineações de estiramento com caimentos para NW (Figura 9.2.13).

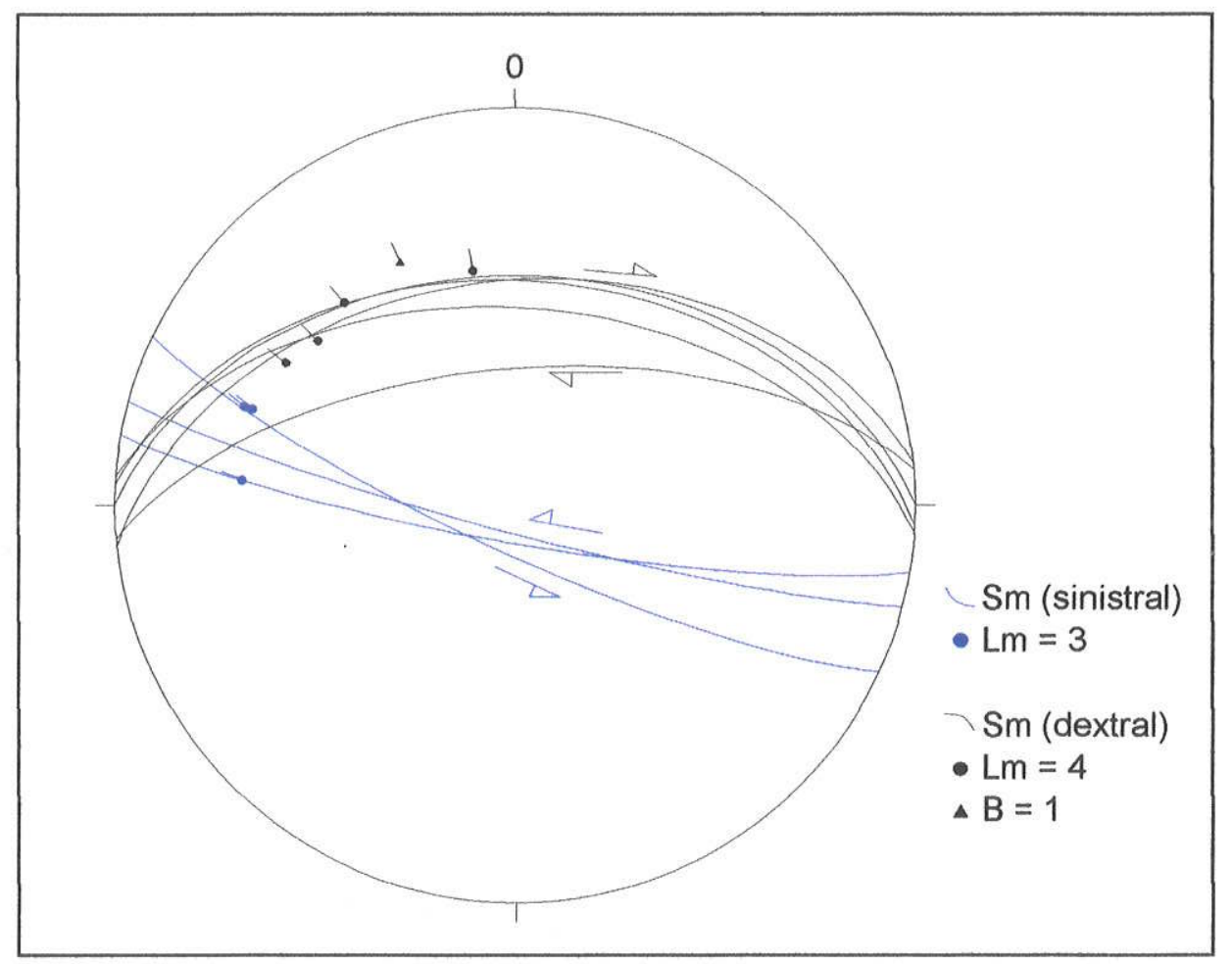

Figura 9.2.13 - Representação estereográfica de foliação milonítica e lineação de estiramento mineral associadas a componente oblíqua compressiva para SE (Fase 2A) setor central - ramo B.

$\mathrm{Na}$ região de Itanhaém, setor extremo leste do ramo B, ocorrem rochas graníticas protomiloníticas, que em associação com material máfico, caracterizam a formação de rochas gnáissicas com feições migmatíticas.

Apresentam foliação milonítica sub-horizontal com lineações de estiramento mineral com caimentos fracos para NW (Figura 9.2.14) caracterizadas pelo forte 
estiramento de feldspato potássico, que apresentam formas sigmoidais ou mesmo formando faixas estiradas (Prancha 23, Foto 3).

A componente de cavalgamento para S70E é observada em local onde a foliação milonítica apresenta mergulhos fracos para SW e lineação de estiramento com caimentos para N70W (Prancha 23, Foto 4).

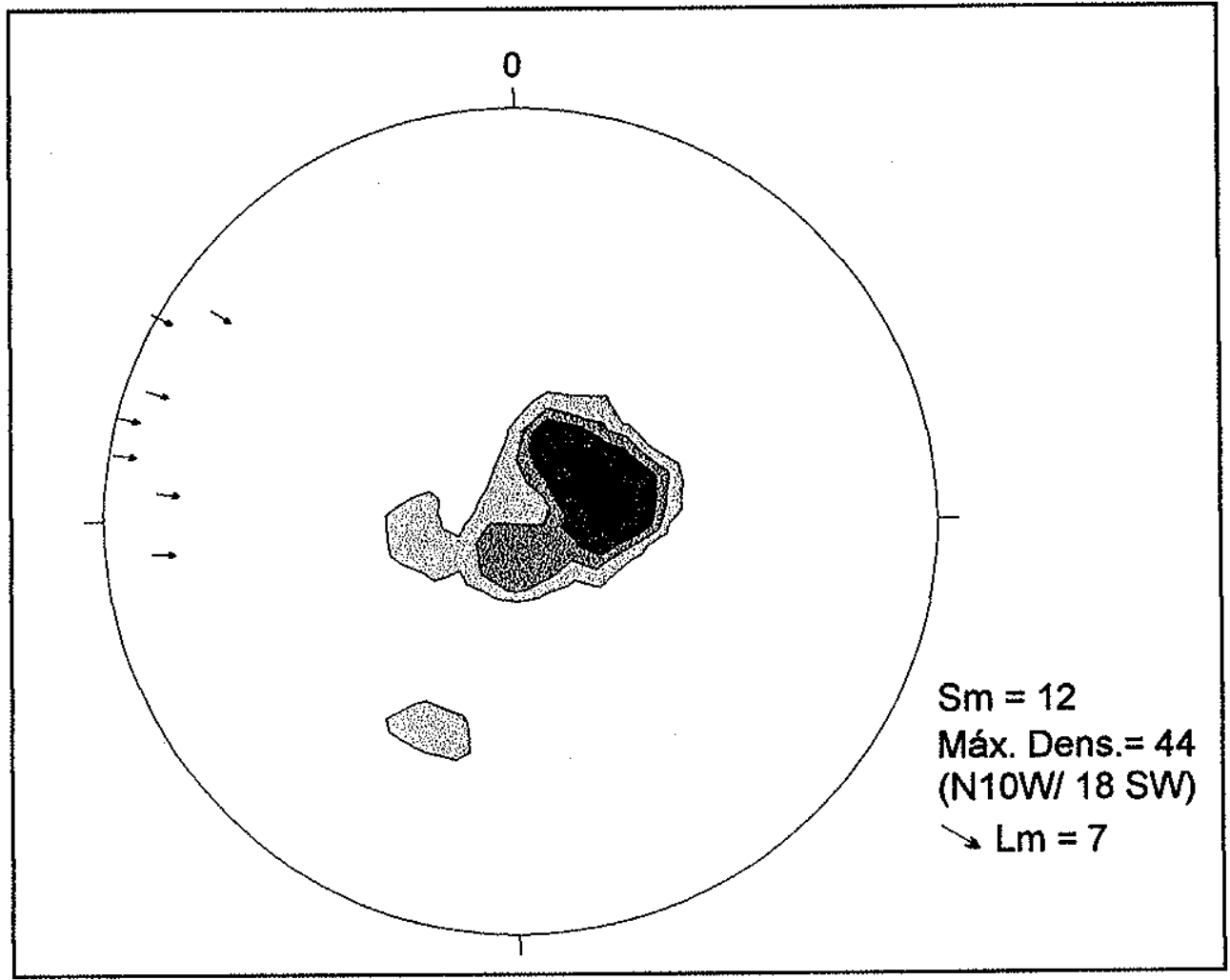

Figura 9.2.14 - Representação estereográfica de foliação milonítica e lineação de estiramento mineral associadas a componente oblíqua compressiva para SE (Fase 2A) setor extremo leste - ramo B.

Em afloramento da porção central da ramificação $B$, pode ser observada a superposição das fases 1 e 2 a (Figura 9.2.15), onde há o registro das foliações miloníticas e lineações de estiramento mineral associadas a movimentação sinistral, com abatimento para $\mathrm{NW}\left(\mathrm{Sm}_{1}\right.$ e $\left.\mathrm{Lm} \mathrm{m}_{1}\right)$, e das foliações e lineações de estiramento mineral associadas a movimentação dextral, com componente compressiva para SE $\left(\mathrm{Sm}_{2}, \mathrm{Lm}_{2}\right)$. 
No afloramento em questão, observa-se que a fase de movimentação sinistral com abatimento para NW deu-se em condições de maior ductibilidade em relação a fase de movimentação dextral com componente oblíqua de cavalgamento para SE.

A movimentação sinistral foi observada através de porfiroclastos sigmoidais e estruturas do tipo S-C, e uma componente dextral oblíqua de cavalgamento posterior, em condições menos dúcteis, observada através do acavalamento dos boudins e dobras assimétricas.

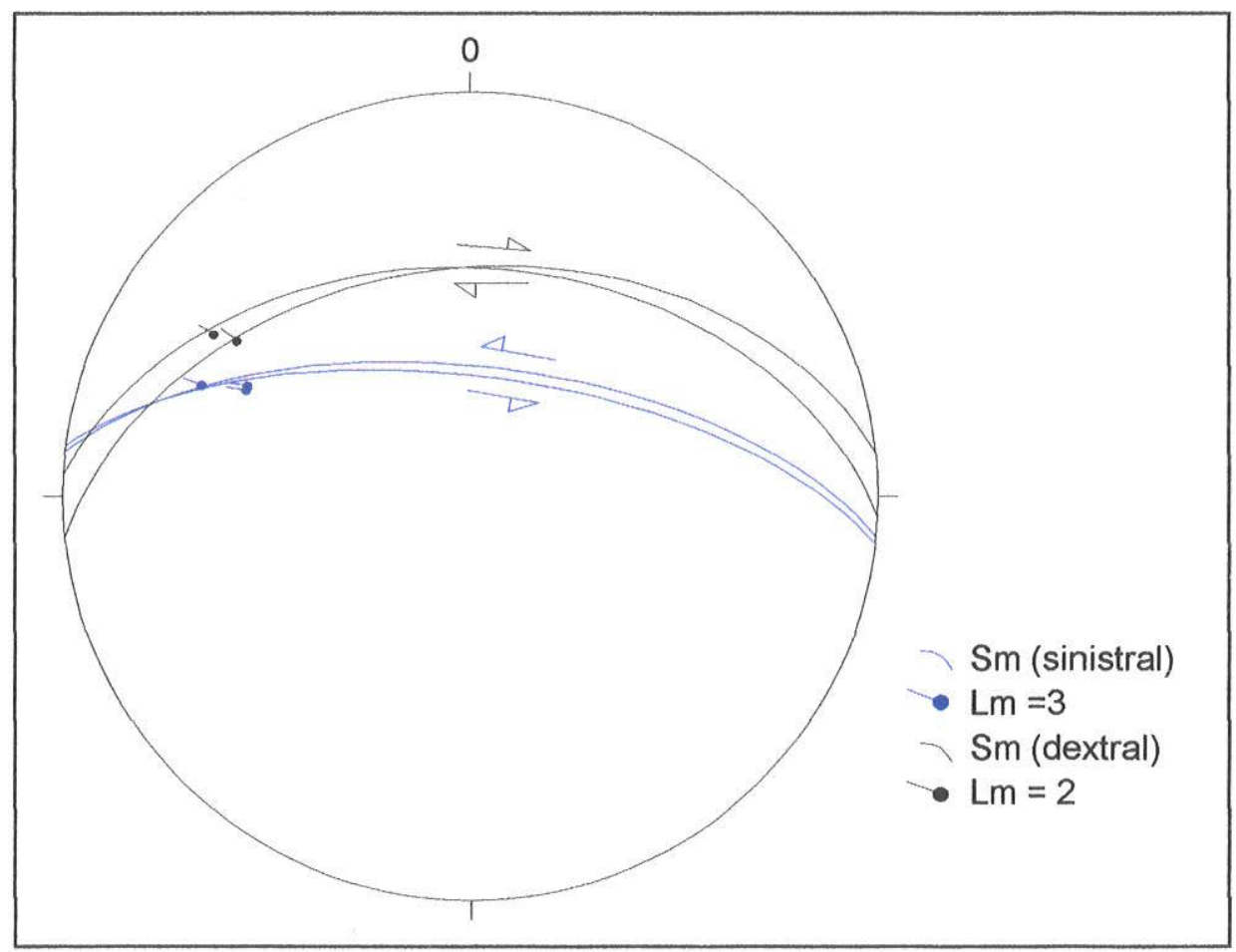

Figura 9.2.15 - Representação estereográfica de foliação milonítica e lineação de estiramento mineral $\left(\mathrm{Sm}_{1}, \mathrm{Lm}_{1}\right)$ associadas a movimentação sinistral e $\left(\mathrm{Sm}_{2}\right.$ e $\left.\mathrm{Lm}_{2}\right)$ associadas a movimentação dextral - ramo B.

Reativações da superfície milonítica, em condições mais rúpteis, podem ser observadas nas ramificações A-B.

Milonitos apresentam foliação milonítica com direção geral NEE / sub-vertical onde mostram a retomada de movimentação com desenvolvimento de estrias com caimentos fracos para W e para $E$ (Figura 9.2.16). 
Nestes locais, há o desenvolvimento de pequenas fraturas e fendas com preenchimento de quartzo. Podem caracterizar-se como fendas de tração com 20-25 $\mathrm{cm}$ de comprimento e $2 \mathrm{~cm}$ de espessura, preenchidas por quartzo fibroso não deformado. Apresentam direção variável no quadrante $\mathrm{NE}$, com mergulhos intermediários e altos tanto para SE quanto para NW (Figura 9.2.16).

Considerando-se a direção das fendas de tração paralelas a direção de maior compressão, estas movimentações posteriores, mais rúpteis, possivelmente estão associadas a movimentações sinistrais da ramificação A-B.

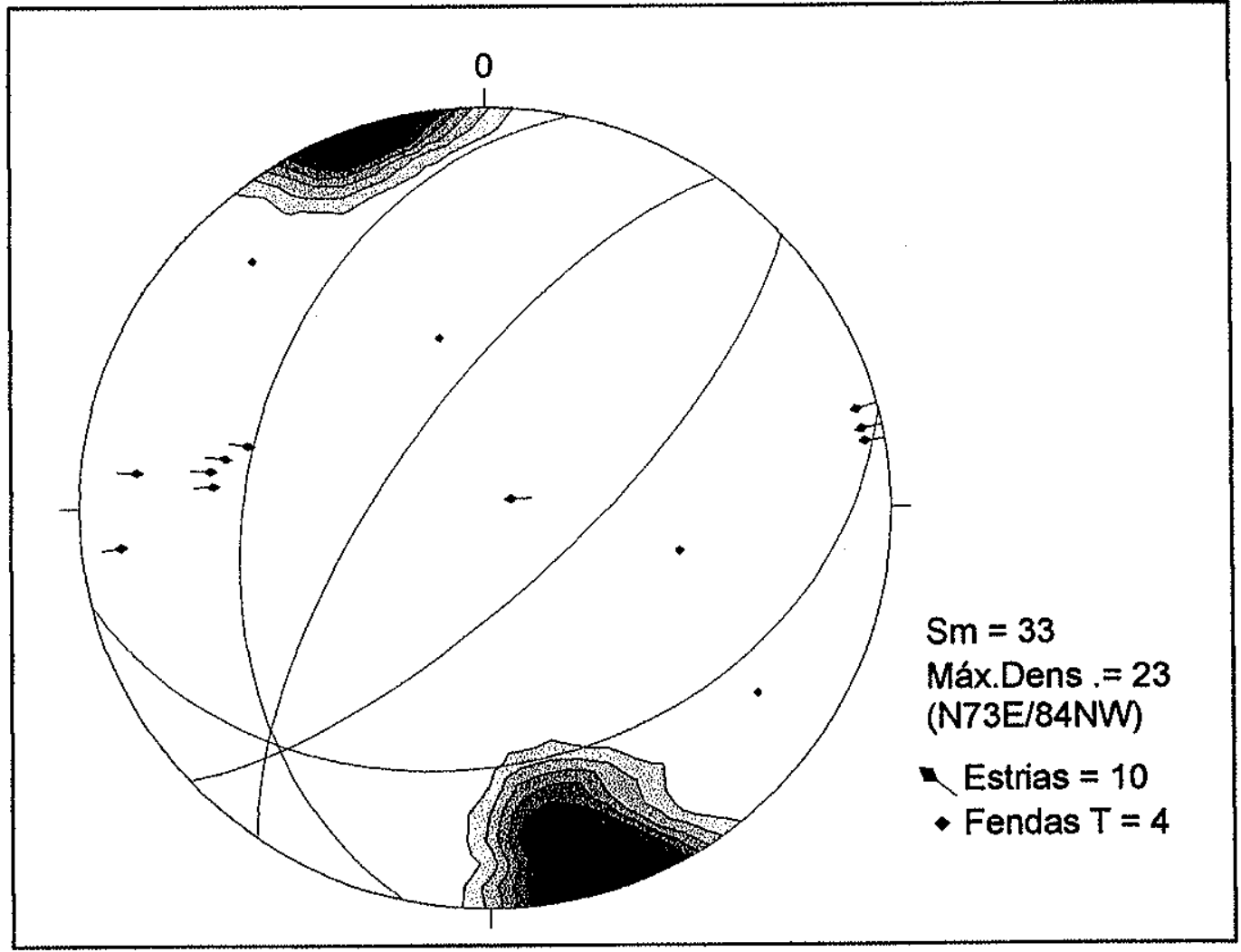

Figura 9.2.16 - Representação estereográfica de foliação milonítica com desenvolvimento de estrias e fendas de traçắo (polos e respectivos planos em vermelho) possivelmente associadas a movimentação tardia sinistral. 
Posteriormente, em condições bem mais rúpteis em relação às movimentações observadas anteriormente, desenvolvem-se falhamentos e fraturamentos que cortam as foliações miloníticas.

Os falhamentos posteriores podem ser bem evidenciados em milonitos porfiroclásticos, com predomínio de porções mesossomáticas, ricas em biotitas, com faixas hololeucocráticas. $O$ falhamento rúptil posterior é praticamente ortogonal à foliação milonítica e provoca arrastos sub-centimétricos (Prancha 23, Foto 5).

Os falhamentos mostram direção preferencial em torno de N40E com mergulhos fortes para NW e SE. Estes falhamentos estão associados a uma movimentação sinistral, gerando estrias com caimentos tanto para NE como para SW. (Figura 9.2.17).

Os fraturamentos posteriores apresentam direção preferencial em torno de NW, com mergulhos sub-verticais para NE e SW.

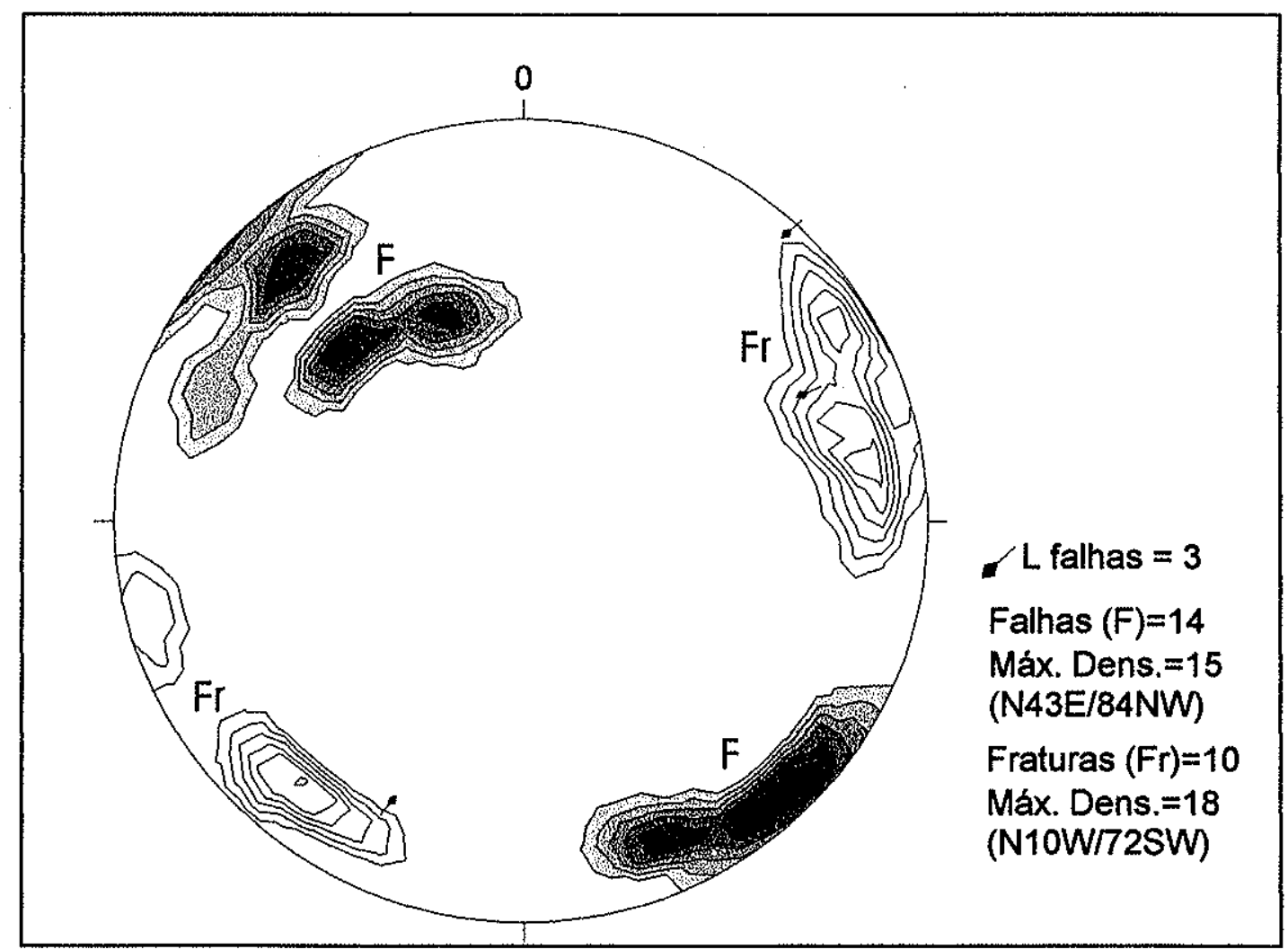

Figura 9.2.17 - Representaçăo estereográfica de fraturas $(F r)$ e falhamentos $(F)$ rúpteis de movimentação sinistral. 


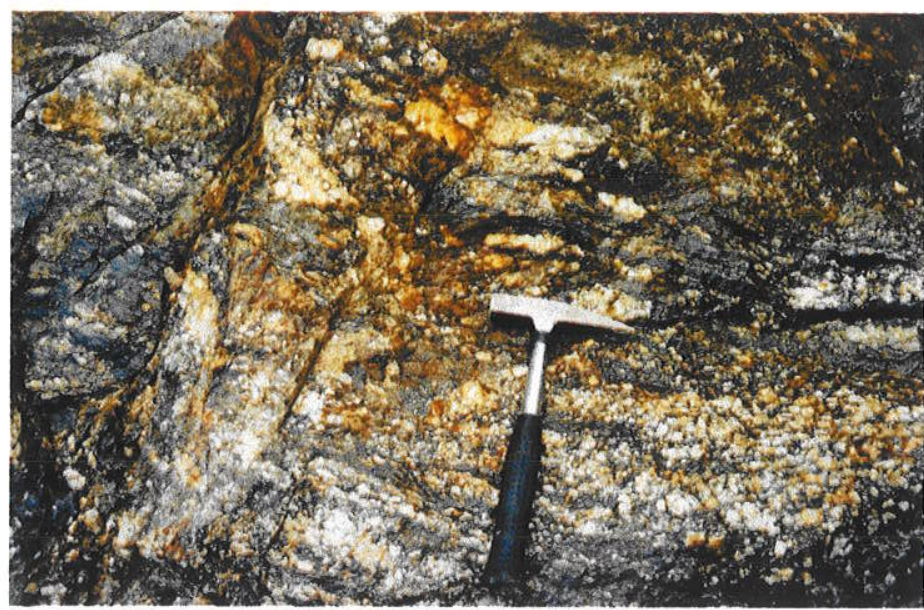

Foto 1 - Rochas gnáissico-migmatíticas afetadas pelo cisalhamento (ramo A). Afloramento K-88. Próximo a Miracatu.

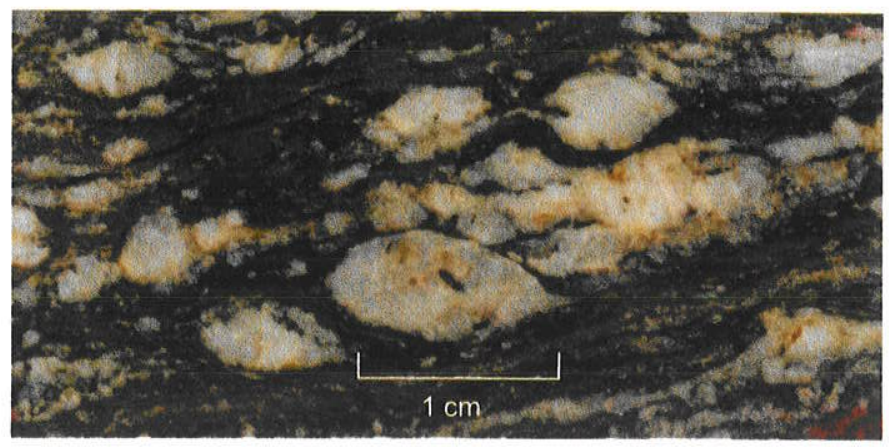

Foto 2 - Milonito de rocha granitóide. Foliação milonítica Sm: N80W/70NE; Lm (estiramento de feldspato): N70W/34. Ramo B (região entre Pedro Barros e Pedro de Toledo). Afloramento K-51 (corte XZ).

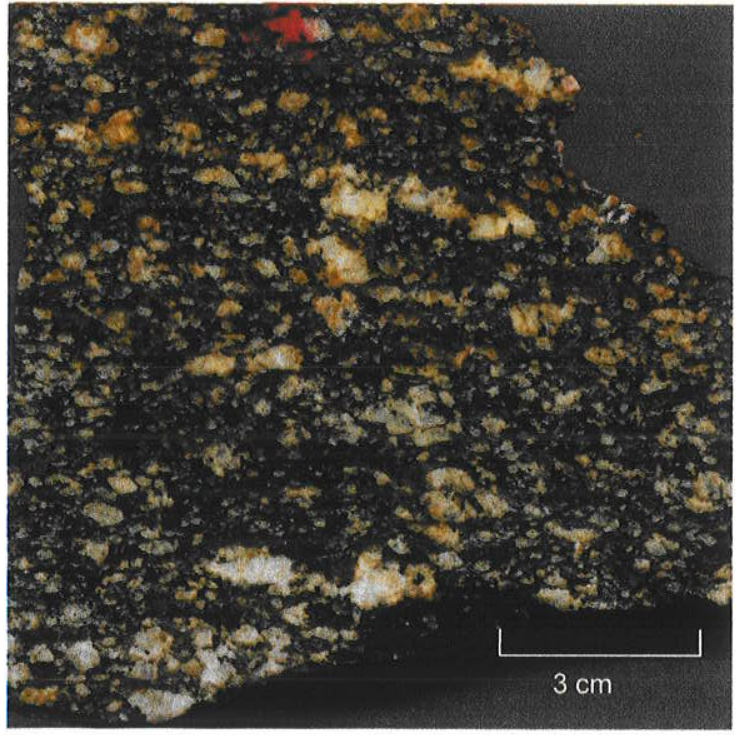

Foto 3 - Protomilonito de rochas granitóide (ramo $\mathrm{B}$ ) entre a região de Itariri e Ana Dias. Sm: E-W/ 60 N; Lm: N80W/19. Afloramento K-55 (corte XZ).

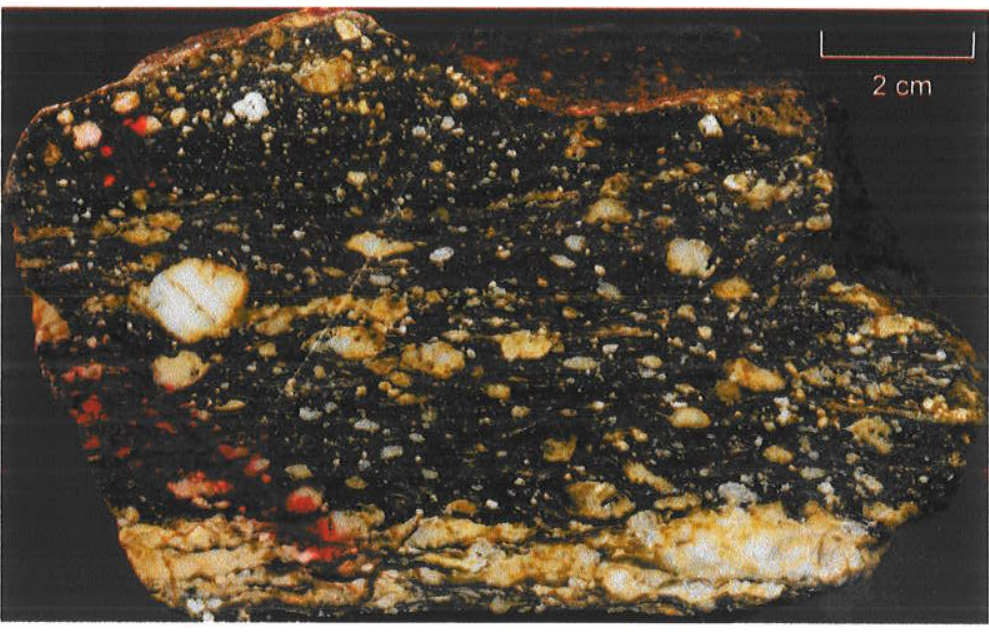

Foto 4 - Milonito de rocha granitóide - ramo $\mathrm{B}$, região próxima a Ana Dias. $\mathrm{Sm}=\mathrm{N} 67 \mathrm{~W} / 47 \mathrm{NE} ; \mathrm{Lm}$ : N10E/47.Afloramento K-57 (corte XZ).

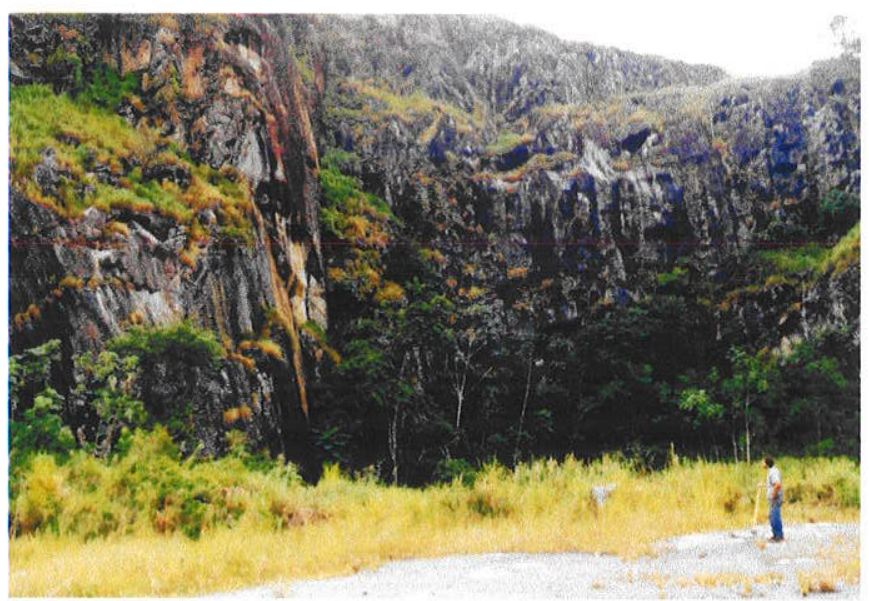

Foto 5 - Pedreira na região entre Pedro Barros e Miracatu (BR116). Ramo A. Sm: N78E/67NW; Lm: N60E/30. Afloramento K11.

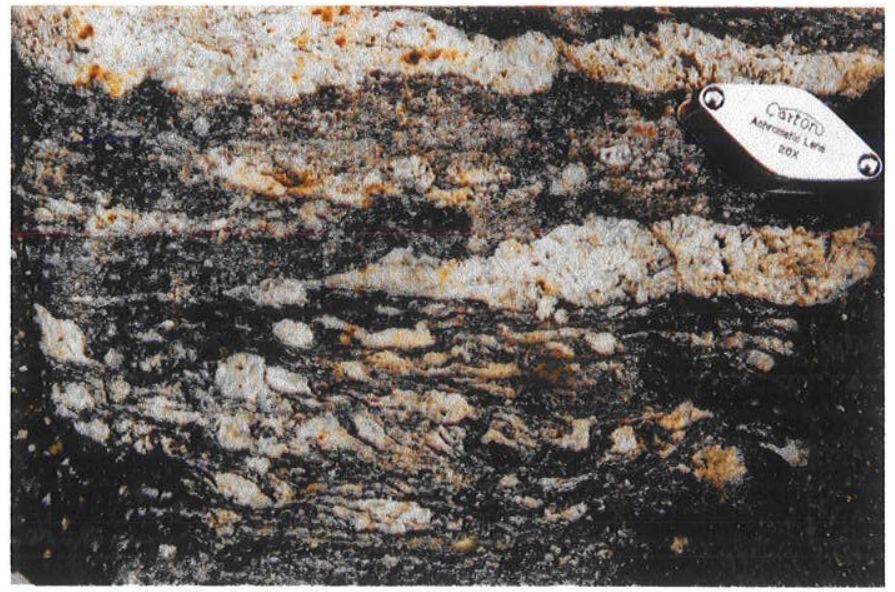

Foto 6 - Milonitos de rocha granitóide apresentando faixas quartzo-feldspáticas estiradas centimétricas e indicação cinemática sinistral. Afloramento K-11 (corte XZ). 


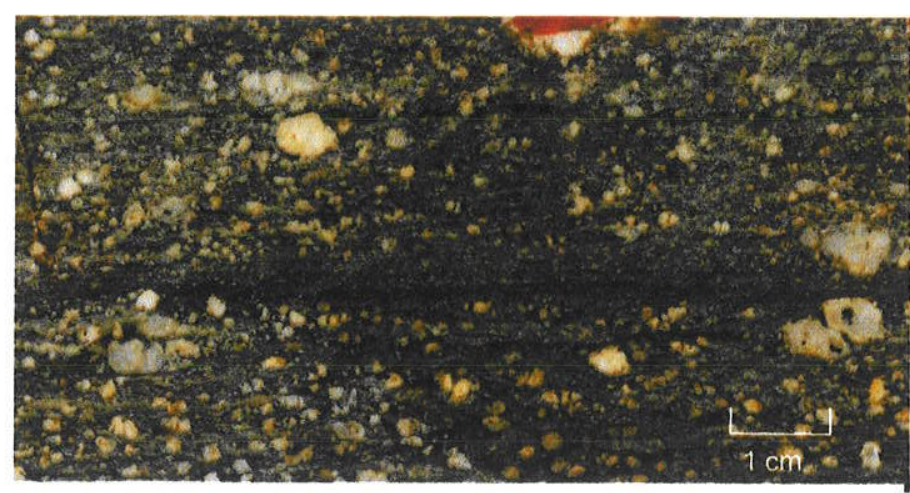

Foto 1 - Milonito porfiroclástico - ramo $\mathrm{A}$, região próxima à Miracatu. Afloramento K-12 (ccorte XZ).

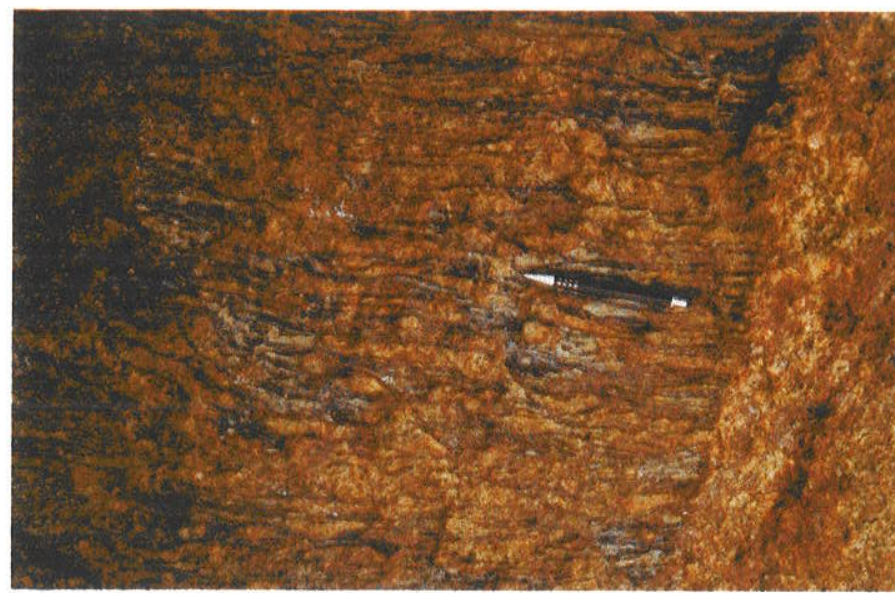

Foto 3 - Protomilonito granítico - Itanhaém. Foliação protomilonítica com forte estiramento de feldspato potássico. Afloramento K-5 (corte XY).

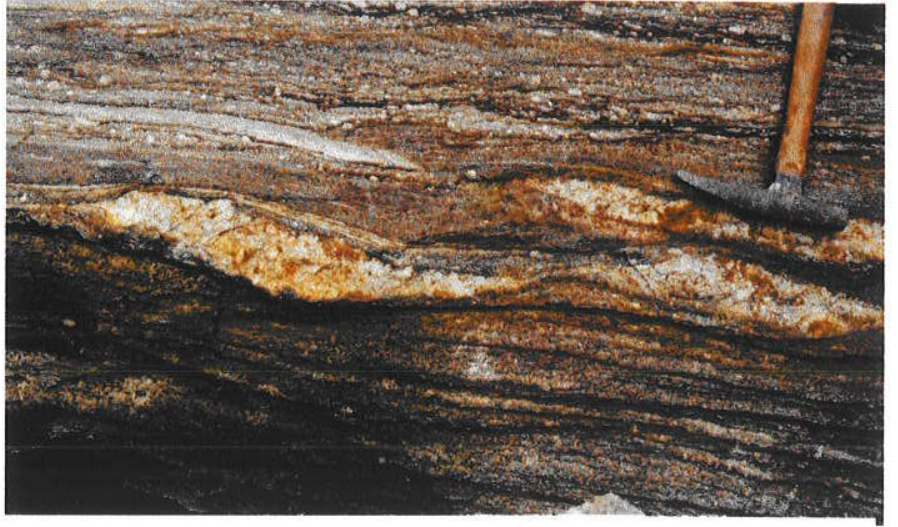

Foto 2 - Remobilizados quartzo-feldspáticos em milonito porfiroclástico, sugerindo indicação sinistral. Afloramento K-12 (corte XZ).

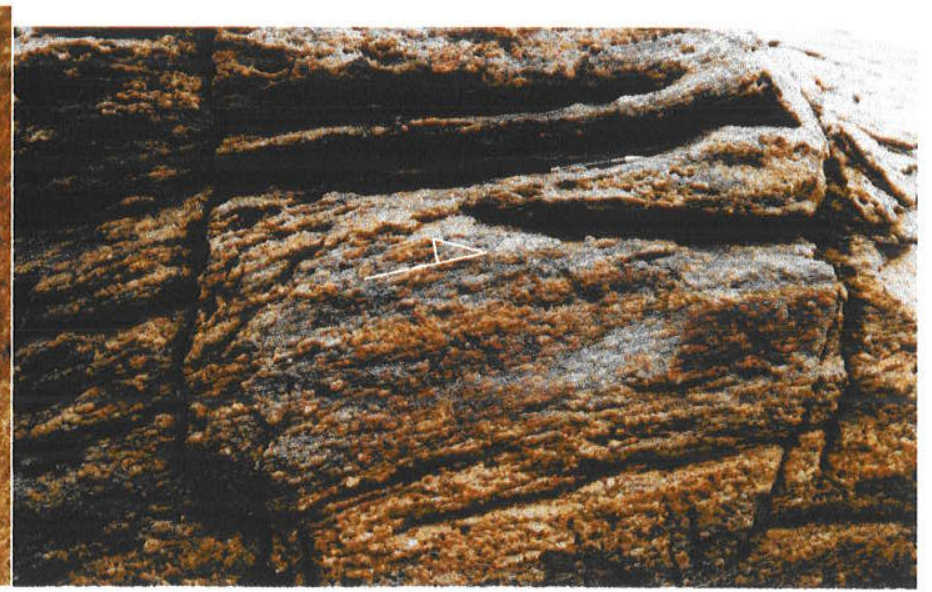

Foto 4 - Protomilonito granítico - Itanhaém. Indicação de componente de cavalgamento para SE através de porfiroclastos assimétricos (caneta como escala). Afloramento K-5 (corte XZ).

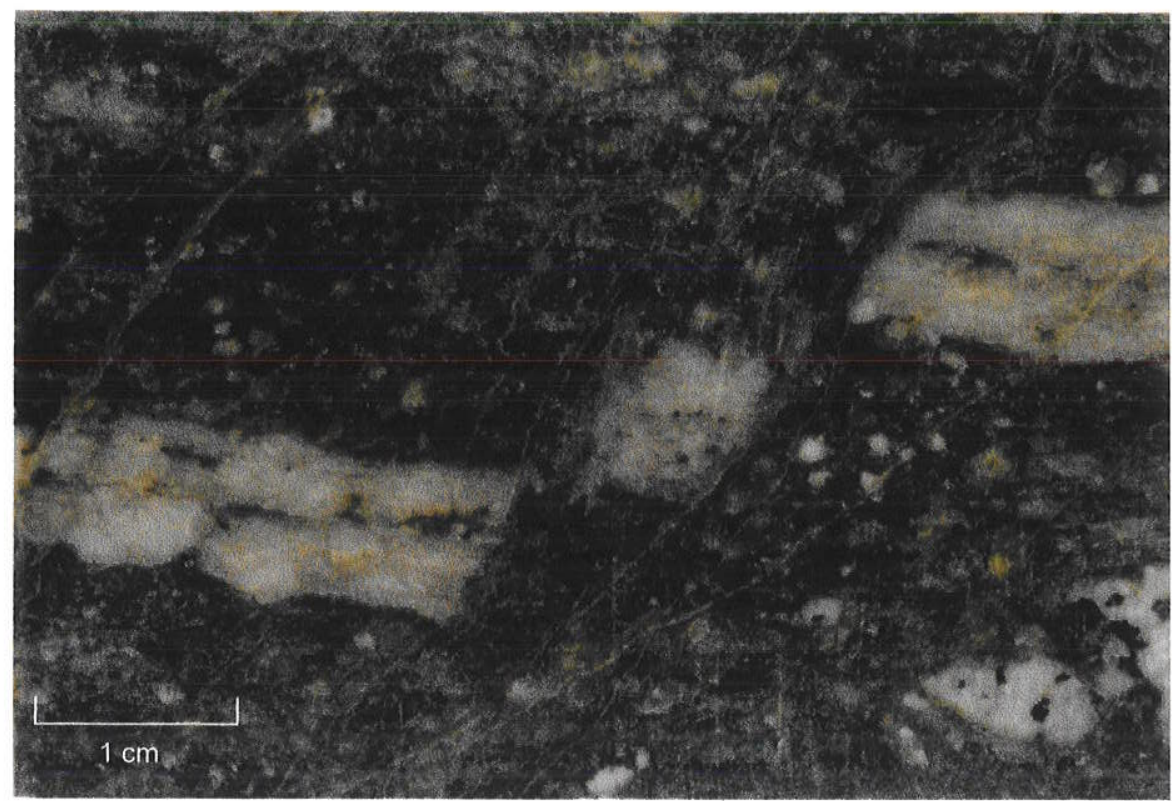

Foto 5 - Protomilonito granítico - ramo A entre Miracatu e Pedro Barros, com falhamento rúptil posterior. Amostra K-11 (corte XZ). 


\section{CARACTERISTICAS MICROSCÓPICAS}

Diversas rochas miloníticas dos ramos $A-B(Z C l)$, registram muito bem a primeira fase de movimentação sinistral distensiva.

Nesta primeira fase, a foliação milonítica é definida por faixas segregadas de quartzo, ou ribbons, que intercalam-se com matriz composta por quartzo microgranular, biotita, sericita e epídoto. Os porfiroclastos mais comuns são de microclínio e plagioclásio, ocorrendo também porfiroclastos de quartzo com extinção ondulante (Prancha 24, Foto 1).

As indicações cinemáticas sinistrais observadas em seção delgada são caracterizadas por porfiroclastos de feldspatos sigmoidais, que desenvolvem sombras de pressão (Prancha 24, Foto 2), granadas pré-cinemáticas com sombra de pressão composta por quartzo e biotita, estruturas do tipo mica-fish (Prancha 24, Foto 3) e estruturas tipo S-C.

Os cristais de quartzo geralmente apresentam-se na forma de ribbons, apresentando contatos tendendo a $120^{\circ}$ (poligonizados), com pouca ou nenhuma extinção ondulante, ou segregados da matriz, em formas sigmoidais. Raramente apresentam-se como cristais maiores com extinção ondulante ou em recuperação. Os ribbons podem apresentar-se totalmente fraturados, indicando a existência de uma fase rúptil mais tardia, como observado a nível macroscópico e mesoscópico. Os ribbons mais comuns, do tipo 2 A (Boullier \& Bouchez, 1978), são policristalinos (Prancha 24, Foto 4) e podem indicar condições de deformação em temperatura relativamente alta (superior a $350-400^{\circ} \mathrm{C}$ ), segundo os autores.

Segundo Simpson (1985), estes ribbons são típicos do grau xisto-verde médio-alto. Há evidência em algumas seções delgadas, da tendência de formação de ribbons policristalinos do tipo 4 ou 3 (Prancha 24, Foto 4), este último, segundo Boullier \& Bouchez (op. cit.), típico do fácies anfibolito. Estes apresentam-se orientados segundo a foliação Ss, indicando movimentação sinistral.

Os cristais de microclínio são normalmente pertíticos (fitas ou maculadas), ocorrendo formações mirmequíticas nas bordas em contato com plagioclásio. Comumente apresentam formas sigmoidais e normalmente a textura 'mortar' é bem desenvolvida, com recristalização nas bordas (Prancha 24, Foto 5). 
Os cristais de plagioclásio podem apresentar-se bastante saussuritizados, sendo comum apresentarem formas sigmoidais (Prancha 24, Foto 6). São comuns fraturas e deformação nas maclas, que mostram-se rompidas ou curvadas. Localmente, apresentam textura 'mortar', com recristalização do oligoclásio em cristais menores, caracteristicamente limpos, sem sericita, e com lamelas retas (Prancha 7, Foto 8).

Cristais de biotita normalmente têm pleocroísmo amarelo claro-marrom avermelhado. Quando presentes nas porções mais preservadas da deformação, são geralmente maiores, ou formam agregados e podem estar um tanto discordantes da foliação milonítica. No entanto, as biotitas mais afetadas pelo cisalhamento, constituem a matriz fina da rocha, estão bem orientadas e circundam os porfiroclastos. Em alguns locais, pode ser observada a recristalização destes cristais com exsolução de opacos nos planos de clivagem e nas bordas.

Cristais de muscovitas podem ocorrer bem orientados e desenvolvidos na matriz.

A paragênese característica, encontrada nestas rochas miloníticas dos ramos A-B $(\mathrm{ZCl})$, relacionada a primeira fase de movimentação, é representada por epídoto - sericita - (muscovita) \pm biotita - microclínio \pm (oligoclásio). Sugere-se, pela paragênese obtida, que a fase metamórfica principal atingiu o grau xisto-verde médio-alto/ ? anfibolito? . A presença da muscovita, recristalização de oligoclásio e caracterização dos ribbons de quartzo (tipo $2 \mathrm{~A}$, e 3), permitem essa interpretação.

Os metassedimentos afetados pela ramificação $B$, apresentam uma foliação milonítica caracterizada pela orientação de biotitas e sillimanitas e de ribbons de quartzo (Prancha 17, Foto 1), que circundam os porfiroclastos de agregados de quartzo, de microclínio e de granada. A matriz, muito fina, é composta por quartzo, biotita e sillimanita, com presença de cristais de zircões muito pequenos. Os ribbons de quartzo intercalam-se com a matriz bem orientada são policristalinos do tipo 4 (Boullier \& Bouchez, 1978) e cristalograficamente bem orientados.

Os cristais de sillimanita estão bem preservados, euedrais a subeuedrais, orientados e rotacionados (Prancha 17, Foto 2), indicando movimentação sinistral. Cristais de biotita mostram-se bem orientados e apresentam pleocroismo de amarelo-claro a marrom claro. Cristais de granada normalmente simétricos, estão fraturados e alterados por óxidos de Fe (Prancha 17, Fotos 1 e 2), podendo conter 
sombras de pressão constituídas por quartzo e biotita. Cristais de microclínio, normalmente em agregados, ocorrem como traços, e podem formar porfiroclastos.

$\mathrm{Na}$ segunda fase de movimentação, dextral no ramo $\mathrm{C}$ e sinistral nos ramos A-B (ZCl), a foliação milonítica é definida por porfiroclastos de plagioclásio e microclínio, ribbons de quartzo, e matriz fina constituída por quartzo serrilhado, biotita, sericita e epídoto (Prancha 25, Foto 1). A rocha mostra-se bastante epidotizada e sericitizada.

Nas rochas protomiloníticas, a foliação mostra-se anastomosada (Prancha 25, Fotos 1 e 2) caracterizada por faixas segregadas de cristais de quartzo, que envolvem e circundam os porfiroclastos de feldspatos.

Indicadores cinemáticos comuns são porfiroclastos sigmoidais e estruturas do tipo S-C (Prancha 25, Foto 3).

A grande maioria dos cristais de quartzo estão segregados em ribbons, onde estão recristalizados com contatos poligonais. São ribbons policristalinos do tipo $2 \mathrm{~A}$ (Boullier \& Bouchez, 1978). Também podem estar em agregados com formas sigmoidais (Prancha 25, Foto 4).

Cristais de microclínio são por vezes pertíticos, apresentando discreta recristalização nas bordas, e cristais de plagioclásio normalmente estão bastante saussuritizados.

Observa-se a sericitização dos porfiroclastos de plagioclásio, que favorece o desenvolvimento de fraturas rompendo o cristal e formando texturas do tipo dominó (Prancha 25, Foto 5). Fraturas $T$ também desenvolvem-se em porfiroclastos de plagioclásio (Prancha 25, Foto 6), indicando a direção de maior encurtamento, paralela à sua direção.

Os cristais de biotita apresentam-se bem orientados, tem pleocroísmo amarelo-claro - marrom escuro e raramente preservam forma euedral.

O falhamento rúptil tardio pode ser observado em seção delgada, mostra movimentação sinistral, que em seção delgada está representada por deslocamento milimétrico a centimétrico de faixas quartzo-feldspáticas (Prancha 25 , Foto 1) associado a forte epidotização e sericitização. 


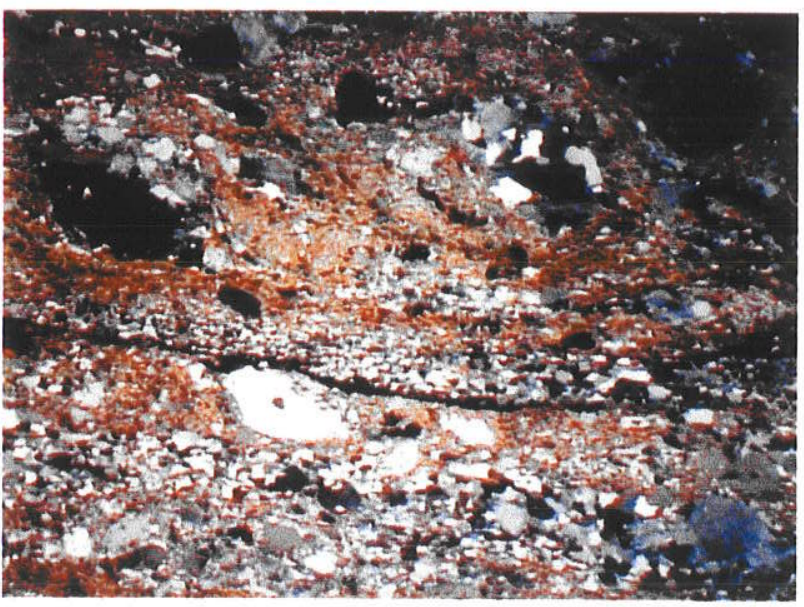

Foto 1 - Fotomicrografia (nicóis X, aumento $5.5 \mathrm{x}$ ). Textura milonítica caracterizada por porfiroclastos de feldspato e quartzo sigmoidais em matriz fina, com presença de faixas segregadas de quartzo recristalizado. Indicação cinemática sinistral. Amostra K-51 (corte XZ).

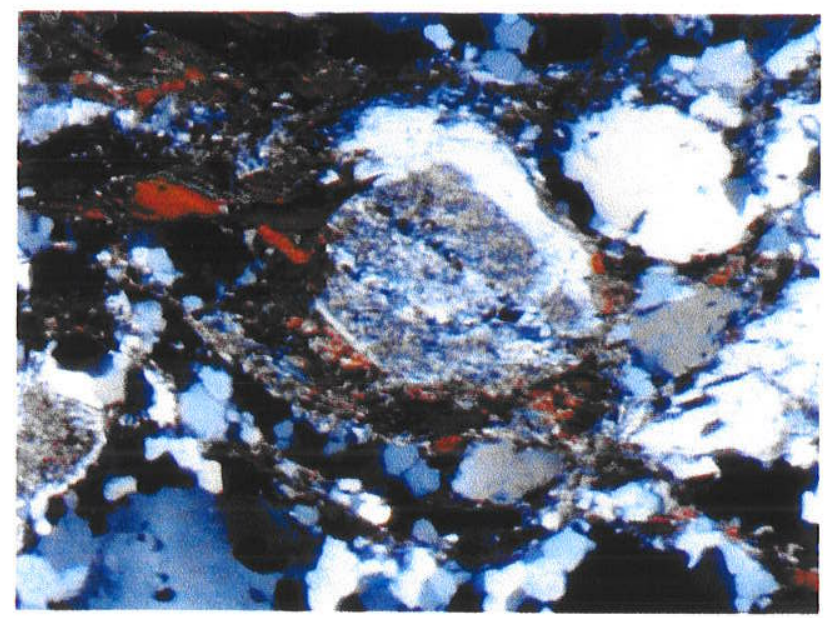

Foto 3 - Fotomicrografia (nicóis $\mathrm{X}$, aumento $35.5 \mathrm{x}$ ). Milonito de rocha granitóide com porfiroclasto de plagioclásio saussuritizado sigmoidal e mica-fish (biotita) indicando movimentação sinistral. Amostra K-88 (corte XZ).

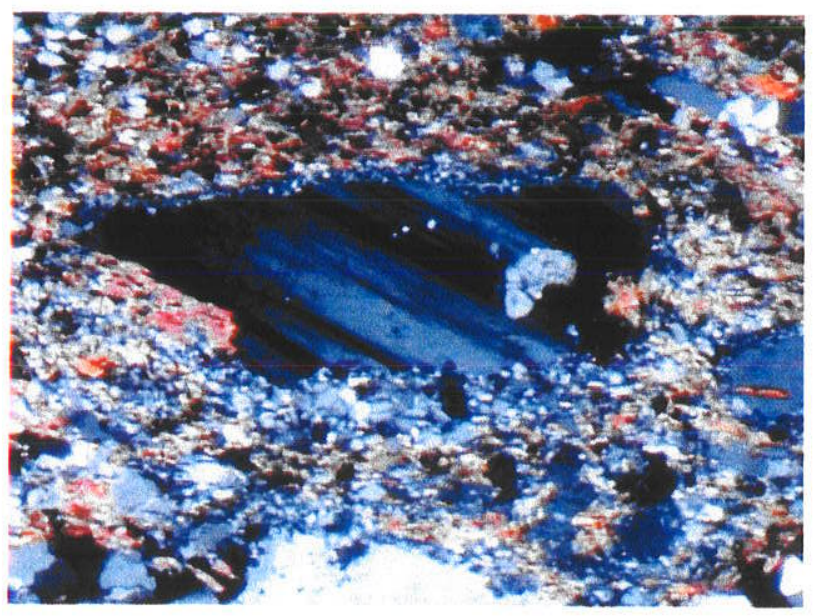

Foto 5 - Fotomicrografia (nicóis $X$, aumento $35.5 \mathrm{x}$ ). Milonito granítico mostrando detalhe de porfiroclasto de microclínio com textura mortar. Amostra K-51 (corte XZ).

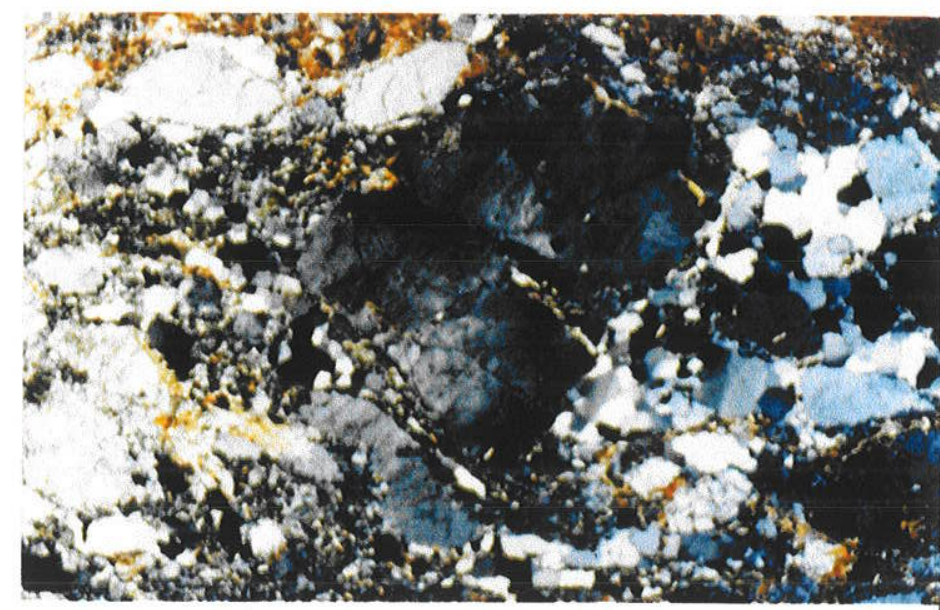

Foto 2 - Fotomicrografia (nicóis $\mathrm{X}$, aumento $25 \mathrm{x}$ ). Milonito granítico com porfiroclasto de feldspato sigmoidal, com sombra de pressão constituída por quartzo. Indicação cinemática sinistral. Amostra K-57 (corte XZ).

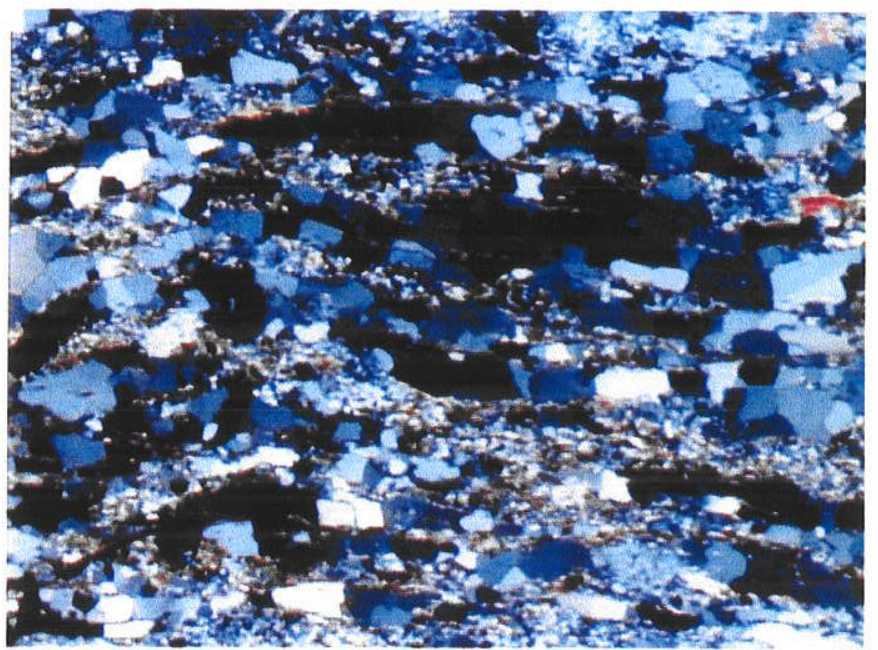

Foto 4 - Fotomicrografia (nicóis $\mathrm{X}$, aumento $20.5 \mathrm{x}$ ). Milonito granítico caracterizado pela formação de ribbons policristalinos do tipo $2 \mathrm{com}$ tendência à formação de ribbons do tipo 3 (Boullier \& Bouchez, 1978). Amostra K-76 (corte XZ).

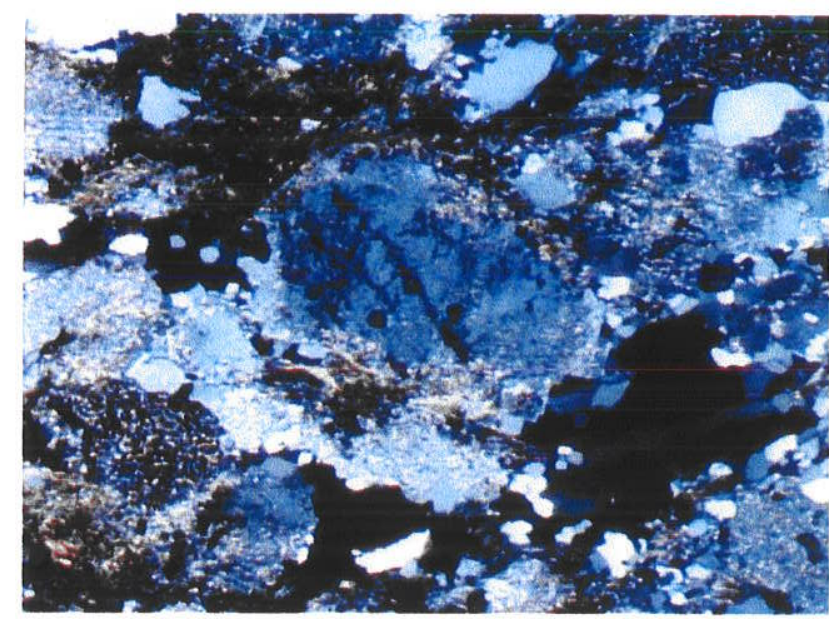

Foto 6 - Fotomicrografia (nicóis X, aumento 20.5 x). Protomilonito granítico com porfiroclasto de plagioclásio sigmoidal, com sombra de pressão constituída por quartzo, indicando movimentação sinistral. Amostra K-14 (corte XZ). 


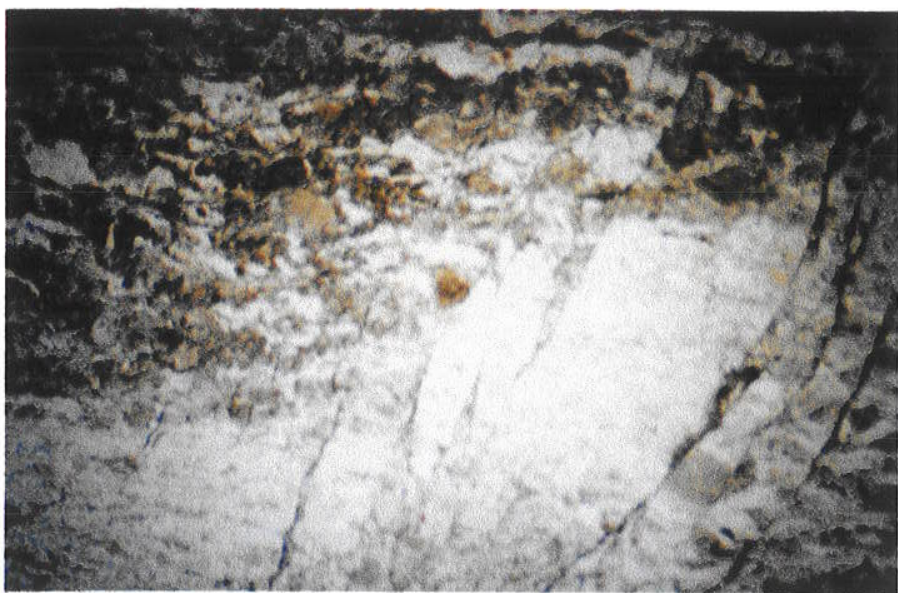

Foto 1 - Fotomicrografia (nicóis $/ /$, aumento $5 \mathrm{x}$ ). Foliação caracterizada pelo estiramento de porfiroclastos de feldspatos e faixas estiradas com segregação de cristais de quartzo em protomilonito granítico. Amostra K-11 (corte XZ).

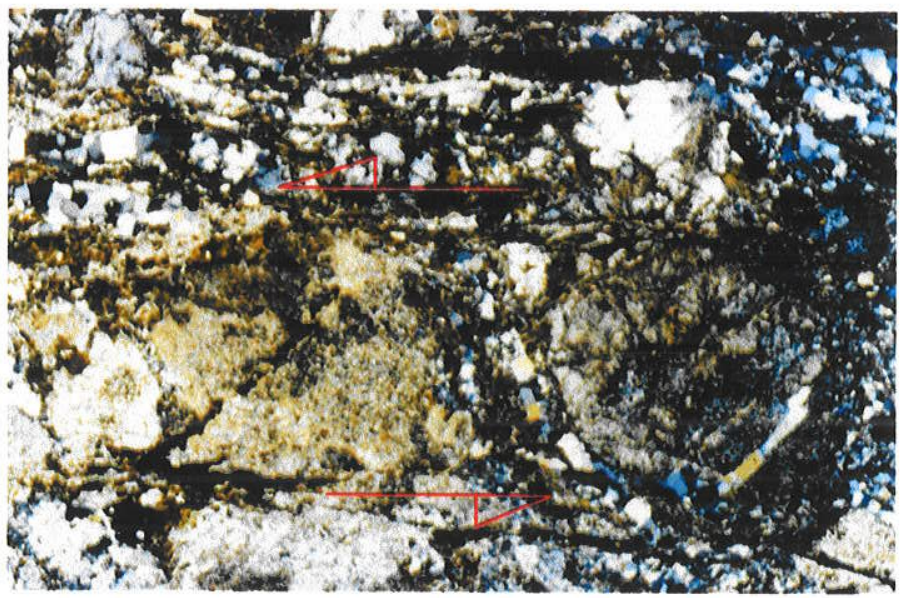

Foto 3 - Fotomicrografia (nicóis $\mathrm{X}$, aumento $25 \mathrm{x}$ ). Milonito granítico com estruturas $\mathrm{S}-\mathrm{C}$, indicando movimentação sinistral. Amostra K12 (corte XZ)

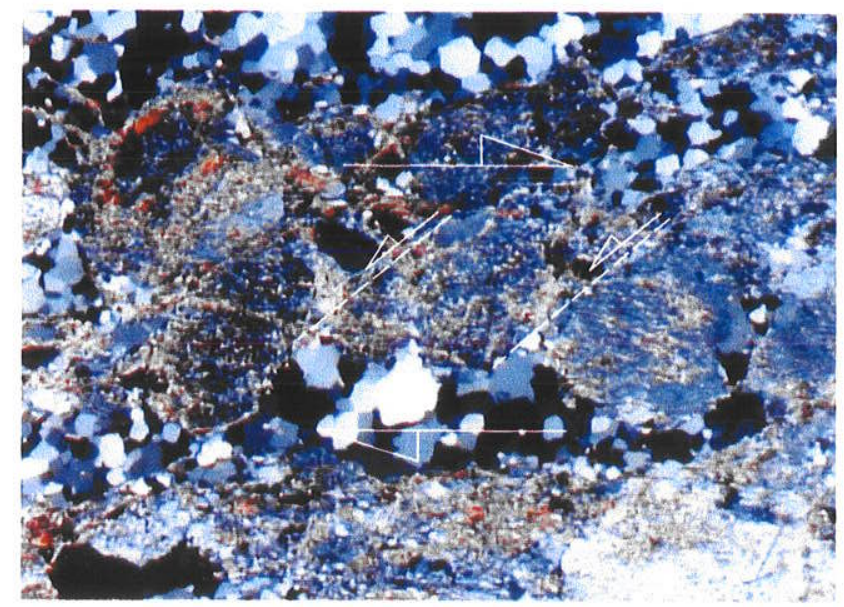

Foto 5 - Fotomicrografia (nicóis $\mathrm{X}$, aumento $25 \mathrm{x}$ ). Protomilonito granítico com porfiroclastos de plagioclásio rompidos, formando estruturas tipo dominó, indicando movimentação dextral. Amostra K-11 (corte XZ).

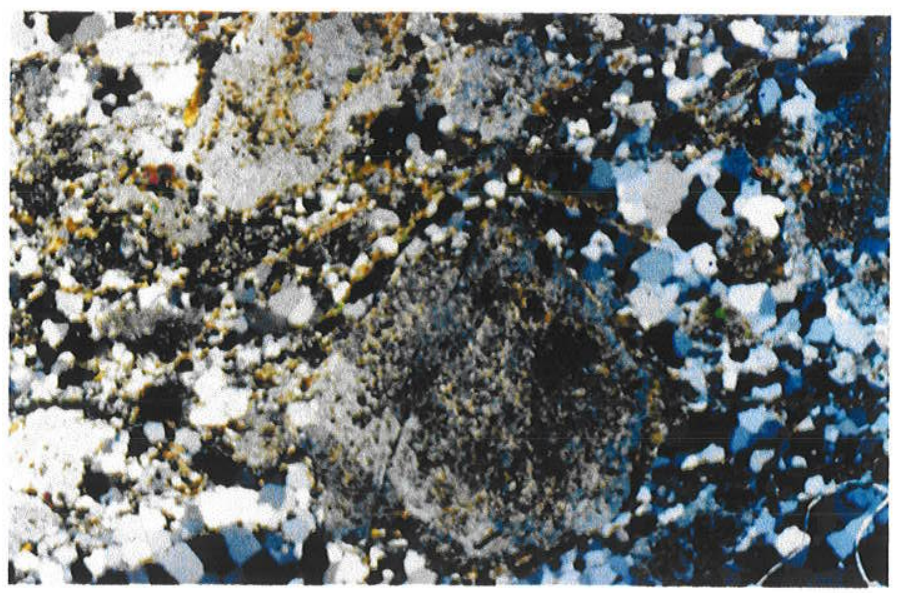

Foto 2 - Fotomicrografia (nicóis $\mathrm{X}$, aumento $25 \mathrm{x}$ ). Foliação protomilonítica com padrão anastomosado, caracterizada por faixas segregadas de quartzo recristalizado que envolvem os porfiroclastos de feldspato. Amostra K-11 (corte XZ).

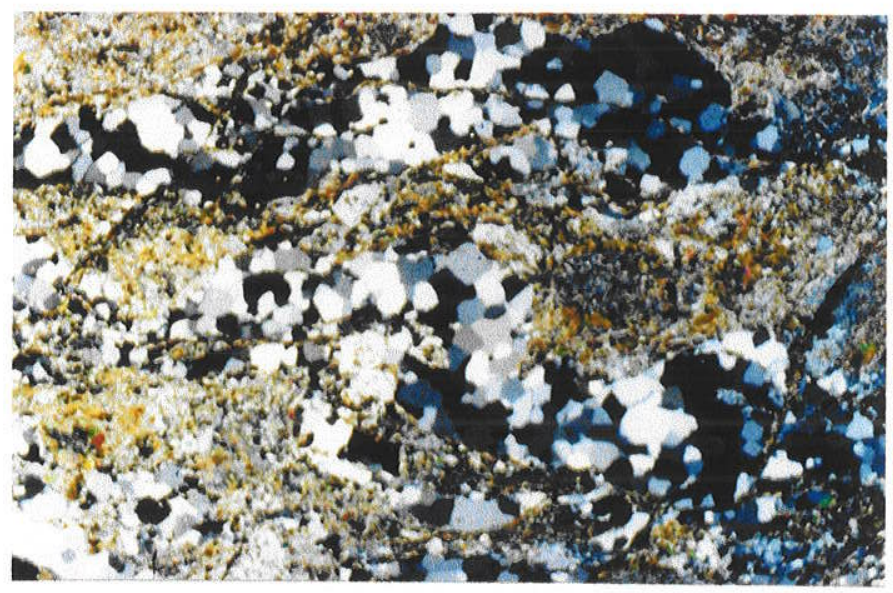

Foto 4 - Fotomicrografia (nicóis $\mathrm{X}$, aumento $25 \mathrm{x}$ ). Cristais de quartzo recristalizados em faixas segregadas de formatos sigmoidais. Amostra K-11 (corte XZ)

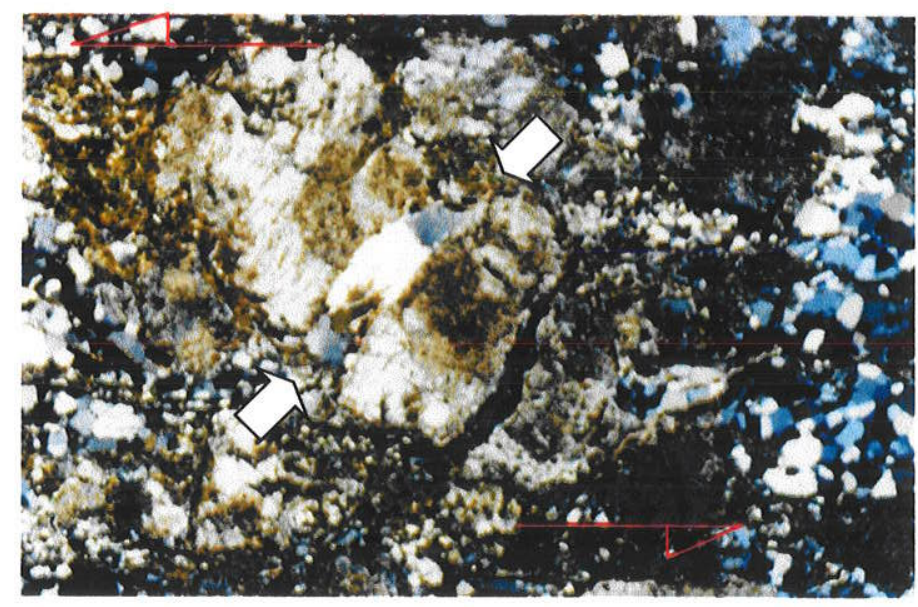

Foto 6 - Fotomicrografia (nicóis $X$, aumento 25 x). Milonito granítico com porfiroclastos de plagioclásio apresentando fraturas $T$, preenchidas por quartzo, indicando movimentação sinistral. Amostra K-12 (corte XZ). 
Foram realizadas análises pelo método de Fry (Fry, 1979, 1999), em seções delgadas de cortes $X Z$ e $Y Z$, em dez rochas graníticas miloníticas ao longo dos ramos $\mathrm{A}-\mathrm{B}$ da $\mathrm{ZCl}$.

As rochas incluem protomilonitos e milonitos do diferentes setores da ramificaçäo $A-B$, incluindo amostras do setor mais oeste $(K-14 ; K-88)$, setor central (K-11; K-12; K-49; K-51; K-53) e setor leste (K-55; K-57; K-76).

A orientação dos eixos principais do elipsóide de deformação estão listados na Tabela 9.2.1, ver Mapa Estrutural - Anexo 2, juntamente com as orientações da foliação milonítica da rocha e lineação de estiramento mineral.

\begin{tabular}{|c|c|c|c|c|c|c|c|c|}
\hline \multirow[b]{2}{*}{ SETOR } & \multirow[b]{2}{*}{ AMOSTRA } & \multirow[b]{2}{*}{ ROCHA } & \multirow[b]{2}{*}{ SM } & \multirow[b]{2}{*}{ LM } & \multicolumn{3}{|c|}{ EIXOS DO ELIPSÓIDE DE DEFORMAÇAO } & \multirow[b]{2}{*}{ MOVIMENTO } \\
\hline & & & & & EIXOX & EixoY & EixoZ & \\
\hline \multirow[b]{2}{*}{ Oeste } & K-14 & protomilonito & N50E/88NW & S52W/67 & N73E/31 & S86W/54 & N17W/22 & Sinistral \\
\hline & $\mathrm{K}-88$ & milonito & N80E/84NW & $\mathrm{N} 80 \mathrm{~W} / 42$ & N50W/22 & $\mathrm{N} 40 \mathrm{E} / 40$ & S40W/12 & Sinistral \\
\hline \multirow{7}{*}{ Central } & $\mathrm{K}-11 \mathrm{a}$ & protomilonito & N82E/59NW & N65W/55 & N40W/40 & N72E/14 & $510 W / 45$ & Sinistral \\
\hline & $\mathrm{K}-11 \mathrm{~b}$ & protomilonito & N82E/59NW & N65W/55 & N65W/65 & $\mathrm{N} 72 \mathrm{E} / 14$ & $\mathrm{~S} 20 \mathrm{E} / 28$ & Dextral \\
\hline & $\mathrm{K}-12$ & milonito & N80E/74NW & N70E/24 & $\mathrm{N} 82 \mathrm{~W} / 34$ & N14E/18 & S8W/28 & Sinistral \\
\hline & $\mathrm{K}-49 \mathrm{a}$ & milonito & N85W/69NE & N8OW/24 & S7E/8 & S47E/60 & $S 83 W / 34$ & Sinistral \\
\hline & $\mathrm{K}-49 \mathrm{~b}$ & milonito & N85W/69NE & N80W/24 & S38W/31 & S47E/60 & N52W/21 & Dextral \\
\hline & $\mathrm{K}-51$ & milonito & N80W/70NE & N70W/34 & S53E/29 & N64W/40 & N36E/45 & Sinistral \\
\hline & $\mathrm{K}-53$ & protomilonito & N65W/60NE & N55W/15 & N84W/2 & N10E/30 & $\mathrm{S} 6 \mathrm{~W} / 24$ & Sinistral \\
\hline \multirow{4}{*}{ Leste } & $\mathrm{K}-55$ & protomilonito & N60W/51NE & $\mathrm{N} 82 \mathrm{~W} / 20$ & N60W/10 & $\mathrm{N} 20 \mathrm{E} / 20$ & S28W/61 & Sinistral \\
\hline & $\mathrm{K}-57$ & milonito & N7OW/53NE & $\mathrm{N} 10 \mathrm{E} / 47$ & N27E/10 & S80W/23 & S85W/77 & Sinistral \\
\hline & K-76a & milonito & N7OW/50NE & N55W/25 & S44E/27 & N/40 & S46W/16 & Sinistral \\
\hline & $\mathrm{K}-76 \mathrm{~b}$ & milonito & N70W/50NE & N55W/25 & S35E/28 & $\mathrm{N} / 40$ & S55W/11 & Sinistral \\
\hline
\end{tabular}

Tabela 9.2.1 - Direção da foliação e lineação mineral principal das amostras analisadas e orientação dos eixos do elipsóide obtidos pelo Método de Fry.

Como pode ser observado na Tabela 9.2.1, e nas figuras obtidas pelo método de Fry (Figura 9.2.18) as rochas miloníticas do ramo $A-B$, como um todo, mostram um padrão heterogêneo na distribuição da deformação, sendo predominante a movimentação sinistral.

A Figura 9.2.18 mostra as elipses e seus respectivos eixos principais obtidos pelo método de Fry. A posição do traço da foliação milonítica nos cortes $X Z$ e $Y Z$ é 
vertical, e a horizontal da direção de cada corte, bem como sua orientação estão indicados na porção superior de cada figura.

As rochas miloníticas do setor oeste (K-14 e K-88) registram a movimentação sinistral (Figura 9.2.18A), com abatimento para $W$ (SWW e NW) havendo concordância entre a orientação dos eixos $X$ do elipsóide de deformação (direção de máxima extensão) e as respectivas lineações de estiramento mineral.

As rochas do setor central, apresentaram dados discordantes entre si, possivelmente devido ao registro de várias fases de movimentação, ocorrendo a formação de dois vazios elípticos (Figura 9.2.18B). Nas amostras $K-11$ e K-49 pode ser observado o registro de uma movimentação dextral com componente de cavalgamento para SE sobre uma movimentação sinistral com abatimento para NW assim como observado no tratamento dos dados estruturais.

$\mathrm{Na}$ amostra $\mathrm{K}-11$, onde ocorrem indicadores cinemáticos sinistrais e dextrais a nível macroscópico e microscópico, observa-se a formação de dois vazios elípticos, de igual elipsidade indicando movimentações opostas.

$\mathrm{Na}$ amostra K-49, observa-se em campo e em seção delgada movimentação sinistral, sendo coerente com o vazio elíptico com $R x z=2.7$. Porém nota-se um vazio perfeito no interior desta com menor elipsidade, $R x z=2.1$, podendo representar registro de uma movimentação dextral posterior mas que não chegou a obliterar totalmente o fabric anterior da rocha.

No setor leste, houve registro da movimentação sinistral, com componente de abatimento para NW, com pode ser observado na amostra K-76. Esta amostra, por sua vez, mostrou dois vazios elípticos associados a movimentação sinistral distensiva (Figura 9.2.18C), mas relacionados a momentos distintos da deformação: um associado a uma fase de maior deformação, com geração da elipsidade $R \times z=2.9$ e outro a uma fase de menor deformação, com elipsidade $R x z=2.0$. Também no setor leste está registrado a movimentação sinistral, com componente de cavalgamento para SW (amostra K-57).

As elipsidades obtidas pelo Método de Fry, Tabela 9.2.2, consequentemente foram utilizados para obtenção dos parâmetros necessários $(R x y, K, D)$ para o conhecimento da forma do elipsóide de deformação (Diagrama de Flinn). 


\begin{tabular}{|l|c|c|c|c|c|c|c|}
\hline Amostra & RXZ & RYZ & RXY & K & D & ELIPSÓIDE & DIAGRAMA DE FLINN \\
\hline K-11a & 2.4 & 1.4 & 1.7 & 1.75 & 0.8 & Prolato & Constriç̧ão aparente \\
\hline K-11b & 1.5 & 1.4 & 1.1 & 0.25 & 0.4 & Oblato & Achatamento aparente \\
\hline K-12 & 2.9 & 2.4 & 1.21 & 0.50 & 1.42 & Oblato & Ach.aparente / uniaxial \\
\hline K-14 & 3.0 & 1.8 & 1.66 & 0.80 & 1.04 & Triaxial & Deformação plana \\
\hline K-49a & 2.7 & 2.0 & 1.35 & 0.35 & 1.06 & Oblato & Achatamento aparente \\
\hline K-49b & 2.1 & 2.0 & 1.05 & 0.05 & 1 & Oblato & Achatamento uniaxial \\
\hline K-51 & 2.3 & 1.5 & 1.53 & 1.06 & 0.76 & Triaxial & Deformação plana \\
\hline K-53 & 1.6 & 1.4 & 1.14 & 0.35 & 0.42 & Oblato & Achatamento aparente \\
\hline K-55 & 1.8 & 1.4 & 1.28 & 0.7 & 0.49 & Triaxial & Deformação plana \\
\hline K-57 & 1.8 & 1.4 & 1.28 & 0.7 & 0.49 & Triaxial & Deformação plana \\
\hline K-76a & 2.9 & 1.6 & 1.81 & 1.35 & 1.01 & Triaxial & Deformação plana \\
\hline K-76b & 2.0 & 1.6 & 1.25 & 0.42 & 0.65 & Oblato & Achatamento aparente \\
\hline K-88 & 1.7 & 1.4 & 1.21 & 0.53 & 0.45 & Oblato & Achatamento aparente \\
\hline
\end{tabular}

Tabela 9.2.2 - Dados obtidos pelo método de Fry e aplicação de Diagrama de Flinn.
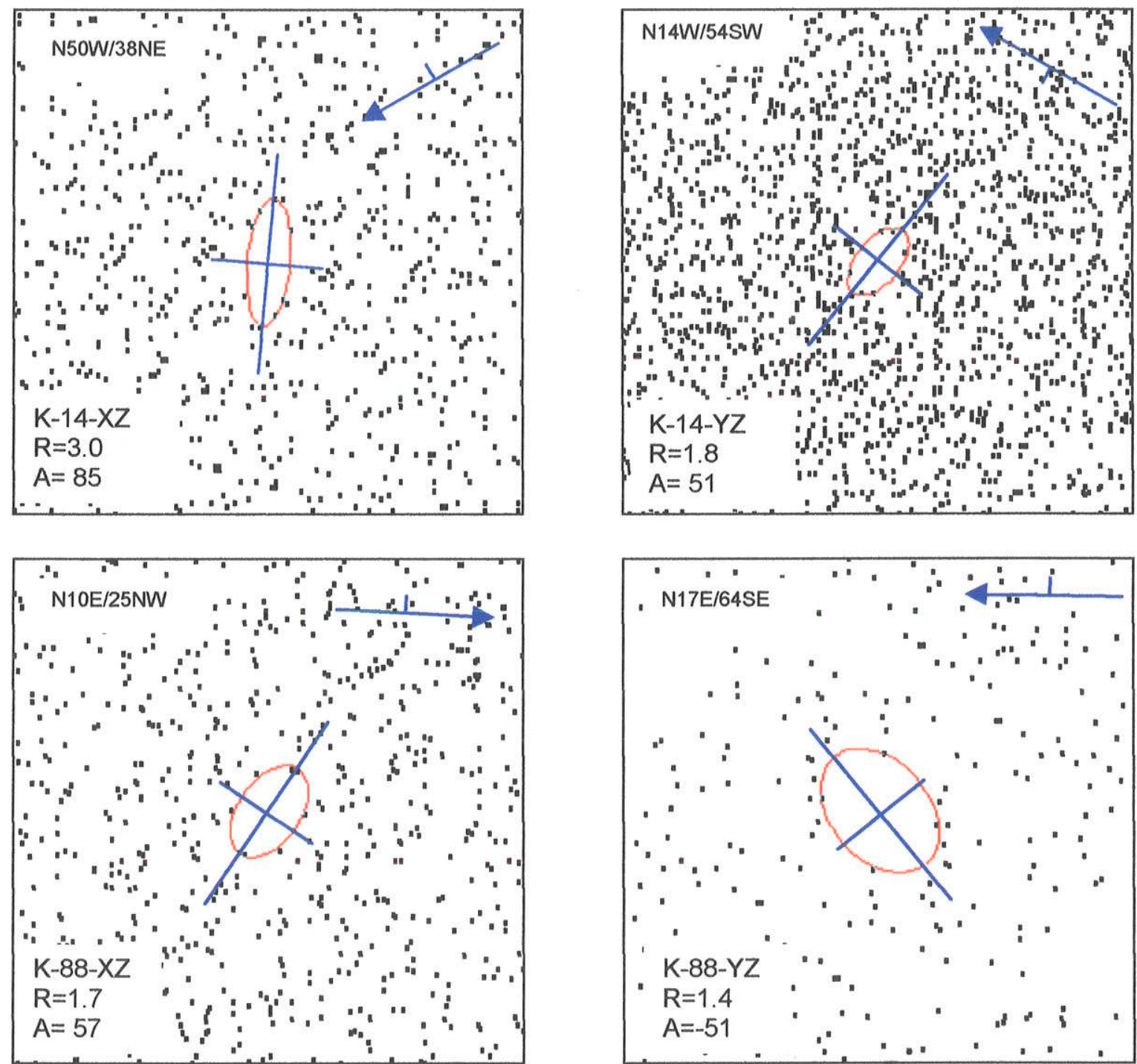

Figura 9.2 18A - Método de Fry. Rochas miloníticas dos ramos A-B - setor oeste - ZCl. 

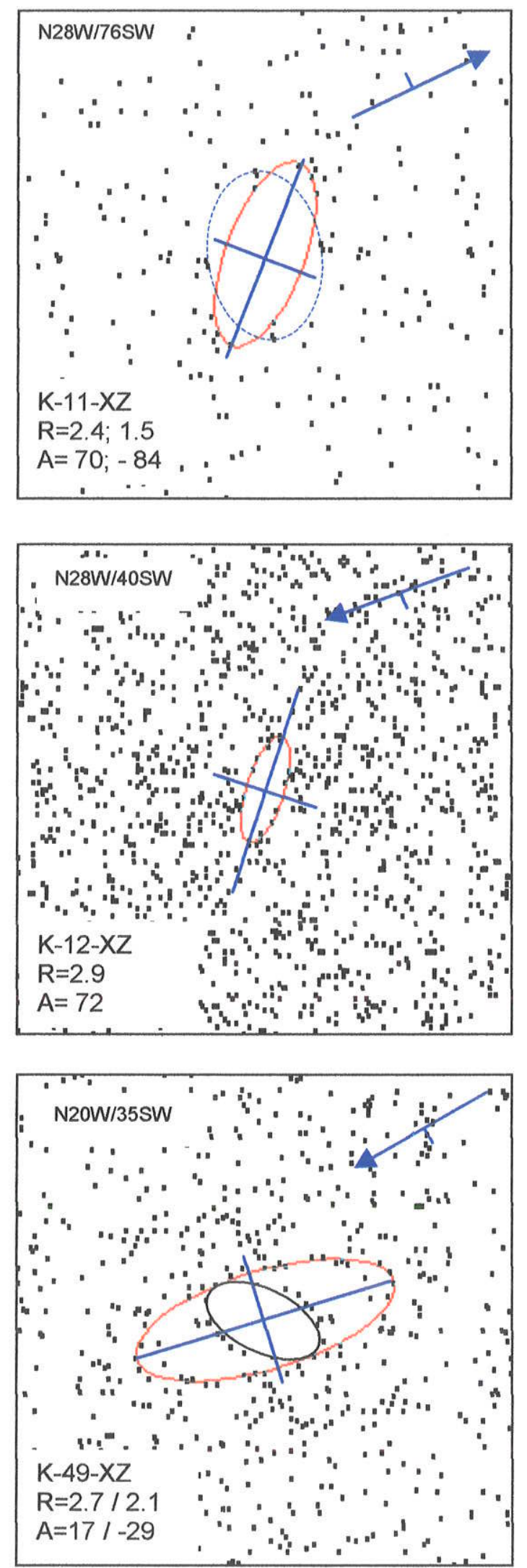
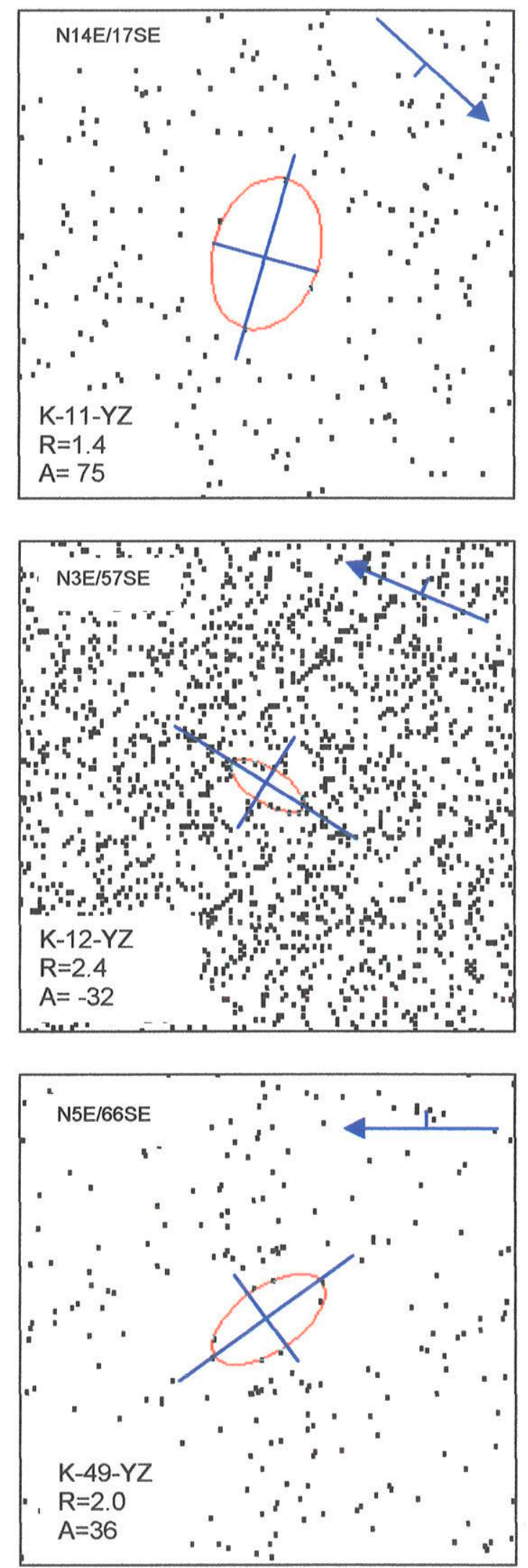

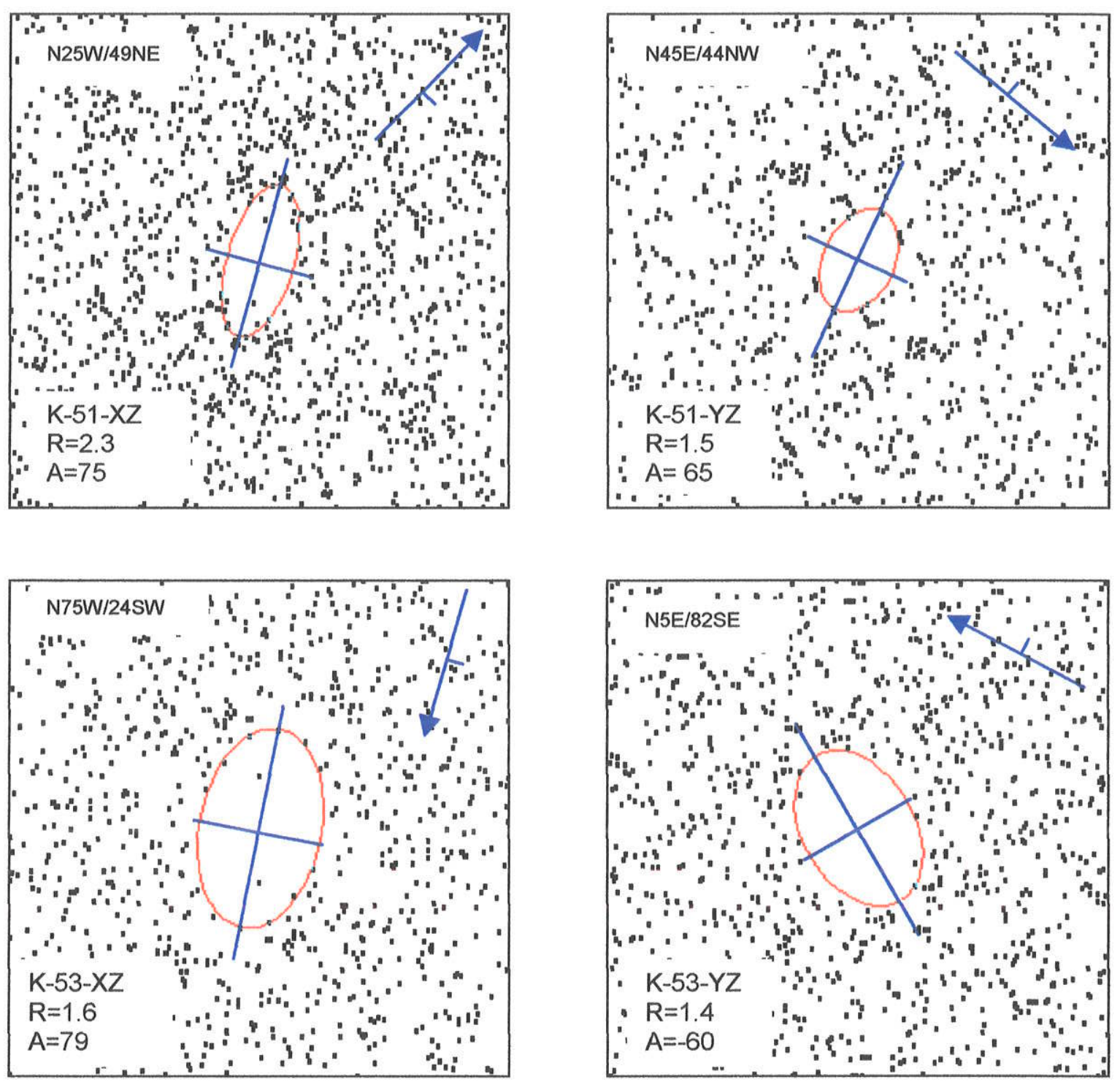

Figura 9.2 18B - Método de Fry. Rochas miloníticas dos ramos A-B setor central - ZCI. 

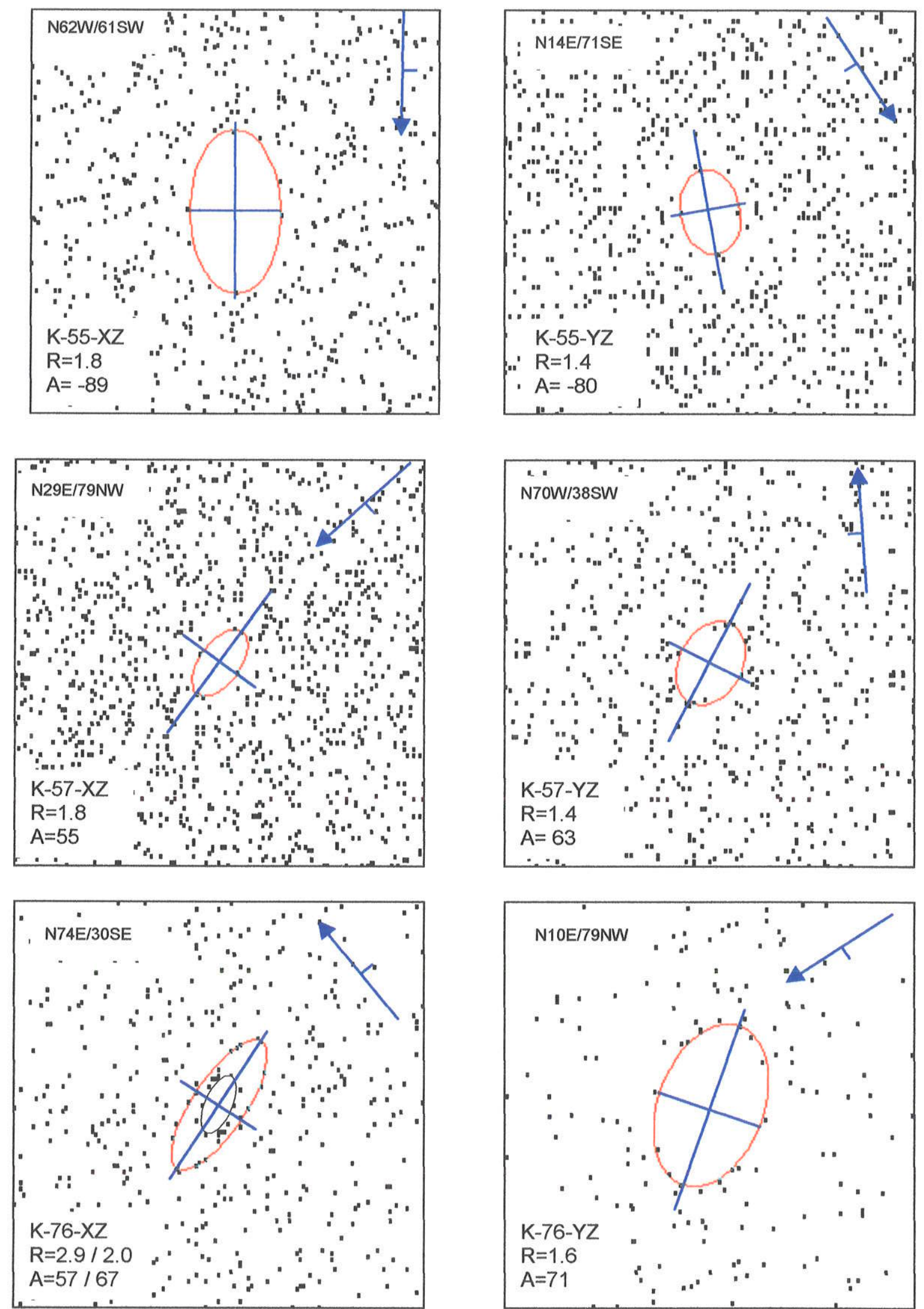

Figura 9.2 18C - Método de Fry. Rochas miloníticas dos ramos A-B setor leste - ZCl. 
A partir das elipsidades obtidas, as amostras analisadas, juntamente com amostras anteriormente estudadas (amostras I-2 e I-3) foram plotadas em Diagrama de Flinn.

As rochas que registraram, pelo método de Fry, a $1^{a}$ fase referente à movimentação sinistral na ramificação $A-B$, com importante componente de abatimento para W, foram plotadas em vermelho (Figura 9.2.19). As amostras que apresentaram registros da movimentação dextral, ou sinistral, com componente compressiva para SW ou SE, estão plotadas na cor azul.

Nota-se que em relação à $1^{\text {a }}$ fase deformacional, há um espalhamento dos elipsóides definidos, desde o campo da constricção geral (elipsóides prolatos), passando pela deformação plana até o campo do achatamento aparente (elipsóides oblatos). Por outro lado, a $2^{\mathrm{a}}$ fase associada a movimentação com componente compressiva, houve concentração dos elipsóides oblatos próximo ao campo do achatamento uniaxial (Figura 9.2.19).

Este comportamento da distribuição dos elipsóides definidos, pode sugerir uma passagem gradual e contínua de uma deformação associada a uma distensão importante, com tendência a aumento de volume para uma deformação onde a componente compressiva predomina.

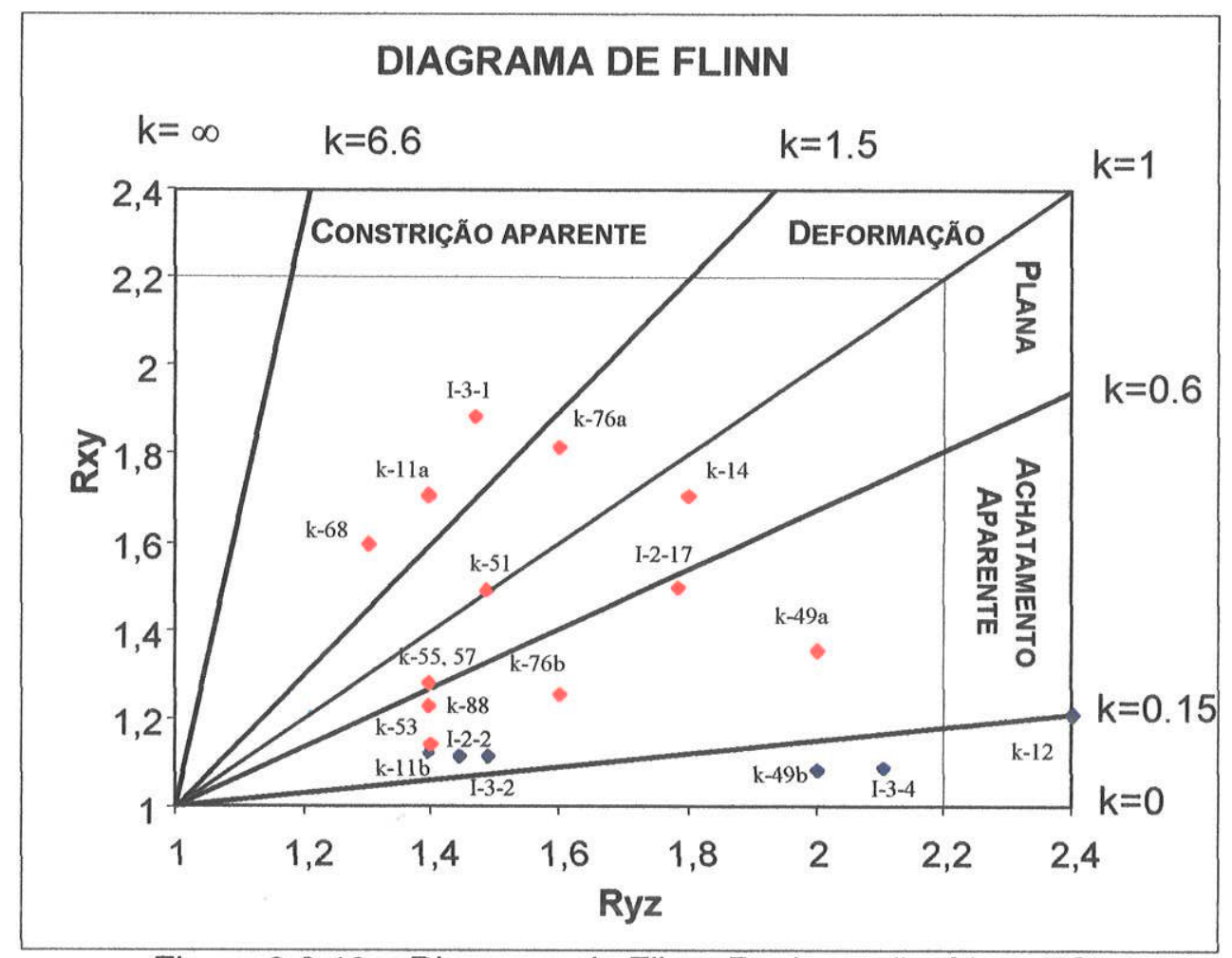

Figura 9.2.19 - Diagrama de Flinn. Rochas miloníticas ZCl. 


\subsection{MÉTODO K-AR}

O método K-Ar foi aplicado em biotitas de granulação fina (em torno de 150 mesh) de milonitos localizados nos ramos A-B da $\mathrm{ZCl}$ (Figura 9.3.1), descritos a seguir.

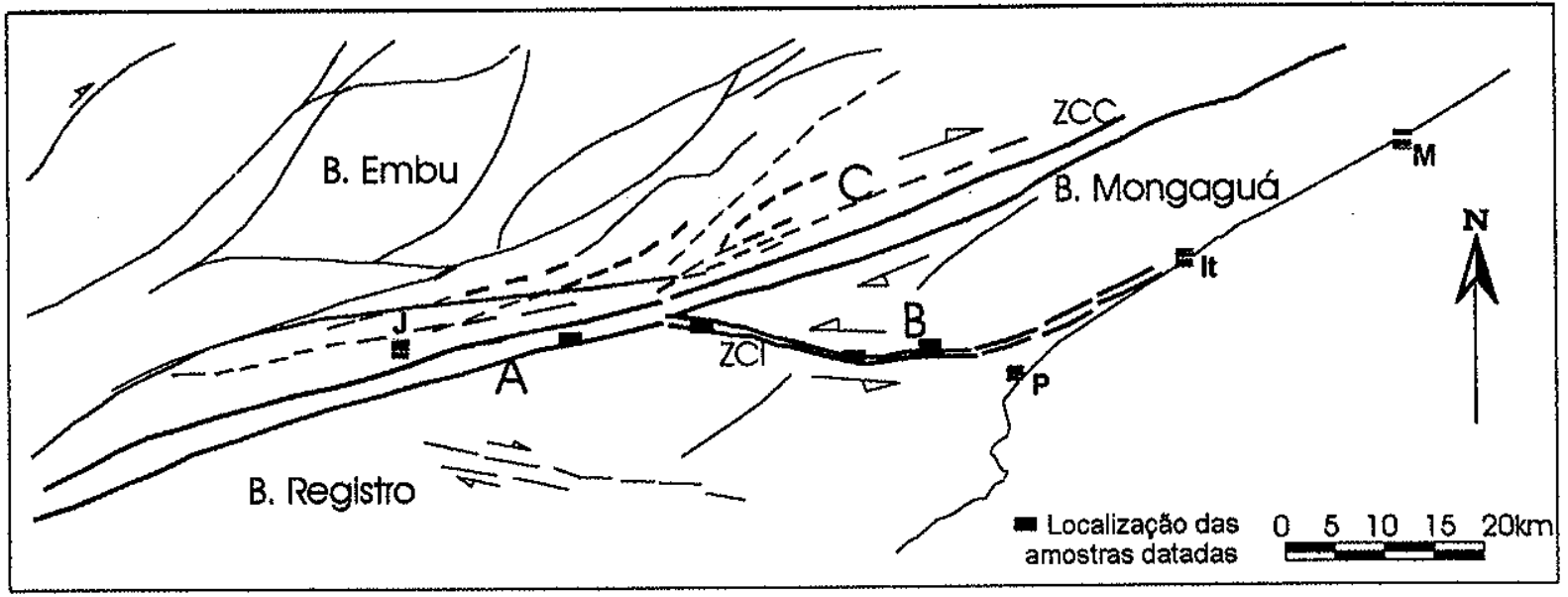

Figura 9.3.1 - Mapa estrutural esquemático com localização das amostras datadas.

Amostra K-11: corresponde a um biotita-gnaisse protomilonítico, caracterizado pela intercalação de bandas máficas com feldspatos brancos esparsos e filmes félsicos. Em seção delgada os cristais de biotitas (amarelo-marrom esverdeado), de granulação muito fina, apresentam-se fortemente orientados na foliação milonítica.

Amostra K-50: milonito gnáissico caracterizado por filmes félsicos, por vezes com porfiroclastos arredondados de feldspato branco, intercalados com bandas máficas, finamente foliada. Em seção delgada, os cristais de biotita (amarelo claromarrom), muito finos, apresentam-se fortemente orientados juntamente com sericita e epidoto.

Amostra K-53: rocha gnáissica protomilonítica caracterizada por filmes félsicos constituídos por feldspato branco e quartzo e banda máfica, predominante, rica em biotita. Em seção delgada, cristais de biotita (amarelo claro-verde escuro), estão orientados conforme a foliação protomilonítica e circundam os porfiroclastos de feldspatos.

Amostra K-76: milonito gnáissico com desenvolvimento de filmes ricos em feldspatos intercalados com filmes ricos em biotitas. Em seção delgada, os cristais 
de biotita (amarelo-marrom escuro) apresentam granulação bem fina, extremamente orientados com sericita e quartzo.

Os resultados analíticos apresentam-se listados na Tabela 9.3.1, e forneceram idades de oeste para leste de $493 \pm 14 \mathrm{Ma}, 413 \pm 9 \mathrm{Ma}, 497 \pm 9 \mathrm{Ma}$ e $368 \pm 7 \mathrm{Ma}$

\begin{tabular}{|c|c|c|c|c|c|c|c|}
\hline $\begin{array}{c}\text { AMOSTRA } \\
\text { RAMO }\end{array}$ & $\begin{array}{c}\text { MATERIAL } \\
\text { ANALISADO DE K }\end{array}$ & ERRO & $\begin{array}{c}\text { AR40 RAD } \\
(* 10-6)\end{array}$ & $\begin{array}{c}\text { AR40 } \\
\text { ATM (\%) }\end{array}$ & $\begin{array}{c}\text { IDADE } \\
\text { MA }\end{array}$ & ERRO MAX. \\
\hline $\begin{array}{c}\text { K-11 } \\
\text { Ramo A }\end{array}$ & Biotita & 7.1788 & 1.5809 & 157.93 & 3.99 & 492.7 & 13.9 \\
\hline $\begin{array}{c}\text { K-50 } \\
\text { Limite A-B-C }\end{array}$ & Biotita & 7.0280 & 0.5000 & 126.69 & 6.65 & 413.0 & 8.8 \\
\hline $\begin{array}{c}\text { K-53 } \\
\text { Ramo B }\end{array}$ & Biotita & 7.6821 & 0.5000 & 170.64 & 3.11 & 496.7 & 9.3 \\
\hline $\begin{array}{c}\text { K-76 } \\
\text { Ramo B }\end{array}$ & Biotita & 7.0683 & 0.5000 & 111.98 & 6.79 & 367.7 & 7.3 \\
\hline
\end{tabular}

Tabela 9.3.1 - Dados analíticos da sistemática K-Ar para rochas miloníticas - ZCl.

As idades mais jovens obtidas para as amostras K-50 e K-76, necessitam de uma reavaliação. Ambas apresentaram teores relativamente mais elevados de $\mathrm{Ar}$ atmosférico, responsável pela obtenção de idade mais baixas ?. Até o momento não se dispõe de uma explicação geológica para idades tão jovens.

Os milonitos do ramo A-B alcançaram condições de resfriamento em torno de $500 \mathrm{Ma}$. Esta idade possivelmente reflete a época de resfriamento associada à movimentação desta zona de cisalhamento. 


\subsection{Discussão dos RESULTADOS OBTIDOS}

No Sistema de Cisalhamento Cubatão - Itariri (SCCI), foram identificadas 2 (duas) fases de deformação principais, seguidas por reativações tardias rúpteis.

A $1^{\text {a }}$ fase deformacional observada, dúctil, registrada nas rochas miloníticas, está associada a uma movimentação sinistral, em zona de cisalhamento de direção $E-W$ (ramificação $A-B$ ), com mergulhos preferenciais para norte. As lineações de estiramento mineral indicam uma componente de abatimento para N80W (Lm com caimentos para $\mathrm{N} 80 \mathrm{~W}$ ) e, subordinadamente, cavalgamento para SW (Lm com caimentos para NE). Esta fase representa a fase metamórfica principal da $\mathrm{ZCl}$, que atingiu o fácies xisto verde alto e possivelmente fácies anfibolito, definidos pela recristalização de feldspatos, e tipos de ribbons de quartzo.

A esta fase deformacional estão associados elipsóides prolatos a oblatos, onde a direção de esforço principal se concentra em torno de N2OE - N40E, como pode ser observado no posicionamento das elipses de deformação (Mapa Estrutural) obtidas nos afloramentos que registram esta fase.

Preliminarmente, sugere-se que esta fase poderia estar associada à justaposição dos dois Blocos mais antigos existentes na área estudada: Bloco Embu e Registro. A idade mais antiga possível para esta movimentação, em torno de 606 $\mathrm{Ma}$ (Capítulo 7, item 7.4), foi obtida em zircões pela metodologia U-Pb, em gnaisse protomilonítico (amostra K-11) situado na ramificação $A$.

Uma segunda fase deformacional, dúctil / dúctil-rúptil, está associada a uma compressão em torno de E-W (observar elipses de deformação com orientação de eixo maior em torno de N-S, Mapa Estrutural), que acarretou em uma movimentação sinistral com componente de cavalgamento para SW na ramificação A-B (registrada nos elipsóides de deformação oblatos) e dextral na ramificação $\mathrm{C}$.

Neste contexto, a ramificação $C$, mais jovem que a ramificação $A-B$, provavelmente retomou a movimentação no ramo $A$, que registra movimentação dextral nas proximidades da junção das ramificações. 
A partir dos dados petrográficos, esta fase, possivelmente, não ultrapassou o fácies xisto-verde.

Esta fase poderia estar associada à formação da 'cunha' formada pela junção das ramificações $A-B$ e $C$, formando o $\mathrm{SCCl}$, com a justaposição do Bloco Mongaguá aos Blocos Embu e Registro.

Concomitante ou posterior à $2^{\mathrm{a}}$ fase, está registrada na porção central do ramo $B$, uma componente oblíqua de cavalgamento para $S E$, denominada de fase $2 \mathrm{~A}$, associada tanto a uma movimentação dextral como sinistral.

Através das datações K-Ar obtidas em cristais de biotita, não foi possivel estabelecer as épocas relacionadas às diferentes fases de movimentações observadas através do tratamento dos dados estruturais. Todas as amostras datadas apresentaram idades em torno de $500 \mathrm{Ma}$.

$\mathrm{Na}$ tentativa de elucidar este problema, estão sendo realizadas datações em rochas miloníticas pela metodologia Ar-Ar, recém implementada no IGc-USP. No entanto, pode-se afirmar que as zonas de cisalhamento iniciaram seu processo de resfriamento há cerca de $500 \mathrm{Ma}$.

Evidências de reativações sinistrais posteriores em condições mais rúpteis são observadas nas ramificações A-B, por retomada da foliação milonítica e geração de estrias.

Falhamentos sinistrais rúpteis de direção aproximada N40E e fraturamentos de direção NW, também são evidenciados, e cortam a foliação milonítica. 


\section{ZONA DE CISALHAMENTO SERRINHA (ZCS)}

\subsection{INTRODUÇÃO}

A Zona de Cisalhamento Serrinha (ZCS) constituída por rochas miloníticas graníticas e metassedimentares, faz o limite entre os Blocos Registro e Iguape (Figura 10.1.1). Na região da Serrinha (Mapa Geológico - Anexo 1), onde foi definida, pode apresentar até $2.5 \mathrm{~km}$ de espessura. Característica marcante desta zona de cisalhamento é o imbricamento de rochas miloníticas graníticas com granada-micaxistos miloníticos.

Apresenta importante ramificação rumo SE, com cerca de $1 \mathrm{~km}$ de espessura, com direção geral N35W.

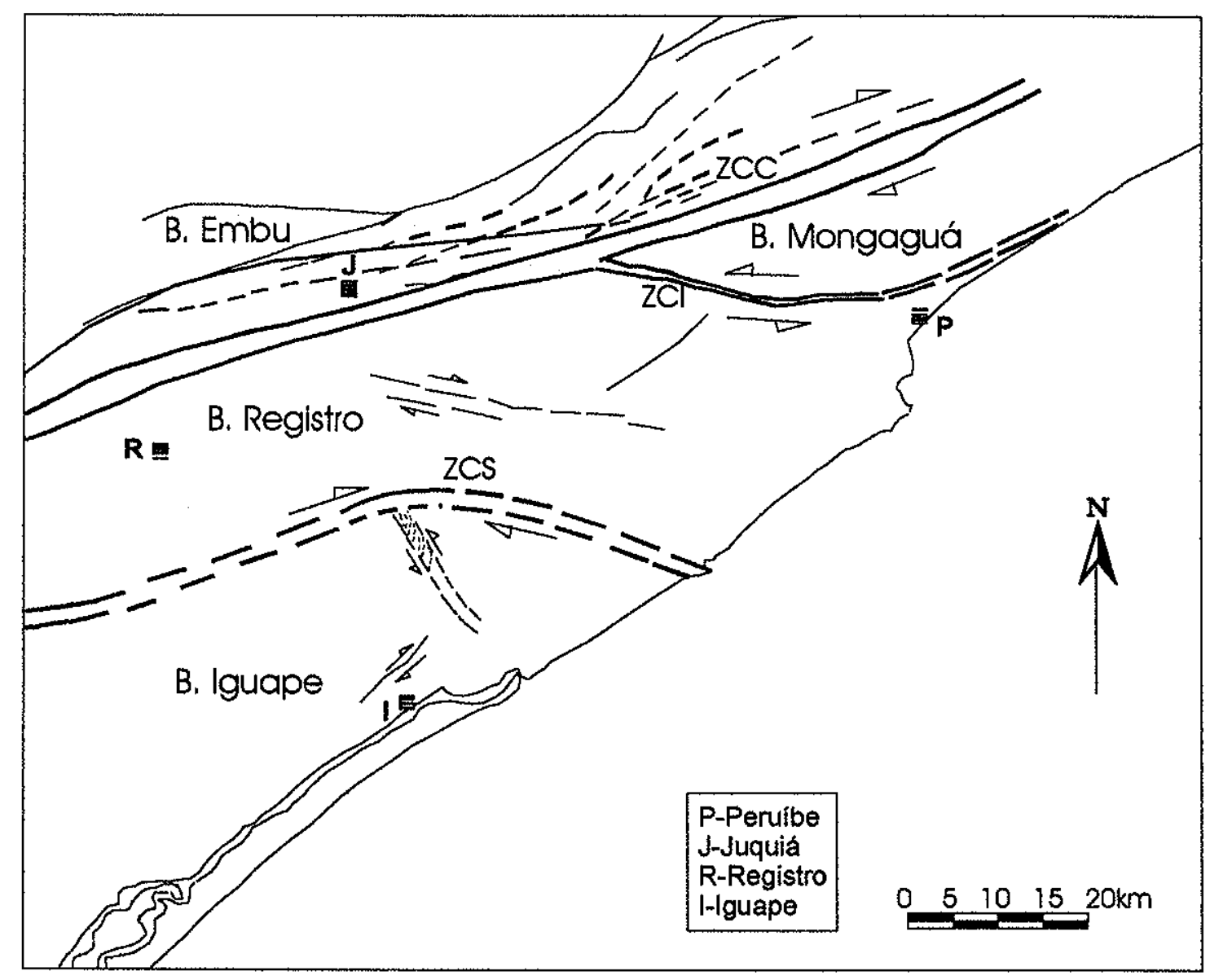

Figura 10.1.1 - Mapa estrutural esquemático da área estudada. 


\subsection{Caracterização Petrográfica-Estrutural}

Esta zona de cisalhamento apresenta uma variação importante nas atitudes de sua foliação milonítica, sendo subdividida em três setores principais: leste, central e oeste (Figura 10.2.1).

Foram estudadas áreas restritas ao longo da ZCS (Figura 10.2.1), por esta apresentar-se, em grande parte, coberta por sedimentos quaternários (Mapa Geológico -Anexo 1).

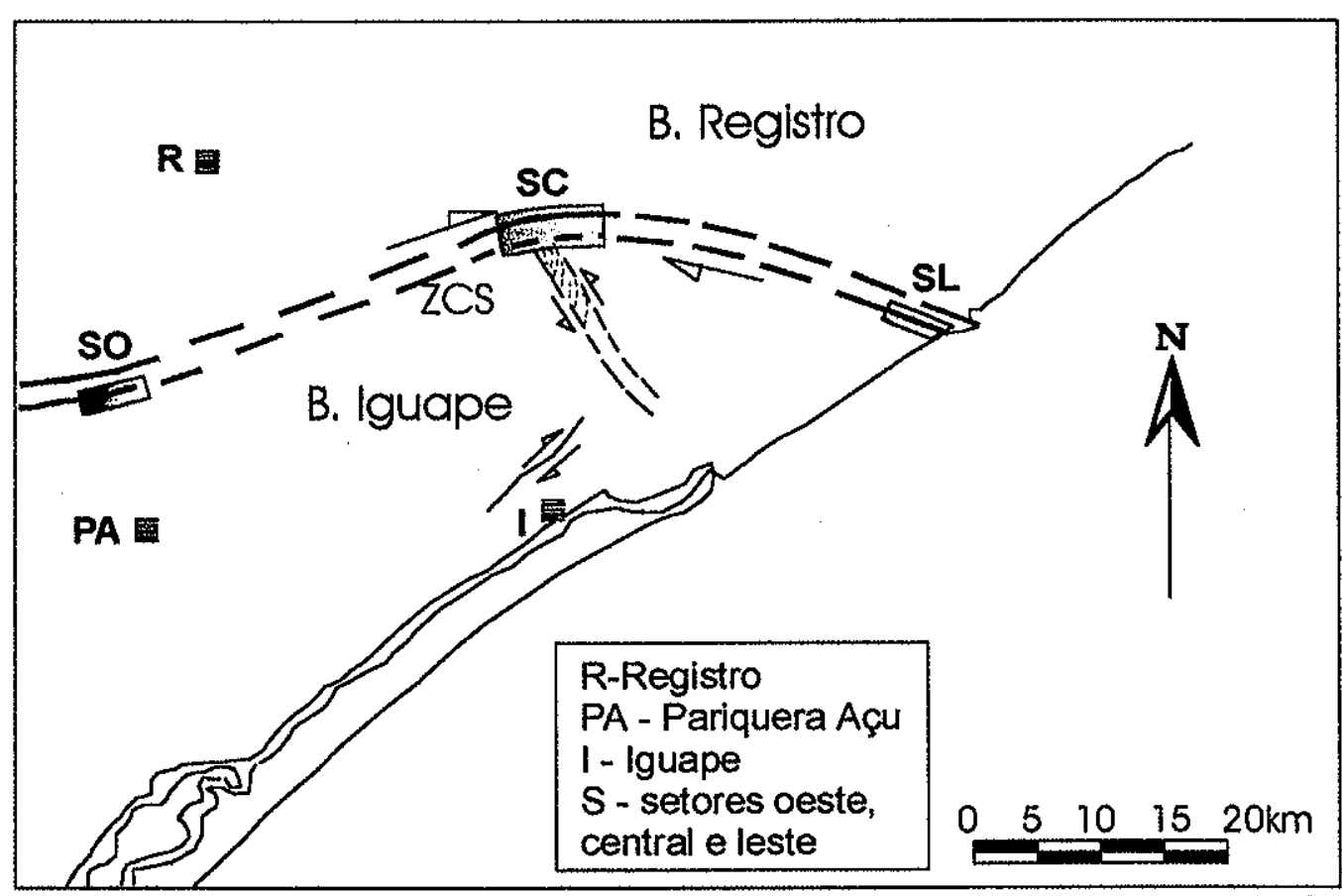

Figura 10.2.1 - Mapa estrutural esquemático dos setores estudados da ZCS.

\section{SETOR OESTE (SO)}

No setor oeste, ocorrem pacotes de rochas metassiltíticas, extremamente alteradas, de cor avermelhada, ricos em muscovitas. Apresenta intercalações com niveis areníticos impuros, centimétricos $(\sim 3 \mathrm{~cm})$, definindo 0 bandamento composicional. Sub-paralelos ao bandamento sub-horizontal, ocorrem lentes e faixas de rocha gnáissica, milonítica, a quartzo, feldspato, biotita e muscovita, extremamente alterada (Prancha 26, Foto 1). Normalmente o contato entre os metassedimentos e o gnaisse é marcado por veios de quartzo subparalelos ao bandamento principal, e alta 
quantidade de cristais de muscovita bem desenvolvidos. O biotita gnaisse imbricado em meio aos metassiltitos comumente se apresenta em forma de boudins (Prancha 26, Foto 2).

Neste setor, a ZCS, tem direção em torno de E-W, e mergulhos fracos para $\mathrm{N}$ (Figura 10.2.2).

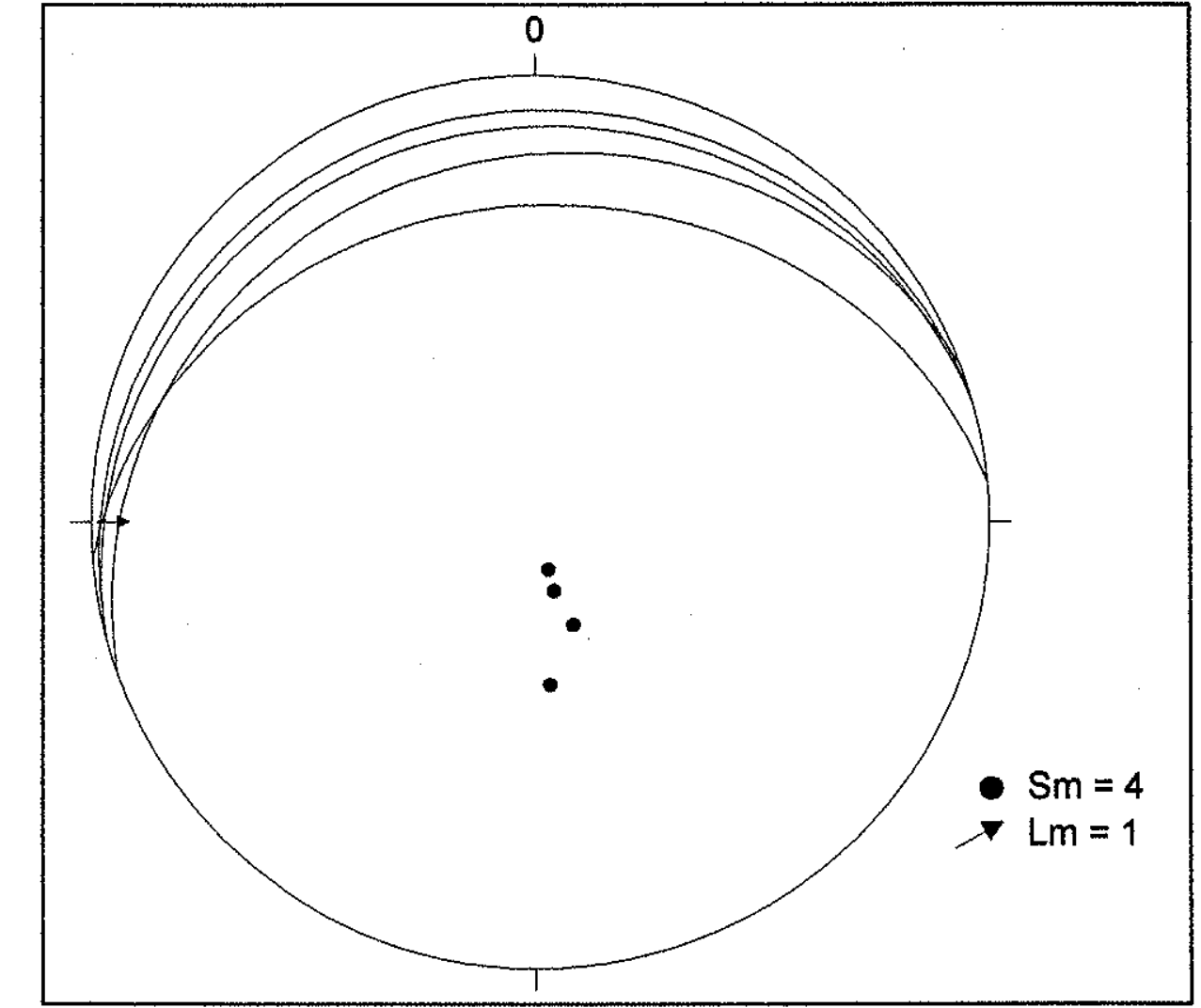

Figura 10.2.2 - ZCS - setor oeste. Milonitos de rochas graníticas e metassedimentares.

\section{SETOR CENTRAL (SC)}

O setor central caracteriza-se pela ocorrência de rochas metassedimentares imbricadas com as rochas graníticas miloníticas (Prancha 26, Foto 3 ).

Os metassedimentos, não foram coletados devido ao seu alto grau de alteração. São granada-biotita-xistos miloníticos, com forte segregação de bandas quartzosas e micáceas. Os porfiroclastos de granada assimétricos sugerem movimentação dextral (Prancha 26, Foto 4). 
As rochas graníticas afetadas pela ZCS, no setor central, caracterizam-se por monzogranitos leucocráticos a mesocráticos, protomiloníticos, (Prancha 26, Foto 5) cuja foliação é caracterizada pela orientação dos porfiroclastos de feldspato branco e forte estiramento de quartzo, intercalados com bandas ricas em biotitas.

Nos milonitos graniticos a foliação mostra-se anastomosada, sendo difícil a caracterização da indicação cinemática. Observam-se indicadores cinemáticos aparentemente opostos, lado a lado, a nível macro e microscópico, e muitos porfiroclastos de forma simétrica, sugerindo a forte atuação de uma componente não rotacional na deformação. No entanto, a movimentação dextral pode ser caracterizada principalmente por porfiroclastos sigmoidais assimétricos (Prancha 26, Foto 5).

Este setor apresenta foliação milonítica de direção em torno de E-W, com mergulhos variáveis para $\mathrm{N}$ e S, e subordinadamente orientação $\mathrm{N} 55 \mathrm{~W}$ com mergulho forte para SW. Lineação de estiramento mineral tem caimento preferencial para SW (Figura 10.2.3).

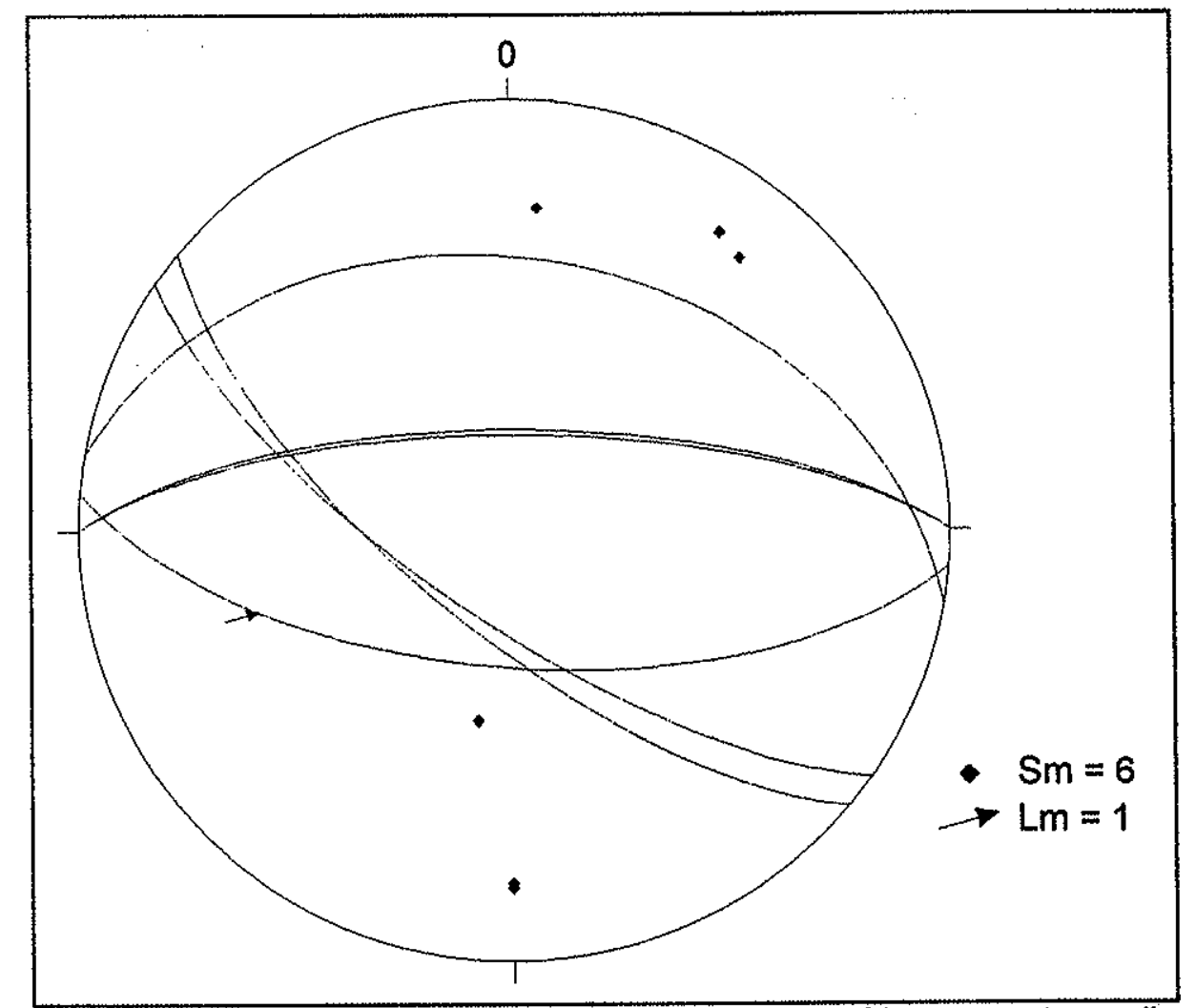

Figura 10.2.3 - ZCS - setor central. Milonitos de rochas graníticas e metassedimentares. 
Petrograficamente os biotita-monzogranitos afetados pela ZCS - setor central, apresentam textura milonítica e protomilonítica (Prancha 26, Foto 6), caracterizadas pelo forte estiramento dos cristais de feldspato e quartzo e orientação de biotita. Apresentam zircão, granada e monazita, como principais minerais acessórios.

Os cristais de quartzo são anedrais, com extinção ondulante, muitas vezes em recuperação, formando sub-grãos ou totalmente recristalizados.

Os cristais de microclínio normalmente são pertíticos e desenvolvem feições mirmequíticas nas bordas. É comum mostrarem-se recristalizados. Cristais de oligoclásio normalmente estão sericitizados e apresentam feições mirmequíticas em contato com microclínio e quartzo.

Biotitas subeuedrais, têm pleocroísmo amarelo-claro a marrom avermelhado. Granadas apresentam-se bastante fraturadas com inclusões de quartzo e fraturas preenchidas por biotita verde.

Neste setor, a ZCS apresenta uma ramificação importante rumo a SE (Figura 10.2.1), com foliação milonítica $S c$ de direção preferencial NW, e mergulhos intermediários a fracos para NE e foliação Ss de direção NE, com mergulhos fracos a intermediários para SE (Figura 10.2.4). As lineações de estiramento mineral têm caimentos preferenciais fracos a intermediários para SE.

Esta faixa milonítica afeta granada-xistos, sendo possível sua continuidade rumo a SE afetando rochas graníticas da região de Iguape.

Mostra movimentação predominante sinistral, com componente compressiva para N50W. Porém, apresenta forte componente não rotacional na deformação evidenciada principalmente pela simetria dos porfiroclastos. 


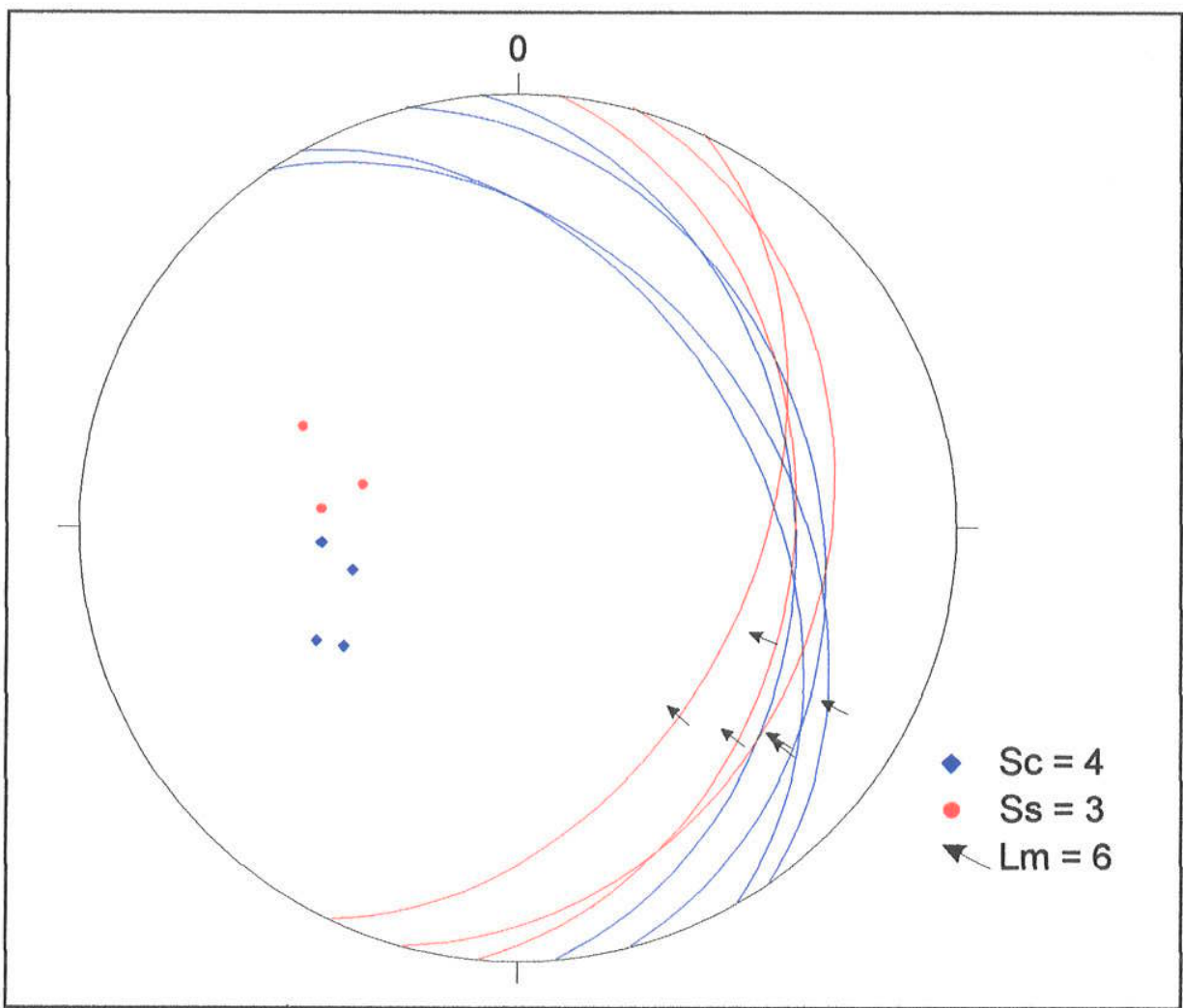

Figura 10.2.4. Ramificação da ZCS - Milonitos.

Em seção delgada, os metassedimentos, afetados pela ramificação da ZCS, são constituídos por quartzo, sericita, biotita, granada, e como mineral acessório zircão.

A rocha apresenta porfiroclastos de quartzo e granada. A matriz, muito fina, é composta principalmente por sericita e biotita (Prancha 27, Foto 1).

Em alguns xistos miloníticos ainda estão preservadas do cisalhamento foliações pretéritas de crenulação.

Os cristais de quartzo formam os porfiroclastos da rocha, são estirados, e tendem a formar ribbons. Normalmente estão em recuperação, e podem apresentar extinção ondulante. Mostram indicação cinemática sinistral (Prancha 27, Foto 2).

Os cristais de biotita na matriz são anedrais e mostram-se bem alterados.

Os porfiroclastos de granada, são na grande maioria simétricos. Feições extensionais (boudins) são observadas em possíveis pseudomorfos de granada, já totalmente substituídos por óxidos de Fe (Prancha 27, Foto 3).

Algumas rochas filoníticas, mostram-se extremamente alteradas, sendo compostas por quartzo, sericita, clorita, epídoto e óxidos de Fe (Prancha 27, Foto 4). 
Nestas rochas, é muito característico a segregação dos grãos de quartzo em bandas, formando pequenos ribbons e sigmóides. Normalmente estão recristalizados ou em recuperação e, apenas alguns grãos maiores ainda registram extinção ondulante.

\section{SETOR LESTE (SL)}

No setor leste, a ZCS afeta rochas gnáissicas da Juréia, sendo sua foliação milonítica caracterizada pelo forte estiramento das porções quartzo-feldspáticas (Prancha 27, Foto 5). Porfiroclastos de plagioclásio sigmoidais indicam movimentação dextral, e porfiroclastos de granada centimétricos são muito comuns e, normalmente mostram-se simétricos (Prancha 27, Foto 6). A descrição petrográfica encontra-se no Capitulo 7, item 7.2.

Neste setor, a foliação milonítica dos paragnaisses da Juréia, apresenta- se dobrada, com direções NW e NEE, com mergulhos desde intermediários a subhorizontais para NE e NW. Apresenta direção principal N54W/30NE (Figura 10.2.5). Mostra movimentação predominante transcorrente dextral.

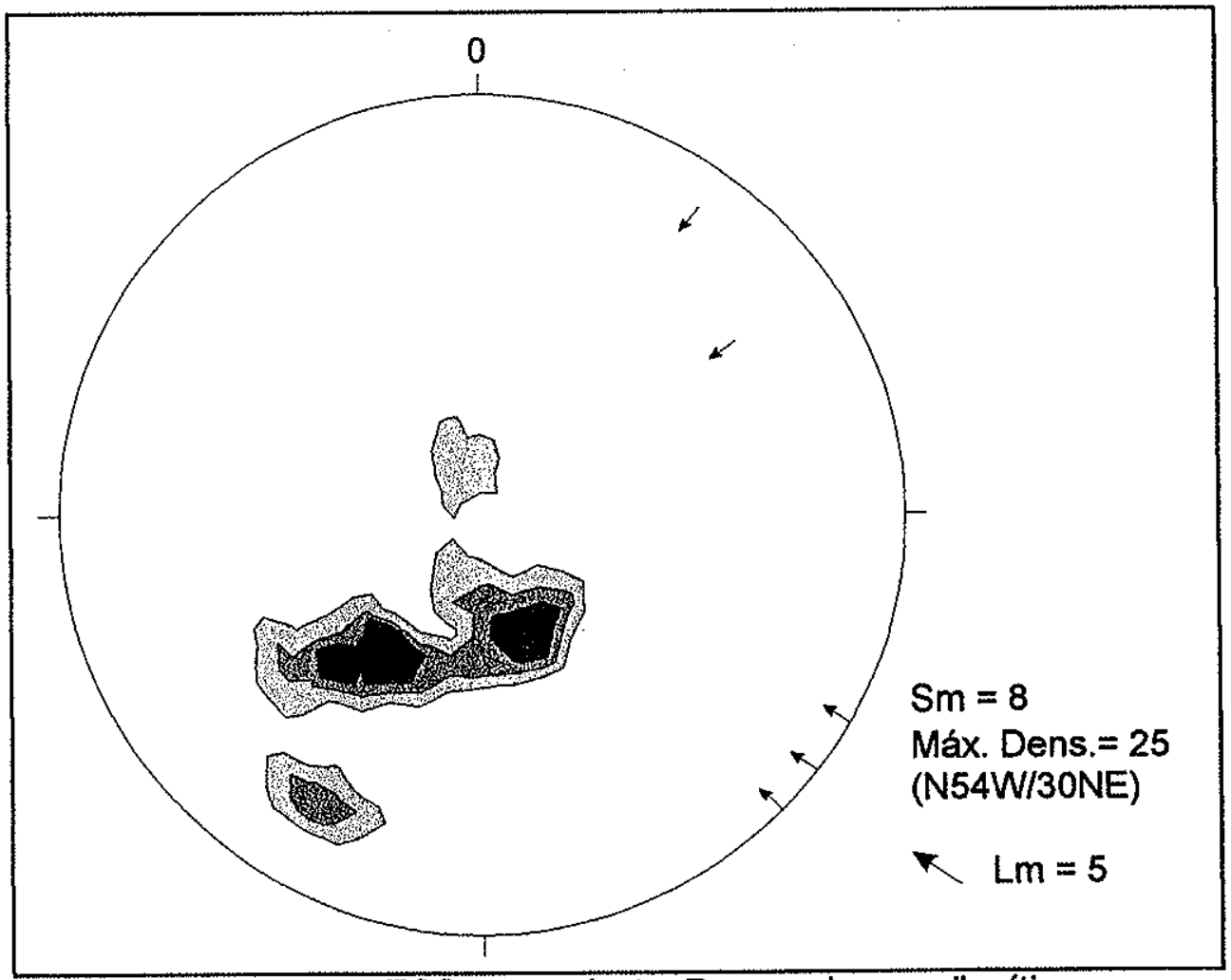

Figura 10.2.5 - ZCS - setor leste. Paragnaisses miloníticos. 


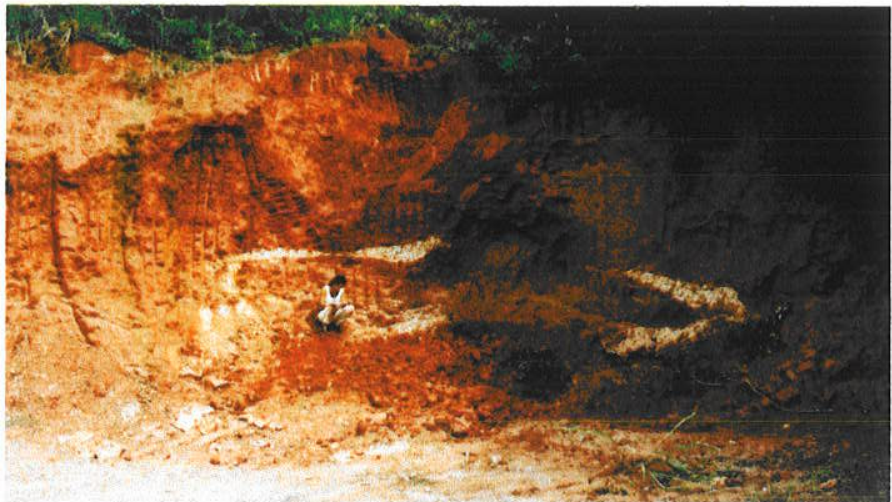

Foto 1 - Setor leste ZCS. Metassiltitos alterados e faixas e lentes deformadas de biotita-gnaisse. Foliação milonítica N70E/20NW. Afloramento K-27. Norte de Pariquera Açu.

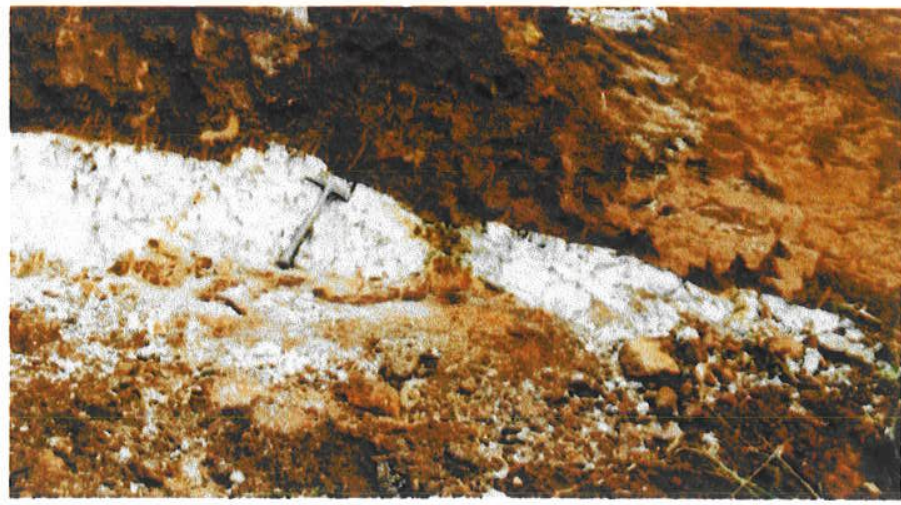

Foto 2 - Setor leste ZCS. Feições extensionais de biotita-gnaisse em meio ao metassiltito. Afloramento K-27.

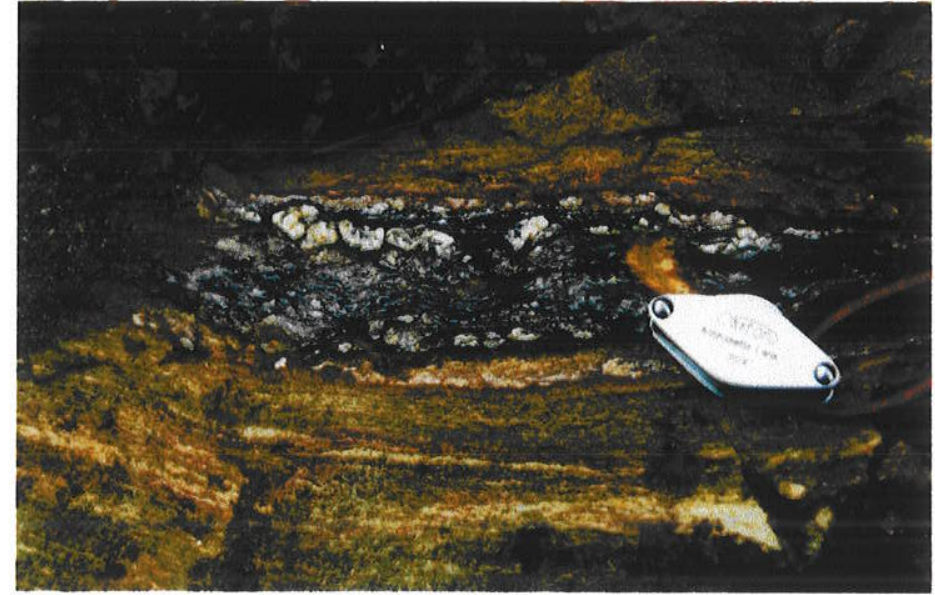

Foto 3 - Setor Central - ZCS. Faixa milonítica com imbricamento de rocha granítica e metassedimentar. Foliação milonítica N55W/73SW. Afloramento K-41 (corte XZ), região de Serrinha.

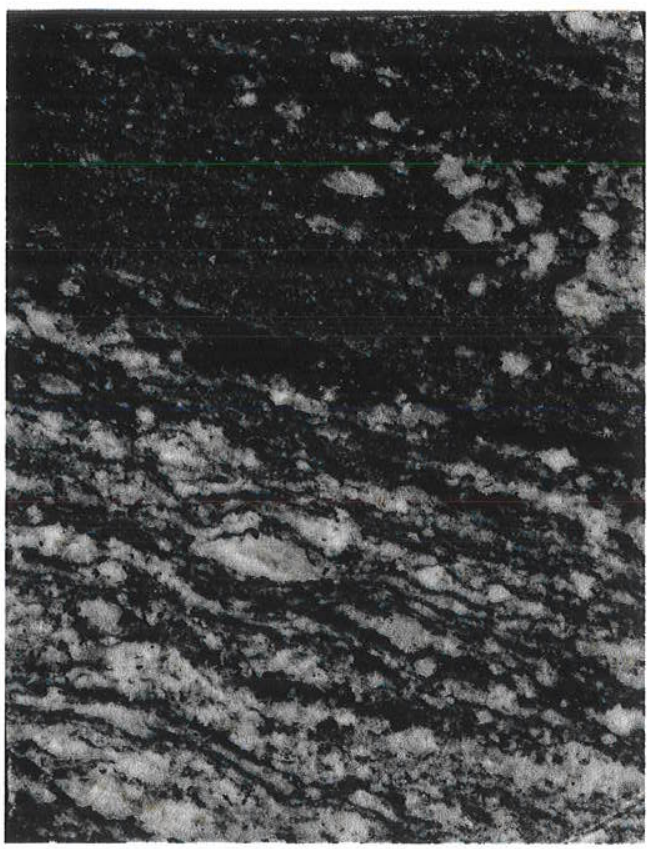

Foto 5 - Setor central ZCS. Protomilonito de granito, mesocrático, com porfiroclastos de feldspato assimétricos, sugerindo movimentação dextral. Afloramento K-102 (corte XZ). Região da Serrra do Pocinho.

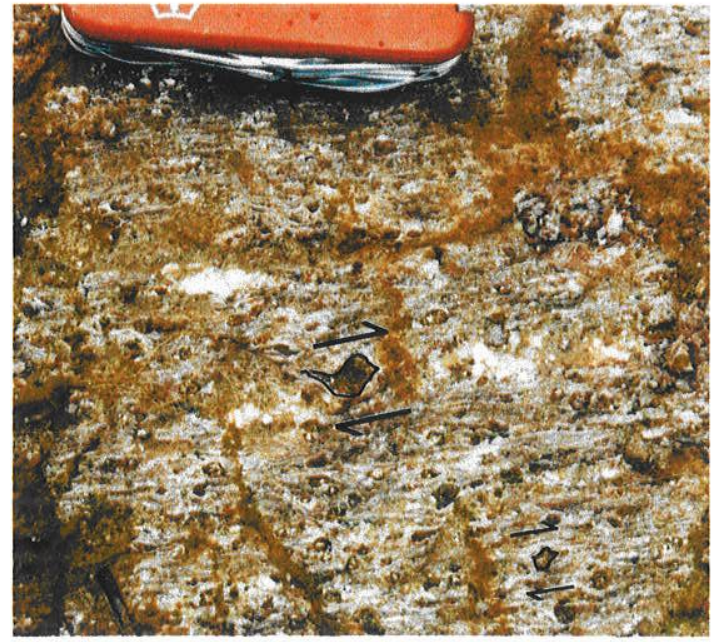

Foto 4 - Setor Central-ZCS Milonito de possível granada xisto, com porfiroclastos de granada indicando movimentação dextral. Foliação milonítica E-W/71N. Afloramento K-42 (corte XZ), reqião de Serrinha.

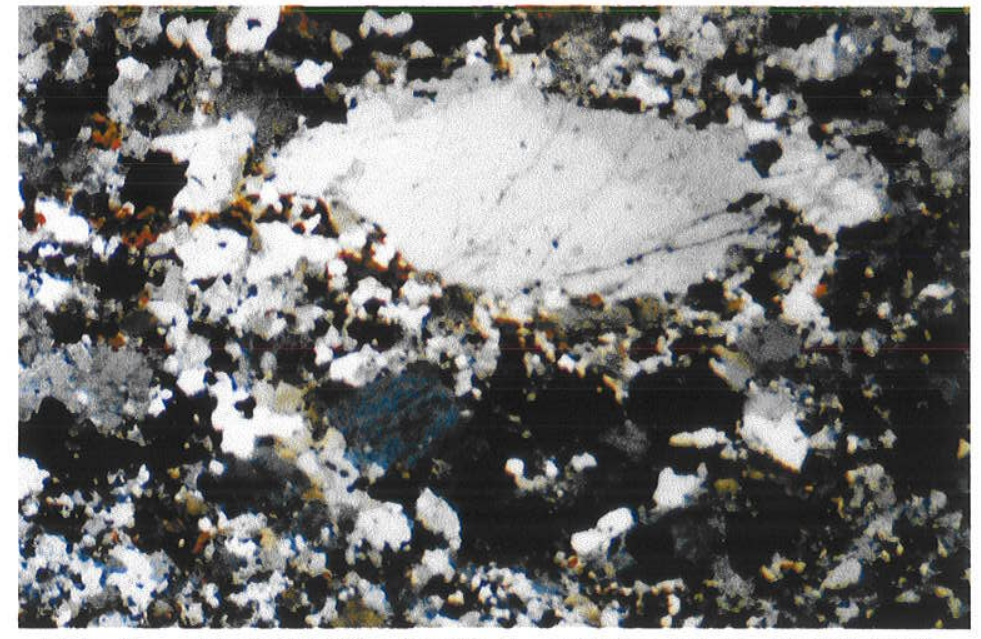

Foto 6 - Fotomicrografia (nicóis $\mathrm{X}$, aumento $10 \mathrm{x}$ ). Protomilonito monzogranítico com textura caracterizada pelo forte estiramento de porfiroclastos de feldspato potássico. Amostra K-102 (corte XZ). 


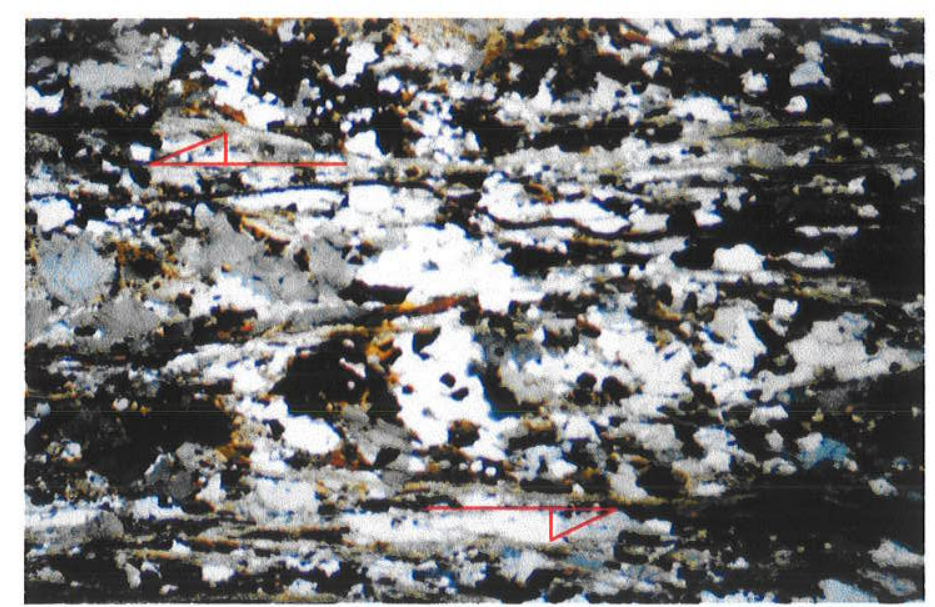

Foto 1 - Fotomicrografia (nicóis $\mathrm{X}$, aumento $7.5 \mathrm{x}$ ). Xisto milonítico com estruturas tipo $\mathrm{S}-\mathrm{C}$, indicando movimentação sinistral. Amostra K-39 (corte XZ). Ramificação setor central ZCS.

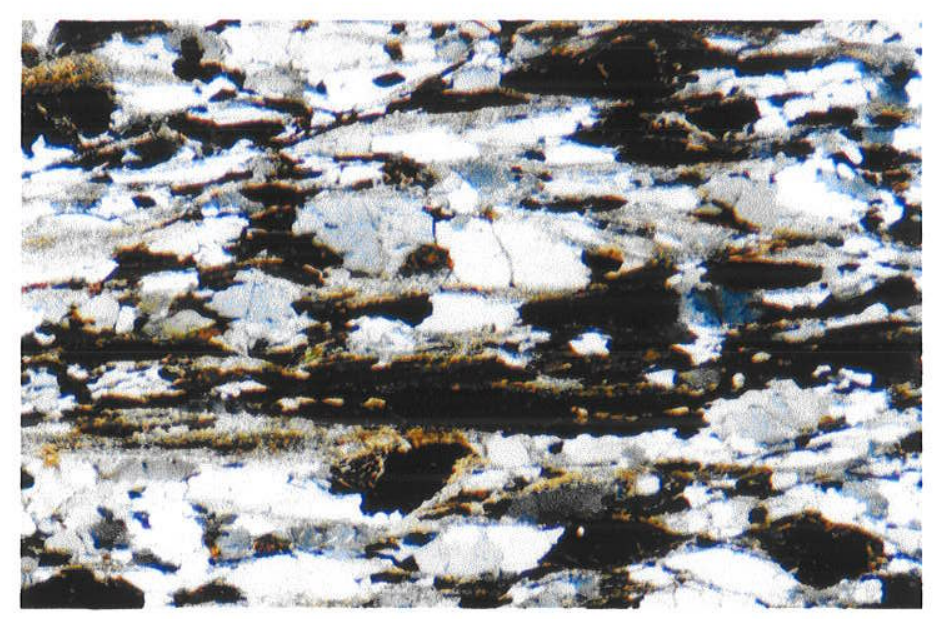

Foto 3 - Fotomicrografia (nicóis $\mathrm{X}$, aumento $25 \mathrm{x}$ ). Xisto milonítico. Pseudomorfo de granada com feiçőes de estiramento (canto inferior direito da foto). Amostra K-39 (corte XZ). Ramificação setor central ZCS.

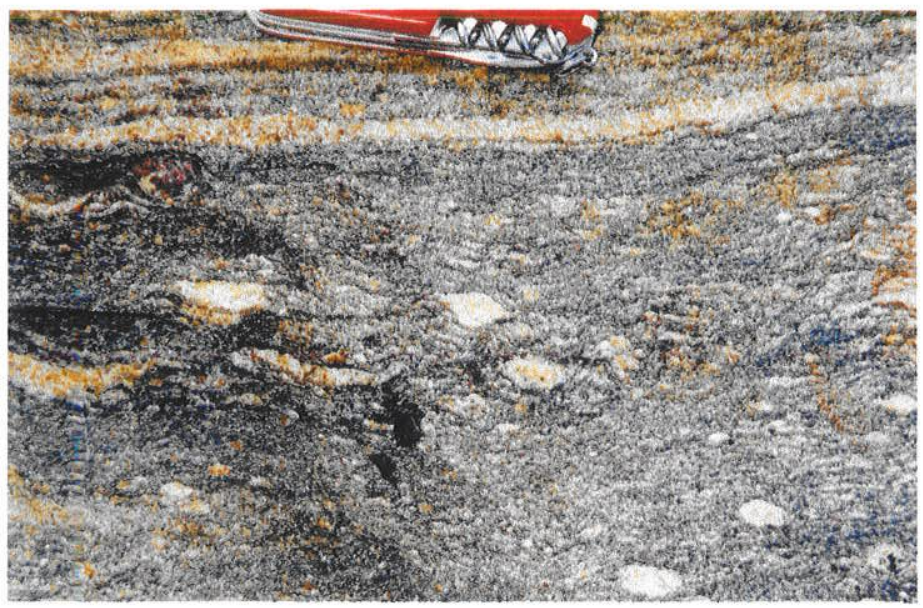

Foto 5 - Setor leste ZCS. Paragnaisse milonítico da Juréia. Foliação milonítica caracterizada por faixas estiradas quartzo feldspáticas, e porfiroclastos de feldspatos e de granada. Afloramento K-96.

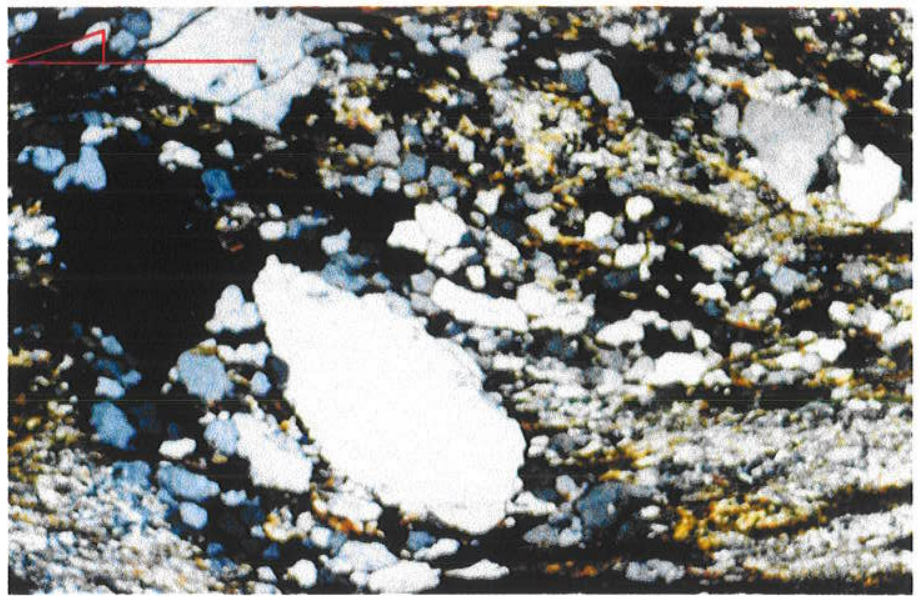

Foto 2 - Fotomicrografia (nicóis $\mathrm{X}$, aumento $25 \mathrm{x}$ ). Xisto milonítico com porfiroclasto de quartzo e ribbons de quartzo indicando movimentação sinistral. Amostra K-39 (corte XZ). Ramificação setor central ZCS.

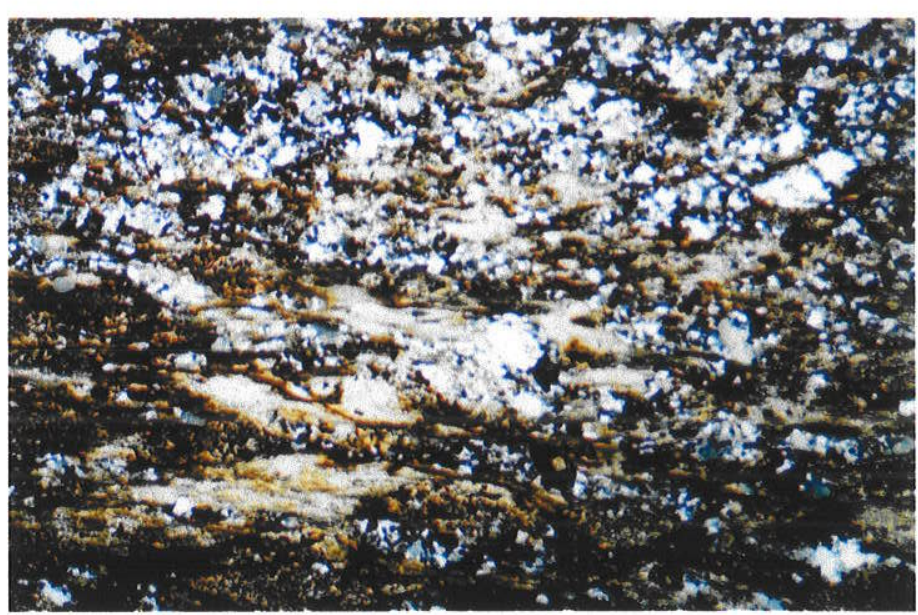

Foto 4 - Fotomicrografia (nicóis $\mathrm{X}$, aumento $10 \mathrm{x}$ ). Rocha filonítica constituída por quartzo, sericita, clorita, epídoto e óxidos de $\mathrm{Fe}$. Amostra K-40 (corte XZ) Ramificação setor central ZCS.

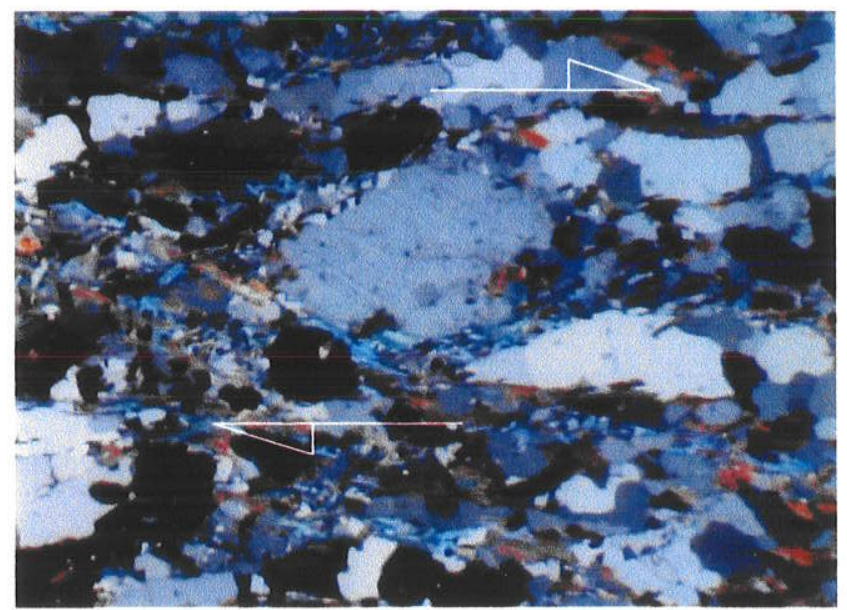

Foto 6 - Fotomicrografia (nicóis $\mathrm{X}$, aumento $10.5 \mathrm{x}$ ). Paragnaisse milonítico da Juréia, setor leste ZCS. Porfiroclasto de plagioclásio com forma sigmoidal, indicando movimentação dextral. Observar porfiroclastos simétricos de granada. Amostra K-97 (corte XZ). 


\section{ELIPSÓIDE DE DEFORMAÇÃO}

A realização de análises pelo método de Fry (Fry, 1979, 1999), foi extremamente prejudicada, devido ao alto grau de alteração das rochas miloníticas da ZCS, como pode ser observado nas Pranchas Fotográficas 26 e 27.

Assim sendo, a confecção de diagramas de Fry foi realizada em apenas três amostras, sendo que em duas amostras, de modo não convencional.

No paragnaisse milonítico da Juréia (K-96), setor leste da ZCS, a amostra coletada não permitiu a análise pelo método, por possuir poucos porfiroclastos de feldspato. No entanto, optou-se por realizar a confecção do diagrama de Fry pelas fotos dos planos XZ (Prancha 18, Foto 1) e YZ (Prancha 18, Foto 2) obtidas no afloramento em questão. Assim sendo, obteve-se os parâmetros necessários para plotagem em Diagrama de Flinn. Por outro lado, a orientação dos eixos $X, Y$ e $Z$, não pôde ser determinada pelo fato das fotos não possuírem a horizontal dos planos.

Em monzogranito protomilonítico do setor central da ZCS (K-102) realizou-se a análise em seções delgadas de cortes $X Z$ e $Y Z$, obtendo-se a orientação dos eixos após confecção do diagrama de Fry. (Tabela 10.2.1).

Em afloramento de xistos miloníticos (K-42), do setor central da ZCS, foi realizada análise pela foto do plano $X Z$ obtida em afloramento (Prancha 26, Foto 4), através de porfiroclastos de granada. $O$ corte $Y Z$ não foi analisado.

A orientação dos eixos principais do elipsóide de deformação estão listados na Tabela 10.2.1, juntamente com as orientações da foliação milonítica principal da rocha e lineação de estiramento mineral.

\begin{tabular}{|c|c|c|c|c|c|c|c|}
\hline \multirow{2}{*}{ AMOSTRA } & \multirow{2}{*}{ ROCHA } & \multirow{2}{*}{ S/SM } & \multirow{2}{*}{ LLLM } & \multicolumn{3}{|c|}{ EIXOS DO ELIPSOIDE DE DEFORMAÇAO } & \multirow{2}{*}{ MOVIMENTO } \\
\hline & & & & EIXOX & EixoY & EIXOZ & \\
\hline $\mathrm{K}-42$ & Xisto milonítico & $\mathrm{E}-\mathrm{W} / 71 \mathrm{~N}$ & & ए। & (1) & फ़े & \\
\hline K-96 & Gnaisse milonítico & N50W/47NE & S52EI & & & & \\
\hline $\mathrm{K}-102$ & Protomilonito granítico & N85W/64SW & S55W/22 & $\mathrm{S} 80 \mathrm{E} / 28$ & $\mathrm{~N} 25 \mathrm{~W} / 55$ & $\mathrm{~N} 10 \mathrm{E} / 12$ & dextral \\
\hline
\end{tabular}

Tabela 10.2.1 - Direção da foliação e lineação mineral principal das amostras analisadas e orientação dos eixos do elipsóide obtidos pelo Método de Fry . 
Como pode ser observado na Tabela 10.2.1, não houve concordância entre a orientação do eixo $X$ do elipsóide de deformação (direção de máxima extensão) e a lineação de estiramento mineral medida na rocha protomilonítica granítica. No entanto, a direção de máximo encurtamento (eixo $Z$ ) a cerca de $90^{\circ}$ da foliação milonítica, confirma com as observações obtidas em campo, que sugerem uma importante componente de cisalhamento puro na deformação destas rochas.

A Figura 10.2.6 mostra as elipses e seus respectivos eixos principais obtidos pelo método de Fry. A posição do traço da foliação milonítica nos cortes $X Z$ e YZ é vertical, e a horizontal da direção de cada corte, bem como sua orientação estão indicados na porção superior de cada figura.

As figuras obtidas pelo método de Fry (Figura 10.2.6) indicaram maior deformação associada à amostra dos paragnaisses da Juréia, e indicação de importante contribuição de cisalhamento puro.

As elipsidades (Rxz e Ryz) obtidas pelo Método de Fry, Tabela 10.2.2, consequentemente foram utilizados para obtenção dos parâmetros necessários ( $R x y, K$, D) para o conhecimento da forma do elipsóide de deformação (Diagrama de Flinn).

\begin{tabular}{|c|c|c|c|c|c|c|c|}
\hline AMOSTRA & $\mathbf{R X Z}$ & $\mathbf{R Y Z}$ & $\mathbf{R X Y}$ & $\mathbf{K}$ & $\mathbf{D}$ & ELIPSÓIDE & DIAGRAMA DE FLINN \\
\hline K-42 & 1.7 & & & & & & \\
\hline K-96 & 1.9 & 1.7 & 1.12 & 0.17 & 0.71 & Oblato & Achatamento aparente \\
\hline K-102 & 1.7 & 1.5 & 1.13 & 0.26 & 0.52 & Oblato & Achatamento aparente \\
\hline
\end{tabular}

Tabela 10.2.2 - Dados obtidos pelo método de Fry e aplicação de Diagrama de Flinn. 

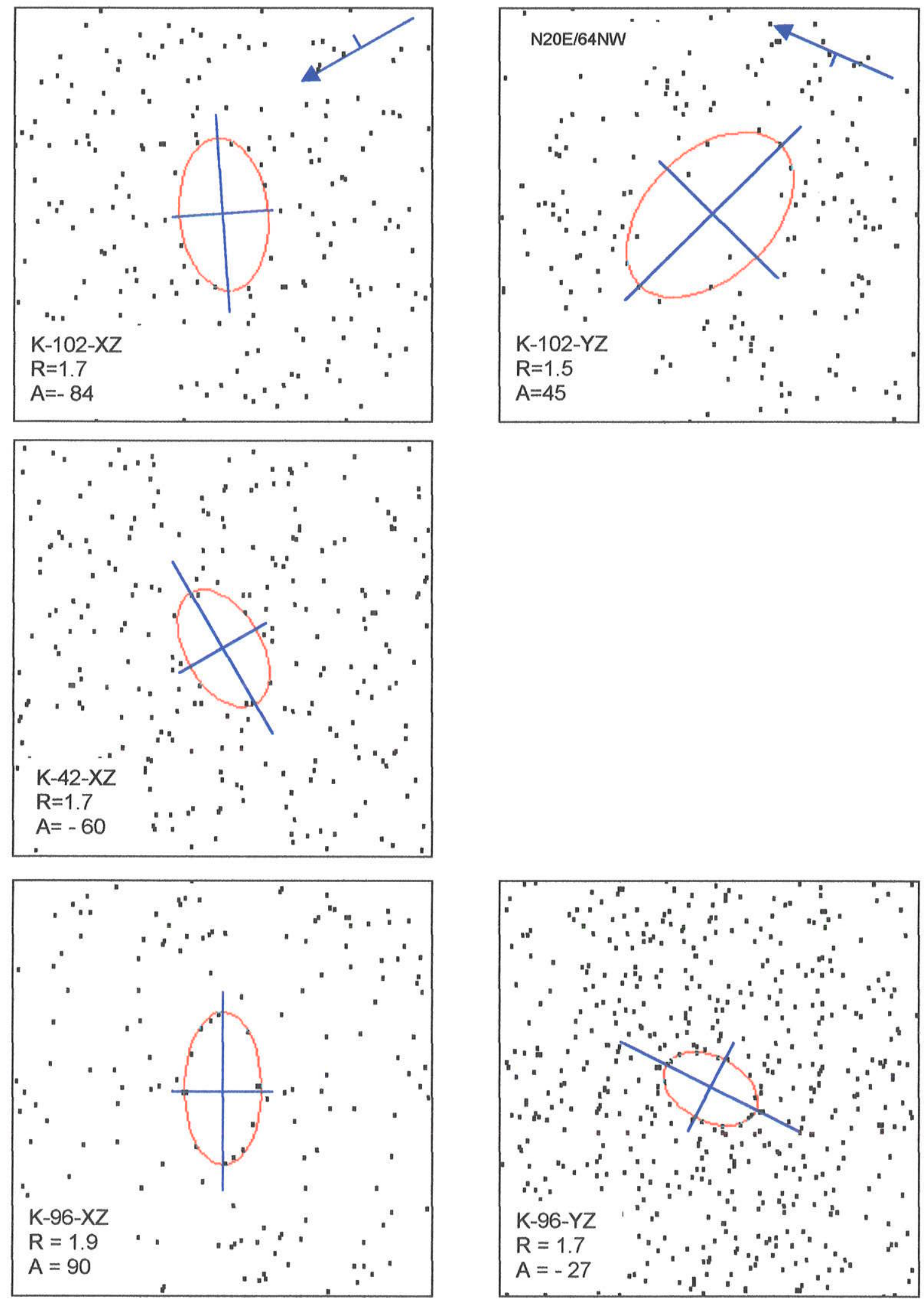

Figura 10.2.6 - Método de Fry aplicado à rochas miloníticas ZCS - setores leste e central. 
O elipsóides definidos foram oblatos (Figura 10.2.7)., associados a uma deformação por achatamento aparente, próximo ao campo do achatamento uniaxial. Nestes casos, o encurtamento na direção $Z$ é acomodado pela extensão que ocorre ao longo dos eixos $X \in Y$, possível quando ocorre perda de volume.

Este tipo de deformação está associado a forte componente compressiva, por cisalhamento puro, corroborando com a forma dos porfiroclastos observados nos cortes $X Z$.

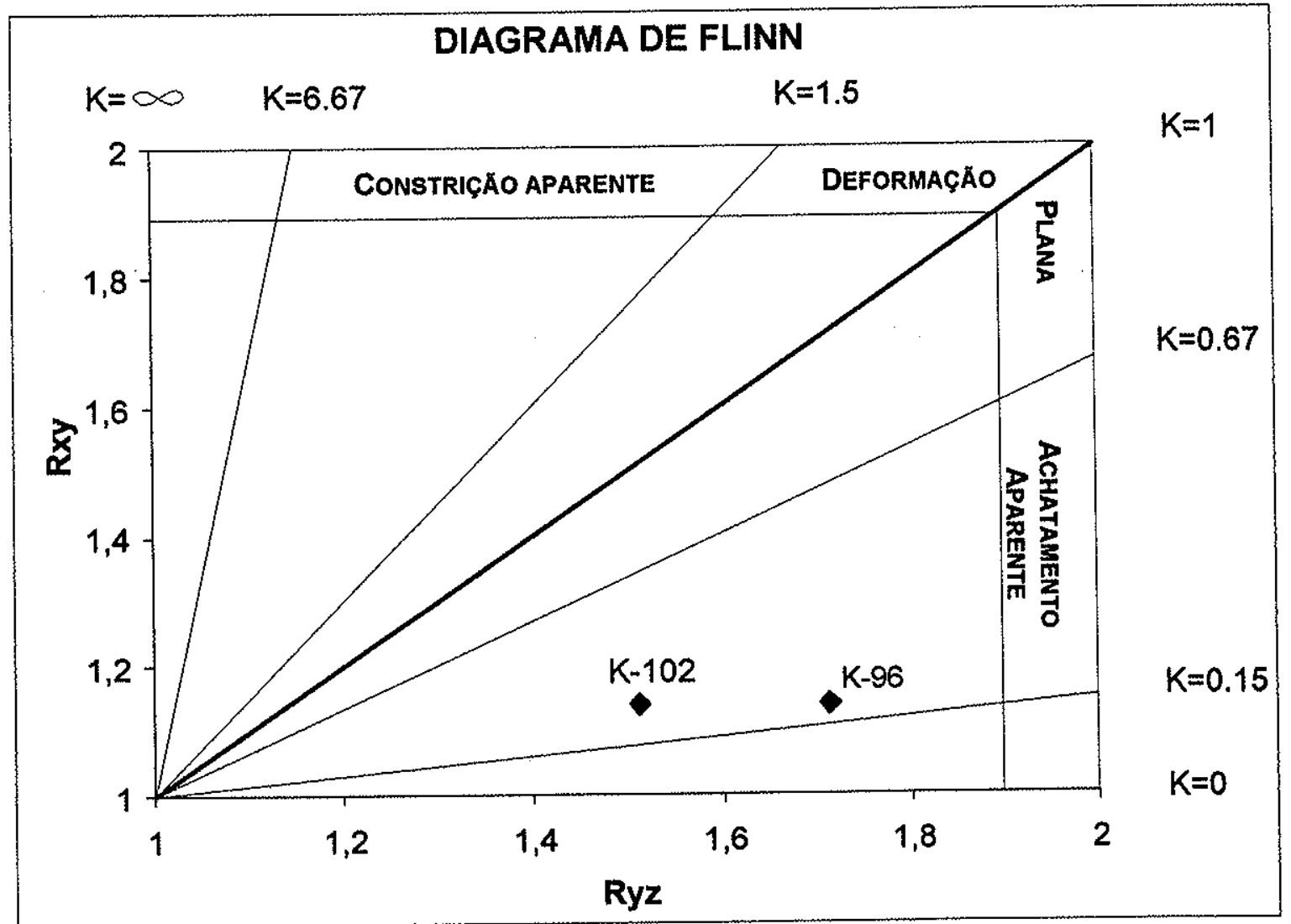

Figura 10.2.7 - Diagrama de Flinn. Milonitos setores leste e central - ZCS. 


\subsection{MÉTOdO K-AR}

O método K-Ar foi aplicado a milonitos dos três setores da ZCS (Figura 10.3.1). No setor leste em biotita de granulação fina, do paragnaisse Juréia (amostra K-96), no setor central em biotita, granulação fina, de protomilonito monzogranítico (amostra K-102), e no setor oeste em muscovita, de granulação grossa, de rocha metassedimentar milonítica (amostra $\mathrm{K}-27$ ). Os resultados analíticos mostraram-se bons e apresentam-se na Tabela 10.3.1 e forneceram idades de leste para oeste de $482 \pm 12 \mathrm{Ma}, 493 \pm 9 \mathrm{Ma}$, e $575 \pm 16 \mathrm{Ma}$.

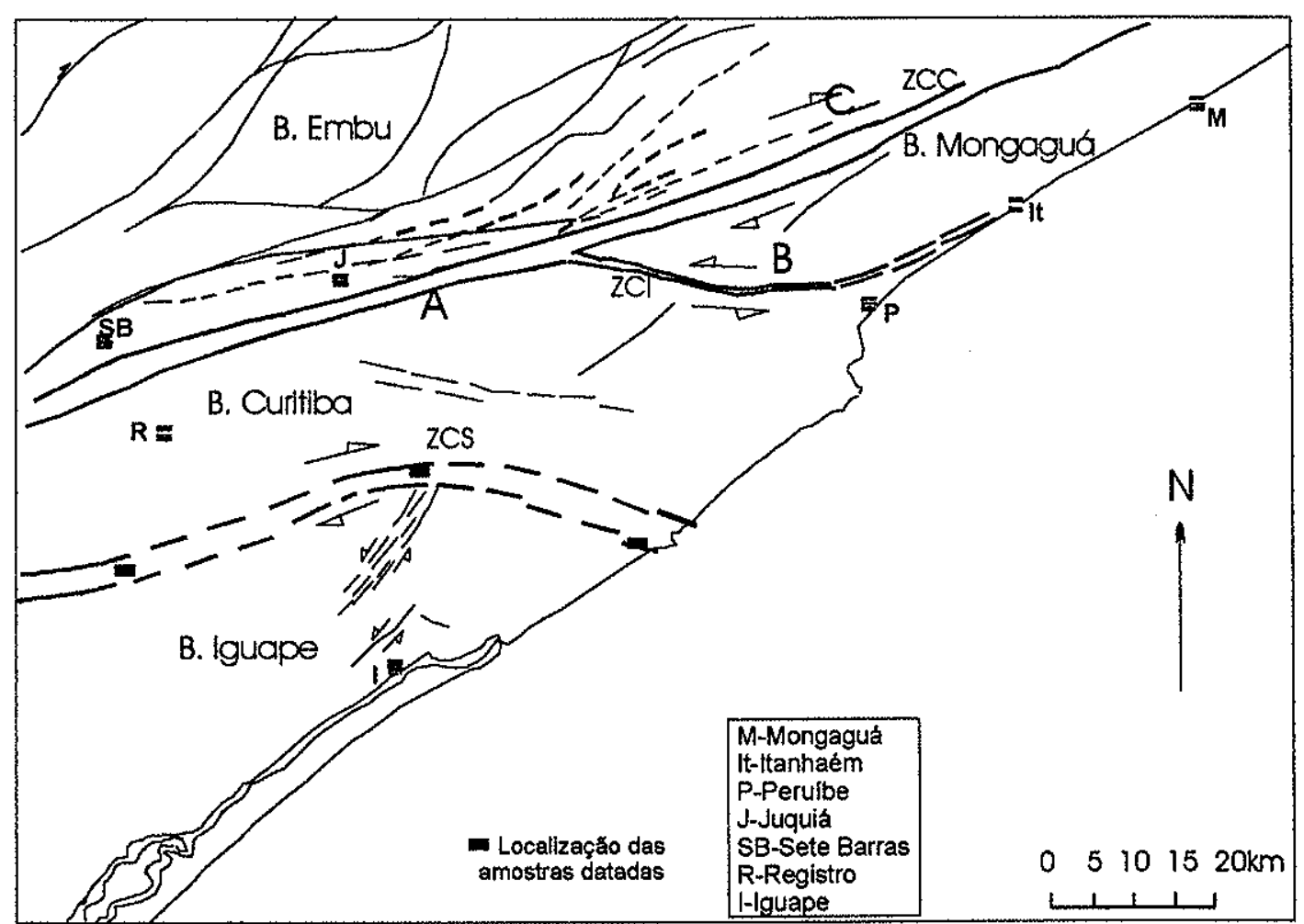

Figura 10.3.1 - Mapa estrutural esquemático com localização das amostras datadas

A idade de $575 \mathrm{Ma}$ em milonito do setor oeste, foi obtida em muscovita de granulação mais grossa ( $\sim 35$ mesh) em relação às demais amostras, podendo ter retido melhor o gás Ar em seu retículo cristalino. Apresentou valor semelhante ao obtido pela metodologia U-Pb em protomilonito granítico do setor central da ZCS (amostra K-102), que em monazitas forneceu idades entre 570 e $580 \mathrm{Ma}$ (Capítulo 8, 
item 8.4). Esta idade em torno de $575 \mathrm{Ma}$, é interpretada como principal época de movimentação desta zona de cisalhamento.

Os demais resultados obtidos em biotitas, podem refletir movimentações tardias desta zona de cisalhamento, podendo representar a época de cessação do aquecimento regional, associado a cinemática dos Blocos tectônicos envolvidos.

Adicionalmente, apesar dos erros analíticos, a idade obtida em biotita no setor central mostrou-se um pouco mais antiga que à obtida no setor leste. Tal fato pode ser sugestivo de que os milonitos do setor oeste alcançaram condições de resfriamento anteriormente aos milonitos do setor central (confirmação necessária através de datação K-Ar em biotitas de mesma granulometria), que por sua vez podem ter se resfriado um pouco antes dos milonitos do setor leste. Este setor (leste) teria permanecido aquecido por mais tempo, ou seja, permaneceu em temperaturas superiores a $250^{\circ} \mathrm{C}$ por um período um pouco mais longo que os demais setores da ZCS.

\begin{tabular}{|c|c|c|c|c|c|c|c|}
\hline $\begin{array}{c}\text { AMOstRA } \\
\text { SETOR }\end{array}$ & $\begin{array}{c}\text { MATERIAL } \\
\text { ANALISADO }\end{array}$ & \% DEK & ERRO & $\begin{array}{c}\text { AR40 RAD } \\
(* 10-6)\end{array}$ & $\begin{array}{c}\text { AR40 ATM } \\
(\%)\end{array}$ & $\begin{array}{c}\text { IDADE } \\
\text { MA }\end{array}$ & $\begin{array}{c}\text { ERRO } \\
\text { MAX. }\end{array}$ \\
\hline $\begin{array}{c}\text { K-96 } \\
\text { Leste }\end{array}$ & Biotita & 7.3501 & 0.8044 & 157.52 & 3.91 & 481.5 & 12.1 \\
\hline $\begin{array}{c}\text { K-102 } \\
\text { Central }\end{array}$ & Biotita & 7.6326 & 0.5000 & 168.25 & 3.98 & 493.4 & 9.2 \\
\hline $\begin{array}{c}\text { K-27 } \\
\text { Oeste }\end{array}$ & Muscovita & 6.3509 & 1.5647 & 167.06 & 3.22 & 575.2 & 15.7 \\
\hline
\end{tabular}

Tabela 10.3.1 - Dados analíticos da sistemática K-Ar para as rochas miloníticas da ZCS. 
A ZCS, definida por Passarelli et al. (2000) faz limite entre o Bloco Registro e Iguape, apresentando rochas miloníticas graníticas imbricadas com rochas miloníticas metassedimentares.

A foliação milonítica apresenta direção geral, em torno de E-W, e associa-se a movimentação predominante dextral com importante componente por cisalhamento puro Esta componente coaxial é observada na porção central da ZCS, através de indicadores cinemáticos dextrais e sinistrais e porfiroclastos simétricos; e na porção leste, através de porfiroclastos boudinados simétricos em planos $X Z$.

Esta deformação associada à transpressão também pôde ser evidenciada nos elipsóides de deformação oblatos determinados, com posicionamento em Diagrama de Flinn próximo ao campo do achatamento uniaxial, e pela orientação dos eixos maiores das elipses de deformação paralela à zona de cisalhamento (Mapa Estrutural - Anexo 2).

A ZCS, apresenta importante ramificação rumo a SE, que apresenta movimentação sinistral, com componente de cavalgamento para $\sim$ N50W. Porém, apresenta forte componente não rotacional na deformação, evidenciado principalmente pela simetria dos porfiroclastos.

Datações obtidas em monazitas de protomilonítico monzogranítico (amostra K-102), situado no setor central da ZCS, apresentaram idades concordantes em torno de 570-580 Ma, interpretadas como representativas da época de importante evento metamórfico, associado à movimentação da ZCS.

A ZCS, pode estar associada à justaposição do Bloco Registro ao Bloco Iguape, este último, correlacionado (Capítulo 8 , item 8.5) ao Domínio Paranaguá (Siga Jr., 1995).

A direção de maior encurtamento definida para a ZCS próximo a N-S, obtida através da observação dos dados de campo, tendo sua confirmação pelos resultados obtidos pelo Método de Fry, pode estar associada à direção da movimentação do Bloco lguape rumo ao Bloco Registro. Esta cinemática mostra-se em concordância com a observada na Zona de Cisalhamento Rio Palmital, que baliza o Domínio Paranaguá, com o Domínio Luis Alves na porção SE do estado do Paraná e NE de Santa Catarina (Siga Jr., op. cit.). 


\section{CONSIDERAÇÕES FINAIS}

Este capítulo encerra as principais conclusões obtidas a partir do estudo realizado na região sul-oriental do estado de São Paulo. Foram reconhecidos quatro blocos tectônicos, que apresentam características litológicas, estruturais, geocronológicas e isotópicas distintas (resumidas na Tabela 11.1), sendo limitados por expressivas zonas de cisalhamento.

$\mathrm{Na}$ área investigada, o Bloco Embu compreende rochas metassedimentares de baixo a médio grau metamórfico, e biotita monzogranitos peraluminosos. Dataçōes U-Pb (monazitas) sugerem idades em torno de 600 Ma para época de cristalização destes granitos que mostram fortes heranças isotópicas nas frações de zircão analisadas, em cerca de $750 \mathrm{Ma}$. Os granitos apresentam idades TDM em torno de $1.9 \mathrm{Ga}$, próximas às encontradas em metassedimentos (entre $1.6-1.8 \mathrm{Ga}$, Dantas et al., 1999 apud Hackspacher et al., 2000).

Pelos dados geocronológicos disponíveis para regiões mais a leste dentro do Complexo Embu, a época em torno de $600 \mathrm{Ma}$ é associada a uma fase de magmatismo crustal tardio dentro da evolução deste terreno (Hackspacher et al., 2000). Através de datações U-Pb (monazitas) realizadas em rochas gnáissicas, a época em torno de $790 \mathrm{Ma}$ (Vlach, 2001) representa o evento metamórfico principal deste Bloco e indica uma fase associada a um processo tectônico convergente. $O$ referido autor, também apresenta um pico metamórfico em $730 \mathrm{Ma}$ (datação U-Pb em monazitas) associado a um evento de cisalhamento ainda pouco compreendido.

As rochas investigadas do Bloco Registro compreendem rochas gnáissicomigmatíticas e rochas paragnáissicas do Maciço da Juréia. O domínio gnáissicomigmatítico abrange rochas granitóides (monzogranitos a granodioritos) interrelacionadas com material máfico diorítico, apresentando-se comumente, com feições migmatíticas. Parte das feições texturais observadas, são interpretadas como processos de mingling entre dois materiais distintos, acarretando no desmembramento de diques sin-intrusivos e formação de enclaves, podendo estar associados a regiōes profundas e distensionais.

As rochas gnáissico-migmatíticas do Bloco Registro apresentaram, idades U$\mathrm{Pb}$ em zircões extremamente discordantes, em posição intermediária entre 0 
intercepto inferior e superior. Pelas características das frações de zircão analisadas, considera-se que as rochas são Neoproterozóicas, apresentando fortes heranças isotópicas paleoproterozóicas. Considerando-se que a estruturação do Bloco Registro é neoproterozóica, é sugerido que este compartimento seja constituído por rochas neoproterozóicas formado às expensas de rochas paleoproterozóicas.

Assim sendo, é sugestão deste trabalho, que os protólitos paleoproterozóicos, se formaram em uma importante fase distensiva $(1.9-2.2 \mathrm{Ga})$, bem preservados na região de Oliveira Barros (afloramento K-16). Este processo pode ter sido responsável pelo metamorfismo do fácies granulito do Complexo Itatins, ocorrido próximo a $2.2 \mathrm{Ga}$ (Picanço et al., 1998). Estas rochas, originadas a partir deste evento distensivo, foram posteriormente deformadas e migmatizadas, em épocas brasilianas.

Pelos dados apresentados, sugere-se que o evento brasiliano pode ter sido muito mais intenso na região em questão do que o observado nas proximidades de Curitiba (local - tipo do Complexo Atuba). Apresentam o intervalo entre 2.7 e $2.9 \mathrm{Ga}$, localmente $2.4 \mathrm{Ga}$ (idade modelo TDM), como época principal de diferenciação dos seus protólitos do manto.

Os paragnaisses aflorantes no Maciço da Juréia, correlacionados aos paragnaisses da Sequência Cachoeira aflorantes no Maciço de Itatins (Dantas et al., 1987) apresentaram idades U-Pb em monazitas em torno de 750 Ma e idade TDM de $2.3 \mathrm{Ga}$. A época de $750 \mathrm{Ma}$, pode ser associada à fase de deformação que atingiu o fácies anfibolito alto (Azevedo Sobrinho, 1995) as rochas do Complexo Itatins e Sequência Cachoeira, em torno de $720 \pm 30 \mathrm{Ma}$ (Picanço 1994, Picanço et al., 1998).

No Bloco Mongaguá, foram identificadas rochas gnáissico-migmatíticas, e rochas graníticas, localmente com feições gnáissico-migmatíticas, Tipo Itariri, e Granitos Tipo Areado e Ribeirão do Óleo.

As rochas gnáissico-migmatíticas, são interpretadas como resultado da interação (mingling/mixing) entre material granítico (monzogranito e sienogranito) e diorítico em cerca de $612 \mathrm{Ma}$, possivelmente em regimes extensionais.

$\mathrm{Na}$ região de Mongaguá, feições como contatos em cúspide, são interpretadas pela baixa viscosidade do material máfico em relação ao material granítico, podendo ser explicada pela alta quantidade de material máfico em relação 
ao granítico, onde o material máfico consegue reter seu calor e manter sua baixa viscosidade. Já na região de Itanhaém, a presença de estruturas como 'net veined complexes' já sugerem uma menor quantidade de material máfico em relação ao félsico, pois o primeiro já apresentava um comportamento um pouco mais rúptil em relação ao último.

As rochas, apresentam estruturas de deformação possivelmente ainda no estado plástico e estruturas indicativas de uma deformação e segregação ocorridos no estado sólido. De fato, tais feições podem ter ocorrido lado a lado, onde a medida que o corpo estava se resfriando e se colocando, em virtude da quantidade relativa de material félsico e máfico, o material apresentava um comportamento reológico distinto, comportando-se ainda de maneira plástica ou não. Estas rochas foram intensamente deformadas, deformação esta associada ao momento de sua colocação, podendo esta estar diretamente associada à justaposição do Bloco Mongaguá aos demais.

As relações de contato entre as diferentes unidades graniticas discriminadas, bem como a relação entre os Granitos Tipo itariri e as rochas gnáissico-migmatíticas de Mongaguá e Itanhaém não foram observadas. As duas unidades graníticas datadas apresentaram idades $\mathrm{U}-\mathrm{Pb}$ em zircões em intercepto inferior imprecisas, de 580 e $640 \mathrm{Ma}$ (Granito Itariri) e $580 \mathrm{Ma}$ (Granito Ribeirão do Óleo), mostrando erros elevados e presença de fortes heranças isotópicas paleoproterozóicas.

As idades modelo TDM obtidas para as rochas pertencentes ao Bloco Mongaguá, distribuem-se em dois grupos bem distintos: entre 1.7 e $1.8 \mathrm{Ga}$ (rochas gnáissico-migmatíticas, Granitos Tipo Areado e Ribeirão do Óleo) e 2.2 Ga (Granitos Tipo Itariii).

Inevitável torna-se a comparação entre os litotipos aflorantes nos Blocos Mongaguá e Registro, que apresentam semelhanças no que diz respeito à geração das rochas gnáissico-migmatíticas através de processos de magma mingling e mixing. Entretanto, diferenças marcantes (além da época associada ao evento distensivo) devem ser destacadas entre os enclaves máficos dioríticos de ambos os blocos e a relação entre eles e suas rochas hospedeiras.

Os enclaves do Bloco Mongaguá apresentam idades TDM, $\varepsilon N d$ ( $t$ ) negativos e $\left(\mathrm{Sr}^{87} / \mathrm{Sr}^{86}\right) \mathrm{i} \sim 0.708$, muito semelhantes aos valores obtidos nas suas rochas 
hospedeiras. Tais características săo indicativas como principal componente para fontes deste magma máfico um manto litosférico enriquecido (Parada et al., 1999). Entretanto, as similaridades isotópicas e quimicas (distribuição dos ETR) observadas nestes dois materiais pode ser indicativo de uma difusão química e isotópica entre os materiais máfico e félsico.

Este comportamento não é regra nos enclaves do Bloco Registro. Apresentam diferenças isotópicas (em locais mais preservados da migmatização) e químicas marcantes com as rochas graníticas associadas. O comportamento de elementos traços nos enclaves, sugerem uma fonte a partir de fontes do tipo $\mathrm{E}$ MORB, que representa magmas gerados dentro da astenosfera em uma zona de mistura entre manto enriquecido e empobrecido e componente de fontes do tipo OIB (basaltos de ilhas oceânicas), Parada et al. (1999).

O contato entre o Bloco Registro e Iguape se faz através da ZCS, que apresenta movimentação dextral com importante componente de cisalhamento puro. Apresenta ramificação de direção SE onde observa-se uma movimentação sinistral associada a componente de cavalgamento para NW.

O Bloco lguape é constituído por rochas metassedimentares de baixo grau e dois grupos de rochas graníticas. Um constituído por granitos que sustentam o Maciço de Iguape, normalmente protomiloníticos, e outro constituído por granitos associados à Suíte Granítica Serra do Mar.

As rochas metassedimentares estudadas são representadas pela intercalação de metarenitos finos, homogêneos, com metassiltitos caracterizando rochas de baixo grau metamórfico. Tais rochas são muito semelhantes às rochas aflorantes no setor setentrional da llha do Cardoso, caracterizadas por um bandamento rítmico (Weber, 1998). O autor apresenta, para estas rochas, idades TDM entre 2 e $2.2 \mathrm{Ga}$, interpretadas como o período mais antigo possível em que os protólitos das rochasfonte dos metassedimentos se diferenciaram do manto.

As rochas estudadas do Bloco Iguape, referentes ao Maciço de Iguape e ao granito protomilonítico da ZCS, podem ser correlacionadas aos granitóides pertencentes ao Domínio Paranaguá, cujos dados geocronológicos foram obtidos de Siga Jr. (1995). Nota-se que as idades U-Pb obtidas neste trabalho (entre $\sim 600$ e $620 \mathrm{Ma}$, Tabela 11.1) são semelhantes às obtidas pelo autor para os Granitóides 
tipo Morro Inglês (614 $\pm 9 \mathrm{Ma}$ ) e Rio do Poço (609 $\pm 28 \mathrm{Ma}$ ). Ambos conjuntos apresentam grande variação nas idades TDM obtidas, no Bloco lguape entre $1.8 \mathrm{e}$ $2.48 \mathrm{Ga}$ (Tabela 11.1) e no Domínio Paranaguá entre 1.9 e $2.6 \mathrm{Ga}$. Por outro lado, os granitos que ocorrem no Bloco Iguape, apresentam $\left(\mathrm{Sr}^{87} / \mathrm{Sr}^{86}{ }_{i}\right)$ sistematicamente mais elevadas (comumente entre 0.710 e 0.714 ) que as observadas no Domínio Paranaguá (entre 0.707 e 0.708 ).

Rochas graníticas associadas à Suite Intrusiva Serra do Mar ocorrem nos Blocos Registro (Granito Votupoca) e Iguape (Serras do Paratiú, Cordeiro e Itapitangui). Representam um magmatismo cálcio-alcalino, de alto $K$, com tendência peralcalina, e características de ambiente intra-placa.

Os Granitos Cordeiro e Votupoca apresentaram idades U.Pb (zircões) em torno de $580 \mathrm{Ma}$, e os Granitos da Suíte Serra do Mar estudados por Siga Jr. (1995) entre 580 e $594 \mathrm{Ma}$. Diferenças são observadas principalmente em relação às idades modelo TDM, sendo as obtidas neste trabalho mais antigas (entre 2.3 e 2.45 Ga, Tabela 11.1) que aquelas observadas na Suíte Granítica Serra do Mar, entre 1.850 e $2.100 \mathrm{Ma}$ (Siga Jr., op. cit.).

Os Blocos acima descritos mostram-se balizados por importantes zonas de cisalhamento, representadas pelo Sistema de Cisalhamento Cubatão Itariri (SCCI), subdividdido em ramificações ( $A, B$ e C) e Zona de Cisalhamento Serrinha (ZCS), que apresentam suas principais características resumidas na Tabela 11.2.

A ramificação $\mathrm{A}-\mathrm{C}$ do $\mathrm{SCCl}$, faz o limite entre o Bloco Embu e os Blocos Registro e Mongaguá, a ramificação $B$, limita o Bloco Mongaguá do Bloco Registro e a ZCS faz o limite entre os Blocos Registro e Iguape.

O SCCl, apresenta como idade máxima de movimentação $606 \mathrm{Ma}$ (U-Pb zircão) obtida em gnaisse protomilonítico, e a ZCS, movimentação provável em 575 $\mathrm{Ma}$ (U-Pb monazitas) obtida em protomilonito granítico.

O quadro tectônico atual observado na porção sul-oriental do Estado de São Paulo, estabeleceu-se no final do Neoproterozóico, como resultado de colagens associadas à formação do Gondwana Ocidental (Brito Neves et al., 1999; Campos Neto, 2000). As rochas estudadas foram afetadas, de modo bastante significativo pela tectônica brasiliana. Os domínios tectônicos mais antigos na área estão representados pelos Bloco Embu e Registro, que apresentam registros de evento 
térmico-metamórfico precoce dentro da evolução do Ciclo Brasiliano. Possivelmente, a justaposição entre estes blocos tectônicos pode ter ocorrido em épocas neoproterozóicas muito próximas. No entanto, a partir dos dados obtidos neste trabalho, juntamente com os dados da literatura, sugere-se a seguir uma cronologia da justaposição que envolveu os blocos tectônicos Embu, Registro, Mongaguá e Iguape.

Uma movimentação sinistral em zona de cisalhamento com direção aproximadamente $\mathrm{E}-\mathrm{W}$, foi registrada nas ramificaçōes $\mathrm{A}-\mathrm{B}$ do $\mathrm{SCCl}$, com uma componente de abatimento para NW e, subordinadamente, cavalgamento para SW. A esta fase está associada uma direção de máxima compressão em torno de N2OEN40E (Mapa Estrutural - Anexo 2). É sugerido que estas movimentações representem a fase metamórfica principal da ramificação $A-B$ do $S C C l$, e podem estar associadas à justaposição do Bloco Embu ao Bloco Registro, apresentando como época máxima $606 \mathrm{Ma}$ (idade U-Pb em zircões de gnaisse milonítico).

Granitos peraluminosos intrusivos no Bloco Embu, com cerca de $598 \mathrm{Ma}$, configuram corpos alongados e encaixados em zonas de cisalhamento sub-paralelas ao $\mathrm{SCCl}$, que apresentam registros de movimentação dextral. A geração destas rochas, associadas à zonas de cisalhamento, pode estar relacionada à compressão aproximadamente E-W (entre N55W e S85W, Mapa Estrutural - Anexo 2), que acarretou na justaposição do Bloco Mongaguá, aos Blocos Registro e Embu. Esta justaposição se deu através de uma movimentação sinistral na ramificação $B$ e dextral na ramificação $C$, provocando áreas de intensa deformação na junção das três ramificações, com geração de rochas ultramiloníticas (região próxima à Pedro Barros). A justaposição do Bloco Mongaguá, está associada a uma componente de cavalgamento em sentido contrário para N50E e S70E (?back thrust?) denominada de fase $2 A$, observada em rochas do setor central, extremo leste do ramo $B$ (região de Itanhaém) e subordinadamente em Mongaguá.

Corpos graníticos peraluminosos que ocorrem no Bloco Mongaguá, como os Granitos Areado e Ribeirão do Óleo, ambos apresentando formas alongadas, podem também representar o magmatismo associado à justaposição deste bloco aos blocos adjacentes.

Como observado na análise da deformação do $\mathrm{SCCl}$, sugere-se que o processo deformacional foi contínuo e progressivo, possivelmente com a passagem 
gradual de um sistema distensivo, com geração de tectonitos tipo L e elipsóides prolatos, para uma deformação plana, com geração de elipsóides triaxiais, e finalmente a um sistema compressivo, gerando elipsóides prolatos.

No Bloco Mongaguá, as rochas gnáissico-migmatíticas (612 $\pm 3 \mathrm{Ma})$, são interpretadas como geradas em regimes extensionais, com direção principal de extensão em torno de E-W, (direção de maior estiramento observada em boudins de enclaves dioríticos na região de itanhaém). A associação deste regime distensivo à cinemática de justaposição do Bloco Mongaguá aos Blocos Embu e Registro (598 \pm $8 \mathrm{Ma}$ ) ainda é incerta, podendo representar um regime distensivo anterior à justaposição dos blocos, ou mesmo um regime distensional associado a esta justaposição. Estas rochas foram intensamente deformadas, deformação esta associada ao momento de sua colocação, podendo esta estar diretamente associada à justaposição deste Bloco aos demais.

A época mais provável da justaposição do Bloco Iguape ao Registro, entre 570 e $580 \mathrm{Ma}$ é sugerida através de datações U-Pb em monazitas de protomilonito granítico da ZCS. Esta zona de cisalhamento apresenta movimentação predominante dextral, com importante componente por cisalhamento puro (Mapa Estrutural - Anexo 2).

Machado et al. (1996) indica que parte significativa da Faixa Ribeira Central, apresenta um pico metamórfico entre 560 e $580 \mathrm{Ma}$ (idades obtidas em monazitas e titanitas). Idades obtidas em titanitas nos Batólitos Graníticos Cunhaporanga e Três Córregos entre 592 e $550 \mathrm{Ma}$, com pico em $560 \mathrm{Ma}$, são interpretadas por Prazeres Filho (2000) como importante evento termal que afetou a Faixa Ribeira Sul.

Datações K-Ar em biotitas em torno de $500 \mathrm{Ma}$, obtidas em rochas miloníticas do $\mathrm{SCCl}$ e da ZCS, são interpretadas como referentes à reativações posteriores ocorridas nestas zonas de cisalhamento. 
Tabela 11.1 - Principais caracteristicas geológicas dos Blocos Tectônicos da porção sul-oriental do Estado de São Paulo.

\begin{tabular}{|c|c|c|c|c|c|c|c|c|c|c|c|}
\hline \multirow{2}{*}{ BLOCO } & \multirow{2}{*}{ UNIDADES } & \multicolumn{2}{|c|}{ PETROGRAFIA } & \multirow{2}{*}{ GEOQUIMICA } & \multirow{2}{*}{ ESTRUTURAL } & \multicolumn{5}{|c|}{ GEOCRONOLOGIAGEOLOGIA ISOTÓPICA } & \multirow{2}{*}{ observaçóes } \\
\hline & & $\begin{array}{c}\text { LITOTIPOS I } \\
\text { MINERALOGIA }\end{array}$ & $\begin{array}{c}\text { GRAU } \\
\text { METAMÓRFICO }\end{array}$ & & & $\begin{array}{l}\text { U-PD } \\
(\mathrm{Ma})\end{array}$ & $\begin{array}{l}\mathrm{K}-\mathrm{Ar} \\
(\mathrm{Ma})\end{array}$ & $\begin{array}{l}\text { TOM } \\
\text { (Ga) }\end{array}$ & ENd (t) & $\mathrm{sr}^{8 \pi} / \mathrm{s} \mathrm{r}^{\mathrm{n}}$ & \\
\hline \multirow{2}{*}{$\sum_{\text {总 }}^{\supset}$} & $\begin{array}{l}\text { Complexo Embu / } \\
\text { Sequëncia Miracatu }\end{array}$ & $\begin{array}{l}\text { musc-qz-xistos } \\
\text { cord-musc-q2-xistos } \\
\text { gra-musc-qz-xistos } \\
\text { sit-musc-qz-xistos }\end{array}$ & Baixo/Médio & & $\left\{\begin{array}{l}S_{2} / \text { Sm: N72W/70sW (máx.) } \\
B_{3}: \text { S79W/50 }\end{array}\right.$ & & & $\mid \begin{array}{l}1.6-1.8 \\
0.600\end{array}$ & & & \multirow{2}{*}{$\begin{array}{l}\text { Limite } S \text { com BI. } \\
\text { Registro: ramo A } \\
\text { Limite } E \text { com BI. } \\
\text { Mongaguar: } \\
\text { framo B }\end{array}$} \\
\hline & Gr. Juquiá/7 Bartas & $\begin{array}{l}\text { bio-monzogranllos } \\
\text { deformados } \\
\text { ac: gra tur zr monaz al }\end{array}$ & & $\begin{array}{l}\text { s. calcio-alcalina } \\
\text { alto K } \\
\text { peraluminosos }\end{array}$ & $\begin{array}{l}\text { Deformaçăo plana } \\
\text { Sm -E-Wisub.vert. } \\
\text { Lm: SW-Wfinterm-sub hor. }\end{array}$ & 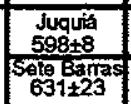 & & $\begin{array}{l}\text { Juguia } \\
1.9 \\
\text { Setiogaras }\end{array}$ & $\begin{array}{l}\text { Jugutín } \\
\text {-14.71 } \\
\text { Sete Barras }\end{array}$ & \begin{tabular}{|l} 
Juqueta \\
0.727 \\
seta Barras
\end{tabular} & \\
\hline \multirow{5}{*}{$\begin{array}{l}\frac{\pi}{2} \\
0 \\
0 \\
0 \\
0 \\
0 \\
0\end{array}$} & \multirow[t]{2}{*}{ Gn.-Migmatiticas } & $\begin{array}{l}\text { leucossoma: anf-blo } \\
\text { sienogra monzogr. } \\
\text { ac.: tital tur musec }\end{array}$ & \multirow{2}{*}{ Alto } & $\begin{array}{l}\text { s. alcalina } \\
\text { atto } K \\
\text { metauninosos }\end{array}$ & \multirow{2}{*}{$\begin{array}{l}\text { S. (bandarnento gnáissico) } \\
\text { N3OE/20 SE } \\
\text { Sm =NSOW/20SW (máx.) } \\
\text { Lm: W/ sub horizontal }\end{array}$} & $612 \pm 3$ & & 1.7 & -7.15 & 0.708 & \multirow{5}{*}{$\begin{array}{l}\text { Ulmitie NW com } \\
\text { BI.Embu: ramo C }\end{array}$} \\
\hline & & $\begin{array}{l}\text { mesossoms } \\
\text { gn. anfibollticos } \\
\text { ac.: tit }\end{array}$ & & $\begin{array}{l}\text { 5. ćakcio-alcalina } \\
\text { sólica / potássica } \\
\text { metaluminosos }\end{array}$ & & & & 1.8 & -7.91 & 0.708 & \\
\hline & Gr. Tipo Itariri & $\begin{array}{l}\text { bio-tonal.a monzogr. } \\
\text { máf. biotita mazrom } \\
\text { ac: musc at gra }\end{array}$ & & $\begin{array}{l}\text { s. cálcio-alcalina } \\
\text { médio a alto } \mathrm{K} \\
\text { peraluminosos }\end{array}$ & 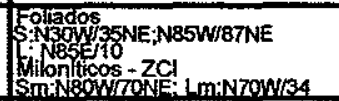 & \begin{tabular}{|l|}
$578 \pm 12$ \\
$647 \pm 8$ \\
$2137 \pm 100$ \\
$1972+2000$
\end{tabular} & $485 \pm 11$ & 2.2 & $-11 a-15$ & $\begin{array}{l}0.710 a \\
0.724 \\
\end{array}$ & \\
\hline & Gr. Tipo Areado & $\begin{array}{l}\text { bio-tonat.a morzogr. } \\
\text { máf. biotita verde } \\
\text { ac: fit al }\end{array}$ & & \multirow{2}{*}{$\begin{array}{l}\text { 8. cálcio-alcalina } \\
\text { alto K } \\
\text { peraluminosos }\end{array}$} & 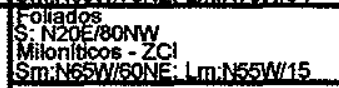 & & & 1.7 & -9.7 & 0.744 & \\
\hline & Gr.Ribeirāo do Óleo & $\begin{array}{l}\text { blo-monzogranitos } \\
\text { ac: tit musc }\end{array}$ & & & $\begin{array}{l}\text { Foliados } \\
\text { S: E-WW6ON }\end{array}$ & $\begin{array}{l}579 \pm 110 \mathrm{i} \\
2350 \pm 370 \mathrm{~s}\end{array}$ & & 4.7 & -10.7 & 0.708 & \\
\hline \multirow{7}{*}{ 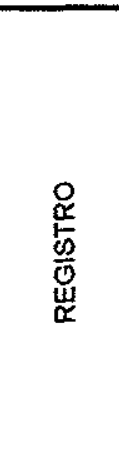 } & \multirow{4}{*}{$\begin{array}{l}\text { Rs. Gr. Gnáissico- } \\
\text { Migmatíticas }\end{array}$} & \multirow{2}{*}{$\begin{array}{l}\text { mat, félsico: anf-bio } \\
\text { granod. a bjo monzogr. } \\
\text { ac.: al zr ep gra <avep ; }\end{array}$} & \multirow{4}{*}{ Alto } & \multirow{2}{*}{$\begin{array}{l}\text { s. cátcio-alcalina } \\
\text { médio K } \\
\text { metaluminosos }\end{array}$} & \multirow{2}{*}{ 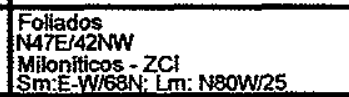 } & \multirow{4}{*}{\begin{tabular}{|l|}
$1894 \pm 26$ \\
$2151 \pm 621$ \\
$506 \pm 60 \mathrm{~s}$ \\
\end{tabular}} & & 2.9 & -22 & 0,722 & \multirow{4}{*}{$\begin{array}{l}\text { Limite NW com } \\
\text { Bi.Embu: ramo A }\end{array}$} \\
\hline & & & & & & & & 2.7 & -20 & 0.717 & \\
\hline & & \multirow{2}{*}{$\begin{array}{l}\text { mat. máfico } \\
\text { hbl-bio gnaisses } \\
\text { ac.: tha ap opac }\end{array}$} & & \multirow{2}{*}{\begin{tabular}{|l|} 
S. alcalina \\
alto K \\
metaluminosos
\end{tabular}} & \multirow{2}{*}{$\begin{array}{l}\text { Foliados/Deformados } \\
\text { S: N50E/subvertical }\end{array}$} & & & 2.8 & -0.04 & 0.712 & \\
\hline & & & & & & & & & -12.5 & 0.716 & \\
\hline & $\begin{array}{l}\text { Rs. Gr. Gnáissicas } \\
\text { (local. migmatíticas) }\end{array}$ & $\begin{array}{l}\text { anf-bio granod.a bio mond } \\
\text { máf. biotita verde } \\
\text { ac: at zr ep <alep> }\end{array}$ & Alto & $\begin{array}{l}\text { s. cálcio-alcalina } \\
\text { alto } K \\
\text { peralum. a metal. }\end{array}$ & $\begin{array}{l}\text { S: N47W/42NE } \\
\text { ST:N5OW/4ONE; Lm: N7OE/36 }\end{array}$ & $\begin{array}{l}2197 \pm 41 \mathrm{i} \\
580 \pm 24 \mathrm{~s}\end{array}$ & $504 \pm 9$ & 2.4 & -21.6 & 0.724 & \multirow{3}{*}{$\begin{array}{l}\text { Limite N/NE com } \\
\text { BI. Mongagua: } \\
\text { ramo B } \\
\\
\text { Limite S com Bt. } \\
\text { guape: ZCS }\end{array}$} \\
\hline & Gr. Votupoca & $\begin{array}{l}\text { bio monzogranitos } \\
\text { ac: al zr ep tit }\end{array}$ & & $\begin{array}{l}\text { 8. calcio-aicalina } \\
\text { alto } K \\
\text { peraluminosos }\end{array}$ & Foliaçăo incipiente & $582 \pm 8$ & & 2.45 & -20.8 & 0.717 & \\
\hline & $\begin{array}{l}\text { Paragnaisse Juréia } \\
\text { Seq. Cachoeira }\end{array}$ & $\begin{array}{l}\text { bio gnaisse } \\
\text { miner: bio qzo musc olig, } \\
\text { ac: gra monaz zr micr tur }\end{array}$ & Médio & $\begin{array}{l}\text { s. cálcio-alcalina } \\
\text { médio K } \\
\text { peraluminosos }\end{array}$ & $\begin{array}{l}\text { STM: NSAWW3ONE } \\
\text { B: NSOW/7 }\end{array}$ & \begin{tabular}{|c|} 
monazitas \\
$741 \pm 7$ \\
$752 \pm 4$
\end{tabular} & $482 \pm 12$ & 2.3 & $\begin{array}{l}T=750 \\
-13.9\end{array}$ & $\begin{array}{l}\mathrm{T}=750 \\
0.730\end{array}$ & \\
\hline \multirow{7}{*}{ 嵌 } & Metassed. Iguape & $\begin{array}{l}\text { metassititios } \\
\text { metaritmitos }\end{array}$ & Baixo & & S: E-WTras (máx) & & $575 \pm 16$ & $\begin{array}{l}1.8-2.2 \\
\text { Wobor (99) }\end{array}$ & & & \multirow{7}{*}{$\begin{array}{l}\text { Umite N com B1. } \\
\text { Registro: ZCS } \\
\\
\text { Limite SE: } \\
\text { Oceano Attántico }\end{array}$} \\
\hline & Gr. Cordeiro & $\begin{array}{l}\text { bio monzograntitos } \\
\text { ac: al musc gra tur }\end{array}$ & & & Isótropo & $581 \pm 4$ & $505 \pm 16$ & & & & \\
\hline & Gr. Sa. Paratiú & $\begin{array}{l}\text { bio monzogranitos } \\
\text { ac: al ap zT }\end{array}$ & & $\begin{array}{l}\text { s. castcio-atcalina } \\
\text { atto K } \\
\text { metal }\end{array}$ & Isótropo & & & 2.3 & -16 & 0.699 & \\
\hline & Gr. Morro Espia & $\begin{array}{l}\text { bio monzogranitos } \\
\text { ac: zr ap musc gra }\end{array}$ & & $\begin{array}{l}\text { 8. Ćkicio-alcatina } \\
\text { atto } \mathrm{K} \\
\text { Deframinosos }\end{array}$ & $\begin{array}{l}\text { Protomilonliticos } \\
\text { Sm: N32E/20NW; Lm: N18E/6 }\end{array}$ & $599 \pm 16$ & & 1.8 & -12 & $0.710 / 713$ & \\
\hline & Gr. NE Iguape & $\begin{array}{l}\text { bio monzogranitos } \\
\text { ac: zr ap musc gra }\end{array}$ & & $\begin{array}{l}\text { s. calcio-acalna } \\
\text { atto K } \\
\text { peraluminosos }\end{array}$ & $\begin{array}{l}\text { Protomilonfticos } \\
\text { Sm:N55E/47SE; Lm:SGOW/26 }\end{array}$ & & & $2.1-2.2$ & -13 & 0.714 & \\
\hline & Gr. ZCS & $\begin{array}{l}\text { bio sienogranifos } \\
\text { ac: zr gra musc monaz }\end{array}$ & & $\begin{array}{l}\text { 8. calcio-akcalina } \\
\text { alto } K \\
\text { peraluminosos }\end{array}$ & $\begin{array}{l}\text { Protomilonlticos } \\
\text { Sm: N85W/64SW; Lm: S55W/22 }\end{array}$ & $\begin{array}{l}616 \pm 20 \mathrm{z} \\
511 \pm 6 \mathrm{mz}\end{array}$ & & 2.5 & -24 & 0.733 & \\
\hline & Gr. Sa. Itapitangui & $\begin{array}{l}\text { anf. bio sienogranitos } \\
\text { ac: zr musc }\end{array}$ & & $\begin{array}{l}\text { 8. chlcio-akalina } \\
\text { alto } K \\
\text { tend. peraicalina }\end{array}$ & $\begin{array}{l}\text { Levemente Deformado } \\
\text { S: NGSE/BSNW; L: N5SE/34 }\end{array}$ & $\begin{array}{l}567 \pm 76 \\
\text { Weber, } 1998\end{array}$ & & 2.3 & -16 & 0.633 & \\
\hline
\end{tabular}


Tabela 11.2 - Características estruturais do SCCl e ZCS.

\begin{tabular}{|c|c|c|c|c|c|c|c|c|c|c|}
\hline \multicolumn{11}{|c|}{ RAMOS A B C: SISTEMA DE CISALHAMENTO CUBATÃO E ITARIRI } \\
\hline \multirow{2}{*}{$\begin{array}{l}\text { FASES } \\
\text { DE DEF. }\end{array}$} & \multirow{2}{*}{ LIMITES / ZC } & \multirow{2}{*}{$\begin{array}{l}\text { CARACTERISSTICAS } \\
\text { PETROGRÁFICAS }\end{array}$} & \multirow{2}{*}{ REGIME } & \multirow{2}{*}{ METAMORFISMO } & \multicolumn{5}{|c|}{ ANÁLISE DA DEFORMAÇÃO } & \multirow{2}{*}{$\begin{array}{l}\text { IDADES K-AT } \\
\text { (BIOTITA) }\end{array}$} \\
\hline & & & & & ESTRUTURAS & ESFORÇOS & CINEMATICA & ELIPSÓIDE & DEFORMACAAO ASSOCLADA & \\
\hline 1 & $\begin{array}{l}\text { Bl. Embu/Bl.Registro } \\
\text { Ramo A-B }\end{array}$ & $\begin{array}{l}\text { Ribbons de qzo tipo } 2 \mathrm{~A}, 3 \\
\text { Recristalizaçăo microclínio } \\
\text { Recrsitalização oligoclásio }\end{array}$ & Dúctil & $\begin{array}{l}\text { Xisto verde alto I } \\
\text { Anfibolito }\end{array}$ & $\begin{array}{l}\text { E-WRON N } \\
\text { Lm: NW }\end{array}$ & $\boldsymbol{\sigma}_{1} \sim \mathrm{N} 10 \mathrm{E}$ & Sinistral & $\begin{array}{l}\text { Prolatos a } \\
\text { Oblatos }\end{array}$ & $\begin{array}{l}\text { Transtensao(abatp/ NW) } \\
\text { franspressao(cavalg.p/ SW) }\end{array}$ & Ramo A: $493 \pm 14 \mathrm{Ma}$ \\
\hline \multirow[t]{2}{*}{$\|$} & $\begin{array}{l}\text { Bl. Mongaguál Embu- } \\
\text { Registro Ramo C } \\
\text { B1. Mongaguál Embu- } \\
\text { Registro parte ramo A }\end{array}$ & \multirow{2}{*}{$\begin{array}{l}\text { Ribbons de qzo tipo } 2 \mathrm{~A} \\
\text { Textura mortar em microclinio } \\
\text { pouco desenvolvida }\end{array}$} & \multirow[t]{2}{*}{ Dúctil } & \multirow[t]{2}{*}{ Xisto verde médio } & $\begin{array}{l}\text { N70E/sub.vert. } \\
\text { Lm: NE }\end{array}$ & $\sigma_{1} \sim E-W$ & Dextral & \multirow[t]{2}{*}{ Oblatos } & \multirow[t]{2}{*}{$\begin{array}{l}\text { Transpressăo } \\
\text { (cavalgamento p/ SW): } \\
\text { predominio de } \\
\text { achatamento uniaxial }\end{array}$} & \multirow{2}{*}{$\begin{array}{l}\text { Limite Ramos A-B-C: } \\
413 \pm 9 \mathrm{Ma} \\
\begin{array}{r}\text { Ramo B: } 497 \pm 9 \mathrm{Ma} \\
368 \pm 7 \mathrm{Ma}\end{array}\end{array}$} \\
\hline & $\begin{array}{l}\text { BI. Mongaguá/Registro } \\
\text { Ramo } \mathrm{B}\end{array}$ & & & & $\begin{array}{l}\text { N86E/60 NW } \\
\text { Lm: NE }\end{array}$ & $\boldsymbol{\sigma}_{1} \sim \mathrm{E}-\mathrm{W}$ & Sinistral & & & \\
\hline 111 & $\begin{array}{l}\text { Falhamentos que } \\
\text { cortam a } \mathrm{ZCl} \text { e ZCC }\end{array}$ & $\begin{array}{l}\text { Forte epidotização e } \\
\text { sericitizaçało }\end{array}$ & Rúptil & Xisto verde baixo & N40E/sub. vert & & Sinistral & & Transcorrência & \\
\hline \multicolumn{11}{|c|}{ ZONA DE CISALHAMENTO SERRINHA } \\
\hline \multirow{2}{*}{ SETOR } & \multirow{2}{*}{\multicolumn{2}{|c|}{ CARACTERISTICAS PETROGRÁFICAS }} & \multirow{2}{*}{ REGIME } & \multirow{2}{*}{ METAMORFISMO } & \multicolumn{5}{|c|}{ ANÁLISE DA DEFORMAÇÄO } & \multirow{2}{*}{ IDADES K-Ar } \\
\hline & & & & & ESTRUT & URAS & CINEMÁTICA & ELIPSOIDE & DEFORMAÇAO ASSOCIADA & \\
\hline$w$ & $\begin{array}{l}\text { Gnaisses miloniticos in } \\
\text { xistos }\end{array}$ & ntercalados com muscovita & Dúctil & & $\begin{array}{l}\text { N7OE/18N } \\
\mathrm{Lm}: \text { W/sub }\end{array}$ & $\begin{array}{l}\text { W (max.) } \\
\text { hor. }\end{array}$ & Dextral & & Transcorrência & $\begin{array}{c}575 \pm 16 \mathrm{Ma} \\
\text { (muscovita: } 60-100 \text { ) }\end{array}$ \\
\hline CENTRAL & \multicolumn{2}{|c|}{$\begin{array}{l}\text { Gra - bio - xistos miloniticos intercalados com } \\
\text { biotita-sienogranitos miloniticos: } \\
\text { recristalizaçăo de microclinio bem desenvolvida }\end{array}$} & Dúctil & Xisto verde alto & \multicolumn{2}{|c|}{$\begin{array}{l}\text { E-W/66N (máx.) } \\
\text { Lm: SW/sub-hor. }\end{array}$} & $\begin{array}{l}\text { Cis.puro } \\
\text { Dextral }\end{array}$ & Oblato & $\begin{array}{c}\text { Transpressão } \\
\text { Achatamento uniaxial }\end{array}$ & $\begin{array}{l}493 \pm 9 \mathrm{Ma} \\
\text { (biotita) }\end{array}$ \\
\hline E & \multicolumn{2}{|c|}{$\begin{array}{l}\text { Paragnaisses miloníticos: } \\
\text { ribbons de quartzo; porfiroclastos de oligoclásio com } \\
\text { recristalizaçåo por rotação, porfiroclastos de granada } \\
\text { com sombras de pressão (bio, musc e qzo) }\end{array}$} & Dúctil & Xisto verde alto & \multicolumn{2}{|c|}{$\begin{array}{l}\text { N54W/30NE } \\
\text { Lm: S40E/40 }\end{array}$} & Dextral & Oblato & Transcorrência & $\begin{array}{l}482 \pm 12 \mathrm{Ma} \\
\quad \text { (biotita) }\end{array}$ \\
\hline RAMO SE & \multicolumn{2}{|c|}{$\begin{array}{l}\text { Rocha granitca a megacristais milonltica intercalada } \\
\text { com gra - bio - xistos miloníticos: } \\
\text { Forte segregaçăo de quartzo: formaçăo de ribbons } \\
\text { e sigmóides }\end{array}$} & Dúctil & Xisto verde alto & \multicolumn{2}{|c|}{$\begin{array}{l}\text { Sc: N35W/4ONE; Lm: S4OE/40 } \\
\text { Ss: N25E/45SE; Lm: S45E/34 }\end{array}$} & Sinistral & & $\begin{array}{c}\text { Transpressão } \\
\text { Cavalgamento para NW }\end{array}$ & \\
\hline
\end{tabular}

N 


\section{REFERÊNCIAS BIBLIOGRÁFICAS}

ALMEIDA, F.F.M.; AMARAL, G.; CORDANI, U.G.; KAWASHITA, K. (1973). The Precambrian Evolution of the South American Cratonic Margin south of Amazon River. In: NAIRN, E.M. \& STEHLI, F.G., 1973. The Ocean Basins and Margins. New York, Plenun. Vol. 1, Cap. 11: $411-446$.

AZEVEDO SOBRINHO, J. M. (1995). Petrologia dos Chamockitos da Região de Itariri (SP). São Paulo, 112 p. (Dissertação de Mestrado apresentada ao Instituto de Geociências da Universidade de São Paulo).

BARBARIN, B. (1999). A review of the relationships between granitoid types, their origins and their geodynamic environments. Lithos, 46: 605-626.

BASEI, M.A.S.; SIGA Jr., O.; REIS NETO, J.M. (1990). O Batólito Paranaguá. Proposição, idade, considerações petrogenéticas e implicações tectônicas. In: CONGRESSO BRASILEIRO DE GEOLOGIA, 36, Natal. Anais...Natal, SBG, v.4, p.1684-1699.

BASEI, M.A.S.; SIGA Jr., O.; MACHIAVELLI, A.; MANCINI, F. (1992). Evolução tectônica dos terrenos entre os Cinturões Ribeira e Dom Feliciano (PR - SC). Revista Brasileira de Geociências, 22(2):216-221.

BASEI, M.A.S.; SIGA Jr., O.; REIS NETO, J.M.; PASSARELLI, C.R.; PRAZERES, H. J.; KAULFUSS, G.; SATO, K.; LIMA, P. S. de (1999). Paleoproterozoic granulitic belts of the Brazilian Southern Region (PR-SC). In: SOUTH-AMERICAN SYMPOSIUM ON ISOTOPE GEOLOGY, II. Extended Abstracts, p.291-294.

BASEI, M.A.S.; SIGA Jr., O.; MASQUELIN, H.; HARARA, O. M.; REIS NETO, J.M.;PRECIOZZI, P. (2000). The Dom Feliciano Belt of Brazil and Uruguai and its forelan domain, the Rio de La Plata Craton: framework, tectonic evolution and correlation with similar provinces of southwestern Africa. In: CORDANI, U.G.; MILANI, E.J.; THOMAS FILHO, A.; CAMPOS, D.A.. Tectonic Evolution of South America, Rio de Janeiro, 2000, p: 311-334.

BATTOLA, Jr., F.; SILVA, A.T.S.F.; FRANCISCONI, O.; GODOY, A.M. (1981). Projeto Integração e Detalhe Geológico no Vale do Ribeira, Rel. Final, vol. 2 e 3, são Paulo, 15 v. BOULLIER, A.M. e BOUCHEZ, J.L. (1978). Le quartz en rubans dans les mylonites. Bull. Soc. Geol. France , (7), t. XX, n.3, p.253-262.

BRITO NEVES, B.B.; CAMPO NETO, M. C.; FUCK, R.A. (1999). From Rodinia to Western Gondwana: An approach to the Brasiliano-Pan African Cycle and orogenic collage. Episodes, 22: 155-166.

CAMPANHA, G.A.C. (1991). Tectónica Proterozóica no alto e médio Vale do Ribeira, Estados de São Paulo e Paraná. São Paulo, 296p. (Tese de Doutorado - IGc - USP). 
CAMPANHA, G.A.C.; BISTRICHI, C.A.; ALMEIDA, M.A. (1987). Consideraçōes sobre a organização litoestratigráfica da Faixa de Dobramentos Apiaí. In: SIMPÓSIO SULBRASILEIRO DE GEOLOGIA, 3, Curitiba. Atas...Curitiba, SBG, v.2, p.725-742.

CAMPOS NETO, M. C. (2000). Orogenic Systems from Southwestern Gondwana: na approach to Brasiliano-Pan African cycle and orogenic collage in southeastern Brazil. In: CORDANI, U.G.; MILANI, E.J.; THOMAS FILHO, A.; CAMPOS, D.A.. Tectonic Evolution of South America, Rio de Janeiro, 2000, p: 335-365.

CAMPOS NETO, M.C.; FIGUEIREDO, M.C.H. (1995). The Rio Doce Orogeny, southeastern Brazil. Joumal of South American Earth Sciences, 8(2): 143-162.

CARNEIRO, C.D.R.; COIMBRA, A.M.; THOMAZ FILHO, A. (1974). Esboço da diferenciação tectônica do Pré-Cambriano Superior no sul-sudeste do Brasil. In: CONGRESSO BRASILEIRO DE GEOLOGIA, 28, Porto Alegre. Boletim $n^{\circ} 1$, Resumos das Comunicações. Porto Alegre, SBG, p.698-700.

CHAPPELL, B.W.; WHITE, A. J.R. (1992). I and S Type granites in the Lachlan Fold Belt. Transactions of the Royal society of Edinburg: Earth Sciences, 83: 1-26.

CORDANI, U.G. (1974). Comentários sobre as determinaçőes geocronológicas disponiveis nas Folhas Assunción e Curitiba. In: MONACO, O.A.; ZIR FILHO, J.A.; VALENTINE, N. (Eds.). Carta Geologica do Brasil ao Milionésimo, Folha Assuncion- SG.21 e Curitiba - SG.22. Brasillia, DNPM, p.58-67.

CORDANI, U.G.; COUTINHO, J.M.V.; NUTMAN A. (2000). Geochronological constraints for the age of the Embu Complex, São Paulo, Brazil. In: CONGRESSO BRASILEIRO DE GEOLOGIA, 39, Rio de Janeiro.

COUTINHO, J.M.V. (1971). O Falhamento do Cubatăo. In: CONGRESSO BRASILEIRO DE GEOLOGIA, 25, São Paulo. Resumos das Comunicações, Boletim Especial, $n^{\circ}$ 1. São Paulo, SBG, p.130-131.

CRESPI, J. M. (1986). Some guidelines for the practical application of Fry's method of strain analysis. Journal of Structural Geology, 8 (7): 799-808.

DANTAS, A.S.L.; GIMENEZ FILHO, A.; TEIXEIRA, A.L.; NAGATA, N.; FERNANDES, L.A.; ALBUQUERQUE FILHO, J.L.; FRASCÁ, M.H.B.O. (1987a). Geologia das folhas Juquiá (SC.23-V-A-1-4) e Miracatu (SG23-V-A-II-3), Estado de Såo Paulo. IPT. Săo Paulo. Relatório Inédito. 
DANTAS, A.S.L.; GIMENEZ FILHO, A.; TEIXEIRA, A.L.; NAGATA, N.; FERNANDES, L.A.; ALBUQUERQUE FILHO, J.L.; FRASCÁ, M.H.B.O. (1987b). Evolução geológica e estrutural da faixa costeira nas regiões de Juquiá e Miracatu, Sul do Estado de São Paulo. In: SIMPÓSIO REGIONAL DE GEOLOGIA, 6. V. Rio Claro, 1987. Anais...Rio Claro, SBG v1, p. 173-189.

DUNNE, W.M.; ONASCH, C.M.; WILLIAMS, R.T. (1990). The problem of strain-marker centers and the Fry method. Journal of Structural Geology, 12 (7): 933-938.

FASSBINDER, E. (1990). Análise estrutural da Falha da Lancinha, Estado do Paraná. São Paulo, 165p. (Dissertação de Mestrado - IGC - USP).

FERNANDES, A, J. (1991). O Complexo Embu no leste do estado de São Paulo: contribuição ao conhecimento da litoestratigrafia e da evolução estrutural e metamórfica. São Paulo, 120 p. (Dissertação de Mestrado - IGc - USP).

FIORI, A. P. (1985). A Falha da Lancinha no Pré-Cambriano Paranaense: Reflexo de uma Falha Profunda? Boletim Paranaense de Geociências, 36: 03-14.

FIORI, A. P. (1985). As Falhas Lancinha e de Morro Agudo e estruturas secundárias associadas. In: SIMPÓSIO SUL-BRASILEIRO DE GEOLOGIA, 2, Florianópolis. Anais. Florianópolis, SBG, p.159-171.

FLINN, D. (1962). On folding during three dimension progressive deformation. Q. Journ. Geol. Soc. London, 118: 385-428.

FRY, N. (1979). Random point distributions and strain measurement in rocks. Tectonophysics, 60: 89-105.

FRY, N. (1999). Fry Plots: warning about summed moments. Journal of Structural Geology, 21: 129-134.

GIMENEZ FILHO, A.; ALBUQUERQUE FILHO, J.L.; DANTAS, A.S.L. FERNANDES, L.A.; NAGATA, N.; TEIXEIRA, A. L. (1987). Geologia da Folha Miracatu, sul-sudeste do estado de São Paulo. In: SIMPÓSIO REGIONAL DE GEOLOGIA, 6. V. Rio Claro,1987. Anais...Rio Claro, SBG v1, p. 225-241.

HACKSPACHER, P.C.; DANTAS, E.L.; SPOLADORE, A.; FETTER, A.H; OLIVEIRA, M.A.F. de. (2000). Evidence of Neoproterozoic Backarc Basin development in the Central Ribeira Belt, Southeastern Brazil: new geochronological and geochemical constraints from the São Roque - Açungui Groups. Revista Brasileira de Geociencias, 30(1): 110-114.

HANMER, S. \& PASSCHIER, C.W. (1991). Shear-sense indicators: a review. Geol. Survey of Canada - Paper 90-17, 72pp. 
HASUI, Y.; CARNEIRO, C.D.R.; COIMBRA, A.M. (1975). The Ribeira Folded Belt. Revista Brasileira de Geociências, 5(4):257-266.

HASUI, Y.; SADOWSKI, G.R. (1976) Evolução Geológica do Pré-Cambriano na região sudeste do estado de São Paulo. Revista Brasileira de Geociências, 6(3):182-200.

HASUI, Y.; CARNEIRO, C.D.R.; BISTRICH, C.A. (1978). Os granitos e granitóides da região de dobramentos sudeste nos estados de São Paulo e Paraná. In: CONGRESSO BRASILEIRO DE GEOLOGIA, 30, Recife. Anais. Recife, SBG, v.6, p.2594-2608.

HASUI, Y.; DANTAS, A.S.L.; CARNEIRO, C.D.R.; BISTRICH, C.A. (1981). O embasamento Pré-Cambriano e Eo-Paleozóico em Săo Paulo. In: INSTITUTO DE PESQUISAS TECNOLÓGICAS DE SÃo PAULO. Mapa Geológico do Estado de São Paulo, Escala 1.500.000. São Paulo. v.1, p.12-45 (IPT- Monografia, 6. Publicação, 1184).

HASUI, Y.; OLIVEIRA, M.A.F. (1984). A Província Mantiqueira, Setor Central. In: ALMEIDA, F.F.M. \& HASUI, Y. (Eds.). O Pré-Cambriano do Brasil. São Paulo, Editora Blücher, 378 p. HIBBARD, M.J. (1995). Petrography to Petrogenesis. Dep. of Geol. Sciences, Univ. of Nevada. Prentice Hall, Englewood Cliffs, New Jersey, 587p.

IRVINE, T.N. \& BARAGAR, W.R.A. (1971). A guide to the chemical classification of the common volcanic rocks. Canadian Joumal of Earth Sciences, 8: 523-548.

JANASI, V.A. (1999). Petrogênese de granitos crustais na Nappe de Empurrão SocorroGuaxupé (SP-MG): uma contribuiçăo da geoquímica elemental e isotópica. $304 \mathrm{p}$. Tese de Livre Docência, IGc - USP, São Paulo.

JANASI, V.A.; ULBRICH. H.H.G.J. (1992). Inventário bibliográfico de Granitos do Estado de Săo Paulo. Boletim IG-USP. Publicação Especial, $n^{\circ} 11.253 p$.

JOHANNES, W.; HOLTZ, F.; MÖLLER, P. (1995). REE distribuition in some layered migmatites: constraints on their petrogenesis. Lithos, 35: 139-152.

KAUL, P.F.T.; CORDANI, U.G. (1994). Aspectos petrográficos, geoquímicos e geocronológicos dos maciços graníticos da Serra do Mar no leste do Paraná e vizinhanças. In: CONGRESSO BRASILEIRO DE GEOLOGIA, 38, Camboriú. Boletim de Resumos Expandidos. Camboriú, SBG, v.2, p.371-372.

KAUL, P.F.T.; TEIXEIRA, W. (1982). Archean and early Proterozoic complexes of Santa Catarina, Paraná and São Paulo states, south-southeastern Brazil: an outline of their geological evolution. Revista Brasileira de Geociencias, 12 (1-3): 172-182.

LE MAITRE, R. W. 1989. A classification of igneous rocks and glossary of terms. Oxford, Blackwell, 193p. 
LOPES, O.F. (1987). Zoneamento metamórfico da Formação Rio das Cobras do pré-cambriano do estado do Paraná. In: SIMPÓSIO SUL-BRASILEIRO DE GEOLOGIA, 3, Curitiba, Atas... Curitiba, SBG, v.1, p.303-312.

MACHADO, N.; VALLADARES, C.; HEIBRON, M.; VALERIANO, C. 1996. U-Pb geochronology of central Ribeira belt (Brazil) and implication for the evolution of the Brazilian Orogeny. Precambrian Research, 79, 347-361.

MACHADO, R.; ENDO, I. (1993). Estruturas transcorrentes na borda sul do Cráton do São Francisco. In: Simpósio sobre o Cráton de São Francisco, II, Salvador, Anais, Salvador, Bahia, SBG, 269-271.

MANIAR, P.D. \& PICCOLI, P.M. (1989). Tectonic discrimination of granitoids. Geol. Soc. Am. Bull., 101:635-643.

MARSHALL, L.A.; SPARKS, R.S.J. (1984). Origin of some mixed magma and net-veined ring intrusions. Journal of the Geological Society of London 141: 171-182.

MELCHER, G.C.; GOMES, C.B.; CORDANI, U.G.; BITTENCOURT, J.S.; DAMASCENO, E.C.; GIRARDI, V.A.V.; MELFI, A.J. (1973). Geologia e petrografia das rochas metamórficas e graníticas associadas ao Vale do Rio Ribeira do Iguape, SP e PR. Rev. Bras. Geoc., 3(2): 97-123.

MIDDLEMOST, E. A. K. (1975). The basalt clan. Earth Sci. Rev., 11:337-364.

MORGENTAL, A.; BATOLA JR. F.; PINTO, G.G.; PAIVA, I. P.; DRUMOND, J. B. V. (1975). Projeto SUDELPA-CPRM, Relatório Final. Geologia, vol.1. São Paulo, 18v, 707p.

NAKAMURA, N. (1974). Determination of REE, Ba, Fe, Mg, $\mathrm{Na}$ and $\mathrm{K}$ in carbonaceous and ordinary chondrites. Geochim. Cosmochim. Acta, 38: 757-775.

NEVES, S.P.; VAUCHEZ, A. (1995). Successive mixing and mingling of magmas in a plutonic complex of Northeast Brazil. Lithos 34: 275-299.

OLIVEIRA, M.C.B. (1989). Petrologia do Maciço Granítico Mandira-SP. 178p. (Dissertação de Mestrado apresentada ao Instituto de Geociências da Universidade de São Paulo).

PARADA, M. A.; NYSTRÖM, J.O.; LEVI, B. (1999). Multiple sources for the Coastal Batholith of central Chile (31-340S): geochemical and $\mathrm{Sr}-\mathrm{Nd}$ isotopic evidence ans tectonic implications. Lithos 46: 505-521.

PASSARELLLI, C. R. ; BASEI, M. A. S.; CAMPOS NETO, M.C.; SIGA Jr. (2000). Geology and U$\mathrm{Pb}$ geochronology of precambrian terranes of southeastern São Paulo State, Brazil. In: CONGRESSO BRASILEIRO DE GEOLOGIA, 39, Rio de Janeiro.

PEARCE, J.A.; HARRIS, N.B.W. \& TINDLE, A.G. (1984). Trace element discrimination diagrams for the tectonic interpretation of granitic rocks. Journ. Petrol., 25 (4): 956-983. 
PICANÇO, J. de L. (1994) Aplicaçăo das sistemáticas Sm/Nd e Rb/Sr no Maciço de Itatins (SP). São Paulo, 140p. (Dissertação de Mestrado - IGC - USP).

PICANÇO J. TASSSINARI, C.C.G., CORDANI, U.G.; NUTMAN, A. P. (1998) - Idades U-Pb (SHRIMP), Sm-Nd e Rb-Sr em rochas do Maciço de ltatins (SP): Evidências de Evolução Policíclica. In: ACAD.BRAS.CIENC, 70 (1) 139-150.

PIMENTEL, M.M. 1992. Reajuste do sistema isotópico Sm-Nd durante o Neoproterozóico em gnaisses do Oeste de Goiás, Rev. Bras. de Geoc., 22(3): 262-268.

PITCHER, W.S. (1991). Synplutonic dykes and mafic enclaves. In: DIDIER, J. \& BARBARIN, B. Enclaves and Granite Petrology. Developments in Petrology, Elsevier, Amsterdam, $n^{\circ} 13$ : 283-391.

PRAZERES FILHO, H. J. (2000). Litogeoquímica, Geocronologia (U-Pb) e Geologia isotópica dos Complexos Granfíticos Cunhaporanga e Trés Córregos, Estado do Paraná. São Paulo, 180 p. (Dissertação de Mestrado - -IGc - USP).

RAMSAY, J. G.; HUBER, M.I. (1987). The techniques of modern structural geology. London, Academic Press. v.2, 700 pp.

SADOWSKI, G.R. (1974a). Tectónica da Serra de Cubatão, SP. São Paulo, 158p. (Tese de Doutorado - IGc - USP).

SADOWSKI, G.R. (1974b). Tectônica do Complexo Migmatítico da Serra do Cubatão. In: CONGRESSO BRASILEIRO DE GEOLOGIA, 28, Porto Alegre, 1974. Boletim $n^{\circ} 1$, Resumo das Comunicações. Porto Alegre, SBG, p.557-561.

SADOWSKI, G.R. (1976). Ativação de Plataforma na América do Sul e as zonas de fratura do Atlântico Sul. In: CONGRESSO BRASILEIRO DE GEOLOGIA, 29, Ouro Preto, 1976. Anais...Ouro Preto, SBG, v.4, p.13-26.

SADOWSKI, G.R. (1984). Estado da Arte do Tema: Geologia Estrutural de grandes falhamentos. In: CONGRESSO BRASILEIRO DE GEOLOGIA, 33, Rio de Janeiro. Anais...Rio de Janeiro, SBG, v.4, p.1767-1793.

SADOWSKI, G.R. (1991). A Megafalha de Cubatão no sudeste brasileiro. Boletim - IG-USP, Série Cientifica, 22: 15-28.

SADOWSKI, G.R; DIAS NETO, C.M.; SILVA, M.E. (1978). Análise do Fraturamento do Maciço de Itatins, Estado de São Paulo. In: CONGRESSO BRASILEIRO DE GEOLOGIA, 30 , Recife. Resumo das Comunicaçסes...Recife, SBG, Bol. 1, p.60.

SADOWSKI, G.R.; MOTIDOME, M. J. (1987). Brazilian Megafaults. Revista Geologica do Chile, 31: $61-75$. 
SATO, (1998). Evolução crustal da Plataforma sul Americana, com base na Geoquimica Isotópica Sm-Nd. 299p.Tese de Doutoramento. São Paulo - IG-USP,

SATO, K.; TASSINARI, C.C.G.; KAWASHITA, K.; PETRONILHO, L. (1995). O método geocronológico Sm-Nd no IG/USP e suas aplicaçōes. Acad. Bras. Cienc. 67 (3):315-336.

SIGA Jr. O. (1995). Dominios tectónicos do sudeste do Paraná e nordeste de Santa Catarina. Geocronologia e evoluçăo crustal. São Paulo, 212 p. (Tese de Doutorado apresentada no Instituto de Geociências da Universidade de São Paulo).

SIGA Jr., O.; BASEI, M.A.S.; REIS NETO, J.M.; BUBA, R.M. (1994). Maciços graníticos da porção sudeste do Paraná e nordeste de Santa Catarina: geocronologia e implicaçőes tectônicas. In: CONGRESSO BRASILEIRO DE GEOLOGIA, 38, Camboriú. Boletim de Resumos Expandidos. Camboriú, SBG, v.2, p.400-401.

SIGA Jr., O.; BASEI, M.A.S.; REIS NETO, J.M.; MACHIAVELLI, A.; HARARA, O.M. (1995). O Complexo Atuba: um cinturão Paleoproterozóico intensamente retrabalhado no Neoproterozóico. Boletim - IG-USP, Série Científica, 26: 69-98.

SIGA Jr, O ; BASEI, M.AS.; REIS NETO, J.M.; HARARA, O.M.M.; PASSARELLI, C.R.; PRAZERES FILHO, H.J.; WEBER, W.; MACHIAVELLI, A. (1997). Ages and tectonic setting of alkaline-peralkaline granitoids of Paraná and Santa Catarina States, southern Brazil. In: SOUTH-AMERICAN SYMPOSIUM ON ISOTOPE GEOLOGY. Campos do Jordão, 1997. Extended Abstracts. p. 301-303.

SILVA, A.T.S.F. (1981). Tentativa de interpretação da gênese e evolução da infraestrutura arqueana exposta entre Peruíbe e Curitiba, SP e PR. In: SIMPÓSIO REGIONAL DE GEOLOGIA, 3. Curitiba, 1981. Atas...Curitiba, SBG v1, p. 133-147.

SILVA, A. T. S. F.; ALGARTE, J. P. (1981). Contribuição à geologia da seqüência Turvo-Cajati entre Rio Pardo e Pariquera-Açu (SP), 1 - Litologia e petrografia. In.: SBG, Simpósio Regional de Geologia, 3, Curitiba, Atas, 109-120

SILVA, A.T.S.F.; CHIODI FILHO, C.; CHIODI, D.K.; ALGARTE, J.P. (1978). Geologia Integrada das Folhas Cananéia e lguape. In: CONGRESSO BRASILEIRO DE GEOLOGIA, 30. Recife, 1978. Anais...Recife, SBG. v1, p. 208-221.

SILVA, M.E. (1981). Análise estrutural das faixas ectiniticas associadas ao falhamento de Cubatão entre as regiōes de Juquiá e Pedro Barros - Estado de São Paulo. São Paulo, 118p. (Dissertação de Mestrado apresentada no Instituto de Geociências da Universidade de São Paulo).

SILVA, M.M.V.G.; NEIVA, A.M.R.; WHITEHOUSE, M.J. (2000). Geochemistry of enclaves and host granites from the Melas area, central Portugal. Lithos, 50: 153-170. 
SIMPSON, C. (1985) Deformation of granitic rocks across the brittle-ductile transition. Jour. Str. Geol., v.7, n.5, pp.503-511.

SMITH, J.V. (2000). Structures on interfaces of mingled magmas, Stewart Island, New Zealand. Joumal of Structural Geology 22: 123-133.

TEIXEIRA, A. L.; GIMENEZ FILHO, A.; FERNANDES, L.A.; NAGATA, N.; DANTAS, A.S.L.; ALBUQUERQUE FILHO, J.L. (1987). Geologia da Folha Juquiá, baixo vale do Ribeira, SP. In: SIMPÓSIO REGIONAL DE GEOLOGIA, 6. Rio Claro, 1987. Atas...Rio Claro, SBG V1, p. 205-223.

TROUW, R.; HEILBRON, M.; RIBEIRO, A.; PACIULLO, F.; VALERIANO, C.M.; ALMEIDA, J.C.H.; TUPINAMBÁ, M.; ANDREIS, R. (2000). The central segment of the Ribeira Belt. In: CORDANI, U.G.; MILANI, E.J.; THOMAS FILHO, A.; CAMPOS, D.A.. Tectonic Evolution of South America, Rio de Janeiro, 2000, p: 287-310.

VASCONCELOS, C. S. (2000). Tectonic evolution of the southern part of the Ribeira Belt, Southeast Brazil. In: CONGRESSO BRASILEIRO DE GEOLOGIA, 39, Rio de Janeiro. VASCONCELLOS, C. S.; DEHLER, N.; YAMATO, A A ; LOPES JR. (1999). PROJETO - CPRM JACUPIRANGA-RIO GUARAÚ. 233p. Relatório interno. Inédito.

VASCONCELOS, C. S.; DEHLER, N.M. \& BASEI, M. A S. (2000). U-Pb zircon ages from granitoid gneisses, south of São Paulo State, Brazil. In: CONGRESSO BRASILEIRO DE GEOLOGIA, 39, Rio de Janeiro.

VLACH, S. (2001). Micropobe Monazite Constraints for na early (ca. $790 \mathrm{Ma}$ ) Brasiliano Orogeny: the Embu Terrane, Southeastern Brazil. In: SOUTH-AMERICAN SYMPOSIUM ON ISOTOPE GEOLOGY. Chile, 2001. Extended Abstracts. (submetido).

VIEIRA, S.R.S.S.; TASSINARI, C.G. (1988). Estudo petrológico e geocronológico das rochas da região de Embu-Guaçu, estado de São Paulo. In: CONGRESSO BRASILEIRO DE GEOLOGIA, 35, Belém. Anais...Belém, SBG, v.3, p.1391-1399.

WEBER, W. (1998). Geologia e Geocronologia da liha do Cardoso, Sudeste do Estado de São Paulo. 86p. (Dissertação de Mestrado apresentada no Instituto de Geociências da Universidade de São Paulo).

WERNICK, E. (1983). Enclaves e seu significado geológico. Geociéncias, São Paulo, 2: 87-96. 
APÊNDICES 
APÊNDICE 1 - DADOS GEOQUÍMICOS 
BLOCO EMBU

\begin{tabular}{|l|l|c|c|c|c|c|c|c|c|c|c|c|c|c|c|c|c|c|c|c|}
\hline UNIDADE & $\mathrm{AMOSTRA}$ & $\mathrm{SiO}_{2}$ & $\mathrm{Al}_{2} \mathrm{O}_{3}$ & $\mathrm{Fe}_{2} \mathrm{O}_{3}$ & $\mathrm{MnO}$ & $\mathrm{MgO}$ & $\mathrm{CaO}$ & $\mathrm{Na}_{2} \mathrm{O}$ & $\mathrm{K}_{2} \mathrm{O}$ & $\mathrm{TiO}_{2}$ & $\mathrm{P}_{2} \mathrm{O}_{5}$ & $\mathrm{LO}$ & $\mathrm{TOTA4}$ & $\mathrm{Ba}$ & $\mathrm{Rb}$ & $\mathrm{Sr}$ & $\mathrm{Ga}$ & $\mathrm{Y}$ \\
\hline Gr. Juquía & $\mathrm{K}-20$ & 70,43 & 14,257 & 3,20 & 0,09 & 0,82 & 2,41 & 2,85 & 4,53 & 0,33 & 0,14 & 0,64 & 99,69 & 420 & 211 & 244 & 16 & 18 \\
\hline Gr. Sete Barras & $\mathrm{K}-23$ & 75,95 & 13,49 & 1,23 & 0,03 & 0,04 & 0,47 & 4,03 & 4,68 & 0,03 & 0,03 & 0,56 & 100,55 & 23 & 477 & 9 & 23 & 66 \\
\hline
\end{tabular}

\begin{tabular}{|c|c|c|c|c|c|c|c|c|c|c|c|c|c|c|c|c|c|c|}
\hline UNIDADE & AMOSTRA & $\mathrm{Nb}$ & $\mathrm{Ta}$ & $\mathrm{Zr}$ & Hff & TI & Th & $\mathrm{U}$ & $\mathrm{Pb}$ & Sc & $\mathrm{V}$ & $\mathrm{Cr}$ & Co & $\mathrm{Ni}$ & $\mathrm{Cu}$ & $\mathrm{Zn}$ & Mo & W \\
\hline Gr. Juquiá & $\mathrm{K}-20$ & 23 & 2,2 & 296 & 7,8 & 1,45 & 39,2 & 6,73 & 37 & 7 & 26 & -20 & 5 & -15 & -10 & 47 & -2 & 0,9 \\
\hline Gr. Sete Barras & $\mathrm{K}-23$ & 24 & 3,1 & 62 & 2,5 & 2,48 & 15,1 & 23,4 & 27 & 4 & -5 & -20 & -1 & -15 & -10 & 42 & -2 & 1,8 \\
\hline
\end{tabular}

\begin{tabular}{|l|l|c|c|c|c|c|c|c|c|c|c|c|c|c|c|c|c|c|}
\hline UNIDADE & AMOSTRA & Sn & Sb & Cs & La & Ce & Pr & Nd & Sm & Eu & Gd & Tb & Dy & Ho & Er & Tm & Yb & Lu \\
\hline Gr. Juquiá & K-20 & 5 & $-0,2$ & 7,4 & 63,9 & 129 & 13,9 & 44,0 & 6,89 & 1,150 & 4,41 & 0,57 & 2,78 & 0,55 & 1,62 & 0,260 & 1,60 & 0,207 \\
\hline Gr. Sete Barras & K-23 & 11 & $-0,2$ & 8,5 & 20,3 & 44 & 5,40 & 17,9 & 5,92 & 0,105 & 5,88 & 1,58 & 10,0 & 2,02 & 5,71 & 0,948 & 5,65 & 0,752 \\
\hline
\end{tabular}


BLOCO MONGAGUÁ

\begin{tabular}{|c|c|c|c|c|c|c|c|c|c|c|c|c|c|c|c|c|c|c|}
\hline UNIDADE & AMOSTRA & $\mathrm{SiO}_{2}$ & $\mathrm{Al}_{2} \mathrm{O}_{3}$ & $\mathrm{Fe}_{2} \mathrm{O}_{3}$ & MnO & $\mathrm{MgO}$ & $\mathrm{CaO}$ & $\mathrm{Na}_{2} \mathrm{O}$ & $\mathrm{K}_{2} \mathrm{O}$ & $\mathrm{TiO}_{2}$ & $\mathrm{P}_{2} \mathrm{O}_{5}$ & LOI & TOTAL & $\mathrm{Ba}$ & $\mathrm{Rb}$ & St & $\mathrm{Ga}$ & $\mathrm{Y}$ \\
\hline Gr. Mongaguá & $\mathrm{K}-03$ & 63,31 & 17,51 & 3,44 & 0,05 & 1,01 & 2,45 & 3,67 & 6,97 & 0,73 & 0,35 & 0,81 & 100,31 & 1729 & 253 & 514 & 23 & 11 \\
\hline Gr. Mongaguá & $\mathrm{K}-3 \mathrm{~A}$ & 59,83 & 18,11 & 5,23 & 0,11 & 1,84 & 3,78 & 3,86 & 6,02 & 1,04 & 0,43 & 0,43 & 100,67 & 1.580 & 216 & 463 & 22 & 42 \\
\hline Dior. Mongaguá & $\mathrm{K}-3 \mathrm{~B}$ & 44,35 & 13,45 & 13,84 & 0,33 & 9,26 & 9,91 & 2,34 & 2,71 & 2,25 & 0,86 & 1,03 & 100,32 & 494 & 180 & 244 & 22 & 42 \\
\hline Gr. Itariri & K-04 & 75,34 & 13,97 & 1,43 & 0,02 & 0,28 & 2,22 & 4,21 & 2,55 & 0,20 & 0,05 & 0,51 & 100,79 & 542 & 123 & 184 & 22 & 11 \\
\hline Gn. Itanhaém & K-05 & 69,49 & 14,45 & 4,28 & 0,06 & 0,95 & 1,93 & 3,80 & 4,45 & 0,82 & 0,24 & 0,18 & 100,66 & 1442 & 148 & 247 & 21 & 33 \\
\hline Dior. ltanhaém & $\mathrm{K}-5 \mathrm{~B}$ & 52,39 & 17,37 & 9,26 & 0,12 & 4,64 & 6,70 & 5,52 & 1,49 & 1,69 & 0,47 & 1,29 & 100,94 & 906 & 49 & 755 & 24 & 21 \\
\hline Gr. Itarii & $\mathrm{K}-52$ & 75,73 & 13,79 & 1,10 & 0,01 & 0,18 & 0,41 & 2,76 & 5,17 & 0,11 & 0,08 & 1,09 & 100,44 & 170 & 401 & 57 & 24 & 27 \\
\hline Gr. Rib. Oleo & $\mathrm{K}-54$ & 70,52 & 15,18 & 2,88 & 0,04 & 1,33 & 2,13 & 4,16 & 3,56 & 0,33 & 0,11 & 0,37 & 100,62 & 1.060 & 149 & 559 & 23 & 4,4 \\
\hline Gr. ltariri & $K-68$ & 77,54 & 14,63 & 3,7 & 0,07 & 1,14 & 3,02 & 2,52 & 2,14 & 0,39 & 0,08 & 1,05 & 100,28 & 436 & 94 & 153 & 0 & 32,1 \\
\hline Gr. Itarii & $\mathrm{K}-78$ & 69,58 & 15,07 & 2,96 & 0,02 & 0,71 & 2,2 & 3,55 & 4,68 & 0,68 & 0,21 & 0,58 & 100,23 & 1473 & 175 & 512 & 0 & 4,52 \\
\hline eado & $\mathrm{K}-81$ & 70,1 & 14,32 & 3,53 & 0,06 & 1,31 & 2,19 & 2,48 & 5,47 & 0,52 & 0,17 & 0,52 & 100,66 & 1055 & 213 & 353 & 0 & 15,2 \\
\hline ado & $\mathrm{K}-82$ & 70,13 & 14,85 & 2,74 & 0,06 & 0,84 & 2,14 & 2,83 & 5,03 & 0,46 & 0,02 & 0,57 & 99,66 & 674 & 225 & 240 & 0 & 18 \\
\hline UNIE & AMOS & $\mathrm{Nb}$ & $\mathrm{Ta}$ & $\mathrm{Zr}$ & $\mathrm{Hf}$ & $T$ & Th & $\mathrm{U}$ & $\mathrm{Pb}$ & Sc & $\mathrm{V}$ & $\mathrm{Cr}$ & $\mathrm{Co}$ & $\mathrm{Ni}$ & $\mathrm{Cu}$ & $\mathrm{Zn}$ & Mo & $w$ \\
\hline ngaguá & $\mathrm{K}-03$ & 16 & 0,64 & 479 & 12 & 1,21 & 2,4 & 1,43 & 34 & 3 & 45 & 20 & 6, & 40 & -10 & 67 & 0,6 & 0,3 \\
\hline ngaguá & $\mathrm{K}-3 \mathrm{~A}$ & 26 & 0,9 & 528 & 12 & 1,17 & 4,58 & 0,99 & 17 & 30 & 68 & 22 & 9 & 23 & 18 & 86 & -2 & 1,1 \\
\hline Dior. Mongaguá & $\mathrm{K}-3 \mathrm{~B}$ & 19 & 1,1 & 337 & 8,5 & 2,50 & 6,87 & 2,04 & -5 & 40 & 313 & 386 & - & 132 & 52 & 251 & -2 & 0,9 \\
\hline Gr. Itariri & K-04 & 12 & 0,7 & 143 & 4,4 & 0,65 & 14 & 2,61 & 34 & 3 & 6 & 18 & 2,2 & -10 & -10 & 46 & 0,7 & $-0,2$ \\
\hline haém & K-05 & 22 & 1,07 & 394 & 10 & 0,69 & 6,19 & 0,55 & 27 & 9 & 41 & 21 & 6, & 34 & -10 & 82 & 0,3 & 0,9 \\
\hline Dior. Itanhaém & $\mathrm{K}-5 \mathrm{~B}$ & 14 & 1,0 & 179 & 4,3 & 0,38 & 2,83 & 1,78 & 8 & 16 & 207 & 24 & 30 & 43 & 13 & 125 & -2 & 0,8 \\
\hline Gr. & $\mathrm{K}-52$ & 26 & 4,3 & 98 & 3,0 & 3,08 & 28,2 & 26,4 & 33 & 3 & -5 & -20 & -1 & -15 & -10 & -30 & -2 & 2,3 \\
\hline Oleo & K-54 & 9,3 & 0,5 & 144 & 3,2 & 1,05 & 14,1 & 3,02 & 21 & 5 & 31 & 50 & $=$ & 31 & 28 & 59 & -2 & 0,2 \\
\hline Gr. I & $K-68$ & 0 & 0 & 136 & 0 & 0 & (2) & 0 & 0 & 12,6 & 76 & 15 & 15 & 15 & 15 & 48 & 0 & 0 \\
\hline Gr. If & $K-78$ & 0 & 0 & 389 & 0 & 0 & 0 & 0 & 0 & 1,82 & 41 & 15 & 15 & 15 & 15 & 84 & 0 & 0 \\
\hline Gr. Areado & K-81 & 0 & 0 & 207 & 0 & 0 & 0 & 0 & 0 & 6,24 & 56 & 36 & 15 & 15 & 15 & 69 & 0 & 0 \\
\hline Gr. Areado & $K-82$ & 0 & 0 & 183 & 0 & 0 & 0 & 0 & 0 & 6,8 & 38 & 15 & 15 & 15 & 15 & 34 & 0 & 0 \\
\hline UNIDADE & AMOS & $\mathrm{Sn}$ & $\mathrm{Sb}$ & $\mathrm{Cs}$ & $\mathrm{La}$ & $\mathrm{Ce}$ & $\mathrm{Pr}$ & Nd & $\mathrm{Sm}$ & Eu & Gd & $\mathrm{Tb}$ & Dy & Ho & $\mathrm{Er}$ & $\mathrm{Tm}$ & $Y_{b}$ & $\mathrm{Lu}$ \\
\hline aguá & 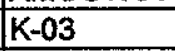 & 2,7 & $-0,05$ & 4,3 & 18,6 & 39,6 & 4,364 & 20,7 & 4,28 & 1,55 & 2,98 & 0,47 & 2,31 & 0,42 & 1,15 & 0,14 & 0,88 & 0,138 \\
\hline jaguá & $K$ & 5 & $-0,2$ & 3,4 & 39,2 & 88 & 11,6 & 51,6 & 12,5 & 2,456 & 10,8 & 1,72 & 7,74 & 1,63 & 4,19 & 0,605 & 3,34 & 0,422 \\
\hline Dior. Mongaguá & $K-3 B$ & $=$ & $-0,2$ & 4,0 & 58,5 & 159 & 21,7 & 96,0 & 18,5 & 4,497 & 14,2 & 1,81 & 7,48 & 1,43 & 3,77 & 0,525 & 3,11 & 0,404 \\
\hline Gr. Itarini & $\mathrm{K}-0.4$ & $-0,5$ & $-0,05$ & 2,6 & 37,6 & 74,4 & 7,507 & 30,7 & 5,21 & 1,092 & 3,05 & 0,47 & 2,3 & 0,39 & 1,07 & 0,131 & 0,83 & 0,134 \\
\hline Gn. Itanhaém & $\mathrm{K}-05$ & 3,6 & 0,12 & 1 & 56,7 & 109 & 12,02 & 51,5 & 9,96 & 2,206 & 6,98 & 1,26 & 6,93 & 1,3 & 3,72 & 0,5 & 2,99 & 0,435 \\
\hline Dior. & $K-5 B$ & 2 & $-0,2$ & 1,4 & 26,4 & 62 & 7,74 & 32,4 & 6,44 & 1,981 & 5,52 & 0,78 & 3,45 & 0,72 & 1,91 & 0,288 & 1,81 & 0,259 \\
\hline $\mathrm{Gr}$. & $K-52$ & 11 & $-0,2$ & 9,5 & 32,4 & 35 & 9,74 & 34,2 & 8,97 & 0,565 & 7,47 & 1,26 & 5,56 & 0,92 & 2,08 & 0,283 & 1,48 & 0,155 \\
\hline Gr. Rib. Óleo & $\mathrm{K}-54$ & 2 & $-0,2$ & 3,9 & 24,4 & 53 & 4,62 & 14,3 & 2,29 & 0,583 & 1,41 & 0,19 & 0,81 & 0,15 & 0,42 & 0,051 & 0,39 & 0,055 \\
\hline Gr. Itariri & $\mathrm{K}-68$ & 0 & 0 & 0 & 20,4 & 39,2 & 0 & 16,5 & 3,66 & 1,1 & 4,05 & 0 & 6,2 & 0 & 3,58 & 0 & 3,59 & 0,54 \\
\hline Gr. Itarin & K-78 & 0 & 0 & 0 & 119 & 221 & 0 & 66,3 & 8,11 & 1,69 & 3,68 & 0 & 1,36 & 0 & 0,82 & 0 & 0,22 & 0,07 \\
\hline Gr. $\mathrm{Ar}$ & $\mathrm{K}-81$ & 0 & 0 & 0 & 64,2 & 120 & 0 & 46,3 & 8,54 & 1,41 & 5,37 & 0 & 3,91 & 0 & 1,53 & 0 & 1,18 & 0,18 \\
\hline it. Areado & 82 & 0 & 0 & 0 & 118 & 239 & 0 & 92,5 & 16,3 & 1,49 & 8,42 & 0 & 4,57 & 0 & 1,19 & 0 & 0,94 & 0,14 \\
\hline
\end{tabular}




\begin{tabular}{|c|c|c|c|c|c|c|c|c|c|c|c|c|c|c|c|c|c|c|}
\hline UNIDADE & AMOSTRA & $\mathrm{SiO}_{2}$ & $\mathrm{Al}_{2} \mathrm{O}_{3}$ & $\mathrm{Fe}_{2} \mathrm{O}_{3}$ & $\mathrm{MnO}$ & $\mathrm{MgO}$ & $\mathrm{CaO}$ & $\mathrm{Na}_{2} \mathrm{O}$ & $\mathrm{K}_{2} \mathrm{O}$ & $\mathrm{TiO}_{2}$ & $\mathrm{P}_{2} \mathrm{O}_{5}$ & LOI & TOTAL & $\mathrm{Ba}$ & $\mathrm{Rb}$ & $\mathrm{Sr}$ & $\mathrm{Ga}$ & $\mathbf{Y}$ \\
\hline Gnaisse $\mathrm{ZCl}$ & $k-11$ & 65,95 & 14,95 & 4,37 & 0,07 & 2,57 & 3,20 & 3,19 & 3,92 & 0,60 & 0,17 & 0,88 & 99,87 & 1.139 & 215 & 496 & 0 & 11 \\
\hline Gran. Ol.Barros & $\mathrm{K}-16$ & 65,02 & 14,52 & 6,49 & 0,11 & 2,61 & 4,29 & 3,43 & 2,73 & 0.55 & 0,20 & 0,71 & 100,67 & 627 & 135 & 381 & 20 & 31 \\
\hline Dior. OI. Barros & $\mathrm{K}-16 \mathrm{D}$ & 45,96 & 14,81 & 14,93 & 0,23 & 5,40 & 9,66 & 1,06 & 4,07 & 1,80 & 0,13 & 2,80 & & 448 & 216 & 247 & 23 & 26 \\
\hline Gr. Ol. Barros & $\mathrm{K}-17 \mathrm{~A}$ & 65,27 & 16,09 & 5,16 & 0,11 & 2,06 & 3,86 & 4,32 & 2,05 & 0,44 & 0,20 & 0,75 & 100,31 & 217 & 112 & 395 & 20 & 10 \\
\hline Dior. Ol. Barros & $\mathrm{K}-17 \mathrm{~B}$ & 48,22 & 14,45 & 13,94 & 0,30 & 7,14 & 9,38 & 2,36 & 2,33 & 1,18 & 0,09 & 0,90 & 100,29 & 255 & 113 & 271 & 21 & 38 \\
\hline Gn Sa. Timirim & $\mathrm{K}-44$ & 68,03 & 14,64 & 4,29 & 0,06 & 2,07 & 2,35 & 3,22 & 4,07 & 0,44 & 0,11 & 0,62 & 99,90 & 911 & 163 & 359 & 0 & 6 \\
\hline Gr. Votupoca & K-92 & 71,5 & 14,36 & 2,25 & 0,04 & 0,32 & 1,31 & 2,94 & 5,33 & 0,3 & 0,03 & 0,72 & 99,1 & 649 & 346 & 137 & 0 & 25,6 \\
\hline Parag. Juréia & K-97 & 71,45 & 14,37 & 4,7 & 0,17 & 1,89 & 1,64 & 1,83 & 2,4 & 0,55 & 0,03 & 0,94 & 99,96 & 667 & 86 & 162 & 0 & 17 \\
\hline
\end{tabular}

\begin{tabular}{|c|c|c|c|c|c|c|c|c|c|c|c|c|c|c|c|c|c|c|}
\hline UNIDADE & AMOSTRA & $\mathrm{Nb}$ & $\mathrm{Ta}$ & $\mathrm{Zr}$ & $\mathrm{Hf}$ & $T !$ & Th & $\bar{U}$ & $\mathrm{~Pb}$ & Sc & $\mathrm{V}$ & $\mathrm{Cr}$ & Co & $\mathrm{Ni}$ & $\mathrm{Cu}$ & Zn & Mo & $W$ \\
\hline Gnaisse ZCl & $\mathrm{K}-11$ & 0 & 0,0 & 206 & 0,0 & 0,00 & 0,00 & 0,00 & 0 & 8,06 & 70 & 102 & 24 & 26 & 14 & 88 & 0 & 0,0 \\
\hline Gran. Ol.Barros & $K-16$ & 16 & 1,2 & 180 & 5,0 & 0,80 & 15,7 & 1,37 & 21 & 14 & 92 & 78 & 16 & 39 & 55 & 83 & -2 & 0,9 \\
\hline Dior. Ol. Barros & K-16D & 5,6 & 0,4 & 91 & 2,4 & 1,01 & 0,66 & 0,24 & 7 & 35 & 436 & 83 & 49 & 90 & 143 & 140 & -2 & 2,2 \\
\hline Gr. Ol. Barros & $\mathrm{K}-17 \mathrm{~A}$ & 7,5 & 0,8 & 158 & 3,9 & 0,69 & 5,21 & 1,49 & 11 & 9 & 59 & 39 & 13 & 27 & 16 & 70 & 4 & $-0,2$ \\
\hline Dior. OI. Barros & $K-17 B$ & 6,6 & 0,5 & 73 & 2,0 & 2,97 & 0,46 & 1,01 & 12 & 41 & 324 & 171 & 64 & 111 & 14 & 162 & -2 & 0,8 \\
\hline Gn Sa. Timirim & $K-44$ & 0 & 0,0 & 241 & 0,0 & 0,00 & 0,0 & 0,00 & 0 & 6,18 & 63 & 33 & 16 & 15 & 19 & 72 & 0 & 0,0 \\
\hline Gr. Votupoca & $K-92$ & 0 & 0 & 249 & 0 & 0 & 0 & 0 & 0 & 3,91 & 33 & 15 & 15 & 15 & 15 & 43 & 0 & 0 \\
\hline Parag. Juréia & K-97 & 0 & 0 & 229 & 0 & 0 & 0 & 0 & 0 & 11,2 & 50 & 70 & 15 & 15 & 15 & 67 & 0 & 0 \\
\hline
\end{tabular}

\begin{tabular}{|l|l|c|c|c|c|c|c|c|c|c|c|c|c|c|c|c|c|c|}
\hline UNIDADE & AMOSTRA & Sn & Sb & Cs & La & Ce & Pr & Nd & Sm & Eu & Gd & Tb & Dy & Ho & Er & Tm & Yb & Lu \\
\hline Gnaisse ZCl & K-11 & 0 & 0,0 & 0,0 & 65,1 & 120 & 0,00 & 38,8 & 5,68 & 1,240 & 3,64 & 0,00 & 2,32 & 0,00 & 0,82 & 0,000 & 1,10 & 0,170 \\
\hline Gran. Ol.Barros & K-16 & 3 & 0,4 & 5,6 & 38,6 & 76 & 8,33 & 32,7 & 6,56 & 1,356 & 5,66 & 0,90 & 4,47 & 0,98 & 2,72 & 0,452 & 2,68 & 0,405 \\
\hline Dior. Ol. Barros & K-16D & -1 & $-0,2$ & 12 & 6,05 & 16 & 2,27 & 11,7 & 3,50 & 1,311 & 3,90 & 0,74 & 4,05 & 0,93 & 2,55 & 0,408 & 2,51 & 0,367 \\
\hline Gr. Ol. Barros & K-17A & 1 & 0,4 & 6,1 & 20,0 & 40 & 4,37 & 16,1 & 3,04 & 0,922 & 2,51 & 0,34 & 1,49 & 0,33 & 0,89 & 0,138 & 0,87 & 0,142 \\
\hline Dior. Ol. Barros & K-17B & 5 & 0,2 & 4,9 & 8,94 & 25 & 3,77 & 17,6 & 5,57 & 1,471 & 5,66 & 1,08 & 5,75 & 1,25 & 3,53 & 0,600 & 3,72 & 0,552 \\
\hline Gn Sa. Timirim & K-44 & 0 & 0,0 & 0,0 & 34,2 & 61 & 0,00 & 21,2 & 3,55 & 1,020 & 2,05 & 0,00 & 1,43 & 0,00 & 0,82 & 0,000 & 0,49 & 0,090 \\
\hline Gr. Votupoca & K-92 & 0 & 0 & 0 & 99,4 & 201 & 0 & 67,7 & 12,2 & 1,01 & 7,52 & 0 & 6,12 & 0 & 2,63 & 0 & 2,31 & 0,35 \\
\hline Parag. Juréia & K-97 & 0 & 0 & 0 & 35,1 & 71,2 & 0 & 28,4 & 5,91 & 0,98 & 4,05 & 0 & 3,69 & 0 & 2,12 & 0 & 2,08 & 0,34 \\
\hline
\end{tabular}




\section{BLOCO IGUAPE}

\begin{tabular}{|c|c|c|c|c|c|c|c|c|c|c|c|c|c|c|c|c|c|c|}
\hline UNIDADE & AMOSTRA & $\mathrm{SiO}_{2}$ & $\mathrm{Al}_{2} \mathrm{O}_{3}$ & $\mathrm{Fe}_{2} \mathrm{O}_{3}$ & $\mathrm{MnO}$ & $\mathrm{MgO}$ & $\mathrm{CaO}$ & $\mathrm{Na}_{2} \mathrm{O}$ & $\mathrm{K}_{2} \mathrm{O}$ & $\mathrm{TiO}_{2}$ & $\mathrm{P}_{2} \mathrm{O}_{5}$ & LOI & \begin{tabular}{|l|} 
TOTAL \\
\end{tabular} & $\mathrm{Ba}$ & $\mathrm{Rb}$ & $\mathrm{Sr}$ & $\mathrm{Ga}$ & \\
\hline Gr. Itapitangui & $\mathrm{K}-31$ & 77,07 & 11,84 & 1,60 & 0,02 & 0,03 & 0.42 & 4,10 & 4,47 & 0,08 & 0,04 & 0,40 & 100,06 & 94 & 338 & 16 & 27 & 159 \\
\hline Gr. NE Iguape & $K-36$ & 75,82 & 13,63 & 0,62 & $-0,01$ & 0,12 & 0,47 & 3,55 & 5,37 & 0,08 & 0,10 & 0,46 & 100,23 & & $(316$ & $(41)$ & 16 & \\
\hline Gr. NE lguape & $K-37$ & 75,12 & 13,53 & 1,39 & 0,04 & 0,21 & 0,71 & 3,37 & 4,73 & 0,13 & 0,10 & 0,74 & 100,07 & (215) & 283 & (75) & 19 & 15 \\
\hline Gr. Sa. Paratiú & $K-60$ & 71,38 & 13,91 & 3,34 & 0,06 & 0,30 & 1,52 & 3,14 & 5,63 & 0,33 & 0,10 & 0,68 & 100,39 & 999 & 259 & 104 & 24 & 65 \\
\hline Gr. Sa. Paratiú & $K-61$ & 75,24 & 12,55 & 2,31 & 0,04 & 0,21 & 1,05 & 3,04 & 5,29 & 0,20 & 0,06 & 0,52 & 100,52 & 430 & 264 & 61,8 & 20 & 74 \\
\hline Gr. Moro Espia & $K-64$ & 72,02 & 13,68 & 3,72 & 0.06 & 0,96 & 1,80 & 3,20 & 3,82 & 0,51 & 0.19 & 0,62 & 100,58 & 461 & 202 & 220 & 22 & 23 \\
\hline Gr. Moro Espia & $K-100$ & 67,49 & 14,94 & 4,71 & 0,07 & 1,28 & 2,09 & 3,07 & 4,77 & 0,69 & 0,23 & 0,71 & 100,05 & 1002 & 197 & 296 & 0 & 18,8 \\
\hline Protom. ZCS & $K-102$ & 69,77 & 14,74 & 3,62 & 0,06 & 1 & 1,99 & 3,07 & 5,28 & 0,58 & 0,29 & 0,36 & 100,75 & 1542 & 160 & 337 & 0 & 14 \\
\hline
\end{tabular}

\begin{tabular}{|c|c|c|c|c|c|c|c|c|c|c|c|c|c|c|c|c|c|c|}
\hline UNIDADE & AMOSTRA & $\mathrm{Nb}$ & $\mathrm{Ta}$ & $\mathrm{Zr}$ & $\mathrm{Hf}$ & $\pi$ & Th & $U$ & $\mathrm{~Pb}$ & Sc & $\mathrm{V}$ & $\mathrm{Cr}$ & $\mathrm{Co}$ & $\mathrm{Ni}$ & $\mathrm{Cu}$ & $\mathrm{Zn}$ & Mo & $w$ \\
\hline Gr. Itapitangui & $\mathrm{K}-31$ & 63 & 4,4 & 315 & 15 & 5,55 & 24,8 & 4,60 & 16 & -1 & -5 & -20 & 4 & -15 & -10 & 87 & -2 & 2,0 \\
\hline Gr. NE Iguape & $\mathrm{K}-36$ & 14 & 2,3 & 54 & 1,5 & 1,91 & 6,60 & 4,13 & 27 & 2 & -5 & -20 & -1 & -15 & -10 & -30 & -2 & 0,9 \\
\hline Gr. NE Iguape & $\mathrm{K}-37$ & 18 & 2,3 & 93 & 2,5 & 1,66 & 16,7 & 3,39 & 29 & 3 & -5 & -20 & -1 & -15 & -10 & -30 & -2 & 1,4 \\
\hline Gr. Sa. Paratiú & $|K-60|$ & 20 & 1,32 & 354 & 9,9 & 1,14 & 16,1 & 2,66 & 33 & 10 & 5 & -10 & 2,9 & 24 & -10 & 75 & 1,6 & 2,4 \\
\hline Gr. Sa. Paratiú & $\mathrm{K}-61$ & 17 & 1,56 & 222 & 6,9 & 1,17 & 27,1 & 5,75 & 40 & 5 & -5 & 11 & 1,9 & 14 & -10 & 54 & 0,9 & $-0,2$ \\
\hline Gr. Moro Espia & $\mathrm{K}-64$ & 24 & 1,94 & 238 & 6,5 & 1,12 & 30,2 & 3,5 & 36 & 6 & 34 & 26 & 7,5 & 20 & -10 & 77 & 1,1 & 1,3 \\
\hline Gr. Moro Espia & $\mathrm{K}-100$ & 0 & 0 & 296 & 0 & 0 & 0 & 0 & 0 & 7,18 & 44 & 15 & 15 & 15 & 15 & 75 & 0 & 0 \\
\hline Protom. ZCS & $\mathrm{K}-102$ & 0 & 0 & 324 & 0 & 0 & 0 & 0 & 0 & 4,4 & 25 & 15 & 15 & 15 & 15 & 73 & 0 & 0 \\
\hline
\end{tabular}

\begin{tabular}{|l|l|c|c|c|c|c|c|c|c|c|c|c|c|c|c|c|c|c|}
\hline UNIDADE & AMOSTRA & Sn & Sb & Cs & La & Ce & Pr & Nd & Sm & Eu & Gd & Tb & Dy & Ho & Er & Tm & Yb & Lu \\
\hline Gr. Itapitangui & K-31 & 13 & $-0,2$ & 4,2 & 73,2 & 142 & 15,7 & 50,3 & 12,7 & 0,240 & 12,3 & 3,04 & 19,2 & 4,61 & 14,6 & 2,477 & 15,1 & 2,126 \\
\hline Gr. NE lguape & K-36 & 4 & $-0,2$ & 2,7 & 9,88 & 20 & 2,22 & 6,92 & 1,62 & 0,177 & 1,36 & 0,34 & 2,19 & 0,47 & 1,48 & 0,250 & 1,71 & 0,241 \\
\hline Gr. NE lguape & K-37 & 3 & $-0,2$ & 6,5 & 25,6 & 52 & 5,55 & 17,3 & 3,54 & 0,445 & 2,51 & 0,46 & 2,25 & 0,47 & 1,36 & 0,212 & 1,38 & 0,191 \\
\hline Gr. Sa. Paratiú & K-60 & 4,4 & $-0,05$ & 7,1 & 76,8 & 164 & 16,79 & 72,3 & 15,2 & 1,724 & 11,6 & 2,18 & 12,1 & 2,41 & 6,86 & 0,977 & 6,29 & 0,879 \\
\hline Gr. Sa. Paratiú & K-61 & 5 & 0,06 & 5,8 & 55,1 & 122 & 13,02 & 56,8 & 13,2 & 0,957 & 10,7 & 2,16 & 12,8 & 2,65 & 7,83 & 1,137 & 7,85 & 1,139 \\
\hline Gr. Moro Espia & K-64 & 3,1 & $-0,05$ & 7,2 & 87,2 & 157 & 15,75 & 60 & 9,77 & 1,248 & 5,33 & 0,92 & 4,49 & 0,82 & 2,39 & 0,319 & 2,02 & 0,302 \\
\hline Gr. Moro Espia & K-100 & 0 & 0 & 0 & 83,4 & 168 & 0 & 57,5 & 10,4 & 1,76 & 6,43 & 0 & 4,67 & 0 & 2,08 & 0 & 1,68 & 0,26 \\
\hline Protom. ZCS & K-102 & 0 & 0 & 0 & 128 & 262 & 0 & 94,4 & 14,4 & 2,01 & 7,38 & 0 & 3,74 & 0 & 1,23 & 0 & 1,14 & 0,17 \\
\hline
\end{tabular}




\section{APÊNDICE 2 - CONSTANTES RADIOMÉTRICAS}

\section{Método K-Ar}

$\lambda \beta=4.962 \times 10^{-10}$ anos $^{-1}$

$K^{40}$ total $=0.581 \times 10^{-10}$ anos $^{-1}$

$\left(\mathrm{Ar}^{40} / \mathrm{Ar}^{36}\right)_{\mathrm{atm}}=295.5$

$K^{40}=0.01167 \% K_{t}$

\section{Método Rb-Sr}

$\lambda_{R b}=1.42 \times 10^{-11}$ anos $^{-1}$

$\left(\mathrm{Rb}^{85} / \mathrm{Rb}^{87}\right)_{\mathrm{N}}=2.59265$

$\left(\mathrm{S}^{86} / \mathrm{Sr}^{88}\right)_{\mathrm{N}}=0.1194$

\section{Método U-Pb}

$$
\begin{aligned}
& \lambda_{238}=1.55125 \times 10^{-10} \text { anos }^{-1} \\
& \lambda_{235}=9.8485 \times 10^{-10} \text { anos }^{-1} \\
& \lambda_{232}=4.9475 \times 10^{-11} \text { anos }^{-1} \\
& U^{238} / \mathrm{U}^{235}=137.88 \\
& a_{0}=\left(\mathrm{Pb}^{206} / \mathrm{Pb}^{204}\right)_{\mathrm{T}}=9.307 \\
& b_{0}=\left(\mathrm{Pb}^{207} / \mathrm{Pb}^{204}\right)_{\mathrm{T}}=10.294
\end{aligned}
$$

\section{Método Sm-Nd}

$$
\begin{aligned}
& \lambda_{147}=6.54 \times 10^{-12} \text { anos }^{-1} \\
& \left(\mathrm{Nd}^{143} / \mathrm{Nd}^{144}\right)_{\circ} \mathrm{DM}=0.513114 \\
& \left(\mathrm{Sm}^{147} / \mathrm{Nd}^{144}\right)_{\circ} \mathrm{DM}=0.222
\end{aligned}
$$




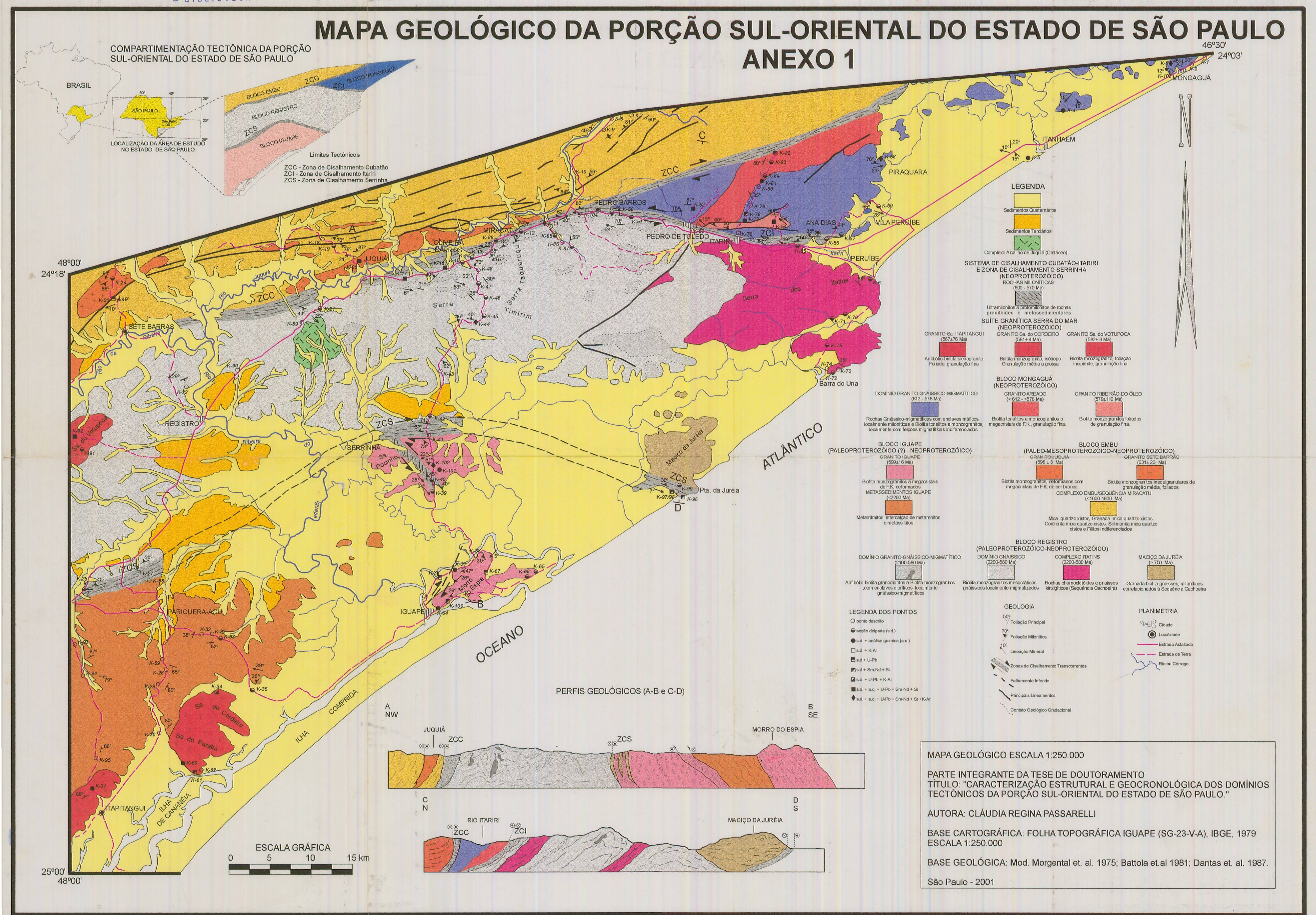


MAPA ESTRUTURAL DA PORÇÃO SUL-ORIENTAL DO ESTADO DE SÃO PAULO ANEXO 2

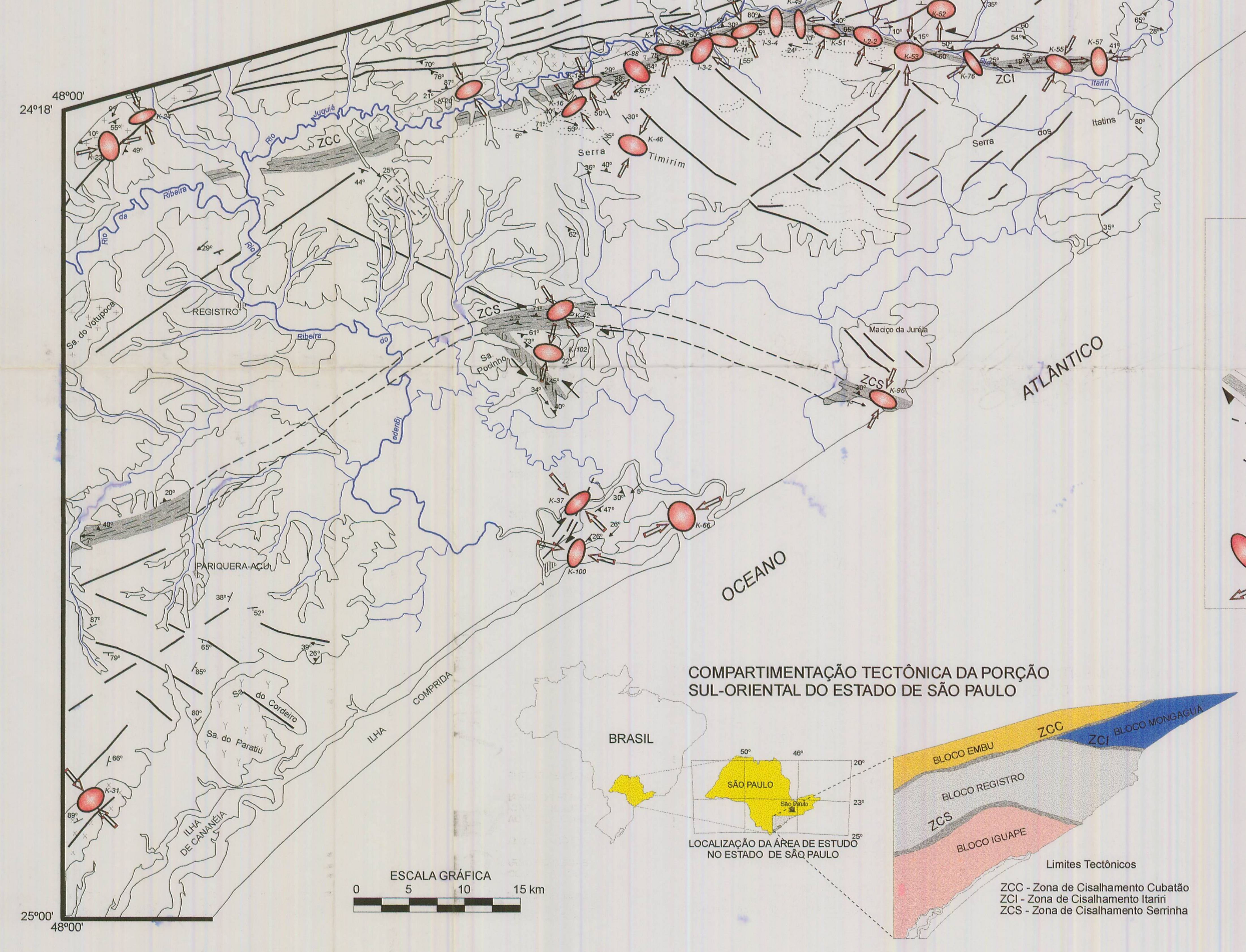

GEOLOGIA

Foliação Principal

$70^{\circ}$

$10^{\circ}$

1 Zonas de Cisalhamento Transcorrentes

Falhamento Inferido

Principais Lineamentos

Contato Geológico Gradacional

Elipses de Deformaçãa (XZ)

Direçăo do Esforço Principal

MAPAESTRUTURAL ESCALA $1: 250.000$

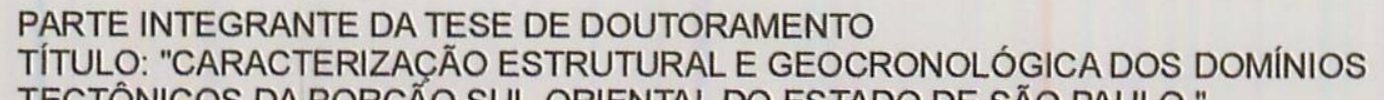
AUTORA: CLAUDAAREGINA PASSAREW

RASE CARTOGRAFICA: FOLHA TOPOGRAFICA IGUAPE (SG-23V-A), IBGE, 1979
ESCALA1:250.000

BASE GEOLÓGICA: Mod. Morgental et. al. 1975; Battola et.al 1981; Dantas et. al. 1987.

Săo Paulo - 2001 